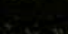



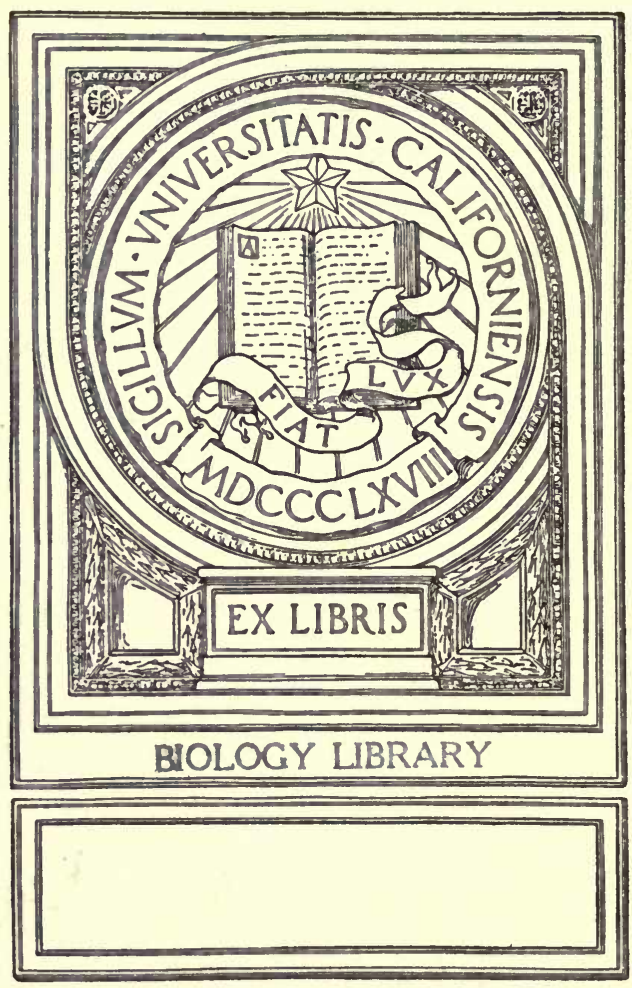


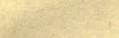

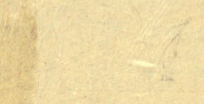




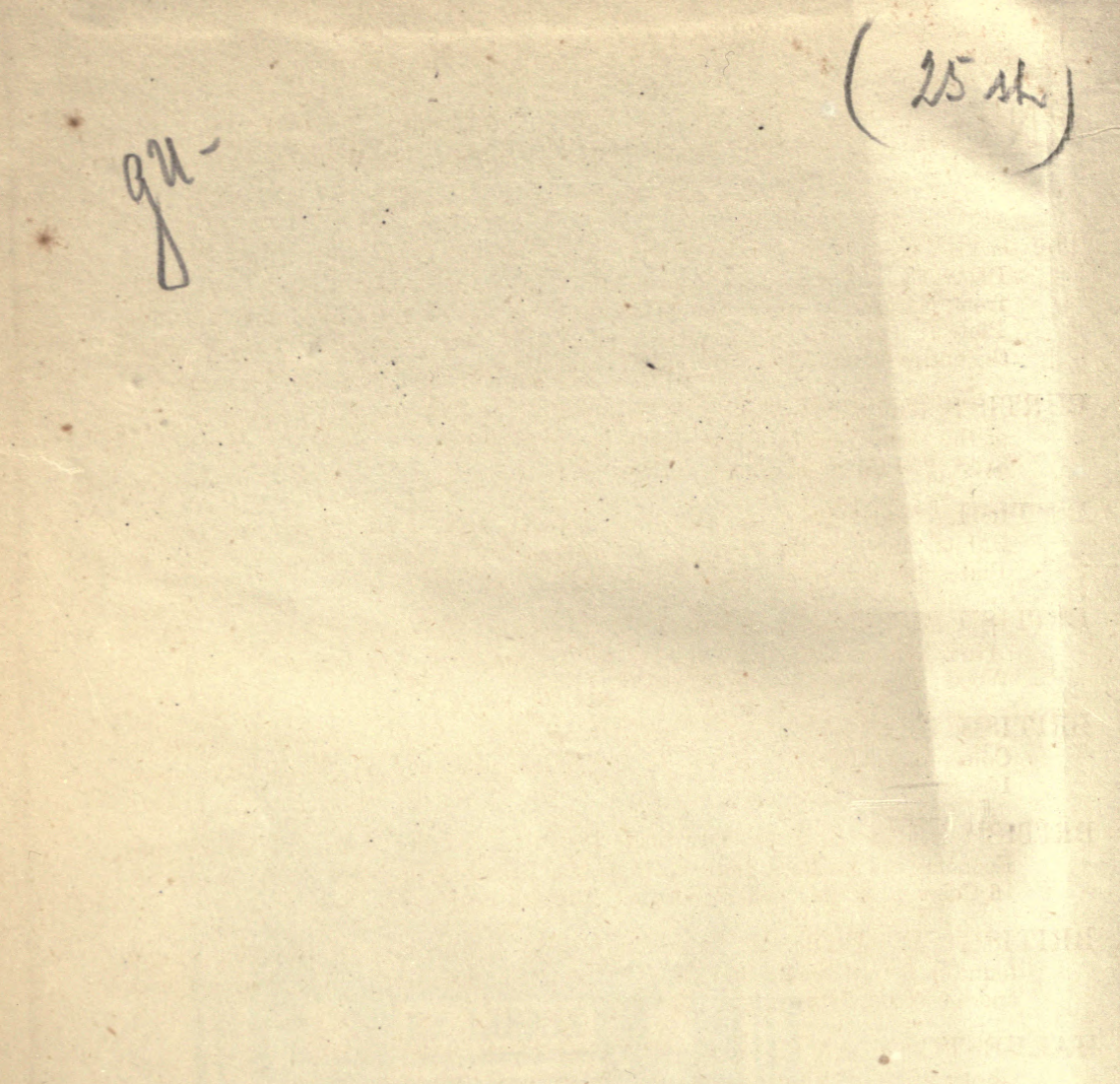




\section{WORKS ON}

\section{ENTOMOLOGY AND CONCHOLOGY.}

The LARV A of the BRITISH LEPIDOPTERA and their FOOD PLANTS. By Owen S. Wilson. With Life-size Figures, Drawn and Coloured from Nature by Eleanora Wilson. Part 1. With 8 elaborately Coloured Plates. 12s. To be completed in 5 Parts. Supplied only to Subseribers for the entire Work. Subscriptions if paid in advance, 508 .

CURTIS'S BRITISH ENTOMOLOGY. Illustrations and Descriptions of the Genera of Insects found in Great Britain and Ireland. 8 vols. Royal 8vo. 770 Coloured Plates. $£ 28$.

BRITISH INSECTS. A Familiar Description of the Form, Structure, Habits, and Transformations of Insects. By E. F. Staveler. 16 Coloured Plates and numerous Wood Engravings. 14s.

BRITISH BUTTERFLIES and MOTHS : an Introduction to the Study of our Native Lepidoptera. By H. T. Stainton. 16 Coloured Plates and Wood Engravings. 10s. $6 d$.

BRITISH BEETLES : an Introduction to the Study of our Indigenous Coleoptera. By E. C. RYE. 16 Coloured Plates and 11 Wood Engravings. 10s. $6 d$.

BRITISH BEES : an Introduction to the Study of the Natural History and Economy of the Bees Indigenous to the British Isles. By W. E. Shuckard. 16 Coloured Plates and Woodcuts. 10s. $6 d$.

BRITISH SPIDERS; an Introduction to the Study of the Araneide found in Great Britain and Ireland. By E. F. Staveley. 16 Coloured Plates and 44 Wood Engravings. 10s. $6 d$.

HARVESTING ANTS and TRAP-DOOR SPIDERS: Notes and Observations on their Habits and Dwellings. By J. T. Moggridgr, F.L.S. With a Supplement and 8 additional Plates, $17 s$. The Supplement separately, cloth, $7 s .6 d$.

ELEMENTS of CONCHOLOGY : an Introduction to the Natural History of Shells, and of the Animals which form them. By LoveLL REEve, F.L.S. Royal 8vo. 2 vols. 62 Coloured Plates. $£ 2.16 s$.

CONCHOLOGIA ICONICA ; or, Figures and Descriptions of the Shells of Mollusks, with Remarks an their Affinities, Synonymy, and Geographical Distribution. By Lovert Reere, F.L.S., and G. B. Sowrrby, F.L.S. Demy 4to. in double Parts, with 16 Coloured Plates. 20s.

A detailed list of Monographs and Volumes published may be had.

CONCHOLOGIA INDICA; Illustrations of the Land and Freshwater Shells of British India. Edited by Srivanus HANLEY, F.L.S., and WilliaM Throbald, of the Geological Survey of India. Complete in one vol. 4to. 160 Coloured Plates, cloth, £8. 5 s.

The EDIBLE MOLLUSKS of GREAT BRITAIN and IRELAND, with the Modes of Cooking them. By M. S. Lovels. 12 Coloured Plates. 8s. $6 d$.

L. REEVE \& CO., 5 Henrietta Street, Covent Garden. 


\section{COLONIAL AND FOREIGN FLORAS.}

FLORA of MAURITIUS and the SEYCHELLES; a Description of the Flowering Plunts anil Ferns of those Islands. By J. G. BAKER, F.L.S. Complete in 1 vol. 24s. Published under the authority of the Colonial Government of Mauritius.

FLORA of BRITISH INDIA. By Dr. J. D. Hooker, F.R.S., and others. Purts I. to IV., 10s. 6d. oach. Vol. I. 328 .

FLORA CAPENSIS; a Systematic Description of the Plants of the Cape Colony, Caffraria, and Port Natal. By Wrlliam H. Harver, M.D., F.R.S., Professor of Botany in the University of Dublin, and OTTo WHHELM SONDER, Ph.D. Vols. I. and III., each 12s. Vol. III. $18 s$.

FLORA of TROPICAL AFRICA. By DANiEL OLIVER, F.R.S., F.L.S. Vols. I. to III, each 20s. Published under the authority of the First Commissioner of Her Majesty's Works.

FLORA AUSTRALIENSIS; a Description of the Plants of the Australian Territory. By G. Bentham, F.R.S., P.L.S., a ssisted by F. MUeller, F.R.S., Government Botanist, Melbourne, Victoria. Vols. I. to VI. 20s. each. Published under the auspices of the several Governments of Australia.

[Vol. VII. completing the work, in the press.

HANDBOOK of the NEW ZEALAND FLORA; a Systematic Description of the Natire Plants of New Zealand, and the Chatham, Kermadec's, Lord Auckland's, Campbell's, and Macquarrie's Islands. By Dr. J. D. Hooker, F.R.S. Complete in 1 rol., 30s. Published under the auspices of the Government of that Colony.

FLORA of the BRITISH WEST INDIAN ISLANDS. By Dr. GRISEBACH, F.L.S. 37s. $6 d$. Published under the auspices of the Secretary of State for the Colonies.

FLORA HONGKONGENSIS; a Description of the Flowering Plants and Ferns of the Island of Hongkong. By George Bentham, P.L.S. With a Map of the Island and Supplement by Dr. HANCE, 18s. Published under the authority of Her Majesty's Secretary of State for the Colonies. The Supplement separately, $2 s .6 d$.

FLORA VITIENSIS; a Description of the Plants of the Viti or Fiji Islands, with an Account of their History, Uses, and Properties. By Dr. Berthold Seemann, F.L.S. Royal 4to, 100 Coloured Plates, complete in 1 vol. cloth, $£ 8$. 5 s.

FLORA of TASMANIA. By Dr. J. D. Hooker, F.R.S. Royal 4 to. 2 vols., 200 Plates, $£ 17$. 10 s. coloured. Published under the authority of the Lords Commissioners of the Admiralty.

On the FLORA of AUSTRALIA; its Origin, Affinities, and Distribution. By Dr. J. D. Hooker, F.R.S. $10 s$.

CONTRIBUTIONS to the FLORA of MENTONE, and to a WINTER FLORA of the RIVIERA, including the Coast from Marseilles to Genoa. By J. Traherne Moogridge. Royal 8vo. Parts I. to IV., each with 25 Coloured Plates, 15s., or complete in one Vol. 63s.

OUTLINES of ELEMENTARY BOTANY, as Introductory to Local Floras. By G. BenthaM, F.R.S., President of the Linnean Society. New Edition. 2s. $6 d$.

LAWS of BOTANICAL NOMENCLATURE adopted by the International Botanical Congress, with an Historical Introduction and a Commentary. By Alphonst de Canpolie. 2s. $6 d$.

I. REEVE \& CO., 5 Henrietta Street, Covent Garden. 
TESTACEA ATLANTICA 
LONDON : PRINTED BY

SPOTTISWOODE AND CO., NEW-STREET SQUARE

AND PARLIAMENT STREET 


\title{
TESTACEA ATLANTICA
}

OR THE

\section{LAND AND FRESHWA'TER SHELLS}

\author{
OF
}

THE AZORES, MADEIRAS, SALVAGES, CANARIES, CAPE VERDES, AND SAINT HELENA

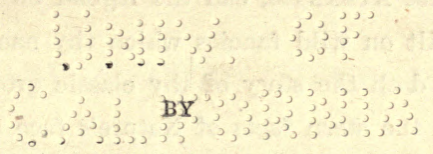

T. VERNON WOLLASTON, M.A., F.L.S.

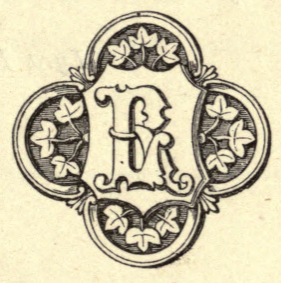

LONDON

L. REEVE \& CO., 5 HENRIETTA STREET, COVENT GARDEN 


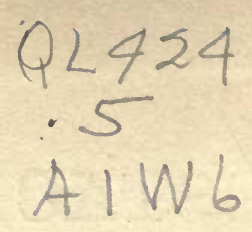

BIOLOGY

LIBRARY

Calm in its beauty lay the western sea; And every rippling wave which leapt around Those craggy isles took up the choral sound Which tells, great pictured Continent, of thee. O blest Atrantis, can the legend be

Built on "wild fancies, 'waich thy name surround?

Or dath the story of thy classic ground

With the stern faists of chature 's face agree?

What if no tongue may tell !-thy halo fair

Still lingers round the isles which slumber there;

And as those towering peaks, sun-gilded, rise

Into the bosom of primeval skies,

Bathed in God's glance, and ocean-girt, they stand, Like trophies left by time to mark that shadowy land.

Lyra Devoniensis, p. 135. 


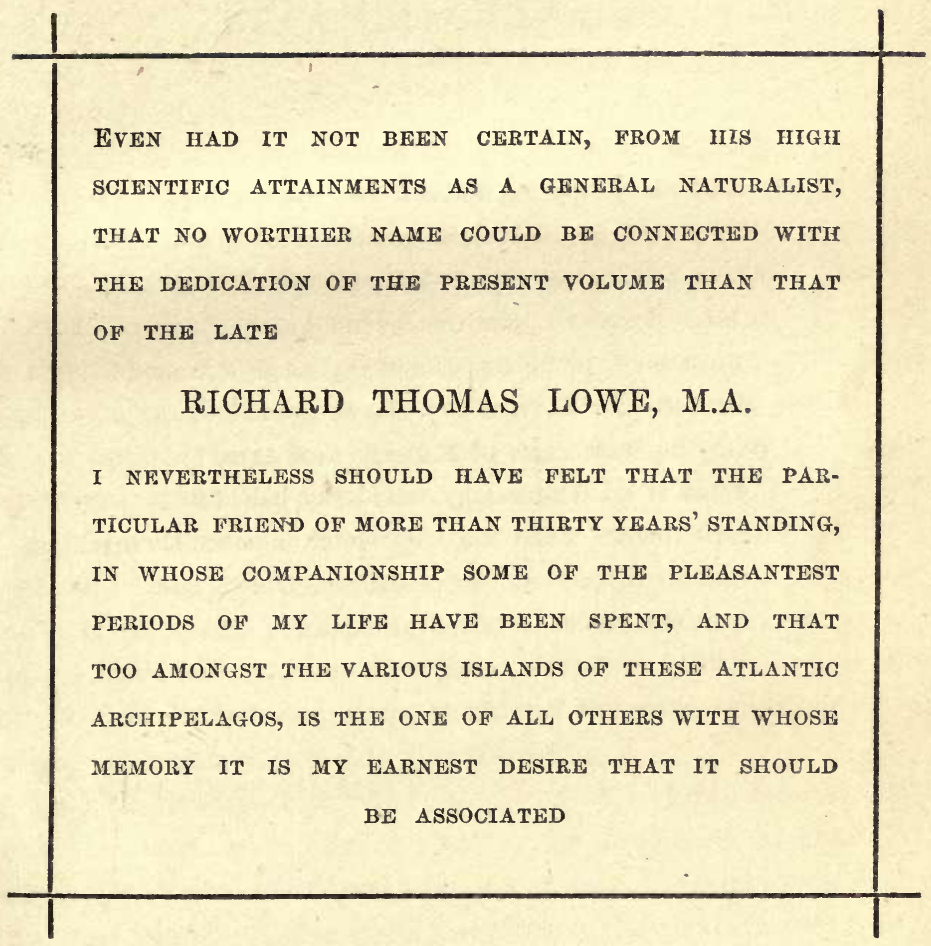





\section{PREFATORY REMARKS.}

IT is now exactly thirty years since I commenced to collect (in the autumn of 1847) the Land-Shells of the various outlying islands and rocks of the Madeiran Group; and although Insects, rather than Mollusca, formed at that time the main object of my researches, I was nevertheless enabled to add a considerable number of unmistakeably new species to the careful and elaborate catalogue which had previously been compiled by my excellent friend, and after-companion, the late Rev. R. T. Lowe. Not to mention the many explorations and encampments which I subsequently enjoyed in Mr. Lowe's company during four successive trips to the archipelago, the last of which occupied the summer of 1855, it was not until January of 1858 that the liberality of John Gray, Esq., gave me the first opportunity of turning my attention to the Canarian fauna.

By a somewhat curious coincidence Mr. Lowe was at that particular time spending the winter in Teneriffe, so that Mr. Gray's yacht was generously placed at our disposal to visit the numerous islands of the widely-scattered Canarian Group; and, although Mr. Gray's sojourn was unexpectedly curtailed, I did not return to England until the following July,-and with the full intention, even then, of making a second expedition so soon as the necessary arrangements could be completed. This, fortunately, did not require long; for I again had a very profitable interval, from February to July of 1859 , in the Canarian archipelago,-joined, as before, by Mr. Lowe.

Seven years now elapsed, during which I was completely taken-up by the working out of the material which had been thus 
lately accumulated; and it was in January of 1866 that Mr. Gray once more offered his yacht for a united trip to the Cape Verdes,-Mr. Lowe, as on the previous occasions, accompanying us. Our stay at the Cape Verdes extended over but a couple of months, added to which the season was unusually dry and unproductive; nevertheless we gained a certain knowledge of the fauna,-sufficient, at any rate, to convince us of its extreme poverty.

I had now an interval of nine years, without anything further to occupy me beyond the gradual elaboration, and occasional readjustment, of the island material,_-according as fresh supplies were transmitted by various naturalists who chanced, from time to time, to visit one portion or another of the Atlantic Groups; but in August of 1875 Mr. Gray again stepped forward with a totally new proposal,-namely, that we should take a a steam into the southern hemisphere and make the acquaintance of St. Helena. Meanwhile our worthy and greatly valued friend, the Rev. R. T. Lowe, had passed to his rest,-a sad accident having overtaken him, on his outward voyage to Madeira, during April of the preceding year; so that we could no longer reap the advantage of his society and experience; nevertheless all that we could do, to supply the deficiency, we did, and were on this occasion joined by Mrs. Wollaston, who had become deeply interested in the Lepidopterous fauna of the islands of the Atlantic. We accordingly made ourselves ready for a last, and thorough, campaign; and, having received, through the kind consideration of the Earl of Carnarvon, special letters to His Excellency the Governor, H. R. Janisch, Esq., and having had quarters allotted to us in the best and most central residence in the island, 'Plantation House,'-a spot from whence the great Cabbage-Tree ridge is the most easily accessible, -we reached the remote little rock on the 4 th of September 1875, and at once commenced our researches. Mr. Gray having decided to move on after a few weeks to the Cape of Good Hope, we remained exactly six months at Plantation; and during that period we were enabled to investigate the Natural History of the island with a fair amount of accuracy.

I have thought it desirable to enter into the above details, 
in order to place on record that the several islands and archipelagos (with the exception of the Azores) which are treated of in this volume have been visited personally by myself. Nevertheless I should hardly have been inclined to undertake so serious a task as the critical examination of the characters and habitats of so many species, had not the bequeathment to me by Mr. Lowe of his extensive conchological collections ( to be distributed to various Museums, though with power to reserve for my own use whatever types I might require) thrown on to my hands a mass of material so unexpected that, in order to do it full justice, I felt that it would be absolutely necessary to treat the whole subject afresh, and to revise (so far as was practicable) every form which has hitherto been published from the islandgroups to which the present memoir has reference.

I will merely add that this Treatise is not intended to be a Monograph, but rather a critical enumeration of all the forms which have been recorded, up to the present date, in the several Atlantic archipelagos; nevertheless in most cases I have given diagnostic remarks which it is hoped will be found useful,-if not in every instance actually to identify the species, at any rate to supplement the published descriptions of them, and to point out more particularly in what they differ from their immediate allies. And since I have the firmest conviction that the question of habitat is even more important (if possible) in a professedly geographical catalogue than elsewhere, I have spared no labour in sifting the evidence for the exact localities (in those instances where $I$ have not been able to vouch for them by personal observation), and have frequently preferred to omit the latter altogether than run the risk of perpetuating confusion by placing upon record what there is every reason to suspect is not strictly accurate. This being the case, I have been less anxious to erect new species than to clear up difficulties concerning the old ones, and have always therefore avoided doing so except in instances where the characters were well defined and it seemed positively essential that the additional forms should not be omitted from the list. Indeed, although the mere titles of a few others have of necessity been altered, the following twenty-nine are the only actual novelties which I have considered it necessary to characterize :- 


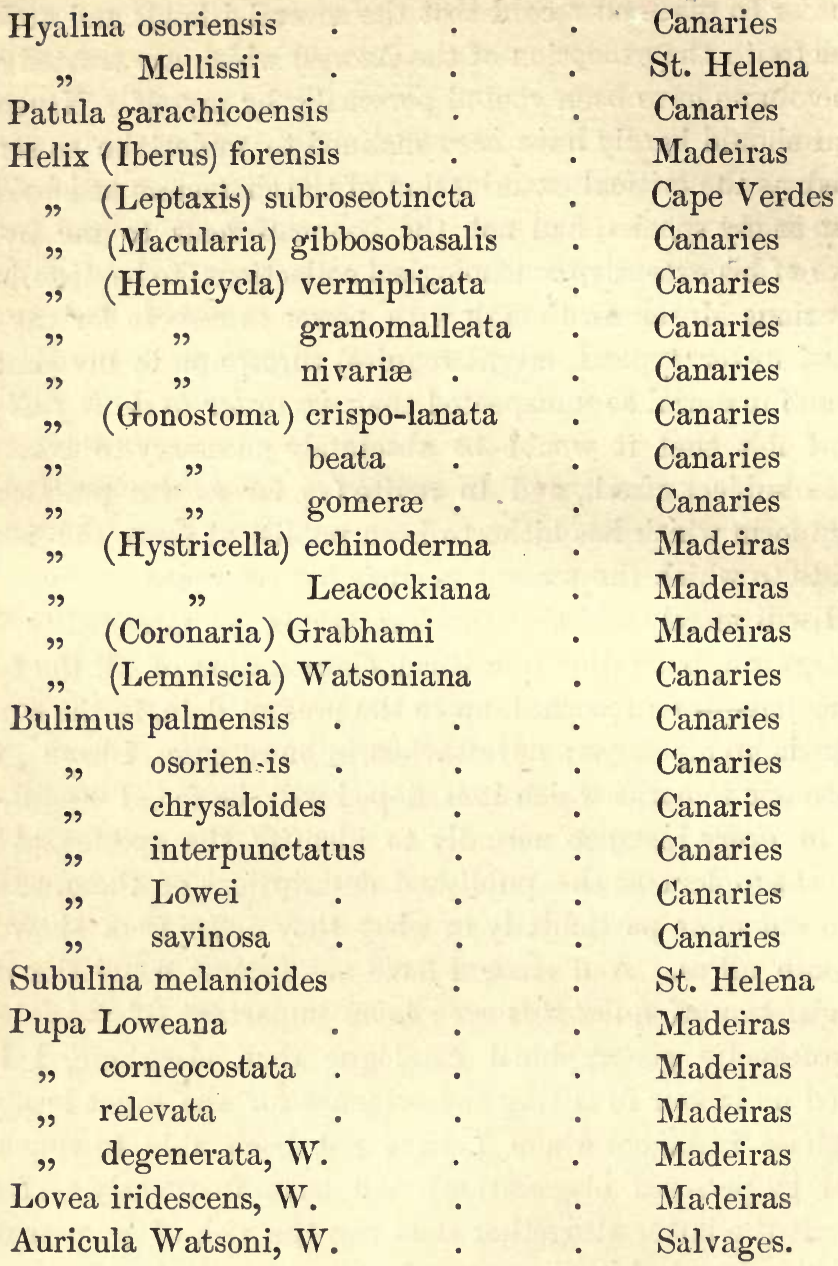

Throughout the various local catalogues (given at the end of each respective section) I have prefixed an asterisk (*) to those species which have been found likewise in a subfossil condition; and when the name is also in italics, it implies that the particular species has hitherto been met with only subfossilized, -in which case, until evidence to the contrary has been adduced, the latter must be regarded practically as extinct.

As a matter of generalization, however, it is only in the Madeiran list that I would place any reliance on the conclu- 
sions to be drawn from the subfossil statistics; for it is in the Madeiran archipelago alone that the Heliciferous deposits (whether calcareous or muddy) have been accurately defined (as regards their extent and character), and systematically investigated; and although it is true that beds of a similar nature exist in the other Groups also, they have not there been pointed out, or localized, with equal precision, and it is to be feared that many of the forms which have been reported, from time to time, by travellers, as 'subfossilized,' were founded upon examples which were merely dead and bleached, and which, in point of fact, were not obtained from any deposits which could ce looked upon as truly subfossiliferous ones. In the Madeiran archipelago, on the contrary, the beds are both well known and rigidly circumscribed, and may therefore be safely reasoned upon in discussing the geological structure of the islands; and, although in reality there may be more of them than those with which we have hitherto become acquainted, it is only from three regions, up to the present date, that the strictly subfossil specimens are recognized,--namely (1) Porto Santo,(2) near Caniçal in Madeira proper, and (3) on the extreme summit of the Southern Deserta. So uniform however is the geological conformation of these various sub-African Groups, that we may feel tolerably confident that the same arguments which apply to the Madeiras will apply with an almost equal amount of truth to the others.

Teignmodti, Oct. 11, 1877. 


\section{CONTENTS.}

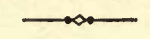

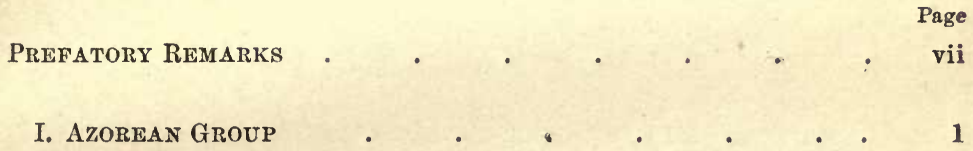

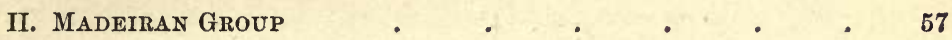

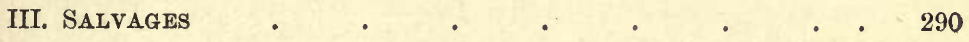

IV. Canarian Group $\quad$ - $\quad$ - $\quad$ - $\quad$ - $\quad$ - 298

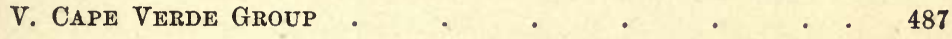

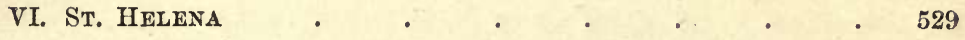

Summary and General Catalogue $\quad$. $\quad$. 561

INDEX : $\quad . \quad \ldots \quad . \quad+\quad 581$ 



\section{TESTACEA ATLANTICA.}

\section{AZOREAN GROUP.}

The islands of the Azorean archipelago are the only ones treated of in this volume with which I have personally no acquaintance; and so desirable do I consider it that some practical knowledge of the principal habitats concerned should be possessed by anybody who undertakes to review critically the natural productions of a given region, that nothing would have induced me to admit the Gastropodous fauna of the Azores into the present catalogue did not the geographical position of the group give it so especial an interest in connection with the Madeiras and the Canaries that I cannot but feel that it is better to waive all scruples with reference to a personal exploration than omit the opportunity of incorporating whatever happens to be known on that branch of our subject which pertains to those particular islands. I shall therefore, with the help of such material as I have been able to examine, rely almost exclusively for my data on the only three works, relating to that archipelago, to which I have access (-the only three, indeed, so far as I am aware, which contain any information which is at all to he depended upon), -namely (1) Notice sur l'Histoire Naturelle des Açores, par A. Morelet, Paris 1860 ; (2) Eléments de la Faune Açoréenne, par H. Drouet, Paris 1861; and (3) a Natural History of the Azores, by Frederick Du Cane Godman, F.L.S., London 1870.

So intimately bound-up are the Azores with the various other islands of (what we may be permitted to designate) this 'Atlantic province,' and so significant is their bearing on the general questions relating to the whole fauna, that we must be thankful for the results of even the comparatively small amount of labour which has hitherto been bestowed upon them. Yet, 
although far less so than either their plants or their Coleoptera (the former of which have been accurately investigated by Dr. Seubert, Mr. H. C. Watson, and others), the Land Mollusca of the archipelago, owing to the observations of Morelet, Drouet, and Godman, have perhaps been better worked-out than the generality of the cdepartments of which, in the aggregate, the Natural History is made up. Yet, judging from the analogy of Ahe southern groupe, it is impossible to believe that the nine islands which compose this widely-scattered assemblage (and which are mapped out, as it were, into three divisions topographically distinct) should possess no more (or even no considerable number more) than the 71 Pulmoniferous Gastropods which have been brought to light, for the most part, by the united exertions of the three independent explorers to whose published volumes I have just called attention. Rather should we suspect that a longer and more careful research, in distant spots and at a high altitude, such as have shown themselves to be so prolific at the Madeiras and Canaries, will sooner or later augment the list to (if not more) at least 100 species.

Perhaps however it will be objected that the Cape Verdes, on the other hand, which include a more extensive area still, and are represented by no less than ten islands, have as yet yielded but 40 Gastropods, and that, moreover, to a larger number of investigators. But to this I would reply, that the cases are not parallel ones: for the unhealthy and povertystricken Cape Verdes have become so deteriorated and dried-up since the destruction of their forests, and after all bave been visited for periods so short and insufficient by each successive adventurer, that the several departments of their Natural History have not stood a fair chance of a proper examination; whereas the Azores, which enjoy one of the dampest atmospheres in the world and are more or less clothed with a rich vegetation (even though seldom aboriginal), present all the conditions except those of soil (which however is much the same in the whole of these Atlantic archipelagos) for the full development of the Terrestrial Mollusks; so that I do not believe that a safe comparison can be instituted, from the data as hitherto ascertained, between the respective faunas of those two particular groups. Far rather should we be content to contrast the Azorean fauna with that of the Madeiras (which already numbers 176 species, well separated from each other), or with that of the Canaries,-which, although less perfectly investigated, has been found to contain (even hitherto) 189 .

When we consider the geographical position of the Azores with reference to Europe, the centre of the group being in much the same latitude as Lisbon, and when we also bear in 
mind the constant intercommunication which is (and long has been) going on between Portugal and the islands, and when we further recollect how eminently liable many of the Terrestrial Mollusks are to accidental transport through indirect human agencies, it is not surprising that we should find a larger European element in the Azorean fauna than what is indicated in the sub-African archipelagos further to the south. Thus, out of the 71 species which have been proved to inhabit the cluster, about 27 (some of which have been established equally in the Madeiras, Canaries, and Cape Verdes) exist on the opposite continent,-leaving 44 extra-European ones, which we may perhaps pause for a few moments to contemplate. Now these 44 members of the Gastropoda are not all of them exclusively Azorean; and it is natural therefore to enquire if they include amongst them anything which is sufficiently characteristic of the (so-called) 'Atlantic province' to tend to affiliate the present group, in any degree whatsoever, with the more southern ones which have yet to be considered. Remembering the marvellous segregation of the extra-European types in the Madeiras and Canaries, the majority of which are confined to their own particular islands and do not permeate even their respective archipelagos, we should $\grave{a}$ priori anticipate that there would be next to nothing in common (when the European element has been removed) between the faunas (whether singly or combined) of those groups and that of the Azores. Yet there are a few points of contact, nevertheless, which seem to me to bespeak a certain unmistakable affinity between them. Thus the Helix erubescens and paupercula and the Patula pusilla, all of them emphatically 'Atlantic,' are represented at the Azores and Madeiras, - the second extending to the Canaries, and third to the Canaries, Cape Verdes, and even St. Helena ; and the Pupa microspora, which is essentially sylvan and unlikely to be introduced by accidental means, crops up likewise in the Azores, the Madeiras, and the Canaries. Then the depauperated phasis of the European Pupa umbilicata, which was separated by Mr. Lowe under the name of $P$. anconostoma (and which I am not aware has been observed on the European continent) is so strictly 'Atlantic " that it ranges from the Azores to St. Helena; and the rather undue development of the Vitrinas and Pupce (the latter under an emphatically Madeiran and Canarian type), as well as of the Leptaxis section of the genus Helix (so suggestive of the Madeiras and Cape Verdes), although under exponents which are themselves distinct, is much in harmony with the idea of this Atlantic 'province' being but portions of a once continnous whole. The appearance, too, at the Azores of that remarkable Cyclostomideous genus Craspedopoma, so 
exceptionally developed in the Madeiran group and which is present also, though more sparingly, at the Canaries, is a fact which should particularly be noticed; as well as the occurrence at the Azores and Canaries of the Bulimus variatus, W. et B., and of that singular little species the Hydrocona gutta,which, of all the members of the Gastropoda, is perhaps the least likely to have been accidentally naturalized. As for the Auriculidoe, which seem to be much the same in the three archipelagos, I lay but little stress upon them,-for those littoral forms, which in their modus vivendi are practically marine, have almost everywhere a wide geographical range.

These few instances, however, of course do not embody all that the archipelagos have in common,-for they are principally 'Atlantic' forms, from which the strictly European element has been eliminated. If we take the actual species into account which the Azores (even as hitherto imperfectly known) would appear to possess conjointly with the more southern groups, we shall find that there are about 26 which occur equally in the Azores and Madeiras, and about 19 in the Azores and Canaries; which (taking the European element for what it is worth) undoubtedly shows an amount of affinity between the three archipelagos which cannot well be ignored. The Rev. H. B. Tristram, in his account of the Pulmoniferous Gastropods of the Azores, published in Mr. Godman's volume, can scarcely have had very reliable data to draw upon in instituting his comparison between the Azorean fauna and those of the two archipelagos the next in succession to the south of it,-for he asserts that it has only 7 species in enmmon with the Madeiras, and 4 with the Canaries; whereas, according to my computation, it possesses (as just stated) at least 26 in common with the Madeiras, and 19 with the Canaries! ${ }^{1}$ Or, if we regard the Madeiras and Canaries as integral portions of a single 'Atlantic province,' no less than 31 species out of the 71 of which the Azorean fauna is made up permeate more or less of the latter, -5 of them ranging even to the Cape Verdes, and 5 to St. Helena. ${ }^{2}$

1 The 26 species which are found equally in the Azores and Madeiras are these:-Arion ater, Limax gagates, maximus, flavus, and agrestis, Testacella Mangei, Hyalina cellaria and crystallina, Patula rotundata and pusilla, Helix pulchella, eruliescens, aspersa, pisana, armillata, paupercula and lenticula, Bulimus ventricosus, Stenogyra decollata, Achatina lubrica, Balea perversa, Pupa microspora and anconostoma, Auricua aqualis and vespertina, and Pedipes afra: whilst the following 19 are those which are common to the Azores and Canaries:-Testacella Maugei, Hyalina cellaria and crystallina, Patula pusilla, Helix pulchella, aspersa, lactea, pisana, apicina, paupercula, and lenticula, Bulimus ventricosus and variatus, Stenogyra decollata, Pupa microspora and anconostomi, auricula aqualis and bicolor, and Hydrocana gutta.

2 Mr. Tristram says, likewise, that 'It should be observed that, of all the Pulmonifera of the Azores, Pedipes afer is the only one common to the 
A good deal has been urged about the 'American affinities' of the Azorean species of Zonites (i. e. Hyalina); but, when we look closer into the matter, it seems to me to be scarcely worth consideration. For, out of the six members of that genus which have hitherto been brought to light, half are ordinary European ones, - namely, the cellaria, crystallina, and fulva (the first and second of which occur likewise at the Madeiras and Canaries, the cellaria ranging even to St. Helena); so that, after all, there are but three remaining, and those bear, confessedly, only a superficial resemblance to certain American forms from which they are specifically quite distinct. Moreover the Hyalinas and Patulas are subject to considerable development in these various Atlantic groups, - the former having at the Canaries 6 extraEuropean exponents (besides 2 European ones), and the latter 11 , all of which are extra-European; whilst even in the Madeiran archipelago there are 1 extra-European and 2 European Hyalinas, and 7 extra-European and 2 European Patulas. Therefore the presence of 3 Hyalinas (extra-European) at the Azores which are primâa facie somewhat suggestive of American ones (though the $H$. atlantica alone appears to me to be worth even mentioning) is hardly a matter, I think, of sufficient geographical significance to warrant a serious discussion on the 'American element' in the fauna.

But as I must reserve any mere speculative observations for the final section of this volume, our present duty being simply to investigate the facts, I will not do more now than refer to Mr. Tristram's remark that 'The class of Gasteropods is by far the most numerous of all the forms of life in the Azores; and among them are found a larger proportion of peculiar species than in any other class,'- for it seems to me that it is a conclusion which is not warranted by what has hitherto been ascertained concerning the Natural History of the islands. For instance, how about the plants? 478 exponents of which (including 40 which are strictly endemic) are registered in Mr. H. C. Watson's latest catalogue; whereas the Land-shells have reached hitherto but 71 species (33 of which, at the utmost, are peculiar). Or, if animal life was meant, and not vegetable, what about the Coleoptera? of which even already 212 representatives have been recorded in Mr. Crotch's carefully prepared list.

Also, in commenting upon the total absence of the freshwater

African continent.' But here, again, I am sorry that I cannot agree with him; for, despite the little that we know (comparatively) of the African fauna, there are certainly 14 of the Azorean species, and probably many more, which abound in Algeria and Morocco:-namely, the Iimax agrestis, Hyalina cellaria and crystallina, Helix aspersa, lactea, pisana, apicina, armillata, and lenticula, Bulimus ventricosus, Stenogyra decollata, Achatina lubrica, Auricula requalis, and Pedipes afra. 
genera in the Azorean archipelago, Mr. Tristram adds : 'There is, however, one singular hiatus in the molluscous fauna. Though there are abundant streams, springs, and lakes, presenting the most favourable conditions for their existence, not a single representative of the Pulmobranchiate Mollusca has yet been discovered. These are to be found in every other portion of the globe. Not an island in the Pacific, not even Greenland and Iceland which are beyond the usual range of the Pulmonifera, are without representatives of this class; yet in the Azores no species of the world-wide genera of Limnoea, Physa, Ancylus, Neritina, Cyclas, or Cyrcena has yet been found.' Now to this, again, I really cannot subscribe ; for, in point of fact, what do we know about ' every other portion of the globe,' and of every 'island in the Pacific'? In all probability we should find plenty of instances in which the aquatic forms are wanting; for, even to come nearer home than the Pacific, the most remote and isolated spot I have hitherto had an opportunity of exploring, namely St. Helena, happens to be in precisely the same predicament as the Azores. There are streams and tanks in the interior of that island, in profusion, trickling rocks, waterfalls, and pools; and yet not a single freshwater species has occurred (beyond a Succinea, which lives as well out of the moisture as in it, and the modus vivendi of which may well be paralleled by that of the Hydroccena gutta at the Azores). And so literally true is this, that the same hiatus is equally observable in the Coleoptera,the Hydradephagous groups of which are altogether absent. Moreover it seems far from unlikely that a similar deficiency may be indicated in the Sandwich Islands; at any rate it appears to be so as regards the water-loving forms of the Coleoptera,-for the Rev. T. Blackburn, writing lately from Honolulu, says (vide ' Ent. Month. Mag.' xiii. 228) 'Notwithstanding the frequent use of the water-net, I have not yet seen a single species of Hydradephaga.'

Perhaps a word or two may be desirable, before I conclude, as regards the various habitats which are cited in the present section. Throughout the other portions of this volume the majority of the localities are added from my own personal observations; and in the generality of the instances where that is not the case, I have had abundant means for testing their accuracy. The Azores, however, are to me a terra incognita; and I have been compelled therefore to rely, almost exclusively, on the passing remarks of MM. Morelet and Drouet. The question consequently arises, where extreme precision is absolutely essential, how far vague and general terms, such as are too often employed with a looseness which is self-evident, can be trusted. Where the actual islands are mentioned by name, it would never occur 
to me to doubt for a single instant the truthfulness of the assertion; but what the exact meaning may be (as Mr. H. C. Watson has pertinently asked) of such expressions as 'all the islands,' ' toutes les îles,' ' tout l'archipel,' \&c., more particularly when usèd by naturalists who confessedly have explored but imperfectly some of the remote detachments of the group, and one of which was not visited by them even at all, is an enigma which I must confess myself totally unable to solve. In my own instance, if out of an archipelago of ten islands a given species had been observed on nine of them, and even if I felt well-nigh certain that it would be met with equally on the tenth, still nothing would induce me to call that species actually 'universal' until the one missing link had been proved to a demonstration. I should undoubtedly express my belief that it would eventually be ascertained to be universal ; but, holding the most perfect accuracy to be a sine quâ non, and knowing by experience how often an organism is non-existent upon an island, or rock, while it absolutely swarms on another which belongs to the same assemblage, I could not risk my reputation by making a positive statement which it is at least possible might turn out ultimately to have been fallacious. Therefore I will not hold myself answerable for the complete truthfulness of the particular idioms, published by others, to which I have just called attention; but in those cases where I have reason to feel dissatisfied with the value of the evidence for these professedly wide habitats, I shall, while indicating (in the local catalogue) the asserted universality by quoting the species under 'all the islands' (as indeed can scarcely be avoided), cite, at the same time, the exact authority, alongside, which must be responsible for the entry.

Although unwilling to make the above remarks, I look upon them nevertheless as neither more nor less than a necessity; for, out of the 176 species which have been ascertained to occur in the Madeiran group, only four (namely the H.erubescens, paupercula, and polymorpha, and the Clausilia deltostoma) have been found as yet to be absolutely universal,-and that too in an archipelago composed of but five islands, and in spite of the most careful researches of many naturalists extending over a period of nearly fifty years; yet, out of the 69 species which were met with by Morelet and Drouet during a single sojourn of five months at the Azores (the $H$. niphas, Pfr., and Bulimus solitarius, Poir., not having been found by them at all, and the $H$. advena, W. et B., being erroneously admitted into the Azorean list), no less than 23, or exactly one-third, are said to inhabit 'tout l'archipel,'-i. e. the whole nine islands which constitute that far more widely scattered cluster. Judging from the analogy of the Madeiras (and the case at the Canaries 
is even stronger still,- -two species only, the $H$. lancerottensis and lenticula, having been ascertained to be positively universal), surely some explanation is required for a fact so unprecedented and remarkable.

If it should be urged however that the smallness of the three Desertas renders it so unlikely that any large number of species would be found upon each one of them separately that the parallel drawn between the 5 Madeiran and the 9 Azorean islands is hardly a just one, I will regard the Desertas as constituting a single detachment of the archipelago. But even in that case the species which have proved hitherto to permeate the entire group (composed of Madeira proper, the Desertas, and Porto Santo) are but 8 in number, out of the 176 ,- which it will be admitted form a striking contrast to the 23 (out of a fauna of only 69) which have been placed on record by Morelet and Drouet as existing on every one of the nine islands of the Azorean cluster.

As in the other local catalogues, I have appended an asterisk $\left({ }^{*}\right)$ to those few species which have been observed also in a subfossilized state; and in those instances where they have been found only subfossilized, under which circumstances they must be looked upon as extinct (at any rate until further evidence shall have proved the contrary), the names have been put likewise in italics.

In accordance with the remark which I have just had occasion to make, the capitals which precede the exceptionally wide habitats given in the Azorean list at the close of the present section indicate the authorities which must be held responsible for their accuracy,-- the letter ' $M$ ' referring to $M$. Morelet, and ' $\mathrm{D}$ ' to M. Drouet.

\section{Sectio I. INOPERCULATA.}

\section{Fam. 1. LIMACID艮.}

Genus 1. ARION, Ferussac.

Arion ater.

Limax ater, Linn., Syst. Nat. (ed. 12) 1081 (1767)

Arion empiricorum, Fer., Tabl. Syst. 17 (1821)

" ater, Lowe, Proc. Zool. Soc. Lond. 162 (1854)

" empiricorum, Alb., Mal. Mad. 11 (1854)

" rufus, Morel., Hist. Nat. des Açor. 137 (1860)

" $\quad$ " Drouet, Faun. Açor. 140 (1861)

" ater, Paiva, Mon. Moll. Mad. 2 (1867) 
Habitat ins. omnes (sec. Morelet et Drouet); sub lapidibus foliisque emortuis, vulgaris.

The Arion ater, Linn. (= rufus, Linn., = empiricorum, Fer.), which is so general throughout Europe and which occurs also at Madeira, appears to have become established in the Azores,-where, according to Morelet and Drouet, it inhabits all the islands of the archipelago.

Although seldom quite black (as its name would imply), the $A$. ater has nevertheless an occasional dark variety, or state. It is more often (indeed in Madeira almost universally) of a dull ochreous- or olivaceous-brown, with the edge of its pedal disk (which is entirely visible from above) of a reddish-yellow inclining to orange and transversely striped with regular but remote dusky lines-which are sometimes very distinct, but at others obscure. As in the Arions generally, this slug has its body totally unkeeled, and furnished at the tip with a mucous pore or gland, its respiratory orifice anterior in position, and its shield (which is even, and not wrinkled - at any rate when the animal is fully extended) closely contiguous to the head in front.

\section{Arion fuscatus.}

Arion fuscatus, Fer., Hist. 65. t. 2, f. 7. .

$$
\text { " fuscus, Drouet, Faun. Açor. } 140 \text { (1861) }
$$

Habitat S. Miguel; juxta Ponta Delgada et Pico do Fogo (sec. Morelet) deprehensus.

A European Arion, which according to Morelet and Drouet occurs sparingly around Ponta Delgada in S. Miguel, and likewise (as stated by the former) on the Pico do Fogo. By Drouet it is identified with the Limax fuscus of Müller, but by Morelet with Ferussac's Arion fuscatus.

\section{Arion subfuscus.}

Limax subfuscus, Drap., Hist. Nat. 125. pl. 9. f. 8 (1805) Arion subfuscus, Morel., Hist. Nat. des Açor. 138 (1860)

$$
\text { " } \quad \text { Drouet, Faun. Açor. } 140 \text { (1861) }
$$

Habitat ins. omnes (testibus Morelet et Drouet); vulgaris in S. Miguel (sec. Drouet).

Likewise a European species, and one which appears to be common at the Azores,-according at any rate to Morelet and Drouet, who state that it occurs on every island of the archipelago. Like the A. fuscatus, it has not yet been observed in the Madeiran group. 


\section{Genus 2. LIMAX, Linné.}

\section{Limax gagates.}

Limax gagates, Drap., Hist. Nat. 122. pl. 9. f. 1, 2 (1805)

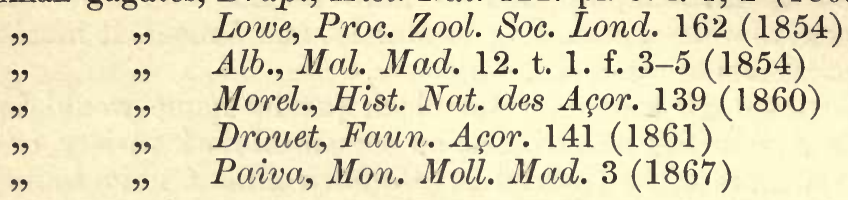
vulgaris..

Habitat ins. omnes (sec. Morelet et Drouet); sub lapidibus

This European slug, which is extremely common in the Madeiran archipelago, and which has become naturalised even at St. Helena, appears to be universal at the Azores according to Morelet and Drouet-who cite it as inhabiting every island of the group.

The strongly carinated, longitudinally sulcate body of the $L$. gagates (the keel of which extends from the extreme end of the tail to the hinder margin of the shield), and its more or less ochreous-black, or sometimes cinereous-brown, hue, added to its not very large size (its greatest length being seldom more than about an inch), and the two rather conspicuous grooves (separated by a raised line) at the top of its neck, will sufficiently distinguish it.

\section{Limax maximus.}

Limax maximus, Linn., Syst. Nat. (ed. 12) 1081 (1767)

". cinereus, Müll., Verm. Hist. ii. 5 (1774)

" antiquorum, var. E., Fer., Tabl. Syst. 20 (1821)

" cinereus, Lowe, Proc. Zool. Soc. Lond. 162 (1854)

" antiquorum, Alb., Mal. Mad. 12. t. 1. f. 2 (1854)

" maximus, Morel., Hist. Nat. des Açor. 138 (1860)

" $\quad$ Drouet, Faun. Açor. 140 (1861)

" cinereus, Paiva, Mon. Moll. Mad. 4 (1867)

Habitat ins. omnés (testibus Morelet et Drouet).

The European $L$. maximus, which has become established at Madeira, appears to have also been naturalised in the Azorean archipelago,-where, like the L. gagates and agrestis and the Arion ater and subfuscus, it is said by Morelet and Drouet to occur on every island of the group.

The $L$. maximus is a species which is extremely variable in size, and a good deal also both in colour and markings; but normally it is more maculated, or blotched, than the generality of the Limaces,-its surface (which is usually of a pale brownishcinereous hue, with the shield a trifle lighter, and with a faint 
ochreous or even lilac tinge) being spotted with large but unequal longitudinal patches of black, - those on the shield however being, most of them, both rounder, smaller, and more isolated or better defined. The blotches on the body seem to be brought about by four or five broken-up longitudinal stripes, which are occasionally subconfluent and suffused, but nearly always more interrupted (or fragmentary) before than posteriorly. It is coarsely sculptured, except on the shield, with a multitude of subconfluent longitudinal grooves or (which amounts to much the same thing) intervening wrinkles; and its hinder part is acutely carinated for about a third of the length from the tip of the tail to the edge of the shield.

\section{Limax flavus.}

Limax flavus, Linn., Syst. Nat. (ed. 12) 1081 (1767)

" variegatus, Drap., Hist. Nat. 127 (1805)

" flavus, Lowe, Proc. Zool. Soc. Lond. 162 (1854)

" variegatus, Alb., Mal. Mad. 12. t. 1. f. 1 (1854)

" " Morel., Hist. Nat. des Açor. 138 (1860)

$" \quad$ " $\quad$ Drouet, Faun. Açor. 140 (1861)

" flavus, Paiva, Mon. Moll. Mad. 4 (1867)

Habitat S. Miguel ; in hortis umbrosis circa Ponta Delegada et Villafranca lectus.

The European L. flavus, Linn. (or variegatus, Drap.) is said by Morelet to occur 'dans les jardins ombragés,' around Ponta Delgada and Villafranca, in S. Miguel,-where, as is the case with it at Madeira, it has doubtless been naturalised. It is a large species, varying from about an inch to nearly two inches in length; and its colour is usually of a pale dirty brownishyellow, but mottled (or coarsely reticulated) with cinereousbrown, - the sides, however, and the foot, being free from markings. Its keel is much abbreviated, extending from the tip of the tail to about a third of the distance to the hinder edge of the shield (the ground-colour of which is often a trifle paler than the rest of the surface, as seen from above).

\section{Limax agrestis.}

Limax agrestis, Linn., Syst. Nat. (ed. 12) 1082 (1767)

\begin{tabular}{|c|c|c|}
\hline & & \\
\hline & $\eta$ & 政 \\
\hline & " & Lowe, Cambr. Phil. S. Trans. iv. 39 \\
\hline & $"$ & Id., Proc. Zool. Soc. Lond. 162 (1854) \\
\hline & " & Morel., Hist. Nat. des Açor. 139 (1860) \\
\hline & " & $\begin{array}{l}\text { Drouet, Faun. Açor. } 141 \text { (1861) } \\
\text { Paiva, Mon. Moll. Mad. } 5 \text { (1867) }\end{array}$ \\
\hline & & \\
\hline
\end{tabular}


Habitat ins. omnes (sec. Morelet et Drouet); vulgaris.

In its comparatively small size, the extremely mucose and variable $L$. agrestis has more in common with the $L$. gagates than with the other slugs which are here enumerated; nevertheless, apart from every minor character, its total freedom from a keel will at once separate it from that species. It is universal throughout Europe; and, according to Morelet and Drouet, it occurs on every island of the Azorean archipelago. Morelet registers a variety from Villafranca in S. Miguel, and another from the valley of the Furnas. In Madeira it is by far the most abundant of all the slugs which have hitherto been brought to light, often swarming in open grassy spots of a high altitude; and considering that it has been placed on record in Mr. Lowe's publications since 1831, it is surprising to me that Morelet should not have been aware that it exists in the Madeiran group,-for, speaking of the four Limaces included in his Azorean catalogue (which are the exact species found at Madeira), he says ' À l'exception du Limax agrestis, toutes les espèces de cette section se retrouvent aux îles Madères.' It is certainly true that Dr. Albers did not happen to meet with it, and so was rash enough to omit it from his exceedingly inaccurate monograph; but Albers passed only a single winter at Madeira, and collected a mere fragment of the species which had been ascertained to occur; whereas Mr. Lowe's researches extended over a period of nearly fifty years, and the results, which had long been made known, were readily accessible. Therefore I cannot understand how any experienced naturalist should have endorsed the evidence given by the former (who had had but a few months' experience in the archipelago), in preference to that of the latter.

\section{Genus 3. VIQUESNELIA, Deshayes.}

\section{Viquesnelia atlantica.}

Viquesnelia atlantica, Morel., Hist. Nat. des Açor. 139. t. 1. f. 1 (1860)

$$
\text { Drouet, Faun. Açor. } 141 \text { (1861) }
$$

Habitat S. Miguel ; juxta Ponta Delgada, Furnas, et eæt., sub lapidibus, præcipue in cultis, parce degens.

This is the most anomalous of the Azorean Limacidor; and its interest is still further increased by the fact that the only other member of the genus which has hitherto been brought to light in a recent state (namely the $V$. Dussumieri, Fischer) is Indian. In a fossil condition, however, the rudimentary remains of a mollusk which would appear to be closely allied to (if not actually identical with) the Azorean one were found abundantly 
in the nummulitic limestone near Feredjik in Roumelia; and it was for the reception of the particular species which they represent that the genus was established by Deshayes (Journ. de Conch. v. 283) in 1859. And shortly afterwards another exponent of the group was met with by M. d'Archiac, in a similar formation, in the Pyrenees. It would seem, therefore, judging from the only evidence to which we have access, as if the type had become extinct on the European continent but that it still lingered at the Azores; though this may in reality be more apparent than real, seeing what large tracts of country both in Spain and Portugal are still practically uninvestigated.

According to Morelet and Drouet, it is only in S. Miguel that the $V$. atlantica has yet been detected, where it occurs sparingly around Ponta Delgada and in the valley of the Furnas,--its movements being described as unusually sluggish and peculiar. The animal is said to be of a somewhat reddish olivaceous-brown, rather attenuated in front, but with its posterior half not only compressed and carinate but very coarsely wrinkled. It seems to be obliquely truncate towards the tip; but whether the subapical angle carries a mucous gland, as its mere outline would lead one to suspect (though the 'dryness' of its surface would perhaps rather militate against that hypothesis), the diagnosis does not specify. Its shield (when the creature is fully expanded) is nearly medial in position,- the hinder half, which covers the internal shell (stated to be somewhat ancyliform and oblong), being elevated and protuberant.

\section{Fam. 2. TESTACELLID压.}

\section{Genus 4. TESTACELLA, Cuvier.}

Testacella Maugei.

Testacella Maugei, Fer., Tabl. Syst. 26 (1821)

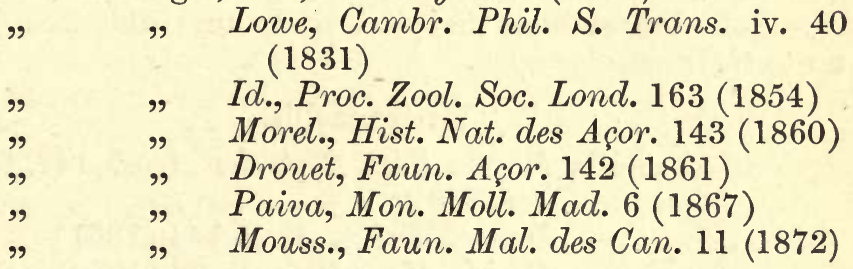

Habitat S. Miguel, Sta. Maria, et Fayal (teste Drouet); præcipue sub lapidibus in cultis.

The European T. Maugei, which is found in the Madeiran and Canarian archipelagos, occurs (according to Drouet) in S. Miguel, Sta. Maria, and Fayal,-principally about gardens and 
other cultivated grounds; but there is no evidence that the nearly-allied $T$. haliotidea has been observed at the Azores.

The rather robust, somewhat ancyliform shell of this Testacella, which is opaque, usually more or less (as it were) eateninto and decorticated, and of a pale dingy olivaceous-yellow externally, but which is whitish, shining, and pearl-like within the enormous aperture, will readily distinguish it. The latter is somewhat parallel-sided and oblong; but the curve at the upper angle of the outer margin is a little interrupted by a slight excavation or sinuosity-which is best seen when the shell is viewed from the direction of the nucleus. The lines of growth, although very irregular, are for the most part exceedingly apparent, - a few deeper and coarser ones than the rest, filledup with a brownish deposit, being also more particularly conspicuous.

\section{Fam. 3. VITRINID庄.}

\section{Genus 5. VITRINA, Drap.}

Vitrina brumalis.

Vitrina brumalis, Morel., Hist. Nat. des Açor. 146. t. 1. f. 4 (1860).

" $\quad$ Drouet, Faun. Açor. 146 (1861)

" $\quad$ Pfeiff., Mon. Hel. vii. 22 (1876) lecta.

Habitat S. Miguel ; in Caldeira de Sete-Cidades præcipue

This Vitrina, which is found in S. Miguel, particularly within the Caldeira of the Sete-Cidades, measures about 9 millimetres across its broadest part; it is excessively thin and fragile, being well-nigh membranaceous; and its spire is remarkably depressed. Its aperture is largely developed; the lower or columellary border of its peristome is exceedingly narrow, and almost wholly membranaceous; and (as in the three following species) its spiral whorls are visible from beneath up to their extreme apex.

\section{Vitrina mollis.}

Vitrina mollis, Morel., Hist. Nat. des Açor. 147. t. 1. f. 5 (1860)

$" \quad$ " $\quad$ Drouet, Faun. Açor. $144(1861)$

Habitat Terceira ; inter Angra et Praya copiose deprehensa.

It is in Terceira that the present Vitrina appears to have been met with, particularly between Angra and the little town of Praya. It is of about the same size as, or perhaps a trifle 
larger than, the last species, and has the spire similarly depressed, and the spiral whorls traceable (from beneath) up to the apex; nevertheless it is more rounded in outline, the basal volution being a little more convex both above and below, its surface is somewhat smoother, and its colour is appreciably deeper or more pronounced. Its aperture, too, is not quite so elongate or produced, and has its columellary border (which is extremely membraneous) less narrowed.

\section{Vitrina brevispira.}

Vitrina brevispira, Morel., Hist. Nat. des Açor. 148, t. 1. f. $6(1860)$

$\Rightarrow \quad$ " $\quad$, Prouet, Faun. Açor. $146(1861)$

Habitat Sta. Maria, et S. Miguel; præcipue, in illâ, ad collum Pico Alto vulgaris.

Judging from the diagnosis and figure, the present Vitrina does not seem to me to differ very materially from the $V$. brumalis; and, although Morelet and Drouet mention it as occurring more particularly in Sta. Maria, it is found also (like that species) in S. Miguel. It is, however, apparently, a trifle smaller, and has its spire a little more minute and lateral, as well as composed of half a volution less. The lower border too of its aperture is, if anything, even narrower and straighter; and its suture is said to be somewhat denticulated.

\section{Vitrina finitima.}

Vitrina finitima, Morel., Hist. Nat. des Açor. 150. t. 1. f. 7 (1860)

$\Rightarrow \quad$ " $\quad$ Drouet, Faun. Açor. $145(1861)$
vulgaris.

Habitat Flores; sub ligno lapidibusque in humiusculis,

In its size and general contour (the shell measuring about 8 millimetres across its broadest part), as well as in the extremely narrow and membraneous lower border of its peristome and the fact of its spiral whorls being visible from beneath up to the extreme apex, the $V$. finitima is very similar to the brevispira; nevertheless, apart from its ultimate volution being just appreciably rounder, it may at once be recognised, both from that species and the others, by the right or upper edge of its peristome being a little thickened and even subreflexed,-a structure which is decidedly anomalous in the members of this genus.

The $V$. finitima was taken abundantly by M. Drouet in 
Flores; but it does not appear to have been observed in any of the other islands.

\section{Vitrina angulosa.}

Vitrina angulosa, Morel., Hist. Nat. des Açor. 191. t. 2. f. 1 (1860)

" $\quad$ " $\quad$ Drouet, Faun. Açor. $144(1861)$

Habitat Sta. Maria; ad basin montis Pico Alto parce reperta.

This is the smallest of the Azorean Vitrinas, measuring only 6 millimetres across its widest part; but, not to mention its diminutive bulk, it may be recognised by its ultimate volution (which is, in proportion, largely developed, and somewhat convex beneath) being appreciably angulose. The colour seems to be of a more brownish-, or even reddish-, green than is usually the case in this genus, and its whorls are about three in number. It was found in Sta. Maria, at the base of the Pico Alto, and would appear to be scarce.

\section{Vitrina laxata.}

Vitrina laxata, Morel., Hist. Nat. des Açor. 144. t. 1. f. 3 (1860)

$" \quad \quad \quad \quad \quad$ Drouet, Faun. Açor. $142(1861)$

Habitat Sta. Maria, et S. Miguel; in convallibus umbrosis præcipue degens.

The $V$. laxata is the largest of the Azorean Vitrinas (measuring about 12 millimetres across its widest part), and one which is said by Morelet to approach nearer than the others to the ordinary European types,--particularly to the $V$. diaphana. It is extremely thin and fragile, with the ultimate whorl very broadly developed or produced, causing the aperture to be exceedingly large or elongated; and, as in the $V$. pelagica, the upper and lower margins of its peristome (the latter of which is bordered by a narrow membrane) are connected across the bodyvolution by an extremely faint lamelliform thickening.

The present Vitrina is found in Sta. Maria and S. Miguel,in the former of which islands a variety is said to occur which is a little more globose and also a trifle less fragile.

\section{Vitrina pelagica.}

Vitrina pelagica, Morel., Hist. Nat. des Açor. 143. t. 1. f. 2 (1860).

$" \quad$ " $\quad$ Drouet, Faun. Açor. $143(1861)$


Habitat Sta. Maria; sub lapidibus, et cæt., versus Pico Alto deprehensa.

The present Vitrina, which is found about the Pico Alto in Santa Maria, is apparently a trifle less fragile, and more Heliciform in its contour, than the other species,-its less largely developed aperture and the widened and somewhat convex base of its ultimate whorl, in conjunction with the margins of its faintly thickened peristome being connected by an extremely thin intervening lamina, recalling somewhat the $V$. Blauneri which is so characteristic of Grand Canary. Its proportions however are not quite the same as those of that species, its spire is less flattened, and the columellary edge of its lower lip is narrowly and shortly expanded and subreflexed,-forming (according to the diagnosis) a kind of very minute umbilical fossette or chink.

\section{Fam. 4. HELICID无.}

Genus 6. HYALINA, Gray.

(§ Radiolus, Woll.)

Hyalina volutella.

Helix volutella, Pfeiff., Proc. Zool. Soc. Lond. 33 (1856) " brumalis, Morel. et Dr., Journ. de Conch. vi. 149 (1857)

Zonites brumalis, Mouss., Viert. der Nat. Zurich, 164 (1858)

Helix volutella, Pfeiff., Mon. Hel. iv. 102 (1859)

" $\quad$ Morel., Hist. Nat. des Açor. 166. t. 3. f. I (1860)

Zonites volutella, Drouet, Faun. Açor. 148 (1861)

Habitat ins. omnes (sec. Morelet et Drouet); sed vix abundans.

A very beautiful little Hyalina which, according to Morelet and Drouet, is found on every island of the Group. It is apparently peculiar to the Azores; and, judging from the diagnosis and figure, it has much the same discoidal outline as the $H$. cellaria, but is considerably smaller and with a more minute (but nevertheless very deep) umbilicus; and its volutions are transversely striped, or radiated, with reddish-brown, or yellowishred, bands. It appears to be subject to slight modifications in the different parts of the archipelago,- - the examples from Fayal and Sta. Maria having their spire more elevated than those from S. Miguel, as well as their striæ more distinct (which latter fact is said to diminish somewhat their brilliancy); whilst those from Graciosa, on the other hand, are not only (when 
adult) less strongly striate, but likewise more solid and of an obscurer surface, being free (according to Drouet) from darker radiating transverse lines.

By Mr. Godman the $H$. volutella was met with in the island of Fayal.

\section{Hyalina miguelina.}

Helix miguelina, Pfeiff., Proc. Zool. Soc. Lond. 33 (1856)

"Vidaliana, Morel. et Drouet, Journ. de Conch. vi. 148 (1857)

Zonites Vidalianus, Mouss., Viert. der Nat. Zurich, 164 (1858)

Helix miguelina, Pfeiff., Mon. Hel. iv. 78 (1859) $" \quad " \quad$ Morel., Hist. Nat. des Açor. 164. t. 2. f. 6 (1860)

Zonites Miguelinus, Drouet, Faun. Açor. 147 (1861)

Habitat Sta. Maria, S. Miguel, et Terceira; sub lapidibus in umbrosis, vulgaris. In Sta. Maria necnon semifossilis invenitur.

Judging from the diagnosis and figure, this Hyalina (which occurs abundantly in Sta. Maria, S. Miguel, and Terceira) seems, in its discoidal contour and widened ultimate whorl, to have much the primâ facie aspect of the $H$. cellaria,-or, perhaps, still more, of the Canarian H. lenis and the immediately allied forms; but it is apparently a little larger with a very much smaller umbilicus, and faintly striped transversely (or radiated) with obscure and irregular (sometimes obsolete) fulvescent lines. According to Morelet and Drouet the specimens from S. Miguel are generally thinner, more brilliant, and more largely developed, than the others; whilst those from Sta. Maria (in which island it is found also subfossilized) are not only smaller, more solid, less shining, and more distinctly striate, but have their last volution rather less dilated; and those from Terceira are a trifle more convex and less narrowly umbilicate.

Mr. Tristram, in alluding to this shell, in his account of the Pulmonifera which had been met with at the Azores by Mr. Godman, ${ }^{1}$ speaks of it as being (like the $H$. atlantica) ' imperforate'; but there can be no doubt that in this respect he was mistaken,-for it is expressly defined by Morelet as 'anguste umbilicata' (Drouet even calling it 'ombiliquée');

' I regret that I am not able to cite Mr. Godman's work amongst my references to the Azorean Gastropods; but as no absolute list is given of the species which he obtained (the chapter by Mr. Tristram containing merely observations on the general catalogue of MM. Morelet and Drouet), it is scarcely possible to allude formally to the volume amongst the absolute synonyms. 
added to which, a decided, though small, perforation is clearly indicated in the figure. And I should very much doubt whether its so-called 'American affinities' are at all more traceable than its Canarian ones.

\section{(§ Lucilla, Lowe.)}

Hyalina cellaria.

Helix cellaria, Müll., Hist. Verm. ii. 28 (1774)

$\begin{array}{lll}" & \quad \text { Lowe, Proc. Zool. Soc. Lond. } 177 \text { (1854) } \\ " \quad & \quad \text { Albers, Mal. Mad. 17 (1854) } \\ & \quad \text { Morel., Hist. Nat. des Açor. } 165 \text { (1860) }\end{array}$

Zonites cellarius, Drouet, Faun. Açor. 149 (1861)

Hyalina cellaria, Mouss., Faun. Mal. des Can. 15 (1872)

Habitat ins. omnes (sec. Morelet et Drouet); vulgaris. In Sta. Maria etiam semifossilis occurrit.

The common European $H$. cellaria is reported by both Morelet and Drouet to occur on every island of the Azorean Group, varying a little in the different parts of the archipelago. The examples from S. Miguel are said to be, on the average, somewhat larger than those from the other islands, those from Sta. Maria (where it exists likewise in a subfossilized state) more solid, and those from Terceira more convex. It is a species of a widely acquired range, it being eminently liable to accidental introduction through indirect human agencies; and it has consequently become thoroughly established in the Madeiras and the Canaries, and even at St. Helena.

\section{(§ Crystallus, Lowe.)}

\section{Hyalina crystallina.}

Helix crystallina, Müll., Verm. Hist. ii. 23 (1774)

" ", Lowe, Cambr. Phil. S. Trans. iv. 47 (1831)

" $\quad$ Albers, Mal. Mad. 17. t. 2. f. 18-21 (1854)

Morel., Hist. Nat. des Açor. 167 (1860)

Zonites crystallinus, Drouet, Faun. Açor. 149 (1861)

Hyalina crystallina, Mouss., Faun. Mal. des Can. 17 (1872)

Habitat ins. omnes (sec. Morelet et Drouet); sub lapidibus, minus frequens.

Said by Morelet and Drouet to be found on all the islands of the archipelago, where it has doubtless become naturalized from the European continent. It is a little species which is eminently liable to accidental transmission, along with consignments of trees and plants; and it has consequently gained a footing both in the Madeiran and Canarian Groups. 
(§ Conulus, Fitz.)

Hyalina fulva.

Helix fulva, Müll., Verm. Hist. ii. 56 (1774)

" $\quad$ " Drap., Hist. Nat. 81. t. 7. f. 12.13 (1805)

Conulus fulvus, Fitzinger, Syst. Verz. 94 (1837)

Helix fulva, Pfeiff., Mon. Hel. i. 30 (1848)

" " Morel., Hist. Nat. des Açor. 169 (1860)

Zonites fulvus, Drouet, Faun. Açor. 150 (1861)

Habitat ins. omnes (sec. Morelet et Drouet); hinc inde sub lapidibus.

According to Morelet and Drouet, the European $H$. fulva, Müll., is found on every island of the Azorean Group; and this is all the more remarkable, inasmuch as it has not hitherto been observed in any of the more southern archipelagos. Considering too its inconspicuousness, one can only conclude, from the fact of its having been detected by those anomalously successful naturalists on nine different islands which are so widely separated from each other, that it must be extremely abundant; yet, curiously enough, they do not give us to understand that this is the case.

(§ Helicella, Beck.)

Hyalina atlantica.

Helix atlantica, Morel. et Dr., Journ. de Conch. vi. 149 (1857)

Zonites atlanticus, Mouss., Viert. der Nat. Zurich, 164 (1858)

Helix atlanticus, Pfeiff., Mon. Hel. iv. 344 (1859)

$" \quad$ " Morel., Hist. Nat. des Açor. 167. t. 3. f. 2 (1860)

Zonites atlanticus, Drouet, Faun. Açor. 149 (1861)

Habitat ins. omnes (teste Godman et Drouet); in Sta. Maria necnon semifossilis occurrit. Sec. Morelet in Sta. Maria, S. Miguel et Fayal invenitur. In Flores, sec. Drouet, ' au milieu des bois de genévriers' copiose vivit.

According to Godman and Drouet, this Hyalina occurs on every island of the Azorean Group; but it is only for Sta. Maria, S. Miguel, and Fayal that Morelet actually refers to it, - though he speaks of it, indefinitely, as ' répandue dans la plupart des îles de l'archipel.'

Drouet, however, mentions expressly' that in Flores ' cette zonite vit en abondance sous les pierres et dans les mousses, au milieu des bois de genévriers."

The complete freedom from an umbilicus is the main point which will at once distinguish the present Hyalina; and in 
that respect it is said to be somewhat on a North-American type,-having, according to Mr. Tristram, a good deal in common with the Helicella suppressa of Say. It is fulvo-corneous in hue, shining, diaphanous, and but feebly striated, but at the same time sufficiently solid in substance; and the columellary border of its peristome is minutely and shortly expanded, or thickened, at the point of its insertion,- - so as to seal-up the spot which is usually occupied by the umbilical perforation.

Both Morelet and Drouet speak of a small variety of this species as occurring in Fayal, and which measures only 5 millimetres (instead of about 9 ) across its broadest part.

\section{Genus 7. PATULA, Held.}

(§ Patula normales.)

\section{Patula rotundata.}

Helix rotundata, Müll., Verm. Hist. ii. 29 (1774)

Patula rotundata, Held, in Isis, 916 (1837)

Zonites rotundatus, Gray, Man. 165, t. 5. f. 44 (1840)

Helix rotundata, Morel., Hist. Nat. des Açor. 174 (1860)

$$
\begin{array}{lll}
" & \quad & \text { Drouet, Faun. Açor. } 156(1861) \\
& \Rightarrow & \text { Paiva, Mon. Moll. Mad.81 (1867) }
\end{array}
$$

Habitat ins. omnes (sec. Drouet); vulgaris, ac late diffusa.

According to Morelet the common European $P$. rotundata 'est extrêmement multipliée aux Açores,' but he does not mention in what particular islands he met with it. Drouet, however, supplies the required information by adding ' Habite tout l'archipel'; though whether that expression (as in other places) is used indefinitely, or whether it means to imply that he has actually taken the species in the whole nine islands of the Group, I have no mean of ascertaining ; and I can therefore only tabulate the range in accordance with the terms in which it is asserted. Morelet speaks of the Azorean examples of this Patula as being slightly different from the ordinary continental ones. 'Elle constitue,' says he, 'dans ces îles, une variété locale, plus convexe que le type, plus fortement striée, et dont les tours de spire sont aussi plus nettement séparés.'

The $P$. rotundata has been introduced within the last few years into Madeira, where however it is extremely rare; but hitherto it has not been observed at the Canaries.

\section{(§ Acanthinulä, Beck.)}

Patula monas.

Helix monas, Morel., Hist. Nat. des Açor. 173. t. 3. f. 5 (1860)

" Drouet, Faun. Açor. 156 (1861) 
Habitat S. Miguel, et Fayal ; in illâ ad Las Furnas, sed in hâc juxta Caldeira reperta.

This extremely diminutive Patula (which is unknown to me except through the excellent figure given by Morelet) appears to recede from the $P$. pusilla, mainly, in being a little less conical (or with the spire more depressed), as well as in being more coarsely costate, and in having a rather wider umbilicus. From the placida, Shuttlew., it is said to differ ' par l'évasement de l'ombilic, et la forme à peu près circulaire de l'ouverture.' It is recorded by Morelet from S. Miguel and Fayal,-namely from the valley of the Furnas in the former, and from the edges of the Caldeira in the latter. Drouet gives only S. Miguel as its habitat,-amongst dead leaves, and under stones, in woods.

\section{Patula pusilla.}

Helix pusilla, Lowe, Cambr. Phil. S. Trans. iv. 46. t. 5. f. 17 (1831)

Pfeiff., Mon. Hel. i. 101 (1848)

" servilis, Shuttl., Bern. Mitth. Diagn.6 (1852)

",$\quad$ Pfeiff., Mon. Hel. iii. 101 (1853)

" pusilla, a. annulata, Lowe, Proc. Zool. Soc. Lond. 176 (1854)

" $\quad$ " $\quad \begin{aligned} & \text { Alb., Mal. Mad. 18. t. 2. f. 7-10 (1854) } \\ & " \quad \text { servilis, Morel., Hist. Nat. des Açor. 173. t. 3. f. } 6\end{aligned}$ (1860)

Drouet, Faun. Açor. 156 (1861)

", hypocrita, Dohrn, Mal. Blätt. 1 (1869)

Patula servilis, Mouss., Faun. Mal. des Can. 25. pl. 2. f. $13-16$ (1872)

Habitat S. Miguel, et Fayal; sub lapidibus in inferioribus (haud procul a mare), sec. Morelet, sed sec. Drouet inter folia emortua in sylvis; rarior.

I have had no opportunity of inspecting Azorean examples of this minute shell; nevertheless if it is rightly referred by Morelet and Drouet to the servilis of Shuttleworth, it is identical with the Madeiran P. pusilla, Lowe,-for there cannot be the slightest doubt whatsoever that Shuttleworth's species and Lowe's are one and the same. Indeed there is hardly a single member of the Atlantic Gastropods which is more widely dispersed than this little Patula; for not only does it occur in the Azorean and Madeiran archipelagos, but likewise at the Canaries and Cape Verdes (from whence it was re-enunciated by Dohrn under the name of $H$. hypocrita), and even in the intermediate districts of St. Helena. Had Morelet been aware (which I am surprised was not the case) that Shuttleworth's 
H. servilis and Lowe's pusilla are conspecific, he would not have fallen into the error of supposing that the species had not yet been observed in the Madeiran Group. But, so far from the latter being the case, it was absolutely first described (in 1831) from Madeira, where it is one of the most abundant of the land-shells.

The $P$. pusilla (assuming Morelet's identification of it to be correct) appears to have been noticed hitherto only near Ponta Delgada in S. Miguel, and in Fayal; in the latter of which islands it is expressly stated by Morelet to have been found in rocky places near the sea. This exactly accords with its usual habitat in the Madeiran archipelago, for it is comparatively seldom that it is to be met with (like the $P$. placida, Shuttl.) in the laurel-woods of a high altitude; nevertheless it does occasionally occur in the latter also, and therefore Drouet's remark that, in Fayal, it exists ' au milieu des feuilles mortes dans les bois de laurièrs et de genévriers' may be likewise applicable,for he would doubtless have at once perceived the difference had the examples to which he alludes been referable to the placida, rather than to the pusilla.

Apart from its diminutive size, the $P$. pusilla (which is a trifle smaller, darker, and more depressed than the placida) may be readily known by a certain number of its oblique, transverse, thread-like striæ being more developed than the rest; for although they are sometimes exceedingly faint, at others they are quite conspicuous and at once distinguishable beneath even an ordinary lens. Morelet's figure, though otherwise good, does not represent this latter character with sufficient precision.

\section{Patula aculeata.}

Helix aculeata, Müll., Verm. Hist. ii. 81 (1774)

$\begin{array}{lll}" & \Rightarrow & \text { Gray, Man. 149. t. 4. f. } 33(1840) \\ " & " & \text { Pfeiff., Mon. Hel. i. 50 (1848) } \\ " & \Rightarrow & \text { Morel., Hist. Nat. des Açor. 175 (1860) } \\ & \text { Drouet, Faun. Açor. 157.(1861) }\end{array}$

Habitat S. Miguel, et Fayal ; in montibus parce lecta.

The European $P$. aculeata is recorded both by Morelet and Drouet from S. Miguel and Fayal, where it appears to occur at a rather high elevation; but it has not hitherto been noticed in any of the more southern archipelagos. According to Drouet it is found in the laurel woods, amongst fallen leaves. 
Genus 8. HELIX, Linné.

(§ Vallonia, Risso.)

Helix pulchella.

Helix pulchella, Müll., Verm. Hist. ii. 30 (1774)

\begin{tabular}{|c|c|c|}
\hline & $"$ & 1831) \\
\hline & " & Alb., Mal. Mad. 45. t. 12. f. 1-4 (1854) \\
\hline & " & Morel., Hist. Nat. des Açor. 175 (1860) \\
\hline & " & Drouet, Faun. Açor. 157 (1861) \\
\hline & , & Mouss., Faun. Mal. des Can. 57 (1872) \\
\hline
\end{tabular}

Habitat ins. omnes (sec. Drouet); sub lapidibus vulgaris.

This common little European Helix - which has established itself in the Madeiras and Canaries, and even at St. Helena, and which is cited also from the Cape of Good Hope-is found, according to Drouet, on every island of the Azorean Group. Morelet indeed does not assert this totidem verbis, but merely states that it occurs in the archipelago; and one can hardly therefore resist the enquiry as to whether the expression 'Habite tout-l'archipel' is used (here as well as elsewhere) merely indefinitely, in order to imply the wide distribution of the species, and its probable occurrence, throughout the cluster, or whether it is to be accepted in its true and literal meaning, and as a positive guarantee that it has been carefully ascertained to exist on each of the nine islands which constitute the entire Group. If the latter fact is intended to be conveyed, MM. Morelet and Drouet deserve unbounded praise for the perfectly incredible proportion of their species which they have succeeded in detecting on all the detachments of an archipelago which is so widely scattered; but if, on the other hand, the term is employed without absolute precision, I cannot too strongly express my belief that loose statements of this kind, which are not strictly in accordance with facts, are neither more nor less than disreputable,-calculated as they are to place on permanent record what is simply and de facto untrue.

\section{(§ Leptaxis, Lowe.)}

Helix vetusta.

Helix vetusta, Morel. et Dr., Journ. de Conch. vi. 152 (1857)

, " Morel., Hist. Nat. des Açor. 176, t. 5. f. 12 (1860)

Drouet, Faun. Açor. 158 (1861)

Habitat Sta. Maria, semifossilis; hactenus recens haud detecta. 
Judging from the diagnosis, and the admirable figure which is given by Morelet, I am inclined to think that the present Helix, which has been found hitherto only in a subfossil condition in the south of Sta. Maria, is perhaps more akin to the likewise subfossilized $H$. chrysomela, Pfeiff. (particularly the larger state of that species, which was subsequently described by Lowe under the name of fuctuosa), than it is to anything else which has yet been brought to light in the various Atlantic archipelagos. Primâ facie it has undoubtedly somewhat in common with certain Canarian members of the Lemniscia section, such as the $H$. tumulorum and phalerata; but in no instances are they wholly imperforate, neither are the margins of their peristome connected by a decided lamelliform callosity; and although this latter character is by no means distinctive of Leptaxis proper, but quite the reverse, it nevertheless is strongly expressed in the $H$. chrysomela-which it is quite impossible to remove from the same actual group which embraces the erubescens and membranacea types. Moreover it appears to be present also in the (equally extinct) $H$. atlantidea, Morel., from the Cape Verdes. The rather straightened and thickened lower lip, too, is much in accordance with what one observes in the Porto-Santan $H$. chrysomela; while its strongly pronounced keel, and what little we are able to trace of its colouring, are marvellously suggestive of that same species.

Whether the $H$. vetusta (which measures about 19 millimetres across its broadest part, and has an altitude of about 11) belongs altogether to a past epoch can hardly be decided, until the numerous submaritime districts of Sta. Maria have been more carefully explored.

\section{Helix erubescens.}

Helix erubescens, Lowe, Cambr. Phil. S. Trans. iv. 40.t. 5. f. 3 (1831)

\begin{tabular}{|c|c|c|}
\hline " & " & $\begin{array}{l}\text { et simia, Pfeif., Mon. Hel. i. } 270 \text { et } 288 \\
(1848)\end{array}$ \\
\hline " & " & Lowe, Proc. Zool. Soc. Lond. 165 (1854) \\
\hline , & , & $\begin{array}{l}\text { Alb., Mal. Mad. } 47 . \text { t. } 12 . \text { f. } 11-16 \\
(1854)\end{array}$ \\
\hline " & " & Morel., Hist. Nat. des Açor. 153 (1860) \\
\hline & , & Drouet, Faun. Açor. 150 (1861) \\
\hline & , & Paiva, Mon. Moll. Mad. 13 (1867) \\
\hline
\end{tabular}

Habitat S. Miguel ; in citranetis, præsertim intra cavernas arborum et sub cortice laxo, sat copiose latitans.

The very beautiful, but inconstant, $H$. erubescens, which is so universal (under various modifications both of contour and 
hue) throughout the Madeiran archipelago, occurs in the orange grounds of S. Miguel,-both around Ponta Delgada, \&c., and even (according to Morelet) in the valley of the Furnas; and considering this singular limitation of its habitat, we may feel tolerably sure that the species is not an aboriginal native of the Azores, but that in all probability it has become naturalized accidentally from Madeira. The fact too that it appears to be confined to a single island of the Group, and that one the most cultivated of them all, is quite in accordance with this supposition. Both Morelet and Drouet lay great stress on the curious fact that it would seem to be attached exclusively to the gardens and plantations where the orange-trees are grown,-concealing itself more especially within the fissures and cavities of the trunks, often in large clusters.

Drouet says that at Madeira the $H$. erubescens is found essentially in woods, but this is absolutely untrue; for although it does occasionally make its appearance in subsylvan spots, as in the chestnut groves of intermediate altitudes, its normal range is most unmistakeably beneath stones on the open mountain slopes (as on the grassy declivities of the Pico da Silva, $\& c$.$) , and within the lichen-covered inequalities of the weather-$ beaten rocks. Indeed on the three Desertas, where it absolutely swarms, there is not so much as a single tree for it to inhabit; and even in Porto Santo, the higher districts (to which it is confined) are, and clearly always have been, totally devoid of wood. ${ }^{1}$

1 Although it is well-nigh superfluous to do so, I may perhaps just notice in this place the H. advena, W. et B.,-which is cited by Morelet, as one of his 69 species, on the strength of its having been recorded by Pfeiffer as occurring not merely at the Cape Verdes [to which it is, nevertheless, absolutely peculiar], but also in the Canaries and Azores. And he even goes on to affirm that Madeira likewise must be added to its range, inasmuch as Albers includes it in his [extremely inaccurate] 'Malacographia Maderensis'; - so that, according to him, 'elle est répandue dans les quatre archipels.' Here then is an accumulation of blunders, both as to habitat and identification, which it is perfectly sad to contemplate. In the first place, the $H$. advena is confined exclusively to the Cape Verdes; the examples which Dr. Albers referred so unhesitatingly to that species, and which he said were found by M. Hartung in Porto Santo, having nothing whatever to do with it. And then, as regards its Canarian claims, I thought it was now generally understood that it was through the excessive carelessness of $\mathrm{Mr}$. Webb that it was ever quoted amongst the Land-Mollusca of that archipelago at all; for, unless I am greatly mistaken, it was communicated originally to the joint authors of the 'Histoire Naturelle,' along with the equally Cape-Verdian Stenogyra subdiaphana, by M. Terver, of Lyons,-whose orchil-infesting Helices (the precise countries of which were guessed at with a recklessness almost unparalleled) have been the means of creating an amount of geographical confusion which perhaps will never be altogether obliterated. This unpardonable mode of treatment was inflicted on other species also, besides those to which I have just called attention,-notably on the $H$. taniata and tiarella of Madeira, which were pronounced to be "Canarian," 


\section{Helix azorica.}

Helix azorica, Alb., Mal. Blätt. 30 (1852)

\begin{tabular}{|c|c|c|}
\hline & " & Pferff., Mon. Hel. 111. 148 (1853) \\
\hline & , & Mouss., Viert. der Nat. Zurich, 165 (1858) \\
\hline & פ & Pfeiff., Mon. Hel. iv. 163 (1859) \\
\hline & " & $\begin{array}{l}\text { Morel., Hist. Nat. des Açor. 154, t. } \\
\text { (1860) }\end{array}$ \\
\hline & , & Drouet, Faun. Açor. $]$ \\
\hline
\end{tabular}

Habitat Sta. Maria, et S. Miguel ; in montibus sub lapidibus, necnon inter ramulos Ericce vulgaris et cæt. latitans, haud infrequens.

The present variable Helix appears to be confined, according to Morelet and Drouet, to the mountains of Sta. Maria and S. Miguel,-where it occurs not only under stones but, in the latter, amongst the shrubs of Erica vulgaris and Myrsine retusa which clothe so much of the uncultivated country in the loftier districts of the island. In the former it was met with on the summit of the Pico Alto.

Judging from their diagnoses and figures, I think there can be little doubt that the present species and the four following ones belong to the same group as the H. erubescens; and, from the analogy of the latter, which at the Madeiras has a more or less different phasis for every detachment of the archipelago, one cannot but feel it possible that some of these forms which cluster around the $H$. azorica may prove in reality to be but insular modifications of a single plastic type. Nevertheless since it is the opinion of Morelet that they may be upheld as specifically distinct, I will cite them in accordance with the conclusions which have been arrived at by himself and $\mathbf{M}$. Drouet.

The $H$. azorica appears to be exceedingly thin and fragile, as well as somewhat shining and pellucid; and, like the other members of this particular section, it is wholly imperforate. Its colour, as in the $H$. erubescens, is eminently inconstant, though the more normal individuals seem to be brownish but mottled with small disjointed (sometimes vermiculiform) markings of a paler or yellowish hue. Occasionally however the latter are obsolete, when the shell is concolorous; and the specimens from Sta. Maria (which are smaller, and a trifle less

and which were received as such (without evidence) by Webb. Indeed the $H$. cyclodon, W. et B., was declared by Terver (in his total ignorance of its actual habitat) to be not only Canarian, but also from the Cape Verdes, the Madeiras, and the Azores, - a statement which was at once accepted by Webb, and even by Pfeiffer; whereas in real fact it has not been detected, as yet, in any of those Groups, except possibly the Canaries (for it is by no means absolutely certain that it was found even there). 
fragile, than those from S. Miguel) are opake, except the nucleus and the base (which are translucid), and of a uniform pallid or nearly straw-coloured hue,-constituting a well-marked variety, the ' $\gamma$. minor' of Morelet. The aperture is a little more rounded in the H. azorica than it is in the cognate forms, and has its columellary margin but very slightly thickened or expanded; and the ultimate volution is rather broader or more developed.

\section{Helix caldeirarum.}

Helix caldeirarum, Morel. et Dr., Journ. de Conch. vi. 150 (1857)

, azorica (pars), Mouss., Viert. der Nat. Zurich, 165 (1858)

" $\quad$ Pfeiff., Mal. Blätt. 81 (1858)
$\Rightarrow \quad$ caldeirarum, Id., Mon. Hel. iv. 347 (1859)
" $\quad \begin{aligned} & \text { Morel., Hist. Nat. des Açor. 156. t. } 2 . \\ & \text { f. } 3(1860)\end{aligned}$
$\quad$ Drouet, Faun. Açor. $152(1861)$

Habitat S. Miguel; sub lapidibus in Caldeira de Sete-Cidades, rarissima.

The $H$. caldeirarum (which measures about 12 millimetres across its widest part), although thin and subdiaphanous, is apparently not quite so fragile and pellucid as the azorica, and it is also more appreciably striate; its surface is of a light uniform corneous-brown, free from paler blotches or irregular markings, but ornamented with a well-defined darker bandwhich occupies the dorsal region, or circumference, of the ultimate whorl, and runs up alongside the suture of the penultimate one; its aperture is not quite so rounded; the columellary margin of its peristome is a trifle thicker or more dilated, and its last volution is rather less broadly developed.

It seems to have been only in S. Miguel that the present Helix has hitherto been observed, where it was met with (though sparingly) by Morelet and Drouet, beneath stones, in the Caldeira of the Sete-Cidades.

\section{Helix niphas.}

Helix niphas, Pfeiff., Proc. Zool. Soc. Lond. 108 (1857)

$\begin{array}{lll}" & \quad & \text { Mouss., Viert. der Nat. Zurich, } 166 \text { (1858) } \\ " & \quad \text { Pfeiff., Mon. Hel. iv. } 159(1859) \\ & \quad & \text { Morel., Hist. Nat. des Açor. 162 (1860) }\end{array}$

Habitat S. Miguel (teste Pfeiffer); ex speciminibus a Dom. Cuming missis descripta. 
The present Helix, which was described by Pfeiffer from examples communicated by the late Mr. Cuming, is said to be from S. Miguel; but it was not met with either by Morelet or Drouet. There can be little doubt that it belongs to much the same type as these immediately allied forms, though its white colour and more solid substance, in conjunction with the fact that its ultimate whorl does not appear (judging from the published diagnosis) to be at all deflected at the aperture, show it to be specifically distinct from them all.

In his observations on the $H$. niphas, Morelet says : ' Il est évident que cette espèce se rattache par des liens étroits au groupe que nous venons d'étudier; ainsi la taille, la forme globuleuse, la spire conique, l'absence d'ombilic, le péristome droit, épaissi au point d'insertion, enfin la direction de la columelle, sont des caractères communs à toutes les coquilles de cette série. Le nombre des tours de spire, leur développement graduel et la simplicité du bord droit, se retrouvent en outre chez l'H. caldeirarum, dont l'espèce de M. Pfeiffer semble se rapprocher d'avantage; mais elle en diffère, ainsi que de toutes les autres, par la solidité, la couleur, et la direction du dernier tour de spire qui ne fléchit pas à sa terminaison.'

\section{Helix terceirana.}

H. caldeirarum (pars), Morel. et Dr., Journ. de Conch. vi. 150 (1857)

"Terceirana, Morel., Hist. Nat. des Açor. 158. t. 2. f. 4 (1860)

" $\quad$ Drouet, Faun. Açor. 152 (1861)

Habitat Terceira ; inter arbusculas Myrsine retusa, necnon sub lapidibus, in Caldeira, copiose lecta.

Apparently very nearly allied to the $H$. caldeirarum, but found in Terceira instead of S. Miguel. It appears to be common in that particular island, where it was found by Morelet and Drouet beneath stones and about the bushes of Myrsine retusa in the great Caldeira.

The $H$. terceirana is more solid, less diaphanous, and more coarsely striated than the caldeirarum (indeed it is said to be sometimes quite free from gloss); its ultimate whorl is rather more flattened beneath; and its peristome is more thickened or bordered internally, and has the columellary margin gradually more flattened or dilated towards its point of insertion. Its colour too is different,-the darker zone of the $H$. caldeirarum being absent, and the surface usually more or less faintly freckled with subopake and slightly paler fragmentary markings. 


\section{Helix Drouetiana.}

Helix Drouetiana, Morel., Hist. Nat. des Açor. 160. t. 2. f. 5 (1860)

Drouet, Faun. Açor. 153 (1861)

Habitat Fayal ; ad orientem montium versus Caldeira ascendentium, sub lapidibus rarissima.

This species appears to be a trifle larger than the three preceding ones, having about the same expanse (13 millimetres) across its broadest part as the $H$. azorica-with which also it agrees somewhat in its general type of colouring, in the fineness of its striation, and in its ultimate whorl being a little widened. It is however more solid and less transparent than the azorica and caldeirarum; its spire is appreciably more acute and prominent; and its peristome is more decidedly thickened within, and has the columellary margin more flattened or expanded. From the $H$. azorica it further differs in its aperture being less rounded, and in its axis being shorter (or less vertically visible) at its point of junction with the lower lip. In ornamentation the $H$. Drouetiana is of a pale yellowish brown, but variegated with more or less evident and irregular transverse radiating lines of a more corneous hue; and there is usually a darker, interrupted, or broken-up zone at the circumference of the basal volution, and which runs alongside the suture of the penultimate one.

The $H$. Drouetiana was met with by M. Drouet in Fayal,towards the east of the mountains which rise so as to form the Caldeira; where, moreover, it would appear to be scarce.

\section{(§ Pomatia, Beck.)}

\section{Helix aspersa.}

Helix aspersa, Müll., Verm. Hist. ii. 59 (1774)

$\begin{array}{lll}" & \quad & \text { Pfeiff., Mon. Hel. i. 241 (1848) } \\ " & \quad & \text { Morel., Hist. Nat. des Açor. 152 (1860) } \\ " & \quad & \text { Drouet, Faun. Açor. 151 (1861) } \\ & \text { Mouss., Faun. Mal. des Can. } 69 \text { (1872) }\end{array}$

Habitat ins. omnes (sec. Morelet et Drouet); in cultis late sed vix copiose diffusa.

According to Morelet and Drouet, the common $H$. aspersa, Müll., occurs on every island of the Azorean archipelago, where doubtless it must have been introduced from the European continent. It is a species which is extremely liable to accidental transmission, along with consignments of trees and plants; and it was in all probability in that manner that it has become thoroughly naturalized at St. Helena. Into Madeira it was imported a 
comparatively few years ago, but I have no evidence that it has succeeded in establishing itself to any appreciable extent; but in Palma of the Canarian Group it has gained a complete footing, and, since it assumes there a slightly local aspect, there is reason to suspect that it may have existed in that island for at all events a considerable period.

\section{(§ Macularia, Alb.)}

\section{Helix lactea.}

Helix lactea, Müll., Verm. Hist. ii. 19 (1774)

\begin{tabular}{|c|c|c|}
\hline צ' & " & $\begin{array}{l}\text { T. et B., Ann. des Sc. Nat. 28. Syn. } \\
\text { (1833) }\end{array}$ \\
\hline & & d'Orb., in W. et B. Hist. ii. 2.55 (1839) \\
\hline & & Morel., Hist. Nat. des Açor. 152 (1860) \\
\hline & & Drouet, Faun. Açor. 150 (1861) \\
\hline & & Can. 70 (1872) \\
\hline
\end{tabular}

Habitat Sta. Maria, et S. Miguel ; in inferioribus, sed haud abundans.

The Mediterranean $H$. lactea, which is found in the Canarian Group, and is very abundant on the coast of Morocco, occurs sparingly around Ponta Delgada in S. Miguel, as well as in a calcareous district in the south of Sta. Maria. Morelet, who remarks that the Azorean examples are very similar to those of Portugal, is of opinion that it has probably been imported into the islands.

\section{(§ Euparypha, Hartm.)}

\section{Helix pisana.}

Helix pisana, Müll., Verm. Hist. ii. 60 (1774)

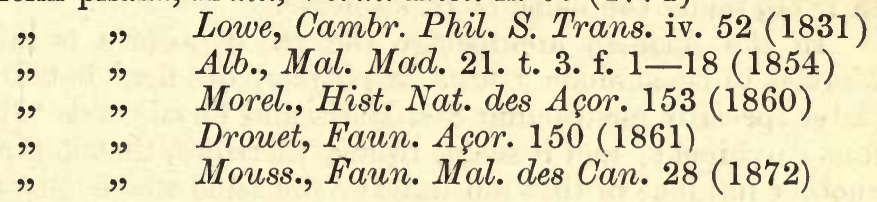

Habitat ins. omnes (sec. Morelet et Drouet); in inferioribus, præcipue cultis, vulgaris.

By both Morelet and Drouet the common European H.pisana is said to occur on every island of the Azorean archipelago,abounding in gardens, and other cultivated spots. It is locally plentiful in the Madeiran and Canarian Groups; and in the latter, as well as on the intermediate isolated rocks of the Salvages, it is developed into several very beautiful and welldefined varieties. Hitherto, however, it has not been observed at the Cape Verdes. 


\section{(§ Xerophila, Held.)}

\section{Helix armillata.}

Helix 'striata, Drap. ?' Lowe, Cambr. Phil. S. Trans. iv. $53(1831)$

" Lowei, Pot. et Mich. (nec Fer. 1835), Gall. des Moll. 91 (1838)

" armillata, Lowe, Ann. Nat. Hist. 113 (1852)

" " Pfeiff., Mon. Hel. iii. 116 (1853)

" $\quad$ "Alb., Mal.Mad. 20. t. 2. f. 32-35 (1854)

" eumæus, Lowe, Proc. Linn. Soc. Lond. ; Zool. 198 (1860)

" armillata, Morel., Hist. Nat. des Açor. 174. t. 3. f. 7 (1860)

, $\quad$ Drouet, Faun. Açor. 155 (1861)

Habitat ins. omnes sec. Drouet, sed ins. fere omnes sec. Morelet; in cultis inferioribus juxta mare, vulgaris. Prope Horta, in ins. Fayal, præcipue abundat.

I cannot feel altogether satisfied that the $H$. armillata, Lowe, should be separated specifically from the smaller and more depressed form of the common European $H$. caperata, (striata, Drap.), which is so often to be met with, commingled. with the larger and typical one, throughout the maritime and submaritime districts of southern Europe ; indeed Mr. Lowe himself regarded it originally as a mere state of that species. At Madeira it is locally abundant; and, according to Morelet, it has been taken lately by MM. Bouvier and de Cessac in S. Vicente of the Cape-Verde Group. It occurs also around Mogador, on the west coast of Morocco,-where it is a trifle more strongly costate-striate, and from whence it was re-described by Lowe, in 1860 , under the name of $H$. eumoeus.

In the Azorean archipelago the $H$. armillata is said by Morelet to be common 'dans la plupart des îles,' but Drouet (after specially mentioning Sta. Maria and Fayal) adds ' Habite tout l'archipel ;' and it seems to me, therefore, that it presents another instance of that sad want of precision which characterizes these vague expressions of universality which we are called upon to believe without the slightest evidence being supplien, to show that they are strictly true. If Drouet really obtained the $H$. armillata on the whole nine islands of the Group, why does he not say so plainly? But, knowing as I do the extreme difficulty of procuring even the commonest forms on every single island' of a widely scattered assemblage, I cannot but feel unbounded surprise that so overwhelming a proportion of the Gastropods of MM. Morelet and Drouet should have been recorded by them as inhabiting ' tout l'archipel.' 


\section{Helix apicina.}

Helix apicina, Lam., Hist. vi. 102, 93 (1822)

Xerophila apicina, Held, in Isis, 913 (1837)

Helix apicina, Morel., Moll. du Port. 63 (1845)

$\begin{array}{lll}" & \Rightarrow & \text { Pfeiff., Mon. Hel. i. } 170(1848) \\ " & \Rightarrow & \text { Morel., Hist. Nat. des Açor. 174 (1860) } \\ " & \Rightarrow & \text { Drouet, Faun. Açor. } 158(1861) \\ & \Rightarrow & \text { Pfeiff., Mon. Hel. vii. } 242(1876)\end{array}$

Habitat Terceira ; forsan ex Europâ introducta.

The European and North-African $H$. apicina, Lam., was found both by Morelet and Drouet in Terceira, 'sur les pelouses au fond de la baie de Praya,'-where it appears to be common; but they did not meet with it in any of the other islands. The only evidence of its occurrence in the more southern archipelagos is embodied in two examples which were taken during the 'Challenger' expedition at Teneriffe.

\section{Helix obruta.}

Helix obruta, Morel., Hist. Nat. des. Açor. 178, t. 5. f. 13 (1860)

" " Drouet, Faun. Açor. 158 (1861)

Habitat Sta. Maria, semifossilis; hodie recens haud inventa.

This rather obscure little Helixe appears to be found subfossilized, in a somewhat calcareous region, towards the southern coast of Sta. Maria; and as it has not been observed hitherto in a recent condition, it may perhaps have become extinct. Still, judging from the analogy of the numerous Madeiran Helices, in a similar predicament, which had long been supposed to have passed away, but which have ultimately been brought to light as members of the present fauna, it would be unsafe to assert this until at any rate the neighbouring districts of the island have been fully and accurately investigated.

Being in an almost colourless state, the characters of the $H$. obruta are not easy to be defined; nor indeed are its affinities very evident, though Morelet compares it with the larger examples of the $H$. armillata. It is, however, less depressed and less angulose than that species, the columellary edge of its peristome is somewhat less expanded, and its umbilicus is narrower. It seems to me to be rather solid, and faintly marked with oblique striæ, measuring about 8 millimetres across its broadest part. 


\section{(§ Spirobula, Lowe.)}

\section{Helix paupercula.}

Helix paupercula, Lowe, Cambr. Phil. S. Trans. iv. 47. t. 5. f. 19 (1831)

\begin{tabular}{|c|c|c|}
\hline & & Pfeiff., Mon. Hel. i. 189 (1848) \\
\hline & "? & Alb., Mal. Mad. 35. t. 8. f. 27-30 (1854) \\
\hline & & Morel., Hist. Nat. des Açor. 175 (1860) \\
\hline פ" & & Drouet, Faun. Açor. 157 (1861) \\
\hline & , & Mal. des Can. 60 (1 \\
\hline
\end{tabular}

Habitat S. Miguel, Fayal, et Pico ; in aridis apricis inferioribus submaratimis, hinc inde ad rupes adhærens necnon sub lapidibus.

The curious little $H$. paupercula, which occurs on the whole five islands of the Madeiran Group (where it is manifestly aboriginal), and which exists likewise (though sparingly) in the eastern part of the Canarian archipelago, has been detected (at the Azores) in S. Miguel, Fayal, and Pico,-where it is found, as in the Madeiras, in dry and rocky places near the coast. Whether it has been naturalized accidentally from the more southern Group, or whether the Azores constitute a portion of its primevally-acquired range, is a problem which it is scarcely possible to solve.

The small size, and flattened, planorbiform outline of this obscurely-coloured, solid little Helix (which has the singular habit of cementing itself over, more or less, with a hardened covering of mud), in conjunction with its whorls being only about four in number, its basal region inflated and convex, its umbilicus large, deep, and spiral, and its aperture (which is a good deal deflexed) powerfully constricted behind, so as to shape out an annular ridge-like prominence, whilst the peristome itself is comparatively thin, well-nigh circular, and elevated, will readily distinguish it. Its average width, across the broadest part, is about $2 \frac{1}{4}$ lines.

\section{(§ Hispidella, Lowe.)}

\section{Helix horripila.}

Helix horripila, Morel. et Dr., Journ. de Conch. vi. 149 (1857)

\begin{tabular}{|c|c|c|}
\hline " & " & Mouss., Viert. der Nat. Zurich, 165 \\
\hline " & " & Pfeiff., Mon. Hel. iv. 303 (1859) \\
\hline " & " & $\begin{array}{l}\text { Morel., Hist. Nat. des Açor. } 170 . \text { t. } \\
\quad \text { (1860) }\end{array}$ \\
\hline "פ & , & Drouet, Faun. Açor. 154 (1861) \\
\hline
\end{tabular}


ITabitat ins. omnes (sec. Morelet et Drouet); præcipue in umbrosis humidis, vel cultis inferioribus vel montosis, vulgaris.

A rather commonplace little Helix which, according to Morelet, and judging from his excellent figure, belongs to much the same type as the $H$. plebeia, hispida, rufescens, sericea, lurida, \&c., though distinct from them all. It is a reddish-brown shell, with a faint yellowish band more or less traceable on the ultimate volution, extremely thin and fragile, and even subdiaphanous. Its surface is densely crowded with minute oblique strix, which are decussated by a few fine but less regular spiral lines (more particularly evident about the dorsal region and the base); and it is conspicuously studded with short erect hairs, which have a tendency to arrange themselves in radiating transverse rows. The peristome is excessively thin and fragile, and has the columellary margin a little reflexed, as well as minutely and triangularly dilated at its insertion so as very slightly to overlap the edge of the umbilicuswhich is, itself, rather small.

According to Morelet and Drouet, the H.horripila is found on every island of the Group; and one cannot but admire the extreme diligence of those two naturalists, who obtained, in one short visit, so overwhelming a proportion of their species on the whole nine detachments of an archipelago which is so remotely scattered as that of the Azores.

\section{(§ Caracollina, Beck.)}

\section{Helix barbula.}

Helix barbula, Charp., in litt.

$\begin{array}{lll}" & \Rightarrow & \text { Rossm., Icon. vii. } 11(1838) \\ " & " & \text { Morel., Moll. du Port. } 57(1845) \\ " & " & \text { Pfeiff., Mon. Hel. i. } 210(1848) \\ " & \text { Morel., Hist. Nat. des Açor. 170 (1860) }\end{array}$

Habitat ins. omnes (sec. Drouet); sub lapidibus, ad muros, et cæt., præcipue in cultis, vulgatissima.

The H. barbula, which is so common in Portugal, is, according to Morelet, ' extrêment multipliée aux Açores ;' and he adds 'se trouve jusque dans les îles lointaines de Flores et Corvo, ce qui fait présumer qu'elle est indigène de l'archipel. On la rencontre au pied des murs, dans les rues même de Horta et de Ponta Delgada.' Drouet, however, cuts the matter shorter by saying ' Habite tout l'archipel ;' and we are therefore bound to accept this statement, until otherwise explained, as a positive guarantee that he has either found it or else ascertained that it occurs in the whole nine islands of the Group. I 
can only hope therefore that this is truly the case, and that in registering it as universal it is strictly in accordance with facts. ${ }^{1}$

\section{Helix lenticula.}

Helix lenticula, Fer., Tabl. Syst. 37, 154 (1821) " subtilis, Lowe, Cambr. Phil. S. Trans. iv. 45. t. 5. f. 13 (1831)

" lenticula, Id., Prod. Zool. Soc. Lond. 196 (1854)

",$\quad$ Alb., Mal. Mad. 43. t. 11. f. 9-12(1854)

" $\quad$ " Morel., Hist. Nat. des Açor. 169 (1860)

" " " Drouet, Faun. Açor. 156 (1861)

$" \quad$ " Mouss., Faun. Mal. des Can. 66 (1872)

Habitat Sta. Maria, S. Miguel, et Pico: sub lapidibus in aridis, rarior.

The South-Furopean H. lenticula, Fer., appears to occur sparingly in Sta. Maria, S. Miguel, and Pico; but it was not observed, by either Morelet or Drouet, in any of the other islands. It seems to be found under stones at the base of walls, as well as anongst the plants of Agave americana (or American Aloe), in dry spots of a low altitude. It is common in the Madeiran and Canarian archipelagos, but less so at the Cape Verdes.

\section{(§ Lemniscia, Lowe.)}

\section{Helix vespertina.}

Helix vespertina, Morel., Hist. Nat. des Açor. 170. t. 3. f. 3 (1860)

, $\quad$ " Drouet, Faun. Açor. 154 (1861)

Habitat Terceira; in montibus juxta craterem magnum Caldeirão dictum parce reperta.

The affinities of this rather insignificant little Helix seem to me to be very dubious; and, unfortunately, Morelet gives us no clue as to its nearest allies. Judging however from his diagnosis and very excellent figure, $I$ am inclined to think that it may perhaps have something in common with the Canarian species (of Lowe's section Lemniscia) around the H. Woodwardia of Tarnier and the comentitia of Shuttleworth; and I would therefore cite it accordingly, though at the same time not without considerable hesitation. It is only in the island of Terceira that it has hitherto been met with, where it was found

1 The H. barbula is well distinguished from the lenticula by (inter alia) its comparatively gigantic size (the larger examples measuring about $5 \frac{1}{2}$ lines across their broadest part), its more numerous volutions, its more strongly costate surface, and by its incrassated peristome, - the columellary and basal margins of which are much more recurved, as well as armed internally with two obtuse, but unequal, tooth-like callosities. 
sparingly on the mountains in the immediate neighbourhood of the great crater known as the Caldeirão.

The $H$. vespertina would seem to be somewhat depressed and lenticular, but with the nucleus nevertheless (as in the $H$. Woodwardia) prominent, very thin in substance, and glabrous, but not shining. It is of a corneous brown, but has a faint paler band immediately below the rather obtuse keel; its whole surface is finely and closely striated; the margins of its peristome are remote, but joined by a very thin lamelliform callus; and its umbilicus is small and shallow, the outer edge being reached (but scarcely overhung) by the very slight columellary dilatation.

\section{Genus 9. BULIMUS, Scopoli.}

\section{Bulimus ventricosus.}

Bulimus ventricosus, Drap., Tabl. de Moll. 68 (1801)

Id., Hist. Nat. 78. t. 4. f. 31-33 (1805)

Helix ventrosa, Fer., Prodr. 377. t. 52 (1807)

Bulimus ventrosus, Lowe, Cambr. Phil. S. Trans. iv. 62 (1831)

" $\quad$ " Alb., Mal. Mad. 54, t. 14. f. 18,19 (1854)

" $\quad$ Morel., Hist. Nat. des Açor.196 (1860)

" $\quad$ Drouet, Faun. Açor. 163 (1861)

Helix ventricosa, Mouss., Faun. Mal. des Can. 46 (1872)

Habitat ins. omnes (sec. Morelet et Drouet); sub lapidibus in aridis, vulgaris.

This Bulimus, which is so widely spread throughout Mediterranean latitudes-occurring in the Madeiran, Canarian, and Cape-Verde archipelagos, as well as on the west coast of Morocco-is found, according to Morelet and Drouet, on every island of the Azorean Group. As elsewhere, it resides principally, beneath stones and about old walls, in dry spots of a low elevation. ${ }^{1}$

\section{Bulimus solitarius.}

Helix solitaria, Poir., Coq. Fluv. et Terr. 85 (1801) ", conoidea, Drap., Tabl. de Moll. 69 (1801)

Theba conoidea, Beck, Ind. Moll. 11 (1837)

Bulimus solitarius, Pfeiff., Mon. Hel. ii. 216 (1848)

" $\quad$ Morel., Hist. Nat. des Açor. 196 (1860)

1 Considering that this common Bulimus was described by Draparnaud, under the name of ventricosus, in 1801, and by Ferussac under that of ventrosus in 1807, it is difficult to understand why so many authors should quote it under the latter title instead of the former. So long as the law of priority is to be recognized, there is a manifest want of consistency in not following it implicitly. 
Habitat Fayal (sec. Dunker); a D. Tams sc. deprehensa.

The Mediterranean B. solitarius (which is well distinguished from the ventricosus by its rather shorter or less produced spire, its more carinated basal whorl, and its larger and more open umbilicus) was not met with at the Azores by either Morelet or Drouet; nevertheless it is stated by Dunker to have been found commonly by Dr. Tams in Fayal.

\section{Bulimus Santa-Marianus.}

Bulimus Sanctæ-Mariæ, Morel. et Dr., Journ. de Conch. vi. 150 (1857)

, Mouss., Viert.der Nat.Zurich, 167 (1858)

" $\quad$ " Pfeiff., Mon. Hel. iv. 474 (1859)

" Santa-Marianus, Morel., Hist. Nat. des Açor. 194. t. 4. f. 6 (1860)

(status junior).

Drouet, Faun. Açor. 163 (1861)

Helix membranacea, Mouss., Viert. der Nat. Zurich, 165 (1858)

Habitat Sta. Maria, et recens et semifossilis; ad montem Pico Alto sub lapidibus detecta.

This is rather a short, broad, and inflated Bulimus, partaking more of the general contour of the $B$. ventricosus than any of the following species; and it is also thin and fragile, semitransparent, of a corneous brown, but usually more or less ornamented with a fascia of darker and paler ray-like, sometimes zigzag markings, - which (although seldom quite obsolete) is occasionally reduced to a narrow line, but which is far more often so wide as to occupy nearly the whole breadth of the penultimate whorl. Its peristome is whitish and very slightly expanded,- the columellary margin however being rather more so, as well as a little dilated (at its point of insertion) over the umbilical chink.

The B. Santa-Marianus, which measures from about 10 to 13 millimetres in length, occurs in Sta. Maria,_especially under stones on the Pico Alto, where it is said to be abundant; and it was met with likewise in a subfossilized condition, in the south of that same island.

\section{Bulimus Hartungi,}

Bulimus Hartungi, Morel. et Dr., Journ. de Conch. vi. 151 (1857) 
Bulimus Hartungi, Pfeiff., Mon. Hel. iv. 503 (1859)

"

99
"

, Morel., Hist. Nat. des Açor. 188. t. 4. f. $2(1860)$

Drouet, Faun. Açor. 162 (1861)

Habitat Sta. Maria, et recens et semifossilis; sub lapidibus in saxosis, parum vulgaris.

The present Bulimus, which is found in Sta. Maria, and which occurs also in a subfossil state on the southern coast of that island, is considerably smaller and less ventricose than the B. Santa-Marianus (it being only about 10 millimetres in length), and it seems to be free from a variegated band or fascia. In point of fact, it is far nearer to the B. vulgaris, of which it might almost be regarded as a small and stunted modification peculiar to Sta. Maria (in which island the typical vulgaris has not yet been observed). Indeed even Morelet admits that occasional 'formes intermédiaires' of the B. Hartungi $i$ are not easy to separate from the vulgaris,-adding, however (which seems to me to involve a petitio principii), ' on ne peut expliquer ici ces déviations du type par l'alliance des deux espèces, car le B. vulgaris ne paraît point exister dans l'île de Sta. Maria.'

The B. Hartungi is described as both 'ruguloso-striata' and 'spiraliter granulata'; and it is said to possess the habit of coating itself over with a hardened envelope of earth,- much as one sees in the Canarian B. Guerreanus, from Hierro, as well as (occasionally) in the darker forms of the B. variatus, W. et B., from Lauzarote, and sometimes even in the badiosus, Fer., of Teneriffe. Its volutions are rather convex, with the sutural line deeply impressed; and the upper and lower margins of its peristome are connected by a thin callus.

\section{Bulimus vulgaris.}

Bulimus vulgaris, Morel. et Dr., Journ. de Conch. vi. 150 (1857)

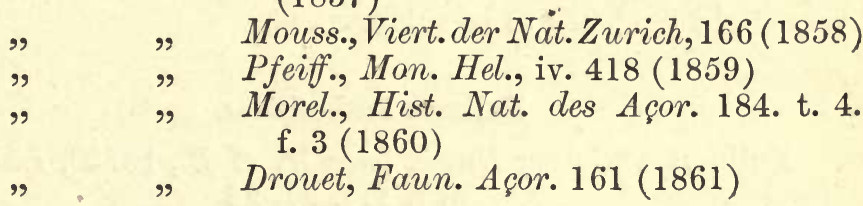

Habitat S. Miguel, et Fayal; inter folia emortua, sub lapidibus, et cæt., sat vulgaris.

A species which appears to be found in S. Miguel and Fayal (in both of which islands it was met with likewise by Mr. Godman), being more particularly abundant in the former,where it occurs beneath stones, under fallen leaves, and at the 
base of the walls. It is compared by Morelet to the common European B. obscurus; but it is a little larger and more ventricose, and its peristome is more obtuse and thickened. It seems to be very variable in stature, its extreme length measuring from about 9 to 11 millimetres.

Morelet calls attention to a shell which exists on the mountains of S. Miguel, in the neighbourhood of the Lagoa do Congro, which is so strictly intermediate between the B. vulgaris and pruninus (the types of which are otherwise altogether dissimilar) that he is quite unable to decide to which of them it should be referred; and he consequently arrives at the conclusion that, in all probability, it is a hybrid between the two species.

\section{Bulimus delibutus.}

Bulimus delibutus, Morel. et Dr., Journ. de Conch. vi. 151 (1857)

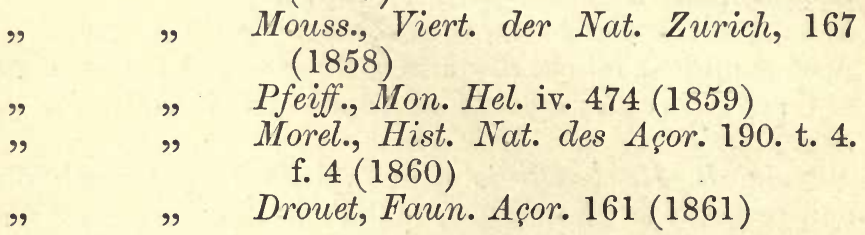

Habitat Terceira, et Fayal; hinc inde in saxosis occurrens.

The B. delibutus, which has been found in Terceira and Fayal, seems to be very near to the vulgaris,-from which it mainly differs in being a trifle slenderer and more shining, and in having its suture obscurely and very narrowly edged with white. It appears also to be more or less lightly marked with spiral undulating lines, sometimes paler and sometimes darker than the ground-colour, but which are apt to become obsolete when the shell happens to be thinner than usual and more transparent. The columellary edge of its peristome is just appreciably wider than is the case in the $B$. vulgaris, and has a very slight tendency to be subrecurved.

\section{Bulimus Forbesianus.}

Bulimus variatus, Dunk. [nec W. et B., 1833], Ind. Moll. 6. t. 1. f. 24,25

Pfeiff., Mon. Hel. iii. 355 (1853)

99 Forbesianus, Morel. et Dr., Journ. de Conch. vi. 151 (1857)

" atlanticus, Mouss., Viert. der Nat. Zurich, 166 (1858)

" $\quad$ Forbesianus, Pfeiff., Mon. Hel. iv. 422 (1859) 
Bulimus Forbesianus, Morel., Hist. Nat. des Açor.192.t.4. f. $5(1860)$

Drouet, Faun. Açor. 161 (1861)

Habitat Terceira, Graciosa, Pico, et Fayal; exemplaribus e Terceira plerumque crassioribus (quare minus translucentibus), ac magis aut etiam omnino concoloribus.

This is apparently larger and more elongated than any of the foregoing species, its average length being about 15 millimetres; and it seems to be somewhat slender and subdiaphanous, rather shining, granulated at the base, and usually marbled or variegated with irregular, more or less confluent and fragmentary, paler lines and spots; though some examples, particularly those from Terceira, are said to be concolorous. There can be little question that it is very closely allied to the $B$. variatus, W. et B. (to which indeed it was originally referred by Pfeiffer); and, considering the extreme inconstancy of that species in the Canarian archipelago, I cannot but feel doubtful whether it ought to be regarded as more than a modification of the latter, and one moreover which is not absolutely similar even in the four islands-Terceira, Graciosa, Pico, and Fayal-on which it is said to occur.

\section{Bulimus variatus.}

Bulimus variatus, W. et B., Ann. des Sc. Nat. 28. Syn. 326 (1833)

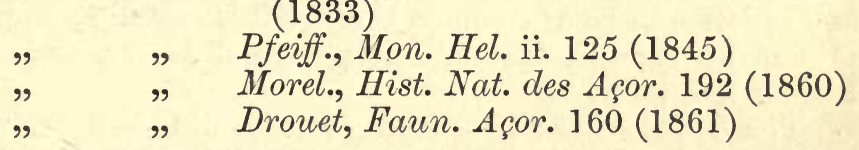

Habitat Sta. Maria, et recens et semifossilis; sub lapidibus haud infrequens.

I have not been able to procure a type from these islands for comparison, but the $B$. variatus, $\mathrm{W}$. et $\mathrm{B}$., which is so widely spread in the Canaries, and which presents so many different modifications for different islands of the Group, is said both by Morelet and Drouet to occur in Sta. Maria; and the latter mentions that it likewise exists in a subfossil state (in company with the Helix vetusta, \&c.) near Praya, on the southern coast. Considering how little in common, as regards their true faunas (i.e. after the manifestly introduced species have been eliminated), the Azorean and Canarian archipelagos have with each other, it is certainly strange that one of the most unmistakeably indigenous members of the latter should be found, both recent and subfossilized, in the former. Judging from Drouet's diagnosis, the examples from the Azores would seem to accord better perhaps with the Teneriffan ones (which represent the 'status 
normalis' of this catalogue) than with those from either Lauzarote or Palma.

\section{Bulimus pruninus.}

Bulimus pruninus, Gould, Proc. Bost. Soc. Nat. Hist. 190 (1846)

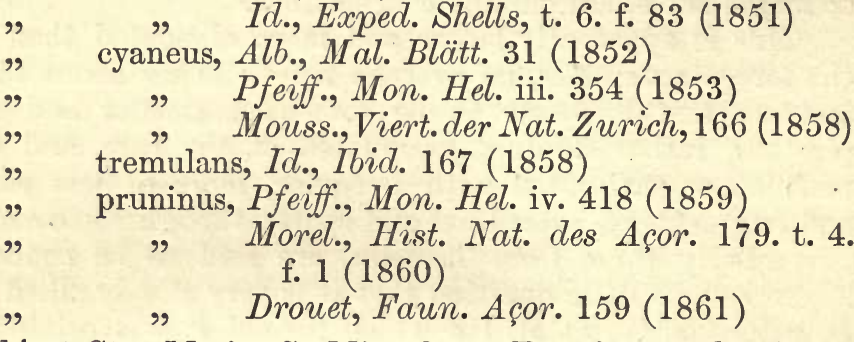

Habitat Sta. Maria, S. Miguel, et Terceira; vulgaris, ac valde inconstans.

This is the largest of the Azorean Bulimi, measuring from about 14 to 18 millimetres in length; and it is, apparently, the most variable shell in the archipelago, - the number of phases, both in colour and sculpture, through which it passes being well-nigh endless. Ten of the more conspicuous of them are alluded to by Morelet, to whose account of the species I must consequently refer. It is in the three eastern islands-Sta. Maria, S. Miguel, and Terceira - that the B.pruninus is found, and it seems to be as common there as it is unstable,-occurring principally beneath stones, amongst dead leaves, and at the bases of the walls.

The $B$. pruninus is a more or less solid shell, and opake, generally roughly striated but sometimes with the striæ obsolete, with the aperture rather angulose at the base, and with the peristome (the upper and lower portions of which are connected by an intervening callus) thickened and (especially towards the columella) expanded. In colour, it is often (except at the apex) blueish or plumbeous, - passing-off however into a yellowish- or corneous-brown, as well as into a rosy-white, and even white; but the blueish or cyaneous tint is often indistinctly traceable in examples in which at first sight it would seem to have totally disappeared.

\section{Genus 10. STENOGYRA, Shuttl.}

\section{Stenogyra decollata.}

Helix decollata, Linn., Syst. Nat. (edit. 10), 773 (1758) Bulimus decollatus, Lowe, Cambr. Phil. S. Trans. iv. 62 (1831) 
Bulimus decollatus, Alb., Mal. Mad. 54, t. 14, f. 16-17 (1854)

Morel., Hist. Nat. des Açor. 196 (1860)

Drouet, Faun. Açor. 163 (1861)
Stenogyra decollata, Mouss., Faun. Mal. des Can. 120 (1872)

Habitat Sta. Maria, et S. Miguel; hinc inde in apricis inferioribus, forsan introducta.

It is only in the islands of Sta. Maria and S. Miguel that the Mediterranean S. decollata has hitherto been observed,-namely, near the fort of San Braz in the former, in company with the $H$. paupercula, and in a somewhat calcareous district of the latter which constitutes the southern base of the Facho. In all probability it has been naturalized in the archipelago.

\section{Genus 11. PUPA, Drap.}

\section{(§ Truncatellina, Lowe.)}

Pupa microspora.

Pupa microspora, Lowe, Ann. Nat. Hist. ix. 275 (1852)

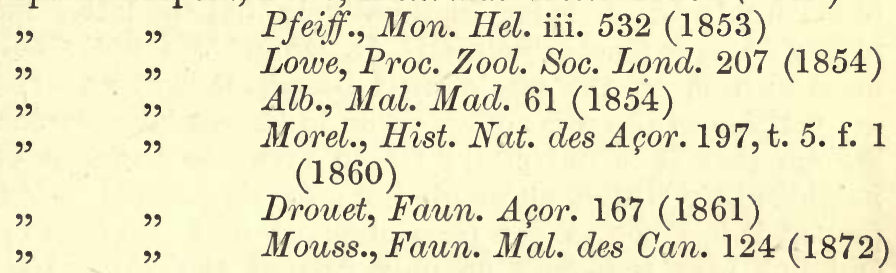

Habitat S. Miguel, Fayal, et Pico; sub foliis dejectis, lapidibus, et inter muscos in umbrosis humidiusculis occurrens.

This fragile, subdiaphanous, conical, edentate little Pupa, which is so abundant, particularly amongst ferns, in the laurelwoods of a high elevation both in Madeira and the Canaries, and which is very nearly allied to the European $P$. edentula, Drap., was found by Morelet and Drouet in S. Miguel, Fayal, and Pico,-in the first and second chiefly in the Caldeiras, and in the third amongst the fallen leaves of the Persea azorica.

\section{(§ Gastrodon, Lowe.)}

\section{Pupa umbilicata.}

Pupa umbilicata, Drap., Tabl. des Moll. 58 (1801)

Helix anconostoma, Lowe, Cambr. Phil. S. Trans. iv. 62.

Pupa t. 5. f. 30 (1831)

Pfeiff., Mon. Hel. ii. 314 (1848) 
Pupa anconostoma, Lowe, Proc. Zool. Soc. Lond. 208 (1854)

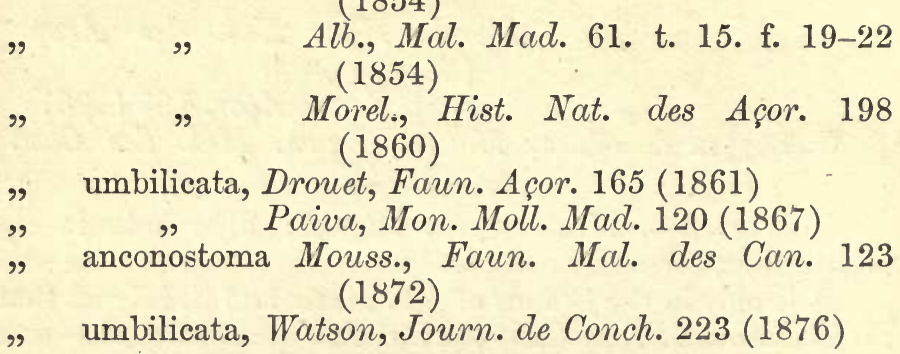

Habitat ins. omnes (sec. Drouet); sub lapidibus necnon ad muros, præsertim in cultis, vulgatissima. In Fayal a Revdo. R. T. Lowe lecta.

The form which this common European Pupa assumes at the Azores appears chiefly to be the rather smaller one, with a less developed ventral plait, to which Mr. Lowe gave the name of anconostoma, and which is so abundant in the Madeiras and Canaries, and which occurs even at St. Helena. Morelet is content to speak of it as 'très commune aux Açores'; but Drouet, less guarded in his mode of expression, adds ' Habite tout l'archipel.' It is far from unlikely that the latter may in reality be true; nevertheless if M. Drouet did not absolutely meet with it on the whole nine islands, it is at least rash (to say nothing of the want of precision in the actual statement) to assume that it is universal; for, to take the instance of the neighbouring Group, although it positively swarms in Madeira proper, it has not as yet been observed in Porto Santo at all, and but very sparingly on only two of the three Desertas. Therefore I cannot but consider it somewhat strange that the nine Azorean islands, which are far more widely separated from each other, should have been ascertained to harbour it both universally and in profusion.

(§ Liostyla, Lowe.)

\section{Pupa fuscidula.}

Pupa fuscidula, Morel., Hist. Nat. des Açor. 202. t. 5. f. 5 (1860)

" Drouet, Faun. Açor. 165 (1861)

Habitat ins. omnes (sec. Morelet et Drouet); sub lapidibus et inter folia emortua degens.

A Pupa which is said by Morelet and Drouet to be found on every island of the Azorean Group ; a range which, judging from the analogy of the allied forms at the Madeiras and the Canaries, 
is certainly a wide one - at any rate for a species which is manifestly aboriginal and which has no appearance of having been naturalized. It is smaller and rather more conical (or less strictly barrel-shaped) than the $P$. tessellata; and its pale corneous surface (which is minutely striated and somewhat shining) is almost entirely darkened or concealed (except beneath, or at the base of the shell) by a fuscous band which more or less covers the whorls. The aperture is relatively a little smaller than in the $P$. tessellata, and not quite so posteriorly-prominent, or downwardly-produced; and it is armed internally with five plaits,-two of which are ventral (the outer one being the larger and more salient, and connected by a corneous sphincter with the angle of the lip), one columellary, and two (which are more immersed or remote) palatial.

Although unmistakeably allied to several Madeiran species of the laurinea and concinna type, I think nevertheless (judging from the diagnosis and figure) that the present Pupa has still more in common with the $P$. castanea of the Canarian archipelago, and (perhaps more particularly) with the $P$. pythiella.

\section{Pupa fasciolata.}

Pupa fasciolata, Morel., Hist. Nat. des Açor. 193. t. 5. f. 2 (1860)

" Drouet, Faun. Açor. 165 (1861)

Habitat ins. omnes (sec. Morelet et Drouet); sub lapidibus et inter folia emortua, una cum specie præcedenti, vulgaris.

Judging from the diagnosis and the very excellent figure which is given by Morelet, this seems to be a more ovate and ventricose little Pupa than the fuscidula, as well as thinner and more pellucid, and less broadly clouded with a dark-brown or castaneous fascia, - the latter (at all events as represented in the plate) being reduced to a somewhat narrower and betterdefined band. Its aperture would appear to have only a single very distinct plica, -namely, in the usual place, on the ventral wall, at a short distance from the angle of the lip; nevertheless there are manifest indications of another, on the columella,which however is deeply immersed, and by no means conspicuous.

The $P$. fasciolata is reported both by Morelet and Drouet as existing on every one of the Azorean islands (' dans toutes les îles de l'archipel'); and it supplies, therefore, another instance of the extreme diligence of those two explorers, - who, during a single visit extending over a period of but five months, succeeded in obtaining no less than one-third of their Gastro- 
podous fauna on the whole nine detachments of a Group which is so widely scattered as that of the Azores. ${ }^{1}$

\section{Pupa tessellata.}

Pupa tesselata, Morel., Hist. Nat. des Açor. t. 5. f. 6 (1860)

" $\quad$ " Drouet, Faun. Açor. 164 (1861)

Habitat Sta. Maria; in sylvis laurorum et Myricoe in montibus copiose degens.

This is the largest of the Azorean Pupoe which have hitherto been detected, and one which has been found only in Sta. Maria, - where it is said to occur abundantly, in the laurel and Myrica woods, on the mountains of the interior. It is very much on the Madeiran type, and seems to me (so far as I can judge from the diagnosis and figure) to have most in common with such species as the P. laurinea and concinna,-with which its somewhat downwardly-produced and trefoil-shaped aperture would still further tend to affiliate it.

The $P$. tessellata is a rather oval or barrel-shaped species, somewhat obtuse at the apex, lightly costulated, and of a fulvescent hue,-but a good deal darkened, or chequered, with irregular, squarish, more or less confluent, castaneous makings; and its aperture has six plaits, - two of which are ventral (the outer one being the larger, and joined by a corneous sphincter to the angle of the lip), two columellary, and two (more internal and less developed) palatial.

\section{(§ Craticula, Lowe.)}

\section{Pupa rugulosa.}

Pupa rugulosa, Morel., Hist. Nat. des Açor. 199. t. 5. f. 3 (1860)

" " Drouet, Faun. Açor. 166 (1861)

Habitat Pico ; in horto quodam versus occidentem insulæ, semel tantum (inter Helicem pauperculam, Lowe) reperta.

The present $P$ upa and the $P$. vermiculosa appear to differ from the other Azorean species here enumerated in being a little more solid and opake, and more distinctly sculptured across the whorls with longitudinal costæ. Indeed, so far as I can judge from the diagnoses and figures, I should say that they are very intimately allied,-the rugulosa, however, being rather the larger of the two, as well as somewhat more oblong

1 And this, I may add, is rendered even still more remarkable when we take into account that at any rate the island of S. Jorge does not appear to have been visited by MM. Morelet and Drouet at all. 
(or less short and ventricose), and with its surface a little more roughened, though its costæ (which are slightly more numerous and regular) are nevertheless not quite so coarse. Its aperture, too, is relatively a trifle smaller, and (according to the diagnosis) is provided with only three plaits,-two of which are ventral (the outer, or larger, one being connected with the angle of the lip by a corneous sphincter), and the third one on the middle of the columella. In the figure, however, there would seem to be indications of a fourth one, on the palate; but this perhaps may be merely accidental.

The $P$. rugulosa is apparently unique,-the single example which served Morelet as a type having been found by Drouet in a garden, in company with the $H$. paupercula, Lowe, on the western coast of Pico.

\section{Pupa vermiculosa.}

Pupa vermiculosa, Morel., Hist. Nat. des Açor. 201. t. 5. f. 4 (1860)

Drouet, Faun. Açor. 166 (1861)

Habitat S. Miguel ; in montibus juxta lacum ad Las Furnas parce lecta.

As already implied, the present $P u p a$ is a trifle smaller and more ovate than the $P$. rugulosa, and its costæ are rather wider apart, - at any rate on the ultimate and penultimate whorls, where they have also a slight tendency to be flexuose or vermiform. Its aperture is said to be armed internally with four plaits (instead of only three); but the fourth one cannot be very conspicuous or well defined, seeing that a different situation is assigned to it by Morelet and Drouet,- - the former citing it as (small and 'punctiform') on the ventral wall, to the left of the usual large and prominent one; whilst Drouet speaks of it as on the 'bord externe' (or palate), in which case (according to him) there is only ' 1 sur la paroi supérieure,' i.e. on the ventral paries. I doubt, therefore, if the aperture can be regarded strictly as more than 3-plicate.

The $P$. vermiculosa was met with in S. Miguel, at the base of the mountains which adjoin the southern border of the lake in the valley of the Furnas.

(§ Staurodon, Lowe.)

Pupa pygmæa.

Pupa pygmæa, Drap., Tabl. d. Moll. 57 (1801)

Vertigo pygmæa, Gray, Man. 201. t. 7. f. 83 (1840)

Pupa pygmæa, Pfeiff., Mon. Hel. ii. 362 (1848)

$" \quad$ " $\quad$ Morel., Hist. Nat. des Açor. $206(1860)$


Habitat S. Miguel ; juxta Ponta Delgada parce deprehensa.

This common and minute European Pupa was found both by Morelet and Drouet in S. Miguel,-where in all probability it must have been introduced accidentally, along perhaps with consignments of shrubs and plants. It would seem to have been found principally near Ponta Delgada, though Morelet alludes to it also as occurring in the Caldeiras.

\section{Genus 12. BALEA, Pridx.}

\section{Balea perversa.}

Turbo perversus, Linn., Fna. Suec. 2172 (1761)

Balea perversa, Pfeiff., Mon. Hel. ii. 387 (1848)

" $\quad$ Lowe, Proc. Zool. Soc. Lond. 215 (1854)

" $\quad$ Alb., Mal. Mad. 69. t. 16. f. 15, 16 (1854)

" nitida, Mouss., Viert. der Nat. Zurich, 168 (1858)

" perversa, Morel., Hist. Nat. des Açor. 206 (1860)

Drouet, Faun. Açor. 167 (1861)

99

Paiva, Mon. Moll. Mad., 140 (1867)

Habitat ins. omnes (sec. Drouet); ad muros, in muscis, et cæt., vulgaris.

Morelet makes no particular mention of the exact range of this common European Gastropod at the Azores, but Drouet adds, more boldly, 'Habite tout l'archipel' ; and we have consequently no option but to accept the latter statement (until at all events it has been otherwise qualified or explained) as literally and dogmatically true. It is therefore interesting to feel assured that the $B$. perversa, which is so nearly absent from the more southern Groups that it has been observed hitherto only on the extreme summit of a basaltic mountain in Porto Santo (where it was detected sparingly by myself), should be absolutely abundant in the whole nine widely-scattered islands which constitute the Azores. Such facts as these are of great geographical importance, and we cannot be too thankful to M. Drouet for having established so conclusively the Azorean universality of this species.

It would appear that the examples of this Bulea from the present archipelago are, on the average, a little more shining than the ordinary continental ones, with their volutions a trifle more tumid, and their aperture (which is just appreciably smaller and rounder) free from a ventral plait; and this circumstance induced Mousson to describe it as new, under the name of $B$. nitida. It is the opinion, however, both of Morelet and Drouet that these distinctions are not permanent ones, - the individuals varying according to the districts in which they are 
found, and some of them having their plait conspicuously developed; so that it is not possible to regard the Azorean specimens as representing more than, at the utmost, a slight geographical variety of the usual type.

\section{Genus 13. ACHATINA, Lamarck.}

(§ Cochlivopa, Fer.)

Achatina lubrica.

Helix lubrica, Müll., Verm. Hist. ii. 104 (1774)

" subcylindrica, Chemn., Syst. Conch. ix. 2. 167. t. 135. f. 1235 (1786)

Achatina lubrica, Pfeiff., Mon. Hel. ii. 272 (1848)

Glandina azorica, Alb., Mal. Blätt. 125 (1852)

Achatina azorica, Pfeiff., Mon. Hel. iii. 54 (1853)

Zua azorica, Mouss., Viert der Nat. Zurich, 167 (1858)

Glandina lubrica, Morel., Hist. Na.t. des Açor. 197 (1860)

„ subcylindrica, Drouet, Faun. Açor. 164 (1861)

Achatina lubrica, Watson, Journ. de Conch. 223 (1876)

Habitat ins. omnes (sec. Drouet), sed Sta. Maria, S. Miguel, et Fayal sec. Morelet; sub lapidibus, et cæt., vulgaris.

According to Morelet and Drouet the Azorean examples of this common European Achatina differ in no respect from the usual ones, and it is therefore utterly inexplicable how Albers could have described them (as he did in 1852) as the exponents of a new species. - It occurs also in the cultivated districts of the Madeiran and (judging from Morelet's list) the Cape-Verde Groups, where there can be little doubt that it must have become accidentally naturalized; but since the Madeiran specimens belong for the most part to the slightly smaller and slenderer phasis of the shell which Mr. Lowe enunciated as the A. maderensis (and which is the one equally alluded to in Dr. Albers' 'Malacographia'), I have not cited the works of either Lowe or Albers amongst the references (as above given) of the species. Nevertheless I might have done so without any real inaccuracy, for there can be little doubt that the rather narrower and depauperated form which was characterised by Mr. Lowe, and which is the almost universal aspect assumed in Madeira, is conspecific with the somewhat larger type.

Morelet speaks of the $C$. lubrica as abundant in Sta. Maria, S. Miguel, and Fayal; but Drouet, as is his wont in so many other similar instances, adds 'Habite tout l'archipel'; though whether that means that he absolutely met with it (or had ascertained positively that it exists) in the whole nine islands, as the expression would inevitably imply, or whether, 
simply, that he thought it must be found upon them all, is a problem which I am altogether unable to solve. At any rate, until cause has been shown to the contrary, we have no choice but to receive his assertion as strictly true.

\section{Fam. 5. AURICULID虑.}

Genus 14. PEDIPES, Adans.

\section{Pedipes afra.}

Le Pietin, Pedipes, Adans., Hist. du Sénég. 11. t. 1. f. 4 (1757)

Helix afra, Gmelin, Syst. Nat. i. 3715 (1790)

Pedipes afra, Lowe, Zool. Journ. v. 296 (1835)

$" \quad$ " Id., Proc. Zool. Soc. Lond. 218 (1854)
$" \quad$ afer, Drouet, Faun. Açor. 169 (1861)
" Paiva, Mon. Moll. Mad. 153 (1867)

Habitat Pico; rupibus maritimis, æstu maris quotidie submersis, adhærens.

The $P$. afra, which is locally abundant along the shores of Madeira, and which occurs likewise at the Salvages, appears to be common on sea-washed rocks in Pico; but it has not hitherto been noticed in any of the other islands of the Azorean archipelago. It is a species of a wide geographical range, and one which seems to be found on many parts of the African coast. Although it has not yet been observed for certain at the Canaries, we may be pretty sure that it must exist equally in that Group.

\section{Genus 15. AURICULA, Lam.}

Auricula æqualis.

Melampus æqualis, Lowe, Zool. Journ. v. 288, t. 13. f. 1-5 (1835)

Auricula æqualis, Id., Proc. Zool. Soc. Lond. 217 (1854)

" Vulcani, Morel., Hist. Nat. des Açor. 207. t. 5. f. 8 (1860)

" $\quad$ " Drouet, Faun. Açor. 167 (1861)

" $\quad$ Mouss., Faun. Mal. des Can. 135 (1872)

" xqualis, Watson, Journ. de Conch. 220 (1876)

Habitat Terceira, et Pico; rupibus saxisque adhærens, in salinis et subsalinis, ad oras rivulorum.

I have mentioned in my account of this Auricula which is given in the section pertaining to the Madeiran Group that I possess the most conclusive evidence that the $A$. Vulcani, of Morelet, described from examples taken in Terceira and Pico, and which is said to occur likewise in Teneriffe, is nothing more 
than a state of the common Madeiran $A$. coqualis, in which the outer lip of the peristome is thickened internally into a central denticle, and in which the impressed spiral lines which are so often traceable (more especially towards the base) in that species happen to be more than usually evident. Judging from an immense series of the $A$. coqualis which I have lately overhauled, composed of nearly two thousand specimens, I find that these particular features on which the $A$. Vulcani was made to rest are liable to be gradually assumed by every phasis of the shell, and moreover to an equal extent, and that consequently they possess no kind of specific significance whatsoever. Indeed I have examples in which they are so rudimentary as to be barely appreciable, and others in which they are more and more expressed until they become comparatively conspicuous; and as for the somewhat 'slenderer' outline of the A. Vulcani, I will merely add that the individuals from the Salvages are almost invariably a trifle narrower and more elongated than those from Madeira, and yet they pass so completely into the ordinary type that it is impossible to regard them as representing more than a very slightly modified local race of the universal Madeiran shell. Whether the strictly normal aspect of the $A$. oxqualis, however, is met with at the Azores, or whether all the examples have the right-hand margin of the aperture thus incrassated, I have no means of deciding. In all probability the examination of a sufficiently long array of specimens would bring to light the existence (as in Madeira) of both varieties.

\section{Auricula gracilis.}

Melampus gracilis, Lowe, Zool. Journ. v. 288 (1835)

Auricula gracilis, Id., Proc. Zool. Soc. Lond. 217 (1854)

" vespertina, Morel., Hist. Nat. des Açor. 210. t. 5. f. 9 (1860)

" $\quad$ " Drouet, Faun. Açor. 169 (1861)

Alexia Loweana, Pfeiff., Mal. Blätt. xiii. 145 (1866)

Paiva, Mon. Moll. Mad. 154 (1867)

Auricula denticulata et Loweana, Wats., Journ. de Conch. 220 (1876).

Habitat Pico; per litora maris, inter rejectamenta, parce (emortua) reperta.

Several examples of this Auricula are stated by Morelet to have been found (dead), amongst rejectamenta, on the sea-shore in Pico; and the excellent figure given by him, accompanied by the equally good diagnosis, leaves no doubt whatever on my mind that his 'A. vespertina' (which is the title under which he describes the species) is identical with the A. gracilis, of 
Lowe, from Madeira. Indeed he himself mentions that he possesses Madeiran examples of the vespertina, differing in no respect from the Azorean ones except that they are a little more purpurascent,-which is one of the most conspicuous features which distinguishes the $A$. gracilis. However, the point, of all others, by which the shell may be recognised consists in the number and relative proportions of the denticles and plaits with which its aperture is furnished,-two (the lower one of which is large and prominent), often increased to three, being on the ventral paries, one on the columella, and from about one to four within the outer lip. Apart however from these primary characters, the $A$. gracilis may be further known by being very much smaller than the aqualis, as well as less ovate (or more strictly fusiform) in outline, and not quite so solid in substance.

\section{Auricula bicolor.}

Auricula bicolor, Morel., Hist. Nat. des Açor. 209, t. 5 . f. 7 (1860)

Alexia bicolor, Mouss., Faun. Mal. des Can. 136 (1872)

Habitat Pico; in salinis subsalinisque ad oras rivulorum, rupibus saxisque adhærens.

A species which has been found in saline and subsaline places in the island of $\mathrm{Pico}$, at those parts of the coast where the rivulets empty themselves into the sea,-so that, like the cognate forms, it appears to live sometimes in salt water and sometimes in fresh. It is identical with an Auricula which was met with abundantly by Mr. Lowe and myself in the north of Lauzarote, in the Canarian archipelago, and which agrees almost precisely with some examples which $I$ have received from Marseilles as the 'A. myosotis, Drap.' ; but since it is possible that the Marseilles shell may have been wrongly identified, I prefer citing the present species under the name which was proposed for it by Morelet.

The A. bicolor is decidedly peculiar in tint, the pale horncoloured surface being more or less conspicuously darkened by a rich purplish bloom, which sometimes quite covers the spire; and its aperture has usually but a single plait (which is large and prominent) on the ventral wall, though there are occasionally indications of a minute tubercle-like second one midway between the former and the insertion of the peristome. Its whorls are a little convex; its extreme nucleus is generally pale, transparent, and tilted; and the entire shell is rather thin and pellucid (for an Auricula),-having at first sight somewhat the appearance of a Limnoea. 


\section{Sectio II. OPERCULATA.}

\section{Fam. 6. CYCLOPHORID $Æ$.}

Genus 16. CRASPEDOPOMA, Pfeiff.

Craspedopoma hespericum.

Cyclostoma hespericum, Morel. et Dr., Journ. de Conch. vi. $152(1857)$

Cyclostomus hespericus, Pfeiff., Mon. Pneum. Suppl. 1. 122 (1858)

Craspedopoma hespericum, Mouss., Viert. des Nat. Zurich, 168 (1858)

Cyclostoma hespericum, Morel., Hist. des Nat. Açor. 212. t. 5, f. $10(1860)$ Drouet, Faun. Açor. 170 (1861)

Habitat Sta. Maria, S. Miguel, Terceira, et Fayal ; in montibus sub foliis emortuis, parum vulgare.

This characteristic little Cyclostomid is quite on the Madeiran type, and is probably more allied to the C. Monizianum of that archipelago than it is to the lucidum. It appears to be smaller than the latter, and less globulose, but with much the same peculiarity of colouring,- namely, a coffee-brown, fadingoff frequently (either wholly or in part) into a yellowish or ochreous tint. Occasionally also it would seem to be somewhat transparent, but it is more often solid and slightly shining.

The $C$. hespericum is recorded by both Morelet and Drouet from the islands of Sta. Maria, S. Miguel, Terceira, and Fayal; where it occurs, beneath fallen leaves, \&c., at a tolerable elevation in the mountains.

\section{Fam. \%. HELICINID正.}

\section{Genus 17. HYDROCENA, Parreyss.}

\section{Hydrocæna gutta.}

Hydrocæna gutta, Shuttl., Bern. Mitth. Syn. 145 (1823)

\begin{tabular}{|c|c|c|}
\hline פי & " & Pfeiff., Mon. Pneum. Suppl. 1. 157 \\
\hline פי & , & $\begin{array}{l}\text { Morel., Hist. Nat. des Açor. 214. t. } 5 . \\
\quad \text { f. } 11(1860)\end{array}$ \\
\hline & & $\begin{array}{l}\text { Drouet, Faun. Açor. } 170 \text { (1861) } \\
\text { Mouss., Faun. Mal. des Can. } 147 \\
\text { (1872) }\end{array}$ \\
\hline
\end{tabular}

Habitat Sta. Maria, S. Miguel, et Fayal; sub foliis emortuis in sylvaticis editioribus occurrens.

Said by Morelet and Drouet to occur in Sta. Maria, S. 
Miguel, and Fayal,-amongst dead leaves in wooded spots of a rather high altitude. In the Canarian archipelago I have taken this very minute shell abundantly, in similar situations, both in Teneriffe and Palma, but always in the dampest places. Indeed it was usually to be met with about the fronds and roots of ferns which were kept in a constant state of douche by the spray of the waterfalls; and I think therefore that Mousson must have fallen into some strange error, in his 'Faune Malacologique des Canaries,' when he states, apparently on the authority of Blauner, that it lives 'sous les pierres dans les lieux arides.' Indeed this modus vivendi is absolutely disproved by his own assertion that it exists in company with the Hyalina Clymene, Shuttl., and the Pupa castanea; for the only spot in which those two species have ever been observed together (indeed the only one in which the former of them has hitherto been found at all) are some trickling rocks, adjoining a small waterfall, between the little town of Garachico and Ycod de los Vinhos, in the north of Teneriffe, - where they are associated likewise with the Ancylus striatus, Q. et G., and the Physa acuta, Drap. I suspect, therefore, that the sylvan localities at the Azores in which the H. gutta is to be met with are, as at the Canaries, at any rate damp ones.

AZOREAN CATALOGUE.

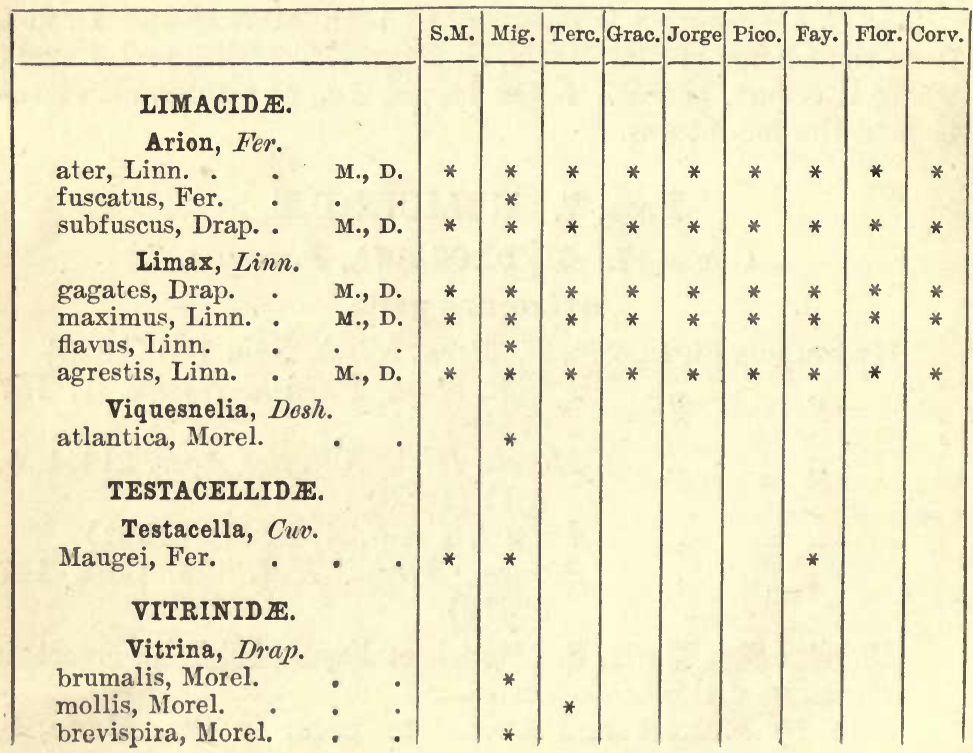


Azorean Catalogue-(continued).

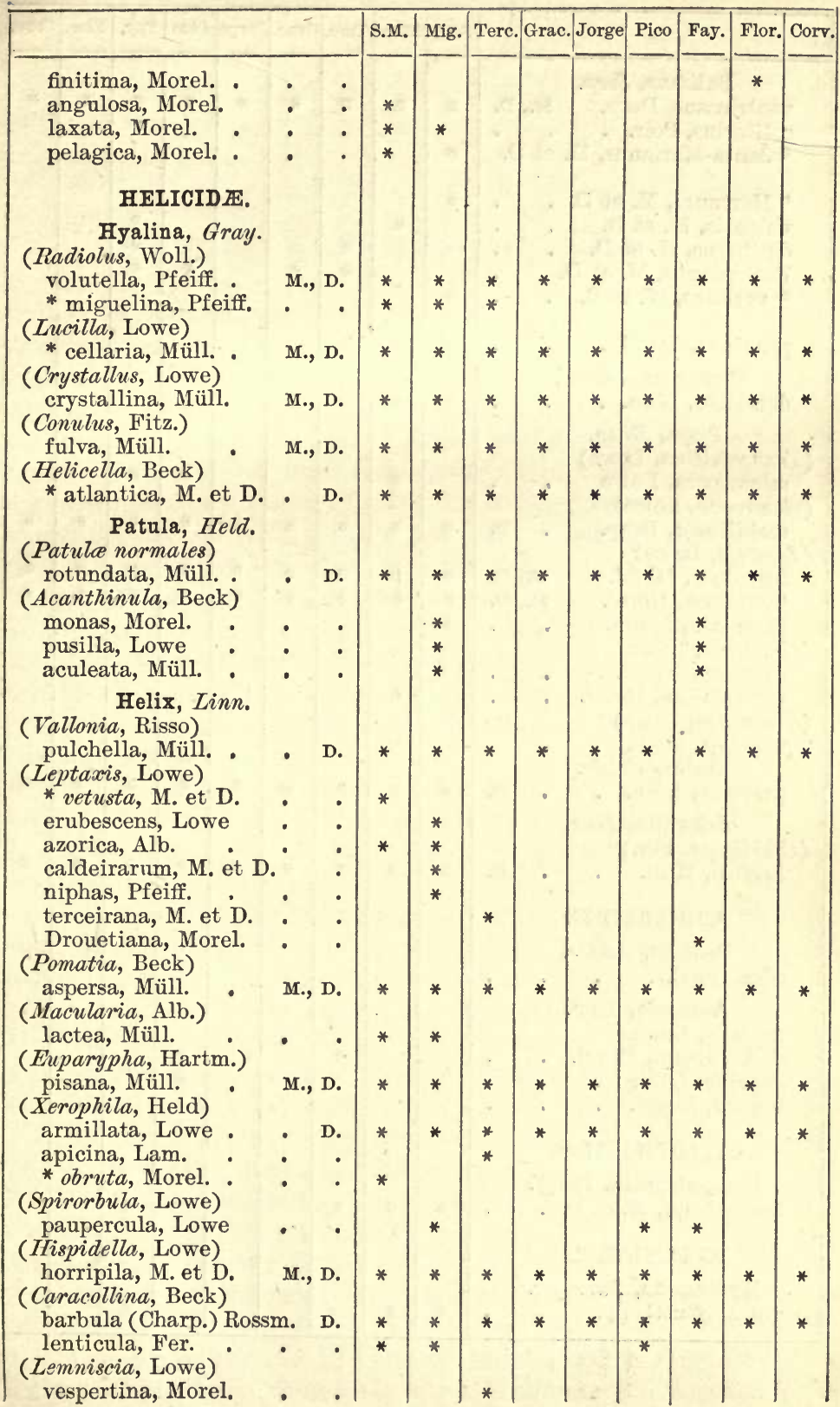


Azorean Catalogue-(continued).

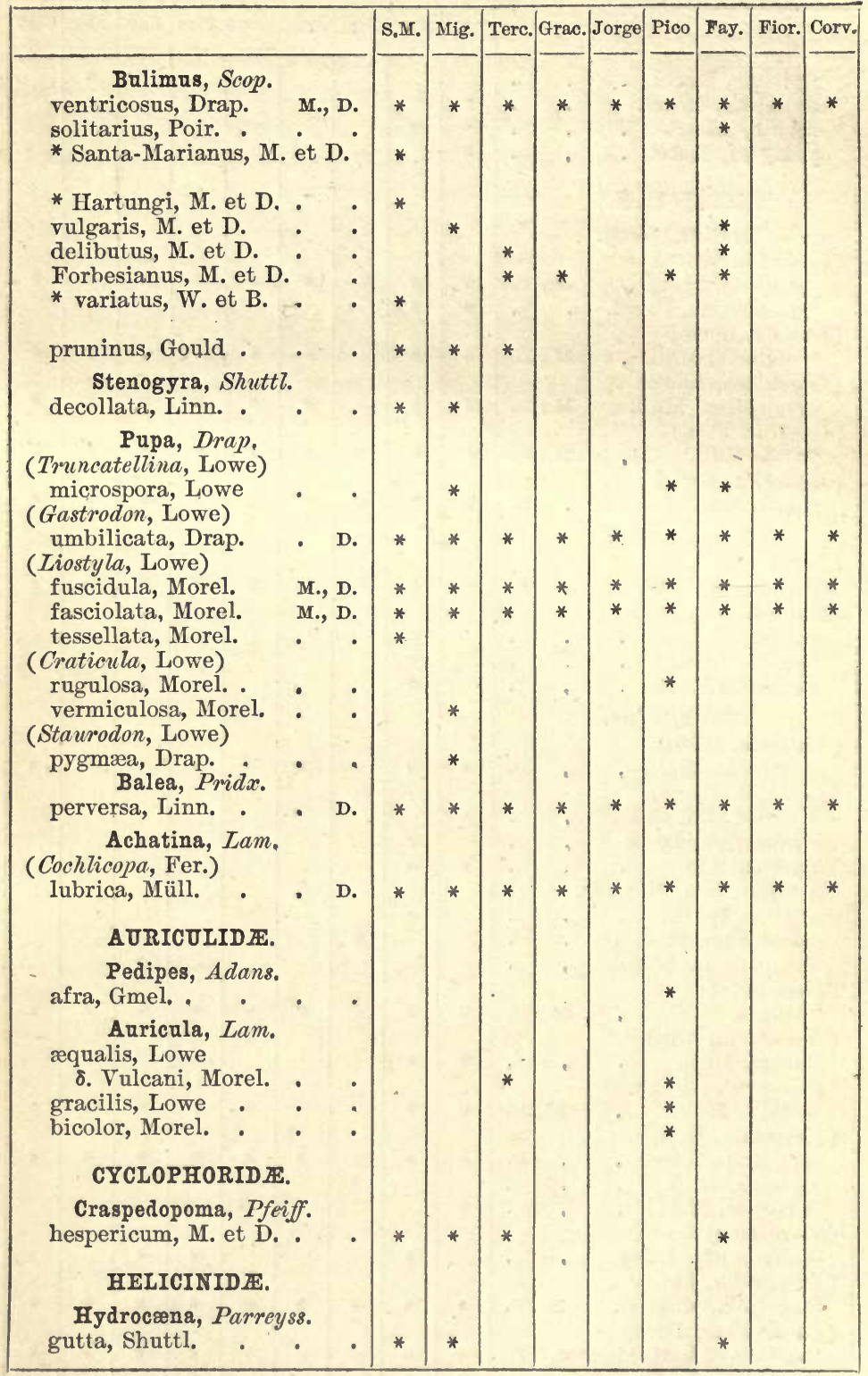




\section{MADEIRAN GROUP.}

OF all the Atlantic Islands, those which constitute the Madeiran Group have been by far the most carefully examined; and I think also that it is not too much to affirm that their species are the most isolated, as regards structure, and peculiar. The observations of the Rev. R. T. Lowe were extended, at intervals, over a period of at least forty years; and they have been well supplemented by those of Mr. Leacock, Senhor J. M. Moniz, the Rev. R. B. Watson, the late Mr. Bewicke, the Barão do Castello de Paiva, Senhor N. Marcial, and others; added to which, the occasional visits to the archipelago of distinguished European naturalists, - such as Dr. Albers, Professor O. Heer, M. Hartung, and Sir Charles Lyell, - have combined to increase our knowledge of the fauna, and to throw additional light on many an obscure problem with which it is connected. My own researches were commenced in 1847 ; and during the thirty years which have since elapsed the Natural History of Madeira, under one or another of its departments, and in connection with that of the more southern clusters, has been well-nigh constantly before me.

In reviewing the Pulmonata of this archipelago (which number, in all, according to my computation, 176 species), the most salient fact which meets us at the outset consists in the marvellous segregation of its several members within areas of the most limited extent. Thus, to take the Terrestrial species only, if we remove the European and North-African ones (represented by the Limaces and Testacelloe, the Hyalina cellaria and crystallina, the Patula rotundata and pygmaea, the Helix pulchella, aspersa, pisana, caperata, armillata, lenticula, and lapicida, the Bulimus ventricosus, the Stenogyra decollata, the Pupa umbilicata, the Balea perversa, the Achatina acicula, and lubrica, and the Lovea folliculus), which in all probability have become accidentally naturalized, and which are no more characteristic of the Madeiras than they are of the Canaries and the Azores; out of the 138 which remain there are absolutely only 7 which have found their way beyond the limits of the 
Group. ${ }^{1}$ And it is highly probable that three of even these seven (namely the Patula pusilla, the Helix erubescens, and the $H$. paupercula) may have been transported from their original centres along with ballast. So that we arrive at the conclusion, that the archipelago, as represented by its extra-European Pulmoniferous Gastropods, is almost wholly independent of those to the north and south of $i t$.

And now, to advance a step further, if we cast an eye down the Madeiran list as given at the close of this section, we shall perceive that, out of the 138 Terrestrial species (extra-European) to which I have just called attention, 61 are peculiar to Madeira proper, 44 to Porto Santo, and 10 to the Desertas,-23 only remaining promiscuous $(i$. $e$. more or less permeating the entire cluster); and of these $23^{2}$ merely five $e^{3}$ have been observed as yet on all the islands. From which we infer, that even within the archipelago itself no great number of its Pulmonata have wandered far from their particular islands, - the areas of an overwhelming majority of them remaining most wonderfully circumscribed.

In making the above remarks I consider it necessary to point out, that the forms on which I have relied are for the most part so distinct from each other that they could scarcely fail to be looked upon, by any careful and experienced naturalist, as otherwise than 'species' (technically so called). Into the abstract questions of derivation and common ancestry I do not now enter,-because all such problems (however ' philosophical') are at the best only speculative, and I hold that no accurate monograph has anything whatever to do with mere speculation. The truth of this becomes at once obvious from the fact, that if a plausible hypothesis were allowed to be made the basis of a treatise like the present one, and the species were to be reduced in consequence to half the number, it would be open to any future naturalist to demand a still further reduction (according to the views which he happened to entertain on the qucsstio

1 These 7 are the minute Patula placida and pusilla (the former of which occurs likewise at the Canaries, and the latter in the Azores, Canaries, Cape Verdes, and St. Helena), the Helix erubescens and paupercula (the former of which is equally Azorean, and the latter Azorean and Canarian), the Pupa microspora and fanalensis (the first of which is found both at the Azores and Canaries, and the second at the Canaries), and the Lovea tornatellina (an example of which was lately detected by Mr. Watson in Grand Canary).

2 The 23 which have found their way into more than a single island are the following:-Vitrina marcida, Patula bifrons and pusilla, Helix erubescens, Bowdichiana, punctulata, vulgata, paupercula, spirorbis, leptosticta, arcta, actinophora, compacta, abjecta, spharula, and polymorpha, Pupa millegrana, Clausilia deltostoma, Achatina eulima, Lovea gracilis, tornatellina, and mitriformis, and Craspedopoma lucidum.

3 Helix emibescens, paupercula, and polymorpha, Clausilia deltostoma, and Lovca mitriformis. 
vexata of ' origin'), - a process which might, and probably would, be again and again repeated until there were no 'species' at all left (as such) either to enumerate or to monograph! Of course, within reasonable limits, every monographer is at liberty, in the first instance, to use his own judgment as to what forms are specific ones and what varietal; indeed he must of necessity do so; but where there is an abundance of material before him, and he possesses a personal knowledge of the principal habitats concerned, he is not likely to make many very serious blunders as regards the value of the characters upon which he has to adjudicate; for where the forms in question cannot be connected by intermediate links (either recent or fossil) and are at once readily separable from their congeners, although he has a perfect right to speculate on their origin in any way (and to any extent) he pleases, he certainly would not be justified in imposing his guesses upon others, or in citing the organisms as otherwise than specifically distinct. In recording what we see, facts and fancies must be kept apart; for if they are permitted to be mixed up unnecessarily in descriptive Natural History, it does not require much foresight to perceive that the result at last will become so shifting and untrustworthy that, sooner or later, they will be mutually destructive of each other. ${ }^{1}$

After what has been said, it will readily be admitted that 'varieties' likewise (properly so called) - i. e. forms which may be connected with their parent types, but which nevertheless have a sufficient permanence about them to be recognisable as modifications, or races, within their respective areas,-no less than species, must have a significant place in a catalogue like the present one. And to return to the subject of segregation, if we take into account the varieties also, we shall find that the same tendency is shadowed forth, and in a manner even more conspicuous still. Thus, for instance, the eminently plastic Helix polymorpha, Lowe, of which I have registered no less than thirteen easily separable (but more or less overlapping) states, may be well-nigh said to possess a slightly different phasis-not only for each of the larger islands (on which there are several of them), but for every minute rock, particularly those around Porto Santo, which has hitherto been landed upon and explored: a fact which bears witness to the same principle of localisation, only in this instance exemplified by 'varieties,' instead of by the

1 Acting upon this principle, I shall reserve until the olosing section of the present volume any mere speculations which I may venture to offer on what will have previously been recorded, and which must be taken for what they are worth,- for they may, or may not, commend themselves to the minds of others. All that we have to do now is to look to our facts, and to use every endeavour to make them strictly accurate. 
more pronounced forms to which the name 'species' must practically be given.

Marvellous however as is the segregation of the various forms in the Madeiran Group which are truly indigenous, - - only about seven actual species (apart from the littoral, subsaline ones, which in their modes of life are practically marine) having apparently been either transmitted to or received from the neighbouring archipelagos, and only about five having been observed as yet on all the islands of the cluster, - I would by no means wish to insinuate that a certain unmistakeable relationship is not plainly indicated between some of the members of certain well-marked types which permeate more or less" of the entire 'province' Thus, for instance, the Helicideous section Leptaxis, which is so characteristic of the Madeiras, may be said, although totally absent from the Canaries, to be the dominant one both in the Azores and Cape Verdes; the section Discula, which is so abundant and universal at the Madeiras, but which is non-existent at the Azores, puts in an appearance (even though, in comparison, feebly) at the Canaries; the Vitrinas and Pupoe are largely developed, and under somewhat analogous modifications, in the three northern Groups; the Bulimi, although totally unrepresented (except under a couple of exponents which have manifestly been introduced) at the Madeiras, are expressed to a monstrous extent both at the Azores and the Canaries; the genus Lovea (allied to Achatina, and lately enunciated by Mr. Watson) reigns supreme in the Madeiran and Canarian archipelagos, but is wanting at the Azores and Cape Verdes; the Cyclostomideous Craspedopoma, which attains its maximum in Madeira, extends into both the Azorean and Canarian Groups; and the minute Hydocoena gutta crops up at the Azores and Canaries, but is absent from Madeira. From which it will be seen, without adducing further instances, that many of the most distinctive types range over more or less of these immediate archipelagos,-being sometimes absent from one of them and sometimes from another, but combining as a whole to give a certain amount of unity to what we may be permitted to call this 'Atlantic region.'

In the preceding remarks I have endeavoured to show that in the actual species of which its fauna is composed the Madeiran Group is almost wholly independent of the others which are to the north and south of it, but at the same time that a consiable proportion of characteristic types which permeate to a greater or less extent the whole of the archipelagos impart nevertheless a certain individuality to the entire province which cannot well be ignored. This general connection of the clusters, 
however (manifest though it be), is immeasurably overbalanced by a consideration of how radically the respective faunas do in reality differ from each other in the vast majority of their absolute details. Thus, to take the Madeiras, which more particularly concern us in this section, the most distinctive forms are peculiar to the Group, not only as regards the species but even as regards the very types. Look, for example, at the section Coronaria, of the genus Helix, and Hystricella, - both of which stand isolated, and apart, as pre-eminently Madeiran; or the little assemblages to which Mr. Lowe applied the names of Placentula, Actinella, Rimula, and Caseolus. Or, to instance the larger modifications, there is the Tectula department, as well as Helicomela, Katostoma, and Cryptaxis,-all of which are restricted to the archipelago. And, apart from the true Helices, facts are not wanting which would likewise tend to separate, as it were, the Madeiras, at any rate to a considerable extent, from the other islands. Thus, the genus Clausilia is not only well expressed there but literally universal ; yet it is without so much as a member at the Azores, Canaries, and Cape Verdes; and the true Cyclostomas, which are so greatly developed at the Canaries, have in the Madeiras no single representative. This latter circumstance however is quite in harmony with the Helicideous section Hemicycla,-which is altogether unknown at Madeira, but which numbers 37 exponents (indeed probably more) in the neighbouring Canarian Group.

As I have already mentioned in the prefatory remarks to this volume, there are certain spots, and even small districts, scattered here and there throughout these several Atlantic archipelagos, which may be defined as essentially subfossiliferous ones. They are either calcareous (partaking sometimes of the nature of sand-dunes), under which circumstances the specimens are for the most part more completely subfossilized, or else muddy,as though composed of earth and refuse which had been washed, at some remote period, into their present positions, by the action of sudden and violent floods; in which latter case the shells, although generally more brittle and broken up, are less altered,-being totally unthickened, and presenting at times faint traces of even colour. The nature, and probable age, of these sedimentary beds I do not propose to discuss, for they scarcely enter into my exact subject, and moreover they involve considerations of great geological difficulty-such as even Sir Charles Lyell was not able satisfactorily to grapple with when he examined those of Madeira and Porto Santo, now many years ago, with considerable care; but since it is pretty evident, I think, that some of them must have been deposited previous to 
the breaking-up of the intermediate land, it is tolerably certain that an enormous period must have elapsed since the shells which are now either deeply imbedded or are else scattered loosely over the surface were in a living condition. Yet in no single instance have they been transformed into 'fossils' (as usually understood by that term), being strictly, and merely, subfossilised.

Whatever be the history of these singular beds, ${ }^{1}$ it is quite clear that they have a direct bearing on the geological structure, and former configuration, of the islands; and therefore in tabulating their contents we must do so with the utmost cau-

1 It has always appeared to me that the drift sand of which the Caniçal beds, and so many of those in Porto Santo, are mainly composed is strictly of a marine nature,-in fact similar to that of the present beaches, with which some of them are in almost immediate proximity ; for the broken-up fragments of sea shells, well distinguished by their solidity and sculpture, abound in it everywhere, and the spines of Echini are also far from uncommon. Moreover, although I have not myself observed it, a microscopic Polystomian was mentioned by Mr. Lowe (Prim., Append. XV., note) as being not more rare, in the Caniçal deposits, than it is in the sand which forms the neighbouring beach. Heer therefore was decidedly in error when he asserted that no Polystomians had been observed in its composition, and that the sand contained exclusively the triturated remains of Terrestrial Mollusks. No doubt the latter occur to a prodigious extent, and may perhaps add largely, when ground down and afterwards decomposed by the action of the elements, to the calcareous matter which binds together considerable portions of the surface and has enabled the infiltrations which have followed the course of various roots and branches to assume definite and often the most grotesque shapes,-standing out, when the loose surrounding drift has been gradually blown away from them, like (what might almost be regarded, at first sight, as) the fossil remains of a former copse or wood. But that these trunk- and root-like concretions (formed of varying proportions of earth and sand soldered together, as it were, by a calcareous cement) have been slowly accumulated around the different parts of shrubby plants (which perhaps were washed down, along with the shells, by overwhelming torrents, from a higher altitude) is rendered all the more probable from the fact that when broken open they will generally be found to be longitudinally hollow in the centre, as though the stems and roots which were originally enclosed had perished,leaving only the clumsy masses which had been solidified, more or less perfectly, around them. But, be this as it may, the sandy portion itself seems to me to be entirely marine,- blown up, in a great measure, from the beach, towards which this particular conchyliferous district uniformly slopes. Nevertheless, on the other hand, the deep layers of somewhat indurated but friable earth with which the calcareous incrustations are here and there commingled, and which more or less teem with land-shells (whether whole or fragmentary, and seldom much thickened or solidified), a large proportion of which are characteristic of the sylvan regions of a lofty elevation, now totally disconnected with this low tongue of land on which the Caniçal beds are placed, point unmistakeably to the action of sudden and violent floods, which must have carried them down, accompanied frequently by the remains of birds, to well-nigh the level of the shore, and that too at a period when the configuration of the adjoining country was very different from nhat we now observe it to be. So that two counter processes would appear to have been concerned in the elaboration of these singular deposits, - namely, the washing down of material from the mountain habitats above, and the gradual drifting up of the marine sand from the beaches beneath. 
tion, lest a too hasty analysis lead to conclusions which are unreliable, and we fail to gain a genuine estimate of the fauna of that distant epoch. Moreover we must at all times be quite certain that the shells upon which we may have occasion to pronounce are truly subfossilised, and not merely bleached and decorticated; a consideration which makes melook with suspicion upon many of the species which are said to have been found in a subfossil condition in the other archipelagos, where the deposits have not been pointed out with the same precision as they have in the Madeiran Group. And so fatal indeed do I consider this element of uncertainty in dealing with the questions arising out of the subfossil fauna that it is only from the Madeiran catalogue that I shall attempt to draw any conclusions at all upon the subject, for at any rate in the Madeiras the beds have been both properly defined and systematically investigated, and in no instances have their contents been mixed up with material from other and doubtful sources. In fact so great has been the desire to avoid all evidence which is untrustworthy, that there are (as already intimated) but three regions in this archipelago from which the subfossil forms have hitherto been acknowledged as absolutely and undeniably genuine,-namely (1) the island of Porto Santo, where the deposits in question (chiefly calcareous) are numerous, and widely scattered at low and intermediate altitudes; (2) near Caniçal, in the east of $M a$ deira proper, where they slope down to well-nigh the level of the sea, but nevertheless contain species many of which are of a mountain character and sylvan habits ; and (3) the extreme summit of the Southern Deserta (or Bugio), where, although small in extent, they are deep and strictly muddy.

The following then is the list of the subfossilized species which have been observed up to the present date, so far as I am able to ascertain, in these three localities of the Madeiran archipelago ${ }^{1}:-$

\begin{tabular}{|c|c|c|c|c|c|c|c|c|c|}
\hline & & & & & & & Pto. Sto. & Mad. & S. Des. \\
\hline Vitrina & a ruivensis, Gould & 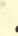 & • & 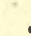 & 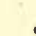 & • & & * & \\
\hline Hyalin: & a crystallina, Müll. & . & . & . & . & . & & * & \\
\hline Patula & bifrons, Lowe. & . & . & 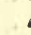 & & . & & * & \\
\hline " & stephanophora, Desh. & se & . & . & . & . & & * & \\
\hline ", & calathoides, Lowe . & & . & . & . & . & & & * \\
\hline ” & pygmæa, Drap. & & • & 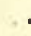 & 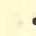 & - & & * & \\
\hline ", & placida, Shuttl. & & - & & 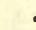 & - & & * & te \\
\hline Helix I & Lowei, Fer. & & • & 。 & & • & * & & 11 \\
\hline$" \mathrm{p}$ & portosanctana, Sow. . & & & . & & & * & & \\
\hline
\end{tabular}

1 Those species to which an asterisk $\left(^{*}\right)$ has been added, and the names of which are printed in italics, have not hitherto been met with in a recent state; and they must therefore be looked upon, until evidence to the contrary has been adduced, as extinct. 


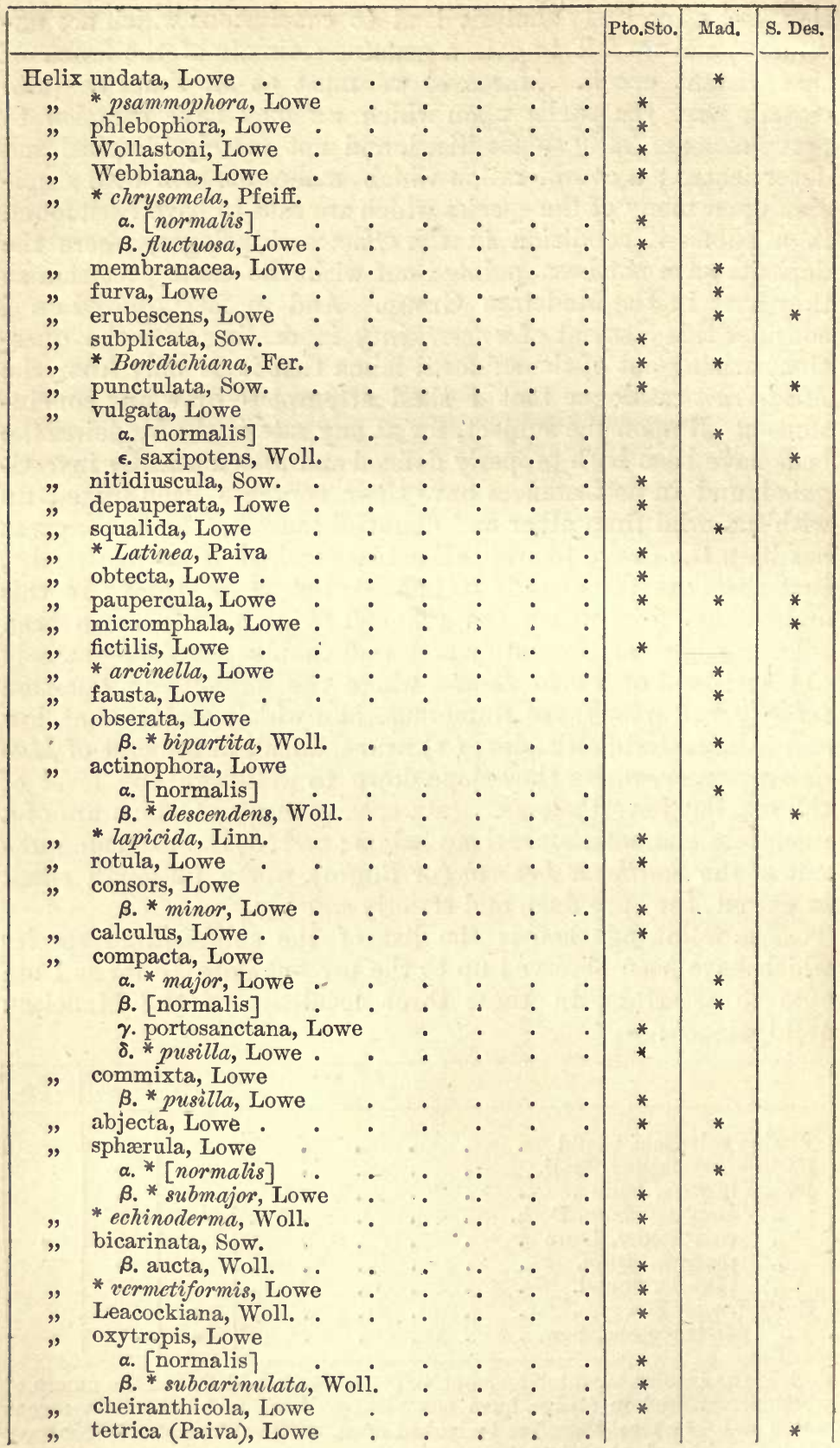




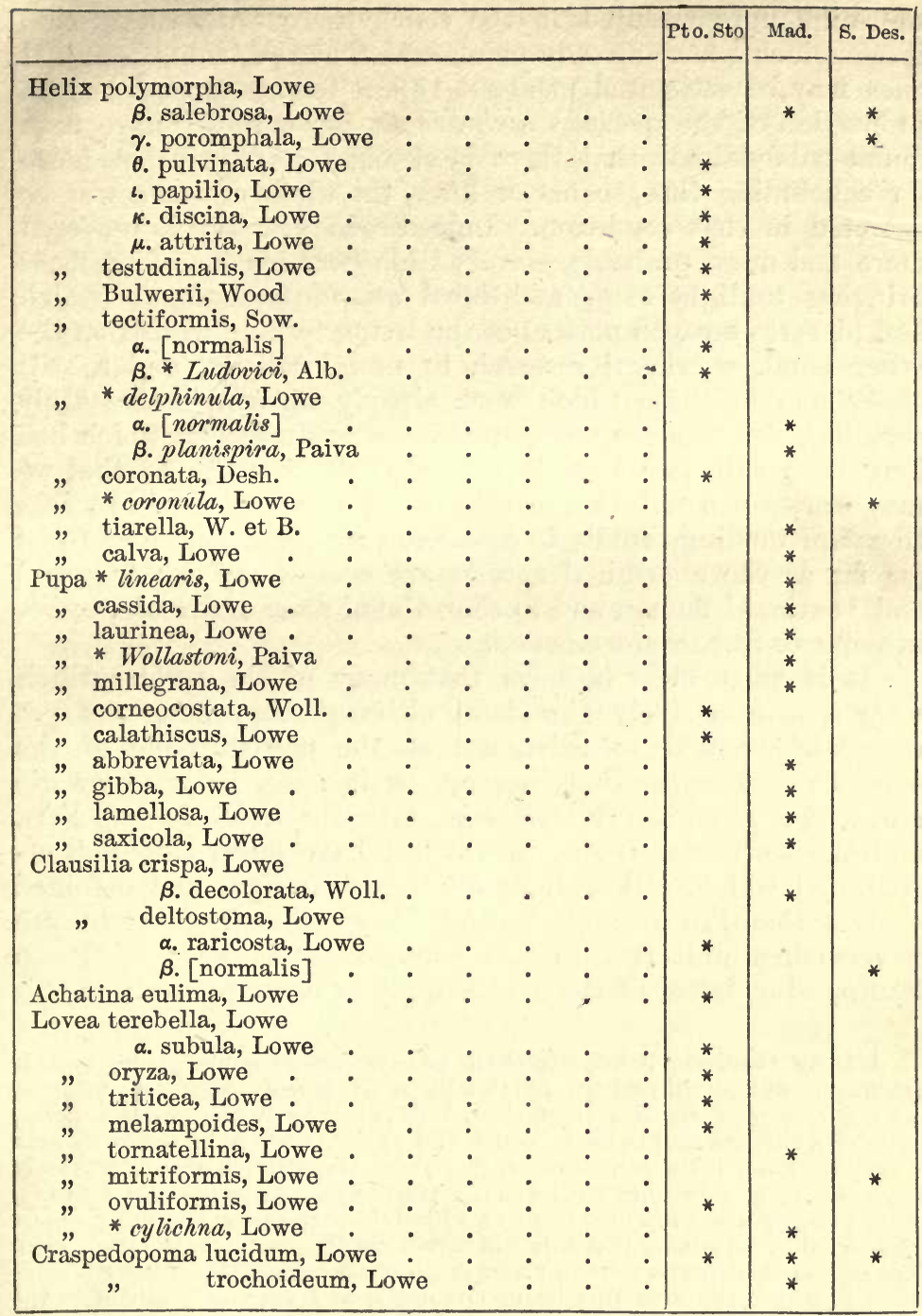

From which we gather that, out of the 176 members of the Pulmonata which have been recorded up to the present time in the Madeiran Group, no less than 82 are met with in a subfossilized state. And inasmuch as these 82 are made up almost exclusively of the species which are manifestly indigenous(those which there is every reason to suspect have been established accidentally within a comparatively recent period being 
well-nigh unrepresented in the conchyliferous deposits $\left.{ }^{1}\right)$, and inasmuch as I have already mentioned that the truly aboriginal ones may be estimated at about 138, it follows that so large a proportion of the species which are strictly endemic have been found subfossilized that there is strong presumptive evidence for concluding that, sooner or later, the whole of them will be detected in that condition. Indeed each year this is rendered more and more probable,-every fresh examination of the beds bringing to light some additional quondam-analogue (which had hithertc escaped notice) of the living forms; whilst, on the other hand, a critical research in new localities, and a still closer one in those which were already known, is constantly revealing the modern representative of some species which had long been supposed to have passed wholly away. ${ }^{2}$ So that we may fearlessly assert that continued and well-directed observations are tending rapidly to equalize what were conceived to be (so far as the aboriginal species are concerned) the 'recent' and 'extinct' faunas, and to show them, more and more, to be, in point of fact, conterminous.

It is quite clear however that many of the species which were once excessively abundant, although they have not yet completely ceased to exist, are at the present time of the utmost rarity,-just lingering on, as it were, before they die out. This is eminently the case with the Helix Lowei, Fer., and the coronata, Desh., to which I have lately called attention, and which, although now extremely scarce, and confined each of them, to a single spot of the most limited extent, are nevertheless universal in the subfossiliferous beds of Porto Santo,- the latter of them absolutely swarming. And on this

1 I say 'well-nigh,' because there are two or three exceptions to this statement which will perhaps require to be explained,- - such, for instance, as the European Hyalina crystallina, Müll., and the Patula pygmaa, Drap., both of which are said to have been found by Mr. Watson in the beds near Caniçal. Even instances, however, like these would seem merely to imply that the species in question, although possessing (like the Helix lapicida, Linn., subfossilized in Porto Santo) a wide European range, had nevertheless succeeded in colonizing this Atlantic region during the remote epoch when the calcareous deposits were in process of formation.

${ }^{2}$ In corroboration of this latter circumstance, I need only allude to the discovery by Senhor J. M. Moniz, on the Ilheo de Cima, off Porto Santo, of the gigantic Helix Lonei, Fer., which for half-a-century had been assumed to be totally extinct; or to that, by myself,-on the extreme eastern peak of Porto Santo, buried deep in the soil beneath slabs of basalt,- of the singular little $H$. coronata, Desh., which is so abundant in all the subfossiliferous deposits of that island; or to that, by Mr. Lowe and myself, of the H.tiarella, W. et B., in the north of Madeira proper,-a species which swarms in the beds near Caniçal, but which up to that date (namely the summer of 1855) had been looked upon as belonging exclusively (despite its enunciation by Webb in 1833, from examples which may or may not have been subfossilized) to a former epoch. 
account, perhaps, it might be more natural to conclude that at any rate some few of the forms have really passed away, even whilst the tendency of every renewed observation is to lessen the number of those which were supposed to be extinct. Indeed one of the most anomalous of all the land-shells which have yet been brought to light-the Helix delphinula of Madeira proper, which teems in the calcareous drift near Caniçal-has up to the present moment altogether eluded detection in a recent state, and we might almost therefore be justified (considering its comparatively large size) in assuming it to belong exclusively to a passed epoch had not the discovery by Mr. Lowe of a form scarcely less conspicuous (the somewhat cognate $H$. delphinuloides), so recently as in 1860, rendered it at least possible that even the $H$. delphinula may still survive in some elevated, remote, sylvan ravine, and may yet reward the researches of future naturalists. But if this should ever be the case, we may confidently anticipate that it will be found, as it were, only just to linger on, in some area of the most reduced dimensions and perhaps well-nigh inaccessible. And the same remarks may hold good for a few other species, such as the H. Bowdichiana, Fer.,-which abounds in the conchyliferous deposits both of Madeira and Porto Santo; for, although it is within the range of possibility that it may represent nothing more than a gigantic quondam-phasis of Sowerby's $H$. punctulata (which is common in Porto Santo and on one of the Desertas), nevertheless since the latter has not hitherto been observed at all in Madeira proper, the extreme abundance of the $H$. Bowdichiana in the Caniçal beds places the species in much the same category as the $H$. delphinula,-which is equally plentiful at Caniçal, but which (in like manner) is unknown to the recent fauna of the central island (and indeed, in this particular instance, to the fauna of the whole group). There is also a minute Achatina (or, more probably, a Lovea, as lately defined by $\mathrm{Mr}$. Watson) to which attention might be drawn, as having escaped discovery in a living condition, and the characters of which are sufficiently peculiar to render it an important member of the general catalogue,-namely the A. cylichna of Madeira proper; and amongst the other Helices, as yet exclusively subfossilized, which we may hope will be made, sooner or later, to augment the recent fauna, I might single out the little Helix arcinella, Lowe, so common at Caniçal, and the curious $H$. coronula, Lowe, from the southern Deserta, or Bugio.

If we add to these five species (namely the Helix Bowdichiana, arcinella, delphinula, and coronula, and the Lovea cylichna) the following seven-Helix chrysomela, Pfeiff., 
Latinea, Paiva, lapicida, Linn., echinoderma, Woll., vermetiformis, Lowe, and the Pupa linearis, Lowe, and Wollastoni, Paiva,-which, in like manner are found only subfossilized, the resulting 12 embody all the forms, regarded by me as truly specific ones, which (so far as our present information would imply) are presumably extinct; but as the seven, last mentioned, are, with the exception of the Helix lapicida and the Pupa linearis, more doubtfully separated from their immediate allies than is the case with the preceding five, $I$ do not consider it worth while to direct any further attention to them than what has already been done in their respective places in the systematic list. Suffice it just to recal that the Helix chrysomela, Pfeiff., is most closely related to the erubescens, the H. Latinea, Paiva, to the depauperata, the $H$. echinoderma, Woll., to the echinulata, the $H$. vermetiformis, Lowe, to the turricula, and the Pupa Wollastoni, Paiva, to the $P$. sphinctostoma; whilst the Pupa linearis, Lowe, is regarded by Mr. Watson (vide 'Journ. de Conch.' 223; 1876), though I cannot quite agree with him in this conclusion, as absolutely identical with the European $P$. minutissima of Ferussac.

In the general Madeiran catalogue, which is given at the close of this section, I have (as in the case of the lists pertaining to the other archipelagos) appended an asterisk (*) to such species as have been found also subfossilized; and in those instances in which the species have occurred only in a subfossilized condition (under which circumstances they must be looked upon, until proved to the contrary, as extinct) the names have been printed likewise in italics.

\section{Sectio I. INOPERCULATA.}

\section{Fam 1. LIMACID理.}

\section{Genus 1. ARION, Ferussac.}

Arion ater.

Limax ater, Linn., Syst. Nat. (ed. 12) 1081 (1767)

Arion empiricorum, var. 1, Fer., Tabl. Syst. 17 (1821)

$$
\begin{aligned}
& \text { " } \quad \text { "a. et } \beta \text {., Lowe, Cambr. Phil. S. Trans. } \\
& \text { iv. } 39 \text { (1831) } \\
& \text { ater, Id., Proc. Zool. Soc. Lond. } 162 \text { (1854) } \\
& \text { " empiricorum, Alb., Mal. Mad. } 11 \text { (1854) }
\end{aligned}
$$


Arion rufus, Morel., Hist. Nat. des Açor. 137 (1860)

" ater, Paiva, Mon. Moll. Mad. 2 (1867)

" "Watson, Journ. de Conch. 221 (1876)

Habitat Maderam; præcipue in editioribus, rarissima.

This European Arion (which is recorded also at the Azores) is decidedly somewhat scarce in Madeira, and is found principally at rather high elevations. I have taken it however pretty plentifully at the Pico do Infante (nearly 3000 feet above the sea), and it was met with by Mr. Lowe in the chestnut woods at the Mount, as well as at Camacha, and on the side (ascending from the Curral) of the Pico Grande. It is a decided Arion,-its respiratory orifice being very anterior in position, the mucous gland at its extremity large and distinct, its body totally uncarinated, and its shield even and arenaceogranulate (instead of being uneven and wrinkled, as in the Limaces).

The colour of this slug (which varies from about $1 \frac{1}{2}$ to 3 inches in length), is usually dusky-brown with an echre tinge (i.e. somewhat of a dark olivaceous-drab), the sides however being gradually a little paler; and it is, therefore, anything but that (at all events when in its normal state, for it is now and then blacker) which is implied by its specific title; and the edge of its pedal disk (or foot) is of a clear ochreous-yellow (sometimes approaching to orange), with the transverse lines dusky, distant, and pretty regular, though occasionally obscure. This edge (the colouring matter of which would seem to be somewhat moveable) appears at times white, with a narrow orange line immediately within it.

\section{Genus 2. IIMaX, Linné.}

\section{Limax gagates.}

Limax gagates, Drap., Hist. Nat. 122. pl. 9. f. 1, 2 (1805) " antiquorum, var. a., Lowe, Cambr. Phil. S. Trans. iv. 39 (1831)

" gagates, Id., Proc. Zool. Soc. Lond. 162 (1854)

" $\quad$ Alb., Mal. Mad. 12. t. 1. f. 3-5 (1854)

" $\quad$ " Morel., Hist. Nat. des Açor. 139 (1860)

" " " Paiva, Mon. Moll. Mad. 3 (1867)

" " Watson, Journ. de Conch.221 (1876)

Habitat Maderam, et Portum Sanctum; in illâ vulgaris, sed in hôc rarior. In graminosis intermediis præcipue degit.

The L. gagates, which is widely spread throughout Europe, and which occurs also in the Azorean Group and even at St. Helena (where it has probably been introduced along with 
shrubs and plants), is extremely common in Madeira proper. I have taken it around Funchal, at the Pico do Infante, and elsewhere; and Mr. Lowe appears to have met with it towards the Alegria, at the Mount, in the Cayados ravine, \&c; and he likewise obtained it in Porto Santo, during our visit to that island in April of 1855. The Porto-Santan examples were found on the summit of the Pico do Castello, and were similar to those of the ordinary Madeiran cinereous-brown state, - the keel being very strong and sharp up to the hinder edge of the shield, which last had the usual depression in the middle with the sides raised or tumid.

This slug, which is easily distinguished from its allies, is of a rusty ochreous- or brownish-black (frequently cinereous-brown, and often of a deep uniform black), but brighter on the shield, and a trifle so at the sides and keel. At the top of the neck there are two longitudinal grooves, with a raised line between; the lateral portion of the shield (the colouring matter of which appears however to be somewhat moveable) is generally of a dusky brown; and the body is coarsely grooved (or striated) longitudinally, the striæ being more or less branched and confluent. Its usual length is from about three-quarters of an inch to an inch.

\section{Limax maximus.}

Limax maximus, Linn., Syst. Nat. (ed. 12) 1081 (1767)

, cinereus, Müll., Verm. Hist. ii. 5 (1774)

" antiquorum, var. E., Fer., Tabl. Syst. 20 (1821)

" cinereus, Lowe, Proc. Zool. Soc. Lond. 162 (1854)

", antiquorum, Alb., Mal. Mad. 12.t. 1. f. 2 (1854)

" maximus, Morel., Hist. Nat. des Açor. 138 (1860)

$" \quad$ cinereus, Paiva, Mon. Moll. Mad. 4 (1867)

" maximus, Watson, Journ. de Conch. 221 (1876)

Habitat Maderam; hinc inde, præsertim in cultis.

This is a very large but inconstant slug, varying from about $1 \frac{1}{2}$ to 4 inches in length, and one which is common throughout Europe, and which has become established in the Azorean archipelago. At Madeira it is not very abundant, but found occasionally around Funchal and elsewhere, particularly in gardens and cultivated grounds-ascending to nearly 2000 feet above the sea. It is generally of a palish cinereous-brown with a warm (but very faint) lilac tinge; its shield (which is sprinkled all over with distinct and well-defined black spots) being a little paler. The shield however (which is subconcentrically striate, or finely wrinkled, and rounded behind, though often when the animal is contracted and quiescent slightly 
apiculate) is occasionally marbled (rather than spotted) with larger black blotches. The body, which is much roughened by longitudinal sulci, has four or five (occasionally ill-defined, and often subconfluent) interrupted stripes of black, which are broken anteriorly into still more isolated spots or patches; and the keel extends scarcely more than a quarter of the length from the tip of the tail to the hinder edge of the shield.

\section{Limax flavus.}

Limax flavus, Linn., Syst. Nat. (ed. 12) 1081 (1767)

" variegatus, Drap., Hist. Nat. 127 (1805)

" $\quad$ " $\quad$ B., Fer., Tabl. Syst. 21 (1821)

" " Lowe, Cambr. Phil. S. Trans. iv. 39 (1831)

" flavus, Id., Proc. Zool. Soc. Lond. 162 (1854)

" variegatus, Alb., Mal. Mad. 12. t. 1. f. 1 (1854)

" $\quad$ "Morel., Hist. Nat. des Açor. 138 (1860)

" flavus, Paiva, Mon. Moll. Mad. 4 (1867)

" " Watson, Journ. de Conch. 221 (1876)

Habitat Maderam; late sed parce diffusa.

Likewise a European Limax, and one which occurs also in the Azores. In Madeira it is widely distributed, and is found occasionally around Funchal (where I have taken it at the Val), at the Praia Bay, in the Curral das Freiras, \&c.; and it has been met with by Mr. Watson in the north of the island. Its average length is from about an inch to an inch and a half; and its colour above is a pale dirty- or brownish-yellow (slightly brighter on the shield), but coarsely reticulated, or mottled, except at the sides and at the edge of the foot (which are immaculate), with dusky cinereous-brown. The keel, as in the $L$. maximus, is short,-reaching scarcely a third of the distance from the tip of the tail to the posterior margin of the shield (which last is transversely, or subconcentrically wrinkled, and appears often, when the slug is contracted, to be somewhat mucronato-rotundate behind or apiculate.

\section{Limax agrestis.}

Limax agrestis, Linn., Syst. Nat. (ed. 12) 1082 (1767)

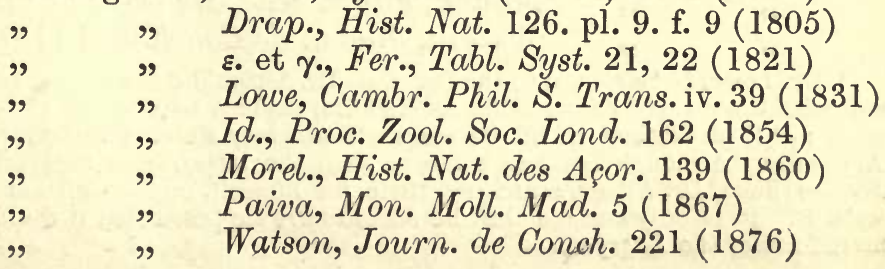


Habitat Maderam; in graminosis editioribus præcipue abundans, sed ubique sat vulgaris.

The European L. agrestis is tolerably common in most parts of Madeira proper, abounding more especially in grassy mountain pastures of a rather high altitnde. I have taken it at the Pico do Infante; and whilst encamped with Mr. Lowe near the Pico d'Arribentão, during April of 1855, it was in great profusion at a place (in the direction of the Ribeira d'Escalas) called the ' cova d'Antonio Caldeira,' about 2600 feet above the sea, exhibiting two tolerably distinct states, which Mr. Lowe defined as the ' $a$. major, pallido-cinerea', and the ' $\beta$. minor, ochraceofusca; '- the first of these (which was the rarer, and nearly an inch in length) being larger and of a creamy pale ash-grey, mottled and punctate with darker markings (agreeing exactly with the common English L. agrestis); whilst the second (which was excessively abundant, and about half an inch long), was slender, of a warm pale bistre-brown, with the head, neck, tentacles, and fore-half of the shield lighter and brighter, the hinder half of the latter and the tail being gradually of a darkish tint.

The $L$. agrestis, which is extremely mucose and has its shield subconcentrically striated (like the lines at the end of one's fingers) may be instantly recognised from the $L$. gagates by, inter alia, its ecarinate body, - which is rounded, or almost flattened, towards the hinder edge of the shield, - the only trace of a keel (and that merely in the 'status a,' as above enunciated, for the 'status $\beta$ ' is quite uncarinated) being at the extreme tip. ${ }^{1}$

\section{Fam. 2. TESTACELLIDEE.}

Genus 3. TESTACELLA, Cuvier. Testacella Maugei.

Testacella Maugei, Fer., Tabl. Syst. 26 (1821)

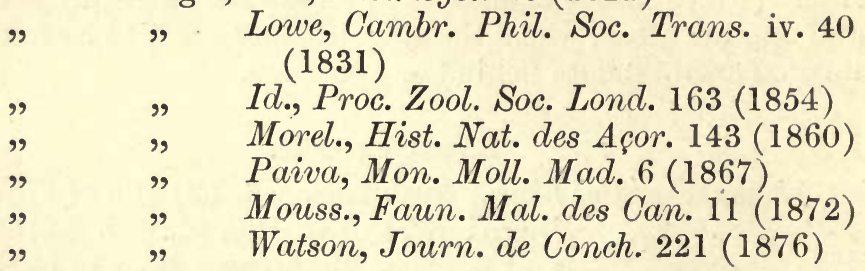

$1 \mathrm{Mr}$. Lowe, in reference to the fact that Dr. Albers did not appear to have met with the present Limax while at Madeira, made a note about it to this effect:- ' Most distinct in all its stages from every state, or variety, of the L. gagates. Although not less common than the latter, from September to May or June, Dr. Albers, searching little for himself, might well not meet with it. It is only strange that he should have supposed that it could be a mere form of the $L$. gagates. 
Habitat Maderam; in hortis cultisque circa Funchal, passim.

This European Testacella, which occurs likewise in the Azorean and Canarian groups, is found occasionally in gardens and other cultivated spots around Funchal, though seldom in any abundance. I have taken it at the $\mathrm{Val}$; and it is reported by the Baron Paiva from S. Gonçalo and Camara de Lobos. Mr. Lowe also met with it, on several occasions, in Dr. Renton's garden at the Val Quinta, as well as near S. Martinho.

The animal of the T. Maugei, which gradually tapers anteriorly and possesses no shield, and which carries the shell on its posterior extremity (where it conceals the respiratory aperture), is of a livid black (sometimes with a faint picescent tinge), and the edge of its pedal disk (as seen from above) is gradually of a pale salmon colour,- the darker hue of the rest of the surface passing into it (not abruptly, but) by means of a number of minute darkish specks. The surface is much roughened (somewhat after the manner of very coarse sealskin), and marked with a number of irregular grooves or reticulations (arranged rather like lattice-work) and with three longitudinal ones (occasionally distinct, but often rendered obsolete by the movements of the creature) running down the dorsal region. It has the power of emitting an extraordinary pile of froth, or mucus, from its subapical orifice beneath the shell, which takes usually a globular form, and appears much like a cluster of very minute soap-bubbles.

The shell (which is somewhat Ancyliform, or limpet-like) of this Testacella is externally of a pale dingy olivaceous-yellow, or yellowish-brown, thick in substance, opake, generally a good deal eroded and decorticated, and coarsely but irregularly striate with a few deeply-impressed lines of growth; but inside its enormous aperture (which is nearly oblong, with the sides almost parallel, and with a slight emargination or sinus at the upper angle of the outer lip) it is shining, whitish, and pear-like, sometimes reflecting an indistinct opaline lustre.

Testacella haliotidea.

Testacella haliotidea, Drap., Tabl. des Moll. 99 (1801)

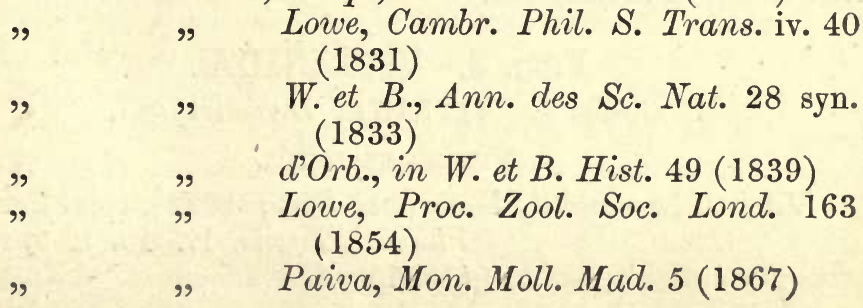


Testacella haliotidea, Mouss., Faun. Mal. des Can. 11 (1872)

Watson, Journ. de Conch. 221 (1876)

Habitat Maderam ; in horto mox supra Funchal olim parcissime capta.

I am a little doubtful whether the T.haliotidea of central and southern Europe can be truly regarded as having established itself at Madeira. It appears formerly to have occurred, though very sparingly, near Funchal; but I have no evidence that it is still to be met with. Indeed the only three examples, so far as I am aware, which have ever been observed in the island were in Mr. Lowe's garden at the Levada de Sta. Luzia, now many years ago, - namely during February of 1830, 'crawling about a small tank, after a long continuance of rain.'

I have not myself had an opportunity of inspecting the animal of the $T$. haliotidea; but, commenting on the specimens to which I have just ealled attention, as having been found near Funchal in 1830, I possess an old note, made by Mr. Lowe, to the effect that it is ' of a unifurm pale clear buffyellow, except the edge of the foot which is tinged with pink or flesh-colour. The disk of the foot beneath and the posterior extremity behind the shell are of the same pink, or salmoncoloured, hue. Two faint grooved lines, and a still fainter one between them (making three in all), run down the middle of the back-which is also marked out from the sides by two stronger grooved lateral ones, ascending upwards towards the shell (much as in the T.Maugei); but this dorsal compartment is not portioned out by coarse oblique grooves so as to become uneven and tumid, or reticulated. The whole creature is more slender than that of T. Maugei; and the shell is of a uniform horn-colour,-the margin appearing, when the shell is in situ, a little pinkish.'

Although Albers has figured and described, in his 'Malacographia Maderensis,' both of the Testacellas which are here enumerated, I have nevertheless refrained from citing his monograph, because it appears to me that he has inadvertently mixed up the characters of the two species, or at any rate has interchanged their shells.

\section{Fam. 3. VITRINID庄.}

Genus 4. VITRINA, Draparnaud.

\section{Vitrina ruivensis.}

Vitrina Lamarckii, Lowe [nec Fér.; 1822], (pars), Cambr. Phil. S. Trans. iv. 40. t. 5. f. 1. b. (1831) 
Vitrina ruivensis (Couthouy), Gould, Proc. Bost. Soc. N.H. ii. 180 (1848)

" \# Pfeiff., Mon.Hel. ii. 507 (1848)

" Behnii, Lowe, Ann. Nat. Hist. ix. 112 (1852)

" Teneriffæ, Id. [nec Q. et G.; 1827], Proc.Zool. Soc. Lond. 163 (1854) ruivensis, Alb., Mal. Mad. 15. t. 2. f. 4-6 (1854) Teneriffæ, Paiva, Mon. Moll. Mad. 9 (186i) ruivensis, Pfeiff., Mon. Hel. vii. 20 (1876)

Habitat Maderam ; in humidis editioribus, præcipue sylvaticis, haud infrequens. In stratu conchylifero ad Caniçal semifossilis parce reperitur.

The Haliotis-shaped outline (the nucleus being lateral, rather than subcentral), enormous aperture, and comparatively depressed form of this large Vitrina, added to its fewer volutions (there being only two of them, or at the utmost $2 \frac{1}{2}$ ), its flattened apex and its consequently indistinct suture, will suffice to separate it from the other species with which we are here concerned. It is not quite so highly polished, usually, as the $V$. nitida (i.e. the V. Lamarckii, Lowe, nec Fér); and there are more appreciable indications beneath a high magnifying power of a few minute, broken-up spiral lines, or (as it were.) scratches. The obsolete transverse plicx, also, or folds, are, for the most part, more curved and radiating.

Although less common than the $V$. nitida, the present Vitrina is tolerably abundant at a high elevation in Madeira proper,-where it occurs in the damp sylvan regions, principally under stones and logs of decaying wood; and it is found sparingly, in a subfossil state, at Caniçal.

As regards its synonymy, this Vitrina is a little complicated. Mr. Lowe originally cited it as a mere phasis of the ' $V$ Lamarckii' as understood by him (i.e. of the nitida, Gould), but he afterwards published it (in 1852) as the V. Behnii-in honour of the Professor at Kiel, who had pointed out to him what he conceived to be its true differential characters. But in the meanwhile it had been (in 1848) described by Gould under Couthouy's manuscript name 'ruivensis,'-which seems to me (as it did, apparently, to Dr. Albers) to be the oldest title for the species on which we can absolutely depend. True it is that Mr. Lowe, in his last enumeration of the Madeiran Mollusca, identified it with the Canarian V. Teneriffoce of Quoy and Gaimard (which bears the date 1827): but then the V. Teneriffece proves to be identical with the genuine, and previously described, V. Lamarckii (which is expressly registered by Férussac as having come from Teneriffe), - as is manifest from the diagnosis of it which is quoted by Pfeiffer, and as indeed 
has recently been acknowledged by Mousson. Moreover it is evident that Mr. Lowe was mistaken in the opinion which he had adopted both of the $V$. Teneriffoe and of the V. Lamarckii (which, as just stated, are one and the same species); for he assumed the former to be identical with the Madeiran V. ruivensis (which is also his $V$. Behnii), and the latter with the other (and more common) Madeiran Vitrina which was described by Gould (in 1846) under the name of nitida. So that I come to the conclusion, that the title ruivensis is the oldest reliable one for our present species.

\section{Vitrina marcida.}

Vitrina marcida, Gould, Proc. Bost. Soc. N. H. ii. 181 (1848)

\section{Pfeiff., Mon. Hel. ii. 507 (1848)} media, Lowe, Proc. Zool. Soc. Lond. 164 (1854)

, marcida, Paiva, Mon. Moll. Mad. 9 (1867)

" $\quad$ Pfeiff., Mon. Hel. vii. 21 (1876)

Habitat Portum Sanctum vulgaris, sed in Madeira rarior ; locos humidos editiores præcipue colens.

I am exceedingly doubtful whether this is anything more than a smaller state of the $V$. nitida (i.e. of the $V$. Lamarckii, Lowe, nee Fér.), - with which in its outline, and in the relative proportions of its aperture, it agrees almost exactly. But, apart from its (on the average) distinctly reduced size, it is further characterized by being almost always of an appreciably paler tint, in its spire being more depressed (though not quite so flattened as in the $V$. ruivensis), indeed in its general contour being a trifle less inflated or convex, and in its lower lip being more broadly and conspicuously membraneous. It has usually, too, half a volution less than the $V$. nitida; and there are for the most part more evident indications of a few abbreviated radiating plicæ just below the suture (and towards the aperture) of the basal whorl.

The $V$. marcida is extremely common on the mountains of Porto Santo,-where it occurs about damp rocks, and under stones in moist grassy places, at a rather high elevation. I am not quite sure that I have myself met with it in Madeira proper; nevertheless it is recorded by Mr. Lowe from the Ribeiro Frio, and it appears to have been found in other sylvan spots of an intermediate altitude.

Vitrina nitida.

Helicolimax Lamarckii, Lowe [nec Fér.; 1822], (pars), Zool. Journ.iv. 338-344(1829) 
Vitrina Lamarckii, Lowe, (pars), Cambr. Phil. Soc. Trans. iv. 40. t. 5. f. 1. a. (1831'

99

9

9

99

99

nitida, Gould, Proc. Bost. Soc. N. H. ii. 180 (1848) Lamarckii, Lowe, Proc. Zool. Soc. Lond. 164 (1854)

nitida, Alb., Mal. Mad. 15. t. 2. f. 1-3 (18.54)

Lamarcki, Paiva, Mon. Moll. Mad. 8 (1867)

nitida, Pfeiff., Mon. Hel. vii. 21 (1876)

Habitat Maderam; in sylvaticis intermediis vulgaris.

This is the universal Vitrina of Madeira proper, where it is more or less abundant throughout most parts of the sylvan districts at intermediate and lofty altitudes,-occurring, like the preceding two, beneath damp stones and refuse, on the mossy trunks of trees, and under logs of decaying wood. But I am not aware that it has been observed for certain elsewhere in the Group ; for although it is true that Mr. Lowe recorded it originally as existing in Porto Santo likewise, he had not at that time distinguished more than a single Vitrina as inhabiting the archipelago, and it was not until 1854 that he separated as specifically distinct (under the name of media) the previously described $V$. marcida, of Gould, which is not only common in Porto Santo, but which may almost be defined as principally Porto-Santan; and as for the Baron Paiva's assertion that it is to be found on the mountains of that island, as well as on the adjacent rock known as the Ilheo da Fonte d'Areia, it must be taken for what it is worth,- - seeing that, by his own admission, he could not himself discriminate the two species in question. ${ }^{1}$ So that I think we must still require evidence of a more positive nature before it will be safe to cite the $V$. nitida as occurring beyond the limits of Madeira proper.

The present Vitrina is, on the average, a trifle smaller, and just appreciably more brilliant and highly coloured, than the ruivensis; and it is also less depressed (or more ventricose and Heliciform), and, instead of there being only two, there are about $3 \frac{1}{2}$ or even 4 volutions. The spire too is less flattened, the nucleus (which is generally paler, and subcentral instead of lateral) being somewhat convex, and the suture is consequently deeper and more conspicuous. The aperture is both less enormous and rounder (causing the left-hand portion of the ultimate whorl, when viewed from beneath, to be relatively wider and more visible); and the surface appears to be almost free (even under a high magnifying power) from any traces of the minute

1 That this was the case, it appears evident from his remark under the $V$. marcida:- 'Species mihi dubia, nec a congeneribus sat distincta.'. 
spiral broken-up lines, or scratches, which are more or less distinguishable in that species. ${ }^{1}$

The $V$. nitida would seem to represent in Madeira the $V$. Lamarckii of the Canarian archipelago ; for my own belief is that the former does not occur at the Canaries at all,-its analogue in that Group being the true Lamarckii of Férussac, which Mr. Lowe unfortunately mistook for this common Madeiran species. Indeed the $V$. Lamarckii proper (which is also the $V$. Teneriffio of Quoy and Gaimard) appears in some respects to be intermediate between the $V$. nitida and the ruivensis,-having the more numerous volutions and subcentral nucleus of the former, with the larger size, less ventricose contour, more flattened apex, and the more outwardly-produced (or less rounded, and more enlarged, elongate) aperture of the latter; and it is perhaps owing to this circumstance that Mr. Lowe fell into the error of identifying it, although confessedly Canarian, under the title of ' $V$. Teneriffoe' with the ruivensis, and under that of 'V. Lamarckii' with the nitida. ${ }^{2}$

\section{Fam. 4. HELICID压.}

Genus 5. HYALINA, Gray.

\section{(§ Lucilla, Lowe.)}

\section{Hyalina cellaria.}

Helix cellaria, Müll., Verm. Hist. ii. 28 (1774)

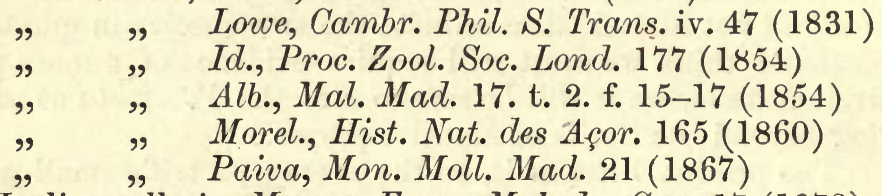

Hyalina cellaria, Mouss., Faun. Mal. des Can. 17 (1872) Helix cellaria, Watson, Journ. de Conch. 222 (1876).

Habitat Maderam, necnon etiam (sec. B. de Paiva) De-

1 The portion of the lip, in the $V$. nitida, which adjoins the columella is sometimes membraneous (though not so conspicuously so as in the $V$. ruivensis), whilst at others it is so comparatively thickened as to be in every respect similar to the remainder of the shell. And I think it is not unlikely that it was from specimens in the latter condition (which are often smaller and a trifle more globose) that Gould's diagnosis of his $V$. nitida (Exped. Shells, $26 ; 1846$ ) was principally drawn out.

2 I may just notice in this place the Vitrina Bocagei of Paiva (Journ. de Conch., Oct., 1866; and Mon. Moll. Mad. 10. t. 2. f. 6. 1867), which was founded on a young example of the Helix Webbiana, Lowe, as has been pointed out by the Rev. R. B. Watson. 'Vitrina Bocagei, Paiva,' says the latter (Journ. de Conch. $219 ; 1876)$, ' est certainement le jeune âge de l'Helix Webbiana, apporté de Porto Santo, et mêlé accidentellement avec les espèces strictement madériennes.' 
sertam Australem; frequens sub lapidibus, præcipue in cultis. Forsan ex Europâ introducta.

The common European H. cellaria (which occurs likewise in the Azorean and Canarian archipelagos, and even at St. Helena) is tolerably abundant, chiefly at rather low elevations and about cultivated grounds, in Madeira proper; but I am not aware that it has yet been observed in Porto Santo. It is recorded, however, by the Baron Paiva, from the Southern Deserta, - a habitat, nevertheless, concerning which I cannot but feel that we require further evidence. In all probability it has established itself, accidentally, from more northern latitudes.

(§ Crystallus, Lowe.)

\section{Hyalina crystallina.}

Helix crystallina, Müll., Verm. Hist. ii. 23 (1774)

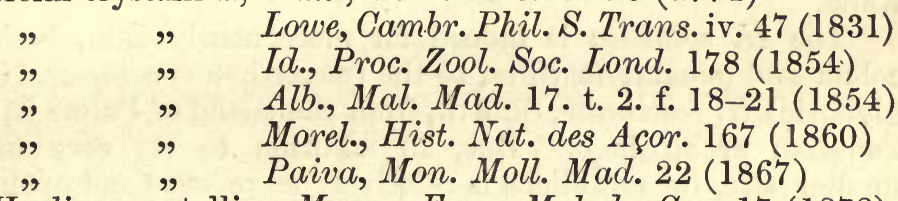

Hyalina crystallina, Mouss., Faun. Mal. des Can. 17 (1872)

Helix crystallina, Watson, Journ. de Conch. 222 (1876)

Habitat Maderam, et Desertam Australem (ab hâc a B. de Paiva recepta); hinc inde in graminosis, sub lapidibus. Etiam semifossilis in calcareis juxta Caniçal a Revdo. R. B. Watson semel lecta.

The European $H$. crystallina, Müll., which is found likewise in the Azorean and Canarian archipelagos (indeed I have myself met with it in Fuerteventura, Teneriffe, Palma, and Hierro, of the latter), is widely spread throughout Madeira proper, though nowhere rery abundant; and it has been recorded by the Baron Paiva from the Southern Deserta, or Bugio. It occurs generally in grassy places, beneath stones; often also in gardens, and other cultivated grounds. I have not, myself, observed it in a subfossil condition; but the Rev. R. B. Watson states (Journ. de Conch. $222 ; 1876$ ) that he obtained a single example of it in the calcareous deposits near Caniçal.

\section{(§ Vermetum, Woll.)}

Hyalina scintilla.

Helix scintilla, Lowe, Ann. Nat. Hist. 115 (1852)

$\begin{array}{lll}\prime & \quad & \text { Id., Proc. Zool. Soc. Lond. } 177(1854) \\ \prime & \quad & \text { Alb., Mal. Mad. 18. t. 2. f. 22-25(1854) } \\ & \quad & \text { Paiva, Mon. Moll. Mad. 23 (1867) }\end{array}$


Habitat Maderam; sub lapidibus detecta, supra urbem Funchalensem. Rarissima.

This extremely minute Hyalina is even smaller than the $H$. crystallina, the largest examples being scarcely a line in diameter; and it may at once be recognized from that species by its very much wider and more open umbilicus, which is spirally visible from beneath (almost as much so as in the Patula rotundata and Guerineana), and by its colour being less white,-fresh examples having always a more or less distinct greenish, or yellowish, tinge. It appears to be of the greatest rarity, and was first detected by Mr. Lowe near Funchal,-namely, beneath stones, at the edge of the Levada de Sta. Luzia; and it has likewise been met with by Mr. Leacock and the Rev. R. B. Watson. The Baron Paiva cites it as having been taken also in the north of the island, at Sta. Anna.

The $H$. scintilla is indeed far more nearly akin, both in colour and general features, to the (nevertheless comparatively gigantic) H. festinans, Shuttl., from the island of Palma in the Canarian archipelago. But, in addition to its very much smaller size, its umbilicus is relatively more wide and open, its spire is not quite so depressed, and its entire surface is a little more polished and less sculptured,--the $H$. festinans appearing, beneath a high magnifying power, to be very minutely subalutaceous, and densely covered with extremely fine hair-like transverse lines.

\section{Genus 6. PATULA, Held.}

(§ Iulus, Woll.)

Patula deflorata.

Helix deflorata, Lowe, Proc. Zool. Soc. Lond. 179 (1854)

" $\quad$ Pfeiff, Mon. Hel. iv. 131 (1859)

" $\quad$ "Paiva, Mon. Moll. Mad. 27 (1867).

Habitat Maderam; in montibus supra Funchal semel, necnon semel a meipso in Rib. de Sta. Luzia, hactenus lecta.

This very obscure species is still represented by a single adult example (for the one which I myself met with in the Ribiera de Sta. Iuzia, in 1848, is immature), which was communicated to me by Mr. Leacock in 1853 as having been found by the late M. Rousset near the Pico d'Arribentão, on the mountains above Funchal; and, judging from its discoidal form, rather large umbilicus, and general aspect, I should be inclined to regard it as a large Patula.

If therefore the sole type which is accessible may be considered to be normal for its kind, the $P$. deflorata is a little 
smaller than the bifrons (it being about $5 \frac{1}{2}$ lines across the widest part), but with somewhat the same primâ facie aspect. It is, however, thinner in substance, paler in hue, and still less shining; its umbilicus is a trifle larger, but at the same time more suddenly (or less gradually) excavated; its spire is appreciably more depressed, although the volutions are rather tumid; the latter are not quite so numerous, or so coarsely sculptured with oblique costate lines; and the basal whorl is conspicuously (though not very greatly) deflexed at the aperture. This character, last mentioned, is indeed rather important; but I do not think it is sufficiently so to remove the deflorata from that particular section of Patula which embraces the gorgonarum, Bouvieri, and Bertholdiana, of the Cape Verde archipelago, and the Canarian $P$. garachicoensis. ${ }^{1}$

\section{(§ Janulus, Lowe.)}

\section{Patula bifrons.}

Helix bifrons, Lowe, Cambr. Phil. Soc. Trans. iv. 46. t. 5. f. 18 (1831)

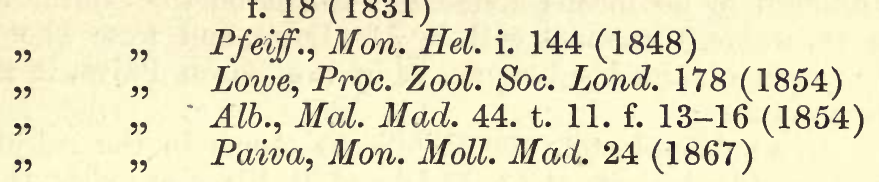

1 A species (which has been identified for me by Dr. Gwyn Jeffreys with the common European H. hispida, Linn.) has been communicated by Mr. Leacock, somewhat allied to the $P$. deflorata but very much smaller, several examples of which were taken many years ago in the garden of Mr. Hollway's house above Camacha, on the mountains to the eastward of Funchal, and which were 'imported from France along with some young apple trees.' Of course it has no connection with the true fauna of Madeira; nevertheless since there is some reason for suspecting that it may have established itself in that particular district (for I am informed by Mr. Leacock that specimens of it were found to have strayed immediately outside Mr. Hollway's grounds), it perhaps ought not to be passed over altogether in silence. It is a trifle larger and more depressed than the common European H. sericea, Drap., with an appreciably larger and more exposed umbilicus, and apparently quite free from hairs. And, as compared with the $P$. deflorata, in addition to its much reduced stature (the examples measuring only from about $3 \frac{1}{2}$ to 4 lines across their broadest part), it has its spire a little less flattened, its umbilicus relatively not quite so large, and its surface somewhat less coarsely costatestriate; its ultimate whorl, also, does not seem to be deflexed (as in that species) at the aperture. It may be briefly characterized as follows :

\section{Helix hispida, Linn.}

T. sat late umbilicata, rotundato-depressa, lenticularis, discoidea sed haud carinata, tenuis, nitidiuscula, leviter et.inæqualiter striatula, calva, pallide cornea sed hinc inde parcissime subalbido-marmorata; spirâ subdepressâ; anfractibus 6, convexiusculis, lente crescentibus, ultimo antice haud deflexo; umbilico spirali, profundo, sed haud valde lato; aperturâ lunatâ, peristomate tenui, acuto, marginibus non approximat is et laminâ subnullâ junctis.-Diam.

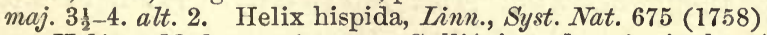

Habitat Maderam (certe a Galliâ introducta); in hortâ quâdam supra Camacha, circa 2,500' s. m., olim (teste D. Leacock) reperta. 
Habitat Maderam (vulgatiss.), Desertam Grandem (rarior), et Desertam australem (rariss.); hinc inde, in intermediis, sub lapidibus. In statu semifossili in Maderâ propriâ ad Caniçal abundat; necnon in summo etiam Desertæ Australis semifossilis exstat, sed ibidem rarior.

This is one of the most universal, and characteristic, of the Land Mollusca of Madeira proper, and one which occurs likewise, though more rarely, on the Desertas : but in Porto Santo it seems to be absolutely non-existent,-there being no traces of it in either a recent or a subfossil condition. In Madeira proper however it is extremely abundant, principally at intermediate but also at comparatively low elevations,-frequently swarming (as on the lofty sea-cliffs towards the Cabo Garajão, or Brazen Head) amongst loose stones and rubbish, as well as amongst the soil around the roots of shrubby plants. On the Northern Deserta (or Ilheo Chão) it has not yet been observed, though we may expect that it will sooner or later be found there; but on the Deserta Grande it is not very uncommon, although by no means abundant; whilst on the Southern Deserta, where it was met with by Mr. Lowe, and from whence it has been obtained subsequently by the Baron Paiva, it is extremely rare.

In a subfossil state the $P$. bifrons teems in the calcareous and muddy deposits at Caniçal; and it likewise exists, though much more sparingly, on the summit of the Southern Deserta.

The $P$. bifrons (which is rather variable in stature, adult specimens ranging from about 5 to 8 lines across the broadest part) may be known by its rather flattened, discoidal contour, pale corneous-yellow hue (often with a faint greenish tinge), and by the oblique and curved costæ with which its very numerous volutions are roughened. Its underside is shining and free from ridges (it being merely sculptured with radiating lines); its umbilicus is deep, but not large; the region about (or immediately before) its aperture is usually of a more decided yellow; and its apical whorls are for the most part whitish or decorticated.

\section{Patula stephanophora.}

Helix stephanophora, Desh., in Fer. Hist. 111. t. 90. f. 8. " calathus, Lowe, Ann. Nat. Hist. ix. (1852)

", stephanophora, Pfeiff., Mon. Hel. iii. 142 (1853)

" calathus, Lowe, Proc. Zool. Soc. Lond. 178 (1854)

" stephanophora, Alb., Mal. Mad. 44. t. 11. f. 17-20

(1854)

, calathus, Paiva, Mon. Moll. Mad. 25 (1867) 
Habitat Maderam; præcipue in intermediis sylvaticis, sed quoque ad rupes umbrosas maritimas, hinc inde vulgaris. In statu semifossili ad Caniçal sat copiose invenitur.

Although locally rather abundant, the $P$. stephanophora is very much rarer than the bifrons; and it is confined, apparently, to Madeira proper,- - where it occurs also in a subfossil state at Caniçal. In most of the damp ravines of an intermediate elevation (as, for instance, in the Ribeiro de Sta. Luzia, and the Ribeiro Frio) it may be taken more or less commonly,principally in the loose soil which has accumulated around the roots of ferns, and on the ledges of the rocks; but it is likewise to be met with on certain of the submaritime cliffs,- - such as the Cabo Garajão, and others in that direction.

The $P$. stephanophora is one of the most beautiful, and well-defined, of the Madeiran Land-Shells; and although its affinities are manifestly with the bifrons (with which it almost agrees in the size and proportions of its umbilicus,- the cavity of which however is rather more suddenly, or less gradually, scooped out), it differs from that species in being smaller and darker, in its under-parts being less shining, in its spire being less depressed, and in its volutions (the outer ones of which are relatively narrower or less developed) being elegantly sculptured with very much more raised, and less oblique, curved transverse costæ.

\section{(§ Patuloe normales.)}

\section{Patula calathoides.}

Helix calathoides (Paiva), Lowe, Ann. Nat. Hist. xii. 338 (1863)

" $\quad$ Paiva, Mon. Moll. Mad. 26. t. 2. f. 4 (186i)

Habitat Desertam Grandem, et (semifossilis) Desertam Australem; ab insulis primus discernit cl. Baronus de Paiva.

This most interesting Patula was obtained in a subfossil condition from the Southern Deserta (or 'Bugio'), by the Baron Paiva, in the spring of 1863 ; and since that period the Baron has recorded its occurrence in a living state on the summit of the Deserta Grande, from whence he received it in 1867 ; though I may add that I have not myself inspected it except from the former of those islands, and semifossilized.

The $P$. calathoides is extremely important localiy, as belonging to the same geographical type as the P. Guerineana of the sylvan districts of Madeira proper, and which differs from that of the common European $P$. rotundata (otherwise closely allied) in its still larger and more open umbilicus, its narrower 
and more numerous volutions, and in the coarser, fewer, and more elevated costæ (or folds) of its upper surface.

Indeed the present Patula (so far as I am able to judge from colourless and subfossilized examples) so nearly resembles the Madeiran P. Guerineana that it might well-nigh be supposed, at first sight, to represent but the quondam phasis of that species. When accurately looked at, however, it will be seen to possess a few differential characters of its own which will suffice to stamp it as a perhaps truly distinct, though proximate, member of the same local assemblage. Thus it is not only a little less flattened both above and below (the spire being just appreciably less depressed, and the under portion of the basal whorl conspicuously broader, convexer, and more developed), but its umbilicus is not quite so wide at the commencement, its keel is less pronounced (or somewhat more obtuse), and the costæ of its upper surface are not only still more elevated and regular, but likewise appreciably less oblique,-being more at right angles to the suture. What its colour may be, when in a recent condition, I have no means of deciding.

\section{Patula Guerineana.}

Helix Guerineana, Lowe, Ann. Nat. Hist. ix. 115 (1852)

", semiplicata, Pfeiff., Mal. Blätt. 63 (1852)

",$\quad$ Id., Mon. Hel. iii. 114 (1853)

" Guerineana, Lowe, Proc. Zool. Soc. Lond. 176 (1854)

" semiplicata, Alb., Mal. Mad. 19. t. 2. f. 11-14 (1854)

" " Paiva, Mon. Moll. Mad. 80 (1867)

Habitat Maderam; in sylvaticis intermediis rarior, sub foliis marcidis necnon in humidis latens.

This is one of the most elegant of the Madeiran IandShells, -its flattened, discoidal contour, added to its enormous umbilicus, its highly polished (and obliquely, though very obscurely, subfasciated) under-region, and the beautifully variegated bue of its coarsely costate volutions (which seem to be striped with alternate, but unequal, transverse bands of a lively reddish-brown and of a dirty whitish-yellow) giving it an appearance which it is impossible to mistake. Until lately it has been regarded as the Madeiran representative of the common European P. rotundata, Müll.; but, as already shown, it belongs to a rather different type,- characterised by its more numerous, narrower, and strongly costate whorls, by its brightly polished, nearly unsculptured inferior portion, and by its still larger umbilicus. And, apart from these points, it is more depressed, and (on the average) a trifle larger, than the $P$. rotundata, and its keel is sharper. Added to which, the latter 
species has itself been brought to light, within the last few years, in no less than two distinct, and distant, parts of the archipelago.

The P. Guerineana is decidedly a rare species, and one which is confined to the damp sylvan districts of Madeira proper at intermediate and lofty altitudes,-where it is most unmistakeably aboriginal, or indigenous. It occurs sparingly in many of the deep wooded ravines, in the interior of the island, beneath stones and decaying vegetable refuse, and was first detected (so far as I am aware) in the Levada of the Ribeiro Frio (into which it had fallen from the overhanging bank above) by Miss J. C. Guerin-after whom the species is named.

\section{Patula rotundata.}

Helix rotundata, Müll., Hist. Verm. ii. 29 (17:4)

Patula rotundata, Held, in Isis, 916 (1837)

Helix rotundata, Pfeiff., Mon. Hel. i. 105 (1848)

$\begin{array}{lll}" & " & \text { Morel., Hist. Nat. des Açor. 174 (1860) } \\ " & " & \text { Paiva, Mon. Moll. Mad. 81 (1867) } \\ " & \quad & \text { Watson, Journ. de Conch. } 222(1876)\end{array}$

Habitat Maderam, et (sec. B. de Paiva) ins. parvam juxta Portum Sanctum 'Ilheo da Fonte d'Areia' dictam; rarissima.

A single example of this common European Patula was obtained by the Baron Paiva (as asserted in his Monograph), during 1864, from the little uninhabited rock off the N.W. coast of Porto Santo known as the Ilheo da Fonte d'Areia; and it would appear that he has since received a few others from the same remote spot. I possess these specimens (which were transmitted to Mr. Lowe), and also several more which were taken by the Rev. R. B. Watson in 1866 at the Jardim da Serra (about 2,000 feet above the sea) in Madeira proper; so that I think we have no option but to admit the species into our catalogue. It would seem highly probable however that its presence at the Jardim da Serra may be the result of an accidental introduction from England during a comparatively recent period, inasmuch as it is well known that the late Consul Mr. Veitch was in the habit of receiving consignments of plants for his garden at the Jardim; but the existence of the shell on a distant and well-nigh inaccessible rock is a fact, if truly to be depended upon, which cannot be glossed over by any such supposition, and one which would tend to place the $P$. rotundata amongst the autochthones of the archipelago. Perhaps however its occurrence in even such a spot is, at any rate, not more remarkable than that of the European Balea perversa on the extreme summit of the Pico de Facho in Porto Santo, or 
than the equally rare appearance, in the subfossil deposits of that same island, of the common H. lapicida of more northern latitudes. However in Madeira proper it is not only at the Jardim that it has been met with, for Mr. Watson obtained a single example on some wild and uncultivated rocks in the Ribeira dos Soccorridos.

The $P$. rotundata may be known from the $P$. Guerineana (which is so characteristic of, and unmistakably indigenous in, the damp sylvan districts of Madeira proper) by being on the average a trifle smaller, but at the same time less flattened and less strongly keeled; by its volutions being wider, convexer, and less numerous, as well as regularly striated with sharp, hairlike, oblique ridges (instead of broad and irregular plicæ), and very much more obscurely clouded with suffused bands; by its umbilicus being smaller; and by the under-region of its basal whorl being not only larger and more inflated, but likewise almost opake and conspicuously sculptured with coarse radiating costate lines.

\section{(§ Pyramidula, Fitz.)}

\section{Patula pygmæa.}

Helix pygmæa, Drap., Hist. Nat. 114. t. 8. f. 9, 10 (1805).

$\begin{array}{lll}" & " & \text { Pfeiff., Mon. Hel. i. } 97(1848) \\ " & " & \text { Paiva, Mon. Moll. Mad. 78 (1867) } \\ " & \quad & \text { Watson, Journ. des Conch. } 222(1876)\end{array}$

Habitat Maderam, rarissime ; in Ribeiro de Vasco Gil, prope Funchal, a Revdo. R. B. Watson, A.D. 1866, reperta. Etiam semifossilis prope Caniçal a Dom. Watson occurrere dicitur.

This common little European Patula is one of the two or three Madeiran land-shells which I have not myself had an opportunity of inspecting. Indeed its introduction into the catalogue is comparatively recent, - a few examples having been found by the Rev. R. B. Watson, in the Ribeira de Vasco Gil, near Funchal, in 1866. Hitherto the P. pusilla, Lowe, has been looked upon (though, as it has always seemed to me, very erroneously) as the representative in Madeira of this minute species of more northern latitudes; but now that the true pygmoea has been brought to light, this can no longer be the case, unless indeed the latter should owe its presence in the island to recent accidental introduction from Europe,-a supposition, however, which will hardly be tenable if the assertion that it has been detected also in a subfossil state at Caniçal be correct. 


\section{Patula placida.}

Helix pusilla (pars), Lowe, Cambr. Phil. S. Trans. iv. 46. (1831)

" placida, Shuttl., Bern. Mitth. 140 (1852)

" " Pfeiff., Mon. Hel. iii. 82 (1853)

" pusilla, $\beta$. sericina, Lowe, Proc.Zool. Soc. Lond. 176 (1854)

" Luseana, Paiva, Journ. de Conch. xiv. 342. pl. 11. f. 9 (1866)

Id., Mon. Moll. Mad. 80. t. 2. f. 3 (1867).

Patula placida, Mouss., Faun. Mal. des Can. 25. pl. 2. f. 9-12 (1872)

Habitat Maderam ; sub cortice arborum, necnon inter muscos lichenesque ad truncos laurorum, in sylvaticis editioribus præcipue gaudens. Semifossilis prope Caniçal a Revdo. R. B. Watson, reperitur.

This minute Patula formed a portion of Mr. Lowe's $H$. pusilla (enunciated in 1831), and which in 1852 he separated from the still smaller, browner, and more depressed examples (the habits of which are different, and which have a tendency to be sculptured with remote hair-like costæ) as the ' $v a r . \beta$. sericina.' In the meanwhile however it had been published by Shuttleworth, under the name placida, from the Canarian archipelago.

I think there can be little doubt that the $P$. placida is truly distinct from the smaller and less turbinate form which constituted the type of the pusilla, Lowe; and its mode of life, too, is not the same,-for, whilst the pusilla (which possesses a very wide geographical range) occurs principally under stones, and within the hollows and crevices of scoriæ, in dry spots of a comparatively low elevation, the placilla, on the other hand, is attached normally to the sylvan districts of a higher altitude, where it congregates beneath the bark of trees, as well as amongst moss and lichen on the damp trunks of the old laurels. Under such circumstances it is universal throughout the wooded portions of Madeira proper, but it has not yet been observed in any of the other islands of the Group. In the Canarian archipelago it is equally common as at Madeira; and I have myself met with it in the forest regions of Teneriffe, Palma, and Hierro.

I may add that in Madeira the $P$. placida appears to be found likewise in a subfossil condition,-the Rev. R. B. Watson having informed me that he obtained it sparingly (along with the true $P$. pygmoca, Drap.) in the calcareous deposits near Caniçal. 
The $P$. placida is, on the average, a trifle larger than the pusilla, and it is also less depressed, or more turbinate, - the spire being comparatively elevated. It is usually too of a pale olivaceous brown, there being nearly always either a green or a yellowish tinge; and its surface, which has a somewhat sericeous appearance, is very densely and regularly crowded with minute hair-like lines,-unmingled with any coarser ones, such as are more or less conspicuous in the $P$. pusilla, and which are at times even sublamelliform.

The $P$. placida is a little smaller than the common European $P$. pygmoea, and with at least one volution less, its umbilicus is relatively not so large, and its colour is altogether different,the pygmoea being usually of a dark coffee-brown. The striæ also of the pygmoea, at any rate those on the underside, are more oblique.

\section{(§ Acanthinula, Beck.)}

Patula pusilla.

Helix pusilla, Lowe, Cambr. Phil. S. Trans. iv. 46. t. 5. f. 17 (1831)

Pfeiff., Mon. Hel. i. $101(1848)$
$" \quad$ servilis, Shuttl., Bern. Mitth. $140(1852)$
$" \quad$ Pfeiff., Mon. Hel. iii. $101(1853)$
$" \quad$ pusilla, a. annulata, Lowe, Proc. Zool. Soc. Lond. 176 (1854)

" $\quad$ Alb., Mal. Mad. 18. t. 2. f. 7-10 (1854)

", servilis, Morel., Hist.Nat.des Açor. 173. t. 3. f. 6 (1860)

" $\quad$ Paiva, Mon. Moll. Mad. 79 (1867)

" hypocrita, Dohrn., Mal. Blätt. 1 (1869)

Patula servilis, Mouss., Faun. Mal. des Can. 25. pl. 2. f. 13-16 (1872)

Habitat Maderam, et Desertam Grandem; sub lapidibus, necnon in fissuris scoriæ, præcipue in aridis inferioribus, latens.

As already mentioned, this extremely minute Patula is the type of Mr. Lowe's Helix pusilla,-the rather larger, less depressed, and olivaceous $P$. placida, which was mixed up with it by him, having been separated in only his later catalogue (under the name 'var. $\beta$. sericina') as at any rate a distinct form. Mr. Lowe's original diagnosis (in 1831) seems to have been drawn out from the typical (or smaller) shell; whilst his 'Habitat in Maderæ sylvis' manifestly applies to the larger one,-afterwards treated by him as the 'var. $\beta$. sericina,' but previously published by Shuttleworth (in his Canarian diagnoses) under the name of $H$. placida. The pusilla proper, which is smaller, browner, and more depressed than the placida (or 
pusilla, $\beta$. sericina' of Lowe), occurs, unlike the latter, in dry and rocky spots of a comparatively low altitude,- where it may be met with more particularly beneath stones, on old walls, and within the cavities of scoriæ. In such situations it abounds throughout Madeira proper, and was obtained by Mr. Lowe and myself, not uncommonly, on the Deserta Grande.

The $P \cdot$ pusilla is manifestly, however, a species of a widely acquired range, - for it is found in the Azorean and Canarian groups, and five examples of it are now before me which were communicated by Dr. H. Dohrn (having been described by him under the name ' $H$. hypocrita') from S. Antão in the Cape Verde archipelago. I may add that I have inspected these types of the hypocrita with the greatest care, and that they are absosolutely undistinguishable (so far as I can perceive) from the ordinary Madeiran and Desertan specimens of the pusilla. I likewise met with the species, during 1875 and 1876, in the intermediate districts of even St. Helena.

This minute Patula differs from the $P$. placida in being a little smaller, browner, and more depressed (its spire being appreciably less elevated), and in its volutions having a greater or less tendency to be furnished with a few additional, remote, more decidedly raised, hair-like lines, which are occasionally so much developed as to be quite conspicuous, and even to appear (at first sight) almost lamelliform. These thread-like lines, however, are more often so indistinct that they can be observed only beneath a high magnifying power.

\section{Genus 7. HELIX, Linné.}

\section{(§ Vallonia, Risso.)}

\section{Helix pulchella.}

Helix pulchella, Müll., Hist. Verm. ii. 30 (1774)

\begin{tabular}{|c|c|c|}
\hline & " & Lowe, Cambr. Phil. S. Trans. iv. 45 (1831) \\
\hline & 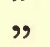 & Id., Proc. Zool. Soc. Lond. 176 (1854) \\
\hline & " & Alb., Mal. Mad. 45.t. 12. f. 1-4 (1854) \\
\hline & , & Paiva, Mon. Moll. Mad. 77 (1867) \\
\hline & $\eta$ & Mouss., Faun. Mal. des Can. 75 (1872) \\
\hline & , & Watson, Journ. de Conch. 222 (1876) \\
\hline
\end{tabular}

Habitat Maderam, et (sec. B. de Paiva) etiam Desertam Australem; hinc inde sub lapidibus, præcipue in cultis.

This widely spread little Helix, so common throughout Europe, and which occurs also in the Azorean and Canarian archipelagos, and which I met with at St. Helena, and which was taken by Mr. Benson even at the Cape of Good Hope, is tolerably abundant around Funchal (and in similar cultivated 
districts) in Madeira. I have not myself observed it in any of the other islands of the group, but it is recorded by the Baron Paiva as existing sparingly on the Southern Deserta or Bugio; though I cannot but suspect that this latter habitat must be regarded as still requiring corroboration.

\section{(§ Campylaa, Beck.)}

\section{Helix Lowei.}

Helix portosanctana, $\beta$. gigantea, Lowe, Cambr. Phil. S. Trans. iv. 46. t. 5. f. 16 (1831)

" Lowei, Fer., Bull. de Zoolog. $89(1835)$
$" \quad$ " Pfeiff., Mon. Hel. iii. 233 (1835)
$" \quad$ " $\quad$ Lowe, Proc. Zool. Soc. Lond. 169 (1854)
$" \quad$ Alb., Mal. Mad. 82. t. 17. f. 11, 12 (1854)

Habitat Portum Sanctum; in statu semifossili vulgaris. Etiam recens cl. J. M. Moniz, sub lapide magno (quasi sepulta), in ins. parvâ ' Ilbeo de Cima' dictâ, semel detexit.

The $H$. Lowei (the larger examples of which measure upwards of two inches across the broadest part) stands pre-eminent amongst the Madeiran Helices for its gigantic stature; but it has been a question, with various monographers, whether it should be regarded as anything more, in reality, than the quondam, highly-developed state of the present $H$. portosanctana-which in nearly all respects except size it closely resembles. Without entering into this problem, which is perhaps unsolvable, I will merely add that it has more often been looked upon latterly as specifically distinct; a supposition which is rendered none the less probable from its having been lately ascertained not to belong altogether to a fauna that has passed away,-a single living example, which was found by Senhor J. M. Moniz beneath a large stone (and at a considerable depth underground) on the little island known as the Ilheo de Cima, proving to a demonstration that the species, in an unaltered condition, still lingers on, and that too in company with its modern analogue the $H$. portosanctan $\alpha$.

But considering how abundant the $H$. Lowei is in the subfossiliferous beds of Porto Santo, there can be little doubt that the species (which is now practically all but extinct) was once dominant; whilst the comparative rarity of the $H$. portosanc$\tan a$ in a semifossilized condition would seem as if the former had in some measure been supplanted by the latter (which at present is so universal). Still, I do not think that we have sufficient evidence for assuming that the one has been, by any fancied process, altered into the other,-for intermediate links do 
not occur (either subfossil or recent), and there would seem to be a few characters, apart from the very great dissimilarity of stature, which may serve to separate the two forms. Thus the H. Lowei appears to be less evidently subpunctulated (or minutely asperate), even beneath a high magnifying power ; and the three large fasciæ which are nearly always more or less traceable on the portosanctana, and which are at times so broadly developed as to be. subconfluent, are uniformly reduced in the $H$. Lowei (when in a sufficiently perfect condition for the colour to be preserved at all) to two narrow, thread-like lines, - - the upper cloudy band, below the suture, being obsolete. And there is likewise no appearance of the $H$. Lowei having been (like the portosanctana) infinitesimally hispid; though this perhaps may be merely owing to the surface having been necessarily somewhat worn, or altered, in the process of decortication.

The $H$. Lovei is locally abundant in many of the subfossiliferous deposits in Porto Santo, and it is also common in those on the immediately adjoining Ilheo de Baixo; but the single example to which I have already alluded, as having been taken by Senhor Moniz on the Ilheo de Cima, embodies the only instance (so far as I am aware) in which the species has been observed in a recent state.

\section{Helix portosanctana.}

Helix portosanctana, Sow., Zool. Journ. i. 57. t. 3. f. 5 (1824)

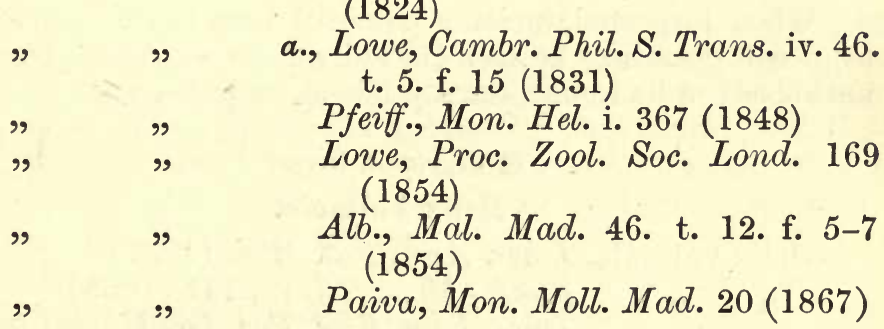

Habitat Portum Sanctum, insulas̃que parvas adjacentes; sub lapidibus vulgaris. In statu semifossili minus frequens.

As already mentioned, the $H$. portosanctana (which is peculiar to Porto Santo and the immediately adjacent islets) may be regarded as the modern representative of the subfossil, and comparatively gigantic, $H$. Lowei ; yet, for reasons which have been assigned, I do not think that we possess sufficient evidence for considering the two to be but altered phases of a single species. The fact that both of them were members of the ancient fauna (the portosanctana being then scarce, and the Lowei abundant), 
and that both are still living (the Lowei being all but extinct, whilst the portosanctana is universal), in conjunction with the circumstance that there are no traces of genuine intermediate links (either fossil or recent), would seem to imply, at any rate to my mind, that the two forms were aboriginally distinct, but that they have been slowly changing places as regards ascendency.

The $H$. portosanctana passes through. many degrees of colour and outline,-some examples being abruptly banded, and others with the fasciæ so greatly increased and suffused that they appear at first sight to be well-nigh unicolorous; whilst many specimens have the spire comparatively elevated, and others comparatively depressed. But there is one form (amongst the numerous others, more or less slightly differing) which may properly be noticed as more salient than the rest, but which does not seem to have been sufficiently brought forward by Mr. Lowe. I allude to the particular phasis which occurs more especially (though intermingled with the ordinary type) on the Ilheo de Cima, and which is (on the average) rather larger, flatter, and thinner than is usually the case, with the umbilicus generally wide and open, and with the surface for the most part darker (the fasciæ being broad and suffused), as well as (when viewed beneath a high magnifying power) more thickly and decidedly subpunctulate. This aspect of the shell, which I think perhaps is the only one which it is worth while to single out as a positive 'variety,' we may be permitted to record as the 'var. $\beta$. cimensis.'

When inspected under a powerful lens, the $H$. portosanctanc will generally be seen (in individuals which are fresh and unrubbed) to be infinitesimally hispid, or pubescent.

\section{(§ Cryptaxis, Lowe.)}

\section{Helix Vulcania.}

Helix vulcania, Lowe, Ann. Nat. Hist. (1852)

\begin{tabular}{|c|c|c|}
\hline פי & " & Pfeiff., Mon. Hel. iii. 147 (1853) \\
\hline , & 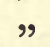 & Lowe, Proc. Zool. Soc. Lond. 168 (1854) \\
\hline & , & (́pars), Alh., Mal. Mad.48.t.13.f.4-6 (1854) \\
\hline & و & Mon Moll Mad 17 (1867) \\
\hline
\end{tabular}

Habitat Desertam Borealem, et Desertam Grandem; sub lapidibus vulgaris.

The $H$. portosanctana, the Vulcania (with its closely allied $H$. leonina), and the undata may be regarded as strictly ' representative' species, - the first being peculiarly Porto-Santan, the second Desertan, and the third Madeiran ; yet it is impossible to treat them practically as, in any degree, insular modi- 
fications of each other. Indeed the portosanctana belongs to a rather different type (characteristic of Beck's section Campy$l o c a)$, in which the umbilicus is open, and the tendency of the surface is to be very minutely hispid or pilose; whereas in Cryptaxis, Lowe, which embraces the other two forms, the umbilicus is closed up (at any rate in the adult shells), and the surface, although more or less malleated or uneven, is glabrous : and it will be gathered therefore from this circumstance, that the exponents from Madeira proper and the Desertas are more nearly akin inter se than they are to the one from Porto Santo.

The H. Vulcania has been found hitherto only on the Northern and .Central Desertas, ${ }^{1}$ its place on the southern island being supplied by the very intimately related (but more largely developed) $H$. leonina-which likewise makes its appearance towards the southern extremity of the Central Deserta (or Deserta Grande). And indeed were it not for this lastmentioned fact, I should certainly have been inclined to treat the H. leonina as a mere enlarged and exaggerated phasis (or insular modification) of the Vulcania; but since the two forms co-exist on the central island, that conclusion would hardly be tenable. Nevertheless I am by no means satisfied that the $H$. leonina is more in reality than the (locally) more southern aspect of the Vulcania, for it must be admitted that we have a very gradual and curious progression, as regards contour, from the Northern Deserta (or Ilheo Chão) to the southern one (or Bugio), - the examples from the former of those islands being a little flatter and less malleated than the ones (equally referable to the Vulsania proper) from the Deserta Grande ; whilst the characters of the leonina, which makes its first appearance towards the southern end of the Deserta Grande, and which reigns supreme on the Bugio, are merely those of the $\mathrm{H}$. Vulcania but (particularly on the southern island) exaggerated. However since both the Vulcania and leonina exist on the Deserta Grande, I think that we may practically refuse to treat them as insular states of each other, and may so find it more convenient to register them as distinct.

The H. Vulcania (and leonina) may be said, in a general sense, to combine the fasciated surface of the portosanctana with the closed-up umbilicus and more or less malleated sculpture of the Madeiran $H$. undata. However, the lower band, which is nearly always present in the portosanctana, is in the

1 The Baron Paiva cites the Southern Deserta also for the $H$. Vulcania; but since his material was never obtained by himself, but was brought to him by paid collectors (who were neither over-accurate nor over-scrupulous), I cannot without further evidence place any reliance on that particular labitat. 
Vulcania obsolete,-causing the basal volution to be two-, instead of three-fasciated; and the upper band (just below the suture) has a greater or less tendency to be broken-up or interrupted,-giving a somewhat dappled, or tessellated, appearance to the anterior region of each whorl. The ground-colour of the $H$. Vulcania is an olivaceous brown; and the volutions are obliquely striated with irregular, sub-undulating, more or less confluent ribs,-imparting a malleated character to the whole.

The examples of this shell from the Northern (or Flat) Deserta may be looked upon as the most typical ones for the species, and they are (on the average) a little more depressed (and perhaps a trifle smaller) than those from the Deserta Grande, the basal whorl being somewhat less inflated and with a more evident tendency to have an obsolete keel; and their surface is rather more closely, and not quite so coarsely striate, or so conspicuously malleated. The very slightly altered aspect of the $H$. Vulcania from the Deserta Grande, or central island, we may perhaps cite as the 'var. $\beta$. desertoe'

The $H$. Vulcania was first detected by Mr. Leacock, in June, 1848; and it has subsequently been met with by Mr. Lowe, myself, and others, in considerable profusion, on both of the more northern Desertas.

\section{Helix leonina.}

Helix leonina, Lowe, Ann. Nat. Hist. ix. (1852)

"Vulcania, var., Pfeiff., Mon. Hel. iii. 148 (1853)

" leonina, Lowe, Proc. Zool. Soc. Lond. 168 (1854)

"Vulcania, var. $\beta$., Alb., Mal. Mad. 48. t. 13. f. 1-3 (1854)

" leonina, Paiva, Mon. Moll. Mad. 18 (1867)

Habitat Desertam Australem, vulgaris; necnon etiam (var. a. intermedia) Desertam Grandem, sed ibidem rarior.

As already mentioned, this may perhaps represent but an enlarged and local modification of the $H$. Vulcania ; nevertheless it certainly is not an insular one, inasmuch as it co-exists with that species on the Deserta Grande; and, whatever therefore be the true state of the case, I think that it will practically be more eonvenient to cite it as distinct.

The $H$. leonina is larger and more highly coloured than the Vulcania, -its basal volution being more inflated, and with the two bands (the anterior one of which has scarcely any tendency to be broken-up or tessellated) more broadly developed; its surface is even still more coarsely malleated; and its columella is proportionately longer.

It is on the Southern Deserta (or Bugio) that the H. leonina 
is more particularly dominant, and where it may be said to attain its maximum. In the central island it just makes its appearance, on the abrupt eastern side (towards the south), in a spot known as the Feijãa Grande ; where however the specimens, which we may register as the 'var a. intermedia,' are (on the average) a little smaller and darker than those from the Bugio.

\section{Helix undata.}

Helix undata, Lowe, Cambr. Phil. S. Trans. iv. 41. t. 5. f. 5 (1831)

\begin{tabular}{|c|c|c|}
\hline & "צ & Pfeiff., Mon. Hel. i. 191 (1848) \\
\hline & פי & Lowe, Proc. Zool. Soc. Lond. 168 (1854) \\
\hline & " & Alb., Mal. Mad. 50. t. 13. f. 13-16 (185 \\
\hline
\end{tabular}

Habitat Maderam ; sub lapidibus necnon ad muros, præcipue in cultis inferioribus, congregans. In stratu conchylifero ad Caniçal semifossilis occurrit.

This is one of the most universal, and characteristic, of the Land-Shells of Madeira proper,- to which island it would seem to be peculiar, and where it often swarms, beneath stones and about old walls, chiefly at rather low elevations and in cultivated spots; and it occurs likewise in a subfossil state, though in no great profusion, at Caniçal.

The $H$. undata is more nearly related to the $H$. Vulcania and leonina, of the Desertas, than to any other species which has hitherto been brought to light. Indeed with the 'var. $a$. intermedia' of the latter, from the Deserta Grande, it has a good deal in common; nevertheless it is considerably smaller and less inflated (or globose), even still more undulate in its sculpture, and also of a uniform and paler brown,- - there being no traces whatsoever of fascia, or bands, on any of the volutions.

\section{(§ Katostoma, Lowe.)}

\section{Helix psammophora.}

Helix psammophora, Lowe, Ann. Nat. Hist. ix. 113 (1852)

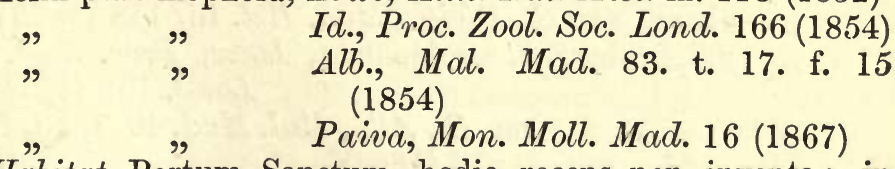

Habitat Portum Sanctum, hodie recens non inventa; in arenâ calcareâ conchyliferâ semifossilis reperitur.

This Helix, which is peculiar to Porto Santo, has been found hitherto only in a subfossil state,-it being rather 
common in many of the calcareous deposits, where I believe that it was first met with by myself.

The H.psammophora belongs to the same type as the phlebophora,-from which however it differs in its somewhat smaller size and more elevated spire, in its basal volution being a little more deflexed at the aperture (which is just appreciably rounder), and in its entire surface being (instead of coarsely malleated and confluently costate-striate) densely crowded with large granules, which are elegantly arranged (not exactly on ridges, but) in oblique irregular rows.

In general size and cuntour the $H$. psammophora has more in common with the 'var. $\delta$. craticulata' (which was detected by myself on the Ilheo de Ferro) than with any other form of the $H$. phlebophora; nevertheless its totally different sculpture (the $\delta$. craticulata being quite free from granules, and even more malleated than the ordinary type) will at once separate it.

\section{Helix phlebophora.}

Helix phlebophora, Lowe, Cambr. Phil. S. Trans. iv. 41. t. 5. f. 6 (1831)

" nivosa, Pfeiff., Mon. Hel. i. 192 (1848)

" phlebophora, a. chlorata, Lowe, Proc. Zool. Soc. Lond. 166 (1854)

" $\quad$ "Alb., Mal. Mad. 49. t. 13. f. 7, 8 (1854)

var. $\beta$ " Paiva, Mon. Moll. Mad. 15 (1867)

Helix phlebophora, $\beta$. planata, Lowe, Proc. Zool. Soc. Lond. 166 (1854)

" $\quad$ (pars), Alb., Mal. Mad. 49. t. 13. f. 9, $10(1854)$

var. $\gamma$. nivosa [pallida, immaculata].

Helix nivosa, Sow., Zool. Journ. i. 56. t. 3. f. 3 (1824)

" phlebophora, $\gamma$. decolorata, Lowe, Proc. Zool. Soc. Lond. 166 (1854)

var. $\delta$. craticulata.

Helix craticulata, Lowe, Ann. Nat. Hist. ix. 113 (1852)

" nivosa, var. B., Pfeiff., Mon. Hel. iii. 148 (1853)

" phlebophora, $\delta$. scrobiculata, Lowe, Proc. Zool. Soc. Lond. 166 (1854)

99 var. $\beta .$, Alb., Mal.Mad. 49. t. 13. f. 11, $12(1854)$

" $\quad$ " var. a., Paiva, Mon. Moll. Mad. 15 (1867)

Habitat Portum Sanctum, insulasque parvas adjacentes; 
vulgatissima. Necnon in solo arenoso semifossilis occurrit. Var. $\delta$. craticuata ad insulam 'Ilheo de Ferro' solum recens pertinet; sed in statu semifossili in Portu Sancto ipsissimo late reperitur.

This is one of the most abundant and universal of the Helices of Porto Santo, - to which island, and the immediately adjacent rocks, it would seem to be peculiar; and it is tolerably common in a subfossil state,-particularly under the phasis which I have eited as the ' $\delta$. craticulata,' Lowe, which in a recent condition occurs now only on the Ilheo de Ferro.

The $H$. phlebophora may be known by its more or less globose, strictly Helix-shaped, or subtrochiform, contour, and by its variegated (or fasciated) surface, which is more or less coarsely malleate and beset with oblique and very irregular subconfluent costate lines, - a peculiarity of sculpture which imparts a wrinkled appearance to the whole.

The present species, however, passes through many degrees of colour, outline, and sculpture,- the four principal ones being [1] the normal state (corresponding with the ' $a$. chlorata,' Lowe), in which the shell is comparatively globose, and the corrugations of the surface are more developed than the costæ; [2] a more depressed form (answering to Lowe's ' $\beta$. planata'), in which the spire is a little less raised, the surface, on the average, a trifle paler and more variegated (the bands being narrower, and more broken-up or interrupted), and in which the oblique irregular costæ are more sharply developed; [3] a yellowish-white, almost colourless or albino variety, free from fasciæ and markings but otherwise agreeing with the " $a$. chlorata,' Lowe, - and which represents the $H$. nivosa of Sowerby; and [4] a smaller, darker, and a more beautifully dappled phasis, with the corrugations very coarse and large but with the ridges almost obsolete, and with the spire relatively a little more elevated, peculiar apparently (at any rate in a recent condition) to the small islet known as the Ilheo de Ferro (where it was first detected by myself), - and which was described by Mr. Lowe in 1852 (under the name of $H$. craticulata) as distinct, but which in 1854 he suppressed as a species, citing it as the 'var. $\delta$. scrobiculata' of the H. phlebophora.'

1 By a glance at the synonyms given above, it will be seen that in reality Sowerby's name 'nivosa' is the prior one for this Helix, by many years, - it having been published in 1824, whereas Mr. Lowe's 'phlebophor'a' did not make its appearance until 1831. If therefore it be insisted that priority outweighs every other consideration whatsoever (even, for instance, the employment of a title which conveys an absolutely false idea of the species to which it has reference), the change in the nomenclature must of course be made. Under ordinary circumstances I should myself have marle it; but since the name phlebophora has almost universally been allowed for this Helix, on 
(§ Tberus, Monf.)

\section{Helix Wollastoni.}

Helix Wollastoni, Lowe, Ann. Nat. Hist. ix. (1852)

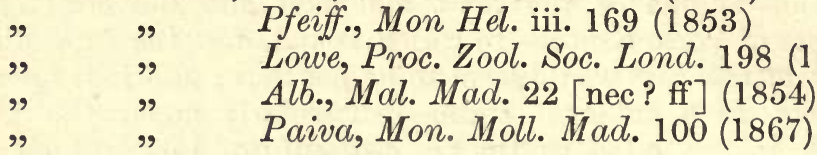

Habitat Portum Sanctum; in monte orientali 'Pico do Concelho,' sub lapidibus vulgaris. Semifossilis ad, necnon juxta, Zimbral d'Areia præcipue invenitur.

Peculiar to Porto Santo, where it was first detected (in a recent state) by myself, during Aprll of 1849, on the slopes of the Pico do Concelho, in the east of that island,-having, however, been found in a subfossil condition by Mr. Lowe so far back as in 1828. It swarms, beneath stones, on that particular mountain, but I have never met with it elsewhere ; and even in a subfossil state it is only at the Zimbral d'Areia (which abuts on the base of the Pico do Concelho), and in its vicinity (as, for instance, in the muddy deposits of a sea-cliff below the Pico dos Maçaricos), that it has hitherto, so far as I am aware, been brought to light. ${ }^{1}$

The $H$. Wollastoni may be known by its acutely carinated basal volution, and minutely granulose, obliquely plicate surface,-the plicæ being more or less undulate, irregular, and here and there confluent. In colour it is usually of an olivaceous- or yellowish-brown, and with two very obscure darker bands on each whorl,-generally so obscure as to be barely traceable, but often appreciably developed; and the under-part of the ultimate volution is either altogether concolorous, or else ornamented with a narrow darker fascia at $\alpha$ little distance from the keel.

The present Helix belongs to the same type as the subfossil Canarian $H$. digna, Mouss., from Gomera, and (more especially) as the Sicilian H. scabriuscula, Desh. (Encycl. Meth. ii. 130), with which latter indeed it has a great deal in common. It is, however, smaller and rather less flattened than the scabriuscula (its spire being more exserted), its oblique transverse rugce are more elevated or developed, its keel (which is less compressed)

account of the unfortunately selected one which was previously imposed upon it by Sowerby, I have thought it sufficient merely to call attention to the fact,-leaving the alteration in the hands of those who may regard it as necessary.

' In the Baron Paiva's Monograph an albino state of the H. Wollastoni is mentioned as occurring on the Pico Branco; but I feel it exceedingly probable that that habitat was inserted through a lapsus calami, or by mistake. 
merges entirely into the suture at the commencement of the penultimate whorl (instead of being minutely raised above it, and so more or less faintly traceable up the spire), its umbilicus is always completely closed over, its peristome has the two lips more evidently connected by a corneous callosity, and the portion towards the axis internally broader, and its surface is not only more opake and granulated but totally different in hue,being dark and often obscurely banded, instead of nearly white.

I possess eight examples of the $H$. Wollastoni which are so nearly intermediate between that species and the phlebophora (!) that it is almost impossible to tell at first sight, to which of the two they should be assigned. They are smaller and less granulated than the ordinary type, and very much less distinctly keeled; and I may perhaps cite them as the 'var. a. subdubia.'

\section{Helix forensis, n. sp.}

T. omnino imperforata, subdiscoidea, utrinque convexiuscula, mediocarinata, opaca, ubique densissime granulata plicisque valde obliquis remotis subundulatis subirregularibus instructa, supra subinæqualiter vel marmoratim rufo-brunnea nucleo (læviore, prominente) subroseo, sed subtus in medio (i.e. intus fasciam latam marginalem) pallidior aut magis flavescens; anfractibus $5 \frac{1}{2}$ planiusculis, ultimo antice valde descendente, sutura distinctissimâ, impressâ; aperturâ valde obliquâ, labris conniventibus, laminâ callosâ, incrassatâ, albidâ (intus roseâ) junctis; peristomate roseo, basi reflexiusculo, axin versus incrassato et ibidem dilatato-plano.-Diam. maj. 9 lin.; alt. $4 \frac{1}{2}$.

Helix Wollastoni, Alb., Mal. Mad. t. 4. f. 1-3 [nec diagn.] (1854)

Habitat ins. parvam 'Ilheo de Fora' dictam, juxta Portum Sanctum [nec Ilheo de Fora juxta Maderam; nec etiam in Portu Sancto ipsissimo]; a DD. Leacock et Moniz olim communicata.

Obs.-H. Wollastoni affinis, sed nisi fallor vere distincta. Differt testâ minore, densius rugosiusque granulatâ (quare omnino opacâ), necnon obscurius coloratâ,-sc. submarmoratim rufo-brunneâ (nucleo magis prominulo, læviore, roseo), nec supra etiam obscure fasciatâ, subtus in medio solum pallidiore, fasciâ exteriore usque ad carinam ipsam extendente; aperturâ paululum magis rotundatâ (aut subminus carinatim angulatâ), labris callo crassiore junctis.

Several examples of this shell (which Albers appears to have figured as the $H$. Wollastoni, Lowe, whilst drawing out his 
diagnosis from the type of the latter) were communicated by Mr. Leacock and Senhor J. M. Moniz, about 15 years ago, as having been taken on the 'Illheo de Fora,'-a little islet off the eastern coast of Porto Santo, opposite to the Pico do Concelho (of the mainland) which is the sole locality (so far as I am aware) for the H. Wollastoni; and others have since been received from the same spot by the Baron Paiva. They have consequently been placed aside, for a considerable period and without further examination, as representing in all probability a smaller phasis, or variety, of the $H$. Wollastoni, which in most of their features they nearly resemble; and it must be admitted that the situation of their habitat-namely a little islet exactly facing the particular mountain in Porto Santo which seems alone to harbour the $H$. Wollastoni-would tend to favour the idea of an 'insular modification' of that species. Still, when closely inspected, the distinctive characters appear to me to be too important and numerous to render it safe to treat the present Helix as a mere phasis of the last one; and although it is not alsolutely impossible that in reality it may be so, I will only remark that there would be a primâ facie inconsistency about admitting it as such, while at the same time allowing the specific claims of the $H$. Iyelliana, as distinct from the Bulveriana, or those of the Lowei and Bowdichiana, as distinct from the portosanctana and punctulata.

Judging from a long array of examples which are now before me, the $H$. forensis differs from the $H$. Wollastoni in being smaller, and more densely and roughly granulated, and therefore more opake, in its spire being somewhat more raised, the nucleus especially (which is more shining, lightly sculptured, and rosy) being more prominent, in its aperture being a little rounder (or less sharply angled at the keel), in its upper and lower lips being joined across the body-volution by a more thickened corneous process, and by its colour being considerably darker, or of a more reddish marbled-brown. Indeed its coloration is on a rather different pattern,- the volutions not being ever (even indistinctly) fasciated, but unequally suffused all over with the obscurer tint; whilst the single band on the underside is broad and completely lateral, - extending to the very edge of the keel, instead of being (when present at all) narrow and removed to a certain distance from it.

\section{(§ Mitra, Albers.)}

\section{Helix Webbiana.}

Helix Webbiana, Lowe, Cambr. Phil. S. Trans. iv. 44. t. 5. f. 10 (1831) 
Helix Webbiana, Pfeiff., Mon. Hel. i. 219 (1848)

" " Lowe, Proc. Zool. Soc. Lond. 197 (1854)

" $\quad$ Alb., Mal. Mad. 53. t. 14. f. 13-15 (1854)

V" Paiva, Mon. Moll. Mad. 98 (1867)
Vitrina Bocagei, Paiva [testa junior] 1. c. 10. t. 2. f. 6 (1876)

Habitat Portum Sanctum, et ins. parvam adjacentem ' Ilheo de Cima'; sub lapidibus in graminosis montium degens. In statu semifossili parcissime reperitur.

This most remarkable of the Helices of the Madeiran archipelago appears to be confined to Porto Santo, and the little adjacent island of the 'Ilheo de Cima' (where it was taken sparingly by Senhor J. M. Moniz); and, although not very generally abundant, it is locally far from uncommon,-beneath stones, and usually at a rather high altitude. It is true that the Baron Paiva cites it as occurring likewise on the Southern Deserta ; but I can only say that no traces of it were observed there either by Mr. Leacock, Mr. Lowe, or myself, and that until further evidence therefore has been adduced I shall refuse to regard it as in any way connected with that remote and little-known rock,--and more particularly so, since the Baron's material was seldom, if ever, obtained by himself, but was merely brought to him (at intervals) by paid collectors sent out from Funchal. But on many of the higher mountainslopes of Porto Santo it has been met with by Mr. Lowe, Mr. Leacock, myself, and others, in tolerable numbers,--especially on the ascent of the Pico Branco, the Pico do Concelho, aud the Pico de Baixo. In a subfossil condition it is scarce, but was taken by Mr. Lowe and myself at the Zimbral d'Areia, and in several of the other calcareous deposits.

In the paucity of its whorls, its brownish-green hue, its thin, shining, subpellucid substance, its total freedom from an umbilicus, its enormous aperture, and in its upper and lower lips being quite unconnected by a corneous lamina, the $H$. Webbiana has a slight primâ facie element in eommon with the genus Vitrina; ${ }^{1}$ and it is further conspicuous by its acutely developed keel, and by the fact of its being more or less studded with coarse and remote granules,-which however become gradually evanescent towards the inner portion of the (very obliquely striated) volutions. Its peristome is a good deal

1 It is remarkable that the Vitrina Bocagei of Paiva (Mon. Moll. Mad. 10. t. 2. f. 6), recorded (evidently through an error) to have been taken in Madeira proper, was established, as I am assured by the Rev. R. B. Watson, on an immature example of the Helix Webbiana! (cf., also, Journ. de Conch. 219 ; 1876.) 
reflexed, and the central part of its underside is of a paler and more olivaceous tint than the rest of the shell.

The $H$. Webbiana has a greater affinity with the $H$. cuticula, Shuttl., of the Canarian Group, than with anything else with which I am acquainted; and, although abundantly distinct, there can be little doubt that the two species have something in common. The $H$. cuticula, however, is a great deal smaller, being in fact comparatively diminutive; and, although perhaps not quite so shining, it is vory much thinner, paler, greener, more pellucid, and more Vitrina-like; its keel too is not only more compressed, but also not completely merged into the suture at the penultimate volution,- it being traceable up the spire (which is relatively a trifle more elevated); and its peristome is not reflexed.

\section{(§ Leptaxis, Lowe.)}

\section{Helix chrysomela.}

Helix œnostoma, Lowe (olim), in litt.

" chrysomela, Pfeiff., Mon Hel. i. 281 [sed vid. p. 447] (1848)

" $\quad$ " Lowe, Proc. Zool. Soc. Lond. 167 (1854)

" fluctuosa, Alb., Mal. Mad. 82, t. 17. f. 13-14 (1854)

" $" \quad$ var. a. chrysomela, Paiva, Mon. Moll. Mad. 19 (1867)

var. $\beta$. fluctuosa.

Helix fluctuosa, Lowe, Ann. Nat. Hist. ix. (1852)

$" \quad$ " $\quad$ Id., Proc. Zool. Soc. Lond. 167 (1854)

Habitat Portum Sanctum, hodie recens non inventa; in solo calcareo semi-fossilis copiose reperitur.

The $H$. chrysomela has been found hitherto only in a subfossil state, and only in Porto Santo,-where it is extremely common, both in its smaller and its larger phasis. It is to the former of these that the name chrysomela was applied (in 1848) by Pfeiffer (who, however, by mistake cited the species as Brazilian),- - the larger one having been subsequently enunciated by Mr. Lowe, in 1852, under that of fluctuosa, as specifically distinct. And thus, on the principle of priority, Pfeiffer's title takes the precedence, and the race which he described must be treated as the type. And this being the case, it is perhaps somewhat fortunate that they are both about equally abundant, and that it matters but little, therefore, which of them be looked upon as normal.

Owing to the necessarily bleached condition of semifossilized specimens, it is well-nigh impossible to detect the law of colo- 
ration in this species; but in some examples there are evident traces of a narrow darker interrupted (or tessellated) fascia on the hinder edge of each volution, which is particularly visible above the keel of the basal one, and likewise a similar one (at some distance from the keel) on the underside; and in the smaller (or typical) state of the shell the peristome and the lamelliform callosity which unites its upper and lower halves preserve an abruptly-defined and conspicuous reddish-yellow hue. Indeed this last-mentioned peculiarity is one of the main distinctive features in Pfeiffer's diagnosis; nevertheless occasional specimens of even this smaller phasis have the peristome colourless, whilst the exponents of the larger race (or fuctuosa, Lowe) have never any indication of a brilliant hue about the aperture (which is uniformly white). But, apart from its diminished size and this colouring of the peristome, the typical state differs from the larger one (or fluctuosa, Lowe) in having its keel less acutely developed, its whorls just perceptibly more tumid, and its entire surface more uneven or malleate, though rather less evidently sculptured with minute oblique striæ. Nevertheless, in nearly all their features, I think that the two aspects of the shell pass imperceptibly into each other. Both of them also (particularly however the larger one) have, as just mentioned, a slight tendency to be freckled, or blotched, with a few opake milky markings, -in all probability occupying the positions of former interrupted fasciæ, or patches.

The affinities of the $H$. chrysomela are manifestly with the $H$. erubescens, Lowe ; and indeed the larger state (which I would register as the ' $\beta$. fluctuosa') has so much in common primâ facie with the Porto-Santan phasis of the latter (or ' $a$. portosancti') that I had at first imagined that the two might prove perhaps to be but the subfossil and recent homologues of each other; nevertheless a closer inspection of them would seem to imply that they pertain in reality to slightly different types,the $H$. chrysomela being not only more keeled and less globose (which is particularly observable in the state ' $\beta$. fluctuosa') but having likewise its columella shorter, and its lower lip straighter and more horizontal, as well as much more thickened internally, the incrassated portion too extending throughout nearly its entire length, instead of being gradually terminated at only a short distance from the axis.

\section{Helix membranacea.}

Helix membranacea, Lowe, Ann. Nat. Hist. ix. (1852)

Pfeiff., Mon. Hel. iii. 38 (1853)

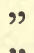

99

Lowe, Proc.

Soc. Lond

165

(1854) 
Helix membranacea, $A l b$., Mal. Mad. 47. t. 12. f. 8-10 (1854)

Paiva, Mon. Moll. Mad. 11 (1867)

Habitat Maderam; in sylvaticis intermediis umbrosis, necnon sub foliis arborum emortuis, degens, sed nunquam vulgaris. In statu semifossili ad Caniçal Rev. R. T. Lowe parcissime collegit.

The $H$. membranacea, which is widely, though not very abundantly, scattered over the wooded districts, particularly in the damp shady ravines, of Madeira proper, may be known by its extremely thin, flexible, pellucid, Vitrina-like substance, by the paucity of its volutions (which vary from about 4 to $4 \frac{1}{2}$ ) and the largeness of its aperture, and by its pale yellowish- or even greenish-corneous hue, which has often an obsolete rosy additional tinge, - as though to affiliate the species with the closely-allied $H$. erubescens. Its basal whorl is rather distinctly keeled, the keel however becoming evanescent at the aperture (the margins of which are simple and acute, with the upper one not at all deflexed); its umbilicus is altogether absent ; and its entire surface is malleated and lightly transverse-plicate, as well as freckled all over with yellowish-white, subopaque, irregular specks and broken-up, elongate, more or less confluent millky markings-which are usually condensed about the keel into something approaching to a narrow but disjointed fascia.

The Baron Paiva records this Helix as occurring also on a little uninhabited rock off the north of Porto Santo, known as the 'Ilheo da Fonte d'Areia ;' but the species is so eminently characteristic of the damp sylvan districts, at a rather high altitude, in Madeira proper that I cannot but suspect that some error must have arisen concerning the former habitat (and more particularly so, since the Baron's material was not collected by himself). I think therefore that further evidence is required before the H. membranacea can safely be cited as Porto-Santan, or even indeed as extra-Madeiran.

\section{Helix furva.}

Helix furva, Lowe, Cambr. Phil. S. Trans. iv. 40. t. 5. f. 2. (1831)

\begin{tabular}{|c|c|}
\hline & Pfeiff., Mon. Hel. i. 29 (1848) \\
\hline " & Lowe, Proc. Zool. Soc. Lond. 165 (1854) \\
\hline , & Paiva, Mon. Moll. Mad. 12 (1867) \\
\hline
\end{tabular}

Habitat Maderam; in excelsioribus (vel graminosis vel sylvaticis) occurrens. In statu semifossili ad Caniçal rarissime invenitur. 
Readily known from all the varieties of the $H$. erubescens (which in size, contour, and sculpture it much resembles) by its uniformly rich, deep, brownish-yellow, or yellowish-brown, hue, its rather stronger substance and more shining surface, and by its volutions having a narrow, dark, interrupted, or disjointed, tesselated fascia at their base (very conspicuous on the ultimate one,-where it is just above, and immediately adjoining, the indistinct keel), and generally faint traces of a very obsolete and paler (but equally fragmentary) one, often altogether absent, on their anterior edge (fringing the suture). The peristome, likewise, is a little less developed and reflexed than in the $H$. erubescens; the basal whorl descends somewhat more abruptly in front; the keel is, if anything, a trifle more expressed ; and the surface is perhaps, on the average, less malleated but more perceptibly striate.

The $H$. furva (which is found also in a subfossil condition, though very rarely, at Caniçal) is widely spread over the intermediate and lofty regions of Madeira proper, to which island it would seem to be peculiar. On the mountains above Funchal it is at times comparatively abundant, - particularlyin the chestnutwoods at the Mount, towards the Pico d'Arribentão, at the Pico do Infante, and on the southern slopes of the Pico da Silva; and it was met with by Mr. Lowe and myself at the extreme head of the Ribeira do Inferno (on the Paul de Serra), in the north-west of the island.

\section{Helix erubescens.}

Helix erubescens, Lowe, Cambr. Phil. S. Trans.iv. 40. t. 5. f. 3 (1831)

$\begin{array}{ccc} & \Rightarrow \quad & \text { et simia, Pfeiff., Mon. Hel. i. } 270 \text { et } 288 \\ (1848)\end{array}$

var. porto-sancti, Woll.

Helix fluctuosa, var. a., Paiva, l. c. [vide Obs. p. 14] (1867) var. advenoides, Paiva.

Helix advena, Lowe [nec W. et B.], Proc. Zool. Soc. Lond. 165 [vid. Obs. 2] (1854) var. hyoena, Lowe.

" erubescens, var. $\gamma$, advenoides, Paiva, l. c. 14 (1867)

Helix hyæna, Lowe, Ann. Nat. Hist. ix. (1852)

Pfeiff., Mon. Hel. iii. 200 (1853)

", erubescens, var. $\delta$., Lowe, Proc. Zool. Soc. Lond. 165 
Helix erubescens, var. $\beta$., Alb., Mal. Mad. 47. t. 12. f. 14$16(1854)$

var. a. major, Paiva, l.c. 14 (1867)

Habitat ins. omnes Maderenses (sc. Maderam, tres Desertas, et Portum-Sanctum); in intermediis editioribusque degens. In statu semifossili ad Caniçal Maderæ, necnon in summo etiam Desertæ Australis, reperitur.

This is one of the most widely diffused, and variable, of the Maderan Helices,-it having been met with by Mr. Lowe, Mr. Leacock, myself, and others on the whole five islands of the archipelago (namely Madeira proper, the three Desertas, and Porto Santo); and it is reported even from San Miguel, in the Azores. Until within a comparatively recent period it was supposed to be non-existent in Porto Santo (where its place seemed, at first sight, to be supplied by the larger state (or ' $\beta$. fluctuosa') of the more keeled, and rather differently constructed, semifossilized H. chrysomela); but in May of 1855 it was found by myself, and subsequently by Mr. Lowe, on the ledges of the damp rocks on the northern side of the extreme summit of the Pico de Facho, in that island,-from whence it has since been obtained by the Baron Paiva.

In a subfossil condition the $H$. erubescens is rather common at Caniçal, in Madeira proper, and it was detected by Mr. Lowe on also the extreme summit of the Southern Deserta (or Bugio); but it has not been observed hitherto, so far as I am aware, in any of the deposits (whether calcareous or muddy) in Porto Santo.

The $H$. erubescens passes through an almost infinite number of changes, both in outline and hue,-as regards the latter, scarcely two specimens being precisely alike. Sometimes the volutions are elegantly banded, at others some of the fasciæ are obsolete and at others the latter are more or less broken-up into tessellated fragments; while many individuals are unicolorous, being entirely devoid of markings. The ground-colour (apart from the darker bands) varies chiefly from a pale pinkishbrown and whitish-yellow, into a dusky yellowish-grey; and there is generally (though by no means always) a more conspicuous rosy tinge about the peristome; and the surface is more or less wrinkled, or malleated, as well as marked with oblique irregular striæ, which however are often extremely indistinct.

But perhaps the principal aspects under which the H. erubescens presents itself may be arranged, topographically, as follows :

a. porto-sancti, Woll.--Rather less globose than the type, being a trifle more flattened both above and below, with the aperture a little more straightened or horizontal, and the basal volution 
just appreciably keeled. The surface is less malleated than in the other varieties, but the minute striæ are somewhat more regular and apparent. Although very variable in hue, this is usually a highly decorated state, the ground-colour being often of a comparatively clear yellow. Detected by myself and $\mathrm{Mr}$. Lowe on the northern side of the extreme summit of the Pico de Facho, in Porto Santo.

$\beta$. [normalis].-This is the phasis which obtains throughout the intermediate and lofty elevations of Madeira proper, and on the Deserta Grande ; and it is rather less flattened (or more inflated) than the Porto-Santan one, with the aperture less straightened, and the surface more appreciably malleated, but somewhat less evidently striate. It is often extremely thin and semi-transparent; and its colour is so inconsistent that it may be said to pass through almost every gradation (in that respect) to which the species is liable. Even its contour is by no means fixed, some examples having the spire more raised than others; and, on the whole, the specimens from the Great Deserta may perhaps be said to be a trifle larger and more globose, as well as more highly decorated, than those from Madeira proper.

$\boldsymbol{\gamma}$. advenoides, Paiva.-A rather larger (on the average) but less globose form, which is characteristic of the Northern Deserta (or Ilheo Chão), but which likewise makes its appearance in the extreme east of Madeira proper,-namely on the São Lourenço promontory, which stretches out in the direction of that small and flattened island. It was inadvertently regarded by Mr. Lowe as identical with the $H$. advena, W. et B., -a species wrongly stated to be Canarian, but which however appears equally to be not Madeiran (it being peculiar to the Cape Verde Group). ${ }^{1}$ The ' $\gamma$. advenoides' is not merely a little larger than the type, but relatively a trifle more depressed; its surface is a good deal roughened and malleated; its substance is perhaps rather more solid; and its colour is of a more or less pale, but dull, yellowish-brown, with the bands for the most part considerably broken-up and interrupted,-giving a slightly tessellated appearance to the whole. There is seldom anything of a rosy tinge about this variety, not even around the peristome (which is nearly always white).

$\delta$. hyoena, Lowe.-The largest of all the phases of the $H$. erubescens, - some of the examples attaining a comparatively gigantic stature (being ten lines across the widest part, and six

1 The H. advena, W. et B., is a more shining and unmalleated shell, but with the transverse striæ nevertheless much more distinctly and regularly developed; its apex is a little more obtuse, its aperture is a trifle more rounded (there being no tendency to a keel), and its upper lip is not so much deflexed. Its plan of coloration too, which involves often a faint phumbeous (or leaden) tinge, is different. 
high). It is the state which the shell assumes par excellence on the Southern Deserta (or Bugio), where it swarms; but which also makes its appearance at a spot called the Feijãa Grande, towards the southern end of the Deserta Grande. Apart from its increased bulk, it is a coarsely malleated form, rather globose in outline, and of a pale yellowish-brown with the bands often a good deal interrupted, or broken-up. Although generally free from a rosy tinge (except now and then, indistinctly, about the peristome), it is on the average of a just appreciably warmer tint than the (somewhat smaller and less globose) ${ }^{6} \gamma$. advenoides.' This aspect of the shell, which however has clearly no claim for anything more than varietal separation, was described by $\mathrm{Mr}$. Lowe, in 1852, under the name $H$. hyoena, as specifically distinct.

\section{(§ Pomatia, Beck.)}

\section{Helix aspersa.}

Helix aspersa, Müll., Verm. Hist. ii. 59 (1774)

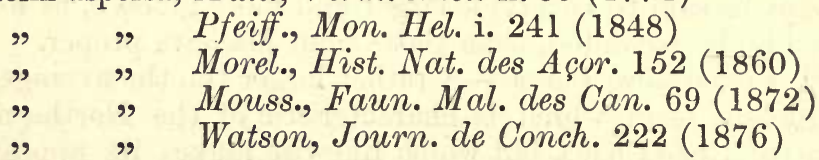

Habitat Maderam ; in hortis circa Funchal parcissimè occurens, nuper ex alienis introducta.

This common European Helix, which has established itself in the Azorean Group and in the island of Palma at the Canaries, and which has likewise been naturalized even at St. Helena, occurs very sparingly in Madeira proper,-namely in certain of the gardens around Funchal,-where it has been introduced, within a comparatively few years, from more northern latitudes. Although of course totally unconnected with the true Madeiran fauna, it can scarcely be omitted from our catalogue,-which contains, of necessity, like most local lists, a certain modicum of species which were manifestly, and without doubt, originally, but imported ones.

\section{Helix subplicata.}

Helix subplicata, Sow., Zool. Journ. i. 56. t. 3. f. 1 (1824)

\begin{tabular}{|c|c|}
\hline " & f. $4(1831)$ \\
\hline & Pfeiff., Mon. Hel. i. 24 (1848) \\
\hline & Lowe, Proc. Zool. Soc. Lond. 171 (1 \\
\hline & 2. Moll. Mad. 72 (1867) \\
\hline
\end{tabular}

Habitat ins. parvum 'Ilbeo de Baixo,' juxta Portum 
Sanctum ; et recens et semifossilis. In Portû Sancto ipsissimo semifossilis solum occurrit.

Although unmistakeably aboriginal, the $H$. subplicata belongs to the same subgeneric type as the common European $H$. aspers $\alpha$; and next to the $H$. Lowei, Fer., it is the largest of the Helices of the Madeiran archipelago. It is peculiar to Porto Santo and the small adjacent islet known as the Ilheo de Baixo, which latter indeed may be regarded as its present head-quarters ; for although it is tolerably common in a subfossil condition in many of the calcareous deposits of the former (as, for instance, at the Zimbral d'Areia, and on the Campo de Baixo), it is only on the Ilheo de Baixo that it has hitherto been observed in a recent (as well as subfossil) state,-it having been first detected there, alive, by myself and the late Rev. W. J. Armitage, in the spring of 1848 (up to which date it had been universally lonked upon, though it was not so recorded by Pfeiffer, as extinct). ${ }^{1}$

The $H$. subplicata is perhaps, on the average, a trifle larger than the common $H$. aspersa, Müll., with its spire more elevated, its suture more impressed, and its whole contour more globose; but it is par excellence remarkable for its uniformly pale olivaceous- or yellowish-brown surface, which is quite devoid of markings or bands, and for the very coarse and rather irregular oblique curved plicæ with which it is roughened,-the nucleus alone (which is usually decorticated, and more or less plumbeous) being comparatively free from sculpiure. There is no trace of an umbilicus, or perforation; the shell is thin, and opake (though brightly polished, and somewhat opaline, within the large subcircular aperture ); there are more or less decided indications of coarse granules on and between the ribs; and the basal whorl is broad and inflated, with the peristome acute and but very slightly recurved.

(§ Helicomela, Lowe.)

\section{Helix Bowdichiana.}

Helix Bowdichiana, Fer., Hist. i. 225. t. 28 B. f. 5,6

" punctulata, $\gamma$, Pfeiff., Mon. Hel. i. 194 (1848)

" Vargasiana, Id., Proc. Zool. Soc. Lond. 109 (1848)

" Bowdichiana, Lowe, Proc. Zool. Soc. Lond. 172

(1854)

$\begin{array}{ll}\Rightarrow \quad & \begin{array}{c}\text { Alb., Mal. Mad. 83. t. 17. f. } 16,17 \\ (1854)\end{array} \\ \quad & \quad \text { Paiva, Mon. Moll. Mad. } 73(1867)\end{array}$

1 Sowerby's original diagnosis of the species was consequently drawn-up from a subfossilized, and almost colourless, example. 
Habitat Maderam, et Portum Sanctum, semifossilis; in calcareis copiossissime occurrens.

The present Helix is one of the most abundant of the subfossil species, both at Caniçal in Madeira and throughout the calcareous deposits of Porto Santo; and (as in the case of the H. Lowei, when contrasted with the portosanctana) there has always been a question as to whether it represents anything more than the former aspect of the present $H$. punctulata, Sow. The same observations which I had occasion to make under the $H$. Lowei will apply here, for I believe that the problem is simply unsolvable, and that it must be decided (so far as that is possible) by each naturalist for himself,-in accordance with the exact views which he may happen to entertain of the breadth, and character, of specific variation.

I am content, for my own part, to cite the $H$. Bowdichiana as distinct from the punctulata,-first, because it has been generally so acknowledged in the more recent monographs; secondly, because we have no certain intermediate links of stature to connect the two (otherwise very similar) forms; and, thirdly, because in at any rate Madeira proper, where it absolutely swarms in a subfossil condition, the $H$. punctulata does not appear even to occur;--for although it is of course possible that the $H$. Bowdichiana may have ceased to exist without initiating a more modern depauperated substitute, yet there seems no reason why it should have done so if the contrary be assumed to have been so eminently the case in Porto Santo that the $H$. punctulata is now quite as abundant (in that island) as the Bowdichiana ever could have been while the era of the subfossil forms was at its height. Moreover in Porto Santo the two shells, during that particular epoch, lived side-by-side, -although the smaller one (or punctulata), which has become absolutely universal, was then manifestly rare, whilst the larger one (or Bowdichiana), which was then everywhere dominant, has passed entirely away. But if it be replied to all this that the $H$. Bowdichiana might properly die out in both islands, and yet leave a depauperated progeny in only one of them, I may further remark that on the Southern Deserta the 'depauperated progeny' (so-called) occurs without the faintest trace of its ever having possessed a more highly developed progenitor,the $H$. punctulata, being rather common on that remote rock (both in a recent and a subfossil condition), without there being any indications in the muddy deposits of its surface that the Bowdichiana had at any time an existence there. So that, from whatever point of view we look at it, the two forms in question would seem to have been originally distinct.

Apart from its more thickened and nearly colourless, pallid 
surface (both of which may be chiefly due to the long process of semifossilization to which it has been exposed), and apart also from its comparatively gigantic stature, the $H$. Bowdichiana is a trifle more inflated and globose than the punctulata, as well as more coarsely sculptured; its basal volution descends somewhat more abruptly in front, causing the aperture to be less regularly and uniformly rounded (or more subsinuate) below the insertion of the right margin; and the peristome is more incrassated,- especially the lower, or columellary, portion of it, which is conspicuously broader than in the $H$. punctulata.

\section{Helix punctulata.}

Helix punctulata, Sow., Zool. Journ. i. 56. t. 3. f. 2 (1824)

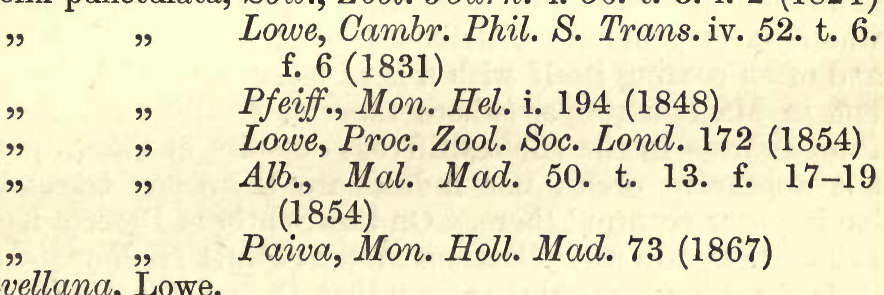

var. avellana, Lowe.

Helix punctulata, var. B., avellana, Lowe, Proc. Zool. Soc. Lond. 172 (1854)

var. a. avellana, Paiva, 1. c. 74 (1867)

Habitat Portum Sanctum (insulasque parvas adjacentes), et Desertam Australem; in illis vulgatissima. Semifossilis, et in Portû Sancto et in Desertâ Australi, parce reperitur.

I have already pointed out in what the $H$. punctulata, Sow., differs from its nearly-allied but comparatively gigantic analogue,- the (extinct) H. Bowdichiana, Fer. In point of mere colour the two forms, as we now view them, are of course totally unlike; but that is simply without significance (as regards the quoestio vexata of their specific identity, or otherwise), the process of subfossilization to which the Bowdichiana has been so long exposed having bleached it into a more or less chalky or calcareous white.

The $H$. punctulata varies a good deal in its markings, and (like so many of the Helices) it has now and then a pure, whitish-yellow, unmaculated, albino state; but, in a general sense, it may be said to be of a deep, warm, reddish-brown hue, with the central portion beneath more or less pale, and with a narrow (often indistinct) medial band, which is lost sight of in the suture of the penultimate volution (just above the aperture), of the same paler tint;-under which circumstances the shell may be described as unifasciate. Occasionally however the 
anterior portion also of the large basal whorl (immediately below the suture) is diluted in colouring, being almost as pallid as the umbilical region; in which case the ultimate whorl may be defined as bifasciate,-two dark bands being shaped-out, instead of a single central pale one. Apart from mere ornamentation, the H. punctulata is (like the Bowdichiana) globose and compact in contour, with its small chink-shaped perforation very nearly closed over, and with its surface (which is covered with irregular oblique lines, or slight plicæ) studded with asperated punctures, - out of each of which, except in old and worn examples, a minute bristle will be seen (when viewed beneath a high magnifying power) to proceed.

As already mentioned, the $H$. punctulata is a most abundant shell in Porto Santo (and the immediately adjacent islets), where it is generally distributed,-occurring beneath stones, and often coating itself with a hard layer of the dry dusty soil; but in Madeira proper (where the closely-allied H. Bowdichiana swarms in the subfossiliferous deposits at Caniçal) it does not appear to occur, nor indeed are there any traces of its having ever occurred there. On the Southern Deserta however (where there are no indications of the extinct $H$. Bowdichiana) it is far from uncommon; and that it is not a recent introduction on that remote rock (brought about by some accidental means, as might perhaps be supposed, from Porto Santo) is proved to a demonstration by the twofold fact-that it is found there in a subfossil condition (as well as recent), and that it also assumes a slight local modification (unimportant in itself except topographically) which is just sufficient to enable us to recognize it as an insular race.

The examples referred to, from the Southern Deserta (or Bugio), are on the average a little smaller than the PortoSantan ones, with their spire relatively a trifle more exserted or raised, and with their surface, if anything, somewhat more setose or hispid; their substance, too, is very thin. This slight insular phasis was defined by Mr. Lowe as the 'var. $a$. avellana.'

\section{(§ Euparypha, Hartm.)}

\section{Helix pisana.}

Helix pisana, Müll., Verm. Hist. ii. 60 (1774)

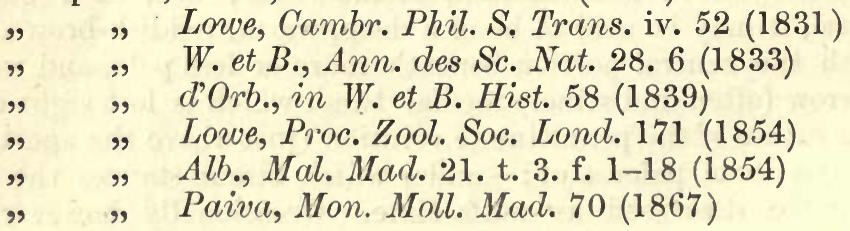


Helix pisana, Mouss., Faun. Mal. des Can. 28 (1872)

" " Watson, Journ. de Conch. 222 (1876)

Habitat Maderam, et Portum Sanctum; in arenis calcareis juxta mare hinc inde abundans. Etiam in stratu semifossilifero prope Caniçal parcissime occurrere a Barone de Paiva dicitur; sed, nisi fallor, vix vere semifossilis (tantum antiqua emortua decorticata) reperitur.

The common European H. pisana, Müll., which occurs both in the Azorean and Canarian archipelagos (abounding also in the latter, as well as at the Salvages, under two or three additional aberrant phases), swarms in the sandy calcareous district near Caniçal in Madeira proper, as well as on the low calcareous plains of Porto Santo; but it has not yet been observed in the other islands of the Group. It is recorded by the Baron Paiva to be found likewise (though rarely) in a subfossil condition, both in Madeira and Porto Santo; but, so far as I am aware, it has never yet occurred in a truly subfossil state, and I strongly suspect that the Baron's specimens were only bleached and decorticated ones, - - such as have often been obtained by Mr. Lowe and myself, in both islands, and which had all the primâa facie appearance of being semifossilized, though a closer inspection invariably proved them to be but faded and worn examples densely filled-up with drifted sand.

The $H$. pisana goes through, in the Madeiran Group, the usual amount of changes, both in colour and outline; but on the whole it is normal in its character, and has shaped out no decided 'varieties' (properly so called), such as the geminata, Mouss., and Grosseti, Tarnier, which manifest themselves at the Canaries.

\section{(§ Xerophila, Held.)}

\section{Helix caperata.}

Helix caperata, Mont., Test. Brit. 430. pl. 11. f. 11 (1803)

" striata, Drap., Hist. Nat des Moll. 106. pl. 6. f. 18, $19(1805)$

? " lauta, Lowe, Cambr. Phil. S. Trans. 53. t. 6. f. 9 (1831)

„ . caperata, Pfeiff., Mon. Hel. i. 167 (1848)

Habitat Portum Sanctum, rariss.; inter Helices varias in Portû Sancto certissime collectas, duo specimina (vix adulta, sed sine dubio cum $H$. caperata, Mont., congruentia), unum sc. nuper sed alterum in 1863 , detexi.

Two undoubted examples of this common Helix of more northern latitudes have been detected by myself (one of them quite recently, and the other in 1863) amongst some miscel- 
laneous, but unquestionably veritable, Porto-Santan shells which were obtained by the Baron Paiva; and I have no hesitation, therefore, in admitting the species into the Madeiran catalogue.

Important however as is the addition of the $H$. caperata to the fauna of the Atlantic islands, it suggests a far more interesting enquiry-as to whether the unique $H$. lauta, Lowe, which has baffled all subsequent observations for nearly fifty years (and which Mr. Lowe, in his last enumeration of the Madeiran Land-Mollusca, in 1854, struck out of the list as having been introduced on insufficient evidence), may not prove to be, after all, but a largely developed phasis of this variable European Helix. The original type, which is now before me, and which was given to Mr. Lowe by the late G. B. Sowerby as having been found in Porto Santo by Mr. Bulwer, differs in scarcely any respect (so far as I can perceive) from these two examples (likewise Porto-Santan) of the $H$. caperata, except that it is a little larger and rather more globose,- the ultimate volution being rounder, or more inflated and obtuse (having no tendency whatever to be keeled), and therefore more broadly developed. This peculiarity of its basal whorl seems to me to be the only feature which could by any possibility be laid hold of to separate the H. lauta; for the shell is not at all larger than occasional specimens of the caperata from more northern localities [indeed it is not so large as the more coarsely and less evenly striated race, with a slightly wider umbilicus, which is abundant around Mogador, on the opposite coast of Morocco, and which was enunciated by Mr. Lowe as the 'caperata, var. $\beta$. mogadorensis'], whilst its sculpture is absolutely identical with that of the latter, and its umbilicus (though certainly a trifle more covered-in) is but very slightly 'smaller,' its ' pallid hue' being probably the mere result of Mr. Bulwer's unique example having been found dead, bleached, and decolorated (not ' decorticated ') on the dry calcareous plains of Porto Santo.

Whether however this somewhat greater tumidity of the ultimate volution, and the just appreciably diminished umbilicus, of the $H$. lauta are of sufficient importance to separate it from the $H$. caperata, may still perhaps be open for consideration; though my own belief is, that the species can scarcely be regarded as having been founded upon more, in reality, than a mere accidentally globose individual of the latter,-a supposition which is rendered all the more probable, now that the caperata in its normal condition has unexpectedly been brought to light in the very island in which Mr. Bulwer was said to have obtained the actual type on which the $H$. lauta was esta- 
blished. Perhaps future researches in Porto Santo, or on the immediately adjacent islets, will reveal some-local modification of the caperata, in which this slightly increased bulk of the basal whorl may constitute more or less a distinctive feature. ${ }^{1}$

\section{Helix armillata.}

Helix 'striata, Drap.?' Lowe, Cambr. Phil. S. Trans. iv. $53(1831)$

"

99

99

99

99

99

99

99

99

99

Lowei, Pot. et Mich. [nec Fer., 1835], Gal. des Moll. 91 (1838)

Pfeiff., Mon. Hel. i. 149 (1848)

armillata, Lowe, Ann. Nut. Hist. 113 (1852)

" Pfeiff., Mon. Hel. iii. 116 (1853)

" Lowe, Proc. Zool. Soc. Lond. 170 (1854)

" Alb., Mal. Mad. 20. t. 2. f. 32-35 (1854)

eumæus, Lowe, Proc. Linn. Soc. Lond.; Zool. 198 (1860)

armillata, Paiva, Mon. Moll. Mad. 68 (1867)

\# Morelet, Journ. de Conch. 236 (1873)

"- Watson, Journ. de Conch. 222 (1876)

Habitat Maderam ; in aridis apricis inferioribus juxta Funchal, hinc inde vulgaris.

I am extremely doubtful whether the present rather insignificant little Helix is more in reality than a small and perhaps slightly modified phasis of the common $H$. caperata, Mont. ( = striata, Drap.), which is so widely spread throughout the maritime regions of central and southern Europe; and so indeed it was at first registered, although in doubt, by $\mathrm{Mr}$. Lowe. Subsequently however he described it under the name ' armillata'; adding ' $H$. striatoe, Drap., affinis.'

I cannot however feel satisfied (and Mr. Watson, judging from his remarks, would appear to be of the same opinion) that it merits separation from the depauperated state of that species,-which is extremely common about Lisbon and Cintra, and which in fact is generally to be met with wherever the

1 With regard to Mr. Lowe's after-rejection of the $H$. lauta from the Madeiran list, I would refer to his observations at $p$. viii of the Appendix to the reprint (in 1851, by Mr. Van Voorst) of his original papers 'Primitiæ et Novitiæ Faunæ et Floræ Maderæ et Port ûs Sancti,' which were contained in the fourth volume of the 'Transactions of the Cambridge Philosophical Society.' I cannot but think however that he was mistaken in supposing that the $H$. lauta is more akin to the virgata, Mont., than it is to the caperata; and I also fail to perceive that its umbilicus is very decidedly 'smaller' than that of the latter,-though it is certainly a little smaller, as well as just appreciably more closed-over by the lamellated portion of the peristome which adjoins the columella. 
more typical (or larger) one occurs. Still, I will not attempt to do more than record my belief thus far; but will only mention that the $H$. armillata (as understood by Mr. Lowe) seems to differ from the caperata proper, merely, in its smaller size and altogether somewhat more depressed form, and in its umbilicus being relatively a trifle larger. Beyond these points (which appear almost equally to characterize the ordinary smaller phasis, as universally understood, of the $H$. caperata), I can detect nothing even tending towards a specific difference.

The $H$. armillata is locally common in certain dry and sunny spots, generally of a low altitude, around Funchal. It was first discovered by Mr. Lowe, on Jan. 21, 1830, in a garden near the Mount road (and it has lately been found by Mr. J. Y. Johnson in almost the same spot); and it was afterwards met with by Mr. Leacock (during September 1847) both to the east and to the west of the town. Since which time, however, it has been obtained in much greater numbers-by Mr. Leacock, the Baron Paiva, Mr. Watson, myself, and others -on and around the Pico da Cruz, as well as near the Gorgulho and elsewhere.

The $H$. armillata occurs likewise at the Azores, and it has been recorded lately by Morelet from the Cape Verde archipelago, - where it is stated to have been found, by MM. Bouvier and de Cessac, in S. Vicente. And since I myself possess it from Mogador, on the coast of Morocco, it would appear to have a tolerably wide geographical range. ${ }^{1}$

\section{(§ Plebecula, Lowe.)}

\section{Helix vulgata.}

Helix nitidiuscula, Lowe [nec Sow., 1824], Cambr. Phil. S. Trans. iv. 52. t. 6. f. 6 (1831)

Pfeiff. [nec Sow.], Mon. Hel. i. 196
$(1848)$

1 The H. eumaus, Lowe (Proc. Iinn. Soc. Lond., Sect. Zool., 198; 1860), described from examples taken at Mogador (and which seem to differ in no respect from others which have been met with subsequently by Mr. T. Blackmore at Tangier), appears to me to be absolutely conspecific with the armillata, - the few characters alluded to in the diagnosis which are supposed to be differential being (with the exception perhaps of the appreciably stronger costæ of the Morocco shell) scarcely more than imaginary. The H. Irus, however, of Lowe, is totally distinct,-approaching closely, except in sculpture, to the $H$. apicina, Lam. 
Heliz nitidiuscula (pars), Alb., Mal. Mad.51.t. 14. f. 1-3 (1854) var. ß. deserticola, Woll.

Helix vulgata, a. major, Paiva, Mon. Moll. Mad. 75 (1867)

var. $\beta$. giramica, Lowe.

Helix nitidiuscula, $\beta$. major, Pfeiff., Mon. Hel. i. 197 (1848)

" giramica, Lovee, Ann. Nat. Hist. ix. (1852)

" vulgata, var. $\gamma$. giramica, Id., Proc. Zool. Soc. Lond. $173(1854)$

" nitidiuscula, var. $\beta .$, Alb., Mal. Mad. 51. t.14. f. 7-9 (1854)

var. $\delta$. pulchra, Paiva.

Helix vulgata, $\delta$. pulchra, Paiva, Mon. Moll. Mad. 75 (1867)

var. E. saxipotens, Woll.

Helix vulgata, $\delta$. pulchra (pars), Paiva, l. c. 75 (1867)

Habitat Maderam et tres Desertas [a Portû Sancto solo absens]; a litore maris usque ad 3000' s.m. ascendens, vulgatissima. In statu semifossili prope Caniçal abundat, ubi $H$. canicalensem, Lowe, æquat; necnon in summo Desertæ Australis (sub varietate minutâ ' $\varepsilon_{0}$ saxipotens,' mihi, occurens) reperitur.

This is perhaps the most abundant, and variable, of all the Madeiran Helices, - the $H$. polymorpha only excepted ; and it appears to occur on every island of the Group except Porto Santo and the adjacent rocks, where its place is taken by the allied (but extremely distinct) $H$. nitidiuscula, Sow. In Madeira proper and on the three Desertas it absolutely swarms,assuming many aspects, however (in size, clothing, and colour), according to the exact district in which it is found. In a subfossil condition it exists in profusion both at Caniçal and on the summit of the Southern Deserta,-in the former of which localities it represents the $H$.canicalensis, Lowe (which seems to me to have absolutely nothing to distinguish it, beyond its thickened calcareous substance and bleached colourless surface, from the usual type), whilst in the latter (where it is small and depauperated, with a much reduced umbilicus) it answers to my 'var. E. saxipotens.'

In a general sense the $H$. vulgata may be described as a rather highly coloured, fasciated species, less strictly opake than the Porto-Santan $H$. nitidiuscula, and more or less evidently clothed (when the specimens are fresh and unrubbed) with short, remote, and excessively minute hairs, - each of 
which arises out of a small granule or asperated point; for, although (like so many of the Helices) it has an occasional yellowish-white albino state perfectly devoid of markings, its usual aspect is a more or less banded one. When the fasciæ are three in number, rather narrow, and well defined, the shell may be said to be in its normal condition; and under this aspect it is generally to be met with throughout the greater portion of Madeira proper and on the two southern Desertas.

On the northern (or flat) Deserta, however, the $H$. vulgata assumes a comparatively gigantic phasis; the bands are broader and more conspicuous (the third, or subsutural, one now-andthen disappearing, or becoming merged into the second), and the surface is more coarsely setose,-the setæ (however small, and fragile in their nature) being thick and remarkably visible. This corresponds with my 'var. $\beta$. deserticola;' and it is singular that it should have been confounded by Mr. Lowe (and subsequently by Dr. Albers) with the 'var. $\gamma$. giramica,' of Madeira proper, which has next to be considered. In reality it is (on the average) a still larger shell than even the ' $\gamma$. giramica ;' and it is also somewhat less depressed, less shining, much more setose, and with the umbilicus less open, and its bands are usually three in number,- - being but seldom only two as in that particular form.

The two previous states may be described as trifasciated ones; but there are three others, worth placing upon record, which are bifasciated. In the first of these (the ' $\gamma$. giramica' of the present catalogue) the shell is large and rather depressed (though perhaps not quite so large, on the average, as the ' $\beta$. deserticola' from the Ilheo Chão), its surface is more shining and bald, there being hardly any vestiges of minute bristles, its umbilicus is appreciably wider, or more open, and its upper (or subsutural) band is lost in the central one, the lower one also being greatly increased in width. This conspicuously and broadly bifasciated state is found for the most part about the Cabo Giram, in the south-west of Madeira proper ; and it was described, in 1852, as a distinct species, by Mr. Lowe, as the H. giramica.

The next state which merits notice is a smaller and (on the average) more beautifully ornamented one than any of the preceding three, and I have generally met with it in the north of Madeira proper,-as, for instance, near Săo Vicente, Seissal, Ribeira da Janella, and Porto Moniz; and it seems to correspond with the 'var. pulchra' of the Baron Paiva's Monograph (mentioned as occurring around Sta. Anna), though he appears to have confused or mixed it up with the very minute subfossil aspect of the shell, with a reduced umbilicus, from the southern 
Deserta,-the ' $\varepsilon$. saxipotens' of this list. The present variety (or' $\delta . p u l c h r a$,' Paiva) is smaller than any of the foregoing ones, but not so small as the subfossil form from the Southern Deserta; and it is generally highly decorated,-the ground-colour being often of a comparatively clear yellowish tinge, with the two darker bands broadly and abruptly defined. But, owing to the incrustation of dirt with which it is the habit of the species, more or less, to encase itself (and which perhaps is more apparent in this particular variety than in the others), the brightness of its ornamentation is not usually very apparent until the shells have been well cleaned.

Lastly, in the muddy deposits on the top of the Southern Deserta there is a very dwarfed subfossil form of the $H$. vulgata, smaller than even the ' $\delta$. pulchra,' which I would cite as the 'var. $\varepsilon$. saxipotens.' In addition to its comparatively diminutive bulk (adult examples measuring from about 4 to 5 lines across the broadest part), its umbilicus is relatively much more reduced than in the other phases of the shell; and, so far as I can judge from white and practically colourless specimens, its two bands are (or, rather, were) narrowed and line-like. Whether this still exists in a living condition I am unable to say; but as the Baron Paiva alludes to a small state of the $H$. vulgata as recent on the Bugio (though treating it as identical with the ' $\delta$. pulchra' from the north of Madeira), it is not unlikely that it may yet linger on.

\section{Helix nitidiuscula.}

Helix nitidiuscula, Sow., Zool. Journ. i. 57. t. 3. f. 4 (1824)

" lurida, Lowe, Cambr. Phil. S. Trans. iv. 52. t. 6. f. 5 (1831)

" $\quad$ Pfeiff., Mon. Hel. i. 197 (1848)

" $\quad$ " Lowe, Proc. Zool. Soc. Lond. 174 (1854)

" nitidiuscula, var. ., Alb., Mal. Mad. 52. t. 14. f. 4-6 $(1854)$

? $\quad$ "Hartungi, Alb., l.c. 42. t. 10. f. 26-28 (1854)

" lurida, Paiva, Mon. Moll. Mad. 75 (1867)

Habitat Portum Sanctum; in calcareis et graminosis sub lapidibus degens. In statu semifossili copiose reperitur.

This has generally been regarded as the Porto-Santan representative of the common $H$. vulgata of Madeira proper and the Desertas, and perhaps in reality it may be; nevertheless its characters (not only of size and contour, but also of colour and sculpture) are so unmistakeable and well-marked, that I scarcely see how a mere supposition can be made use of 
to invalidate its specific claims,-for, after all, it is not more surprising that the $H$. vulgata, which is so abundant in the other islands of the Group, should be absent from Porto Santo than that the H. punctulata, which occurs in the Porto Santo and the Desertas, should be wanting in Madeira. No doubt the H. nitidiuscula belongs to the same geographical type as the vulgata; but it also makes an evident approach towards the H. depauperata of the next section (Irus, Lowe), and, to me at least, it seems altogether as rigidly defined, from a specific point of view, as any Helix throughout the entire fauna.

As compared with the very variable $H$. vulgata, the nitidiuscula may be described as being considerably smaller and rather more lenticular or depressed (its greatest diameter being from 4 to 5 lines, instead of from about 5 to $7 \frac{1}{2}$, and the spire being more obtuse, or less pointed, at the apex), and with its surface not only appreciably more opake and free from the minute setæ which are generally more or less traceable in its ally, but likewise very differently sculptured,- the entire shell, except beneath, being closely beset with extremely diminutive, elongated granules, which are just sufficiently removed from each other to shape-out interspaces which have somewhat the appearance of reticulations. ${ }^{1}$ And there is also a peculiarity about the aperture which will never fail to distinguish the $H$. nitidiuscula from every state, or variety, of the vulgata,-namely the more vertical prolongation of the axis into the columellary portion of the peristome, giving a less rounded (or narrower and more subquadrangular, or externally flattened) appearance to the whole.

Although merging into each other by imperceptible gradations, the $H$. nitidiuscula has in colour two extreme opposite phases, - one of them white and bleached (though at times with a faint flesh-coloured tinge), and quite destitute of markings, having much the appearance at first sight of being subfossilized; and the other (which must be regarded as the normal one) of a more or less dirty lurid yellow, but clouded on its upper side with two (rarely three) extremely obscure brownish bands. This

1 This was well defined by Mr. Lowe as 'confertim reticulato-granulata ;' yet Dr. Albers (whose eyesight must clearly have been at fault) professed himself unable to see it !-' cl. auctor,' says he, 'testam minutissime reticulato-granulatam significat; sub lente fortiori, tamen, nil nisi rudimenta setularum, æque ac in formâ typicâ, observavi.' No wonder, after this, that he should treat the $H$. nitidiuscula as only a 'var. $\gamma$ ' of the vulgata; and more particularly so, since he gives us no reason to suppose that he had even so much as observed the absolutely invariable character of the more vertical direction of the columellary portion of the lower lip. With two such features as these having escaped his notice, I am the more inclined to suspect that his $H$. Hartungi (in the diagnosis of which no mention is made of anything but strix on the surface) may be only the paler phasis of the $H$. nitidiuscula. 
latter phasis of the shell was the one described by Sowerby (in 1824) as his H. nitidiuscula, and by Mr. Lowe (in 1831) as his H. lurida The former (or pallid) one I cannot help suspecting may be the $H$. Hartungi of Albers; though as I have not been able to procure a type of the latter for examination, I must necessarily speak with some amount of reserve.

In a subfossil condition the $H$. nitidiuscula is tolerably common throughout many of the calcareous deposits of Porto Santo. At the Zimbral d'Areia it was met with by Mr. Lowe and myself (during May of 1855) in considerable profusion; and I may add that the pallid variety of the shell was equally abundant in a living state on the same actual spot. From their general size and contour, semifossilized examples might sometimes be confounded primâ facie with those of the $H$ depauperata; but the peculiar conformation of their aperture (resulting from the more vertical prolongation of the axis) will always suffice, on a closer inspection, to separate them.

\section{(§ Irus, Lowe.)}

\section{Helix laciniosa.}

Helix laciniosa, Lowe, Ann. Nat. Hist. ix (1852)

$\begin{array}{lll}" & \Rightarrow & \text { Pfeiff., Mon. Hel. iii. 151 (1853) } \\ " & \Rightarrow & \text { Lowe, Proc. Zool. Soc. Lond. 174 (1854) } \\ " & \quad & \text { Alb., Mal. Mad. 33. t. 8. f. 16-19 (1854) } \\ & \text { Paiva, Mon. Moll. Mad. } 56(1867)\end{array}$

Habitat Desertam Borealem, et Desertam Grandem; in illâ præcipue abundans.

It is on the northern (or flat) Deserta that this curious little Helix attains its maximum ; for although it is found likewise towards the northern end of the Deserta Grande, it exists there very sparingly, and with all the appearance of having been accidentally introduced from the smaller island... On the latter, however, although separated from the Deserta Grande by so narrow a channel, it absolutely swarms,-occuring in clusters, beneath the stones. It was first detected there, during June of 1848, by Mr. Leacock; and it has subsequently been taken, on several occasions, by Mr. Lowe, myself, and others. ${ }^{1}$

The $H$. laciniosa (the greatest diameter of which is only

1 I take no notice of the Baron Paiva's additional habitat for this extremely local little species, - the Iheo de Ferro, off the NW. coast of Porto Santo,because I feel satisfied that it must have been cited on evidence which is not trustworthy. The loose and unsatisfactory manner in which the Baron's material was brought to him, by mere paid collectors, and his own extreme inaccuracy (which I have often had occasion to deplore) in mixing up his specimens from different islands, would fully account for an occasional mistake as regards his localities. 
from about 4 to $4 \frac{1}{2}$ lines) displays much the same type of colouring as the broadly bifasciated state of the $H$. vulgata; nevertheless its two bands are usually very wide, and frequently subconfluent, - so as to cause nearly the whole upper surface (except a few detached, transverse, irregular, somewhat line-like but broken-up, white fragments, across the fasciæ) to be dark brown, the umbilical area alone showing a ground-hue of a dusky yellowish-white. The character of its aperture, however, which is comparatively circular, the peristome being raised and continuous across the body-volution, throws it into a different section from that species; the entire shell is a little less globose (or more lenticular) than the $H$. vulgata, the whorls are rather prominent and subangular, and the whole surface is not only roughly sculptured with very coarse and irregular transverse curved subfluent costæ, but more or less clothed, when the specimens are fresh and unrubbed, with small fragile membraneous laciniæ.

\section{Helix depauperata.}

Helix depauperata, Lowe, Cambr. Phil. S. Trans. iv. 51.

\begin{tabular}{|c|c|c|}
\hline 9 & , & Pfeiff., Mon. Hel. i. I 66 (1848) \\
\hline 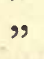 & 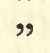 & Lowe, Proc. Zool. Soc. Lond. 174 \\
\hline & " & 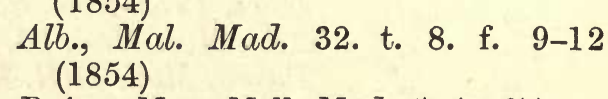 \\
\hline & " & Paiva, Mon. Moll. Mad. 57 (1867) \\
\hline
\end{tabular}

Habitat Portum Sanctum, insulasque parvas adjacentas ; et recens et semifossilis, vulgaris.

This is one of the most general, and widely spread, of the Helices of Porto Santo, to which island (and the immediately adjacent rocks) it is peculiar,-occurring abundantly both in a recent and subfossil condition; and it may be regarded perhaps as the Porto-Santan representative of the $H$. squalida of Madeira.

The $H$. depauperata is a rather insignificant Helix, either of a uniformly pale brown or of a dingy brownish-white, rather rounded (but not globose) in outline, with a distinct umbilicus, and with its surface (which is opake) very minutely and delicately granulated, but at the same time much roughened with coarse transverse folds, - which are so exceedingly irregular and subconfluent as to cause the shell to appear well-nigh submalleate. Its aperture is not quite so continuous as in the H. laciniosa, nevertheless its upper and lower portions are joined across the body volution by a corneous lamina so conspicuous as to make it appear almost circular. 


\section{Helix squalida.}

Helix squalida, Lowe, Ann. Nat. Hist. ix. (1852)

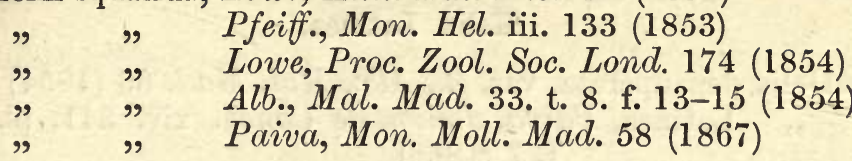

Habitat Maderam; ad rupes excelsas umbrosas, interdum etiam maritimas, sæpe in terrâ quasi sepulta, rarissima. In statu semifossili ad Caniçal abundat.

The $H$. squalida, although abundant in a subfossil condition at Caniçal, is one of the rarest of the recent species of Madeira proper,-to which island it seems to be peculiar. Nevertheless in distant places along the northern coast (as, for instance, between Ribeira da Janella and Porto Moniz, and near São Vicente and Seissal) it has been met with, both by Mr. Lowe and myself, in tolerable numbers, - though more often dead and decorticated, than living. I have likewise found it in the Ribeira de Sta. Luzia, above Funchal ; and the Baron Paiva records it at the Curral das Romeiras.' 1

We may regard the $H$. squalida as representing in Madeira proper the Porto-Santan H. depauperata. It is, however, a little smaller than the latter, and with its spire more depressed at the apex; its volutions (which are equally opake) increase more gradually (the ultimate and penultimate ones being narrower, or less enlarged), its umbilicus is relatively wider and more spiral or open, its colour generally is of a darker coffeebrown, and the granulations of its entire surface (although beautifully expressed) are both very much more minute and more densely packed together. ${ }^{2}$ The mode of life, too, of the H. squalida, is different from that of the depauperata; and it has a singular habit (like the $H$. obtecta in Porto Santo, and the $H$. latens in Madeira) of coating itself with a thick mass of earth, or hardened mud,-which often makes it difficult to detect amongst the loose dry rubble, and fine vegetable mould,

1 The Baron Paiva cites the H. squalida as occuring also, at any rate in a subfossil state, in Porto Santo; but I think that we must obtain better evidence than this before we regard the species as extra-Madeiran,-for its Porto-Santan analogue is clearly the $H$. depauperata, and (as I have already mentioned) the Baron's material was so hastily and inaccurately brought together that his habitat-islands were often (to my own certain knowledge) sadly mixed-up and confused.

2 Although nothing could possibly be more constant, and elegant, than this well-defined sculpture of the $H$. squalida, which is quite appreciable under an ordinarily powerful lens, Dr. Albers appeared quite as unable to see it as he was that of the $H$. nitidiuscula,-for he absolutely described the surface as 'egranulata!' 
mixed up with which it is so frequently found, at, and about, the bases of the perpendicular rocks.

\section{Helix Latinea.}

Helix depauperata, var. $\beta .$, Alb., Mal. Mad. 33 (1854) " Latinea, Paiva, Journ. de Conch. xiv. 341. pl. 11. f. 7 (1866)

" $\quad$, Id., Mon. Moll. Mad. 58 (1867)

Habitat Portum Sanctum, semifossilis ; in arenâ calcareâ vulgaris.

At first sight this species, which seems to occur only in a subfossil state in Porto Santo (where it is extremely abundant in many of the calcareous deposits), might be looked upon as a variety either of the $H$. depauperata or of the obtecta,-to both of which it is very closely allied; nevertheless, after a careful consideration of its distinctive characters, I do not quite see how it can be referred to either of them,- - though, on the whole, I think that it has more in common with the latter than with the former. ${ }^{1}$

Although agreeing with the $H$. obtecta in its larger size, ruder sculpture, more circular aperture, and elevated, continuous peristome, the $H$. Latinea is nevertheless totally unkeeled, and possesses a still wider and more spirally open umbilicus, and that too in combination with the regular spire (though it is not quite so much elevated) and somewhat more numerous whorls of the depauperata,-thus wanting entirely the anomalously depressed, subconcave apex, but nevertheless deep suture and prominent volutions, which form so striking a feature in the spire of the $H$. obtecta.

On the other hand, when compared with the depauperata (of which Dr. Albers has cited it as a 'var. $\beta$.'), the H. Latinea is considerably larger and more depressed, its umbilicus is very much wider, more spiral, and more open, and its aperture is more decidedly rounded, - the peristome being both more raised and more continuous. Its general surface, too, is a little more coarsely sculptured,-though perhaps not quite so uneven as that of the $H$. obtecta.

1 This was also the opinion of Mr. Lowe, to whom in March of $1856 \mathrm{I}$ forwarded an example which had been communicated to me by Mr. Leacock. That single specimen (which was all that he had to judge from) Mr. Lowe was inclined to regard as ' a curious monstrosity of the $H$. obtecta, of which it possesses the large umbilicus, the more constricted aperture, and the coarser sculpture, combined with the regular spire of the $H$. depauperata.' But could he have seen the shell in sufficient numbers, I feel sure that he would have come to the conclusion that it is no mere 'monstrosity,' but as true and constant in its characters as any of these immediately-allied species. 


\section{(§ Spirorbula, Lowe.)}

\section{Helix obtecta.}

Helix obtecta, Lowe, Cambr. Phil. S. Trans. iv. 47. t. 5. f. 20 (1831)

$\begin{array}{lll} & & \text { Pfeiff, Mon. Hel. i. } 188 \text { (1848) } \\ " & \quad & \text { Lowe, Proc. Zool. Soc. Lond. } 175(1854) \\ " & \quad & \text { Alb., Mal. Mad. 34. t. 8. f. 20-22 (1854) } \\ & \quad & \text { Paiva, Mon. Moll. Mad. } 60 \text { (1867) }\end{array}$

Habitat Portum Sanctum; et recens et semifossilis, præsertim in aridis apricis calcareis, vulgatissima.

The H. obtecta, Lowe, is peculiar to Porto Santo and the immediately adjacent rocks, where it is one of the most abundant and universal of the Helices,-occurring more especially in the driest and most calcareous spots; and it is almost equally common in a subfossil condition. On the summit of the Ilheo de Baixo it swarms; and from its habit of coating itself with a hard covering (strongly cemented together) either of earth or of calcareous sand, it has often a very remarkable and misshapen appearance.

The flattened spire and almost concave apex of the $H$. obtecta, the whorls of which are nevertheless raised and tumid, with the suture deeply impressed, added to its rough, uneven (though minutely and obsoletely granulated), and opake surface, its dingy-brown hue, its rounded aperture and elevated, continuous peristome, and its appreciably keeled or subangulated basal volution (which is also obscurely eroded, or subconcave, immediately above the keel), will sufficiently distinguish it.

\section{Helix latens.}

Helix latens, Lowe, Ann. Nat. Hist. ix (1852)

$\begin{array}{lll}" & \quad \text { Pfeiff., Mon. Hel. iii. 115 (1853) } \\ " & \quad \text { Lowe, Proc. Zool. Soc. Lond. 175 (1854) } \\ " & \quad \text { Alb., Mal. Mad. 34. t. 8. f. 23-26 (1854) } \\ & \quad \text { Paiva, Mon. Moll. Mad. 59 (1867) }\end{array}$

Habitat Maderam; inter detritus radicesque plantarum ad basin rupium in humidis editoribus sylvaticis præcipue degens, rarior.

Although diametrically opposed to it in the extreme thinness and fragility of its substance (which, as regards texture, is almost membranaceous), the present Helix may nevertheless be regarded as the Madeiran representative of the $H$. obtecta of Porto Santo. And indeed in their general outline and somewhat Planorbis like contour (the nucleus of both being so 
much depressed, or sunken, as to seem well-nigh concave), no less than in their few and rapidly-increasing volutions, and their singular habit of coating themselves over with an envelope of hardened mud, the two species have undoubtedly a vast deal in common. And yet they are completely, and utterly, distinct. Apart from the thinness and flexibility of its composition, the $H$. latens differs from the excessively solid and robust $H$. obtecta in being smaller and (when denuded of its muddy covering) of a more or less olivaceous or greenish-brown tinge, in its umbilicus being relatively a little narrower and less spiral, and in its having a volution less. ${ }^{1}$

In its mode of life the $H$. latens may be described as the exact opposite of the $H$. obtecta; for while the latter occurs in the driest, sunniest, and most calcareous spots which even the barren and exposed island of Porto Santo can furnish, the present species is confined to the damp sylvan districts of Madeira proper at intermediate and lofty elevations,--where it is usually to be met with amongst loose rubble, and coarse vegetable detritus, on the ledges, and at the base of, the perpendicular rocks which form so marked a feature throughout the wooded ravines. I first detected it, about thirty years ago, in the Ribeira de Sta. Luzia, above Funchal; and it has since been obtained by Mr. Leacock, Mr. Lowe, Mr. Watson, Senhor Moniz, the Baron Paiva, myself, and others, in somewhat similar spots, in various parts of the island.

\section{Helix paupercula.}

Helix paupercula, Lowe, Cambr. Phil. S. Trans. iv. 47.t. 5. f. 19 (1831)

\begin{tabular}{|c|c|c|}
\hline & " & Pfeiff., Mon. Hel. i. 189 (1848) \\
\hline & , & Lowe, Proc. Zool. Soc. Lond. 175 (1854) \\
\hline " & 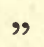 & Alb., Mal. Mad. 35. t. 8. f. 27-30 (1854) \\
\hline & 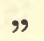 & Mouss., Schw. Denksch.xv. 135 (1857) \\
\hline & 9 & Paiva, Mon. Moll. Mad. 61 (1867) \\
\hline & 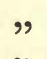 & - Mouss., Faun. Mal. des Can. 60 (1872) \\
\hline & & n. de Conch. 222 (1876) \\
\hline
\end{tabular}

Habitat ins. omnes Maderenses [sc. Maderam, Portum Sanctum, et tres Desertas]; in aridis apricis inferioribus submaritimis, hinc inde vulgatissima. Semifossilis in Portû

1 Pfeiffer was certainly mistaken in describing the H. latens as pilose. There is no trace of pilosity in any of the numerous specimens which I have ever examined; and indeed even if there had been, until the shells were thoroughly cleaned (a most difficult operation with subjects so unusually fragile and flexible), it would have been completely concealed from view. As in most of these immediately allied forms, the surface is minutely and very delicatcly (but perhaps somewhat unevenly) granulated. 
Sancto abundat, necnon minus copiose prope Caniçal Maderæ; atque in summo etiam Desertæ Australis, semifossilis invenitur.

The singular little $H$. paupercula, which occurs also in the Azorean and Canarian archipelagos, is locally abundant in the Madeiran Group,-though less general in Madeira proper than elsewhere; indeed in this latter island I am not aware that it has been observed hitherto except on the Ponta de São Laurenço (where it was first detected by Mr. Lowe in 1827, and where it has recently been found by Dr. Grabham on the Ilheo de Fora) and about Sta. Cruz and Caniço, though the Baron Paiva cites it likewise from Porto Moniz. But in Porto Santo, as well as on the immediately adjacent rocks, it swarms, ascending moreover to a tolerable elevation; and on the whole three Desertas I have myself met with it, though it does not appear to be very common on any of them.

In a general sense, however, the $H$. paupercula is eminently a species which is found in low, rocky, and calcareous places near the coast, -where it often exists in company with the $H$. pisana and lenticula, the Bulimus ventricosus, \&c.; and it is easy, therefore, to understand how liable to accidental transportation it might occasionally become,-a consideration which may perhaps account for its appearance in the equally Portuguese islands of the Azores, which must have been long subject to intercommunication with Madeira. At the Canaries it has been observed only in Lauzarote, in the extreme east of that archipelago, where it was first found by M. Hartung, and afterwards by Mr. Lowe; but it is not difficult to conceive how some unsuspected method of dispersion may possibly have conveyed it even there,-ordinary fishing-boats, and ballast, being amongst the first means which suggest themselves. But, be this as it may, in at all events the Madeiran Group the $H$. paupercula appears manifestly to have been aboriginal. $\mathrm{Mr}$. Watson speaks of it as ' recently introduced' at the Canaries, but I am not aware that there is any positive evidence for that conclusion.

In a subfossil condition the $H$. paupercula is rather plentiful in Porto Santo, particularly at the Zimbral d'Areia and (though less so) on the Campo de Baixo; but in the Caniçal deposits of Madeira proper it is decidedly scarce, and still rarer in those on the summit of the Southern Deserta,-where it was nevertheless found by Mr. Lowe and myself, during June of 1855.

It is surprising to me that Mr. Watson (Journ. de Conch. $230 ; 1876$ ) should have felt any doubt whatever concerning the right of this curious little Helix to be regarded, when occurring in the calcareous beds, as genuinely subfossilized; for although 
it is perfectly true that (like the $H$. pisana and lenticula) it often exists in a living state on the selfsame ground where its subfossil representatives are to be met with, and that therefore occasional bleached examples might well be mistaken at first sight for subfossilized ones, nevertheless out of all the shells which I have myself ever obtained in a decidedly subfossil condition there is certainly none which is less equivocal than the $H$. paupercula. Although unquestionably scarce about Caniçal, at the Zimbral d'Areia in Porto Santo I have gathered it in absolute profusion, along with the numerous other species of that prolific locality, and quite as much thickened and superficially decomposed as any of them.

Like the $H$. obtecta and latens, this insignificant but solid little Helix (which measures only about $2 \frac{1}{4}$ lines across its broadest part) has the habit of covering itself over with a coating of hardly-cemented earth; but when the outer envelope has been removed it will be seen to be of either a reddish brown or else of a pale cinereous-grey, with the surface opake and most minutely and densely granulated all over, and with the transverse lines of growth tolerably apparent. It is a flattened and planorbiform shell, composed of about 4 whorls,-the spire being extremely depressed, indeed often a little concave (though variable in that respect, for sometimes the nucleus is gradually raised and prominent), and the base inflated and convex. Its umbilicus is somewhat large, deep, and spiral; and its aperture (which is very suddenly, and a good deal, deflected) has a powerful constriction immediately behind it (shaping-out an annular, ridge-like projection), with the peristome thin, almost circular, continuous, and raised.

\section{(§ Placentula, Lowe.)}

\section{Helix compar.}

Helix compar, Lowe, Cambr. Phil. S. Trans. iv. 48. t. 5. f. 23 (18.31)

\begin{tabular}{|c|c|c|}
\hline צ' & " & n. Hel. i. 214 (1848) \\
\hline و & " & Lowe, Proc. Zool. S'oc. Lond. 195 (1854) \\
\hline " & ", & Alb., Mal. Mad. 29. t. 7. f. 1-4 (1854) \\
\hline & " & 8 \\
\hline
\end{tabular}

Habitat Maderam; præcipue in Pico do Rancho (juxta promontorium Girão), et circa Camara de Lobos, degens.

The closely allied Helices of this immediate type, although by no means large, are more or less solid, flattened, and lenticular (being slightly convex beneath), with a rather wide and spiral umbilicus, and with a raised, circular, and continuous peristome; their surface is often strongly sculptured either with 
elevated ridges or with smaller and more densely packed costate lines; and they have usually a single narrow fascia (rarely absent) both above and below the keel.

The $H$. compar is remarkable for the coarse and powerfully raised, equidistant, whitish, oblique, transverse costæ with which it is furnished both on its upper and its under side, and for its total freedom from all other sculpture,-there being. no indication of intervening granules even towards the aperture. It is intimately related to the $H$. maderensis, of which it has occasionally been looked upon (perhaps without sufficient reason) as an extreme development; wevertheless, apart from the peculiarities of its sculpture (which are so marked and conspicuous), its basal volution is very decidedly less angulated or keeled, its aperture is less suddenly deflected, its umbilicus is just appreciably larger, and (although possessing the same single darker band both above and below) its general colour is, on the average, somewhat deeper and richer.

It is chiefly about the Cabo Girão, the great south-western promontory of Madeira proper, that the $H$. compar is found (indeed I am not aware that it has been observed hitherto in any other district), - where it was first met with by Mr. Lowe, during December of 1828, on the Pico do Rancho (a lower offshont, or semi-detached compartment, of the Cape Girão); and the Baron Paiva records its occurrence nearer to, and around, the village of Camara de Lobos.

\section{Helix tæniata.}

Helix tæniata, W. et B., Ann. des Sc. Nat. 28. Syn. App. 224 (1833)

" $\quad$ d'Orb., in W. et B. Hist. 63. t. 3. f. 18-20 (1839)

" $\quad$ Pfeiff., Mon. Hel. i. 189 (1848)

" maderensis, major, Lowe, Proc. Zool. Soc. Lond. 195 (1854)

" tæniata, Mouss., Faun. Mal. des Can. 57 (1872)

Habitat Maderam; in collibus maritimis, præcipue occidentalibus et præcipue versus Paul do Mar, sub lapidibus congregans. [Etiam in ins. Canariensibus a cl. Webb occurrere dicitur; sed procul dubio ex exemplaribus Maderensibus, in sarcinis Roccelloe tinctorioe lectis, descripta.]

It is rather surprising that so accurate an observer as $\mathrm{Mr}$. Lowe should have failed to perceive anything about the present Helix except its larger size, to distinguish it from the common H. maderensis,-for its characters seem to me to render it quite as worthy of specific separation as those of the $H$. compar 
do, from the latter. Not only is the H. toeniata very much larger, on the average, and more depressed, than the maderensis (the most highly developed examples measuring about $4 \frac{1}{2}$ lines, instead of only abont 3 , across the widest part), but it possesses an extra whorl (namely 8 , instead of 7 ), its umbilicus is appreciably wider and more spiral, its keel is considerably more acute, and continued almost to the actual peristome, and its volutions are extremely flattened,--the basal one, moreover, being granulated to a much greater distance from the aperture.

The $H$. tweniata would seem to occur principally about the cliffs, and rocky maritime hills, in the vicinity of Paul do Mar, in the west of Madeira proper,-where it was taken by Mr. Lowe, on various occasions, in considerable abundance; but it does not appear to have been known, at any rate as a definite form, either by Dr. Albers or the Baron Paiva,-who merely remark (the latter, evidently, having copied from the former), in their observations under the H.maderensis - "Variat insuper spirâ elatiore conoideâ, et fere ["omnino," according to the Baron] planâ.'

Neither does it appear to have been generally understond that the present Helix (whether regarded as distinct from the H. maderensis, or not) is, without any doubt, the $H$. toeniata, W. et B.,-most unwarrantably admitted by Webb into the Canarian fauna, with which it has clearly notbing to do. It was originally detected, by Terver, along with the $H$. tiarella (an equally characteristic Madeiran form), in some bags of dried Orchil, the origin of which was even confessedly obscure; yet, so great was the desire of Mr. Webb to augment his very meagre list that he seems, singularly enough, to have had no scruple in quietly assuming both of these species, and that too without so much as a fragment of evidence, to have come from the Canaries!- - thus importing an element of uncertainty into the local catalogue which perhaps, however convinced we may be of its injustice, can never be altogether eradicated. ${ }^{1}$

1 That Webb really knew next to nothing about the proper habitats of these various Orchil-species of M. Terver's, some of which he seems to have appropriated so ingeniously to augment his Canarian fauna, is evident from an old letter of his, in my possession, which was written to Mr. Lowe, and which bears the date 'Paris, Aug. 26, 1833.' Speaking of his 'Synopsis,' which then had been just published, he says : 'At the end of our Synopsis you will find an appendix containing some shells found in the Orchilla at Lyons, by a most indefatigable collector Mr. Terver. Out of all he found,tro-thirds are yours from Madeira and Porto Santo: but where the rest come from $I$ know not.' And yet a certain number of these very species are still cited in Monographs, on Webb's authority, as 'Canarian!'

Considering too that Mousson was equally satisfied concerning the unsatisfactory nature of the evidence for the original admission of the $T$. taniata and tiarella into the Canarian list, and considering also that he was fully aware that the latter at any rate is a distinctively Madeiran species, and 
Helix maderensis.

Helix maderenșis, Wood, Ind. Test. Supp. t. 8. f. 84 (1828)

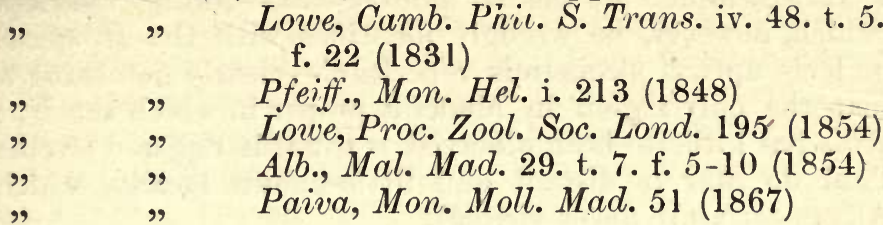

Habitat Maderam; in aridis apricis submaritimis, a litore maris usque ad $2000^{\prime}$ s.m. copiose ascendens.

The present Helix may be regarded as the central one, or type, of the little group of forms of this immediate pattern,combining much the same sculpture as the torniata, with the smaller size, less depressed spire, and less carinated outline of the compar. It is, however, distinctly, more keeled than the latter, and its sculpture (as already mentioned) is quite different,-its upper surface being merely crowded with closelyset costate lines (instead of remote and elevated ridges), some of which are rather larger and paler than the rest, with the addition of a few coarse granules scattered sparingly towards the aperture. Its umbilicus is relatively a trifle narrower than that of either the compar or the tomiata.

The mere variations of colour, in this and the two preceding species, are scarcely important enough to deserve notice,- - the single narrow band with which they are ornamented, both above and below the keel, being occasionally (though not often) so increased in width as to be comparatively conspicuous, whilst at other times, on the contrary, it is nearly, or even altogether, absent. Specimens in this latter condition, which are frequently smaller and less developed than the average, would seem to have been mistaken by Albers (as is evident both from

that even the former belongs to a distinctively Madeiran type, it is much to be regretted that he should not have rejected them in toto from his late volume-as forms (to say the least) of uncertain habitat, and such as ought never to have been introduced into the Catalogue at all. Speaking of the $H$. taniata, he says: 'Cette espèce n'a pas été recueillie dans les Canaries, mais a été trouvée par M. Terver dans un ballot d'Orseille d'origine inconnue. Sa forme rappelle tellement les espèces de Madère, qu'il est bien plus probable qu'elle appartienne réelement à ce second groupe d'îles, où se récolte également ce lichen.' And of the tiarella he adds: 'Cette espèce se trouve vivante et subfossile dans Madère, et il n'est guère probable, vu la différence des deux faunes, qu'elle se retrouve dans les Canaries. Son origine en effet est tout aussi douteux que celui de la treniata, puisque, comme elle, la tiarella ne s'est trouvée dans de l'Orseille de source inconnue.' And he then observes: - La patrie bien établie de l'une de ces deux espèces donne la clef pour celle de l'autre;' so that, on his own shewing, as he acknowledged one of them to be undoubtedly Madeiran, the other must have been Madeiran likewise. Therefore why did he not eliminate them immediately? instead of perpetuating, by not doing so, a geographical error. 
his habitat and figures) for the H. spirorbis, Lowe, which appears really a good species. He cites them, very properly, as a 'var. $\beta$. minor' of the $H$. maderensis, - adding 'Varietas $\beta$. [which, however, he wrongly identifies with the $H$. spirorbis] in locis apricis siccissimis reperitur,'-clearly not being aware that the only region in Madeira proper in which the $H$. spirorbis has hitherto been observed is towards Feijãa d'Ovelha and Paul do Mar (a distant and little-known locality which Dr. Albers certainly never visited).

The $H$. maderensis seems to be confined (like the very much rarer and more local $H$. compar and toeniata) to Madeira proper, where it is one of the most abundant of the Helices; nevertheless, although so common, it is extremely circumscribed in its distribution,-it being well-nigh confined to the hot seacliffs, and submaritime hills, which form the lower, and outer, zone of the island. It occurs from the level of the sea to an altitude of about 2,000 feet, often swarming in dry and semicultivated grounds.

\section{Helix spirorbis.}

Helix spirorbis, Lowe, Ann. Nat. Hist. ix (1852)

", maderensis, var. $\beta$., Pfeitf. [sec. Albers], Mon. Hel. iii. 164 (1853)

" spirorbis, Lowe, Proc. Zool. Soc. Lond. 195 (1854)

" $\quad$ "Paiva, Mon. Moll. Mad. 52 (1867)

Habitat Maderam, et (sec. Paiva) Desertam Australem; in collibus aridis apricis submaritimis, præcipue juxta Feijãa d'Ovelha sub lapidibus congregans.

This is the smallest of the $H$. madererisis group, and a form which, in its more granulate, less banded surface, and somewhat thinner substance, makes a manifest approach to the leptosticta type; though its relatively much larger umbilicus, its coarser granulations, and the fact of its fasciæ (however obscure) being at any rate both more conspicuous than in that well-nigh unicolorous species (the under one, when present, being moreover ditierently placed) will immediately remove it from the latter.

The present Helix is more intimately related to the $H$. maderensis than it is to anything else, nevertheless I think that Mr. Lowe was perfectly justified in separating it therefrom,its smaller size and more obtuse spire, added to its slightly less solid and more transparent texture, its appreciably wider umbilicus, its more convex volutions and more deeply impressed suture (the former of which are only 6 in number, instead of 7), and its different colour and sculpture, giving it a character essentially its own. As regards colour indeed, the ordinary fascix of the $H$. maderensis type are in the $H$. spirorbis occa- 
sionally so obscure as to be barely traceable; though the whole of the upper portion of the shell is more often suffused with a perceptibly browner tint, which is only relieved by a few irregular transverse distant whiter line-like dashes which mark the positions of some of the larger costæ. Then, its sculpture is peculiar,-the closely-set costate lines being finer than in the maderensis, the smaller ones however having a tendency to be broken-up into elongate granules, which give the entire upper surface a rather coarsely granulated appearance. The underside, on the contrary, apart from the usual scattered granulations towards the aperture, is nearly free from sculpture,-it being a trifle more smooth and shining than is generally the case in its ally.

The only district in which I am aware that the H. spirorbis has hitherto been observed is near Feijãa d'Ovelha and Paul do Mar, in the west of Madeira proper,-where it was obtained in great profusion by Mr. Lowe, during April 1860, congregating in clusters beneath large slabs of stone on the dry submaritime hills, or cliffs, in the direction of the coast,-though at an elevation of, perhaps, 1,200 feet above the sea. The Baron Paiva records its existence on the Southern Deserta also (or Bugio), and I am inclined to think that this habitat may be trusted; though the species was not met with in that island either by Mr. Leacock, Mr. Lowe, or myself. But, if true, the fact is topographically important,-implying, as it does, that, of the four allied Helices of the $H$. maderensis type, the $H$. spirorbis is the only one which has yet been detected beyond the limits of Madeira proper. ${ }^{1}$

\section{Helix leptosticta.}

Helix leptostica, Lowe, Cambr. Phil. S. Trans. iv. 49. t. 5. f. 24 (1831)

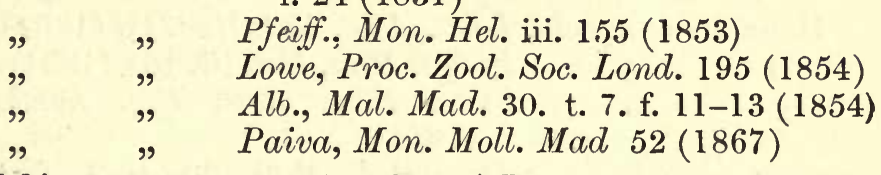

Habitat Maderam, et (sec. Paiva) Desertam Australem; in collibus aridis maritimis orientalibus, præsertim versus Cabo Garajão, gaudens.

The $H$. leptosticta is about as large as, or a little larger than, the $H$. maderensis; but it differs from that species and its immediate allies, essentially, in its less carinated (indeed

1 The exact spot, near Feijãa d'Ovelha, where Mr. Lowe met with the IH. spirorbis, is on the Lombo do Canario,-below (or, rather, down) the Lombada dos Marinheiros, beyond the Lombo Farrobo, towards the verge of the sea-cliffs. 
nearly uncarinated) form and smaller umbilicus, in its thinner and more transparent substance, in its pale corneous, well-nigh unicolorous, almost efasciate surface, and by its sculpture being both finer and of a different kind,-the oblique transverse lines being comparatively indistinct, but the whole portion visible from above densely crowded with minute granules. The under region is likewise granulated, but much less evidently so; and it is also rather more shining. Its peristome, although continuous, is not quite so regularly rounded across the body-volution, nor is it so much raised; and its basal whorl is not so suddenly deflected in front.

As regards hue, this species is practically unicolorous,-it being of a light horny brown above, and rather paler beneath ; nevertheless when carefully inspected, it will generally be seen to have a narrow and most obscure obsolete band immediately below the dorsal line (or the position of the keel). Indeed in fresh and highly developed examples the faintest possible trace of even an upper one is sometimes just distinguishable,-but so suffused and lost sight of as merely to infuscate that portion of the surface with a rather more cloudy tint. At any rate the species, despite its primâ facie appearance, can hardly be detined as perfectly ' efasciate.'

The $H$. leptosticta is eminently characteristic of the lofty cliffs and dry maritime hills to the eastward of Funchal, in the direction of the Cabo Garajão (or Brazen Head),-where it is rather abundant; but $I$ have not myself observed it in any other district. It is recorded, however, by the Baron Paiva from the Southern Deserta, - a habitat which, although certainly requiring corroboration, is not altogether an improbable one.

\section{Helix micromphala.}

Helix micromphala, Lowe, Ann. Nat. Hist. ix. (1852)

\begin{tabular}{|c|c|c|}
\hline & פי & Pfeiff., Mon. Hel. iii. 151 (1854) \\
\hline & ", & $\begin{array}{l}\text { Lowe, Proc. Zool. Soc. Lond. } 195 \\
(1854)\end{array}$ \\
\hline & פ" & $\begin{array}{c}\text { Alb., Mal. Mad. 30. t. 7. f. } 14-16 \\
\text { (1854) }\end{array}$ \\
\hline & & Paiva, Mon. Moll. Ma \\
\hline
\end{tabular}

Habitat tres Desertas (sc. Borealem, Grandem, et Australem); vulgaris. Semifossilis in Desertâ Australi reperitur.

This Helix is so closely allied to the H. leptosticta that, had not the latter been recorded by the Baron Paiva from the Bugio, it might almost have been looked upon as a highlydeveloped Desertan modification of that species. It seems to differ in being a little larger and less flattened, or more globose, 
in being altogether more solid and robust, and in its umbilicus being relatively a trifle smaller. In addition too to its spire being more exserted (or less obtuse), it possesses an extra whorl (namely 7 , instead of 6 ); the granulations of its upper portion are slightly coarser and rougher; its basal volution is more suddenly deflected in front; and it is usually of a rather whiter tint beneath, but of a somewhat deeper brown above,- the region towards the aperture, however, being gradually diluted in hue, or subflavescent. Like the $H$. leptosticta, it will generally be seen, when accurately inspected, to possess obscure traces of an obsolete band immediately below the dorsal line (or the place which, had it been carinated, would have been occupied by the keel).

The H. micromphala is essentially a Desertan species, on the whole three islands of which I have myself met with it. It was first found by Mr. Leacock, in June 1848; and it has subsequently been obtained by both Mr. Lowe and the Baron Paiva, on various occasions. On the summit of the Southern Deserta (or Bugio) it is not uncommon in a subfossil state.

\section{Helix dealbata.}

Helix dealbata, Love, Cambr. Phil. S. Trans. iv. 48. t. 5. f. 21 (1831)

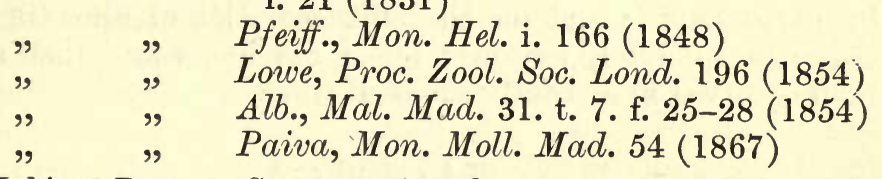

Habitat Portum Sanctum (insulasque parvas adjacentes); vulgaris.

The $H$. dealbata and fictilis are peculiar to Porto Santo and the adjacent rocks ; and although, in a general sense, sufficiently distinct inter se to be easily separated, intermediate states (in outline, sculpture, and size) do nevertheless occur which so far connect the two as to render it at times not quite apparent to which of the forms they should be assigned. Still, as they have been universally acknowledged hitherto, and are in most instances at once recognisable, I will not do more than record a passing doubt as to the possibility of their being in reality but well-marked phases of a single type. ${ }^{1}$

1 Even Mr. Lowe seems to have had the difficulty in the precise identification of some of these occasional intermediate forms practically brought home to him; for the 'var. $\beta$. levis' of his original $H$. dealbata (in 1831) he subsequently treated (both in 1851 and 1852) as a 'var. $\beta$.' of the fictilis. But two years afterwards he referred it back again (vide 'Proc. Zool. Soc. Lond.' 196 ; 1854) to the dealbata, with which, on further consideration, he appears to have thought that it would, after all, be better associated. 
Both the $H$. dealbata and fictilis are solid, depressed, and somewhat turbo-lenticular shells, with a small but distinct umbilicus, and with their peristome continuous, but neither much raised nor much rounded across the body-volution. In its normal state the dealbata is larger, less flattened, and more solid than the fictilis, its sculpture is altogether rougher (the transverse costate lines being coarser and the granules more numerous), and its surface has usually a whitened and bleached appearance, - with only a faint trace (sometimes indeed none at all) of an infra-carinal band, but with the aperture within, and the peristome, more or less obscurely ochreous. In certain examples, however, which can hardly be treated as representing a definite 'variety,' the colour is darker, being of a slightly yellowish- or plumbeous-brown; and in others the granulations are both fewer in number and well-nigh obsolete.

From the $H$. micromphala the dealbata may be known by being larger, paler, more solid, and more depressed, by its surface being more coarsely costate-striate but less roughly (and less thickly) granulated, by its umbilicus being relatively a trifle wider, by its basal volution being less suddenly deflected in front, and by its aperture (which is more developed) being ochreous internally.

The $H$. dealbata is most abundant in dry calcareous places in Porto Santo; and on the adjacent islet of the Ilheo de Baixo it absolutely swarms; but I am not aware that it has been observed in a strictly subfossil state.

\section{Helix fictilis.}

Helix fictilis, Lowe, Ann. Nat. Hist. ix. (1852)

\begin{tabular}{|c|c|c|}
\hline " & " & Iel. iii. 154 (1853) \\
\hline " & . & l. Soc. Lond. 196 (185 \\
\hline & פ, & $\begin{array}{l}\text { Alb., Mal. Mad. 31. t. 7. f. 17-24 (1854) } \\
\text { Paiva, Mon. Moll. Mad. } 55(1867)\end{array}$ \\
\hline פ" & " & \\
\hline
\end{tabular}

Habitat Portum Sanctum (insulasque parvas adjacentes); hinc inde congregans. In statu semifossili invenitur, sed multo rarius.

As already implied, the $H$. fictilis, which is abundant in many districts of Porto Santo, and which occurs also (though much more rarely) in a subfossil condition, is typically a smaller and a flatter shell than the dealbata, its spire being more depressed; and it is also rather less solid and robust, not quite so coarsely striated, and with only a few scattered granules on each volution towards the suture; and its ultimate and penultimate whorls are more angulated, or less rounded and inflated. The colour, too, is not quite the same,-those 
examples which are not pale and bleached (and the pallid ones are exceptional with the $H$. fictilis) being of an irregular, or clouded, plumbeous- and cinnamon-brown, gradually a little diluted in hue towards the aperture, and whitish beneath, but with an infra- and supra-carinal band tolerably conspicuous, though often blended or confluent. The peristome, also, is less decidedly ocbreous than in the $H$. deaibata.

\section{(§ Actinella, Lowe.)}

\section{Helix lentiginosa.}

Helix lentiginosa, Lowe, Cambr. Phil. S. Trans. iv. 49. t. 5. f. 25 (1831)

\begin{tabular}{|c|c|c|}
\hline$"$ & ", & Pfeiff., Mon. Hel. iii. 164 (1853) \\
\hline & " & Lowe, Proc. Zool. Soc. Lond. 180 \\
\hline & , & $\begin{array}{l}\text { (pars), Alb., Mal. Mad. 38. t. } \\
\text { (1854) }\end{array}$ \\
\hline & פ & Paiva, Mon. Moll. Mad. 32 (1867) \\
\hline
\end{tabular}

Habitat Maderam ; sub foliis Sempervivorum aridis emortuis, ad rupes (præsertim maritimas) crescentium, vulgaris.

The $H$. lentiginosa is a depressed, rounded, sublenticular little species (about $2 \frac{1}{2}$ lines across its broadest part), thin and fragile in substance, with a distinct and open umbilicus, and densely sculptured with coarse transverse costate lines, as well as sparingly clothed with squamiform hairs, or hair-like laciniæ. Its surface is nearly opake and of a pale corneous brown, but more or less blotched or marbled with a few irregular whitish transverse patches and streaks; and its peristome, although slightly interrupted across the body-volution, is expanded and a good deal developed.

I am not aware that the present Helix has occurred beyond the limits of Madeira proper; for although it is recorded by the Baron Paiva from the Southern Deserta, yet there is so much doubt attaching to many of his various habitats (through the fact of his material having simply been brought to him, at intervals, by mere paid collectors sent out from Funchal, and often inadvertently mixed up afterwards, even by himself, with specimens from other localities) that I cannot but regard the present one as somewhat, dubious, or at any rate as requiring further confirmation. But in Madeira proper the H. lentiginosa is decidedly a common little species, and one which occurs principally amongst the dead and dried-up leaves of the rosettelike plants of Sempervivum which stud the faces of the rocks both at low and intermediate altitudes. Along the line of abrupt sea-cliffs, in the north of the island, from São Vicente to Sta. Anna, it is more or less abundant, as also westward to 
Seissal, the Ribeira da Janella, and Porto Moniz; and it likewise is found in the Ribeira de Sta. Luzia, the Curral dos Romeiros, and elsewhere, on the southern side, above Funchal.

The nearest Canarian ally of the $H$. lentiginosa is the $H$. torrefacta (wrongly regarded, as I cannot but think, by Mousson, as a Patula), - which was detected by myself and Mr. Lowe on dry and exposed rocks in the extreme north of Lanzarote. That species however is a little larger, and much more conspicuously ornamented with irregular white transverse markings; its ground-colour is of a deeper reddish-brown above, but paler beneath; its umbilicus is rather larger; the upper and lower margins of its peristome are more widely interrupted across the body-volution; and its entire surface is both differently sculptured and differently clothed,- the transverse costate lines being finer, closer, and more regular (although minutely undulated), and crossed, or decussated, by infinitesimal spiral striæ, whilst the coarse laciniæ of the $H$. lentiginosa are replaced by excessively diminutive and short squamiform bristles.

\section{Helix stellaris.}

Helix stellaris, Lowe, Ann. Nat. Hist. ix. (1852)

" " Pfeiff., Mon. Hel. iii. 123 (1853)

$" \quad$ " $\quad$ Lowe, Proc. Zool. Soc. Lond. 180 (1854)

" lentiginosa, var. B., Alb., Mal. Mad. 38. t. 9. f. 21, $22(1854)$

"stellaris, Paiva, Mon. Moll. Mad. 34 (1867)

Habitat Maderam; in aridis apricis subinferioribus, haud longe ab urbe Funchalensi sitis, hinc inde sub lapidibus.

The present insignificant little Helix is closely allied to the $H$. lentiginosa, of which indeed it was treated by Dr. Albers as a 'var. $\beta$. minor.' Nevertheless I am satisfied that it is perfectly distinct; and it is surprising to me how a conchologist like Albers should have come to the conclusion, that there was nothing on which to separate it from that species except its smaller size. ' Præter magnitudinem,' says he, ' non diversa a forma typica'; whereas, apart from its greatly reduced dimensions, it is appreciably flatter and more carinated than the $H$. lentiginosa (its spire being less exserted), its umbilicus is relatively larger, it has only $4 \frac{1}{2}$ (instead of $5 \frac{1}{2}$ ) volutions, its aperture is rather more oblique and oval, and its transverse costate lines are much less coarse and less evident, whilst, on the contrary, its hair-like filaments, or laciniæ, are proportionately more developed,-being enlarged about the region of the keel (when the specimens are fresh and unrubbed) into ragged whitish rays, giving the entire shell a somewhat star-like 
appearance. Its peristome, although narrowly interrupted, is greatly expanded and recurved.

In its mode of life, too, the $H$. stellaris is altogether different from the lentiginosa; for whilst the latter occurs almost exclusively (as indeed I have already mentioned) under the plants of Sempervivum which stud the faces of the rocks, both along the abrupt sea-cliffs and in the ravines of an intermediate elevation, the stellaris, on the other hand, resides beneath stones, like the $H$. arcta, in dry and exposed places only slightly removed above the level of the sea,-where moreover it has the curious habit of coating itself over with a covering of hardened mud. Even Dr. Albers was not able to ignore in toto this essential difference in their habitats,-adding: 'Formæ duæ non promiscue degunt; major enim [i.e. the H.lentiginosa] ab oppido Funchal versus orientem, ad promontorium Cabo Garajäo dictum, occurrit; varietas pusilla autem [i.e. the H. stellaris] in cacumine tantum promontorii supra Praia Formosa, ab oppido Funchal versus occidentem, collegitur (l. c. p. 39). He might however have made the case very much stronger.

The $H$. stellaris was first detected by myself, during April 1848 , beneath stones, at the east end of the cliff, or basaltic ledge, overlooking the Praia Bay, about three miles to the westward of Funchal, - a locality in which it was shortly afterwards (namely on the 1st of May of the same year) taken by $\mathrm{Mr}$. Leacock. . The Baron Paiva records it from other places within the Funchal district, - such as the Pico da Cruz, the Feijãa dos Asnos, the Ribeira de Sta. Luzia, and the Ribeira de Vasco Gil.

\section{Helix arcta.}

Helix arcta, Lowe, Cambr. Phil. S. Trans. iv. 42. t. 5. f. 7. $(183 i)$

$\quad \quad$ Pfeiff., Mon. Hel. i. 404 (1848)
$\Rightarrow \quad$ " Lowe, Proc. Zool. Soc. Lond. $180(1854)$
$" \quad$ " Alb., Mal. Mad. 40. t. 10. f. 5-10 (1854)
$\quad \quad$ Paiva, Mon. Moll. Mad. 33 (1867)

Habitat Maderam, et (sec. Yaiva) Desertam Australem; in collibus aridis maritimis subinferioribus hinc inde copiose congregans.

The H. arcta is one of the smallest of the Madeiran Helices (the larger examples measuring only about a line and a half across the broadest part); and it is one which is more particularly gregarious in dry submaritime places of a rather low altitude. It abounds on the Cabo Garajão (or Brazen Head), as well as towards Caniço and Sta. Cruz, and (in the west of 
the island) at Feijãa d'Ovelha, and on sea-cliffs at the Ponta de Pargo, - in which last-mentioned locality it was first detected by Mr. Lowe, during December of 1826 .

In its more or less obliquely-mottled (or streaked) surface, as well as in its rounded, depressed, sublenticular outline, the $H$. arcta has much the primâ facie appearance of the H. lentiginosa; nevertheless, both in its structure and mode of life, it is essentially distinct from that species. Thus it is not only smaller and flatter, but altogether more thickened, solid, and robust; it has a volution less (namely $4 \frac{1}{2}$, instead of $5 \frac{1}{2}$ ); its umbilicus, although open and conspicuous, is relatively a trifle smaller and more punctiform; and it is not only more coarsely costate-striate, but nearly (if not indeed altogether) bald, or free from every trace of minute hair-like laciniæ. Its peristome too is more continuous and incrassated, as well as more corneous, whiter, and more recurved; and (which is its most important feature) it possesses a white, elongate, oblique callosity or tooth, within the aperture on the ventral wall.

There is, however, a slightly smaller phasis of this shell (the 'var. $\beta$. minor' of Lowe) which is a little thinner in substance and not quite so strongly costate, and in which the ventral tooth is either almost or entirely obsolete. This was first met with by myself, during January of 1849, on the 'Telegraph Hill' (or Pico da Cruz), above the Race Course, to the westward of Funchal,-particularly on the slope descending towards the Gorgulho; and the same form has been found subsequently at Calheta.

The Baron Paiva records the occurrence of the $H$. arcta on the Southern Deserta; but whether this habitat may be trusted I have no means of deciding. The Bugio, however, is not at all an improbable locality for the species.

\section{(§ Rimula, Lowe.)}

\section{Helix arcinella.}

Helix fausta, $\beta$. et $\gamma$. , Lowe, Prim. ; Append. xiv. (1851) " arcinella, Id., Proc. Zool. Soc. Lond. 181 (1854)

" " Paiva, Mon. Moll. Mad.35 (1867)

Habitat Maderam, semifossilis; in stratu conchylifero juxta Caniçal, sat vulgaris.

This little Helix, which was regarded originally by $\mathrm{Mr}$. Lowe as merely a small state ( the 'var. $\gamma$. minima') of his $H$. fausta, has been observed hitberto only in a subfossil condition at Caniçal, -where it is tolerably common. In general size and proportions it has much the primâ facie aspect of the smaller examples of the $H$. arcta; nevertheless it may be known readily 
from that species by being not only more globose both above and below, with its umbilicus almost (or, more often, entirely) closed up by the expanded lamina of the lower lip, but likewise by its ventral plait being obsolete, and the aperture narrower and very differently shaped,-in fact somewhat semi-lunate, instead of subcircular, with the peristome broadly interrupted (instead of being sub-continuous) across the body-volution, and the labra themselves nearly parallel.

I may observe that a single mutilated example which may possibly belong to the $H$. arcinella was found by Mr. Lowe in Porto Santo, namely at the Fonte d'Areia, in 1828; but as it seems to me to differ a little from the Madeiran type, in being somewhat more granulated below and with its ventral plait more appreciably developed, I think it safer until further material has been obtained not to record the $H$. arcinella as PortoSantan,-seeing that it is not impossible that this broken specimen may in reality prove to be the exponent of some closely allied species, as yet uncharacterised.

\section{Helix arridens.}

Helix arridens, Lowe, Cambr. Phil. S. Trans. iv. 43. t. 5. f. 9 (1831)

$\begin{array}{lll}\prime & \quad & \text { Pfeiff., Mon. Hel. i. } 217(1848) \\ " & \quad & \text { Lowe, Proc. Zool. Soc. Lond. } 180(1854) \\ & \quad & \text { Alb., Mal. Mad. 39. t. 9. f. 23-26(1854) }\end{array}$
vulgaris.

Habitat Maderam; in intermediis præcipue occurrens,

The members of the section Rimula,-which include the present species, the preceding one, and the following three,-have their umbilicus either nearly or altogether closed over by the outwardly expanded lamella of the lower lip; and they are all of them rather small in stature, and more or less clothed (though it is impossible to assert this absolutely of the H. arcinella, which is known only in a subfossil and decorticated state) with squamiform hairs, or hair-like laciniæ.

The $H$. arridens is decidedly the commonest of this particular type,-it being generally distributed over the intermediate regions of Madeira proper, to which island it seems to be peculiar. Like the $H$. lentiginosa it is often abundant under the dried and brittle leaves of the Semperviva which stud the faces of the rocks in the shady ravines; but it is almost equally to be found in other situations, - as, for instance, about the roots of plants, and amongst detritus, on the ledges of the rocks, and beneath the dead and loosened bark of the old laurels. Under 
such circumstances it may be met with in nearly all the ravines, both in the north and sunth of the island; and, within what may be called the Funchal district, it is frequently common in the Ribeira de Sta. Iuzia, as well as above the Mount, at the Curral dos Romeiros, and elsewhere.

Like its immediate allies, the $H$. arridens (which is about $2 \frac{1}{2}$ lines across the broadest part) is rounded, but depressed and sublenticular; and it is also thin and subpellucid in substance, of a pale yellowish horny-brown, and only obscurely streaked (sometimes indeed not so at all) with irregular transverse markings, and with its surface opake, but clothed (when the specimens are fresh and unrubbed) with pointed, but curved, subtriangular, somewhat hook-shaped, hair-like laciniæ. Its basal volution is appreciably keeled; and its aperture is much flattened, or narrow and horizontal, - the lower lip (the expanded lamella of which more than half conceals the umbilical perforation) being produced in a comparatively straight, subhorizontal line, from the axis. The upper and lower lips are wide apart at their insertion, but joined by a thin corneous plate across the body-volution; and the aperture is free from internal teeth or callosities.

\section{Helix capsella.}

Helix capsella, Lowe, Proc. Zool. Soc. Lond. 181 (1854) " " Paiva, Mon. Moll. Mad. 30 (1867)

Habitat Maderam; in apertis editioribus (ultra sylvaticis), sub lapidibus, minus frequens.

This is one of the most obscure, and least satisfactorily defined, of the Madeiran Helices; and had it not been already established by Mr. Lowe, I am not certain that I should have ventured to treat it as more than a permanent variety of the H. arridens.' And yet it certainly will not altogether quadrate with that species, either in configuration or habits; and it is about equally removed also from the $H$. fausta, with which in general colouring and contour it has much in common. Indeed it may perhaps be said to be about intermediate, in its features, between the arridens and the fausta; though partaking rather more, I think, of the characters of the former than of those of the latter.

In mere size, as well as in its nearly closed-over umbilical perforation, the $H$. capsella does not differ materially from the arridens; nevertheless it is a little less depressed than that species (it being a trifle more convex both above and below), its keel is not quite so pronounced, the upper and lower lips of its peristome (the latter of which is not quite so straightly, and horizontally, produced from the axis) are less evidently joined by a thin 
lamella, and its surface is darker and of a more reddish-brown hue, as well as less densely studded with hair-like laciniæ, but with the costate lines somewhat coarser and more apparent.

From the $H$. fausta the capsella may be known by being a trifle smaller and less globose (it being scarcely so convex as that species, either above or below) by its keel being consequently less decidedly rounded or obtuse, by its perforation not being wholly closed-over by the reflexed margin of the peristome, and by its aperture being a little less elongated and depressed, with the lower lip free from any indication of an internal thickening or corneous bi-sinuosity.

The $H$. capsella was detected by myself and the late Rev. W. J. Armitage, during 1848, beneath stones, in a little dried-up gulley on the southern slopes (towards the summit) of the Pico da Silva,-about four miles from Funchal, up the Caminho do Meio, at an elevation of perhaps 3,500 feet; and I also met with it, in 1849, on the hills above Machico. It is recorded by the Baron Paiva, likewise, from the vicinity of Sta. Anna and S. Jorge, in the north of the island.

\section{Helix fausta.}

$T$. imperforata, obtuse conoideo-discoidea, obsolete subcarinulata, subtus inflato-convexa, tenuiuscula, subopaca, plus minus pubescens aut hispida, utrinque tenuiter et indistincte costulatostriata, fusco-cornea sed parce et irregulariter substrigoso-marmorata ; anfr. $5 \frac{1}{2}-6$ convexiusculis, ultimo antice subito deflexo et constrictiusculo; aperturâ depressâ, angustâ, lunatâ; peristomate interrupto, albido, expanso, sed acuto, marginibus laminâ tenui junctis, basali versus insertionem late expanso adpresso, intus quasi in dentem abrupte desinente.-Long, maj. $2 \frac{1}{2}-3$; alt. 2 lin.

Var. $\beta$. robusta.-Sensim major, ac paulo magis carinata, quare subminus globosa.

Helix fausta, Lowe, Cambr. Phil. S. Trans. iv. 43. t. 5. f. 8 (1831)

$\Rightarrow \quad$ Pfeiff., Mon. Hel. i. 422 (1848)
$" \quad$ Lowe, Proc. Zool. Soc. Lond. $182(1854)$
$" \quad$ Alb., Mal. Mad. 39. t. 10. f. 1-4 (1854)
$\Rightarrow \quad$ Paiva, Mon. Moll. Mad. 31 (1867)

Habitat Maderam ; ad rupes, vel submaritimas vel in castanetis sitas, versus insulæ borealem. Rarissima. In statu semifossili prope Caniçal invenitur.

The H. fausta and obserata differ from the capsella and arridens, amongst other particulars, in having their umbilical perforation entirely closed over, or sealed, by the expanded edge of the lower lip; and as they are species which might be some- 
what apt to be confounded with each other, I have thought it desirable to give an emended diagnosis of them both. The $H$. fausta is more globose (and, on the average, somewhat smaller) than the obserata, as well as less keeled, its spire (although obtuse) being more elevated; its aperture is a trifle less narrowed and horizontal, the columella being just perceptibly longer; and its surface is not only more hispid or pubescent (the H. obserata being practically bald), but marked with very much finer and more obsolete lines. It is also a little less solid in substance, and appreciably more opaque.

There is, however, a state of the shell, which I have enunciated as the 'var. $\beta$. robusta,' which is distinctly larger and a little more keeled, or less globose, thus making an approach towards the $H$. obserata ; nevertheless it is quite as thickly pubescent as the typical one, and its sculpture is quite as fine.

In size, outline, and colouring, the $H$. fausta has much the general appearance (at all events in its normal condition) of the H. capsella. But it is a trifle larger than that species, and more globose (being convexer both above and below), it possesses half a volution more, its perforation is altogether closed over, instead of but partially so), its aperture is narrower and more depressed, and there are more evident traces of a corneous thickening, shaping out an obsolete tooth, within the lower margin of the peristome.

The H. fausta occurs only in Madeira proper, where it is one of the rarest of the Helices. It was first detected, during October of 1829 , by Mr. Lowe, who found a single example of it under the dead leaves of a Sempervivum, on a dry rock, in the chestnut-woods of the Boa Ventura (about two miles up the ravine from the sea), on the western side of the Ribeira. For twenty-six years this specimen remained unique; but in the summer of 1855 the species was again met with, though very sparingly, by Mr. Lowe and myself, in the same spot in the Boa Ventura in which he took his original type; and we also obtained a few examples of it in the Ribeira de São Jorge, as well as at the Passa d'Areia near São Vicente, and others (still further to the westward) between the Ribeira da Janella and Porto Moniz. The Baron Paiva records its occurrence, likewise, in the Ribeira Funda, near Seissal.

In a subfossil condition, the $H$. fausta is tolerably common near Caniçal.

\section{Helix obserata.}

$T$. imperforata, orbiculato-discoidea, lenticularis, distincte carinata, subtus inflato-convexa, solidiuscula, subnitida, fere (vel omnino) calva, utrinque grosse obtuse et subflexuose plica- 
tulo-striata (striis hinc inde confluentibus, ad basin radiantibus), fusco-cornea sed parce et irregulariter sublentiginoso-marmorata ;

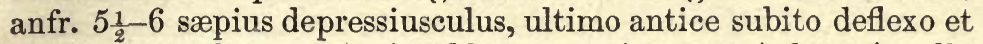
constrictiusculo; aperturâ valde depressâ, angustâ, lunatâ, callo ventrali obsoleto (interdum nullo) coarctato, columellâ brevissimâ ; peristomate interrupto, albido, expanso, sed acuto, marginibus laminâ tenui junctis, basali versus insertionem late expanso adpresso, intus leviter sub-biplicato (rarius subsimplici), plicis sinu plus minus distincto separatis.-Long. maj: 3 ; alt. 2 lin.

Var. $\beta$. bipartita.-(semifossilis). Sensim minor, plicâ exteriore dentiformi distinctiore, ab interiore (callum basalem terminante) obsoletiore, sinu distincto separatâ.

$$
\begin{aligned}
& \text { Helix obserata, Lowe, Ann. Nat. Hist. ix (1852) }
\end{aligned}
$$

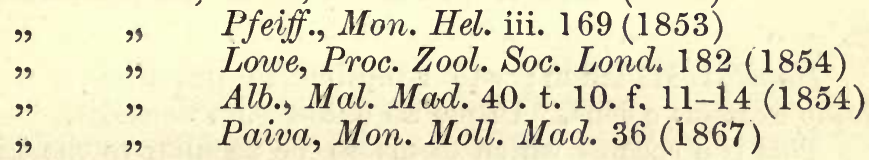

Habitat Maderam ; in intermediis, et borealibus et australibus, parce occurrens. Juxta Caniçal semifossilis, sed in statu minore (='var. $\beta$. bipartita,' mihi), reperitur.

The $H$. obserata is the most decidedly keeled of these immediate species, as well as (proportionately) a trifle more flattened above but more convex beneath; and it is comparatively free (often altogether so) from short hairs or bristles, but its surface is more coarsely and distinctly ribbed. As in the $H$. fausta, its perforation is completely closed over or sealed; and the lower margin of its peristome, although sometimes nearly simple, is often distinctly thickened within into a corneous bi-sinuosity (rather than a medial tooth-like plica), -a structure which is more particularly evident in the subfossil specimens from near Caniçal, where this incrassated inner process takes the form of two tolerably conspicuous, though unequal, gibbosities (sometimes the inner one preponderating, but more frequently the outer), separated from each other by an excavation or sinus. This latter phasis of the shell is rather smaller than the ordinary recent one, and corresponds with the ' $\beta$ ' ' of Mr. Lowe; and we may perhaps, therefore, further characterise it (as above) as the 'var. $\beta$. bipartita.'

The present Helix is both local and rather scarce, though occasionally far from uncommon at intermediate elevations in Madeira proper,-more particularly in the interior and towards the south of the island. It has been taken by Mr. Leacock in the Vasco Gil ravine, and towards the Great Curral; though the Baron Paiva reports it also from the vicinity of Sta. Anna, in the north,-- from whence I have likewise examined a 
specimen (in the collection of Mr. Leacock), considerably reduced in stature, which was met with, in 1858 , by Mr. Rice. By Senhor J. M. Moniz it was also found in the north of the island, namely in the Ribeira de São Jorge.

\section{(§ Hispidella, Lowe.)}

\section{Helix Armitageana.}

Helix Armitageana, Lowe, Ann. Nat. Hist. ix. (1852)

" $\quad$ " Pfeiff., Mon. Hel. iii. $122(1853)$

" $\quad$ Lowe, Proc. Zool. Soc. Lond. 179 (1854)

"

Alb., Mal. Mad. 19. t. 2. f. 2⿺辶-31 (1854)

Paiva, Mon. Moll. Mad. 27 (1867)

Habitat Maderam; sub lapidibus in graminosis, regiones valde excelsas colens. Usque ad 6,000' s.m. ascendit.

This is a species which seems to be peculiar to the highest elevations of Madeira proper, where it is decidedly both rare and local,-having been detected by myself and the late Rev. W. J. Armitage, in January 1849, near the Ice House Peak and the Pico dos Arrieros, at an altitude of about 5,500 feet above the sea; though a single young and (but for these later ones) indeterminable example had been taken by Mr. Lowe, so far back as March of 1827, on the slopes of the Pico Ruivo.

The $H$. Armitageana (which measures about 3 lines across its broadest part) is extremely thin and brittle in its substance, and semi-transparent, and (like the $H$. pavida at the Canaries) it often coats itself over with an outer envelope of dirt; its umbilicus, although not large, is distinct and cylindrical; its peristome, although acute, is rather expanded and developed; and its surface, which is asperated all over (when the specimens are fresh and unrubbed) with elongate-triangular file-like squamiform filaments (rather than hairs), is of a greenish- or olivaceo-corneous hue, and there are generally obscure indications (at any rate on the basal whorl) of two narrow indistinct (sometimes obsolete) browner bands.

We may regard the $H$. Armitageana as the Madeiran representative of the $H$. pavida, Mouss., of Teneriffe and Palma,with which, in its general features and mode of life, it has a good deal in common. The Canarian shell, however, although equally fragile and (when freed from its covering of dirt) subpellucid, is smaller and altogether more insignificant, its spire is more depressed, its umbilicus is relatively larger, its peristome is less developed, its surface is minutely frosted with very short infinitesimal laciniæ-like bristles, and (in lieu of the two indis- 
tinct darker bands observable in the $H$. Armitageana) there are more or less evident traces along the dorsal region (or place of the keel) of a broken-up fragmentary paler fascia, formed of irregular-yellowish-white blotches.

( Gonostoma, Held.)

\section{Helix actinophora.}

Helix actinophora, Lowe, Cambr. Phil. S. Trans. iv. 45. t. 5. f. 14 (1831)

\begin{tabular}{|c|c|c|}
\hline & " & Pfeiff., Mon. Hel. i. 140 (1848) \\
\hline & & Lowe, Proc. Zool. Soc. Lond. 180 (1 \\
\hline & & $\begin{array}{l}\text { Alb., Mal. Mad. } 43 \text { t. 11. f. 5-8 (18) } \\
\text { Paiva, Mon. Moll. Mad. } 28 \text { (1867) }\end{array}$ \\
\hline
\end{tabular}

Habitat Maderam, Desertam Grandem, et Desertam Australem; in intermediis editioribusque haud infrequens. Semifossilis prope Caniçal Maderæ, necnon in summo Desertæ Australis (in hâc sub formâ minore, 'var. $\beta$. descendens' æquante), reperitur.

The $H$. actinophora is not uncommon at intermediate and rather lofty elevations in Madeira proper; and I took a single example of it on the summit (a little beyond the central point) of the Deserta Grande, as well as an abundance of others in a subfossil condition on the Southern Deserta,- - from which island it has since been received by the Baron Paiva in a living state also. The subfossil specimens from the Bugio are a trifle smaller than the Madeiran ones from Caniçal, which are themselves smaller than the ordinary recent type ; and they have their keel very acute, their umbilicus relatively a little narrower, and their basal volution more deflexed at the aperture; and I have cited them in the present catalogue as representing a 'var. $\beta$. descendens.'

In Madeira the present Helix is to be met with both in the moist shady ravines, and amongst loose rubble and coarse vegetable detritus on the ledges of the abrupt submaritime cliffs. I have taken it abundantly in the Ribeira de Sta. Luzia, above Funchal, and also at the Ribeiro Frio; and it occurs likewise near S. Antonio da Serra, Sta. Anna, and elsewhere.

In the $H$. actinophora (the larger examples of which measure from about 4 to $4 \frac{1}{2}$ lines across their broadest part) the shell, although nearly opake, is thin in substance and well-nigh subpellucid, and of a pale yellowish horny-brown, - often with a faint olivaceous tinge, but uniformly free from streaks and markings. In general contour it is lenticular or depressed,the basal volution being acutely keeled, but tumid and convex beneath; its umbilicus, although not large, is open and conspi- 
cuous; and its whorls (which are only 5 or $5 \frac{1}{2}$ in number) are flattened on the spire (the nucleus of which is, nevertheless, rather prominent), and very densely crowded with sharply defined, but minute, transverse lines, which on the ultimate and penultimate volutions are minutely sub-undulated,-a certain number of them, moreover, being irregularly raised (along a portion of their length) into short lamelliform ridges (much resembling those of a file), which last are developed on the underside and about the region of the keel into longer hook-shaped hairs or filaments, and generally enlarged along the keel (when the specimens are fresh and unrubbed) into ray-like processes. The margins of its peristome are wide apart at their insertion, but connected by a very thin corneous plate; and its basal whorl descends but very slightly, and for only a very short distance, in front.

\section{( Caracollina, Beck.)}

\section{Helix lenticula.}

Helix lenticula, Fer., Tabl. Syst. 37. 154 (1821)

", subtilis, Lowe, Cambr. Phil. S. Trans. iv. 45. t. 5. f. 13 (1831)

" lenticula, d:Orb., in W. et B. Hist. 66. t. 2. f. 10-12

"
(1839)

Pfeiff., Mon. Hel. i. 211 (1848)

Lowe, Proc. Zool. Soc. Lond. 196 (1854)

Alb., Mal. Mad. 43. t. 11. f. 9-12 (1854)

Paiva, Mon. Moll. Mad. 96 (1867)

Dohrn., Mal. Blätt. xvi. 3 (1869)

Mouss., Faun. Mal. des Can. 66 (1872)

Watson, Journ. de Conch. 222 (1876)

Habitat Maderam, et Portum Sanctum; in aridis apricis inferioribus, præcipue cultis, parce degens.

The common Mediterranean H.lenticula-so easily recognized by its flattened, strongly carinated form, its rather large and spiral umbilicus, its bald, opake, finely striated surface, and its corneousbrown hue-occurs sparingly both in Madeira and Porto Santo (in the latter of which it was first obtained by myself in 1849), at low elevations and in more or less cultivated spots. In Madeira proper it was originally detected, during May of 1827 , about the Piedare chapel (above the fossil-bed) on the Ponta de Săo Lourenço, by Mr. Lowe,-who likewise met with it, early in the following year, at the Praia Bay. By myself and others it has more often been taken around Funchal,- - where it is frequently found about old walls, and beneath stones in dry places amongst the Opuntia Tuna, or Prickly Pear. In the first ravine (and on the adjoining cliffs) to the eastward of Funchal, 
on the Caniço road, and near the Lazaretto, it is sometimes comparatively plentiful.

The $H$. lenticula is a species of a widely acquired range; and the nature of its habitat, within the cultivated districts, is at once suggestive of a variety of methods by which it may have been accidentally transported from one island, or country, to another. It has established itself at the Azores, and I have myself obtained it in the whole seven islands of the Canarian archipelago ; and it was found by Dr. H. Dohrn in São Nicolão of the Cape Verdes.

I am not aware that the $H$. lenticula has occurred hitherto, at all events in the Madeiran ${ }^{1}$ Group, in anything but a recent state, - the manifest indication, too, which it possesses, of its having been originally naturalized, being against the hypothesis that it was ever an associate of the various species of the subfossil period; and yet the Baron Paiva records it in a subfossil condition from Porto Santo. I believe however it would be found, on enquiry, that his specimens were merely bleached and decorticated ones (such as I have often met with), - filled up with hardened sand, and drifted by the wind on to the calcareous beds in which the ordinary subfossil forms lie loose and scattered over the surface, and not unfrequently intermingled with others in a living state. And this is all the more probable, through the Baron having likewise cited as subfossil, both from the same island and Madeira, the H. pisana, Müll.,-which I have every reason to believe does not exist truly semifossilized. ${ }^{2}$

\section{(§ Cheilotrema, Leach.)}

Helix lapicida.

Helix lapicida, Linn., It. Oel. et Gotthl. 8 (1764)

$\begin{array}{lll}" & \quad & \text { Drap., Hist. Nat. 111. t. 7. f. 35-37 (1805) } \\ " & \quad & \text { Pfeiff., Mon. Hel. i. 370 (1848) } \\ " & \quad & \text { Lowe, Proc. Zool. Soc. Lond. } 197(1854) \\ & \text { Paiva, Mon. Moll. Mad. } 97(1872)\end{array}$

1 At the Canaries it is a little more questionable,-I myself having met with it, as it seems to me truly sufossilized, in the sandy and well-nigh uninhabited district of El Charco (beyond Maspalomas) in the extreme south $\mathrm{nf}$ Grand Canary. And Mousson cites a 'var. virilis,' from Fuerteventura, concerning which he seems somewhat doubtful as to whether it belongs to the present fauna or to one which has passed away; though as he does not enter it into his ultimate catalogue as subfossil, it would appear as if he had come to the conclusion that the specimens (which were obtained by Fritsch) were merely bleached and decorticated ones.

2 The Baron has, in point of fact, however unwittingly, settled this question about the $H$. pisana, to at all events a certain extent, even himself ; for after defining his so-called 'subfossilized' Portosantan phasis of the shell as the 'a. altispira, semifossilis' (thus implying it to be an exclusively subfossil form), in the very next sentence he proceeds to describe the 'Animal'! 
Habitat Portum Sanctum, semifossilis ; exemplare unico in arenis calcareis, A.D. 1849, a meipso, aliisque duobus a Barone de Paiva, repertis.

A single example of the common European H. lapicida was taken by myself, during 1849, in a subfossil state, in Porto Santo; and two more have since been obtained by the Baron Paiva from the Zimbral d'Areia in the same island; so that we have no option but to admit this northern form, no traces of which have as yet been discovered in a recent condition, into the extinct fauna of the archipelago. The examples before me are genuinely subfossilized, and were found under precisely similar circumstances as the various other species, and indeed associated with them; and we cannot doubt, therefore, that the H. lapicida was at a remote period living in Porto Santo.

Singular however as is the presence of this familiar European Helix in the subfossil deposits of so isolated a locality, I am not at all sure that there is any greater anomaly about it than what is indicated by the appearance (equally unintelligible) of the well-known $H$. caperata, Mont., in a recent state, or of the Balea perversa in the fissures of the basaltic rocks on the extreme summit of the Pico de Facho, the highest mountain of Porto Santo (where it was detected by myself during the same year), and which, although it has since been retaken in the identical spot and on an adjacent peak, has not been observed elsewhere throughout the whole of these Atlantic Groupsexcept at the Azores, where it is all but universal. Nor indeed is it more extraordinary than the existence (if true) of the common European Patula rotundata, Müll., on the uninhabited and nearly inaccessible rock, off the north-western coast, known as the Ilheo da Fonte d'Areia. Such facts as these are of unusual geographical interest, to be accounted for if we are able to do so, but absolutely unaltered if they cannot be made to quadrate with any particular theories of our own.

With evidence thus incontrovertible, I cannot but feel surprised that Mr. Watson (Journ. de Conch. 229; 1876) should think it necessary to call in question the right of the H. lapicida to be quoted amongst the indigenous species of Porto Santo. For, in the first place, he is scarcely accurate in asserting that its sole claims rest upon a single individual which was found by myself at the Zimbral d'Areia; seeing that two more were obtained subsequently, from the same locality, by the Baron Paiva, and in a precisely similar state of subfossilization. These specimens are now in my possession; and I can see no more reason for doubting the genuineness of the $H$. lapicida as Porto-Santan than of any other Helix of which only three examples might happen hitherto to have been met with. Con- 
sidering the number, and great extent, of the Porto-Santan conchyliferous deposits, not a tenth part of which have as yet been thoroughly explored, there is absolutely no ground whatever for concluding that these few examples, which have as yet been brought to light, occupy a position in any degree different from those of the other species with which they are associated, or that they require to be accounted for by methods of transmission, during the remote past, concerning which we can form no kind of idea that rises above the merest speculation. "Mais d'où est venue,' says Mr. Watson, 'et quand est venue cette coquille? Une coquille morte, abandonnée par un oiseau, même à une époque préhistorique, ne suffit pas pour faire placer l'espèce au nombre des formes indigènes.' For my own part I cannot but think that no apology is required for the occurrence of these tbree examples of the H. lapicida in the subfossiliferous beds of Porto Santo; and indeed I shall be much suprised if some future explorer in the island does not exhume the species in far greater abundance.

I may just mention that the Porto-Santan examples of the H. lapicida have been examined with the greatest possible care by Mr. Lowe, Mr. Watson, and myself, with all the desire (if it were possible) to detect some peculiarity about them sufficient to justify their separation as a distinct species, and that they correspond in every particular with the more northern type. ${ }^{1}$

\section{(§ Callina, Lowe.)}

\section{Helix rotula.}

Helix rotula, Lowe, Cambr. Phil. S. Trans. iv. 53. t. 6. f. 10 (1801)

$\begin{array}{lll} & \quad & \text { Pfeiff., Mon. Hel. i. } 216(1848) \\ " & \quad & \text { Lowe, Proc. Zool. Soc. Lond. } 183(1854) \\ & \quad & \text { Alb., Mal. Mad. 28. t. 6. f. 16-18 (1854) }\end{array}$

Habitat Portum Sanctum; in montibus vulgaris. In arenâ calcareâ Heliciferâ hinc inde semifossilis parce reperitur.

The $H$. rotula (which measures about 6 lines across its broadest part) is one of the commonest of the Helices of Porto Santo, to which island it is peculiar. It may be known by its solid substance, its depresso-conoidal, acutely-keeled form, its small and nearly closed-up perforation, its rather numerous and flattened volutions, and by its entire surface being sculptured

$1 \mathrm{Mr}$. Lowe, in reference to this point, says : - Diu et sedulo scrutanti, ad amussim cum exemplaribus Britannicis recentibus exemplar vel optime conservatum fossile hoc pretiosissimum, mihi comparandi causa benignissime commissum, omnino congruere compertum est.' (Proc. Zool. Soc. Lond., 1854, p. 197). 
with transverse subconfluent lines, which are more or less interrupted (or broken up) into elongated granules. Its colour is reddish-brown above, and rather paler beneath, - the umbilical region and the portion of the basal whorl outside the aperture being gradually more or less ochreous; and there is a narrow and generally obscure, medial fascia both above and below the keel. The peristome is a good deal thickened internally, and there is a more or less evident white callosity (sometimes obsolete) within the aperture on the ventral wall.

Like so many of the Helices, the $H$. rotula has occasionally a well-nigh colourless, albino state; and sometimes the volutions are unnaturally extended or drawn-out, causing the keel (as it were) to overhang the suture and to be conspicuous up the spire.

In a subfossil condition the $H$, rotula is decidedly rare, nevertheless I have taken it in the calcareous deposits at the 'Zimbral d'Areia,

(§ Cascolus, Lowe:)

\section{Helix consors.}

Helix consors, Lowe, Cambr. Phil, S, Trans. iv, 51. t. 6. f. 3 (1831)

" $\quad$ "Pfeiff., Mon.Hel. i. 195 (1848)

$" \quad$ " Lowe, Proc. Zool. Soc. Land. 184 (1854)

" $\quad$ Alb., Mal. Mad. 41. t. 10. f. 23-25 (1854)

" $\quad$ Paiva, Mon. Moll. Mad. 38 (1867)

Habitat Portum Sanctum; in montibus vulgaris. Semifossilis vulgatissima.

The $H$. consors is peculiar to Porto Santo, where it is one of the commonest of the Helices,-abounding, however, still more in a subfossil than in a recent state. The subfossilized specimens are, on the average, rather smaller than the recent ones; and they are consequently difficult at times, from their colourless and decomposed condition, to distinguish from those of the $H$. compacta, though in a general way they are pretty easily separated.

The whole of the members of this immediate type are solid in substance; and, although more or less strongly sculptured, they are perfectly bald,- - having no tendency whatever to be hispid or pilose ; and the H. consors, calculus, and compacta are somewhat globose and compact in outline, altogether unkeeled, and with a very small and punctiform perforation,which is a trifle further removed from the recurved margin of the peristome in the last of those species than it is in the first and second. The $H$. consors is, however, on the average, very much the largest of the three (highly developed examples mea- 
suring about 5 lines across the broadest part), and it is also more inflated, particularly as regards the basal whorl (both above and below), the upper and lower portions of its peristome are more widely separated at their points of insertion, and its ultimate volution is more suddenly deflected (so as to shape out a more decided angle) in front.

Both in colour and sculpture, too, the $H$. consors differs slightly from its immediate allies,-it being more dappled, or variegated, above, with irregular transverse whitish fragmentary markings on either a brownish or a yellowish-brown ground, as well as more or less roughened with comparatively large and elongated granules (formed by the partial breaking up of the coarse costate lines), which however are liable at times to become evanescent. Its minute umbilical perforation, also, absolutely adjoins the thickened portion of the lower lip.

\section{Helix calculus.}

Helix calculus, Lowe, Proc. Zool. Soc. Lond. 184 (1854). ", compacta, var. $\beta$. Alb., Mal. Mad. 41. t. 10. f. 19-22 (1854)

, calculus, Paiva, Mon. Moll. Mad. 39 (1867)

Habitat Portum Sanctum, insulamque parvam adjacentem 'Ilheo de Cima' dictam; hivc inde gregaria, sed minus frequens. Semifossilis rarissima.

Like the last one, the present species is peculiar to Porta Santo, where however it is both somewhat scarce and exceedingly local; and I think that I have met with it more abundantly on the small adjacent rock known as the Ilheo de Cima than anywhere else. It is, however, recorded by the Baron Paiva from the Pico d'Anna Ferreira, and the Pico Branco. In a subfossil condition it seems to be decidedly rare. ${ }^{1}$

The $H$. calculus might well-nigh be looked upon as a large and totally granulated phasis of the compacta; nevertheless it is in some respects intermediate between that species and the consors,-being considerably smaller than the latter, but a little larger than the former. In its general aspect and its almost unvariegated hue $i$ has certainly more in common with the compacta than with the consors; nevertheless it is both larger and rather more inflated or globose than that species, its perforation is more after the exact pattern which obtains in the

1 The Baron Paiva cites the $H$. calculus in a subfossil condition from the Southern Deserta; but as I have no evidence for the accuracy of that habitat, and so many of the Baron's localities (and identifications) are, to say the least, doubtful, I must decline, until further and more reliable information has been obtained, to regard the species as otherwise than exclusively Porto Santan. 
consors, its basal volution is less constricted at the aperture, and the minute and sharply defined granules with which it is everywhere beset (both above and below), and which constitute its most peculiar feature, will still further tend to distinguish it.

\section{Helix compacta.}

Helix compacta, Lowe, Cambr. Phil. S. Trars. iv. 50. t. 6. f. 2 (1831)

\begin{tabular}{|c|c|}
\hline & Pfeiff., Mon. Hel. i. 198 (1848) \\
\hline " & Lowe, Proc. Zool. Soc. Lond. 184 (1854) \\
\hline פ & (pars), Alb., Mal. Mad. 41. t. 10. f. 15-18 \\
\hline " & Paiva, Mon. Moll. Mad. 40 (1867) \\
\hline
\end{tabular}

Habitat Maderam, Portum Sanctum, et (sec. Paiva) Desertam Australem; in Portû Sancto vulgatissima, sed in Maderâ promontorium 'São Lourenço' tantum colens. Semifossilis, et in Maderâ et in Portû Sancto, abundat.

This is a little Helix which attains its maximum in Porto Santo, in which island it is both general and abundant; nevertheless it exists also on the Ponta de São Lourenço of Madeira proper, the low rocky promontory which stretches out to the eastward and which has many features in common not only with Porto Santo but likewise with the Desertas,-combining, as it were, to a certain limited extent, the faunas of the three compartments of the Group. The Baron Paiva cites, also, the H. compacta from the Southern Deserta,-which is not an unlikely locality, though I have no means of testing its accuracy.

In a subfossil condition the $H$. compacta abounds throughout the calcareous deposits of Porto Santo ; and it is likewise common at Caniçal, where some of the specimens (which represent the 'var. $\beta$. major' of Lowe) are of a slightly larger size and possess more the characters (so far as one is able to judge from examples which are both colourless and superficially decomposed) of the $H$. consors.

Although variable in size and sculpture, the $H$. compacta may be regarded normally as being a good deal roughened above, both with costate lines and granules, but smoother and comparatively unsculptured beneath,- the lines being there lighter and finer, and the granules obsolete. In the Madeiran examples (i.e. from Point São Lourenço) the striæ and granules are less coarse than in the ordinary Porto-Santan ones, and the spire is just appreciably less depressed. These were considered as typical by $\mathrm{Mr}$. Lowe,-by whom they were first detected, about the Piedade and the fossil-bed, during April and May of 1827. The Porto-Santan ones however (which correspond with 


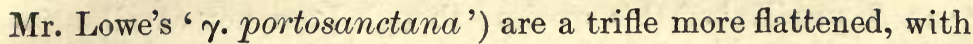
the granules larger, and the costate lines (or at any rate a portion of them) stronger and more elevated. And there is, in addition to these, a subfossil form (which appears to be now extinct) in Porto Santo, in which the stature is very much reduced, the surface is almost totally ungranulated (both above and below), and the umbilicus is relatively a little more open. This last-mentioned phasis is the ' $\delta$. pusilla;' of Lowe.

\section{Helix commixta.}

Helix commixta, Lowe, Proc. Zool. Soc. Lond. 184 (1854) , abjecta, var. a., Paiva, Mon. Moll. Mad. 42 (1867)

Habitat Portum Sanctum, præcipue (nisi fallor) in ins. parvâ adjacente 'Ilheo de Baixo' dictâ; rarior. Semifossilis copiose occurit, sed tantum sub formâ ' $\beta$. pusilla,' Lowe, quæ forsan ad speciem distinctam melius pertinet.

At first sight this Helix might almost be mistaken for an unusually depressed form of the $H$. abjecta, particularly the 'var $\beta$. candisata' of that species; nevertheless it will be seen on examination to be totally distinct,-being not only more flattened or sublenticular, but with its umbilicus relatively larger and more spiral, its sculpture altogether different, its apex more obtuse, and its peristome more continuous, more elevated, and more circular. Indeed its sculpture is exceedingly peculiar, and unlike that of anything else with which we have here to do,- the surface (which is of a dirty or brownish white, practically well-nigh colourless, and remarkably opake) being nearly free from transverse costate lines (though with a few distant, irregular, obtuse, subconfluent transverse folds), but densely crowded with most minute sand-like granules (very accurately expressed hy Mr. Lowe as 'arenulato-granulosa'), which gives it under a high magnifying power somewhat the appearance of fine sealskin. The volutions of the $H$. commixta are tumid, or obtusely angular, and the basal one is rather wide and strongly keeled,- the keel being partially caused by a very slight scooping-out, or obsolete erosion, both above and below.

The $H$. commixta is essentially a Porto-Santan species, and I am not aware that it has been observed hitherto (as above typically defined) in anything but a recent state; though even the living examples have much the colourless, calcareous appearance, at first sight, of being subfossilized. There is however a very minutely subfossilized form (coarsely and less closely granulated both above and below, nearly unkeeled, and greatly resembling in its more globose outline the most diminutive phasis of the H. compacta) which Mr. Lowe regarded as a 
'var. $\beta$. pusilla' of this species; though I am not at all satisfied that it would not be far more natural to treat it as distinct. Still, as it appears to bear somewhat the same relation to the normal $H$. commixta that the 'var. $\delta$. pusilla' of the $H$. compacta does to that species, I am content to cite it as Mr. Lowe has done, - - even whilst feeling extremely doubtful as to its real specific identity with the commixta. In point of fact it would be scarcely separable from the ' $\delta$. pusilla' of the $H$. compacta, were it not that it is powerfully and conspicuously granulated both above and below. Whether properly referred however to the $H$. commixta or not, it is a form which is extremely abundant in most of the calcareous deposits of Porto Santo.

So far as I can at present recollect (for I unfortunately made no particular memorandum, at the time, of their exact habitat), I believe that it was on the Ilheo de Baixo that my specimens of the $H$. commixta were principally found. ${ }^{1}$

\section{Helix abjecta.}

Helix abjecta, Lowe, Cambr. Phil. S. Trans. iv. 50. t. 6. f. 1 (1831)

$\Rightarrow \quad$ candisata, Menke, in Pfeiff. Symb. iii. $70(1846)$
$" \quad$ abjecta, Pfeiff., Mon. Hel. i. $188(1848)$
$" \quad$ " $\quad$ Lowe, Proc. Zool. Soc. Lond. $185(1854)$
$\quad \quad$ Alb., Mal. Mad. 32. t. 8. f. 1-8 (1854)

Habitat Maderam, Portum Sanctum, Desertam Australem, et (sec, Paiva) Desertam Grandem; in Portû Sancto solum vulgatissima. Semifossilis in Portû Sancto copiosissime, sed in Maderâ ad (sec. Paiva) Caniçal rarissime, occurrit.

If the Baron Paiva's statement may be trusted, that he has received it from the Deserta Grande, the $H$. abjecta (however scarce beyond Porto Santo) will have been found in all the islands of the Madeiran Group except the Northern Deserta (or Ilheo Chão). Throughout Porto Santo, and on the immediately adjacent rocks, it absolutely swarms; but it is singular that

1 The Baron Paiva has wonderfully confused this by no means badly defined Helix. In fact he evidently did not know it, practically; though some of his recorded characters were copied clearly from Mr. Lowe's diagnosis. Thus he cites it as the depressed variety of the $H$. abjecta (which, as above mentioned, it most decidedly is not) ; then he asserts it to be a subfossil form, whereas the H. commixta is a living one and has not as yet been observed at all (as typically defined) except in a recent state; and he lastly adds that it occurs likewise on the Southern Deserta, whereas the species from that island is a scarcely altered phasis of the genuine $H$. abjecta! In real truth, in its general contour and rather widened (or, as it were, super-imposed) ultimate volution, no less than in its more circular and raised peristome, the H.commixta makes a very manifest approach towards the Hystricellu group. 
nobody should have yet placed upon record its occurrence in Madeira proper,--though Mr. Lowe, at all events, was perfectly well aware that it is far from uncommon near Porto Moniz on the north-western coast of that island. This fact must consequently have escaped his memory, when compiling (in 1852) his last enumeration of the land-shells of the archipelago. On the Southern Deserta I have myself met with it sparingly, and I have seen a few other examples which had been obtained from thence by the Baron Paiva,-who, by the bye, has fallen into the unaccountable error of citing it as existing in a subfossil state only on that remote rock. ${ }^{1}$

In a subfossil condition the $H$. abjecta is most abundant in the calcareous deposits of Porto Santo; and although I have not myself met with it (subfossilized) except in that island, and have no other evidence of its occurrence elsewhere, it is nevertheless recorded by the Baron Paiva to be found sparingly at Caniçal,-which, considering its existence in a recent state on the northern coast of Madeira proper, is far from unlikely.

The $H$. abjecta is an extremely thick and solid little shell, globose-conical in outline, with an open and conspicuous (though by no means large) perforation, and extremely rough in sculpture,-being coarsely granulated all over (though particularly above), and with strong, irregular, subconfluent, transverse costate lines. Its peristome is white, expanded, continuous, and almost circular; its colour is a brownish-white (sometimes with a few paler radiating lines), passing into a reddish brown; and its volutions are tumid and prominent, though not exactly (at all events in the normal state) keeled. There is, however, a phasis of the shell (corresponding with the ' $\beta$. candisata' of this catalogue) in which the form is rather more flattened and the keel is a trifle more expressed; but it merges so gradually into the other that it can scarcely be looked upon as a permanent 'variety' (properly so called); and the examples from the Southern Deserta (the ' $\gamma \cdot$ nesiotes' of the present list) are, on the average, a little smaller and less conical than the ordinary Madeiran and Porto-Santan ones, somewhat more evidently keeled, and not quite so roughly granulated. Beyond these two forms (the second of which I should not have

1 I have no evidence that the $H$. abjecta has been observed in a subfossil condition at all, hitherto, on the Southern Deserta, though it is extremely probable that sooner or later it will be found there. For the Baron Paiva's assertion that it is only subfossil on that island (' nec recens hodie inventa'), whereas to my own knowledge he procured from thence a certain number of living examples, added to the complete confusion of his ideas in regarding the Porto-Santan $H$. commixta as conspecific with the South-Desertan $H$. $a b$ jecta (the former of which he also misquotes as subfossilized!), renders his evidence altogether contradictory and valueiess. 
noticed had it not been a local one, and neither of which are very decidedly aberrant), I can see no advantage in creating confusion by registering a number of varieties and 'subvarieties' (so-called) which are scarcely distinguishable from each other, and which have been made to depend on the greater or less elevation of the axis, and the greater or less development of the granulations. I will just mentior, however, that the Madeiran examples (from Porto Moniz) have their spire just appreciably more raised than even the most conical ones from Porto Santo.

\section{Helix sphærula.}

Helix subcallifera, Lowe, olim, in litt.

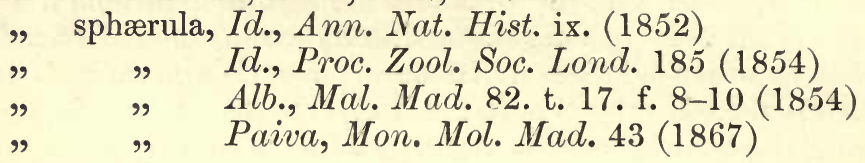

Habitat Maderam (semifossilis), et Portum Sanctum (semifossilis ac recens); rarissima.

Although the smaller and rather more globose pbasis (which is found only in a subfossil condition, and only in the Caniçal beds of Madeira proper) of this species has rather the primâ facie appearance of the $H$. compacta type, yet it will he seen on inspection to be in reality very different,-the larger one, which occurs in a living state on the mountains of Porto Santo, so far explaining the other (which is not only ' smaller' but, from its decomposed surface, practically more obscure) as to render it evident that the $H$. sphoerula makes a most decided approach in the direction of the $H$. cheiranthicola. This is particularly observable, not only in its obtusely conical outline, elevated spire, and ratber flattened base, but likewise in the construction of its aperture and peristome, and even (when the specimens are not simply white, as is generally the case) in its law of colouring, - there being often faint traces of an obsolete fascia encircling the umbilical area, which is never indicated in the true and undoubted members of the section Caseolus.

Mr. Lowe having first enunciated this Helix from the Caniçal form of it (which, as just mentioned, is smaller, rounder, and exclusively subfossilized), we have no option but to treat that particular state as the normal one. Nevertheless in speaking of its characters we must needs do so from the Porto-Santan recent (larger) type, because the distinctive features of the shell are alone readily appreciable in fresh and living examples. It was during our visit to Porto Santo in May of 1855 that the H. spharula was taken by Mr. Lowe and myself on the extreme summit of the Pico Branco,--adhering to the upper parts of 
various plants, especially the culms of Juncus maritimus; and although we found it in considerable profusion in that particular spot, as well as along the commencement of the lofty precipitous promontory immediately behind it, its area even there was remarkably circumseribed, and I am not aware that it has subsequently been met with in any other locality. The subfossilized specimens of Porto Santo (which are extremely scarce, though occurring at the Zimbral d'Areia) are a little smaller than these living ones from the top of Pico Branco in the same island; but as they are nevertheless a trifle larger than the (equally subfossilized) Madeiran ones from Caniçal, we may perhaps adopt Mr. Lowe's arrangement of them as, under the circumstances, the most simple, - namely ' $a$ [normalis] fossilis, minor, sphæruloidea, Maderce; $\beta$. fossilis, submajor, trochoidea, Port $\hat{u}$ Sancto ; $\gamma$. recens, major, trochoidea, Portû Sancto.'

Apart from its rounded-conical outline, elevated (though apically obtuse) spire, and somewhat flattened base, to which I have already called attention, the $H$. sphoerula may be further known by its very minute umbilical perforation, which is partially closed over by the prominently expanded lamina of the lower lip at its insertion into the axis, by its tumid but unkeeled volutions and deeply impressed suture, by its narrow and somewhat horizontal aperture, which has a more or less evident transverse callosity within it on the ventral wall, by the upper and lower divisions of its peristome being widely separated but joined by a corneous plate; and by its surface (the lines of which are rather light, though extremely irregular and subconfluent) being leset with large granules-which are unequal and indistinct (occasionally evanescent) on the upper side, but coarse and arranged as in a file below. Judging from the recent examples now before me, from Porto Santo, the $H$. sphorrula is usually white and without markings, though often with a very faint lilac or plumbeous tinge, - the whole shell, which is thick and solid, having a colourless, bleached, china-like appearance.

\section{(§ Hystricella, Lowe.)}

\section{Helix echinoderma, n. sp.}

T. trochiformis, subtus subplanulata perforata, undique granulis magnis obtusis sat dense obsita ; spirâ elevatâ ; anfractibus convexis, subgibbosis, ultimo subtectiformi acute carinato (carinâ simplici, solum antice gradatim obsolete subduplici); umbilico punctiformi, aperto ; aperturâ subovali-rotundatâ, labris continuis conjunctis, peristomate simplici, expanso, subrecurvo, tenui, relevato.-Long. axis $2 \frac{1}{2}$ lin.; diam. $3 \frac{1}{2}$.

Obs.-H. echinulatce, Lowe, valde affinis, sed multo major 
(sc. quasi maxima), et forsan ejus status antiquus, hodie extinctus.

Habitat Portum Sanctum, semífossilis ; recens haud observata.

The above diagnosis has been compiled from a few subfossil specimens which we obtained when in Porto Santo; and with the exception of their size being comparatively gigantic, they appear to possess nearly all the characteristics of the $H$. echinulata; but since their stature is so monstrous as compared with that of the latter (which is more constant than in almost any Helix with I am acquainted), I cannot but suspect that they must represent some large extinct species which stands in precisely the same relation to the echinulata as the subfossil $H$. vermetiformis does to the bicarinata, or as the subfossil $H$. Lovei and Bowdichiana do to the recent $H$. portosanctana and punctulata. At any rate, each of these forms occupies a similar position with reference to its own particular analogue, and as species they must either stand or fall together.

\section{Helix echinulata.}

Helix echinulata, Lowe, Cambr. Phil. S. Trans. iv. 57. t. 6. f. 19 (1831)

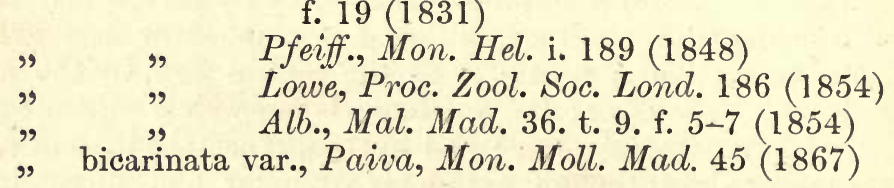

Habitat Portum Sanctum; sub lapidibus in montibus, vulgaris.

A roughened, or asperated, somewhat Trochiform little Helix, which, together with the (primâ facie almost similar) $H$. bicarinata, is very abundant, beneath stones, on the mountains of Porto Santo, and one which may readily be known, apart from its small size and very coarsely tubercled (or wellnigh sub-spinulose) surface, by its reddish-brown hue (which however usually appears darker than it really is, on account of the entire shell being more or less powdered with a rusty deposit from the earth with which it is found in contact), by its subconical upper- and flattened under-portions, and by its punctiform umbilicus and its circular aperture,-the peristome of which is continuous and appreciably elevated or raised. Its volutions (which are convex, and seldom exactly banded) will be seen, when cleaned, to have a few conspicuous darker clouds, or suffused ill-defined dashes (rarely amounting to anything like a band, and some of them longitudinally disposed) at irregular intervals; and the basal one is sharply keeled, with its compara- 
tively flattened under-region generally ornamented with one or two (sometimes obsolete, and occasionally confluent) fasciæ.

The $H$. echinulata, which is less abundant, on the whole, than the bicarinata, is locally common on the mountains of Porto Santo; and, although not easy to separate at the time of capture from its ally (an after-examination being absolutely necessary for that purpose), I believe that it is more often on the Piso Branco that we have met with it, than elsewhere.

The Baron Paiva records the $H$. echinulata in a subfossil state; but, although this is not by any means unlikely, I have no evidence myself that it has yet been observed in any of the calcareous deposits; though its comparatively gigantic analogue (enunciated above as the $H$. echinoderma) is met with occasionally, and it is not impossible therefore that that particular form was regarded by the Baron as sufficiently identical with the recent type.

\section{Helix bicarinata.}

Helix bicarinata, Sow., Zool. Journ. i. 58. t. 3. f. 7 (1825) " duplicata, Lowe, Cambr. Phil. S. Trans. iv. 58. t. 6 , f. 30 (1831)

" bicarinata, Pfeiff., Mon. Hel. ii. 190 (1848)

" $\quad$ Lowe, Proc. Zool. Soc. Lond. 186 (1854)

$" \quad$ " Alb., Mal. Mad. 36. t. 9. f. 1-4 (1854)

" $\quad$ Paiva, Mon. Moll. Mad. 45 (1867)

Habitat Portum Sanctum; sub lapidibus vulgatissima. In statu semifossili parce (sub formâ 'var. $\beta$. aucta,' Woll.) reperitur.

So closely does the present little Helix resemble the $H$. echinulata, that I am far from certain that it is more in reality than a phasis of that species with a double keel ; and this is all the more possible from the fact that a $b i$ - and simply carinated state are by no means uncommon in many Helices. Yet the two forms are so readily separable (for I have never found a single example, out of many hundreds-I might almost say thousands - which I have inspected, which could be regarded as strictly intermediate), that I prefer, inasmuch as they have already been published under different names, to treat them as distinct. The Baron Paiva, in his late Monograph, has assumed them to be conspecific, and it is quite open to any naturalist to adopt that opinion if he pleases; but since it is scarcely possible that the quastio vexata can ever be absolutely settled, I would rather, for my own part, acknowledge them under the titles which they have so long received, than run the risk of error in a speculation which is perhaps unsolvable.

With these remarks I think it sufficient to add, that the $H$. 
bicarinata is a more abundant species (or form) than the echinulata, - swarming beneath slabs of stone on most of the mountain-slopes of Porto Santo, to which island it would seem (like its immediate allies) to be confined. And so gregarious is it in its mode of life, that I have frequently observed clusters of it under a single block composed of absolutely hundreds of closely-adhering individuals.

In a subfossil state, the $H$. bicarinata is decidedly rare; nevertheless I possess many specimens (collected by myself, chiefly at the Zimbral d'Areia) which I have little doubt are conspecific with it,- -though their slightly altered facies, from the process of gradual decay to which they have been subjected, renders their identification with the recent type at first sight somewhat dubious. Thus, for instance, the keels of their volutions appear more conspicuous (and the spaces between them, in consequence, more eroded or scooped out) than is the case in the living individuals, and the granulations of their upper surface have in some instances been altogether worn away. Still, there is no shell except the bicarinata to which they can be referred; and I feel satisfied that they represent the quondam phases of that species, - and that they thus far therefore afford presumptive evidence that the $H$. vermetiformis (which they almost exactly resemble except as regards their comparatively diminutive stature) cannot properly be looked upon as a mere extinct state of the bicarinata.

There is however an appreciably larger form of this species (cited in the present catalogue as the 'var. $\beta$. aucta') to which the subfossil examples might perhaps be better referred,-in which the upper (or medial) keel is a trifle more horizontal and prominent, and the shell is full 3 lines (instead of only about $2 \frac{1}{2}$ ) across its broadest part--which was found in Porto Santo by Mr. Watson, and which I have received from him as the ' recent state of the $H$. vermetiformis, Lowe.' I am inclined to think, however, that it will be more safely regarded as a highly developed race of the bicarinata,-from which it differs in scarcely any respect except in its slightly increased stature. It is of course possible that even the subfossilized $H$. vermetiformis may be in reality but a gigantic extinct phasis of the bicarinata; but as it rests upon precisely similar evidence as that for the retention of the $H$. echinoderma as separate from the echinulata, or as the H. Bowdichiana and Lowei from the punctulata and portosanctana (the 'pros' and 'cons' of which have already been fully discussed), I have thought it desirable to follow Mr. Lowe in treating it as specifically distinct; and this being the case, it will be sufficient to add that it (i.e. the H. vermetiformis) recedes from the 'var. $\beta$. aucta' of the $H$. 
bicarinata in its very much larger size, and in its volutions (the ultimate one of which is not quite so deflected at the aperture) being 7 in number, instead of only 6 or $6 \frac{1}{2}$.

\section{Helix vermetiformis.}

Helix vermetiformis, Lowe, Proc. Zool. Soc. Lond.186 (1854) " " Paiva, Mon. Moll. Mad. 47 (1867)

Habitat Portum Sanctum, in stratu conchylifero semifossilis parce occurrens: recens hodie non inventa.

The present Helix, which has been found hitherto only in a subfossil state-and only in Porto Santo (where it was first detected by myself at the Zimbral d'Areia), belongs to the same geographical type as these immediate forms, - the $H$. bicarinata being manifestly its nearest ally. Indeed it may be said to be intermediate between that species and the ' $a$. pereros $a$ ' of the H. turricula,-being very much larger than the former, with its peristome even more developed (or raised above the bodyvolution), and with its keel perhaps, if possible, still more double throughout; whilst from the latter (which occurs only on the Ilheo de Cima) it recedes in its less elevated spire, its more open umbilicus, and in its surface being very much more coarsely and sparingly granulated. Of the two, however, it has more in common, as it seems to me, with the $H$. bicarinata; and indeed, when closely inspected, its characters will be perceived to differ so little except in degree from those of that species that I cannot feel at all sure that the vermetiformis (as now understood) represents more than some gigantic extinct phasis of it. Nevertheless since I have no vestige of connecting links between the two forms, and they would appear to stand in precisely the same relation to each other as the subfossil $H$. echinoderma does to the recent $H$. echinulata, or as the subfossil $H$. Bowdichiana and Lowei do to their living analogues the $H$. punctulata and portosanctana (which Mr. Lowe, and all subsequent monographers, have held to be, in all probability, distinct), I will not attempt to treat them as otherwise than specifically separate.

The $H$. vermetiformis is not uncommon in the subfossiliferous beds of Porto Santo, at any rate in those towards the south-eastern extremity of the island (in the direction of the Ilheo de Cima). I have met with it both at the Zimbral d'Areia, and in the muddy deposit of an exposed sea-cliff (below the Pico dos Maçaricos) to the east.ward of the Villa.

\section{Helix turricula.}

Helix turricula, Lowe, Cambr. Phil. S. Trans. iv. 58. t. 6. f. $21(1831)$ 

Helix turricula, Pfeiff., Mon. Hel. i. 190 (1848)

$\begin{array}{lll}" & \quad & \text { Lowe, Proc. Zool. Soc. Lond. } 186(1854) \\ \prime & \quad & \text { Alb.,Mal. Mad. 37. t. 9. f. 11-13 (1854) }\end{array}$

Habitat in insulâ parvâ 'Ilheo de Cima' dicta,juxta Portum Sanctum (nec alibi); sub lapidibus magnis congregans.

This is one of the most beautiful, and distinct, of all the land-shells of the Madeiran archipelago; and yet there is not a single species which is more narrowly circumscribed (so far as our united observations have hitherto shewn) as regards its area of distribution,- the little rocky islet known as the Ilheo de Cima, at the south-eastern extremity of Porto Santo, being apparently its only habitat. In that particular locality however it abounds, where it is to be met with (often in clusters) beneath the large blocks of basalt which lie scattered on (more especially) the western slopes. Under such circumstances it has been taken in profusion by Mr. Lowe and myself, on various occasions, as well as by Senhor Moniz and other naturalists; but I have never been able to detect any traces of it in a subfossil state on the mainland,-not even at the Zimbral d'Areia, which is exactly opposite to (and but narrowly separated from) the Ilheo de Cima, nor in the muddy accumulations of the subfossiliferous sea-cliff (below the Pico dos Maçaricos) to the eastward of the Villa. Hence there is every reason to suspect that it has never existed except on that small and nearly inaccessible island. Yet so intimate is its relationship with the subfossil $H$. vermetiformis, which as already stated is par excellence characteristic of the deposits in the direction of the Ilheo de Cima, that it is impossible to resist the enquiry as to whether it might not in reality be some extreme development of that quondam form, which has been gradually matured since the Ilheo de Cima was permanently separated from the mainland. This question however being merely a speculative one, hardly concerns us here, for no amount of evidence can ever succeed in raising it beyond the atmosphere of probability ; and it may be sufficient therefore to add that the $H$. turricula in even its most abbreviated phasis (under which guise alone it bears a primâ facie resemblance, in its shorter contour, more prominent keels, and somewhat disproportionately widened ultimate volution, to the vermetiformis) differs from its unquestionably near ally in its much more elevated spire (and that too when seen in its most reduced and exceptional condition), in its entire surface being very much more finely and closely granulated, and in its umbilicus (which is likewise more concealed by the overhanging edge of the peristome) being less 
open. In its normal aspect, however, the H. turricula is abundantly removed from even the vermetiformis.

As will be inferred from the above remarks, the affinities of the $H$. turricula are, most unmistakeably, with the four preceding and two following species, -its carinated volutions and granulose, reddish-brown surface (the lower portion of which has a tendency, when cleansed from the earthy dust with which it is generally obscured, to be more or less indistinctly fasciated, whilst the upper parts are usually marbled with a few irregular, suffused, ill-defined, longitudinal, sometimes confluent blotches), added to the smallness of its umbilicus, its circular aperture, and its thin, elevated, continuous peristome, assigning it, without the slightest doubt, to the little assemblage of PortoSantan forms to which Mr. Lowe applied the subgeneric title of Hystricella. Yet as a species it is conspicuously distinguished from them all,-its extremely elongate, turret-shaped spire and numerous volutions (which have a keel, very largely developed in the 'a. pererosa," in the centre of each, causing the basal volution to be strongly bicarinated), in conjunction with the comparative fineness and closeness of its granulations, giving it a character which it is difficult to mistake.

\section{Helix Leacockiana, n. sp.}

T. trochiformis, subtus planata perforata, undique granulis obtusis densissime obsita, pallide brunneo-subflavescens sed fasciis (præsertim subtus) nebulisque irregularibus (præsertim supra) rufo-brunneis hinc inde suffuse marmorata; spirâ sat elevatâ; anfractibus convexis, bicarinatis, ultimi (subtectiformis) carinâ exteriore acutissimâ valde exstanti, interiore obtusâ rotundatâ recedente rarius obsoletâ; umbilico punctiformi ; aperturâ subovali-rotundatâ, labris continuis conjunctis, peristomate simplici expanso subrecurvo tenui relevato.-Long. axis $1 \frac{2}{3}$ lin.; diam. $2 \frac{1}{2}$.

Obs. Species H. bicarinatce, Sow., affinis, sed differt testa multo minus grosse sed etiam subdensius granulata, granulis minutioribus obtusioribus (nec spiniformibus), anfractu ultima sensim latiore subtectiformi, sc. carinâ exteriore multo magis

1 This particular state, which would seem to have escaped the observation of Mr. Lowe, passes imperceptibly into the other; nevertheless since it is remarkably different in its extreme (or exaggerated) condition, from what Mr. Lowe described as the normal one, I think perhaps it may be desirable to define it briefly as follows:-

H. turricula, Lowe ; var. B. pererosa.-Plerumque obscurior, spirâ breviore, anfractibus in medio multo grossius carinatis (carinâ altissimâ), ultimo sensim latiore necnon antice obsolete subtortuoso, fere quasi superimposito, aperturât submajore. 
exstanti acutâ distinctâ, sed carinâ interiore magis obtuse rotundatâ faciliusque recedente, interdum etiam obsoletâ.

Habitat Portum Sanctum ; in monte 'Pico d'Anna Ferreira' dicto sat copiose reperta. Necnon in statu semifossili (cum exemplaribus recentibus vix omnino congruens) parcissime occurrit.

This little Helix, which was obtained rather abundantly by myself on the Pico d'Anna Ferreira in Porto Santo, and afterwards by Mr. Lowe (who apparently did not recognise it as specifically distinct), is closely allied to the bicarinata, Sow., and the echinulata, Lowe,- to both of which it stands in much the same relation as the $H$. commixta does to the abjecta. And in the comparative fineness of its sculpture it makes likewise somewhat of an approach to the $H$. oxytropis,-the four species (namely echinulata, bicarinata, Leacockiana, and oxytropis) constituting, in conjunction with the echinoderma, vermetiformis, and turricula, a very natural assemblage.

In the fact of its volutions having an additional central keel (which consequently appears to be doubled on the ultimate one) the $H$. Leacockiana has more in common with the bicarinata than it has with the echinulata; nevertheless in the granulations of its surface being both very much smaller and very much less raised (as well as more densely packed together) it recedes equally from them both. But its more appreciable distinctive character consists in the peculiar shape of its volutions, especially of the last one, which is more strictly tectiform (or roof-shaped), as well as of a relatively somewhat wider dianeter, than in the cognate species,- the edge, or outer keel, being very much more prominent, whilst the inner one is more completely and obtusely rounded-off, and therefore recedes more from the former than is the case in the $H$. bicarinata. These various little features are so conspicuous, when once seen, that it is impossible to confound the $H$. Leacockiana with any of these immediate forms; and it appears to me to have far greater claims for specific separation than the bicarinata has from the echinulata; and indeed I cannot but think that it is removed from them both quite as much as the (very much larger) oxytropis is, though in a different manner.

I possess two subfossil individuals, a trifle larger and somewhat less finely granulated than those now before me of the $H$. Leacockiana, which I have little doubt (from their general contour and proportions) represent the quondam analogue of this species.

I have had great pleasure in naming the present little Helix after my old friend T. S. Leacock, Esq.,--whose long residence in Madeira, and whose continued and careful re- 
searches throughout the entire Group of islands, has contributed so much to our store of knowledge, not merely of the Land-Mollusca but in many other departments of Natural Science.

\section{Helix oxytropis.}

Helix oxytropis, Lowe, Cambr. Phil. S. Trans. iv. 57. t. 6. f. 18 (1831)

$\begin{array}{lll}\eta & \Rightarrow & \text { Pfeiff., Mon. Hel. i. 190 (1848) } \\ " & \Rightarrow & \text { Lowe, Proc. Zool. Soc. Lond. 186 (1854) } \\ " & \Rightarrow & \text { Alb., Mal. Mad. 37. t. 9. f. 8-10(1854) } \\ & \Rightarrow & \text { Paiva, Mon. Moll. Mad. 46 (1867) }\end{array}$

Habitat Portum Sanctum; sub lapidibus in intermediis degens. Semifossilis rariss.; sed in statu majore $(=\beta$. subcarinulata, mihi) paulo magis copiose reperitur.

As already stated, the $H$. oxytropis belongs to the same geographical type as the six preceding species; yet it is thoroughly distinct from them all,-never merging into any of them, so far as I am aware, by even doubtful aberrations. Although exceedingly similar in colouring (which is unmistakeably characteristic), and a good deal so in form and sculpture, to its allies, it has the volutions (the basal one of which is sharply and singly keeled) conspicuously more flattened,causing the upper portion of the shell to be more strictly conical or roof-shaped (though apically somewhat rounded and obtuse). Its granulations, although coarse, are relatively much less developed than those of the $H$. echinoderma, echinulata, bicarinata, and vermetiformis, but rather more so than is the case in the H. Leacockiana and turricula.

The $H$. oxytropis, which is equally confined to Porto Santo with its immediate allies, is less abundant than the echinulata and bicarinata. Nevertheless it is common locally, occurring beneath stones on the mountain-slopes; and so far as my own observations are concerned, it is more prevalent in the southeastern extremity of the island than elsewhere,-particularly on the two closely adjoining peaks opposite to the Ilheo de Cima, known as the Pico de Baixo and the Pico dos Maçaricos.

In a subfossil condition the $H$. oxytropis is found very sparingly; indeed, so far as I have myself observed, I should say that it was decidedly rare. There is, however, a larger phasis of the shell-with the spire relatively more elevated and apically-acute, and with the volutions very obsoletely keeled in the centre-which I have taken on various occasions more abundantly. Under this form, the shell has much the size and prima facie aspect of certain states of the $H$. cheiranthicola; though, on a closer inspection, its more densely granulated 
surface and smaller umbilicus, added to the sharper edge of its ultimate volution and its more raised and continuous peristome, will readily distinguish it from every phasis of that. variable species. Believing it far from unlikely, however, that this particular subfossil Helix to which I am now calling attention may be separated by some future monographer from the oxytropis proper, I will briefly characterize it as follows :

H. oxytropis, Lowe; var. $\beta$. subcarinulata.-Major, spirâ magis elevatâ, ad apicem paulo magis acutâ, anfractibus in medio obsolete subearinulato.-Long. axis $2 \frac{1}{2}$ lin.; diam. $3 \frac{1}{2}$.

(§ Turritella, Woll.)

Helix cheiranthicola.

Helix cheiranthicola, Lowe, Cambr. Phil. S. Trans. iv. 57. t. $6 . \mathrm{f} .17$ (1831)

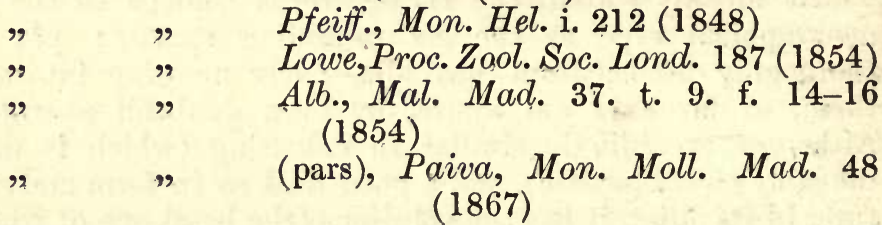

var, mustelina, Lowe.

Helix mustelina, Lowe, Proc. Zool. Soc. Lond. 186 (1854)

" cheiranthicola, $\beta$. minor, Paiva, l. c. 49 (1867)

Habitat Portum Sanctum, insulamque parvam adjacentem 'Ilheo de Baixa' dictam; in montibus hinc inde vulgaris, caulibus Cheiranthi arbusculo, Lowe, sæpissime adherens. Semifossilis, et in Campo de Baixo et in Ilheo de Baixo, parce reperitur.

Owing doubtless to the great elevation of its spire, the $H$. cheiranthicola was placed by Mr. Lowe and Mr. Albers (and, copying them, by the Baron Paiva) in the section Hystricella; but it seems to me to have quite as much in common (indeed even more, in some respects) with the Discula type, and I think therefore that we may safely regard it as exactly intermediate between the two,-though belonging absolutely to neither of them. The Hystricella group is so. wonderfully well definednot only in the continuous, raised, circular peristome of its several members, but likewise in its sculpture and the very great peculiarity of its colouring - that it seems a pity to admit into it a species like the present one, which is so thoroughly different in the generality of its features; whilst, at the same time, the $H$. cheiranthicola is too high and turret-shaped to be properly referred to the section Discula.

The $H$. cheiranthicola occurs on certain of the loftier moun- 
tains of Porto Santo, particularly the Pico Branco,-where it absolutely swarms, towards the summit, within the crevices of the rocks and upon the stems of shrubby plants, especially a native wall-flower (the Cheiranthus arbuscula, Lowe). In a subfossil condition it appears to be scarce, though I have met with it sparingly on the Campo de Baixo and also on the Ilheo de Baixo; but I am not certain that it has been found on the latter adjacent islet in a living state.

Apart from its elevated column and subconical contour, the present Helix may be known by the tumidity of its volutions, which are so prominent as to form a kind of obtuse keel (immediately above the suture) which is usually traceable up the spire, by its umbilicus, although not large, being open and deep, by its surface being coarsely granulated both above and below (the granules, however, being often sub-evanescent about the most prominent part of the whorls), and by its peristome being continuous though not circular, - the upper and lower lips being joined at their insertion by a thick corneous callosity. The shell is extremely solid in substance, or incrassated, and normally of a faintly plumbeous white with two narrow darker bands beneath (one of which is sometimes absent), and another above,-just under (and adjoining) the suture, and continued for a considerable distance up towards the apex. These three bands are occasionally broken-up, or even well-nigh obsolete; but it is scarcely necessary to establish 'varieties' and 'subvarieties' (so-called) upon trifling fluctuations of mere colour.

There is, however, a distinct phasis of the shell, which was detected by myself towards the northern coast of Porto Santo, in the district known as 'Pedragal,' and towards the Pico Juliana, which deserves notice,-inasmuch as it is so permanently different from the typical one as to have been described by $\mathrm{Mr}$. Lowe as a separate species, under the name of $H$. mustelina. I think there can be no question that the intermediate races which occur connect it with the true cheiranthicola type; nevertheless it is a little smaller than the latter and more uniformly and roughly granulated all over, its volutions are flatter (or much less tumid) and with hardly any indications of a keel, its umbilicus is joined (though not exactly overlapped) by the more angularly produced lamina of the lower lip, and its colour is more dingy,- the surface being less evidently fasciated (though sometimes with an obsolete medial band above), but crowded with irregular brownish fragmentary markings. 
(§ Discula, Lowe.)

\section{Helix tetrica.}

Helix tetrica, Paiva, in litt.

$\begin{array}{lll}" & \quad & \text { Lowe, Ann. Nat. Hist. x. } 95 \text { (1862) } \\ " \quad & \quad \text { Pfeiff., Mal. Blätt. xi. 53 (1864) } \\ & \quad \text { Paiva, Mon. Moll. Mad. 87. t. 1. f. } 7 \text { (1867) }\end{array}$

Habitat Desertam Australem ; in præruptis excelsis maritimis rarissima, inter lichenes latitans. Semifossilis parce reperitur.

This is one of the largest and most distinct members of the Discula section (measuring about $7 \frac{1}{2}$ lines across its broadest part), and one which seems to be quite unconnected, so far at least as our present data would imply, with any of the numerous varieties of the protean $H$. polymorpha. It was detected on the Southern Deserta (or Bugio), ' amongst lichens on the seacliffs, in the spring of 1861,' by a man who was sent out by the Baron Paiva to collect for him on that remote rock; and it appears to have been extremely scarce even there. It had however been previously obtained in a subfossil condition by Mr. Lowe, who met with a single example of it during our visit to that island in June of 1855 .

Apart from its larger size, solid substance, and flattened, discoidal, lozenge-shaped form, the $H$. tetrica may be recognised by its extremely wide, open, spiral umbilicus, its not very strongly pronounced keel (which however is placed rather above the dorsal line), and by the coarse and greatly elevated granules with which it is everywhere uniformly asperated. In colour too it is most peculiar, - the fasciæ (in at any rate the few examples which I have had an opportunity of inspecting) being so broadly developed as to cause nearly the entire surface, except the paler and yellowish umbilical area, to be of a dark reddish coffeebrown (which makes the white tubercles remarkably conspicuous). Its aperture, which is of a dingy reddish-brown within, has the peristome (though not perfectly circular) a good deal elevated, the upper and lower portions of it being joined across the body-volution by a thick corneous process.

\section{Helix polymorpha.}

Helix polymorpha, Lowe, Cambr. Phil. S. Trans. iv. 54 (1831)

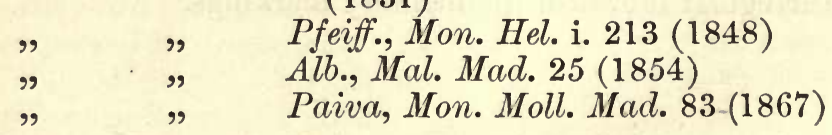

Habitat ins. omnes Maderenses; sub lapidibus, præcipue in 
collibus aridis apricis maritimis, congregans, et vix supra $1500^{\prime}$ s.m. ascendens. Semifossilis, sub formis plurimis diversis, hinc inde sed parce reperitur.

So numerous are the forms which are assumed by this protean Helix, in the various islands and districts of the Madeiran Group, that the more salient ones would seem to demand, each of them, an independent notice. And this is all the more desirable since the major part were described by $\mathrm{Mr}$. Lowe (though not originally) as separate species, and it might still perhaps be a question with certain monographers whether at any rate one or two of those which I have thought it better to treat as varieties might not be retained as distinct. My own belief, however, is, that even more than those which are here placed upon record will be found eventually (when the few remaining localities which have not yet been fully explored shall have been properly investigated) to increase the list of permanent races,- -which, although merging into the immediately allied ones by unmistakeable connective links, are nevertheless sufficiently defined within their own particular provinces to be properly looked upon as 'local modifications,' in the usually accepted sense of that term. Commencing with the phases which are more roughly granulated than the rest, I think that the following thirteen (which almost arrange themselves, as might naturally be anticipated in the case of mere varieties, topographically) may perhaps be accepted as the ones which should principally be noticed.

a. [normalis].

Helix polymorpha, a. irrasa, Lowe, l. c. 54. t. 6. f. 11 (1831)

$\begin{array}{lll}" & \Rightarrow & \text { a. Pfeiff., Mal. Blätt. 81 (1852) } \\ " & " & \text { Lowe, Proc. Zool. Soc. Lond. } 187(1854) \\ " & " & \text { var. a., Alb., l. c. 25. t. 5. f. 7-13 (1854) } \\ " & \text { saccharata, Lowe, olim, in litt. }\end{array}$

Habitat Maderam; ad rupes maritimas versus orientem, præcipue in ins. parvâ 'Ilheo de Fora' dictâ, juxta promontorium Sancti Lourentii, degens.

This is the most conical state which has hitherto been detected of the present variable Helix; and although Mr. Lowe cited it in 1831 as but one variety out of many, he subsequently (in 1854) adopted it as a distinct species,-regarding it, par excellence, as 'the $H$. polymorpha' (properly so called); though I think that it is much to be regretted that he should not have adhered to his original (and, as it seems to me, far more correct) treatment of it. Even in the elevation of its spire this roughly 
granulated race is by no means constant, some examples being much more trochiform than others; whilst as regards colour, it passes through a nearly endless number of changes,--certain specimens being comparatively pale and unbanded, though by far the greater number are very highly decorated, the fasciæ being. so enlarged as to cover most of the surface except a sutural line, the region outside the aperture, and the central area beneath. The umbilicus is tolerably large and spiral, and the keel is rather sharply expressed.

This normal phasis (as we can scarcely help regarding it) of the $H$. polymorpha occurs only in Madeira proper, and is eminently characteristic of the eastern half of the São Lourenço promontory (itself in the extreme east of that island), - attaining its maximum on the detached insular termination of it known as the Ilheo de Fora (where it has been taken in profusion by Mr. Lowe, Mr. Watson, Dr. Grabham, myself, and others). ${ }^{1}$ The examples from the actual Ponta de São Lourenço have all their characters rather less exaggerated than in those from the Ilheo de Fora,thus showing a manifest tendency to merge into the other coarsely granulated but less conical form (the ' $\beta$. salebrosa') which occurs both to the north and south ( $i . e$. towards Porto da Cruz, and towards Machico) of that low rocky tongue of land, and which indeed crops up even so far away as the Ponta de Pargo, the north-western point of Madeira.

Common as it is towards the extremity of the São Lourenço promontory, I am not aware that this typical phasis of the $H$. polymorpha has ever yet been observed in the subfossil deposits (so near at hand) of Caniçal.

ß. salebrosa, Lowe.

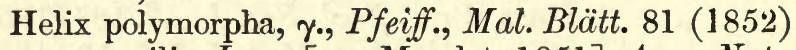

, senilis, Lowe [nec Morelet, 1851], Ann. Nat. Hist. ix. $116^{(1852)}$

" I Id., Proc. Zool. Soc. Lond. 189 (1854)

" polymorpha, var. $\gamma$., Alb., l. c. 26. t. 5. f. 16-18 (1854)

" salebrosa, Lowe, Ann. Nat. Hist. x. 95 [note] (1862)

" polymorpha, var. $\beta .$, Paiva, l. c. 84 (1867)

Habitat Maderam, et tres Desertas; in aridis apricis mariti-

1 I may add that this shell has never been observed by at any rate either Mr. Lowe or myself in the neighbourhood of the fossil-bed and the Piedade, but always on the red Tufa soil nearer to the actual Point,-where, during the winter months, it may be found attached to the stems of plants and low bushes (particularly of Salsola fruticosa), beyond (i.e. to the eastward) of the arch-rock in Labra. 
mis hinc inde vulgatissima. Semifossilis ad Caniçal Maderæ parcissime sed in summo Desertæ Australis copiosius invenitur.

While the last (or normal) state of the $H$. polymorpha is characteristic of a limited district in the extreme east of Madeira proper, the present one makes its appearance in many parts of the eastern and northern coast of the same island, extending likewise to the Desertas, - on the whole three of which it occurs, though more particularly on the central or larger one. The Madeiran examples however are not usually quite similar to those of the Desertas,-being, on the average, a little more sharply keeled and more coarsely granulated; and they are generally too a trifle thinner (or less solid), and not so highly coloured : indeed I possess a series of them from the Ponta de Pargo (perhaps somewhat exceptional) which are nearly devoid of markings.

Although extremely variable in the elevation of its spire, the ' $\beta$. salebrosa' is considerably less conical than the (so-called) type, it being altogether flatter and more lenticular; but the Madeiran phasis of it is, I think, quite as strongly asperated as the latter with powerful granules. The Desertan specimens are usually less coarsely granulated, particularly above, and their keel is a little more obtuse; but both of these features are subject to considerable variation. As for the mere development of the bands (which are for the most part more conspicuous in the Desertan race than in that from Madeira), hardly two examples have them precisely alike.

The ' $\beta$. salebrosa' (which is so common on the Desertas, particularly on the central island) was found by Mr. Lowe in Madeira proper, - namely on the Larana promontory below Porto da Cruz, and at the Ponta de Pargo; and it occurs likewise between Machico and Sta. Cruz. In a subfossil condition it is not uncommon on the summit of the Southern Deserta, but extremely rare in the calcareous deposits near Caniçal. ${ }^{1}$

$\boldsymbol{\gamma}$. poromphala, Lowe.

Helix polymorpha, $\delta .$, Pfeiff., Mal. Blätt. 81 (1852)

" poromphala, Lowe, Ann. Nat. Hist. ix. 116 (1852)

" senilis (pars), Id., Proc. Zool. Soc. Lond. 189 (1854)

" polymorpha, var. $\delta .$, Alb., l. c. 26. t. 5. f. 19, 20 (1854)

$" \quad$ var. $\beta$. (subv. 1), Paiva, l. c. 84 (1867)

Habitat tres Desertas ; præcipue in insulis Boreali et Australi congregans. In Deserta Australi semifossilis quoque reperitur,

'As regards the synonymy of this shell, I may add that the name 'senilis' having been preoccupied by Morelet during the preceding year to that in which it was employed by Mr. Lowe, it became necessary for the latter to propose a fresh one,-which he consequently did in 1862. 
It is only on the Desertas that the present race of the $H$. polymorpha has been found; and although it occurs on the whole three of them, it is principally on the northern and southern islands that it abounds, - the ' $\beta$. salebrosa' being the dominant form in the Deserta Grande. There is, however, very little difference between that modification and the present one, the much smaller umbilicus of the ' $\gamma$. poromphala' being its main distinctive feature; though it is likewise, on the average, a smaller shell altogether, descending on the Bugio (where it was also found in a subfossilised condition, by Mr. Lowe and myself, during June of $1855)$ to a comparatively diminutive stature, the most reduced examples measuring only about four lines across their broadest part.

8. Pitta, Paiva.

Helix senilis, var. $\gamma .$, pusilla, Lowe, Proc. Zool. Soc. Lond. 189 (1854)

"Pittæ, Paiva, Journ. de Conch. xiv. 340 t. 11. f. 5 (1866)

" $\quad$ "Id., Mon. Moll. Mad. 41.t. 1. f. 3(1867)

" polymorpha, $\beta$. (subv. 2. minor), Id., ibid. 85 (1867)

"' Pittæ, Pfeiff., Mon. Hel. vii. 352 (1876)

Habitat Desertam Australem : præsertim in statu semifossili (an vere recens?) occurrens.

This is the most minute form under which the $H$. polymorpha has hitherto been ascertained to exist,- the examples measuring only from about 3 to $3 \frac{1}{4}$ lines across their broadest part ; and it is one which seems to be peculiar to the Southern Deserta, - where it was met with by Mr. Lowe and myself, during June of 1855, and from whence it has subsequently been obtained by the Baron Paiva. ${ }^{1}$ But it was only subfossilized that we found it; and I have no evidence hitherto that it occurs in a living state,- - for it is almost certain that the individual from which the Baron $(l . c .85)$ professed to describe the 'animal' was merely a small one of the common ' $\gamma$. poromphala.' This variety however seems to differ in no respect (either as regards sculpture or relative proportions) from the ' $\gamma$. poromphala' (though its worn and colourless condition may give it at first sight a somewhat peculiar aspect) except in its extremely reduced stature, and in its possessing only $6 \frac{1}{2}$

1 The Baron therefore was not altogether accurate in adding, concerning this particular variety, 'In Desertâ Australi a meipso primum inventa;' for, in the first place, it was found by Mr. Lowe and myself more than ten years previously, and, in the second place, it is well known that he never collected on the Desertas at all,-his material having simply been brought to him by men, not always very trustworthy, whom he sent out from Funchal. 
volutions (instead of $7 \frac{1}{2}$ ), and it is surprising to me how the Baron Paiva could have so far confused its affinities as to have recorded it not only (as above indicated) as a stunted phasis of the $H$. polymorpha, but likewise as a distinct species (under the name of $H$. Pittce) of the Caseolus group! Yet that this is certainly the case I am able to vouch, having received types of his $H$. Pittce from the Baron himself. It is also to be noted that in his diagnosis of the $H$. Pitto he does not even allude to the fact that his types were subfossilized (as is nevertheless clear, not only from those which he transmitted to me, but also from his own remark 'Animal hodie non observare licet'), but describes them as ' cinereo-plumbea' (a very common tint for a bleached, subfossilized surface), thus leaving the impression that the $H$. Pittce is characterized by an eccentricity of hue which certainly does not belong to it.

ع. Alleniana, Paiva.

Helix Alleniana, Paiva,Journ. de Conch. xiv. 342. p. 11 . f. 10 (1866)

$$
\text { , } \quad \quad \quad I d ., \text { l. c. 86.t.1. f. } 4 \text { (1867) }
$$

Habitat Maderam; in collibus apricis submaritimis prope Sta. Anna lecta.

This modification of the $H$. polymorpha was first taken by the late Mr. Bewicke at Sta. Anna in the north of Madeira proper, and it appears to have been met with subsequently by Senhor J. M. Moniz; but it is one of the few Helices which was never obtained either by $\mathrm{Mr}$. Lowe or myself. It is in some respects intermediate between the ' $\beta$. salebrosa' and the ' $\zeta$. lincta,' though differing from them both in its somewhat more shining and lightly sculptured surface, and in its granules being much more minute and elongated, and transversely arranged,being formed by the breaking-up, or interruption, of the fine transverse lines, and having more the appearance at first sight of narrow abbreviated impressions than of granules.

The ' $\varepsilon$. Alleniana' (which is certainly not recognizable, as I understand it, from the Baron Paiva's published figures) is a flattened, lenticular shell, with the keel acutely expressed; and its underside is usually of a clear porcelain-white, with a narrow reddish-brown band encircling the umbilical area, and another broader one (sometimes two) towards the keel. Its upper side, in the only fresh and perfect example which I possess for inspection, is irregularly mottled with dusky-white and reddish-brown, the latter preponderating. Its umbilicus is much about the same as in the average of the ' $\beta$. salebros $\alpha$,' but a trifle smaller than in the ' $\zeta$. lincta'; but in the widely separated, almost un- 
connected margins of its peristome it has more in common with the latter than with the former. ${ }^{1}$

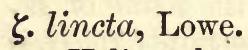

Helix polymorpha, $\beta$. depressiuscula, Lowe, l. c. 54. t. 6. f. $13(1831)$

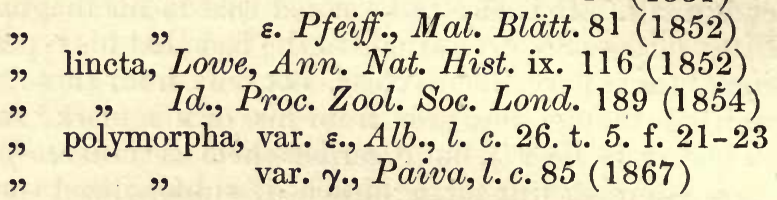

Habitat Maderam; in collibus apricis maritimis haud longe ab urbe Funchalensi, sc. ad et versus promontorium Garajão dictum, copiossime sub lapidibus.

This is the common modification of the $H$. polymorpha on the dry, sunny, maritime hills and cliffs to the eastward of Funchal,- - towards, and around, the Cabo Garajão (or Brazen Head). It may be known by its keel being somewhat blunt or obtuse, and its underside slightly shining and comparatively free from sculpture, - the lines being very light, and the granules nearly evanescent. Its upper region however has the granules coarser, though rather wide apart. In colour it is generally of a clear yellowish-white beneath, with a distinct band encircling the umbilical area, and another, usually broken -up and more or less fragmentary (sometime obsolete), between that and the keel; whilst above it is dappled, or dingily variegated, with whitish and brownish irregular transverse markings, the region outside the aperture (which has the margins of its peristome wide apart, and scarcely connected across the body-volution by a thin corneous lamina) being gradually paler.

$\eta$. arenicola, Lowe.

Helix polymorpha, $\gamma$. arenicola, Lowe, l. c. 54. t. 6. f. 13. (1831)

$$
\begin{aligned}
& \text { ", lincta, var. } \beta \text {. } \\
& 190 \text { (1854) }
\end{aligned}
$$

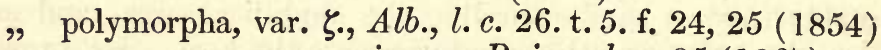

$$
\begin{aligned}
& \text { " } " \quad \text { var. } \gamma_{0} \text { cinerea, Paiva, l.c. } 85 \text { (1867) }
\end{aligned}
$$

Habitat Maderam; in aridis calcareis arenosis, præsertim

1 The Baron Paiva speaks of the ' $\epsilon$. Alleniana' as subfossilized in the Ribeira de São Jorge ; but I suspect that he must allude in reality to dead and decorticated examples (of which I possess several from Sta. Anna),-for I am not aware that there is any strictly subfossil deposit in the S. Jorge ravine. 
ad basin montis Piedade, ad promontorium Sancti Lourentii, vulgaris

The ' $\eta$. arenicola' scarcely differs from the ' $\zeta$. lincta' except that it is, on the average, a little smaller, perhaps a trifle more depressed, not quite so solid in substance, and altogether of a paler, yellower, and less brightly variegated hue. It appears to be confined to the region of the Fossil-bed and around the Piedade, at the base of the São Lourenço promontory, in the east of Madeira proper,-where it is extremely common, beneath stones, on the sandy calcareous soil above the sea-beach and up the adjoining slopes; but, being a mere local race peculiar to that immediate calcareous district (so exceptional in Madeira), I am not aware that it has occurred elsewhere in the island.

Ө. Barbosae, Paiva.

Helix Barbosæ, Paiva, Journ. de Conch. xiv. 341. pl. 11. f. 8 (1866)

\# $\quad \quad \quad I d .$, l. c. 90 . t. 1. f. 6 (1867)

Habitat Portum Sanctum, aut potius ins. parvam adjacentem 'Ilheo da Fonte d'Areia' dictam; sat vulgaris.

The present Helix was obtained by the Baron Paiva, in 1864, from the small and uninhabited rock off the north-western coast of Porto Santo known as the Ilheo da Fonte d'Areia ; and it has certainly no more right to be specifically separated from the numerous modifications of the $H$. polymorpha than any of the others (indeed not so much as several of them); yet the Baron erects it along with two equally insignificant forms into (socalled) 'new species', and that too whilst suppressing the $H$. pulvinata, discina, papilio, lincta, and senilis, of Lowe,-which, although (as I fully believe) mere varieties also, are nevertheless quite as worthy of distinction as these three of his own; whilst the fact that they had been already defined and published, ought to have given them in reality a superior claim.

The ' $\theta$. Barbosce' is a tolerably large and subconical shell, the spire being a good deal elevated, with the volutions flattened, and the keel rather acute; its basal portion is somewhat inflated and pulvinate (or cushion-shaped), with the umbilicus distinct and spiral ; its peristome is rather thin, with the upper and lower margins but imperfectly connected by a thin corneous lamina; and its surface (which is finely granulate all over, and has the transverse lines conspicuous above) is somewhat peculiar in colouring,--being darkly clouded on the upper side with irregular brownish and reddish-brown markings, with the addition of a more or less faint livid (or plumbeous) tinge or bloom, but paler below in the centre, outside of which the fasciæ are gene- 
rally fragmentary and sub-obsolete (being often only traceable as a few detached, transverse, griseous, zigzag streaks and shapeless blotches).

๑. pu?vinata, Lowe.

Helix polymorpha, $\zeta$. pulvinata, Lowe, l. c. 56. t. 6. f. 16 (1831)

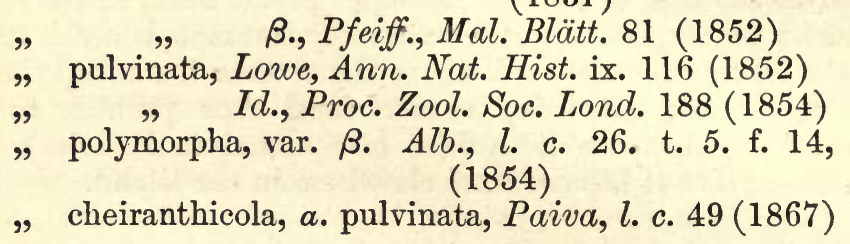

Habitat Portum Sanctum, insulasque parvas adjacentes; in aridis apricis calcareis arenosis inferioribus præcipue et copiose congregans. Semifossilis rarissima, sed ad Zimbral d'Areia parce collegi.

In its somewhat cushion-shaped, basally inflated, ultimate volution and open umbilicus, as well as in its more or less conical or elevated spire and its rather finely and thickly granulated surface, the present race of the $H$. polymorpha has a good deal in common with the last one; nevertheless it is a trifle smaller and less acutely keeled, its peristome is more continuous (the upper and lower margins being joined by a much thicker corneous process), its whorls are a little more tumid or convex, and its colour is totally different, - the entire shell being more or less pale and (as it were) bleached in appearance, even the darkest examples being seldom more than obscurely variegated above with a few irregular, transverse, brownish markings. ${ }^{1}$

The ' $\iota$. pulvinata' is one of the most abundant Helices in Porto Santo, to which island and the adjacent rocks it is peculiar, -occurring more particularly in the driest and most calcareous spots of a low elevation. Thus it often swarms beneath stones in the Ribeira de Cochim and about the sandy edges of the Campo de Baixo, and indeed generally around the Villa; but it is found likewise at a rather higher altitude. Like most of the modifications, however, of the $H$. polymorpha, it is decidedly rare in a subfossil condition; though it was met with sparingly, by Mr. Lowe and myself, at the Zimbral d'Areia and elsewhere.

1 By the Baron Paiva the present Helix is treated as a variety of the H. cheiranthicola; but it is difficult to understand on what single character it can be separated from the Discula group,--its rather elevated spire being more than paralleled in the typical phasis of the $H$. polymorpha, and quite equalled in the 'var. $\theta$. Barbosa.' 
к. papilio, Lowe.

Helix polymorpha, e. calcigena, Lowe, l. c. 56. t. 6. f. I5 (1831)

" $\quad$ O., Pfeiff., Mal. Blätt. 81 (1852)

" papilio, Lowe, Ann. Nat. Hist. ix. 116 (1852)

" $\quad$ " Id., Proc. Zool. Soc. Lond. 190)(1854)

" polymorpha, var. ı., Alb., l. c. 27. t. 6. f. 7-11 (1854)

" testudinalis, a. minor, Paiva, l. c. 92 (1867)

Habitat ins. parvam juxta Portum Sanctum 'Ilheo de Baixo' dictam ; in aridis calcareis vulgaris. Semifossilis quoque invenitur.

This is so near to the ' $\lambda$. discina' that I should hardly have noticed it as a separate race had it not been published by $\mathrm{Mr}$. Lowe as a distinct species. However it is not quite similar to that modification (as typically defined), it being somewhat intermediate between it and the ' $\iota$. pulvinata.' Thus it is a little less sharply keeled than the former, and perhaps not quite so flattened, its surface is altogether paler or less brightly variegated, and its granulations are nearly obsolete below,-where it has a slightly shining or china-like appearance. And, as compared with the latter (the ' $\iota$ pulvinata'), although not very different from it in its somewhat pallid hue and but faintly dappled volutions, it is a trifle more lenticular, or less conical, its keel is rather more evident, and its upper portion is a little more finely and densely granulated, whilst the lower one is comparatively free from sculpture and even (as just mentioned) appreciably shining. The peristome too is less continuous, the upper and lower margins of it being wider apart, and almost unconnected by a corneous plate.

The ' $\kappa$. papilio' is the phasis which the $H$. polymorpha assumes on the dry calcareous island adjoining Porto Santo known as the Ilheo de Baixo; and although occasional examples of the ' $\lambda$. discina,' found elsewhere, may at first sight be scarcely separable from it, yet as typically defined it must be regarded as characteristic of that particular locality. ${ }^{1}$

$\lambda$. discina, Lowe.

Helix polymorpha, $\eta .$, Pfeiff., Mal. Blätt. 81 (1852) " discina, Lowe, Ann. Nat. Hist. ix. 117 (1852)

1 Although so near (as just stated) to the ' $\kappa$. discina' as to be barely separable from it, the Baron Paiva treats the present modification of the $H$. polymorpha as a 'var. minor' of the $H$. testudinalis,--one of the largest and most distinct members of the Discula section, and one which would seem to be better separated than almost any other from these immediate forms. Indeed it appears to me (as it did to Dr. Albers) to be sufficiently well defined to merit specific isolation. 
Helix discina, Lowe, Proc. Zool. Soc. Lond. 190 (1854)

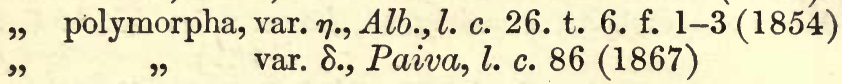

Habitat Portum Sanctum, insulasque parvas adjacentes; in aridis apricis vulgatissima. Semifossilis multo rarius exstat.

The ' $\lambda$. discina' is one of the most abundant of all the phases of the $H$. polymorpha, being universal in Porto Santo and on most of the immediately adjacent rocks,-.. I having myself met with it on the Ilheo de Baixo, the Ilheo de Cima, and the Ilheo de Ferro. It is a central form which is less easily defined than the generality of others, - partaking, as it does, of the features of many of them ; but it may be described as, on the average, rather flat and lenticular, with the keel sharply pronounced, and the umbilicus (although not large) open and spiral. It is finely granulated both above and below; its whorls are usually depressed, with the suture hardly at all sunken; the margins of its peristome are wide apart, and nearly unconnected by a corneous lamina; and its surface, although seldom very brightly coloured, is either fasciate or efasciate below, and more or less obscurely mottled above with darker and paler irregular transverse markings.

Like most of the modifications of the $H$. polymorpha when found at all in anything but a recent state, the present one is undoubtedly scarce subfossilized. Nevertheless it has been met with sparingly, by Mr. Lowe, myself, and others, on the Campo de Baixo, as well as at the Zimbral d'Areia.

$\mu$. Gomesiana, Paiva.

Helix Gomesiana, Paiva, Journ. de Conch. xiv. 340. pl. 11. f. 6 (1866)

" $\quad$ Id., l. c. 89. t. 1. f. 5 (1867)

Habitat ins. parvas ' Ilheos de Nordeste' dictas, juxta Portum Sanctum; vulgaris.

The present modification of the $H$. polymorpha was obtained by the Baron Paiva, in 1863, from the almost inaccessible rocks off the north-eastern coast of Porto Santo known as the 'Ilheos de Nordeste.' It differs but little from the ' $\lambda$. discina'; but having been published by the Baron as a distinct species, it must of necessity be noticed.

Judging from the types before me, the ' $\mu$. Gomesiana' is (on the average) a trifle smaller than the ' $\lambda$. discina,' and more thickly granulated; its keel is not quite so sharply expressed; its volutions are not quite so flattened; its upper portion is less variegated, being more darkly and uniformly diffused with a warm reddish-brown tint; and its base is more decidedly opake, 
with the umbilicus more contracted above, but broader and more cylindrical within,-its sides (much as in the var. attrita) being more abruptly, or more suddenly and perpendicularly, scoopedout.

ע. attrita, Lowe.

Helix tectiformis, Wood [nec Sow., 1824], Suppl.t. 8. f. 83 (1828)

" polymorpha, $\delta$. attrita, Lowe, l. c.55. t. 6. f. 14(1831)

". attrita, Lowe, Ann. Nat. Hist. ix. 116 (1852)

" " Pfeiff., Mal. Blätt. 89 (1852)

$" \quad$ " Lowe, Proc. Zool. Soc. Lond. 188 (1854)

" polymorpha. var. к., Alb. l. c. 27. t. 6. f. 12-15 (1854)

" attrita, Paiva, l. c. 88 (1867)

Habitat Portum Sanctum ; in monte 'Pico d'Anna Ferreira' dictâ præcipue occurrens. Semifossilis in Campo de Baixo rarissime exstat.

Amongst the numerous phases of the $H$. polymorpha, the present one (which is peculiar to Porto Santo) was selected by Pfeiffer as specifically distinct; and certainly the structure of its umbilicus and aperture might well seem at first sight to give it a greater claim for separation than some of the others. Yet I am persuaded that it has no more right, in reality, to be thus treated than any of the rest,-its umbilicus (as regards the singularity of its form) merging so completely into the ordinary shape which obtains in the ' $\lambda$. discina' and its allies that several examples which are now before me might be assigned almost equally to either modification; whilst the thickening within its somewhat more angular aperture is merely the same thing, only a little more pronounced, as what we observe in several of the preceding aspects of the species. Indeed the umbilicus of the ' $\mu$. Gomesiana,' although a trifle wider and more cylindrical, differs very little indeed from that of the present variety,-partaking more of the attrita- than of the discina-pattern.

Apart from its contracted and abruptly, or suddenly, excavated umbilicus (the result, in part, of the somewhat unnaturally inflated base of its ultimate volution), the present shell is extremely solid, acutely carinate, and lenticular, with its volutions greatly flattened, and its surface rather powerfully granulate both above and below. Its aperture (which is much incrassated within) is rather angulated, or subtriangular, in outline, the margins of its peristome being wide apart, and almost unconnected by an intervening lamina. Its colour is much that of the ' $\lambda$. discina' the surface being either fasciate or efasciate beneath, but obscurely marbled above with brownish and whitish 
irregular transverse markings, though gradually and conspicuously paler outside the aperture.

So far as my own experience is concerned, the present modification of the $H$. polymorpha is peculiar to the Pico d'Anna Ferreira (and its immediate vicinity), - a remarkably isolated mountain of Porto Santo, to the south-west of the great central mass; and I may add that this is in exact accordance with the equally repeated observations of Mr. Lowe,-who first met with it, on the Pico d'Anna Ferreira, in 1828; yet the Baron Paiva cites it from two other mountains, as well as from the Ilheo de Ferro. I can only add, however, that, as the Baron's material was not collected by himself, and was consequently subject at times to great inaccuracies as regards habitat, I must be permitted to look with some amount of suspicion upon these additional localities for the 'var. $\nu$. attrita.' At any rate I have myself paid considerable attention to the manner in which this particular variety is (so to speak) concentrated on the Pico d'Anna Ferreira, and have repeatedly observed that the examples which were obtained at a certain distance from the base of the latter are gradually less and less pronounced in their features, according to the length of the intervening area, until they completely merge (as it has seemed to me) into the ordinary ' $\lambda$. discina,'- the umbilicus especially (in such specimens) being more or less intermediate between what obtains respectively in the two types (as normally defined).

In a subfossil condition the ' $\nu$. attrita' has been taken sparingly, both by Mr. Lowe and myself, on the Campo de Baixo (which well-nigh abuts upon the base of the Pico d'Anna Ferreira); but, like every other modification of the $H$. polymorpha which occurs at all except in a recent state, it is extremely scarce.

\section{Helix tabellata.}

Helix tabellata, Lowe, Ann. Nat. Hist. ix. 116 (1852)

" $\quad$ Pfeiff., Mal. Blätt. 90 (1852)

" " Id., Mon. Hel. iii. 164 (1853)

" $\quad$ " Lowe, Proc. Zool. Soc. Lond. 189 (1854)

$" \quad$ " Alb., Mal. Mad.28.t.6. f. 19-21 (1854)

$" \quad " \quad$ Paiva, Mon. Moll. Mad.95 (1867)

Habitat Maderam; in collibus aridis maritimis, præcipue ad promontorium ' Garajão' prope Funchal, sub lapidibus gregaria.

This is the smallest member of the Discula section which has hitherto been found in the Madeiran archipelago, measuring only about 3 lines across its broadest part; for although the most reduced examples of the 'var. poromphala' of the 
H. polymorpha (described by the Baron Paiva as his ' $H$. Pittoe ) descend to a still smaller stature, the 'var. poromphala' does nevertheless represent, on the average, a very much larger and more robust shell than the present one. The $H$. tabellata is also thinner, or less solid in substance, than most of these immediate forms; and I think that its specific separation from the various races of the $H$. polymorpha is fully warranted by the general peculiarity of its structure. ${ }^{1}$

In the extreme flatness of its upper portion (the spire, which is composed of only six whorls, being perfectly tabuliform) and the inflation of its base, causing the keel to be ante-medial as well as prominently and very sharply expressed, the $H$. tabellata has a primâ facie aspect essentially its own; and, although somewhat fragile in substance, it is nevertheless strongly sculptured,-it being much roughened with coarse irregular subconfluent palish transverse lines, and besprinkled with large palish granulations or tubercles. Its umbilicus is small, but abruptly and perpendicularly scooped-out (much after the fashion of the 'var. attrita' and the 'var. Gomesiana' of the $H$. polymorpha); the margins of its peristome are wide apart and well-nigh unconnected by an intervening lamina, the lower one moreover being subflexuose and slightly recurved; and in colour it is of a dingy griseous- or yellowish-white,--either uni- or bifasciate (or even efasciate) below, but very obscurely mottled above with brownish and paler transverse markings, the former of which so greatly predominate as to cause the surface to seem at first sight to be (apart from the tubercles and lines) almost uniformly brown.

The $H$. tabellata, which appears to be peculiar to the south of Madeira proper, was first detected, I believe, by Mr. Leacock, on the dry maritime slopes of the Cabo Garajão, or Brazen Head ; and it has subsequently been met with by Mr. Lowe, myself, and others, in the same locality. The Baron Paiva records its occurrence also towards the Cabo Girão, to the westward of Funchal.

\section{Helix testudinalis.}

Helix testudinalis, Lowe, Ann. Nat. Hist. ix. 117 (1852)

1 The Baron Paiva (evidently copying a somewhat hasty remark of Mr. Lowe's) states that the $H$. tabellata is intimately related to the $H$. maderensis, Wood $!$; but it is difficult to conceive any two species more utterly removed from each other in all their characters, - the circular and elevated peristome of the Placentula section being sufficient even of itself to distinguish its members from those of the Discula group. Although widely separated from it specifically, perhaps the nearest ally of the $H$. tabellata, both in the structure of its umbilicus and the inflation of its under-parts, is the Porto-Santan 'var. attrita' of the $H$. polymorpha; but it has likewise a good deal in common with the $H$. argonautula, W. et B., of the Canarian archipelago. 
Helix testudinalis, Pfeiff., Mon. Hel. iii. 161 (1853)

$\begin{array}{lll}" & \quad & \text { Lowe, Proc. Zool. Soc. Lond. 191 (1854) } \\ " & \quad & \text { Alb., Mal. Mad. 25. t.5. f. 4-6 (1854) }\end{array}$

Habitat Portum Sanctum ; in saxosis intermediìs versus oram borealem, præcipue in regione Pedragal dictâ, sub lapidibus. Semifossilis in Campo de Baixo parcissime occurrit.

The $H$. testudinalis (which measures about $8 \frac{1}{2}$ lines across its broadest part) is the largest number of the Discula section which has hitherto been brought to light in either the Madeiran or Canarian Groups; and it seems to be peculiar to a certain limited district, known as the Pedragal, in the north of Porto Santo, - where it was first detected by myself and the late Rev. W. J. Armitage, particularly on the promontory called the Ponta de Guilherme, in 1848, and where it was again met with by Mr. Lowe and myself on the 21 st of April 1855. In a subfossil condition it is extremely scarce, though to be found occasionally on the Campo de Baixo.

Apart from its large size and open spiral umbilicus, the present species (which is slightly shining and subpellucid, and coloured somewhat after the manner of tortoiseshell) may be known by its flattened lozenge-shaped outline (the nucleus however of the spire being a little papilliform or prominent), by its keel being rather obtuse, and by its granules and transverse lines being (particularly on the underside, where the former are nearly evanescent) both fine and minute, Its peristome, which is recurved and internally white, has the margins wide apart and merely connected by the thinnest possible intervening lamina; and its basal portion is of a clouded, or unequal, yellowishcorneous hue, with a broad castaneous band encircling the umbilical area, and the fragments of a second (obsolete) one towards the keel ; whilst above, it is of a pale olivaceous brown freckled with a few irregular cinereous transverse markings, and ornamented with a more or less evident narrow castaneous medial fascia which is usually traceable up the spire,-an arrangement of colouring which gives the volutions, at first sight, a very obsoletely subcarinated appearance about their oentral or dorsal line. The ultimate whorl, which is deflected a good deal in front, is more or less brightly ochreous outsịde the aperture.

( Tectula, Lowe.)

Helix Lyelliana.

Helix Lyelliana, Lowe, Ann. Nat. Hist. ix. 117 (1852).

$2 ?$

,

Pfeiff., Mon. Hel. iii, 161 (1853), 
Helix Lyelliana, Lowe, Proc. Zool. Soc. Lond. 191 (1854)

"Bulwerii, $\beta$., Alb., Mal. Mad. 24. t. 4. f. 19-22 (1854)

"Lyelliana, Paiva, Mon. Moll. Mad. 93 (1867)

Habitat Desertam Grandem; in promontorio alto graminoso occidentali 'Pedragal' (aut, sec. Paiva, 'Ponta dos Castanheiros') dicto, sat vulgaris sub lapidibus. 'Var. $\beta$. gigas' ad Feijãa Grande invenitur.

A rather large and sharply keeled Helix which has been found hitherto only on the Deserta Grande, where it was first detected by myself and the late Rev. W. J. Armitage during January of 1849 , and where, in company with Mr. Lowe, I again met with it in June 1855. We obtained it only on the lofty western promontory known, I believe, as the 'Pedragal' (but cited by the Baron Paiva as the Ponta dos Castanheiros), where it was tolerably common on the open grassy slopes beneath stones; but there is a larger phasis of the shell (the 'var. $\beta$. gigas' of this catalogue) which was collected for us at the time in an almost inaccessible spot further to the south, on the eastern side of the island, called the Feijãa Grande. The Baron Paiva, after speaking of its habitat, remarks briefly 'subfossilis rarior;' but as there is no record hitherto of a subfossiliferous deposit on the Central Deserta, there is a rashness about this short observation which inclines me to suspect that the Baron was not sufficiently accurate in his data, and that he probably mistook some examples which were old, bleached, and decorticated for semifossilized ones.

In their general aspect and colouring the Desertan $H$. Lyelliana and the Porto-Santan H.Albersii and Bulwerii have a good deal in common; but I think that they are nevertheless quite as well separated inter se, by a number of small but constant and readily appreciable characters, as could reasonably be expected with species which belong to the same topographical assemblage, and which are naturally therefore allied; and I consequently do not agree with Dr. Albers, who professed to see nothing about them to indicate more than races of a single type. Of course it is quite possible to take that view; but those who adopt it are at least bound to be consistent with their own principles, and to apply the same synthetic treatment (which Albers certainly has not done) to a host of other forms which are similarly ciroumstanced, and the non-recognition of which would create incalculable oonfusion, and render all our specific limits a matter of mere speculation and caprice. It is true that this method of dealing with closely related forms is at times unmistakeably forced upon us; but I will only add, that the case in question is by no means analogous to that of the numerous modifications of the $H$. polymorpha,-most of which 
are manifestly connected by intermediate grades, and which belong to a type which is essentially a variable one. But no such links have as yet been discovered between the $H$. Lyelliana, Albersii and Bulwerii (the second and third of which moreover are associated in the same actual area, and are consequently subjected to the same local influences); and I do not see, therefore, that we have any right to proceed upon a mere hypothesis (such as we practically decline to apply in so many other instances of a similar nature) and to treat them as otherwise than specifically distinct.

The $H$. Lyelliana (which measures about $7 \frac{1}{2}$ lines across its broadest part) is a lenticular and strongly carinated shell,- the keel being just traceable, in the form of a slightly elevated thread-like sutural line, up the column; its umbilicus is rather small but spiral; and, with the exception of a few minute granules immediately below the keel, the surface is altogether ungranulated. In colour it is of a pale whitish-yellow beneath, the umbilical area being encircled by a dark castaneous band, between which and the keel there is generally a second one (the two however being sometimes confluent, and occasionally more or less obsolete); whilst above, it is of an unequal castaneous brown, mottled with a few irregular transverse yellowish lines and markings (with an obscure narrow castaneous mential fascia), and gradually paler outside the aperture,-where there is often also a clear rosy or orange tinge.

We may regard the $H$. Lyelliana as representing in the Deserta Grande the Porto-Santan H. Albersii. It is, however, on the average, a trifle smaller and more solid than that species; its umbilicus is narrower, and more closed-up internally; its surface has the transverse lines much coarser, but is free from granulations except immediately beneath the keel; the latter is not quite so prominent and tectiform; its aperture is a little more deflected in front; its base is rather more convex; its keel is traceable as a minute thread-like line up the spire; and its colour is altogether clearer, brighter, and more variegated, with the darker bands more abruptly and strongly expressed.

The 'var. $\beta$. gigas' of this species is not only considerably larger (measuring nearly 9 lines across its broadest part), but it has its keel a little more acute and prominent, though not so traceable (or thread-like) up the spire; its aperture is not quite so deflexed in front; and its volutions are 9 in number, instead of only 8 .

\section{Helix Albersii.}

Helix Albersii, Lowe, Ann. Nat. Hist. ix. 117 (1852) "Bulwerii, $\beta .$, Pfeiff., Mon. Hel. iii. 161 (1853) 
Helix Albersii, Lowe, Proc. Zool. Soc. Lond. 192 (1854)

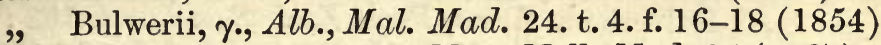

" Bulweriana, a., Paiva, Mon. Moll. Mad. 95 (1867)

Habitat Portum Sanctum; in montibus vulgaris, una cum H. Bulwerii sæpe degens.

Although they have been generally much confused inter se, the present Helix and the H. Bulwerii, which live in company on the mountains of Porto Santo, are nevertheless very readily separated when once their diagnostic features are fairly grasped; and as the latter (out of many hundred examples which I have inspected) appear practically quite invariable, I scarcely see how we can refuse to accept the conclusions arrived at by Mr. Lowe in regarding the two as specifically distinct. At any rate, as he has published them, and has defined their characters with great precision, I will not undertake to suppress as a species either the one form or the other; and more particularly so, since my own experience inclines me to think that they are as easily recognizable as any two members of a topographical assemblage can be which are closely allied.

The $H$. Albersii is, on the average, a little smaller and paler in colouring than the $H$. Bulwerii, its under-region (which is more convex) being of a clearer yellowish- or olivaceous-brown, whilst the upper one is not so dark, more evidently unifasciate, and gradually ochreous outside the aperture; its umbilicus is a little less cylindrical; its keel is not quite so prominent or tectiform; its spire is not so cupola-shaped, or obtuse; its surface is somewhat less densely granulate; and its aperture, which is less angulate in the middle and has the upper margin of the peristome more curved, is appreciably deflected (instead of being quite horizontal) in front. The entire shell, too, is a trifle more solid, or less fragile. Its distinctions from the Desertan $H$. Lyelliana have already been pointed out.

It is chiefly on the higher mountain-slopes of Porto Santo that the $H$. Albersii and Bulwerii are to be met with; and although they are pretty general at a tolerable altitude, I have usually observed them in greater profusion on the ascent of the Pico do Facho than elsewhere,-a district in which they were obtained in large numbers by Mr. Lowe and myself during April and May of 1855 .

\section{Helix Bulwerii.}

Helix Bulwerii, Wood, Suppl. t. 8. f. 82 (1828)

"Bulveriana, Lowe, Cambr. Phil. S.Trans. iv. 44. t. 5.

f. $11(1831)$

" Bulweriana, Pfeiff., Mon. Hel. i. 208 (1848) 
Helix Bulwerii, Pfeiff., Mon. Hel. iii. 161 (1853)

" Bulveriana, Lowe, Proc. Zool. Soc. Lond. 192 (1854)

" Bulwerii, Alb., Mal. Mad. 24. t. 4. f. 12-15 (1854)

"Bulweriana (pars), Paiva, Mon. Moll. Mad.94 (1867)

" rota, Lowe, olim, in litt.

Habitat Portum Sanctum; in montibus una cum specie præcedenti degens. Semifossilis parcissime collegi.

As already mentioned, the $H$. Bulwerii is essentially a Porto-Santan species,-occurring on the mountain-slopes of a rather high elevation, often in company with the $H$. Albersii. In a subfossil condition it is extremely scarce, though I have taken it out of the sandy, or muddy, deposit of a sea-cliff below the Pico dos Maçaricos, to the westward of the Villa.

The $H$. Bulwerii (the specific title of which appears to have bsen unwarrantably altered by $\mathrm{Mr}$. Lowe, in 1831 , into ' Bulveriana') is, on the average, a trifle larger than the $H$. Albersii; and it is also a little less solid in substance, and of a darker hue,-it being browner, or more castaneous, both above and below, though the whorls have their single medial band obsolete, and the ultimate one (which is more strongly and acutely carinated, and not deflected in front) is free from the pale ochreous tinge, or dilution, behind the aperture. Its spire is more rounded and obtuse at the apex, or dome-shaped, the volutions being even still flatter and in a more continuous curve, -an arrangement which causes the keel to be more downwardly inclined, and more tectiform or produced. Its entire surface is a little more densely and evidently granulated; its base is somewhat flatter, with the umbilious just perceptibly deeper and more cylindrical; and its aperture, which is more angulated in the middle, has the upper margin of the peristome straighter, or less inwardly curved.

Like the $H$. rotula, and indeed like so many of the Helices, particularly in Porto Santo, the $H$. Bulwerii has an occasional somewhat greenish-white, almost colourless, albino state; but as the same tendency to decoloration exists in so large a number of the species, I can scarcely regard that peculiar (and, as it were, accidental) condition as representing a distinct 'variety,' -properly so called.

Helix tectiformis.

Helix tectiformis, Sow., Zool. Journ. i. 57. t. 3. f. 6 (1824)

"

9

99

29
99

,

99

9

Lowe, Cambr. Phil. S. Trans. iv. 45,t.5.

f. 12 (1831)

Pfeiff., Mon. Hel. i. 208 (1848)

Lowe, Proc. Zool. Soc. Lond. 192 (1854)

Alb., Mal. Mad. 22. t. 4. f. 4-6 (1854) 
Helix tectiformis, Paiva, Mon. Moll. Mad. 99 (1867) var. $\beta$. [fasciata], cingenda, Woll.

Helix tectiformis, subvar. 2., Lowe, Proc. Zool. Soc. Lond. $192(1854)$

var. $\gamma$ " [subfasciata], suffusa, Woll.

$$
\text { S., Paiva, l.c. } 100 \text { (1867) }
$$

Helix tectiformis, subvar. 3., Lowe, Proc. Zool. Soc. Lond. $192(1854)$

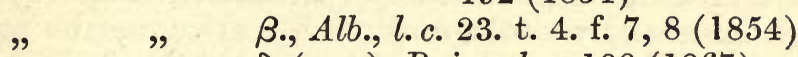

$" \quad \quad \quad \quad \quad$. (pars), Paiva, l.c. $100(1867)$

var. $\delta$." [submajor, sublenticularis, semifossilis, extincta], Ludovici, Alb.

Helix Ludovici, Alb., Mal. Blätt. 187 (1852)

$\Rightarrow \quad$ Pfeiff., Mon. Hel. iii. 642 (1853)
$\Longrightarrow \quad$ tectiformis, a., Mal. Mad. Paiva, l.c. 100 (1867) 9 (11 (1854)

Habitat Portum Sanctum, insulamque parvam adjacentem ' Ilheo de Baixo' dictam; in aridis calcareis vulgaris. Semifossilis (præsertim in statu ' $\delta$. Ludovici') copiosissime invenitur.

The H. tectiformis, which is peculiar to Porto Santo and the adjoining islets, is one of the most singular, though at the same time most variable, land-shells of the Madeiran archipelago; and common as it is on the low calcareous slopes and dry sandy plains of that island, as well as on the adjacent rock of the Illheo de Baixo, it appears to have been even more abundant still at a former period,-it being one of the universal species in all the subfossiliferous deposits. On the Campo de Baixo and at the Zimbral d'Areia it swarms in a subfossil condition (particularly under a slightly larger and more lenticular aspect which was described by Dr. Albers, under the title of $H$, Ludovici, as specifically distinct), where it would seem to take the place of the equally anomalous $H$. delphinula of Madeira proper, - which is almost as plentiful in the beds near Caniçal as the H. tectiformis is in those of Porto Santo.

In its normal state the present Helix (which measures from about 7 to 8 lines across its broadest part) is so completely white, bleached, and colourless that it sometimes is not easy to tell at first sight whether the examples are living or subfossilized. But it is liable occasionally to be tinged with a lividor leaden-brown hue, - the result of two (generally indistinct) fasciæ below, and one above. When these bands are tolerably defined, the individuals represent the 'var. $\beta$. cingenda' of this catalogue; but when they are suffused (the basal ones being entirely confluent), so as to obscure the greater part of the surface, the 'var. $\gamma$. suffusa' is indicated. 
In its obtuse, cupola- or dome-shaped upper portion, and its downwardly-produced tectiform keel, as well as in its ultimate volution having no tendency to be deflected at the aperture, the present shell has very much in common with the $H$. Bulwerii. Nevertheless it is (on the average) a trifle smaller than that species, its roof-like keel is broader and even still more expressed, its umbilicus is a little more suddenly and perpendicularly scooped-out, its granulations (particularly beneath) are, although extremely variable, very much coarser, and its colour is altogether different, - it being either of a bleached calcareous white, or else (though much more rarely) more or less suffused with a pale livid brown. Its granulations, although so inconstant as regards their size and development, have a curious tendency (at any rate at the base) to be split-up, each of them, into several compartments, by minute intersecting. lines,-so that in examples where they are largely expressed and elongated; each one has somewhat the appearance of a bundle, or fascicle, of smaller ones placed side by side (like the closed-up club of a Coleopterous Lamellicorn antenna).

'The 'var. $\delta$.' of the present enumeration, which was enunciated by Dr. Albers, under the name of H. Ludovici, as specifically distinct, is merely a rather larger and more flattened (or lenticular) phasis of the shell, with generally a more open umbilicus, which appears (so far at least as I have been able to ascertain) to have died out; for although it possesses several small features of its own which will suffice usually to separate it at first sight from the ordinary type, it nevertheless merges so gradually and completely into the latter that I am satisfied it can not be upheld as more than a modification, or race, which may formerly perhaps have represented the normal aspect of the species. In its most exaggerated state (under which circumstances it measures about 9 lines across its broadest part) it is not only somewhat larger and more depressed than the one which is now so abundant, but it has its keel a trifle less rooflike or pronounced, and its basal region appreciably more inflated or convex. The volutions, too, of its somewhat less cupola-shaped spire are not quite so decidedly flattened, having a tendency to be a little gibbose or convex behind the suture; but many of the examples now before me possess these various characters so doubtfully that it is impossible to decide whether they pertain to the ' $\delta$. Ludovici' or not.

\section{(§ Craspedaria, Lowe.)}

\section{Helix delphinula.}

'Delphinula sulcata, Lam.?' Bowdich, Exc. in Mad. 140. f. $33 . a, b .(1825)$ 
Helix Delphinula, Lowe, Cambr. Phil. S. Trans. iv. 64 [note] (1831)

"

Id., Ann. Nat. Hist. ix. (1852)

Id., Proc. Zool. Soc. Lond. 193 (1854) Alb., Mal. Mad. 80. t. 17. f. 1, 2 (1854)

Paiva, Mon. Moll. Mad. 66 (1867)

Habitat Maderam, semifossilis; in arenis calcareis juxta Caniçal vulgaris, hodie recens hactenus haud observata.

Of all the subfossil Helices of the archipelago, the somewhat large and singular $H$. delphinula (which measures from about 9 to 11 lines across its broadest part, and which is peculiar to the calcareous deposits near Caniçal) is by far the most remarkable one which has not yet been discovered in a recent condition. It is not unlikely however that more careful researches in some of the less-known ravines towards the northeast of the island may still establish it as a member of the present fauna,-just as the equally wonderful $H$. delphinuloides, which had escaped the united observations of so many naturalists through more than half a century, was detected so lately as in 1860, by Mr. Lowe, at the edges of the new Levada which has opened-out a previously unexplored district in the Ribeira do Fayal. That it must have been once extremely common is evident from the great abundance in which it now exists in the sandy, subfossiliferous beds near Caniçal,-where it may be said, perhaps, to take the place in Madeira proper of the nevertheless very dissimilar (though in some respects analogous) $H$. tectiformis of Porto Santo.

From only subfossil specimens it is not easy to say what the exact colour of the $H$. delphinula may have been when in a living state; but judging from the analogy of the $H$. tectiformis, as well as of the $H$. delphinuloides and of the various other members of the section Coronaria, we may be well-nigh certain that it was either a calcareous-white or nearly so. But, apart from all considerations of hue, the $H$. delphinula (which has something in common with the H. turcica, Chemn., from Moroceo) may be known by its somewhat lenticular outline, but nevertheless cupola-shaped, extremely obtuse spire; by its horizontally-expanded, more or less foliaceous, tectiform keel (which is traceable up the majority of the whorls, overlapping the suture like a narrow plate); and by its enormous but abruptly scooped-out umbilicus, which is not only spirally visible to the extreme apex, but has its sides coarsely sculptured with concentric spiral costæ (decussated by irregular, undulating, lighter transverse ones) similar to those which roughen the entire inferior surface (except the lamina-like keel) of the basal volu- 
tion. Its aperture, which is suddenly and greatly deflected, is most peculiar,--being externally angulated at the keel, and produced into a sharp beak-shaped process, whilst the peristome is much developed and continuous, being considerably raised above (or, rather, as it were, hung down below) the ultimate whorl, with the basal margin conspicuously reflexed. The sculpture of the upper portion of the shell is very much finer and lighter; but there are evident traces (in the specimens which are better preserved) of minute spiral ridges, crossed by exceedingly indistinct, irregular, and still finer transverse lines, though other examples have a more coarse and malleated appearance.

The 'var. B. planospira' is merely a little larger and flatter than the ordinary type (the spire being less elevated), with the umbilicus somewhat more gradually (or less perpendicularly) scooped-out, and with the sculpture on the upper side rather finer.

\section{(§ Coronaria, Lowe.)}

\section{Helix delphinuloides.}

Helix delphinuloides, Lowe, Ann. Nat. Hist. vi. 44. pl. 3. f. 1-3 (1860)

$\begin{array}{cc}" & \text { Pfeiff., Mal. Blätt. xi. 54. t. } 2 . \\ & \text { f. } 14-16(1864) \\ & \text { Paiva, Mon. Moll. Mad. 67. t. } 1 . \\ & \text { f. } 1(1867)\end{array}$

Habitat Maderam ; in Ribeira do Fayal, ad alt. circa 4000' s.m., ad terram inter gramina et herbas latitans, a Revdo. R. T. Lowe, A.D. 1860, copiose reperta.

This is not only one of the most anomalous of the Madeiran Helices, but by far the most remarkable one which has been brought to light of late years, - it having been discovered, by Mr. Lowe, so recently as in 1860. It was at an elevation of about 4000 feet, in the Ribeira do Fayal, that Mr. Lowe met with it, and moreover in considerable abundance,- - on the surface of the somewhat moist, loose, friable, black vegetable mould, amongst tufts of grasses, ferns, \&c., on a steep, dry, sunny bank clothed with shrubs of Vaccinium and Heath, and mixed with a few scattered trees of Laurus, at the foot of perpendicular crags, along the new Levada called the Levada da Fajãa dos Vinhaticos.'

The $H$. delphinuloides (which measures about 8 lines across. its broadest part) is almost exactly intermediate between Mr. Lowe's sections Craspedaria and Coronaria, so that it might with nearly equal propriety be assigned to either of them; yet although its very much larger size than any of the members 
hitherto detected of the latter, in combination with its enormous umbilicus, might seem to render it desirable to refer it to the former, I nevertheless believe that its true affinities are with the Coronaria group. At the same time it has very much in common, also, with the remarkable $H$. delphinula (the only exponent hitherto detected of the section Craspedaria); and it is singular that while that species abounds in a subfossil condition near Caniçal, and has not yet been discovered anywhere alive, there are, on the other hand, no traces whatever of the $H$. delphinuloiles occurring subfossilized.

The present extraordinary shell is rather thin and fragile in substance, extremely roughened, perfectly opake, and of a uniform dull pale-brownish flesh-colour varying into a chalky white. It is flattened, rounded, and planorbiform, with its spire greatly depressed, its umbilicus excessively wide and open (being visible spirally to the very apex), with its aperture much deflected, and with its peristome acute, broadly developed, continuous, circular, elevated, and considerably recurved; and although there is a raised dorsal ridge, which is very conspicuous on the basal volution, it has no angular keel (properly so called).

The sculpture of this curious Helix is very complicated, and not easily to be described: but the upper edge of each whorl is roughened with a series of short, equidistant, transverse ribs, radiating from the suture and extending about a third of the distance across: beneath which there are a few spiral costæ (crossed, or cancellated, by a few finer, remote transverse ones which are a prolongation of the abbreviated basal ribs), which however do not usually fill-up the entire remaining space, but which leave the posterior zone of each volution more or less free and concave. On the ultimate whorl these spiral costæ, above the dorsal line, are for the most part only about two in number, the hinder one being the more prominent and constituting a kind of medial thread-like keel; whilst beneath, the spiral ribs are not only more numerous, but become narrower and more elevated as they approach the umbilicus,- - the sides of which they completely crowd, as in the $H$. delphinula. Like the upper series, these lower spiral ridges are crossed, or decussated, by smaller radiating transverse ones; and, in addition to all this, there are more or less evident indications on the upper side (at any rate on the basal whorl) of some very oblique and irregular waved lines or subconfluent impressions.

\section{Helix coronata,}

Helix coronata, Desh., in Fer. Hist. i. 71. t. 69. k. f. 1-4. " juliformis, Lowe, Ann. Nat. Hist. ix. (1852) 
Helix coronata, Pfeiff., Mon. Hel. iii. 146 (1853)

$\begin{array}{lll}" & \quad & \text { Lowe, Proc. Zool. Soc. Lond. } 194(1854) \\ " & \quad & \text { Alb., Mal. Mad. 35. t. 8. f. 31-34 (1854) }\end{array}$

Habitat Portum Sanctum, et (sec. Paiva) ins. parvam adjacentem 'Ilheo de Cima ;' recens a meipso in cacumine extremo orientali 'Pico de Baixo' dicto, A.D. 1848, detecta. Semifossitis ubique (in Portû Sancto) copiosissime reperitur.

Although not differing much from them in breadth, the $H$. coronata (which measures scarcely 3 lines across its widest part) is the smallest of the six members of the section Coronaria which have hitherto been detected; and although it is a most abundant species in nearly every subfossiliferous deposit of Porto Santo (to which island, and the Ilheo de Cima, it is peculiar), it was not until 1848 that it was ascertained to belong to the present fauna,-it having been found by myself, during that year, in a living state, on the north-east side of the extreme summit of the eastern peak (opposite to the Ilheo de Cima) known as the Pico de Baixo. I obtained it, in that particular spot, in profusion, beneath slabs of stone and at a considerable depth underground,-the specimens adhering together in clusters; and the Baron Paiva states that examples were sent to him in 1863, as having come from the Ilheo de Cima,- - which, topographically considered, is a sufficiently probable habitat. ${ }^{1}$

The $H$. coronata is a rounded, flattened, sublenticular little shell, solid in substance, but nevertheless (when in a living state) rather shining (which is peculiar for the present section) and subhyaline; it is also strongly though sparingly sculptured (or embossed), and either of a very pale whitish horny-brown or else of an undiluted clear white. Its umbilicus is rather large and spiral; its aperture (which is constricted behind, and very suddenly deflexed) is small, sinuate, distorted, and subtriangular, - the base of the triangle, or outer lip, heing armed internally with a thick, powerful, obtuse tooth; and its peristome is acute and continuous, and a good deal developed.

1 Although I have admitted the Ilheo de Cima, on the authority of the Baron Paiva, as a locality for this species, I really cannot, without further and better evidence, cite its occurrence, as he has done, in the subfossiliferous deposits of Madeira proper,-for no other naturalist has reported it beyond the limits of Porto Santo, and the extreme inaccuracy as regards habitat of the Baron's material, which was almost invariably brought to him by paid collectors sent out from Funchal, and which was sometimes (as I have proved to a demonstration) indiscriminately mixed up afterwards even by himself, renders it more than likely that some of his Porto-Santan examples had become accidentally transposed (as was so often the case in other instances) into his Madeiran boxes. At any rate I feel that it is better to omit it from the Madeiran list than run the risk of perpetuating what might possibly be, and probably is, a serious topographical blunder. 
The sculpture of the $H$. coronata, although sufficiently elaborate, is somewhat less complex than that of either the $H$. delphinuloides or of the following four species. The keel, however, is perhaps more pronounced than in any of them,- consisting as it does, of a single, prominent, compressed, thread-like line, simple (or undentate); but there is a series of large, greatly raised, subconfluent nodules (or, in reality, oblique, centrallyelevated ribs), forming a kind of chain, in the middle of each volution on the upper side, which gradually becomes evanescent as it approaches the nucleus, - occasioning the anterior and posterior zones of each whorl to be as it were sunk (along with the suture) into a groove, aud causing the keel of the ultimate volution to be more shaped-out and prominent than it would otherwise have been.' These abbreviated, tubercleshaped ribs are continued on the under side (i.e. beneath the keel), in the form of waved or undulating concentric ridges, up to the umbilicus, and even within it; and between them very minute spiral superficial lines (or line-like markings) can just be traced beneath a high magnifying power,-as though to proclaim its affinity with the other, immediately allied forms.

\section{Helix coronula.}

Helix coronula, Lowe, Ann. Nat. Hist. ix. (1852)

$\begin{array}{lll}" & \quad & \text { Pfeiff., Mon. Hel. iii. } 146(1853) \\ " & " & \text { Lowe, Proc. Zool. Soc. Lond. 194 (1854) } \\ " & \quad & \text { Alb., Mal. Mad. 81. t. 17. f. 5-7 (1854) } \\ " & \text { (pars), Paiva, Mon. Moll. Mad. } 63 \text { (1867) }\end{array}$

Habitat Desertam Australem, semifossilis; recens hactenus haud inventa.

The $H$. coronula was, I believe, first detected by $\mathrm{Mr}$. Leacock, in a subfossil condition, on the extreme summit of the Southern Deserta (or Bugio), - a locality in which it was subsequently met with, in abundance, by Mr. Lowe and myself, in June of 1855 ; and it has since been obtained from the same spot by the Baron Paiva. It is wrongly said by the latter to have been found by Senhor J. M. Moniz, in a recent state, on the Deserta Grande,- the species which was discovered by Moniz being in reality altogether distinct. ${ }^{2}$

1 The somewhat angular termination behind of this central chain-like projection of the lower whorls, which (by creating a depression, or groove, beneath it) causes the true keel to be strongly shaped-out, was mistaken by Mr. Lowe (both in the present species and in the $H$. coronula) for a second or ' upper' keel ; but a very slight examination will shew that it has, in reality, nothing to do with the keel (properly so called) at all.

2 Apart from his mistake concerning the H. Grabhami (point ed out below), the Baron Paiva has strangely mixed up not only the charactcrs but also the 
The $H$. coronula (which is a little larger than the coronata, Desh., measuring fully 3 lines, or a trifle more, across its broadest part) is a round, depressed, and somewhat lozengeshaped shell, the anterior half of each volution, although sculptured with coarse abbreviated radiating ribs, being horizontally flattened. This horizontality of the anterior zone of each whorl causes the line of transverse radiating ribs (which are abruptly terminated behind) to shape out a kind of medial dentate keel which is traceable up the spire, and which is very prominent on the basal volution. Nevertheless it is not the true keel, which latter is represented by a string-like, irregularly-dentate dorsal line below this great central ridge-like prominence, and which is visible well-nigh up to the nucleus, in the shape of a jagged or lacerated narrow lamella almost overlapping the suture. The umbilicus of the $H$. coronula is wide, open, and spiral; and the entire basal region (including the umbilical wall) is most beautifully and sharply sculptured with large spiral costæ, which are crossed, or decussated, by less elevated transverse radiating ones. The aperture (which is constricted behind) is considerably larger and less triangular than that of the PortoSantan $H$. coronata, and (as in the H. Grabhami, Moniziana, and tiarella) destitute of an internal tooth.

\section{Helix Grabhami, n. sp.}

T. fulvo-lactea, latissime et perspective umbilicata, subdepresso-trochiformis, solidula, opaca, bicarinata, subtus spiraliter costata et obsoletius transversim decussata ; spirâ subcon-

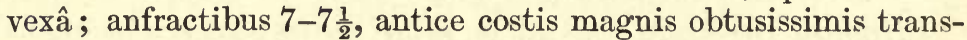
versis remotis radiantibus subalbidis, a suturâ usque ad (aut ultra) medium continuatis et ibidem abrupte terminatis (carinam superiorem undulatam exstantem efficientibus), elegantissime instructis, carinâ propriâ distinctâ, sed vix dentatâ aut laceratâ, fere ad nucleum (ad suturam applicatâ) conspicuâ; umbilico magno, aperto, pervio, profundo ; aperturâ angulatim

habitats of this Helix and his nearly allied one taken (in a living condition) in the east of Madeira proper, and which he described ultimately under the name of $\boldsymbol{H}$. Moniziana. This latter was regarded by Mr. Lowe (evidently without much consideration) as the recent state of the South-Desertan subfossil $H$. coronula, and as such it was published by him in 1862 ; and it is evident that the Baron wrote his diagnosis of the coronula (or had it written for him) on the strength of this conclusion of Mr. Lowe,-for his 'var. $a$. minor ... ad excelsos montes septentrionales insulæ Maderæ, rarissima, ad herbarum radices fere sepulta,' although wrong in its diagnostic details, is only explicable on that hypothesis. Finding afterwards however that the Madeiran shell was not really conspecific with the Desertan one, he seems to have described it under the title of $H$. Moniziana, but at the same time to have omitted to strike out of his original diagnosis the Madeiran habitat. Thus a degree of confusion has been created unnecessarily which is altogether quite unpardonable. 
subrotundatâ, postice constrictâ, peristomate relevato, soluto, continuo, expanso, acuto.-Diam. maj. 4 ; alt. $2 \frac{1}{4}$ lin.

\section{Helix coronula (pars), Paiva [nec Lowe], Mon. Moll. Mad. 63 (1863).}

Habitat Desertam Grandem; ad rupes inter lichenes, versus borealem insulæ, a cl. J. M. Moniz reperta. Species elegantissima, distincta, et in honorem amici M. Grabham, M.D., in ins. Maderæ longe lateque celebris, ob gratias mihi oblatas, citata.

This new and very interesting exponent of the Coronariasection is due to the researches of Senhor J. M. Moniz, who detected many examples of it (amongst lichen growing upon the rocks) towards the northern end of the Deserta Grande; and it was wrongly cited by the Baron Paiva as identical with the subfossil $H$. coronula, Lowe, of the Southern Deserta (or Bugio). So long indeed as the other members of this curious assemblage are to be regarded as specifically distinct from each other (and they have, all, an abundance of characters by which they may easily be recognized), it would be the height of inconsistency to single out any one of them as a local phasis or variety, whilst acknowledging the claims of the rest to be treated as species; and, in point of fact, if the H. Grabhami is to be looked upon as a modification of some cognate form, there is quite as much reason for assigning it to the $H$. tiarella of Madeira proper as there is to the South-Desertan H. coronula,-for, both in outline and sculpture, it is as nearly as possible midway between the two. I am satisfied therefore that they must, all of them, be either accepted as species, or else as insular modifications of a single plastic type; and I imagine that there are few monographers, if indeed any, who would be prepared to endorse the latter somewhat wild (and, as it seems to me, utterly untenable) hypothesis.

By the Baron Paiva a vast amount of unnecessary confusion has been created by the rash manner in which he has mixed up the features and habitats of these immediately-allied Helices; for not only has he registered the one which we are now discussing as coincident with the (apparently extinct) $H$. coronula of the Southern Deserta, but he seems also to have recorded originally the species from the south-east of Madeira proper which he subsequently described under the title of $H$. Moniziana as a small variety of the coronula (from which however it is totally distinct). But, bad as it is, this unfortunately is not all; for, having treated it as such in his original manuscript, he nevertheless omitted to strike it out as a variety of the coronula after that he had made up his mind that it was a 
separate species and had enunciated it accordingly! The consequence of which is, that the H. Moniziana figures in his monograph both as a distinct species and as a variety of the H. coronula!

As regards the shell, however, from the Great Deserta, with which alone we are now concerned, I may add that it is, on the average, larger than the subfossil $H$. coronula of the southern island (indeed it is the largest, with the exception of the comparatively gigantic $H$. delphinuloides, of the six representatives of the Coronaria-group which have hitherto been brought to light), with its spire very much more conical (or less flattened), and its umbilicus even wider still (or more open). Moreover it has from 7 to $7 \frac{1}{2}$ whorls (instead of only from 5 to 6 ); the anterior zone of each volution (which is embossed by the coarse, broad, abbreviated, radiating, transverse, whitish ribs) is more tilted, as in the $H$. tiarella, or very much less horizontal; and its true keel (below the extra, medial one, formed by the abrupt termination of the wide ridge-like prominences), which is traceable up the spire and well-nigh overlaps the suture, is conspicuously less lacerated or dentate.

Feeling confident that it cannot properly be assigned to the subfossilized $H$. coronula of the Bugio, any more than it can to the H. tiárella or the H. Moniziana (both of which are recent, and occur in Madeira proper), I have had much pleasure in dedicating the Great-Desertan shell to my friend Dr. Grabham of Funchal, -- whose well-known attainments in so many branches of physical science have rendered his name a household word amongst the numerous class of visitors who have formed, at intervals, a temporary home, during the past fifteen or sixteen years, in the central island of the Group.

\section{Helix Moniziana.}

Helix coronula [recens], Lowe, Ann. Nat. Hist. (August) (1862)

" " a. minor, Paiva, Mon. Moll. Mad. 64 (1867)

„ Moniziana, Id., l. c. 64 . t. 2. f. 1 (1867)

Habitat Maderam; prope Caniço et Gaula, ad orientem insulæ, A.D. 1862, parcissime detecta.

This is a species which was found in the vicinity of Gaula and Caniço, in the south-east of Madeira proper, by a collector who was employed by the Baron Paiva, in 1862, and which was referred to by Mr. Lowe, in the 'Ann. of Nat. Hist.' for August of that same year, as a recent state of the Southern-Desertan (subfossilized) $H$. coronula. In this, however, Mr, Lowe was 
manifestly mistaken; for a single glance at the two species, placed side by side, will shew an abundance of characters by which they may be at once separated from each other,-for, in point of fact, this Caniço shell is about midway between the South-Desertan $H$. coronula and the (very dissimilar) $H$. tiarella of Madeira proper. Yet, unless I am much mistaken, the Baron Paiva (as mentioned in the preceding foot-note) had his diagnosis of the South-Desertan shell drawn out (probably after Mr. Lowe's report in 1862), with the addition of a 'var. $\boldsymbol{a}$. minor' for a Madeiran form of it (which was clearly intended, although inaccurate as to its details, for this particular one from the neighbourhood of Caniço and Gaula); but, finding afterwards that the latter was specifically distinct, he enunciated it (in 1867) as the ' $H$. Moniziana,'-unfortunately, however, omitting (as it seems to me) to erase the 'var. a.' from the other and previous description! But that this 'var. a. minor' of his $H$. coronula is one and the same thing with his afterdefined $H$. Moniziana is I think well-nigh certain ; and indeed his mere habitats would tend, even of themselves, to imply as much, - the former one being 'ad excelsos montes septentrionales insulæ Maderce, rarissima, ad herbarum radices fere sepulta;' whilst the latter is ' rara sub lapidum acervis, in solo humido fere sepulta prope vicos insulæ Maderøe Caniço et Gaula.' ${ }^{\prime}$

As just stated, the $H$. Moniziana is about midway between the South-Desertan $H$. coronula and the Madeiran $H$. tiarella, though at the same time perfectly distinct from both of them; in which respect it is analogous to the Great-Desertan $H$. Grabhami, which is equally intermediate between those two species, and yet altogether distinct from the Moniziana. In its comparatively wide and open umbilicus, as well as in the peculiar character of its (nevertheless much more feebly indicated) basal sculpture, it partakes of the former (i.e., of the coronula); whilst in the shape and details of its upper portion (though the spire is much less elevated, and the sculpture is much less coarse, than that of the $H$. tiarella) it has more in common with the latter. It is however a rather thinner shell than either of them; and its surface is of a uniform, dull, opake, griseous-white, instead of being slightly variegated as in the H. tiarella.

\footnotetext{
1 As though to make matters even still more complicated, the Baron Paiva, after speaking of his $H$. Moniziana (which was found by the collector whom he sent out to work for him), adds 'Primus anno 1864 inveni ;' yet, by his own acknowledgement on the preceding page, he had already transmitted it to Mr. Lowe in 1862 ! So that I am compelled to arrive at the conclusionthat his statements, diagnoses, and habitats are so untrustworthy and confused that little reliance can be placed upon them, and that we must consequently proceed on independent evidence (which, fortunately, in this instance, happens to be accessible).
} 
The H. Moniziana has the anterior zone of its whorls less horizontal than in the $H$. coronula, but somewhat less oblique (or tilted) than in the tiarella; and the abbreviated ribs, which radiate from the suture over that anterior zone (particularly on the ultimate volution, for on the penultimate one they are nearly obsolete), are much less elevated than in the former, and a little less so than in the latter. The string-like keel is tolerably raised, and irregularly subdentate; and as there are no spiral lines immediately beneath it, it is more isolated, and therefore more conspicuous (even whilst less prominent) than in the $H$. coronula.

\section{Helix tiarella.}

Helix tiarella, W. et B., Ann. des Sc. Nat. 28. Syn. 316 (1833)

" $\quad$ d'Orb., in W. et B. Hist. 62. t. 1. f. 26-28 (1831)

" " $\quad$ I'feiff., Mon. Hel. i. 191 (1848)

" $\quad$ " Lowe, Proc. Zool. Soc. Lond. 194 (1854)

" $\quad$ "Alb., Mal.Mad.81. t. 17. f. 3, 4 (1854)

" $\quad$ Paiva, Mon. Moll. Mad.62 (1867)

" $\quad$ Mouss., Faun. Mal. des Can. 58 (1872)

Habitat Maderam; ad rupes præruptas maritimas, præcipue borealem versus insulæ, hinc inde degens. Semifossilis prope Caniçal copiosissime occurrit.

The $H$. tiarella, which seems to be peculiar to Madeira proper, was until 1855 supposed to be extinct,-it being extremely abundant, in a subfossilized state, in the calcareous bers near Caniçal ; but during July of that year it was first detected in a recent condition by myself, and afterwards by Mr. Lowe, along the sea-cliff road between the mouth of the Ribeira de Janella and Porto Moniz, - where we succeeded ultimately in obtaining about forty examples. It would appear however to be pretty general along the whole line of the northern coast; for later on in the summer we again met with it between Seissal and São Vicente, as well as at the Passa d'Areia (to the eastward of the São Vicente ravine), where we secured at least 120 specimens,not only in the loose rubble at the sides of the road (where many of them were dead), but also sticking (alive) on to the bare rocks, -and, in a similar situation, at the Entrorza Pass, between Ponta Delgada and Sta. Anna. ${ }^{1}$

1 This eminently Madeiran shell was described originally by Webb as Canarian, on the strength of some specimens which had been obtained, along with others of the H.tceniata (an equally distinctive Madeiran form), by M. Terver, of Lyons, from a bag of dried Orchil, the precise origin of which was confessedly unknown! But there can be no doubt whatever that it was from Madeira, and not the Canaries, that the consignment of Roccella had been 
In outline the $H$. tiarella differs from all the other members of the Coronaria and Craspedaria sections in the fact of the cupola-shaped, apically-obtuse spire being very much more raised; and it is also less decidedly colourless than any of them,-for, although often (when in even a living state) scarcely more than of a dull chalky-white, it has far more frequently a more or less brownish tinge, the ribs and other prominences being paler, which gives the entire surface a very beautiful and embossed appearance. The short radiating ribs on the anterior zone of its ultimate and penultimate volutions are exceedingly conspicuous, whilst the posterior zone has the spiral costæ extremely coarse, broken-up, irregular, subconfluent, and fragmentary,-a peculiarity of sculpture which obtains equally on the basal portion of the shell, where there are also scarcely any traces (except at the entrance of the actual umbilicus) of the radiating transverse lines which are more or less evident in the allied species. Its umbilicus, too, is almost (in part) overhung by the largely expanded edge of the circular and much raised peristome, - which is not the case in any of the preceding members of the group.

\section{( Lemniscia, Lowe.)}

\section{Helix Michaudi.}

Helix Michaudi, Desh., in Encycl. Méth. ii. 263 (1830)

" bicolor, Lowe, Cambr. Phil. S. Trans. iv. 58. t. 6. f. $22(1831)$

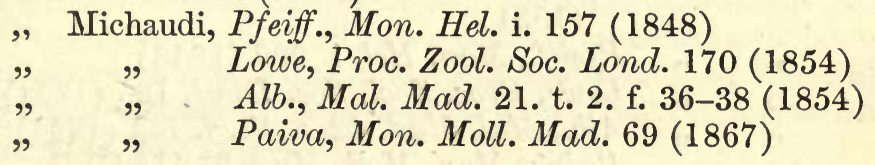

sent, and that the species has no kind of claim to be regarded as even extraMadeiran. Under these circumstances it is much to be regretted (as indeed I have already mentioned at p. 131 of this volume) that Mousson should have admitted it, as well as the $H$. taniata, into his late monograph of the Canarian Land-Mollusca;- - for to perpetuate, however unintentionally, a glaring geographical error (even though qualified by remarks as to the uncertainty of the habitat) seems to me to be scarcely counterbalanced by the adding of two additional species to augment a local list. My own belief is, that the $H$. tiarella does not occur beyond the limits of the central island even in the Madeiran archipelago; and I look therefore with unbounded suspicion on the Baron Paiva's brief remark 'rarissima ad Zimbral d'Areia in Portosancto insulâ,'-because no other naturalist has yet observed it in the Porto-Santan deposits, and the repeated visits of Mr. Lowe and myself (extending to four and five weeks at a time) to that island, during which the examination of the calcareous beds was one of our primary objects, never revealed so much as a vestige of this species which is so abundant in Madeira proper; whilst, at the same time, the extreme looseness, as regards habitat, of the Baron's material (which was seldom, if ever, collected by himself) I have had occasion more than once to touch upon. 
Habitat Portum Sanctum ; in montibus excelsioribus, vel inter lichenes in rupium fissuris vel plantis adhærens, vulgaris.

This brightly fasciated and elegant little Helix appears to be peculiar to Porto Santo, ${ }^{1}$ where it is common on most of the higher peaks (particularly towards their summits),-occurring principally among lichen, or adhering to the stems of plants, within the fissures, and upon the ledges, of the rocks. In such situations it has been met with abundantly, by Mr. Lowe, myself, and others, on the Pico do Facho, the Pico do Castello, the Pico Juliana, the Pico Branco, the Pico d'Anna Ferreira, \&c.; from several of which it has subsequently been received by the Baron Paiva.

The H. Michaudi is a solid and rather globosely-conical, or sub-trochiform, little species; and its surface (which is shining, anc. somewhat distinctly striated with the irregular, oblique, transverse lines of growth) is more or less white, but beautifully ornamented with dark purplish-brown bands or fasciæ,- two of which are on the (slightly flattened) underside of the shell, and become gradually lost sight of within the aperture, whilst a third one is placed above the (obtuse and ill-defined) keel, running along the centre of the volutions, uninterruptedly, to nearly the apex. Its perforation is extremely minute, and almost entirely concealed by the reflexed columellary edge of the peristome.

\section{Helix calva.}

Helix calva, Lowe, Cambr. Phil. S. Trans. iv. 49. t. 5. f. 26 (1831)

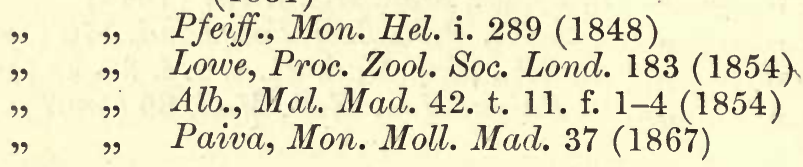

Habitat Maderam; sub lapidibus in graminosis montosis excelsioribus degens. Semifossilis ad Caniçal copiose reperitur.

The situation of the present Helix, in a natural arrangement, is rather difficult to point out. In some respects it has a little in common with the bifrons, Lowe, and the stephanophora, Desh.; yet its minute and almost concealed umbilicus, in conjunction with its margined peristome, will of themselves remove it from the section Janulus, - and indeed, as it seems to me, from the whole of the Patulas. By Mr. Lowe it was placed alongside the H. obserata, in his section Rimula, but I scarcely think that even that position is a more suitable one; and on the whole I am inclined to the Leminiscias as not altogether incapable o

1 The $H$. Michaudi is stated by Deshayes to occur in Teneriffe; but that is clearly an error. 
receiving it,-and more especially so since the recently discovered $H$. galeata, which is but just separable from the calva, has a very marked analogy, in its general proportions and obtuse helmet-shaped (or somewhat cupola-like) outline, with the Canarian $H$. lemniscata ; whilst the $H$. calva itself has some remote points of contact, both in habits and in structure, with the H. Michaudi, Desh., and perhaps with even (though this is more doubtful) the $H$. monilifera, W. et B. Still, the wellnigh unornamented surface and thicker substance, added to the minute spiral lines, of both the calva and galeata, isolate them, to a certain extent, from these immediate forms.

Apart from its spiral lines above mentioned (which, however, although of considerable significance, are nevertheless so minute as to be appreciable only beneath a high magnifying power), and its small and nearly concealed umbilicus, the $H$. calva may be further known by its almost uniform pale-brown, or yellowishcorneous, hue (the two fasciæ, although occasionally conspicuous on the basal whorl, being for the most part obsolete); and by its upper region being nearly opake and sculptured with coarse and irregular, but oblique and curved, costæ, whilst beneath it is more shining and less roughened.

The $H$. calva is confined exclusively to Madeira proper, where it is locally abundant,- - for the most part beneath stones on the grassy mountain slopes of a high elevation, ascending from about 2,500 feet above the sea to the summits of the peaks. It is also extremely common in a subfossil state at Caniçal (in company with various Helices and Pupoe), -having doubtless been washed down to that comparatively low region, at some remote period, from the neighbouring heights, under conditions, and influences, of the surrounding country, which were totally different from those which now obtain.

\section{Helix galeata.}

Helix calva, $\gamma \cdot$ galeata, Lowe, Ann. Nat. Hist. (1862) " galeata, Pfeiff., Mal. Blätt., March. (1864) " " Paiva, Mon. Moll. Mad.37. t. 1. f. 2 (1867)

Habitat Maderam; a Barone Castello de Paiva in Ribeira do Fayal, præcipue ad radices Pteridis aquilinœe adhærens, A.D. 1861, sat copiose reperta.

The H. galeata was detected by the Baron Paiva in Madeira proper, in 1861; and Mr. Lowe, in his notice of it in the 'Ann. of Nat. Hist.' for the following year, arrived at the conclusion that it is only an extremely developed and obtusely-conical, or beehive-shaped, modification of the $H$. calva,-imagining that it might be connected, or nearly so, with the type, by certain 
subfossil exponents of the species which are abundant at Caniçal. I must confess, however, that I have not myself been able to do this; nor can I see why the numerous and well-marked characters which it possesses should not merit for it a true specific claim,for they appear to me to be far more important than at any rate a vast number which Mr. Lowe had himself for many years recognized, as sufficient for a similar purpose, in various other groups of the Helicidac. And I may likewise add, that it is the opinion of Dr. Pfeiffer that the species is distinct.

Compared with the $H$. calva, the galeata is very much more elevated, or obtusely conical,-the spire (which is composed of about 9 volutions, instead of only from $6 \frac{1}{2}$ to 7 ) being raised into a sort of dome- or cupola-shaped mass; its under portion is appreciably brighter, or more polished; its whorls (in addition to being more numerous and rather less convex) have the basal one longer and more rounded or swollen, as well as more deflexed at the aperture; and its peristome is altogether a little more recurved and thickened.

The $H$. galeata was taken abundantly in the Ribeira do Fayal, during the spring of 1861 , by a man who was employed by the Baron Paiva to collect for him in that remote and littleknown ravine. They were found along the edge of the new 'Levada da Fajãa dos Vinhaticos', near to the place where Mr. Lowe had previously discovered the rare and most singular H. delphinuloides.

\section{Genus 8. BULIMUS, Scopoli.}

(§ Cochlicella, Risso.)

\section{Bulimus ventricosus.}

Bulimus ventricosus, Drap., Tabl. de Moll. 68 (1801)

$$
\text { Id., Hist. Nat. 78. t. 4. f. 31-33 (1805) }
$$

Helix ventrosa, Fer., Prodr. 377. t. 52 (1807)

Bulimus ventrosus, Lowe, Cambr. Phil. S. Trans. iv. 62 (1831)

Helix acuta, W. et B., Ann. des Sc. Nat.28. Syn. 317 (1833) Bulimus ventrosus, Alb., Mal. Mad., 54. t. 14. f. 18, 19 (1854)

Paiva, Mon. Moll. Mad. 103 (1867)

Helix ventricosa, Mouss., Faun. Mal. des Can. 46 (1872)

Bulimus ventricosus, Watson, Journ. de Conch. 222 (18i6)

Habitat Maderam, Portum Sanctum, et (sec. B. de Paiva) etiam Desertam Australem; hinc inde sub lapidibus, præcipue ad muros necnon in cultis.

The B. ventricosus of southern Europe and northern Africa, 
and which has established itself in the Azorean, Canarian, and Cape Verde Groups, is common both in Madeira and Porto Santo,-principally at a low elevation, and within the cultivated districts. It often congregates in dry places about old walls, and beneath stones amongst the plants of Opuntia Tuna, or 'Prickly Pear.' It is stated by the Baron Paiva to occur also on the Southern Deserta, or Bugio; and although it is far from unlikely that this may be the case, yet, since the Baron's material was seldom obtained by himself, but was brought to him by paid collectors (upon whom it was often difficult to depend), I feel that that particular habitat must be accepted with some degree of caution.

In Madeira the $B$. ventricosus is more particularly plentiful in certain spots around Funchal, and here and there on the São Lourenço promontory; and in Porto Santo it was met with by Mr. Lowe and myself near the Villa (especially in the Ribeira de Cochim), as well as (in 1855) on the road to Camaxa, and about an old wall (near the Zimbral d'Areia) at the southern base of the Pico de Concelho. ${ }^{1}$

1 I may just call attention in this particular place to an elongate, narrow, conical, white Bulimus (of the Subulina section), three examples of which were met with (dead) many years ago, by the late Mr. Bewicke, ' in an old bone,' in the garden of 'the Deanery,' near Funchal. There can be no doubt that the species is not a native of the Madeiran archipelago, and I think it is almost equally certain that it has not become even naturalized; nevertheless since it may possibly be found to have established itself in some of the cultivated grounds in the hotter parts of the town, perhaps it ought not to be passed over altogether in this catalogue, even though $I$ have not sufficient evilence to permit me to acknowledge it as an actual member of the fauna. When examining these specimens, two years ago, with the aid of Pfeiffer's Monograph, I came to the conclusion that (even if not absolutely identical with it) they were more nearly related to the Subulina striatella, Rang (a species which occurs in Princes Island, and on various points of the west coast of Africa) than to anything else ; and it is therefore satisfactory that Mr. Watson, to whom I have lately entrusted one of them for comparison with the types in the British Museum, has arrived, quite independently, at precisely the same result,-adding 'Your specimen in form and sculpture exactly resembles an unnamed one, in the British Museum, which appears to be a variety of the striatella, Rang.' And Mr. Watson further remarks (which is important, as tending to throw some light upon the occurrence of this shell at Madeira) 'Judging from memory, it is precisely like a specimen which was found, a few years ago, in Funchal, by Senhor J. M. Moniz, amongst some plants which had been sent to him from the island of St. Thomas in the Gulph of Guinea; and which he gave to me.' Mr. Watson, however, very wisely, was careful not to turn it loose ; and it consequently 'died, on the passage to England.' But this trivial circumstance, although not accounting for Mr. Bewicke's examples, may perhaps afford some possible explanation of the fact, if it should be ascertained hereafter that the Subulina striatella has succeeded in establishing itself at Madeira.

Although its narrow, elongate-conical outline, and its white and densely, sharply, regularly costate-striated surface, in conjunction with its numerous and convex volutions (the ultimate one of which is furnished with an obscure transverse line or keel immediately above its rather small aperture), will sufficiently distinguish the $S$. striatella, should it again occur, I will never- 


\section{Genus 9. STENOGYRA, Shuttl.}

Stenogyra decollata.

Helix decollata, Linn., Syst. Nat. (ed. 10) 773 (1758)

Bulimus decollatus, Lowe, Cambr. Phil. S. Trans. iv. 62 (1831)

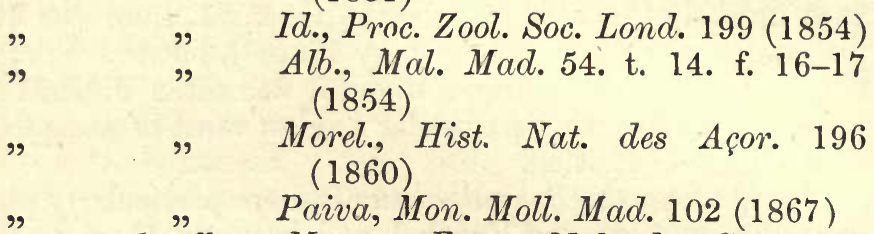

Stenogyra decollata, Mouss., Faun. Mal. des Can. 120 (1872)

Bulimus decollatus, Morel., Journ. de Conch. xiii. 238 (1873)

" $\quad$ Watson, Ibid. $222(1876)$

Habitat Maderam; sub lapidibus in aridis apricis prope Funchal hinc inde lecta. Forsan e Lusitaniâ olim translata.

The widely spread $S$. decollata, which is well-nigh universal in Mediterranean latitudes, and which occurs also in the Azorean, Canarian, and Cape-Verde archipelagos, has established itself in a few spots of a rather low altitude around Funchal,-where it may perhaps have been accidentally naturalized, at some period (not very remote) since the colonization of the island, from south-western Europe. I have taken it abundantly in a small gulley on the arid slopes of the Pico da Cruz, leading down

theless just add the following diagnosis, in order to render it the more easily recognizable.

\section{Subulina striatella.}

T. angustula, subulato-turrita, albida, vix nitidiuscula, argute et confertissime longitudinaliter costulato-striata ; spirâ longissimâ, regulari, elon-

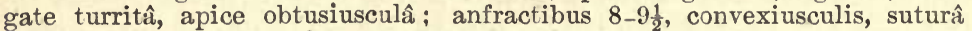
valde impress $\hat{d}$, ultimo ( $\frac{1}{3}$ longitudinis paulo excedente) mox supra aperturam parvam plus minus evidenter angulato-carinato; columellâ brevi, arcuatâ, basi abrupte terminatâ; peristomate simplici, acuto.-Long. lin. circa 7 ; apert. vix 2.

Helix striatella, Rang, Ann. des Sc. Nat. 24. 38.t. 3. f. 7

Stenogyra (Subulina) striatella, Dhn., Mal. Blätt. xiii. 127 (1866)

Achatina striatella, Pfeiff., Mon. Hel. vi. 2236 (1868)

Habitat Maderam (certe introducta); tria specimina (emortua, subdecorticata) in hortâ quâdam juxta Funchal olim invenit Dom. Bewicke.

I may just add that, singularly enough, the $S$. striatella was obtained by Mr. Lowe in Teneriffe, under circumstances almost precisely similar to those under which it was found by Mr. Bewicke at Madeira,-namely (dead) from amongst some refuse in Mr. Hamilton's garden at Sta. Cruz. The oblique truncation of the columella is a little wider in the Madeiran specimens than it is in those from Teneriffe. 
towards the Gorgulho,-a locality in which it was first found, many years ago, by Mr. Lowe, and where it has subsequently been met with by Mr. Leacock, the Rev. R. B. Watson, Senhor J. M. Moniz, and others.

\section{Genus 10. PUPA, Drap.}

\section{(§ Truncatellina, Lowe.)}

\section{Pupa linearis.}

Pupa linearis, Lowe, Ann. Nat. Hist. ix. (1552)

$" \quad$ Id., Proc. Zool. Soc. Lond. $207(1854)$
$" \quad$ minutissima, Watson, Journ. de Conch. $223(1876)$

Habitat Maderam ; in stratu conchylifero ad Caniçal semifossilis haud infrequens; recens hodie non detecta.

The excessively minute size of this little Pupa (the smallest of the Madeiran species with the exception of the $P$. saxicola, and one which has been found hitherto only in a subfossil state), added to its parallel outline, rather tumid, distinctly striated volutions, and its small and perfectly edentate mouth, will sufficiently characterize it. Like most of the Pupre it has a longer and a shorter state, some examples appearing to possess a volution more than the others. It is said to be closely allied to the European P. minutissima, Hartm., indeed Mr. Watson regards it as identical with that species; but it is, I think, more particularly interesting from the fact that it so nearly resembles a diminutive member of the genus from the Cape Verde archipelago, described by Dr. H. Dohrn as the $P$. molecula, that until I had compared the two very accurately I felt almost satisfied that they were conspecific. Indeed even now I am far from convinced that they may not be in reality but geographical phases of a single type; nevertheless since the $P$. linearis seems to be, on the average, a trifle smaller than its representative from the Cape Verdes, with its volutions perhaps not quite so convex, its suture appreciably more horizontal (or less oblique), and its aperture relatively less developed, I will not venture to treat them as otherwise than distinct.

The $P$. linearis is not uncommon in the calcareous, subfossiliferous deposits near Caniçal ; but it has not yet been observed in those either of Porto Santo or the Southern Deserta.

\section{Pupa microspora.}

Pupa microspora, Lowe, Ann. Nat. Hist. ix. 275 (1852)

$, \quad, \quad$ Pfeiff., Mon. Hel. iii. 532 (1853)


Pupa microspora, Lowe, Proc. Zool. Soc. Lond. 207 (1854)

" $\quad$ Alb., Mal. Mad.61 (1854)

" $\quad$ " Morel., Hist. Nat. des Açor. 197. t. 5. f. 1 (1860)

" edentula var., Paiva, Mon. Moll. Mad. 119 (1867)

", microspora, Mouss., Faun. Mal. des Can. 124 (1872)

" edentula, Watson, Journ. de Conch. 223 (1876)

Habitat Maderam editiorem sylvaticam; ad frondes filicum humidas hinc inde congregans.

A small, short, ventricose, somewhat turbinate or roundedconical, posteriorly truncate species, of a pale-brown hue and thin in substance, and one which has all the appearance (in seemingly adult examples) of being immature. Its volutions are tumid, and very densely and minutely striate; and its aperture, which is short (being a little wider than long), is perfectly edentate, with the peristome acute (as though young and unformed) instead of being thickened. It is very closely related to the European $P$. edentula, Drap., of which it may possibly represent a geographioal state; nevertheless it is, not only (on the average) a trifle smaller, and relatively somewhat shorter and very pyramidal, but likewise less shining, and much more coarsely sculptured with exceedingly oblique hair-like striæ, and its ultimate whorl is proportionately a trifle more abbreviated.

The $P$. microspora, which occurs also in the Azorean and Canarian archipelagos, is eminently indigenous in Madeira proper, inhabiting the higher altitudes,-where it is found attached to the fronds of various ferns in moist cloudy spots within the wooded regions. In such situations it was taken abundantly by myself, and subsequently by Mr. Lowe, at the Lombarda das Vacas; and I have likewise met with it at the Fanal, the Montado dos Peceguiros, S. Artonio da Serra, and in numerous other elevated districts.

\section{(§ Paludinella, Lowe.)}

\section{Pupa limnæana.}

Pupa limnæana, Lowe, Ann. Nat. Hist. ix. (1852)

$\Rightarrow \quad$ " $\quad$ Id., Proc. Zool. Soc. Lond. $206(1854)$

Habitat Maderam editiorem; inter muscos in truncis laurorum, necnon inter frondes filicum, in humidis sylvaticis degens, rarissima.

The rather broad, inflated, rounded-ovate, or somewhat globose, Limnous- (or, rather, Paludina-) like form of this remarkable Pupa, in conjunction with its few and ventricose rolutions (which are densely but very finely striated), its pale, 
yellowish-cinereous hue (often becoming whiter towards the more or less decorticated apex), its comparatively thin, fragile substance, and its perfectly edentate aperture and unthickened lip, will at once separate it from its allies. According to Mr. Lowe it has much in common with the European $P$. dilucida (Ziegl.), Rosm. (f. 326); but it is nevertheless one of the most truly and unmistakeably indigenous of the Madeiran Pup occurring sparingly on the trunks of laurels, as well as amongst the fronds of moist ferns, in the damp sylvan districts of an intermediate and lofty elevation. I have met with it at S. Antonio da Serra, and the Lombarda das Vacas; and it has also been taken in the Ribeiro Frio, and the Boa Ventura.

(§ Gastrodon, Lowe.)

\section{Pupa fanalensis.}

Pupa fanalensis, Lowe, Ann. Nat. Hist. ix. (1852)

Id., Proc. Zool. Soc. Lond. 208 (1854)
$"$ umbilicata var., Paiva, Mon. Moll. Mad. 121 (1867)
$"$ debilis, Mouss., Faun. Mal. des Can. $124(1872)$
$" \quad$ anconostoma (pars), Pfeiff., Mon. Hel. viii. 370 (1876)

Habitat Maderam; ad truncos laurorum, necnon in frondibus filicum humidis, in sylvaticis editioribus occurrens.

It is possible that this may be only a depauperated state of the 'var. $\beta$. anconostoma' of the P. umbilicata, which the latter has gradually assumed through having found its way into the higher regions; nevertheless I believe it to be truly distinct, since it not only possesses certain unmistakeable features of its own, but its mode of life is completely and essentially different. Thus, while the $P$. umbilicata (as represented in these islands by the 'var. $\beta$. anconostoma') is emphatically an inhabitant of the dry and cultivated districts, abounding more and more as we descend to the level of the sea, the $P$. fanalensis, on the contrary, has all the appearance of being ultra-indigenous, and seems to be peculiar to nearly the highest altitudes-where it occurs amongst moss and lichen on the trunks of the laurels, as well as adhering to the fronds of ferns (in company with the $P$. limnceana and microspora), in damp sylvan spots. It was met with in profusion, by Mr. Lowe and myself, during July 1855, at the Cruzinhas and the Fanal, in the mountains of Madeira proper, by examining the trees immediately outside our tents; and I have likewise found it at, along with the $P$. cheilogona, the Lombarda das Vacas.

$I$ may add also that $I$ took the $P$. fanalensis in the islands of 'Teneriffe and Palma, of the Canarian archipelago, under cir- 
cumstances precisely similar to those at Madeira, - namely from amongst lichen on the trunks of trees in the lofty wood of Las Mercedas, as well as in the damp sylvan region above Taganana, and near Ycod-el-Alto, of the former ; and at a high elevation in the Barranco da Agua, and on the ascent of the Cumbre above Buenavista, of the latter. My Canarian examples were overhauled with great care by Mousson, who agreed with me in regarding them as the exponents of a $P$ upa which is certainly distinct from Mr. Lowe's P. anconostoma; but as I had not at that time identified them with the Madeiran $P$. fanalensis, he enunciated the species afresh, in his recent Monograph, under the name of $P$. debilis, - adding, as a subsequent remark, 'Les différences constantes de cette forme d'avec la $P$. anconostoma, Lowe, me semblent en justifier la séparation. La $P$. debilis, dont j'ai comparé un bon nombre d'individus est toujours plus petite, plus fragile, oviforme et non cylindracée ; le dernier tour près de la rime n'est pas comprimé, mais arrondi; l'ouverture est relativement plus largement arrondie, et pourvue d'un péristome à peine réfléchi; la paroi ne présente qu'une faible dent qui souvent manque entièrement. Les deux espèces sont à peu près dans le même rapport que le $P$. Semproni, Charp, à l'umbilicata, Drap.'

After a very accurate comparison, I have no doubt concerning the specific identity of Mousson's Canarian species with the Madeiran one,-both of which moreover pass through the same amount of, rather considerable, variation.

Judging from my own observations, and from the numerous types which are now before me, the $P$. fanalensis may be said to differ from the var. $\beta$. anconostoma of the $P$. umbilicata in being on the average very much smaller and more globose, or ventricose; in its substance being thinner, and its surface more white and decorticated (much as in the $P$. limnocana); in the number of its volutions being usually one less; in its aperture being generally a little shorter and rounder ; and in the obsolete indications of a rudimentary plait on the columella which are for the most part just traceable in its ally being quite absent.

\section{Pupa umbilicata.}

Pupa umbilicata, Drap., Tabl. des Moll. 58 (1801)

Helix anconostoma, Lowe, Cambr. Phil. S. Trans. iv. 62. t. 6. f. 30 (1831)

Pupa anconostoma, Pfeiff., Mon. Hel. ii. 314 (1848)

$\begin{array}{ccc}" & \quad & \text { Lowe, Proc. Zool. Soc. Lond. } 208(1854) \\ & & \text { Alb., Mal. Mad. 61. t. 15. f. 19-22 } \\ & (1854) & \end{array}$




\section{Pupa urnbilicata, Drouet, Faun. Açor. 165 (1861)

$$
\text { Paiva, Mon. Moll. Mad. } 120 \text { (1867) }
$$

" anconostoma, Mouss., Faun. Mal. des Can. 123 (1872)

" umbilicata, Watson, Journ. de Conch. 223 (1876)

Habitat Maderam ; in statu typico (i.e. Europæo) a Revdo. R. B. Watson solum, ad Jardim da Serra, detecta. Sed status aberrans (sc. P. anconostoma, Lowe, in ins. Maderensibus Canariensibusque typicus), plicâ ventrali minore necnon peristomate paululum minus expanso, ubique in inferioribus subinferioribusque (præsertim cultis) abundat; atque etiam in ins. Desertis parce occurrit.

After a careful comparison of the $P$. anconostoma, so universal throughout the lower regions of Madeira proper, with examples of the European P. umbilicata, Drap., collected in many countries widely separated from each other (as, for instance, Portugal, England, Spain, and Sicily), I have come to the conclusion that it cannot be regarded as more than a very slightly altered phasis, or geographical variety, of the latterin which the ventral plait is (on the average) rather smaller or less developed (and therefore usually more completely disconnected with the angle of the lip), and the peristome not quite so broad. All the other characters which have been alluded to, as distinctive, in the various published diagnoses of the $P$. anconostoma, seem to me to be purely imaginary (as, for instance, the smaller size, more cylindrical outline, and less tumid volutions, referred to by Mousson, and the different shape of the aperture recorded by the Baron Paiva); whilst even the ventral tooth itself is subject to very great inconstancy,-it being much larger in some of the examples now before me than it is in others, in which case it is joined by almost as evident a callosity with the angle of the lip as in the ordinary ones from more northern latitudes. Amongst some specimens which were taken by Mr. Lowe at Fayal, in the Azores, the two states are intermingled, and pass imperceptibly into each other; but those from the Canarian archipelago correspond better with the ordinary Madeiran ones, - both the tooth and the peristome being less strongly developed.

As expressed by this slightly altered form (which I would consequently quote as the 'var. $\beta$. anconostoma'), the P.umbilicata may be said to be the universal Pupa at low and intermediate altitudes in Madeira proper, abounding about the walls and cultivated grounds, and seldom ascending to higher than about 2500 feet above the sea; and it is not unlikely that it may owe its presence there to accidental introduction at some (not very remote) period since the colonization of the islands. At any rate, apart from the suggestiveness of its distribution, 
no traces of it have yet been met with, so far as I am aware, in any of the subfossiliferous deposits. Although so abundant however in Madeira proper, it is remarkable that there is no record of it hitherto from Porto Santo (where, nevertheless, in all probability it must exist); but its occurrence on the Desertas is just indicated (I think, beyond a doubt), - a single example having been collected by Mr. Lowe's servant on the Deserta Grande 'a little below the house;' and indeed I have lately detected three more in a boz from the Baron Paiva, purporting to have come from that same island. And I mav further add that the Baron mentions its occurrence on the Southern Deserta likewise.

It is but quite recently however (indeed only since 1866) that the $P$. umbilicata in its strictly normal (or European) aspect has been observed at Madeira, several examples having been met with by the Rev. R. B. Watson at the Jardim da Serra ; and this fact might seem at first sight to contradict the assumption that the anconostoma is but a geographical phasis of it, had we not the most positive evidence that land shells are from time to time imported accidentally into the island, along with consignments of plants, from more northern latitudes. I feel satisfied that the contingency just referred to must be the true explanation of the appearance at the Jardim da Serra of the P. umbilicata in its ordinary, unaltered state; for it is well known that the late English consul at Madeira, Mr. Veitch, took unusual pains to introduce plants from England into his garden at the Jardim; and the only remarkable circumstance, at any rate to my mind, is, that a greater number of Terrestrial Mollusks should not have found their way into the island through so favourable a medium of transmission. I think, therefore, that the existence of the P. umbilicata at Madeira in both its typical and aberrant phases need not in any degree predispose us to conclude that the latter (which appears to me moreover to merge completely into the former) is specifically distinct.

The $P$. umbilicata (which occurs also in the Azorean and Canarian Groups, and even at St. Helena) may readily be known by its pale reddish-brown, shining, frequently subpellucid surface, its more or less elongate-ovate outline, its somewhat tumid volutions, and by the single (and in the 'var. $\beta$. anconostoma' not always very conspicuous) ventral plait of its aperture which nearly adjoins the angle of its rather broadly but flatly margined lip. Moreover when closely inspected it will generally be found to possess very faint indications of an obsolete plait, or thickening, on the columella,-which however is often (as in the Madeiran form) so rudimentary as to be barely traceable. 
(§ Scarabella, Lowe.)

\section{Pupa cassida.}

Helix cassida, Lowe, Cambr. Phil. S. Trans. iv. 64 (1831) Pupa cassida, Pfeiff., Mon. Hel. ii. 344 (1848)

$$
" \quad \text { " } \quad \text { " Alb., Mal. Mad. 68. t. 16. f. 7, 8 (1854) }
$$

Habitat Maderam; in humidis editioribus sylvaticis rarissime degens. Semifossilis juxta Caniçal abundat.

The comparatively large size of this magnificent $P u p a$, added to its very solid substance and obese, ovoid form (it being inflated in the middle and acute both before and behind), its flattened, strongly sulcate-striated volutions (which are normally of a reddish-brown, but prettily marked with irregular whitish longitudinal dashes or subconfluent streaks), and the seven thick but unequally developed plaits of its broadly and whitely margined corneous auriform aperture, will abundantly distinguish it from everything else with which we have here to do.

Until within a comparatively recent period the $P$. cassida, although abounding in the subfossiliferous beds at Caniçal, was considered of the utmost rarity as a member of the present fauna; but it was nevertheless met with in tolerable profusion by myself and the late Rev. W. J. Armitage, during March 1849, at the extreme head of the Ribeira de Sta. Luzia, in the south of Madeira proper (in the exact spot where the original and then unique example was taken by Mr. Lowe, on April 13th, 1830),-namel5, amongst vegetable detritus, on the steep buttress, or bank, immediately to the right of the waterfall, and which constitutes the base of the lofty perpendicular rocks; and it has subsequently been obtained by Mr. Leacock, the Rev. R. B. Watson, and others, in the same locality. It occurs however likewise in the north of the island, having been taken by the late Mr. Bewicke in the Ribeira de São Jorge; so that in all probability it will be found to be pretty generally distributed in the damp sylvan ravines of intermediate altitudes.

\section{(§ Liostyla, Lowe.)}

\section{Pupa cheilogona.}

Helix cheilogona, Lowe, Cambr. Phil. S. Trans. iv. 63 (1831)

Pupa cheilogona Pfr., Mon. Hel. ii. 327 (1848)

$\begin{array}{lll}" & \quad & \text { Lowe, Proc. Zool. Soc. Lond. } 208(1854) \\ & \quad & \text { Alb., Mal. Mad 63. t. 15. f. 23, 24 (1854) }\end{array}$


Habitat Maderam editiorem sylvaticam; in frondibus filicum humidis præcipue occurrens.

The rather large side, and conical, subtriangular outline of the $P$. cheilogona - which is much pointed towards the apex, and a good deal widened towards the base, and has the mouth considerably (and obliquely) produced downwards-added to its flattened volutions, its pale-brown, obscurely banded, not very shining surface, its sinuated outer lip (on which the tooth is nevertheless exceedingly obtuse and ill-expressed, causing the 'sinus' to be wide and open), and the large size of its exterior ventral and its lower columellary plaits (the former of which is far removed from, and totally disconnected with, the angle of the peristome), will serve to distinguish it. Its inner ventral plait is also very conspicuous, although much smaller than the outer one; but the upper columellary and the second palatial ones seem to be obsolete.

The $P$. cheilogona (regarded formerly by Mr. Lowe as extremely rare) is one of the most unmistakably indigenous of the Madeiran Pupce, and one which occurs only in the damp sylvan districts (principally towards the north of the island) at a high elevation. I have taken it abundantly at the Lombarda das Vacas, the Montado dos Pecegueiros, \&c., adhering to the fronds of various ferns, - such as the Woodwardia radicans, the Pteris arguta, Vahl., and the Allantodia axillaris, R. Br.; and Mr. Lowe also obtained it from the same localities, during our encampments there in the summer of 1855 .

\section{Pupa vincta.}

Pupa vincta, Lowe, Ann. Nat. Hist. ix. (1852)

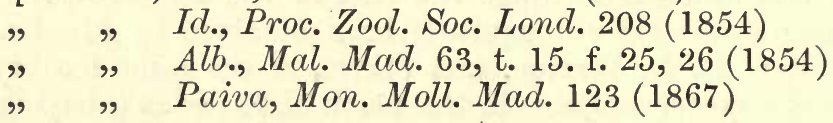

Habitat Maderam, præsertim borealem; ad rupes irriguas aquosas, inter Marchantiam polymorpham, L., hinc inde congregans.

In the number and proportions of the plaits (the exterior ventral one of which is very large, and usually quite unconnected by a corneous callosity, or sphincter, with the angle of the lip) the present Pupa is much on the same pattern as the $P$. cheilogona; and it is, on the average, the largest, with the exception of the $P$. cassida, of the Madeiran members of the genus. It is, however, relatively, a more apically-obtuse (or less pointed) species than the $P$. cheilogona; its surface is more shining and less appreciably striated posteriorly, as also usually of a more olivaceous (or yellowish-green) tinge and with the 
darker bands more frequently developed; and its aperture is proportionately a trifle wider, or not so narrowly and obliquely produced. It has likewise a remarkable tendency to have its apex white and decorticated,- - sometimes to such an extent that the nucleus becomes abortive and partially destroyed, under which circumstances the shell has naturally a more tumid or ventricose appearance. Like many of the Pupce it seems to have a larger and a smaller state,-the representatives of the latter being generally more acute at their extremity than those of the former.

The $P$. vincta, which is confined to damp spots in Madeira proper, appears, like the $P$. cheilogona, to be found more particularly in the north of the island. Yet its habits are not the same as those of that species ; for, whilst the cheilogona is to be met with, almost invariably, adhering to the fronds of ferns at a high elevation, the vincta, on the contrary, infests the dripping masses of Marchantia polymorpha which pad the rocks at a low altitude. Indeed, so far as my own experience is concerned, it may be said to occur especially on the level of the shore; though in all probability it will be found to ascend to a certain slight elevation. It was obtained in great profusion by $\mathrm{Mr}$. Lowe and myself, during June 1850 and August 1855, at the edges of the first waterfall from São Vicente, along the beach road to Seisal ; and Mr. Lowe captured it in a similar situation at the Passa d'Areia, on the other (or eastern) side of the São Vicente ravine. Several boxes of it have also been communicated by the Baron Paiva (containing generally a large admixture of the $P$. Loweana, Woll., regarded erroneously by him as $P$. concinna, Lowe), and which $I$ believe were obtained from the lower regions of the Ribeira do Inferno, and those of the Boa Ventura.

\section{Pupa irrigua.}

Pupa irrigua, Lowe, Ann. Nat. Hist. ix. (1852)

$\begin{array}{ll}" \quad & \quad \text { Id., Proc. Zool. Soc. Lond. } 208(1854) \\ " \quad & \quad \text { Alb., Mal. Mad. 63. t. 15. f. 27, } 28(1854)\end{array}$

Habitat Maderam, præcipue australem ; inter gramina (Deschampsia argentea, Lowe) ad rupes irriguas aquosas, hinc inde vulgaris.

Like the last two species, the $P$. irrigua is rather a large Pupa; but it is more strictly oblong (or less widened posteriorly, and therefore less ovate) than either of them. Its volutions are somewhat flattened, and therefore the suture is not greatly impressed ; in colour it is of a pale yellowish, or olivebrown (occasionally with indistinct bands); and its spire 
is often whitish and decorticated ; but its aperture (which is less outwardly, or more downwardly, produced than is the case in its immediate allies) contains the characters which will more quickly discriminate the species,-the five plaits, especially the outer ventral one (which is sinuate, and united to the angle of the lip by a thick corneous rim or sphincter), being very largely developed, even the upper one of the columella (although smaller than the lower) being exceedingly conspicuous. The tooth of the labrum (which is a good deal nipped-in at that particular point) is rather thick and internally prominent,-almost closing up (the result, however, partly, of the flexuosity of the first ventral plait) the 'sinus respirationis.'

The $P$. irrigua, although locally abundant, appears on the whole to be somewhat scarce,-occurring more, however, so far as has hitherto been observed, in the south of Madeira, than the north. It inhabits the muddy and Marchantia-padded deposits of the damp, trickling rocks, in the shady ravines of intermediate altitudes, adhering likewise to the wiry roots of the coarse grasses which hang loosely in the constant drip of such locálities. It was taken in great profusion by Mr. Lowe and myself, on various occasions, on the perpendicular face of lofty rocks on the right (or eastern) side of the Ribeira de Sta. Luzia, about two-thirds of the entire distance up, and therefore about one-third below the waterfall. Judging also from the Baron Paiva's material, he seems to have obtained it sparingly from the north of the island, - a few examples being mixed up with his large batches of the $P$. Loweana and the $P$. vincta.

\section{Pupa deformis.}

Pupa Wollastoni, Lowe [nec Paiva, 1866], Ann. Nat. Hist. 81 (1867)

Paiva [nec Id., 1866], Mon. Moll. Mad. 128 (1867)

Habitat Maderam borealem, semel lecta; a Barone Castello de Paiva communicata.

I am extremely sorry to be compelled to change the name of this remarkable Pupa, which was enunciated by Mr. Lowe in 1867 as the ' $P$. Wollastoni ;' but that title having been preoccupied by the Baron Paiva in the previous year for a subfossil species from Caniçal, justice requires that the latter should take the precedence. It is true that the Baron, in his late Monograph, suppressed his previously-published name, in consideration of Mr. Lowe having subsequently selected the same, - proposing, instead, for his ' $P$. Wollastoni, the trivial one of canicalensis. But I can only add that in reality he had not 
the power to do this, the universally acknowledged law of priority being unbending in its operation.

The $P$. deformis ( $=P$. Wollastoni, Lowe) was described from a unique example which was obtained by the Baron Paiva from the north of Madeira (he believes from the Ribeira do Inferno), and which was detected by myself amongst a large batch of the $P$. Loweana and vincta which he had transmitted to me for examination. At first sight it might almost be regarded as a mis-shapen, or irregularly developed, monstrosity of the $P$. Loweana; nevertheless if it be a truly normal representative of its kind (concerning which I cannot but have some misgivings), it is thoroughly distinct from everything else which has hitherto been brought to light. Thus its short, thick, squarish, barrel-shaped form, and solid, rather coarsely striate surface, added to the unnaturally abrupt (and somewhat oblique) contraction of the spire beyond the second or third volutions (where it forms an obtuse, decorticated umbo), which latter rise up, each of them, into ' a blunt keel or ridge behind the deeply impressed subcanaliculated suture,' give it a character essentially its own. Still, I think that further material is absolutely necessary before it will be quite safe to regard the species (from the unique and curiously developed specimen which has been taken as the type) as correctly defined. ${ }^{1}$

\section{Pupa Loweana, n. sp.}

$P$. oblongo-ovata, sat dense striatula, subnitens, obscure fusco-umbrina (sæpius versus apicem plus minus albido-decorticata), interdum obscure fasciata; anfractibus convexiusculis, suturâ impressâ; aperturâ auriformi, ringente, angulis rotundatis, 5-plicatâ, sc. plicis 2 (exteriore majore) ventralibus, 2 (inferiore majore) columellaribus, et 1 palatali, ventrali exteriore columellarique inferiore magnis subæqualibus, columellari superiore palatalique minoribus immersis subinconspicuis; labro subincrassato reflexiusculo, denticulo ad sinum distincto intus prominulo, sinu (i.e. inter angulum plicamque ventralem)

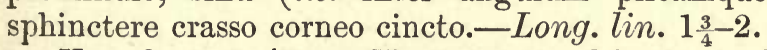

Var. $\beta$. transiens.-Vix minor, subfortius subremotiusque striata; testa plerumque subpallidior ac paulo minus solida (interdum etiam subpellucida, conspicue pallidula), necnon evi-

'In the 'Zoological Record' for 1867 the $P$. deformis (i.e. $P$. Wollastoni, Lowe) is assumed (vide p. 574) to belong to the group Alvearella; but this certainly is not the case,-Lowe's Alvearella having been expressly established to contain the strongly costate little forms which he described under the names abbreviata and gibba. Its affinities are unquestionably with the $P$. Loneana, Woll., and the irrigua,-both of which fall into the section Liostyla, Lowe (which, however, is perhaps hardly separable from Charadrobia, Albers). 
dentius fasciata, plicâ columellari superiore sæpius submagis distinctâ.

Pupa concinna, Paiva [nec Lowe, 1852], Mon. Moll. Mad. 127 (1867)

Habitat Maderam, præsertim borealem; a Barone Castello de Paiva copiose communicata.

The present large, well-defined, and normally somewhat dark $P$ upa, which was obtained abundantly by the Baron Paiva from the north of Madeira ( $\mathrm{I}$ believe principally from the Boa Ventura and the Ribeira do Inferno), appears to have been confounded latterly with the $P$. concinna, Lowe,-from which nevertheless it is totally distinct. Indeed Mr. Lowe bimself (evidently however from a mere superficial glance, and without actual comparison) fell into the error of identifying it with the latter species (which he had previously described with great accuracy); and it was therefore wrongly referred to the concinna by the Baron Paiva in his recent monograph. In reality it is larger and relatively broader than the P.concinna, as well as more ovate (or more widened posteriorly) and less closely striated; its aperture is larger and more open, with the angle of the lip and the exterior ventral plait (instead of being disconnected) united by a coarse and elevated corneous sphincter or rim, and with the lateral tooth proportionately rather less internally-thickened (or prominent), and therefore less completely closing-in the 'sinus respirationis.'

From its being invariably mixed-up, in the Baron Paiva's boxes, with the $P$. vincta, I conclude that in habits the $P$. Loweana is similar to that species, and that it was taken in the muddy drip of Marchantia-padded rocks at a comparatively low elevation; in which respect I may remark that it differs materially from the $P$. concinna, which is found in the higher. altitudes,-adhering to the broken sticks and small stones near the rocky, trickling streams.

The 'var. $\beta$. transiens,' which is on the average a trifle smaller, less solid, and of a paler hue (indeed occasional examples are quite pallid), may perhaps prove to be specifically distinct; though I suspect that it is a mere local race of what I have regarded as the type. It was communicated by the Baron Paiva, but I have no note as to its precise locality.

\section{Pupa cassidula.}

Pupa cassidula, Lovve, Ann. Nat. Hist. ix. (1852)

$\begin{array}{lll}" & \Rightarrow & \text { Id., Proc. Zool. Soc. Lond. } 212(1854) \\ " & \text { Alb., Mal. Mad. 68. t. 16. f. 9-10(1854) }\end{array}$


Habitat Maderam; in humidis editioribus, rarissima.

The $P$. cassidula is a $P$ upa which appears to be extremely rare, and one which is perhaps less satisfactorily defined than any of the others. Nevertheless my examples, which are from the collection of Mr. Lowe, and which were taken by myself and the late Rev. W. J. Armitage at a rather high elevation (amongst vegetable detritus) at the base of lofty, perpendicular rocks in the Ribeira de Sta. Luzia, in the south of Madeira proper,-a locality in which it has subsequently been met with by $\mathrm{Mr}$. Watson,-have I think sufficient peculiarity about them to establish the species as distinct from its allies; though I must confess that I should be glad to see a large number, and in a more highly coloured condition, in order to test the accuracy of the diagnosis.

The true affinities of the $P$. cassidula are, I imagine, with the $P$. Loweana, particularly with what $I$ have defined as the 'var. $\beta$. transiens ;' but it is paler, and a little more coarsely striated; and the lateral denticle of its outer lip is somewhat more prominent internally, causing the sinus (which is appreciably smaller) to be less open, or more narrowly closed-in behind.

\section{Pupa concinna.}

Pupa concinna, Lowe, Ann. Nat. Hist. ix. (1852)

$\begin{array}{lll}" & \quad & \text { Pfeiff., Mon. Hel. iii. } 544 \text { (1853) } \\ " & \quad & \text { Lowe, Proc. Zool. Soc. Lond. 212 (1854) } \\ & \quad & \text { Alb., Mal. Mad. 65. t. 16. f. 11-12 (1854) }\end{array}$
sima.

Habitat Maderam editiorem sylvaticam; in aquosis raris-

The $P$. concinna, which was well defined by Mr. Lowe in his original diagnosis, appears (as already stated) to have been confounded latterly, both by himself and others, with the larger and more ovate species which I have just enunciated under the name of $P$. Loweana. In reality however it is smaller and much more oblong (or less widened posteriorly) than the latter, and therefore in proportion a little more obtuse at the apex; its surface is a trifle more coarsely and closely striated; and its aperture has the first ventral plait not only more oblique, so as to close-in more completely (in conjunction with the relatively somewhat larger lateral denticle) the sinus, but likewise totally unconnected by a corneous sphincter with the angle of the lip.

The habits also of the $P$. concinna appear to be different from those of the $P$. Loweana; for whilst the latter haunts the dripping masses of Marchantia polymorpha which mat the rocks at a low elevation, the $P$. concinna occurs, on the contrary, in almost the highest altitudes,-where it is to be met 
with adhering to the broken sticks and small stones near the minute trickling streams, as well as beneath damp moss. Under such circumstances it was first taken by myself, and subsequently by Mr. Lowe, on the 18th of July 1850, at the extreme head of the Ribeira de João Delgada; and it was afterwards found by Mr. Lowe on the north side of the Pico Casado at the head of the Boa Ventura.

In outline and size the $P$. concinna is in reality more nearly related to the $P$. laurinea; nevertheless it is darker, as well as more densely and coarsely striated, than that species, and its two ventral plaits are more flexuose and oblique, or less vertical (causing the sinus to be even still more closed in), the external one being also more completely unconnected by even a rudimentary callosity with the angle of the lip.

\section{Pupa laurinea.}

\begin{tabular}{|c|c|c|}
\hline \multicolumn{3}{|c|}{ Pupa laurinea, Lowe, Ann. Nat. Hist. ix. (1852) } \\
\hline " & " & Pfeiff., Mon. Hel. iii. (1853) \\
\hline " & " & Lowe, Proc. Zool. Soc. Lond. 209 (1854) \\
\hline " & " & $\begin{array}{l}\text { Alb., Mal. Mad. 64. t. 15. f. 31, } 32 \text { (1854) } \\
\text { Paiva, Mon. Moll. Mad. } 126 \text { (1867) }\end{array}$ \\
\hline " & " & \\
\hline
\end{tabular}

Habitat Maderam sylvaticam; ad truncos Laurorum, inter muscos, degens. In statu semifossili juxta Caniçal reperitur.

The $P$. laurinea is in some respects intermediate between the concinna and sphinctostoma. Indeed in its rather short, obtuse, cylindric-oval form and general size and proportions it almost coincides with the former; nevertheless it is a little wider (relatively), and more obese, than the concinna, as also less distinctly striate, and (on the average) a trifle more shining and brightly coloured,-it being usually of a more or less clear olivaceo-yellowish brown and appreciably (often indeed conspicuously) banded. Moreover its 'sinus' is rather less decidedly closed-in behind (the result principally of the first ventral plait being more vertical in its direction, or less oblique), whilst anteriorly it is nearly always bounded by a more or less developed (though occasionally thin) corneous sphincter, between the ventral plait and the angle of the lip. Indeed this sphincter not unfrequently assumes the shape of a nearly separated tuberculiform process, or transverse plait-like tooth; and in a very few (exceptional) instances I have remarked it to be even obsolete.

From the exceedingly variable $P$. sphinctostoma the laurinea differs mainly in its shorter, obtuser, and relatively broader form, and in its colour being of a clearer olivaceous brown, with the volutions (which are rather more striate) appre- 
ciably banded. Its aperture too is not exactly similar, - the sphincter, which joins the first ventral plait with the angle of the lip, being less thickened and differently shaped; whilst the palatial plaits, which are so strongly developed (although deeply immersed) in the $P$. sphinctostoma, seem in the laurinea to be reduced (from three) to one,-the upper and lower ones being apparently obsolete.

From the $P$. Loweana the laurinea may be known by being, inter alia, rather paler and more shining (or less appreciably striate), and also more decidedly banded: its outline too is more oval (or less ovate), not being so much widened posteriorly; its aperture is more produced downwards (instead of outwards); and the sphincter which connects the angle of the lip with the first ventral plait is usually very much less thickened or developed.

The $P$. laurinea occurs chiefly about the trunks of old laurels in the sylvan districts of intermediate altitudes. It has been taken by Mr. Lowe (and also more sparingly, by myself and others) in various places, - such as the Ribeiro Frio, S. Antonio da Serra, and the Boa Ventura. In a subfossil state, it is not very uncommon at Caniçal.

\section{Pupa Wollastoni.}

Pupa Wollastoni, Paiva, Crosse, Journ. de Conch. (Oct. 1866)

" canicalensis, Id., Mon. Moll. Mad. 131 (1867)

Habitat Maderam, in stratu conchylifero ad Caniçal semifossilis lecta; recens hodie non observata.

As already implied under the $P$. deformis, the present $P u p a$ was enunciated by the Baron Paiva in October 1866 as the $P$. Wollastoni-a name which he suppressed (in his Monograph) during the following year, in favour of a newly-suggested one ( $P$. canicalensis), the title 'Wollaston $i$ ' having been inadvertently selected by Mr. Lowe for another member of the same genus after the publication of his (the Baron Paiva's) diagnosis in Crosse's Journ. de Conchyliologie. I need here therefore only repeat, that I have no option but to restore for the subfossil species from Caniçal the name originally proposed for it by the Baron,- the latter in reality not having the power to violate the acknowledged law of priority, which requires absolutely that a title once given, unless afterwards found to be either pre-occupied or utterly inappropriate, cannot under any circumstances be changed. I have therefore, in this instance, adhered to the name which was first given by the Baron Paiva, and have proposed a new one for the P. Wollastoni of Lowe. 
The Pupa now under consideration, which has been observed hitherto only in a subfossil state at Caniçal, was cited by Mr. Lowe as the P. fusca; but although its affinities are unquestionably, to a certain extent, with that species, I feel satisfied that the two are not specifically identical,-for not only is the $P$. Wollastoni considerably smaller than (and perhaps not quite so coarsely and thickly striated, at any rate posteriorly, as) the fusca, but it entirely wants the tumid volutions which are so eminently characteristic of that species ; and the lateral denticle of its lip is less developed or internally prominent. Added to which, the number of its whorls appears generally (as it seems to $\mathrm{me}$ ) to be one less.

But, in point of fact, the $P$. Wollastoni seems to be far nearer, unless indeed I am much mistaken, to what I would regard as the typical state (namely the ' $\beta$. arborea') of the $P$. sphinctostoma, - of which it might almost be looked upon as a small, or depauperated, race. Nevertheless it differs from the latter in its comparatively diminutive size, and somewhat obtuser apex; in its body-volution being nearly free from any indications of sculpture, whilst the succeeding ones are, on the contrary, more coarsely striate; and in its lateral denticle being less developed.

\section{Pupa sphinctostoma.}

Helix sphinctostoma, Lowe, Cambr. Phil. S. Trans. iv. 63 (1831)

Pupa sphinctostoma, Pfeiff., Mon. Hel. ii. 335 (1848)

\begin{tabular}{|c|c|c|}
\hline "9 & $"$ & $\begin{array}{l}\text { Lowe, Proc. Zool. Soc. Lond. } 209 \\
\text { (1854) }\end{array}$ \\
\hline & " & $\underset{(1854)}{A l b ., \text { Mal. Mad. 64. t. 15. f. } 29-30}$ \\
\hline & " & Paiva, Mon. Moll. Mad. 124 (1867) \\
\hline
\end{tabular}

Habitat Maderam; vel (var. a. rupestris) sub foliis emortuis Sempervivi tabulaeformis, Haw., in rupibus maritimis crescentis, vel (var. $\beta$. arborea) inter muscos atque sub cortice laxo in truncis Laurorum, latens.

The $P$. sphinctostoma is perhaps the most difficult and inconstant of all the Maderan Pupo, and yet certainly it is one of the most truly indigenous ones, occurring in various situations, and at diverse altitudes, throughout. Madeira proper, to which island it seems to be peculiar. In a general sense it may be said to assume two opposite phases, which might well be regarded as specifically distinct did they not pass into each other by almost imperceptible gradations. In the former of these (the 'var. a. rupestris,' Lowe) the outline is less parallel, or more attenuated towards the apex, the consistency is much 
harder or more solid, the colour is darker, and the volutions are very much more coarsely ribbed or striate; added to which the angle of the lip is more produced outwards into an ear-shaped process, and the plaits (the lower columellary one of which is usually more oblique, or less horizontal, in its direction) are rather more developed. This particular state seems to attain its maximum at a comparatively low elevation, and to occur principally (often in company with the $P$. fusca and recta) about the roots and dead leaves of the Sempervivum tabulceforme, and a few other plants, which stud the faces of the more or less dry and exposed rocks. Under such circumstances it frequently abounds in the north of the island, and indeed in many other districts, especially towards the coast.

The second state (which is the 'var. $\beta$. arborea,' Lowe) is characterized by the shell being altogether thinner, paler, more parallel, and much less coarsely striated; the angle of the lip is less outwardly-prominent, and the lower plait of its columella is for the most part more horizontal (or less oblique). This is eminently the form of a somewhat higher altitude, and one which obtains more particularly within the sylvan regionswhere its habits are mainly arboreal and subcortical. It abounds, under this aspect, at the Ribeiro Frio, at S. Antonio da Serra, in the Ribeira de Santa Luzia, and indeed throughout the wooded districts generally.

I am far from satisfied that these two normally opposite states (namely the ' $a$. rupestris and the ' $\beta$. arborea.') may not in reality be specifically distinct; nevertheless since there is certainly an intermediate form which appears more or less (in colour, outline, and sculpture) to connect them, and since it was the opinion of Mr. Lowe that they are but different aspects of a single, plastic species, I will not attempt to treat them as separate,-deeming it sufficient, for all practical purposes, to have called attention to the fact that the phases in question (whether specific ones or not) are to be noted, as being in the main easy to recognize.

Under all circumstances the $P$. sphinctostoma is remarkable for its numerous and largely developed plaits, and for the extremely thickened corneous sphincter which unites the first ventral one with the angle of the lip; and it is likewise (except in its aberrant, strongly-striated state) a linear, or cylindrical species.

Pupa lævigata.

Pupa lævigata, Lowe, Ann. Nat. Hist. ix (1852)

$" \quad$ " Pfeiff., Mon. Hel. iii. 544 (1853)

" $\quad$ Lowe, Proc. Zool. Soc. Lond. 210 
Pupa lævigata, Alb., Mal. Mad. 65 (1854)

" $\quad$ "Paiva, Mon. Moll. Mad. 125 (1867)

Habitat Maderam australem; in Rib. de Santa Luzia a meipso detecta.

It is possible that this Pupa may represent but a rather large and aberrant, or even depauperated, state of the $P$. sphinctostoma, in which the plaits are reduced and the outline of the mouth is modified; nevertheless I do not think that it would be at all safe to treat it as such. It seems to differ from the $P$. sphinctostoma, not only in being on the average somewhat larger or more elongate, as well as a little more tapering towards its apex and more appreciably striated (at any rate more so than the normal phasis of that species, though not so much so as the 'var. a. rupestris' which I cannot lut think may prove eventually to be distinct), but likewise in its aperture being much more rounded (or less produced-outwards) at the angle of the lip, and with the tooth which bounds the ' sinus,' as well as all the plaits, much less developed. Indeed so far as the latter are concerned, the outer ventral one (which is unconnected with the angle by a corneous sphincter, or rim) is alone elongate and conspicuous, and even it is shorter, thinner, and more oblique than is generally the case in the various states of the $P$. sphinctostoma,-the upper columellary and the upper and lower palatial ones being apparently obsolete; whilst even the interior ventral, the lower columellary and the central palatial ones are small, inconspicuous, and deeply immersed.

The only locality, so far as I am aware, in which the $P$. lavigata has hitherto been observed is towards the head of the Ribeira de Santa Luzia, in the south of Madeira proper,where I have often met with it sparingly, in company with the large and pallid variety of the Clausilia crispa, beneath the dead and loosened bark of old laurel-trunks.

\section{Pupa recta.}

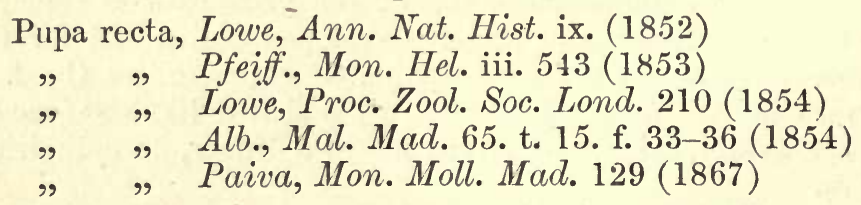

Habitat Maderam; sub foliis aridis emortuis Sempervivi tabuloeformis ad rupes maritimas, necnon interdum in rupium fissuris, hinc inde vulgaris.

The elongate, parallel, cylindric form, and dark-brown (though obscurely banded), subopake, and densely (but very 
minutely, obsoletely, and obliquely) striated surface of this large $P$ upa, added to its somewhat flattened volutions, and its rather open, laterally-rounded aperture, which has the whole five plaits except the first ventral one remote and immersed, and the lateral denticle but very slightly thickened or developed (causing the sinus to be rather wide and unclosed behind), and the first ventral plait connected with the angle of the lip by a corneous sphincter, will sufficiently separate it from its allies.

The $P$. recta is a species which occurs almost exclusively, so far as I am aware, around the roots and amongst the dried leaves of the masses of the Sempervivum tabuloeforme which stud the faces of the rocks, particularly towards the coast, in various districts of Madeira proper,-though for the most part at a rather low elevation, and in the north of the island. In such situations it often abounds, in company with the $P$. fusca and the 'var. a. rupestris' of the $P$. sphinctostoma, on the sea-cliffs below São Vicente and towards the Ribeira da Janella, and indeed along the whole range of the northern shore.

\section{Pupa macilenta.}

Pupa macilenta, Lowe, Ann. Nat. Hist. ix. (1852)

" recta, var. $\beta .$, Pfeiff., Mon. Hel. iii. 543 (1853)

" macilenta, Lowe, Proc. Zool. Soc. Lond. 210 (1854)

" recta, var. $\beta .$, Alb., Mal. Mad. 66 (1854)

" recta, var. a., Paiva, Mon. Moll. Mad. 129 (1867)

Habitat Desertam Grandem; in rupium fissuris hine inde congregans. (In Maderâ propriâ vix, nisi fallor, adhuc detecta.)

Perhaps the present Pupa may be but a depauperated and less highly coloured state of the $P$. recta peculiar to the Deserta Grande, and as such it was originally regarded in doubt by Mr. Lowe; nevertheless it differs from that species in being somewhat smaller, paler, thinner, and just appreciably more distinctly striate, in its ultimate volution being a trifle shorter, and in its two palatial plaits being greatly reduced in dimensions, - the lower one indeed being obsolete, and even the upper one considerably narrower and more abbreviated. The denticle of its outer lip, also, is a little more apparent.

Although stated by Mr. Lowe to have occurred likewise, though sparingly, in Madeira proper (it having been found there, according to him, by Mr. Leacock and myself), I cannot now recal any satisfactory evidence of its existence except on the Deserta Grande, where two dead specimens were first taken by Mr. Leacock in June 1848; and where it was afterwards met with in profusion by myself and the late Rev. W. J. Armitage, on the 20th of January 1849, as also by Mr. Lowe and myself 
in May 1850 and June 1855, within crevices and hollows of the red volcanic soil on the great western promontory of that island known as the 'Pedragal'-from whence it has likewise been obtained, more recently, by the Baron Paiva.'

(§ Craticula, Lowe.)

\section{Pupa fusca.}

Pupa fusca, Lowe, Ann. Nat. Hist. ix (1852)

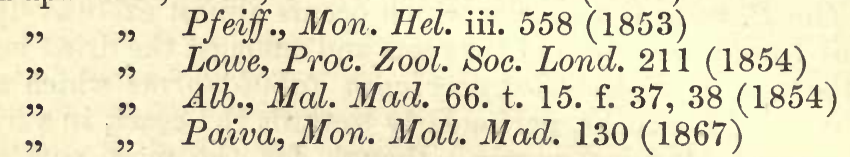

Habitat Maderam, præsertim borealem; sub foliis Sempervivi tabulofformis, Haw., ad rupes submaritimas crescentis, hinc inde abundans.

Although, like many of the Pupce, with a smaller and rather less parallel state, the $P$. fusca is, like the recta and macilenta, a cylindrical species. It is however (although occasional large examples approach those of the latter) smaller on the average than either of them, its volutions are much more tumid, or less flattened, its colour is darker, and its surface (although not exactly costate) is very much more coarsely, and a trifle less obliquely, striated. As regards its mouth, the lip is (as in the $P$. recta) rounded externally, and not sinuate, or nipped-in, at the denticle (which last, although not large and thick, is very sharply defined, and internally prominent); the angle is united with the first ventral plait by an incrassated corneous sphincter; and of the six plaits which are more or less developed, the inner ventral, the lower columellary, and the upper palatial ones are subequal, whilst the upper columellary and the lower palatial ones are rudimentary and often almost obsolete.

The habits of the $P$. fusca are precisely those of the recta, it being found beneath the dried leaves of the rounded masses of the Sempervivum tabuloeforme which stud the faces of the rocks in various parts (particularly towards the north and west) of Madeira proper,-frequently swarming in such situations along the whole line of coast below São Vicente, Ribeira da Janella, and Porto Moniz, as well as near Feijãa d'Ovelha and Ponta de Pargo.

1 I may add that several examples of an elongate, cylindrical Pupa were collected by Mr. Lowe and myself on the ascent from the landing-place at the extreme southern end of the Ilheo de Baixo, off Porto Santo, which we concluded at the time to belong to the P. macilenta, and which Mr. Lowe even cited as such. A recent comparison however of these specimens has shewn me that they are altogether distinct, and pertain in reality to a now and powerfully costate species, of the essentially Porto-Santan type, which I have described below as the $P$. relevata. 


\section{Pupa millegrana.}

Pupa millegrana, Lowe, Ann. Nat. Hist. ix (1852)

$\begin{array}{lll} & \quad & \text { Pfeiff., Mon. Hel. iii. 558 (1853) } \\ & \quad & \text { Lowe, Proc. Zool. Soc. Lond. } 211(1854) \\ & \quad & \text { Alb., Mal. Mad. 66. t. 15. f. 39, 40 (1854) }\end{array}$

Habitat Maderam, Desertam Grandem, et Desertam australem ('Bugio'); sub lapidibus aridis, necnon in rupium fissuris submaritimarum, sese occultans. In stratu conchylifero Canicalensi Maderæ semifossilis reperitur.

With the exception of the $P$. saxicola and linearis, this is the smallest of the Madeiran Pupce; and in its dark-brown colour, linear outline, and tumid volutions, its primâa facie aspect is precisely that of what might be supposed to be a very diminutive $P$. fusca. Apart however from its excessively minute size, it will be found on inspection to be relatively more coarsely, and not so closely, costate-striate; its volutions appear to be not quite so numerous; whereas its plaits are rather more so, or at any rate more developed. These latter are seven in number,-namely 2 ventral (which may be almost said to be subequal), 2 columellary (the upper one of which is inconspicuous), and 3 palatial (the central one being large), and which seem almost to fill up the inner cavity of the mouth.

The $P$. millegrana occurs principally under stones and within the hollows of scoriæ in dry and exposed places of a rather low elevation towards the coast. It has been found in the south of Madeira proper, and on the two Southern Desertas. On the Deserta Grande it was first taken by Mr. Leacock, in June 1848 , and subsequently by myself and the late Rev. W. J. Armitage in January 1849, as well as by Mr. Lowe and myself during May 1850 and June 1855. And a single example was met with by Mr. Lowe, at the last-mentioned date, on the Southern Deserta (or 'Bugio').

In a subfossil state, the $P$. millegrana is tolerably abundant near Caniçal ; but I am not aware that it has yet been observed in the muddy deposits on the summit of the Southern Deserta.

\section{Pupa corneocostata, n. sp.}

$P$. relevato affinis, sed paulo minor, minus elongata, et subremotius costata; umbilico conspicue latiore; anfractibus plerumque paulo magis evidenter subfasciatis (rarius omnino concoloribus), anfr. ultimo sensim subbreviore; peristomate lato corneo subreflexo sed minus continuato (i.e. inter columellam et plicam ventralem exteriorem subinterrupto) necnon conspicue minus exstanti aut minus relevato; aperturâ magis 
sinuatâ auriformi (aut minus subrotundatâ) atque 7- (nec sub. 4-) plicatâ,-sc. plicâ columellari superiore (tamen minutâ) haud omnino obsoletâ, necnon $1 \mathrm{ma}$ et 3 tia palatalibus parum distinctis sed immersis.-Long. lin. $1 \frac{1}{2}-v i x 2$.

Var. $\beta$. resticula.-Paulo minus elongata; peristomate inter columellam et plicam ventralem exteriorem magis corneo, insrassato.

Pupa ferrariæ pars, Paiva [nec Lowe], Mon. Moll. Mad. $132(1867)$

Habitat Portum Sanctum; hinc inde in rupium fissuris submaritimarum congregans. Ad 'Cabeço da Malhada', in parte insulæ occidentali, sec. Barone Castello de Paiva, præcipue abundat. In stratu conchylifero, semifossilis, parce occurrit.

The present Pupa might almost be regarded at first sight as a smaller or less elongated form of the $P$. relevata; and although $I$ am by no means certain that this may not in reality be the case, I nevertheless think that it possesses features of sufficient importance to be treated as specifically distinct. Thus, in addition to its being shorter than (though at the same time quite as linear, or parallel, as) the $P$. relevata, it differs in its umbilicus being wider, or more open, and in its aperture being more ear-shaped or upwardly-sinuate, with the peristome not only less prominent (or less raised above the body-volution) but also less continuous, -it being sub-interrupted between the columella and the outer ventral plait. Its colour too is of a less uniform cinereous-brown, the volutions, although sometimes equally concolorous, having a tendency in highly-coloured examples to be more or less obscurely fasciated; and the plaits themselves, although deeply immersed, are a little more developed,-the upper columellary one, although minute, being quite traceable, whilst the first and third palatial ones are likewise comparatively conspicuous ; thus causing the mouth to be better defined as 7- (than 4-) plicate.

The 'var. $\beta$. resticula' is in some respects intermediate between the $P$. corneocostata and the relevata,-its larger size and more developed peristome making a decided approach to what are the main features of the latter; nevertheless the ultimate volution is appreciably shorter, and the aperture (although with a thickened peristome between the outer ventral plait and the columella) is both less raised and differently shaped.

Many examples of the $P$. corneocostata were obtained from Porto Santo a few years ago by the Baron Paiva, and were forwarded by him both to Mr. Lowe and to myself as the ' $P$. 
ferraria'-from which nevertheless they are totally distinct. I wrote expressly to the Baron at the time, in order to find out the exact spot in which they were collected; and in a letter now before me, dated Dec. 1st, 1864, he says: ' Je peux vous assurer avec toute certitude que la $P$ upa que vous demandez a été prisé en abondance dans un seul endroit du Porto Sancto, que les naturels du pays appellent "Cabeço da Malhada," qui est situé dans l'extremité occidentale de Porto Sancto, vis-à-vis de l'Theo de Baixo.' From which it would appear that its habitat is not very remote from that (namely the Ilheo de Baixo) in which its near ally, the $P$. relevata, was met with by Mr. Lowe and myself.

In a subfossil state, the $P$. corneocostata occurs sparingly in the calcareous deposits of the island,-it having been found, both by Mr. Lowe and myself, I believe at the Zimbral d'Areia.

\section{Pupa relevata, n. sp.}

P. elongata, parallela, cylindrica, solida, opaca, brunnea (obsolete subcanescens), argute costata; anfractibus 7-8 convexis; aperturâ subrotundatâ, peristomate corneo protenso aut relevato (i.e. completo aut undique continuato, et ultra anfr. ult. exstante,-quasi collo brevi separato), 4-plicatâ, plicis brevibus et (exteriore ventrali paululum exceptâ) valde immersis inconspicuis, sc. 2 ventralibus, 1 columellari, et 1 (mediâ) palatali; columellari 2dâ superiore nullâ, palatalibusque 1mâ et 3 tiâ minutis, rudimentalibus, fere obsoletis ; ventrali internâ parvâ, profunde immersâ; labro extus vix sinuato, denticulo minutissimo interno et fere obsoleto, sinu indistincto.-Long. lin. $1 \frac{3}{4}-2$.

Habitat ins. de Baixo, juxta Portum Sanctum; a Revdo. R. T. Lowe et meipso in rupium fissuris submaritimarum lecta.

The elongate, linear, cylindric form of this large and solid $P$ upa, added to its opake reddish-brown surface (which is generally a little whitened, or as it were powdered, with a sort of calcareous deposit), its rather tumid and powerfully costate volutions, and (above all) the peculiar construction of its aperture the peristome of which is much developed and continuous, standing-out from the body-volution by almost an appreciable neck-will sufficiently distinguish it from its allies. Its plaits are short and very deeply immersed, the first ventral one being alone conspicuous: of those on the columella the upper one is entirely absent, and even the lower one abbreviated and remote; whilst of the palatial three, the upper and lower ones are small and rudimentary.

The $P$. relevata was detected by Mr. Lowe and myself, 
within crevices of the exposed weather-beaten rocks at the extreme southern point of the Ilheo de Baixo, off Porto Santo,when ascending from the landing-place to the higher parts of that calcareous island. And I have lately examined a few specimens which were obtained by the Baron Paiva; and although I have no note of their precise habitat, I think it is more than probable that they likewise came from the Ilheo de Baixo.

\section{Pupa ferraria.}

P. elongata, parallela, cylindrica, subopaca, læte rufo- aut subnigrescenti-brunnea, dense et argute costulata, paulo minus dura; anfractibus convexis, vel concoloribus vel læte fasciatis; apertura magnâ, rotundato-auriformi, 4-plicata, sc. 2 ventrali (exteriore tenui, lamelliformi, obliquâ, flexuosâ, interiore parvâ brevi et profunde immersâ) 1 columellari (superiore nullâ), et 1 palatali (1 ma et 3tia nullis); peristomate angusto, tenui, acutiusculo, labro extus rotundato (nec sinuato), denticulo obsoleto, sinu indistincto aperto.-Long. lin. $\operatorname{circa} 1 \frac{2}{3}$.

Pupa ferraria, ${ }^{1}$ Lowe, Ann. Nat. Hist. ix. (1852)

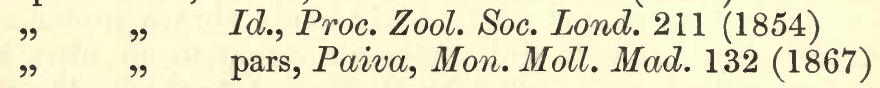

Habitat Portum Sanctum ; in monte 'Pico d'Anna Ferreira' dicto præcipue, in rupium fissuris, latitans. Mense Decembri ineunte A.D. 1848 a meipso detecta.

I have thought it desirable to give a fresh diagnosis of the $P$. ferraria, in order to point out in what it differs from its immediate allies; for until accurately examined it might easily be confounded (as indeed it evidently was by the Baron Paiva) with at all events the $P$. corneocostata. There can be no question however that it is truly distinct from that species, although doubtless belonging to the same geographical assemblage,-for it is not only (on the average) a trifle larger and relatively broader and more elongate, as well as less solid (or more thin in texture), but its costæ are likewise somewhat less coarse and more closely set together, and its aperture is proportionately a little larger and more rounded-outwards at the lip,-the peristome moreover being not only acuter and less developed, but more completely and widely interrupted between the outer ventral plait and the columella. The callosity also between that plait (which is itself thinner or more lamelliform) and the angle

1 Although there was already a Pupa (from northern Italy) which was published by Porro, in 1848, as the P. Fer"rari (vide Mal. Com. 57. t. i. f. 4) I nevertheless have not deemed it necessary to propose a fresh name for this Porto-Santan species, seeing that the two titles (however near orthographically) are not absolutely identical. 
of the lip is considerably less thickened, being occasionally even sub-obsolete; the inner ventral plait is still smaller, it being very short and deeply immersed; and the upper one on the columella, as well as the first and third palatial ones, appear to be absent.

The $P$. ferraria is locally abundant on the mountains of Porto Santo, particularly in the western division of the island, - where it was first detected by myself, on the 7th of December, 1848 , within the crevices of the exposed weather-beaten rocks of the Pico d'Anna Ferreira. I subsequently obtained it in the same locality during April 1849; and it was met with hy Mr. Lowe and myself (the former having also found it on the Pico d'Espigão) in May of 1855.

The localities given for the $P$. ferraria by the Baron Paiva, in his late monograph, are not to be trusted, seeing that he confounded it with the $P$. corneocostata (from the Cabeço da Malhada) and the $P$. relevata (from the Ilbeo de Baixo). I have little doubt therefore that the 'Ilheo de Baixo' and the 'Ilheo de Ferro,' which are cited by him (in addition to the Pico d'Anna Ferreira) for its habitat, pertain in reality to those two species.

\section{Pupa degenerata, n. 'sp.}

P. subconico-cylindrica (sc. apicem versus obsolete subattenata), opaca, pallide brunnea, remote sed argute et oblique costata; anfractibus convexis, valde tumidulis, interdum obsolete subfasciatis ; aperturâ parvâ, rotundatâ, distincte 1- (indistincte 4-) plicatâ, sc. 2 ventralibus (etiam exteriore parvâ brevi, interiore minutâ valde immersâ inconspicuâ), 1 columellari parvâ profunde immersâ (superiore nullâ), et 1 palatali immersâ subobsoletâ ; peristomate subcompleto (i. e. inter plicam ventralem exteriorem et columellam tenuiter continuato); labro extus rotundato, denticulo obsoleto, sinu aperto indistincto.-Long. lin. $1-1 \frac{1}{2}$.

Habitat Portum Sanctum; exemplaribus quatuor (cum $P$. monticola var. $\beta$. commixtis) a Barone Castello de Paiva communicatis.

The four examples from which the above diagnosis has been compiled, and which were mixed up with some specimens of the 'var. $\beta$. pumilio' of the $P$. monticola which were obtained by the Baron Paiva from Porto Santo, I at first thought might represent some degenerated state of the latter, in which the aperture was reduced in dimensions and unusually rounded, and the plaits almost obsolete; nevertheless since they display a number of other peculiarities, and moreover appear to stand in exactly the same relation to that species as the $P$. loevigata does, in Ma- 
deira proper, to the $P$. sphinctostoma, it seems impossible not to acknowledge them as truly and specifically distinct.

Judging therefore from the material now before me, the $P$. degenerata may be said to differ from its immediate allies, and more particularly from the $P$. monticola, in being less strictly cylindrical (it having a decided, though not very conspicuous, tendency to be slightly and gradually attenuated towards the apex), in its volutions (which are exceedingly tumid) having their costæ very coarse, remote, and oblique, and in its aperture being extremely small and rounded, with the plaits so unusually diminished in size as to be almost obsolete. Indeed even the outer ventral one is very short and small; whilst the only other three which are traceable (namely the inner ventral one, the lower one on the columella, and the middle palatial one) are greatly reduced, inconspicuous, and deeply immersed.

\section{Pupa monticola.}

Helix monticola, Lowe, Cambr. Phil. S. Trans. iv. 63. t. 6. f. 33 (1831)

Pupa monticola, Pfeiff., Mon. Hel. ii. 335 (1848)

$\begin{array}{lll}" & \Rightarrow & \text { Lowe, Proc. Zool. Soc. Lond. } 212(1854) \\ " & \Rightarrow & \text { Alb. Mal. Mad. 67. t. 16. f. 3, 4 (1854) } \\ & \quad & \text { Paiva, Mon. Moll. Mad. } 133(1867)\end{array}$

Habitat Portum Sanctum; status typicus præcipue in cacuminibus montium, sed 'var. $\beta$. pumilio' in rupium fissuris in locis minus elevatis plerumque congregat.

This little costate Pupa is locally abundant in the fissures, and on the ledges, of the rocks in Porto Santo, to which island it seems to be peculiar,-occurring both amongst small stones and vegetable detritus at a high elevation (like the $P$. calathiscus), and likewise in exposed spots of a comparatively low altitude. In the former case it is, on the average, a trifle larger and paler, with the ultimate volution just appreciably more developed, the costæ a little more flexuose and remote, and the upper palatial plait not quite so strongly expressed; and as this is the particular state which was originally described by $\mathrm{Mr}$. Lowe, it must perhaps be regarded as the normal one. Under this phasis the species occurs sparingly, often in company with the $P$. calathiscus, on the summits of the Pico de Facho, the Pico Branco, \&c. Nevertheless, so far as my own observations are concerned, it is far more abundant in certain exposed, weather-beaten spots but slightly raised above the sea-level; and in such situations the shell is usually a trifle smaller, darker, and more solid, with its costæ a little less sinuate and more closely set together, and with its ultimate volution and aperture just 
appreciably less developed, the third palatial plait, on the contrary, being more so, and distinctly longer.

The latter of the two states just alluded to $I$ would define as the var. $\beta$. pumilio; and were it not that I appear to possess examples which constitute a complete passage into the other, I might have been inclined to regard it as specifically distinct from (however intimately allied to) the normal $P$. monticola. But, as it is, I think there can be no doubt that the forms in question are but slightly differing races of a single species, assumed respectively in the higher and the lower districts.

The 'var. B. pumilio' was taken in profusion by Mr. Lowe and myself, on the 10th of May 1855, within crevices of the exposed rocks, at a low elevation, on the northern coast of Porto Santo,-namely in the abrupt and almost inaccessible region behind (and below) the Pico Branco, facing the Ilheos de Nordeste ; and several examples of it are also now before me, which were obtained from Porto Santo by the Baron Paiva, but I have no memorandum of the precise locality in which they were found. This particular phasis of the $P$. monticola may be enunciated thus: Var. $\beta$. pumilio.-Curtula, obtuse cylindrica, subopaca, rufo-brunnea, dense costulata; anfractibus convexis, tumidulis, interdum fasciatis; aperturâ parvulâ, rotundatoauriformi, distincte 6- (indistincte 7-) plicatâ, sc. 2 ventrali (exteriore obliquâ flexuosâ, interiore minore immersâ sed parum magnâ), 1 columellari (superiore subobsoletâ), et 3 palatalibus (remotis, sed elongatis conspicuis); peristomate incompleto (sc. inter plicam ventralem exteriorem et columellam late interrupto), labro extus subrotundato (vix sinuato), denticulo obsoleto, sinu parum distincto.-Long. lin. 1-1 $\frac{1}{4}$.

Occasional large examples of this particular variety of the $P$. monticola might at first sight be almost mistaken for abnormally small ones of the $P$. corneocostata; nevertheless the fact of their peristome being completely interrupted between the outer ventral plait and the cclumella will, apart from other minute characters, generally serve at once to separate them from the latter.

The P. monticola is stated by the Baron Paiva (Mon. Moll. Mad. p. 134) to occur in a subfossil state at the Zimbral d'Areia; and although it is far from unlikely that this may be the case, I feel that further evidence is necessary before his assertion can be accepted; for, in the first place, the Baron does not appear to have even known the $P$. monticola properly (as is evident from his doubts concerning its true distinctness from the $P$. millegrana, a species with which it has almost nothing in common), whilst his confusion of the $P$. corneocostata with the $P$. ferraria leads me to suspect that the former of those two spe- 
cies is the subfossil one (at the Zimbral d'Areia) to which he alludes.

\section{Pupa calathiscus.}

Helix calathiscus, Lowe, Cambr. Phil. S. Trans. iv. 64. t. 6. f. 34 (1831)

Pupa calathiscus, Pfeiff., Mon. Hel. ii. 244 (1848)

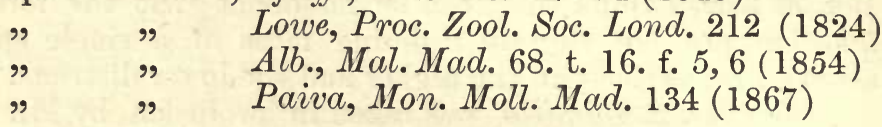

Habitat Portum Sanctum; ad cacumina montium in rupium fissuris latitans. Semifossilis hinc inde haud infrequens.

The comparatively large, and beautiful, $P$. calathiscus (although belonging to the same solid, and strongly costate, geographical type as the $P$. monticola and corneocostata, which are equally Porto-Santan) may be known from its allies not only by its greater bulk and more oval form, but likewise by the ribs of its extremely ventricose and appreciably banded volutions being still coarser, as well as more curved and remote; and by its aperture having the lip a good deal developed and often subpellucid, and the three palatial plaits subconfluent, the lower one being almost lost, or absorbed, in the general callosity, whilst the middle one is elongated backwards into a subtriangular process, and the upper one is appreciable but short, being abruptly terminated internally, as well as suffused into the (sometimes obsolete) lateral denticle. The upper plait of the columella appears to be absent; the inner ventral one is small and immersed; and the outer ventral one is connected with the angle of the lip by a thick corneous rim, which occasionally takes the shape (as in the Madeiran P. laurinea) of a sub-isolated tubercle.

The $P$. calathiscus, which is apparently peculiar to Porto Santo, has much the same habits as the P. monticola (in its normal state),-occurring more particularly on the ledges, and within the crevices, of the rocks at a high elevation. Under such circumstances it is tolerably common, amongst vegetable detritus, on the summits of the Pico de Facho, the Pico Branco, \&c.; but I have never observed it at a decidedly low altitude.

In a subfossil state the $P$. calathiscus is not generally abundant; nevertheless at the Zimbral d'Areia it was met with by Mr. Lowe and myself in tolerable profusion. The subfossil examples are a little smaller than the recent ones. 
( Alvearella, Lowe.)

\section{Pupa abbreviata.}

Pupa abbreviata, Lowe, Ann. Nat. Hist. ix. (1852)

$\begin{array}{lll}" & \Rightarrow & \text { Id., Proc. Zool. Soc. Lond. } 213 \text { (1854) } \\ , & \# & \text { Alb., Mal. Mad. 84 (1854) }\end{array}$

Habitat Maderam; recens rarissime. In stratu conchylifero ad Caniçal magis frequenter, tamen parce, semifossilis occurrit.

The present small Pupa, which appears to be almost unique in a recent state, may be known by its short, broad, obtuse, cylindric-oblong form, and by its rather closely but coarsely costate surface; and with the exception of the $P$. gibba it is the only one of the strongly ribbed species which has the outer lip externally sinuate, the denticle powerfully developed, and the volutions (the basal one of which is, as in the $P$. gibba, unusually short) not tumid. Its costæ are oblique and slightly flexuose ; its first ventral plait (which is united to the angle of the lip by a thick corneous sphincter) is oblique and prominent, the inner one is deeply immersed, and the upper one of its (likewise very oblique) columella seems to be absent.

The $P$. abbreviata, in a subfossil condition, is not very uncommon in the calcareous deposits near Caniçal (where I believe it was first detected by myself); but it has not been observed, in the similar subfossiliferous beds, out of Madeira proper.

\section{Pupa gibba.}

Pupa gibba, Lowe, Ann. Nat. Hist. ix. (1852)
" $\quad$ " Pfeiff., Mon. Hel. iii. 552 (1853)
" " $\quad$ Lowe, Proc. Zool. Soc. Lond.213 (1854)
" $\quad$ Alb., Mal. Mad. 69 (1854)

Habitat Maderam; et recens et semifossilis rarissima.

This solid little $P u p a$ is a trifle smaller, and still more shortened or obtusely cylindric, than even the $P$. abbreviata,its outline being almost subquadrate; and its volutions are more decidedly flattened, as well as more powerfully but more sparingly costate. In the obliquity of its columella and plaits (and therefore in the shape of its mouth), as well as in its sinuated lip and its strongly developed, or internally prominent, denticle, it is much the same as that species; nevertheless its two ventral plaits are very different from those of the $P$. abbreviata, - the outer one (which although rather close at its origin to the angle of the lip, is nevertheless almost unconnected with 
it) being exceedingly prominent, but suddenly truncated, or almost emarginate, internally; whilst even the inner one is likewise unusually prominent and developed, it being thicker and less immersed (in proportion to the size of the shell) than in any $P$ upa which $I$ have hitherto examined.

The $P$. gibba seems, in a recent condition, to be of the utmost rarity; indeed the only two examples, so far as I am aware, which have as yet been detected were found by myself, amongst loose vegetable detritus, at the base of the lofty perpendicular rocks towards the head of the Ribeira de Sta. Luzia, in the south of Madeira proper. But although thus scarce in a living state, it is not so particularly rare in the subfossiliferous beds at Caniçal; though its minute size is apt to render it somewhat liable to escape observation.

\section{(§ Mastula, Lowe.)}

\section{Pupa lamellosa.}

\begin{tabular}{|c|c|c|}
\hline & ell & \\
\hline & פי & Pfeiff., Mon. Hel. iii. 556 \\
\hline & & Lowe, Proc. Zool. Soc. Lond. 214 (1854) \\
\hline & ", & Alb., Mal. Mad. 66 (1854) \\
\hline & " & Paiva, Mon. Moll. Mad. 138 (1867) \\
\hline
\end{tabular}

Habitat Maderam; recens semifossilisque rarissima.

The $P$. lamellosa, although short, small, and strongly costate, belongs to a totally different type from any of the preceding species, - its abbreviated, turbinate form (the apex being unusually truncated or immersed), and less hardened texture, added to the tendency of its very oblique and widely separated ribs to be occasionally somewhat foleaceo-dilated in the centre (as though slightly and obsoletely spinulose) and the shortness of its aperture (which is rather wider than long, with the lip acute, and exteriorly rounded or unsinuate), giving it a character which it is impossible to mistake. Its three basal volutions are extremely tumid ; and its outer ventral plait (which is totally unconnected by a callous sphincter with the angle of the lip) is exceedingly lamelliform and obliquely curved, whilst the inner ventral one (like the palatial ones and the upper one on the columella) is obsolete,- the lower columellary one, however, being tolerably developed. The 'sinus' is hardly at all expressed.

The $P$. lamellosa is one of the rarest of the Pupoe, and has been observed hitherto only in the south of Madeira proper-at intermediate elevations. It has been taken sparingly by Mr. Leacock in the Vasco Gil ravine,-where I have myself also met with it, as likewise in the Ribeira de Sta. Luzia. 
In a subfossil state the P. lamellosa occurs, though very rarely, in the calcareous beds near Caniçal.

\section{(§ Staurodon, Lowe.)}

Pupa saxicola.

Pupa saxicola et seminulum, Lowe, Ann. Nat. Hist. ix. (1852)

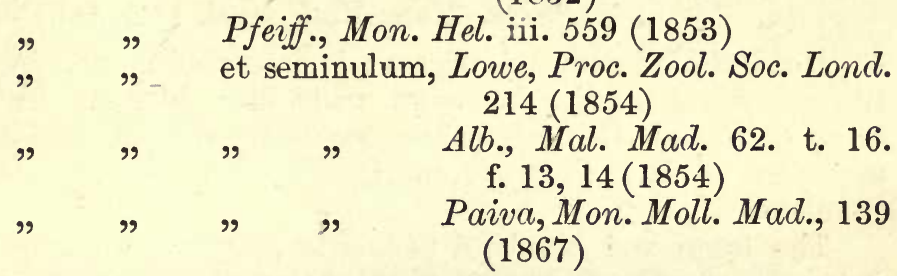

Habitat Maderam : sub lapidibus in aridis saxosis submaritimis hine inde vulgaris. In statu semifossili juxta Caniçal parce occurrit.

Well distinguished from all the other members of the genus here enumerated by its extremely minute size (it being the smallest of the Madeiran Pupce), by the paucity of its subventricose volutions (in which respect it agrees with the $P$. fanclensis), by its outline being somewhat obesely oblong, or almost equally attenuated before and behind, by its surface being subopake and very densely and delicately striated, and by its aperture being rather small and a good deal rounded,- - the 'sinus' and labial tooth being obsolete. Its plaits too are somewhat peculiar,- the outer ventral one forming a small but prominent tubercle nearly adjoining the angle of the lip, whilst the four inner ones are large but deeply immersed.

The $P$. saxicola occurs beneath stones and scorix in dry rocky spots, of a low elevation, in the south of Madeira proper, and was first taken by myself, during April 1848, at the Praia Bay, to the westward of Funchal (where it was also met with by Mr. Leacock on the 1st of May of the same year),- under loose pieces of basalt, at the top of the cliff, at the eastern end ; and it has likewise been found, according to the Baron Paiva, at the Feijãa dos Asnos and the Cabo Girão.

The $P$. seminulum, Lowe, which was detected by Mr. Leacock at the Cabo Garajão, or Brazen Head, does not appear to me to differ specifically, in any single particular, from the present species.

In a subfossil condition the $P$. saxicola is not uncommon in calcareous deposits near Caniçal. 


\section{Genus 11. CLAUSILIA, Drap.}

\section{Clausilia crispa.}

Helix crispa, Lowe, Cambr. Phil. S. Trans.iv. 65. t. 6. f. 36 (1831)

Clausilia crispa, Pfeiff., Mon. Hel. ii. 484 (1848)

$" \quad$ " Lowe, Proc. Zool. Soc. Lond. 215 (1854)

" $\quad$ "Alb., Mal. Mad. 70. t. 16. f. 17-19 (1854)

" " Paiva, Mon. Moll. Mad. 142 (1867)

Habitat Maderam sylvaticam; in intermediis, præcipue ad truncos et sub cortice laurorum arido laxo, degens. In statu semifossili, ad Caniçal, parce occurrit,- -ibidem varietatem majorem ( = var. decolorata, mihi), sed paulo grossius costulata, simulans.

The large and beautiful Clausilia crispa (so remarkable, inter alia, for the fine costæ of its entire surface being densely crowded together, and on the basal volutions very minutely undulating) is confined to Madeira proper, where it occurs principally beneath the loosened bark of old laurels within the damp sylvan districts of intermediate altitudes; and it is surprising to me that Mr. Lowe, in spite of his almost unparalleled accuracy, should have failed to record (even whilst possessing an abundance of material from which to judge) that it puts on two very opposite phases, which might well nigh have been treated as specifically distinct did they not merge into each other by intermediate gradations. The form which he described under the name of C. crispa (and which must therefore be accepted as the typical one) is the smaller of them, and is of a more or less dark brown but elegantly marbled with irregular yellowishwhite cloudy dashes and smaller longitudinal streaks (the latter of which are many of them subconfluent); whilst the other (which I would define as the 'var. $\beta$. decolorata') is considerably larger, of a more or less pale yellowish-brown, or brownishwhite (and therefore concolorous, or free from pallid blotches and streaks), and with the peristome not only a little more deltoid in outline, but likewise broader and more outwardly flattened or developed. This latter state, which I have met with commonly on the trunks of old laurels at S. Antonio da Serra, as well as in the Ribeira de Sta. Luzia and elsewhere, I would enunciate briefly as follows :-

Cladsiuia crispa, var. $\beta$. decolorata.-Major, plus minus obscure fulvescenti-albida, concolor (nec marmorata), costulis undique paululum magis elevatis, aperturâ vix magis deltiformi, peristomate latiore aut magis expanso.-Long.6-8 lin.; diam. maj. 2. 
The C. crispa occurs also, though sparingly, at Caniçal, in a subfossil condition; but all the examples which $I$ have yet inspected pertain to the larger form, just described as the 'var. $\beta$. decolorata;' yet the majority of them differ from their recent analogues in being a trifle more coarsely and not quite so closely sculptured,- the so-called 'striæ' in some examples amounting to appreciably separated, well-defined costæ. In spite however of the latter peculiarity (a character which is eminently unstable in the Madeiran Clausilias), I cannot detect anything about them to warrant their isolation as even a decided 'variety.'

\section{Clausilia deltostoma.}

Helix deltostoma, Lowe, Cambr. Phil. S. Trans. iv. 65. t. 6. f. 37 (1831)

Clausilia deltostoma, Pfeiff., Mon. Hel. ii. 410 (1848)

$\begin{array}{ccc}" & \text { Lowe, Proc. Zool. Soc. Lond. } 2 \text { i5 } \\ & \text { (1854) }\end{array}$

Habitat ins. omnes Maderenses; sub lapidibus vulgatissima. In statu semifossili parce occurrit in Portu Sancto, necnon in ins. Desertâ Australi.

This is the universal Clausilia throughout the whole Madeiran archipelago, and one which is so eminently variable, both in solidity and in the number and development of its costæ, that were it not for the intermediate links which most assuredly connect them, it would be almost impossible to believe that the two extremes of form (when viewed per se) could be conspecific with each other. It would appear however to be singularly dependent, not only upon the nature of the soil, and district, in which it occurs, but likewise upon the elevation of the latter, - the examples from low and arid regions towards the coast being more solid in substance, and with their ridges more coarsely matured (particularly when, as in Porto Santo, the area of distribution is for the most part a calcareous one), than those which have been collected in higher and damper localities further removed from the sea. Indeed it is not often that the $C$. deltostoma ascends at all above the altitude of about 2500 feet; and even the individuals from the upper limits of that range are usually smaller and thinner than the others, as well as more glossy and less coarsely (and more closely) sculptured, and frequently too of a paler tint. It was the race which 
is characterized by these peculiarities that Mr. Lowe defined as the ' $\delta$. depauperata.' The $C$. deltostoma is also very unstable, like certain of the Pupce, in the exact number of its volutions; and in the ' $\delta$. depauperata' the latter are nearly always slightly less numerous, and therefore (as a consequence) relatively somewhat enlarged and lengthened.

It is however in the lower and submaritime tracts that the present Clausilia attains its maximum, - where it is extremely abundant beneath stones, and even within the crevices of the walls in cultivated spots. Throughout Madeira proper and on the three Desertas the specimens from such situations (although more or less variable inter se) constitute, as a whole, the typical ones ; and to these Mr. Lowe applied the additional distinctive name of ' $\delta$. crebristriata.' They are on the average larger and more solid than those which constitute the ' $\delta$. depauperata,' with generally an extra whorl and the spire a trifle more attenuated or drawn-out; and their surface is for the most part appreciably more opake, while the costæ are not only less densely packed together but likewise somewhat more raised.

But the examples from the eminently dry and calcareous island of Porto Santo have the characters of the normal (or last-mentioned) state (as it were) unduly exaggerated,-the shell being, if possible, even more solid still, with the ridges monstrously developed (those of them which are the most elevated being, as a general rule, reduced in number, so as often to appear exceedingly remote). This Porto-Santan race represents the ' $a$. raricosta' of Lowe; and it is in some instances so distinct from the typical one (which abounds in Madeira and on the Desertas), not merely in its greatly enlarged costæ but in the tumidity of its volutions, that it was proposed by Dr. Albers as a separate species-under the title of ' $C$. Lowei.' That it is no more however than an insular modification, peculiar to Porto Santo and the small adjacent islets, there cannot I imagine be any question. And, so far as its distribution is concerned, I may add en passant that I have myself met with it on the Ilheo de Cima and the Ilheo de Baixo; whilst from the Ilheo de Ferro it was obtained by the Baron Paiva, as well as from the Ilheos de Nordeste-the ashy-purplish tint of the examples from which induced him to apply to them the varietal name of 'purpurina.'

There is however one more phasis of this protean Clausilia which stands out from the less important varieties as worthy of notice, and which at first sight appears so peculiar that Mr. Lowe in (1863) described it, under the name of $C$. obesiuscula, as specifically distinct. This particular form was obtained by Senhor J. M. Moniz near the Levada Debaixo, not far from 
Caniço, in the south-east of Madeira proper, from beneath the dead leaves of Sempervivum glandulosum, Ait., - which implies a modus vivendi resembling, apparently, that of the $C$. exigua. The more obtuse, fusiform outline, and greater obesity, of the shell, the whorls of which are slightly diminished in number, and consequently somewhat elongated and enlarged, added to its surface being less opake and its costæ both closer and less elevated, give it such a different aspect, when viewed alongside (for instance) the 'status a. raricosta' from Porto Santo, that it is difficult to believe that it can be conspecific with that very solid and powerfully ribbed modification of the $C$. deltostoma. Yet Mr. Lowe, even whilst publishing it provisionally as new, recorded his doubts as to whether it would prove in reality to be more than ' a mere local form or variety of the extremely polymorphous common Madeiran $C$. deltostoma,-adding that it approached so nearly to his 'status $\delta$. depauperata' of that species that it seemed to be almost connected (through the latter) with the ordinary type. And indeed there can be little doubt, I think, that it is connected,-the ' $\delta$. depauperata' possessing the same peculiarity of volutions, surface, and sculpture, as the obesiuscula, from which it mainly differs in its smaller size, its rather less thickened outline, and its more pallid, unspeckled hue. Therefore it seems to me that we must be content, despite its essentially different aspect from the opposite extreme of the species, to regard the obesiuscula as representing only another, but remarkable, phasis of the marvellously plastic $C$. deltostoma.

In a subfossil state the $C$. deltostoma occurs sparingly in Porto Santo (where I have met with it at the Zimbral d'Areia), and on the Southern Deserta ; but I am not aware that it has yet been observed in Madeira proper.

\section{- Clausilia exigua.}

Helix exigua, Lowe, Cambr. Phil. S. Trans. iv. 66. t. 6. f. 39 (1831)

Clausilia exigua, Pfeiff., Mon. Hel. ii. 485 (1848)

$$
\begin{array}{lll}
" & \text { Lowe, Proc. Zool. Soc. Lond. } 216(1854) \\
" & \quad & \text { Alb.,Mal. Mad 71. t. 16. f. 20-22 (1854) } \\
& \quad & \text { Paiva, Mon. Moll. Mad. } 144(1867)
\end{array}
$$

Habitat Maderam; sub foliis Sempervivi aridis emortuis ad rupes submaritimas crescentibus præcipue latitans.

This little Clausilia has much the outline, fewer volutions, and thinner substance, of the 'status $\delta$. depauperata' of the last species; nevertheless it is still smaller and somewhat more apically-obtuse, its whorls are a trifle more convex, its costæ are 
more closely set together and more flexuose, its surface is more opake, and its colour is of a uniform dark brown. Its mode of life too is not the same, it being found almost exclusively under the dead leaves of the Semperviva which stud the faces of the rocks in Madeira proper at low and intermediate altitudes; though it is now and then to be met with (as at Caniçal), sparingly, even beneath stones. In this peculiarity of its habitat it would seem, it is true, to have something in common with the 'status $\gamma$. obesiuscula' of the $C$. deltostoma; nevertheless the latter is exceptional, as regards its modus vivendi, for that species, the $C$. deltostoma (in its numerous phases) being nearly always found adhering to stones,--whether about houses and walls, or in dry and exposed spots near the coast.

\section{Genus 12. BALEA, Pridx.}

\section{Balea perversa.}

Turbo perversus, Linn., Fna. Suec. No. 2172 (1761)

Balea perversa, Pfeiff., Mon. Hel. ii. 387 (1848)

\begin{tabular}{|c|c|c|}
\hline & " & Lowe, Proc. Zool. Soc. Lond. 215 (1854) \\
\hline & و & Alb., Mal. Mad. 69. t. 16. f. 15, 16 (1854) \\
\hline & " & Morel., Hist. Nat. des Açor. 206 (1860) \\
\hline & " & Paiva, Mon. Moll. Mad. 140 (1867) \\
\hline & פ & Watson, Journ. de Conch. 223 (1876) \\
\hline
\end{tabular}

Habitat Portum Sanctum; in summo ipsissimo montis 'Pico de Facho' dicti, a meipso, tempore vernali 1848, in rupium fissuris basalticarum, parce lecta.

The common European $B$. perversa was detected by myself, during the spring of 1848 , in Porto Santo,-namely within fissures of the exposed, basaltic, almost inaccessible, weather-beaten rocks on the northern (and very precipitous) side of the extreme summit of the Pico de Facho (about 1665 feet above the sea); a locality in which I again met with it in April 1859. And it has subsequently been obtained by the Baron Paiva, though very sparingly, from the same spot,-which, so far as I am aware, represents its only ascertained habitat throughout the Madeiran, Canarian, and Cape Verde archipelagos. ${ }^{1}$ It appears however to exist rather abundantly in the Azores.

1 The Baron Paiva states that it occurs also on the summit of the Pico Branco; but as his Porto-Santan material was not obtained by himself, I think that that particular habitat (although by no means an improbable one) requires further corroboration. 


\section{Genus 13. ACHATINA, Lamarck.}

(§ Acicula, Risso.)

\section{Achatina acicula.}

Buccinium acicula, Müll., Verm. Hist. ii. 150 (1774)

Helix acicula, Lowe, Cambr. Phil. S. Trans. iv. 59 (1831) Achatina acicula, Pfeiff., Mon. Hel. ii. 274 (1848)

Lowe, Proc. Zool. Soc. Lond. 201 (1854)
Glandina acicula, Alb., Mal. Mad. 59. t. 15. f. 17, 18 (1854)

Cæcilianella nyctelia, Bourg., Rev. et Mag. Zool. 430 (1856)

Achatina acicula, Paiva, Mon. Moll. Mad. 114 (1867)

Cionella acicula, Mouss., Faun. Mal. des Can. 135 (1872)

Achatina acicula, Watson, Journ. de Conch. 223 (1876)

Habitat Maderam, Portum Sanctum, Desertam Grandem, et Desertam Australem; sub lapidibus in herbidis humidiusculis (sæpius parum inferioribus), hinc inde congregans.

The European and north-African A. acicula (which I met with also towards the western coast of Palma in the Canarian archipelago) is not uncommon in Madeira proper,-where it occurs beneath stones in rather moist and grassy places, particularly at a somewhat low elevation and in the vicinity of the coast. I likewise found it very sparingly on the Deserta Grande, and it appears to have been obtained from the Southern Deserta by the Baron Paiva. In Porto Santo it was not taken either by Mr. Lowe or myself; but it is recorded from thence, as well as from one of the adjacent islets, by Mr. Watson.

The extremely narrow, acicular, but conical form of this little Achatina, added to its fragile, subpellucid substance, its pale, whitish, almost colourless, and glossy surface, its produced spire, very oblique suture and elongate penultimate volution, its short, arcuated, and basally truncate columella, its thin, acute peristome, and the complete freedom of its aperture from callosities and plaits, will suffice to distinguish it from every other member of the group with which we are concerned.

I have re-examined the Madeiran specimens of this Achatina with the greatest care, and I cannot see that they differ in any respect from the ordinary European ones, or from those which were taken by myself in Palma of the Canarian archipelago; and I have no hesitation therefore in treating the A. nyctelia, of Bouguignat, as absolutely identical with the acicula. 


\section{Achatina eulima.}

T. linearis, angustissime cylindracea, gracillima, interdum obsoletissime arcuatim subcurvata aut eccentrica, polita, hyalina, albida; spirâ elongatâ, subconico-cylindricâ, apice obtuso, suturâ obliquissimâ et distincte marginatâ; anfractibus $6 \frac{1}{2}$, planis, etiam intermediis elongatis; aperturâ (spirâ multo breviore) subovatâ, antice acuminatâ, postice latiuscùle arcuatorotundatâ, pariete ventrali in medio uniplicato (plicâ transversâ, intrante, distinctâ); peristomate simplici, acuto, marginibus laminâ crassiusculâ junctis, dextro rotundato, in basalem et columellarem regulariter curvatim (nec angulatim) continuo ; columellâ curvatâ et haud contortâ, postice non abrupte truncatâ,-sc. in marginem basalem gradatim et facile mergente.Long. lin. $2 \frac{1}{2}-3$; lat. maj. $\frac{3}{4}$.

Achatina eulima, Lowe, Proc. Zool. Soc. Lond. 210 (1854)

$" \quad$ " $\quad$ Paiva, Mon. Moll. Mad. 115 (1867)

Habitat Maderam, et Portum Sanctum, rarissime; in illâ recens, sed in hâc semifossilis, a meipso detecta.

Obs.-Ab A. acicula, Müll., valde distincta; differt testâ longiore, angustiore, magis lineari, ac magis cylindricâ, interdum obsolete etiam subcurvate excentricâ; anfractibus intermediis longioribus magisque plano-cylindricis, apicali semigloboso-obtusulo, suturâ obliquissimâ ; aperturâ subbreviore et postice latiore, sc. ibidem magis exstante rotundatâ; pariete ventrali plicâ mediâ instructo; necnon columellâ ipsâ omnino simplici (haud postice abrupte terminatâ), in marginem basalem gradatim et facile coëunte.

This most little remarkable little Achatina has hitherto been known only from a subfossilized example, in a fractured condition (its apex having been accidentally destroyed), which was found by myself, many years ago, at the Zimbral d'Areia, in Porto Santo; and, although I have had no opportunity of observing the animal, its manifest relationship with the $A$. acicula (even though differing from it, in some measure, structurally) justifies me, nevertheless, in treating it as a true Achatina (of the Acicula section), rather than as a Lovea.

The original type of the A. eulima, which was described by Lowe in 1854, is now in the University Museum at Oxford, and I have consequently not been able to compare it with the examples (in a recent state) which were taken by myself in Madeira proper, and which are at the present moment before me; nevertheless the diagnostic features of the species are so well-marked, and peculiar, that I think it is impossible to err in identifying the Madeiran individuals with the subfossilized 
Porto-Santan one,-even though the latter is, so far as I can recollect, a trifle more curved, or eccentric, in its general contour than those from which the above (emended) diagnosis has been compiled.

The most important feature which separates the A. eulima from the acicula consists in the presence of a conspicuous medial plait on its ventral paries; but it has other characteristics also which combine to separate it from that species. Thus it is not only longer, more cylindric, and proportionately still slenderer, with a tendency to be obsoletely bent (as in the marine genus Eulima), but its whorls (particularly the intermediate ones) are altogether more lengthened-out and flattened; and its aperture is relatively a little shorter, as well as broader (and more rounded) posteriorly, - the basal margin being more obtusely arcuate, and merging almost without an intervening angle into the columella, which is narrowed gradually (and is not abruptly truncated) behind. The suture is exceedingly oblique, and its surface is of a hyaline white.

Not suspecting them to be otherwise than rather narrow and elongated individuals of the acicula, I unfortunately made no note as to the exact spot where my specimens of the A. eulima were met with in Madeira proper; but they were certainly obtained by myself, and in all probability within the Funchal district. The species however is manifestly rare, for I find only four of them, out of nearly 90 examples of the A. acicula which I have just overhauled.

\section{(§ Cochlicopa, Fer.)}

\section{Achatina lubrica.}

Helix lubrica, Müll., Verm. Hist. ii. 104 (1774)

Glandina lubrica, Morel., Hist. Nat. des Açor. 197 (1860) subcylindrica, Drouet, Faun. Açor. 164 (1861)

Achatina lubrica, Watson, Journ. de Conch. 223 (1876) var. $\beta$. maderensis, Lowe.

Helix lubrica, var., Lowe, Camb. Phil. S. Trans. iv. 61. t. 6 . f. 29 (1831)

Achatina lubrica, $\gamma .$, Pfeiff., Mon. Hel. ii. 273 (1848)

Bulimus maderensis, Lowe, Ann. Nat. Hist. ix. 119 (1852)

Achatina maderensis, Pfeiff., Mon. Hel. iii. 504 (1853)

" " Lowe, Proc. Zool. Soc. Lond. 199 (1854)

Glandina maderensis, Alb., Mal. Mad. 55. t. 14. f. 20, 21 (1854)

Achatina maderensis, Paiva, Mon. Moll. Mad. 104 (1867) Habitat Maderam; sub lapidibus in inferioribus inter- 
mediisque, præsertim cultis, late diffusa. Forsan ex Europâ introducta.

It is only recently that the strictly typical form of this common and widely spread European Achatina has been found in Madeira,-the Rev. R. B. Watson having collected several examples of it, during the summer of 1866, in the garden of the late English Consul, Mr. Veitch, at the Jardim da Serra, more than 2000 feet above the sea. The specimens which have been obtained elsewhere (and the species is well-nigh universal within the cultivated districts) are rather smaller and narrower (or less ventricose) than the ordinary ones of more northern latitudes, and relatively somewhat longer,-the volutions being appreciably less convex, and the penultimate one perhaps a trifle less abbreviated; but I do not think that they can be regarded as representing more than a slight and unimportant geographical phasis of the European type, an opinion which has been expressed also by Mr. Watson and others. Indeed even Mr. Lowe himself treated them as such originally, though he subsequently registered them, under the trivial name of maderensis, as distinct from the lubrica.

The species, which has doubtless been introduced into Madeira, would appear to have established itself equally in the Azorean archipelago, where the examples are said to be precisely similar to the ordinary European ones; and it is likewise quoted by Morelet (Journ. de Conch. xiii. $242 ; 1873$ ), though he does not mention upon what authority, as having been found in the Cape Verdes.

\section{Genus 14. LOVEA, Watson.}

This is a genus which has lately been established by the Rev. R. B. Watson (vide ' Proc. Zool. Soc. Lond.' 677 ; 1875) to contain the truly indigenous species in the Madeiran archipelago which have hitherto been cited as Achatinas; and it would seem, from Mr. Watson's remarks, to possess just about a similar claim for generic separation as Arion does from Limax or as Nanina does from Helix. Its main distinctive feature consists in the highly significant fact that the tail of the animal, which is obliquely lopped-off at the tip, is furnished with a mucous gland on the angle which is formed by the truncation, at a short distance behind the extreme apex. And, as a further peculiarity, 'the mantle,' adds Mr. Watson, ' extends beyond the edge of the aperture all round. It is thinly spread over the outside of the shell, and extends like a tongue backwards behind the posterior corner of the aperture.' All the members of the genus have the shell highly polished,-6its 
brilliant lustre being obviously connected with the perpetual movement upon it of the mantle, and especially of its posterior prolongation (a movement eminently characteristic, likewise, of Nanina).'

The precise species which were examined by Mr. Watson are the melampoides, tornatellina, triticea, and oryza; and, through the kinduess of Senhor J. M. Moniz, I have since been enabled to forward to him living examples of what we have hitherto regarded as the folliculus, Gron., but which Mr. Watson (believing that the caudal gland could not possibly have been overlooked in the widely distributed Gastropod which is known on the continent by that name) has lately re-described under the title of 'Lovea Wollastoni.' Into this particular question I will not now enter (my own conviction, nevertheless, being that the Madeiran and Mediterranean shells do not differ specifically from each other, and that the important structure upon which the genus Lovea is based has simply, in the case of the folliculus, Gron., escaped the observation of European naturalists); but, be the nomenclature what it may, there can at any rate be no question that the subterminal gland is just as conspicuous in the 'folliculus' (whether rightly or wrongly so called) of Madeira as it is in the few species which were overhauled originally by Mr. Watson, and that consequently it is a true and veritable exponent of his genus Lovea. As no less than five of these immediately aliied forms have therefore been ascertained to possess the peculiarity to which attention has just been drawn, we shall perhaps be warranted in assuming it for the remainder, - at all events until it has been actually proved that it does not exist. ${ }^{1}$

Two species however which were examined by Mr. Watson seemed to be destitute of the structure to which I have above referred, and they must consequently be excluded from the genus as defined by him. These are the common European $A$. acicula and lubrica, enumerated above,-which are mere importations into Madeira, and belong apparently to a different type.

(§ Ferussacia, Risso.)

Lovea folliculus.

Helix folliculus, Gronov., Zoophyl. fasc. 3. 296. t. 19. f. 15, $16(1781)$

Achatina folliculus Pfeiff., Mon. Hel. ii. 283 (1848)

${ }^{1}$ As for the Canarian species, they are too nearly related to the distinctively Madeiran ones, and to the folliculus, not to be admitted (by presumption) into the same genus; but I would wish, nevertheless, to state that their animals have yet to be examined. 
Achatina folliculus, Lowe, Proc. Zool. Soc. Lond. 200 (1854)

Glandina folliculus, Alb., Mal. Mad. 57. t. 15. f. 3, 4 (1854)

Achatina folliculus, Paiva, Mon. Moll. Mad. 106 (1867)

Lovea Wollastoni, Watson, Proc.Zool. Soc. Lond. 334 (1877)

Habitat Maderam australem; sub lapidibus in aridis apricis inferioribus, præcipue inter dumeta Opuntice Tuno, Dill., haud infrequens.

The Achatina folliculus of Mediterranean latitudes (-a species which occurs more particularly in south-western Europe and the north of Africa) is not uncommon at low elevations, around Funchal, in Madeira proper,-where it was first detected by Mr. Leacock, and where it is far from unlikely that it may have become naturalized from Portugal. It is found chiefly, beneath stones, in hot and rocky situations, near the coast, amongst plants of the Opuntia Tuna (or 'Prickly Pear'), - as, for instance, above the Lazaretto, and slightly further to the eastward in the direction of the Brazen Head; but I have also met with it to the west of Funchal, towards the Gorgulho,within the crevices of the friable soil (especially after showers) in the early spring; and it is recorded likewise from the hill immediately above the last-mentioned district, namely the Pico da Cruz, as well as from the Pico de São João.

In its rather large size and pale yellowish-corneous hue the L. folliculus has somewhat the primâ facie aspect of the tornatellina; nevertheless its obtuser and more oblong (or perhaps fusiform) outline, in conjunction with its more oblique suture, its almost simple columella ${ }^{1}$ and its totally different aperture, which is very much shorter and is not produced backwards (or acuminated obliquely) along the body-volution, will at once distinguish it-not merely from that species, but likewise from the whole five exponents of the particular section (Amphorella, Lowe) to which the L. tornatellina belongs.

The L. folliculus is stated by Webb and Berthelot to be found also in the Canaries; but this, according to Mousson, appears to have been a mistake, - the species which was probably referred to by them being distinct, and described by the latter (Faun. Mal. des Can., 129) under the trivial name of 'Reissi.' I am exceedingly doubtful however whether the Reissi (or indeed whether the equally allied $L$. Vescoi, Bourg., from Malta) is anything more, in reality, than a slight geographical phasis of the $L$. folliculus. ${ }^{2}$

1 The Madeiran examples have the columella nearly simple; but there is said by Mr. Lowe to be a rather more evident callosity in those from Portugal.

2 Judging from some examples, in a living state, which I observed when 


\section{Lovea Leacockiana.}

Achatina Leacociana, Lowe, Ann. Nat. Hist. ix. 119 (1852)

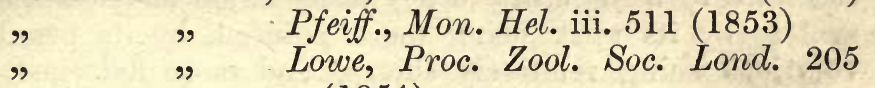
(1854)

Glandina Leacociana, Alb., Mal. Mad. 57 (1854)

Achatina Leacociana, Paiva, Mon. Moll. Mad. 105 (1867)

Habitat Maderam; sub lapidibus, præsertim in humidiusculis inferioribus, rarissima.

I cannot agree with Mr. Lowe that the present shell has a stronger affinity with the Porto-Santan L. ovuliformis than it has with his common Achatina maderensis (i.e.lubrica, Müll.) of Madeira proper, though its rather small size and its extremely thin substance and subhyaline surface are points in which it makes an evident approach to the former ; for in the slight (though certainly very slight) tumidity of its volutions, as well as in its general outline and its perfectly edentate mouth, it is most unquestionably more in accordance with the latter. There can however be no possibility of actually confounding it with the $A$. lubrica,-its smaller size, rather narrower outline, and even still more transparent substance, added to its somewhat less blunted apex, its more elongate and more laterally-straightened aperture, its more acute (or less thickened) peristome, and the fact of its columella being dilated into a posteriorly-truncate process, being abundantly sufficient to distinguish it from that species.

The L. Leacockiana occurs sparingly in Madeira proper, at rather low and intermediate elevations, and was first detected by T. S. Leacock, Esq., in the Ribeira de João Gomes; above Funchal, and subsequently by the Rev. R. B. Watson,-near, I believe, to the Levada da Senhora do Bom Successo; and there are examples of it in Mr. Lowe's collection which would appear to have been found in the north of the island, in the vicinity of Porto Moniz.

The Baron Paiva records a larger state of this species from the Ponta de São Lourenço, in the extreme east of Madeira; but as I have not seen a type of the particular form to which he alludes, I cannot vouch for its being strictly conspecific with the L. Leacockiana. Possibly indeed it may be identical with the one which I have enunciated below as the L. iridescens,

in Madeira, the animal of the $L$. folliculus (including the pedal disk) is of pale clear greenish-yellow, with the tentacles (and less so the neck) of a slatey-grey. It is carinated behind, wrinkled with oblique lines on either side, and has the subapical prominence or gland very distinguishable when the creature is in certain positions, though less easy to be traced when the body is much straightened out. 
and which I obtained from the (likewise eastern) region between Sta. Cruz and Caniço,-but which differs from the Leacockiana by being (inter alia) rather larger and less fragile, as well as by its apex being more pointed, by its penultimate volutions being relatively shorter and more flattened, by its columella (although less posteriorly-dilated) being more flexuose, and by its entire surface being appreciably iridescent.

\section{(§ Fusillus, Lowe.)}

\section{Lovea gracilis.}

Helix gracilis, Lowe, Cambr. Phil. S. Trans. iv. 61. t. 6. f. 28 (1831)

Achatina gracilis, Pfeiff., Mon. Hel. ii. 284 (1848)

" $\quad$ \%. vitrea, Lowe, Proc. Zool. Soc. Lond. 200 (1854)

Glandina gracilis, Alb., Mal. Mad.56.t. 14. f. 24, 25 (1854) Achatina gracilis, $\beta$. vitrea, Paiva, Mon. Moll. Mad. 107 (1867)

Habitat Portum Sanctum (hinc inde in montibus vulgaris), necnon Desertam Grandem Desertamque Australem (rarissima).

The L. gracilis was considered by Mr. Lowe to include three well-marked phases, - namely the 'var. vitrea' (which is small, thin, extremely glossy and hyaline, and which, from its being the state which was originally described and figured by him as the 'Achatina gracilis,' must be regarded as the typical one $^{1}$ ); the 'var. subula' (which is larger and more elongate, thicker in substance, less shining in surface, less transparent, and somewhat yellower in hue); and the 'var. terebellu' (which is altogether larger still, and more ventricose and convex, and has its aperture a trifle longer, wider, and more outwardlyrounded and developed). But, after much consideration, I am inclined to think that it will be more natural to regard at any rate the 'var. vitrea' as specifically distinct, in which case it alone will represent Mr. Lowe's Achatina gracilis. And this is all the more desirable, inasmuch as that particular form is not merely Porto-Santan (like the subula and terebella), but one which occurs likewise on the Desertas, - it having been taken on the Deserta Grande by myself, and obtained from the Southern Deserta by the Baron Paiva.

As thus limited, therefore, the $L$. gracilis may be known by its small size and somewhat slender outline, by its extremely

1 Although this is mentioned expressly by Mr. Lowe in his 'Synopsis Diagnostica,' I am likewise able to corroborate it from my own observation,inasmuch as I possess the two original examples from which his figure (in the 'Transactions of the Cambridge Philosophical Society') was taken. 
thin, almost colourless, and transparent substance, and by its rather wide (or expanded) but nevertheless simple (or basally untruncate) arcuated columella. Although it has been found sparingly (as just stated) on the two Southern Desertas, it is a species which is more particularly characteristic of Porto Santo,-where I have met with it in profusion, beneath stones, on the exposed mountain ridge which connects the Pico de Facho with the Pico do Castello. Mr. Lowe's original examples, however, were from the Pico Branco.

\section{Lovea terebella.}

Achatina terebella, Lowe, Ann. Nat. Hist. ix. 120 (1852) " gracilis, a. terebella, et $\beta$. subula, Lowe, Proc. Zool. Soc. Lond. 200 (1854)

Glandina terebella, Alb., Mal.Mad.56.t. 14. f.22, 23 (1854) Achatina gracilis, a. subula, et $\gamma$. terebella, Paiva, Mon. Moll. Mad. 107, 108 (1867)

\section{, Lowei, Id., Ibid. 108 (1867)}

Habitat Portum Sanctum,-a. subula præcipue in insulis parvis adjacentibus 'Ilheo de Cima' et 'Ilheo de Baixo' dictis; sed $\beta$ (normalis) in montibus excelsioribus Portûs Sancti proprii, præsertim in Pico Branco occurrens. In arenâ calcareâ, semifossilis, parcissime invenitur.

As already stated, the present Lovea, which seems to branch off into two tolerably distinct forms, was regarded by Mr. Lowe as conspecific with his Achatina gracilis; but I think it will be more natural to treat it (as indeed Dr. Albers has done) as separate from the latter. Indeed I am far from certain that even the two phases into which it is supposed to develope would not be isolated by some monographers; though as they seem to me almost to pass into each other, I will not attempt to disassociate them. The forms in question correspond with $\mathrm{Mr}$. Lowe's 'var. subula' and 'var. terebella' of his Achatina gracilis; and I should have preferred to retain the first of those names, as perhaps expressing the species (as now limited) the more accurately, had not that title been already preoccupied by an Achatina by Dr. Pfeiffer (Wiegm. Archiv. i. 352) in 1839, - thirteen years before it was employed by Mr. Lowe. Hence, since 'terebella' must of necessity be accepted as the title, it follows that the particular shell to which Mr. Lowe intended the latter to apply must be looked upon as the normal aspect of the $L$. terebella as here understood.

The two forms into which the $L$. terebella separates itself (although nearly, as it seems to me, if not indeed quite, merging into each other) may be defined as (1) a smaller one, which 
is likewise relatively narrower and more acute, and with the lip of the aperture less externally-rounded,-the 'var. subula' of Lowe; and (2) another, which is appreciably larger and more ventricose and convex, and with the outer lip more rounded posteriorly (causing the aperture to be a trifle wider and altogether more developed), - which corresponds with the 'var. terebella' of Lowe's Achatina gracilis. The first of these phases I have taken abundantly on the islands adjoining Porto Santo, known as the Ilheo de Cima and the Ilheo de Baixo, as well as on the Pico de Baixo (of the mainland) exactly opposite to the former; whilst the second occurs at a higher altitude, and has been found principally, so far as I can now recollect, on the Pico Branco.

In a subfossil condition the L. terebella appears to be scarce, and the few examples of it which I possess are somewhat intermediate between the states above alluded to; though on the whole I think that they agree better perhaps with the a. subula than with the larger (or typical) form.

Were I to judge solely from six examples which are now before me, and which were communicated by the Baron Paiva, the 'Achatina Lowei' of the latter (recorded by him from the Pico Branco in Porto Santo) is absolutely identical with the common $L$. oryza,-there being no difference in them whatsoever, so far as I can detect, on which to found even a 'variety.' Nevertheless I am so satisfied, from the Baron's diagnosis, that the species to which he really alluded is the larger (or normal) phasis of the $L$. terebella, that I have not the slightest hesitation in referring his Achatina Lowei to that particular form. Indeed his following diagnostic observation expresses so exactly the precise points in which the L. terebella differs from the oryza that I quote it verbatim:-' $A$. oryzo, Jowe, quodammodo analoga; testâ vero tenuiore, aperturâ ampliore, pariete aperturali tuberculo destituta distinguitur.' ${ }^{1}$

\section{Lovea oryza.}

Helix triticea, $\beta$. edentula, Lowe, Cambr. Phil. S. Trans. iv. 61. t. 6. f. 26 (1831)

1 There is a 'var. $\delta$. ventricosa' of the L. gracilis which is recorded by the Baron Paiva as having been taken by Mr. Watson on the Ilheo de Fora, at the extremity (in Madeira proper) of the Ponta de São Lourenço, and which, from its being placed by him in juxta-position with the terebella, ought here to be noticed. Having no type for comparison, I am not able to satisfy myself concerning its affinities, and I deem it sufficient therefore to call attention to the fact, that either the L. tercbella or some closely allied form appears to exist on the particular point of Madeira proper which is nearest to the island of Porto Santo. 
Achatina Paroliniana (pars), W. et B., Ann. des Sc. Nat. 28. syn. 320 (1833)

$" \quad " \quad$ d'Orb., in W. et B. Hist. 73 (1839)

" triticea, B. edentula, Pfeiff., Mon. Hel. ii. 278 (1848)

" oryza et tuberculata, Lowe, Ann. Nat. Hist. ix. $120(1852)$

99

Tandoniana, Shuttl., Bern. Mitth. 293 (1852) oryza et tuberculata, Lowe, Proc. Zool. Soc. Lond. 204 (1854)

Glandina oryza, Alb., Mal. Mad. 58. t. 15. f. 7-10 (1854) Achatina triticea, var., Paiva, Mon. Moll. Mad. 110 (1867) Cionella Tandoniana, Mouss., Faun. Mal. des Can. 129 (1872)

Lovea oryza, Watson, Proc. Zool. Soc. Lond. 680 (1875)

Habitat Portum Sanctum; sub lapidibus in montibus vulgaris. Semifossilis in arenâ calcareâ hinc inde reperitur.

This and the L. triticea are the common Loveas of Porto Santo, to which island they would seem to be peculiar; but, of the two, the $L$. oryza is perhaps rather the less abundant. In size and general aspect, indeed, they are almost coincident,except that the oryza is, on the average, of a paler hue, as well as destitute of the strong medial ventral plait which is so conspicuous within the aperture of its ally; a small and obsolete tubercle being all that is ever apparent to represent the powerfully developed plait of the $L$. triticea.

Yet the L. oryza appears to me to have, like so many of the species, two tolerably well-defined states, which nevertheless pass into each other by imperceptible gradations,-namely a larger and more ventricose one, which was treated by Mr. Lowe (under the name of tuberculata) as specifically distinct, in which the two rudimentary ventral callosities (i.e. the longitudinal upper one and the medial tubercle) are, together with that on the columella, rather more expressed; and a smaller one, which is appreciably less convex, and which has the callosities above referred to only just traceable. This phasis, last mentioned, is the normal Achatina oryza of Lowe; and it is extremely abundant at most elevations in Porto Santo, - often swarming beneath large slabs of stone, particularly on the mountain slopes of a somewhat high altitude.

In general size and aspect the $L$. oryza has a considerable prima facie resemblance to the larger (or typical) form of the terebella; nevertheless on a closer inspection it is impossible to confound it with that species,-it being not only a trifle less elongated, or more ventricose, with its aperture relatively some- 
what shorter, but the entire shell is very much more solid and robust, of a more decided yellowish-white (with no tendency to be subtransparent), with its peristome thicker, and with the two ventral callosities (which appear to be absent in the $L$. terebella), although very slight and rudimentary, quite traceable.

In a subfossil condition the $L$. oryza is tolerably common, though less so than the triticea. It was met with subfossilized, both by Mr. Lowe and myself, at the Zimbral d'Areia.

I have little doubt that this is the particular 'Achatina' which, through the unpardonable inaccuracy of Webb and the after-confusion of d'Orbigny, has been allowed to figure in the Canarian catalogue, for now so many years, and in conjunction with the closely allied $L$. triticea, - first as a portion of the 'A. Paroliniana,' W. et B. (from which it is specifically quite distinct), and subsequently (i.e. since 1852) as the ' $A$. Tandoniana,' Shuttl. There can be no question that Mr. Webb's carelessness in introducing Madeiran species into his very meagre Canarian list was well-nigh unprecedented. To say nothing of Cape Verde forms which were equally pressed into his service, I need only allude to such Helices as the H.toeniata and tiarella, which are confined to the single island of Madeira proper but which were cited by him as Canarian, in support of this; and, therefore, since I happen to be aware that during $1828 \mathrm{Webb}$ collected with Mr. Lowe in Porto Santo, where these two Loveas absolutely swarm (and to which they are peculiar), I should be tolerably prepared, under the circumstances, not to feel greatly surprised if Webb should have so far confused their habitats as to assign them a place in his Canarian 'Synopsis' on which he was shortly afterwards engaged. This at least has long been an à priori conjecture of my own, which I have been anxious to put to the test whensoever an opportunity for sifting the evidence might arrive; and it was therefore quite in accordance with my preconceived idea that on examining lately an original type of the 'A. Paroliniana' in the d'Orbignyan collection at the British Museum, I found it to be absolutely and unmistakeably nothing but the $L$. triticea, Lowe, of Porto Santo! This therefore disposed at once of Webb's 'A. Paroliniana;' but there was still the further question - as to what the so-called 'edentate form' should be referred, which was mixed-up with the 'A. Paroliniana' (i.e. the triticea), but of which the type, although said to be in the British Museum, was nowhere to be found. Fortunately the specimens in the cabinet of Moquin-Tandon (who was the first person to discover that two distinct shells had been confounded by Webb under the title of 'Paroliniana') are 
said to be labelled 'Pico Branco,'-a fact which at once solves the mystery; for 'Pico Branco' is evidently the very mountain in Porto Santo where these two Loveas are found in the greatest abundance, and associated! I know of no other 'Pico Branco' throughout the whole of these Atlantic archipelagos, and I have the most positive evidence that Webb ascended Pico Branco many times, in 1828, in company with Mr. Lowe, for the express purpose of collecting shells and plants. So that I have no more doubt that the 'A. Tandoniana,' which Shuttleworth eliminated (in 1852) from Webb's previously described ' $A$. Paroliniana,' is the Porto-Santan $L$. oryza, Lowe, than I have that the A. Paroliniana proper is (as is proved to a demonstration by the British-Museum type) the equally Porto-Santan L. triticea.

\section{Lovea triticea.}

Helix triticea, a. biplicata, Lowe, l. c. 61. t. 6. f. 25 (1831) Achatina Paroliniana (pars), W. et B., l. c. Syn. 320 (1833) Bulimus Parolinianus " d'Orb., in W. et B. Hist. 73 (1839)

Achatina triticea, a. biplicata, Pfeiff., Mon. Hel. ii. 278 (1848)

Lowe, Proc. Zool. Soc. Lond. 205 (1854)

Glandina triticea, Alb., Mal. Mad. 57, t. 15. f. 5, 6 (1854)

Alsobia Paroliniana, Bourg., Amen. Mal. ii. 94 (1858)

Azeca Paroliniana, Pfeiff., Mon. Hel. iv. 646 (1859)

Achatina triticea (pars), Paiva, Mon. Moll. Mad.109 (1867)

Azeca Paroliniana, Mouss., Faun. Mal. des Can. 128 (1872) Lovea triticea, Watson, Proc. Zool. Soc. Lond. 680 (1875)

Habitat Portum Sanctum; sub lapidibus, præsertim in editioribus, una cum $L$. oryza degens, copiosissime occurrit. In statu semifossili in calcareis invenitur.

This is the commonest of the Loveas of Porto Santo,where it occurs beneath stones, often in great profusion, and more or less associated with the $L$. oryza, on most of the mountain slopes. I have already mentioned that it very closely resembles the latter; nevertheless there can be no possibility of confounding the two species, - the strongly developed medial ventral plait within the aperture of the $L$. triticea, added to the fact that the callosity of its columella is likewise appreciably increased, being of themselves quite sufficient to distinguish it from its ally. It is also, perhaps, on the average, just perceptibly smaller than the normal state of the oryza; its colour is usually darker, or of a more corneous brown; and there seems to be no indication of the subvertical ventral 
callosity towards the angle of the outer lip which is always faintly traceable in the smaller (or typical) aspect of that species, and which is more conspicuously developed in the larger one (or ' $\beta$. tuberculata').

In a subfossil condition the $L$. triticea is more abundant than the oryza, though perhaps nowhere exactly common. In the calcareous deposits at the Zimbral d'Areia it was met with in tolerable abundance by Mr. Lowe and myself, during our encampment there in the spring of 1855 .

I called attention under the $L$. oryza to the fact that this common Porto-Santan Lovea is unquestionably the species (as is proved to a demonstration by an original type which is now in the British Museum) which Webb described as $C a-$ narian under the name of 'Achatina Paroliniana,'-from examples which he had himself collected, in company with Mr. Lowe, on Pico Branco, in 1828! Considering that he was engaged so shortly afterwards in the compilation of his Canarian 'Synopsis,' it is simply disgraceful that an error so gross, as regards habitat, could possibly have been committed; but those who, like Mr. Lowe, were personally acquainted with Webb, were well aware of his extreme inaccuracy-not merely on the question of localities, but also in the unnecessary mixing up of his various material; and it was quite in accordance, therefore, with this particular idiosyncrasy that he should have pressed into his service (apparently to augment his very meagre Canarian list) not only Madeiran forms, like the present and preceding Loveas and such distinctive Helices as the H. toniata and tiarella, but others from even the Cape Verdes! In the instance now under consideration, however, he fell into the additional mistake of not merely citing the species as Canarian and giving no less than three separate islands as its habitat (which all subsequent experience has shown to be false), but also of mixing up with it a totally distinct form-which I have already shown can pertain to nothing else than the equally Porto-Santan $L$. oryza, and which was subsequently eliminated by Shuttleworth (in 1852) as the 'Achatina Tandoniana.' As for d'Orbigny's share in all this unnecessary confusion, he unfortunately made matters still worse by figuring a shell as his 'Bulimus Parolinianus' which could not by any possibility be made to quadrate either with his own diagnosis or that of $\mathrm{Mr}$. Webb! - and which consequently has to be ignored altogether as being not only valueless but even deceptive. 
( $\$$ Amphorella, Lowe.)

\section{Lovea melampoides.}

Helix melampoides, Lowe, Cambr. Phil. S. Trans. iv. 60. t. 6. f. 24 (1831)

Achatina tornatellina, $\beta .$, Pfeiff. Mon. Hel. ii. 277 (1848) " $\quad$ Lowe, Proc. Zool. Soc. Lond. 203 (1854)

Glandina melampoides, Alb., Mal. Mad. 59.t. 15. f. 13, 14 (1854)

Achatina tornatellina, $\gamma$. maxima, Paiva, Mon. Moll. Mad. 112 (1867)

Lovea melampoides, Watson, Proc. Zool. Soc. Lond. 679 (1875)

Habitat Portum Sanctum, aut potius in ins. parvâ adjacente 'Ilheo de Cima' dictâ; sub lapidibus magnis vulgaris. In statu semifossili etiam in Portu Sancto ipsissimo occurrit,-sc. in rupe quâdam lutosâ maritimâ, haud procul ab oppidulo, a meipso lecta.

The present species and four following ones may be known from the rest of the Loveas here enumerated by (inter alia) the peculiar conformation of their mouth,-which is extremely elongate, or acuminated backwards (and that, too, obliquely), so as to shape out a narrow and very acute space for its hinder region. And of the five more or less closely allied species which have hitherto been brought to light, the $L$. melarnpoides is conspicuous for being much the largest and the most solid, the shell being remarkably thick in substance.

At first sight indeed the L. melampoides might almost be supposed to represent some gigantic and strongly developed race of the $L$. tornatellina, but I think that it has too many peculiarities of its own to render that conclusion a safe one. Thus, it not only differs in its bulk and solidity, but it is likewise a little less glossy, and less ventricose (or rounded) in outline, its aperture is wider (or more expanded outwards) posteriorly, its columella is broader and less tortuous, its outer lip is not quite so obliquely sloped-off, and the two rudimentary ventral callosities which (although sometimes indistinct) are always traceable in that species are apparently quite obsoleteor even altogether absent. Moreover the L. melampoides has a tendency to merge occasionally into a very bea'stiful albino, or snowy-white, state (which assumes almost the appearance of china or marble),-a peculiarity which is quite unknown in the tornatellina. At any rate as I have seen nothing approaching to a connective link between the $L$. melampoides and the tornatellina, I do not understand on what prin- 
ciple we have a right to treat the one as a mere development of the other; and, $\grave{a}$ fortiori, therefore, I cannot but think it extremely rash that the Baron Paiva should have ventured to record as conspecific (as it seems to me, without even a semblance of evidence) the whole of the members of this section, and that too whilst recognising the claims of the far more intimately related forms around the Helix polymorpha, and even himself proposing several of them as specifically distinct!

In its present area of distribution the $L$. melampoides is marvellously circumscribed, - the little island known as the Ilheo de Cima, off the south-eastern extremity of Porto Santo, being the only spot in which it has hitherto been observed; and there might have been some show, therefore, of plausibility, in assuming it to be a local or insular modification of the $L$. tornatellina, did it not exist in a subfossil condition on the mainland likewise, - thus proving to a demonstration that its exaggerated features as now displayed (if we may be permitted so to call them) are not due to any fancied influences of isolation on a remote and almost inaccessible rock; for I have myself met with it in the muddy deposit of an exposed sea-cliff (below the Pico dos Maçaricos) to the eastward of the villa, or town. Hence, since the L. tornatellina (so common in Madeira proper, and less so on the Desertas) is found likewise (though sparingly) in Porto Santo, I do not see how we can escape the conclusion that the melampoides is truly distinct from that species, and has no claim to be regarded as even a Porto-Santan (and still less a more confined insular) modification of it, or one either which has been gradually matured since the close of the subfossil period. ${ }^{1}$

\section{Lovea tornatellina.}

Helix tornatellina, Lowe, Cambr. Phil. S. Trans. iv. 59. t. 6. f. 23 (1831)

1 The $L$. melampoides is said by the Baron Paiva (who, as just stated, treated it as an enlarged phasis of the tornatellina) to occur likewise on the Ilheo de Baixo and the Theo de Ferro, and sparingly on even the Deserta Grande; but I cannot but look with suspicion on these habitats, particularly the last one,-and all the more so because the Baron's material was collected by various people, and brought to him at Funchal; and to my own certain knowledge a large number of the boxes of specimens which he transmitted to me, from time to time, for examination, were wrongly labelled as regards their localities, - Madeiran, Desertan, and Porto-Santan forms (all of them quite unmistakeable) being often mixed up indiscriminately. Until therefore further evidence has been obtained, I shall look upon the $L$. melampoides as still confined (in its recent state) to the Iheo de Cima; though, at the same time, I think it far from unlikely that it may be met with also on the Illeo de Baixo. 
Achatina tornatellina (pars), Pfeiff., Mon. Hel. ii. 277 (1848) " " Lowe, Proc. Zool. Soc. Lond. 203 (1854)

Glandina tornatellina, Alb., Mal. Mad. 58. t. 15. f. 11, 12 (1854)

Achatina tornatellina (pars), Paiva, Mon. Moll. Mad. 111 (1867)

Lovea tornatellina, Watson, Proc. Zoul. Soc. Lond. 680 (1875)

Habitat Maderam, vulgaris; in Deserta Grandi et Desertâ Australi, necnon in cacuminibus montium Portûs Sancti, multo rarior. In statu semifossili ad Caniçal, Maderæ, sat copiose reperitur.

This is the common Lovea in Madeira proper, where it is well nigh universal; and it occurs also, though much more rarely, on the two Southern Desertas as well as on the summit of the Pico Branco in Porto Santo; and, like so many of the members of the genus, it seems to present two or three slightly different phases, which however merge into each other by intermediate gradations. The first of these, $a$ [major], is found principally in the sylvan districts of a comparatively high altitude in Madeira proper, and is typically rather large, ventricose, and highly coloured, with the subvertical ventral plait elongate and narrow, and the columella a good deal (and abruptly) expanded at the base; the second, $\beta$. [minor], which is also common in Madeira proper, but is more particularly characteristic of the exposed submaritime cliffs, is, on the average, smaller, and not quite so rounded, generally a trifle paler in hue, with the subvertieal ventral plait a little shorter and more dentiform (or more abruptly terminated behind), and with the columella not quite so broad; whilst the third, $\gamma$. [intermedia], which is met with sparingly on the two Southern Desertas and on the summit of the Pico Branco in Porto Santo, is somewhat intermediate in stature between the ' $a$ ' and ' $\beta$,' and has the subvertical ventral plait (although scarcely dentiform as in the ' $\beta$.') distinctly expressed and rather further removed from the angle of the lip, and the inner medial tubercle not altogether obsolete,-it being, although indistinct, quite appreciable. These varieties, however, pass gradually into each other, and are of too trifling importance to need separate subspecific titles.

Three examples of this very abundant Madeiran Lovea were taken in Porto Santo, by the Rev. R. T. Lowe, in 1828,namely on the summit of the Pico Branco; and it has been obtained sparingly from the two southern Desertas by the Baron Paiva. 
In a subfossil condition, the L.tornatellina is tolerably common at Caniçal; but I am not aware that it has been observed in the deposits of either Porto Santo or the Bugio.

Although regarded hitherto as quite peculiar to the Madeiran archipelago, I may just add that a single example of it, which I have inspected with the greatest care, was met with by Mr. Watson, a few years ago, in Grand Canary.

\section{Lovea mitriformis.}

Achatina mitriformis, Lowe, Ann. Nat. Hist. ix. 120 (1852) Azeca? mitriformis, Pfeiff., Mon. Hel. iii. 522 (1853) Achatina mitriformis, Lowe, Proc. Zool. Soc. Lond. 203 Glandina (1854)

Glandina $\quad$ Alb., Ma

Achatina tornatellina (pars), Paiva, Mon. Moll. Mad. 112 (1867)

Habitat Maderam Desertasque tres (præsertim has), vulgaris : in Portu Sancto rarissima,-sc. semel tantum, in summo monte 'Pico Branco' dicto, adhuc lecta. In statu semifossili in ins. Desertâ Australi invenitur.

It is far from impossible that this may be in reality but a rather narrow and slightly elongated form of the L. tornatellina, in which the subvertical ventral plait is more appreciably dentiform; and all the more so, since the examples of it in Madeira proper have the latter less abruptly expressed than in those from the Desertas and Porto Santo. Nevertheless since the shell has undoubtedly a different outline and facies, and it was the opinion of Mr. Lowe that it is not absolutely conspecific with the tornatellina, I will not attempt (as the Baron Paiva has done) to suppress it. Indeed the mere fact of its occurring on the whole five islands of the Group, and often in company with the tornatellina, would supply a certain amount of at any rate presumptive evidence that it is at least no local phasis of that universal species. But these abstract questions of 'species' and 'variety' are so difficult (indeed in many instances so impossible) to solve, that where any given form is sufficiently well defined to be easily recognisable, and it is not connected with its nearest ally by decided intermediate links, I prefer for my own part (at any rate in those instances where it has already been enunciated and published) to accept it as specifically distinct.

With these remarks I may add that the $L$. mitriformis is separable from the tornatellina, mainly, by its relatively somewhat narrower and more elongate outline (the form being less ventricose, the spire a trifle more produced, and the suture 
sensibly more oblique), and by the fact of the subvertical plait of its aperture having a tendency to become more strictly toothlike (or abruptly terminated behind). It is true that the state ' $\beta$.' of the tornatellina has that callosity more dentiform than the state ' $a$. ,' and that it consequently makes an approach in that respect to the mitriformis ; and it is equally certain that the Madeiran individuals of the latter have the same plait more narrow and linear than those from the other islands; but I have merely to remark that, in all instances, where one specific feature seems to fail, the others (as though to guard against confusion) are expressed; and I arrive therefore at the original conclusion (which was adopted by Mr. Lowe) that the two shells are more safely to be treated as specifically distinct.

In certain ravines of Madeira proper (as, for instance, the Ribeira de Sta. Luzia) the L. mitriformis is tolerably abundant, for the most part amongst the detritus on the ledges (and at base) of the lofty perpendicular rocks ; and on the three Desertas I have myself taken it, in common with Mr. Lowe and others, in considerable profusion. In the examples from those islands the subvertical plait is unusually prominent and tooth-like, and the species may consequently be said to attain there its maximum, or normal phasis. The individuals from the Flat Deserta (or Ilheo Chão) are rather pallid in hue, whilst those from the Southern island (or Bugio) are comparatively dark and highly coloured.

In Porto Santo the L. mitriformis appears to be extremely scarce. Indeed its existence there at all is vouched for by merely a single dead example which was found by Mr. Lowe, in 1828, on the Pico Branco. That the latter however is truly identical with the mitriformis (and not with the tornatellina) I am able to assert (apart from the assurance of Mr. Lowe) by actual observation,- the example alluded to, in every respect characteristic of the mitriformis, being now before me.

The $L$. mitriformis is common in a subfossil state on the Southern Deserta, where I have myself met with it in the muddy depnsits on the extreme summit of that almost inaccessible island ; but it has not, I believe, been observed in the calcareous beds either of Madeira proper or Porto Santo.

\section{Lovea producta.}

Achatina producta, Lowe, Ann. Nat. Hist. ix. 120 (1852)

$" \quad$ " $\quad$ Pfeiff., Mon. Hel. iii. $505(1853)$

Glandina producta, Alb., Mal. Mad. 60 (1854) 
Achatina tornatellina (pars), Paiva, Mon. Moll. Mad. 113 (1867) rarissima.

Habitat Desertam Australem; inter herbas lapidesque,

The present Lovea and the following one would fall strictly under Lowe's section Hypselia, in which the outline is relatively narrower and slenderer than in Amphorella, the substance thinner and rather transparent, the suture more oblique, the penultimate volution more elongated, and the aperture perfectly free from callosities and plaits. Yet since the mouth and columella have the peculiar structure which is so characteristic of A mphorella, I hardly think that the L. producta and iridescens will require us to acknowledge a separate subgenus for their reception. At the same time, with such manifest peculiarities as those to which I have just called attention, I must protest against the extreme rashness of the Baron Paiva in treating the former of those species (for the latter one still remains to be enunciated) as a mere variety of the $L$. tornatellina.

Indeed were it not for the structure of its aperture and columella, the $L$. producta would have more in common with the section Fusillus than it has with Amphorella,-its narrowed contour, oblique suture, and subpellucid surface, in conjunction with its freedom from callosities and plaits, being more suggestive of such species as the terebella than of the mitriformis and tornatellina.

So far as has been observed hitherto, the L. producta is found only on the Southern Deserta (or Bugio),-where it was first detected by Mr. Leacock, and whence it has been obtained subsequently by Mr. Lowe and myself, and more recently by the Baron Paiva; but we did not meet with it in the muddy, subfossiliferous deposits on the summit of that island.

\section{Lovea iridescens, n. sp.}

T. angustula, cylindrico-subulata, fragilis, subpellucida, iridescenti-nitens, spirâ productâ ; anfractibus subconvexiusculis, suturâ distinctâ obliquâ ; aperturâ angustâ, supra attenuatâ aut retro oblique productâ, omnino edentulâ; peristomate tenui, acuto, labro dextro rectiusculo ; columellâ abbreviatâ, arcuatâ, subtortâ, subexpansâ sed basi vix prominulâ.-Long. vix 3 lin.

Habitat Maderam; inter Caniço et Sta. Cruz, ad Euphorbiarum radices adherens, lecta.

The present Lovea, which appears to be quite distinct from every member of the group which was described by Mr. Lowe, belongs to exactly the same type as the South-Desertan $L$. producta, its rather narrow, subulate outline, oblique suture, 
fragile consistency, and perfectly edentate, backwardly (and obliquely) acuminated mouth being strongly suggestive of that species. Nevertheless specifically it is quite distinct, - its smaller size, darker hue, and conspicuously iridescent surface, in conjunction with its slightly shorter and more attenuated spire, its rather less flattened volutions (the penultimate one of which is not so elongate), its still thinner and more pellucid substance, and the fact of its columella being less twisted and not so prominent at the base, being more than enough to separate it immediately from the $L$. producta.

My diagnosis of this Lovea is drawn out from eight examples which I obtained in a rather singular manner. Whilst residing at S. Antonio da Serra, in the spring of 1870 , I sent down to the drF, eastern district between Caniço and Sta. Cruz to procure some plants of the Euphorbia piscatoria, which were consequently brought to me in considerable abundance; and adhering to the earth around their roots were several common Madeiran Helices (such as the $H$. arcta and maderensis), and intermingled with the latter were these individuals which seem to me to represent a Lovea which is unquestionably new. It is probable therefore that the species, when searched for in the proper localities, may be found to be tolerably abundant.

\section{(§ Cylichnidia, Lowe.)}

\section{Lovea ovuliformis.}

Helix ovuliformis, Lowe, Cambr. Phil. S. Trans. iv. 61. t. 6. f. 27 (1831)

Achatina ovuliformis, Pfeiff., Mon. Hel. ii. 278 (1848)

Tornatellina ovuliformis, Id., Ibid. iii. 523 (1853)

Achatina ovuliformis, Lowe, Proc. Zool. Soc. Lond. 206 (1854)

Glandina ovuliformis, Alb., Mal. Mad. 56. t. 15. f. 1, 2 (1854)

Achatina ovuliformis, Paiva, Mon. Moll. Mad. 115 (1867)

Habitat Portum Sanctum; in montibus excelsioribus hinc inde vulgaris. In statu semifossili rarissima.

The L. ovuliformis, which is peculiar to Porto Santo (where it occurs principally amongst loose soil and vegetable detritus on the ledges, and within the crevices, of the rocks, on the summits of the highest peaks), is remarkable for its small size and oval, or obtuse and pupæform, outline, as well as for its thin, subpellucid substance, its short, curved, and broadly expanded columella, and for the ventral wall of its aperture being armed with a large, medial, prominent, trans- 
verse plait. It has likewise a tendency (which seems to have been overlooked by Mr. Lowe) to possess a corneous sphincter across its ultimate volution, commencing near the angle of the outer lip and merging (as in the case of the L. cylichna, where however it is much more expressed), in an unbroken curve, into the columella.

This callosity is usually very faint, and often (as in the type from which Mr. Lowe's original diagnosis was compiled) obsolete; but it is sometimes exceedingly apparent, and occasionally indeed so much developed that it shapes out at its commencement (near to the angle of the lip) an abrupt and almost dentiform subvertical process. Examples thus furnished might well be supposed, at first sight, to belong to a separate species, did they not pass into the opposite extreme of form by the closest intermediate gradations. I would merely therefore record this phasis of the shell as the 'var. $\beta$. pseudopsis,' deeming it sufficient to have called attention to the fáct that it is connected so intimately with the other that it seems to me quite impossible to regard the two extremes as specifically distinct.

The L. ovuliformis occurs on most of the highest mountains of Porto Santo; but I think that I have myself usually met with it more abundantly on the Pico de Facho than elsewhere,-which indeed was the locality in which Mr. Lowe's original types were obtained. In a subfossil condition it is decidedly scarce, but I have taken it sparingly at the Zimbral d'Areia.

\section{Lovea cylichna.}

Achatina cylichna, Lowe, Ann. Nat. Hist. ix. 119 (1852)

". Id., Proc. Zool. Soc. Lond. 206 (1854)

Glandina cylichna, Alh., Mal. Mad. 84. t. 17. f. 19, 20 (1854)

Achatina cylichna, Paiva, Mon. Moll. Mad. 116 (1866)

Habitat Maderam, hodie non observata ; in statu semifossili ad Caniçal abundans.

This little Lovea, which has been found hitherto only in a subfossil state at Caniçal in Madeira proper, is certainly the most remarkable of all the species here enumerated, and one which in the development of the teeth and plaits of its aperture, no less than in the obtuseness of its outline, makes such a manifest approach to the Pupoe that it might almost seem to merit generic (and not merely sectional) separation, did not the $L$. ovuliformis, which is more evidently on the Lovea pattern, and which possesses a prominent ventral plait (though, at the same time, no indication of palatial ones) tend to connect it with the ordinary type. 
The L.cylichna is abundant in the calcareous deposits at Caniçal ; and it may be known from everything else with which we have here to do, not merely by its minute size and blunt, cylindric-oblong, pupoform outline, but more particularly by the structure of its narrow, elongate, backwardly-acuminated mouth, - the ventral wall of which has a thick, corneous, sinuated sphincter, or rim, commencing suddenly at a short distance from the angle of the outer lip (where it shapes itself into an abruptly terminated subvertical plait), and continuing in an unbroken arch to the very extremity of the columella (where it is sharply truneated so as to form a conspicuous angular projection), whilst in the centre of the same (ventral) region there is a very prominent and powerfully developed transverse plait, which occasionally almost touches the outer lip. But what is more particularly anomalous (so far as I am aware) for a member of the present genus, is the fact that (as in many of the P ирсе) there are three palatial plaits (in addition to the ventral ones),-namely one elongate, filiform, submedial, and deeply immersed, and two minute ones (not always easily recognizable) which are placed close together on the inner margin (but on the upper portion) of the outer lip, opposite to the triangular space which is shaped-out by the two ventral plaits. This array of teeth and callosities give the aperture of this curious little Lovea a very singular appearance.

\section{Fam. 5. AURICULID无.}

\section{Genus 15. PEDIPES, Adans.}

\section{Pedipes afra.}

Le Pietin, Pedipes, Adans., Hist. du Senég. 11. t. 1. f. 4 (1757)

Helix afra, Gmelin, Syst. Nat. i. pars 6 (1790)

Pedipes afra, Lowe, Zool. Journ. v. 296 (1835)

$$
\begin{aligned}
& " \quad \text { ", Id., Proc. Zool. Soc. Lond. } 218 \text { (1854) } \\
& , \quad \text { afer, Drouet, Faun. Açor. } 169(1861) \\
& \text { " Paiva, Mon. Moll. Mad. } 153(1867)
\end{aligned}
$$

Habitat Maderam, vulgaris, sub lapidibus maris æstu quotidie submersis.

The widely spread $P$. afra (which occurs in the Azorean Group and is exceedingly common on the African shores, and which was obtained by Mr. Lowe at Lisbon) abounds below the high-water mark in Madeira proper, particularly towards the north of the island; and it has been received also by the Baron Paiva from the Salvages. It may readily be known by its con- 
vex, Helix-shaped form, its solid consistency, its opake, pallid, concolorous, yellowish-fulvescent surface (which is coarsely sculptured with regular, but not very closely set, transverse, or ' spiral,' striæ), and by the peculiar construction of its large, wide, open, somewhat semicircular aperture,-which is furnished with an enormously developed, curved, elongate ventral plait, or process, at a short distance from the angle of the lip, and two smaller ones on the extremely broad, flattened, white, corneous columella (the upper one, however, being larger than the lower). Its outer lip is acute, but the lower half of it (or, more properly, perhaps, the central region) has a gradually-thickened callosity inside, which developes into a blunt medial tooth, and a much less elevated, obscurer one immediately above,-the two being intimately connected by the incrassated inner space.

\section{Genus 16. MELAMPUS, Montf.}

\section{Melampus exiguus.}

Melampus exiguus, Lowe, Zool. Journ. v. 291 (1835)

Auricula exigua, Id., Proc. Zool. Soc. Lond. 218 (1854)

Melampus exiguus, Pfeiff., Mal. Blätt. xiii. 133 (1866)

$$
" \quad " \text { Paiva, Mon. Moll. Mad. } 150 \text { (1867) }
$$

Habitat Maderam; sub lapidibus juxta mare, præcipue ad litus boreale Promontorii ' Ponta de São Lourenço' dicti, necnon prope Seissal, rarior,-unà cum Auriculâ oqquali, Pedipede afrâ, et Truncatellâa truncatulâa degens.

The greatly abbreviated and broad (but apically acute) spire and elongate aperture of this little Melampus, which give the shell (which is extremely variable in size) a rather turbinate or coniform outline, added to its solid consistency, it pale yellowishbrown hue (accompanied often by a rosy, or even lilac, tinge,which is particularly appreciable in the examples from the Salvages), the fine, sub-undulating transverse (or 'spiral ') striæ with which it is sculptured, its completely edentate outer-lip (which however is furnished internally with a thickened longitudinal callus, parallel to the margin, but vanishing before it reaches the angle), its plicate columella, and its bi-plicate ventral region (the upper of the two callosities being often minute, and occasionally even obsolete) will suffice to distinguish it from its few allied forms with which we have here to do.

The $M$. exiguus appears to be somewhat rare, and was first detected by Mr. Lowe on the northern shore of the Ponta de São Lourenço in the east of Madeira proper,--where it resides beneath stones, in company with the Auricula cequalis, Pedipes afra, and the Truncatella truncatula, below the high-water 
mark. And it was obtained by the Baron Paiva (who likewise procured it from the Great Salvage), under a rather smaller form, from the vicinity of Seissal.

\section{Genus 17. AURICULA, Lam.}

After a careful examination of the Auriculas enumerated in this volume, and a comparison of them with other species, it seems to me that it is impossible to treat the two Sections under one or the other of which they would usually be distributednamely Marinula, King, and Alexia, Pfeiff.-as in any sense distinct from each other, the particular points which are supposed, respectively, to separate them being not only in themselves extremely variable but often united with those which characterize the opposite group. Thus the outer lip of the aperture, which is defined as simple in the former but more or less denticulated in the latter, is in the $A$. oxqualis (which is an undoubted Marinula) generally altogether unarmed, but nevertheless now and then thickened internally about the middle, and sometimes to such a decided extent as to shape-out an appreciable tooth,- - under which circumstances indeed examples have been described as specifically distinct. Then, the solidity of the shell, which is said to be less perfect in Alexia than in Marinula, is often (as in the Alexia Paivana, Pfeiff.) quite as great in the former as in the latter; whilst the plaits of the ventral paries are equally inconstant, as regards their number and development, in both departments. Hence I shall not attempt to regard the latter as having the slightest claim for separation inter se, though I will add short diagnoses of the few members of the genus with which we are here concerned in order to render their specific details the more intelligible.

\section{Auricula æqualis.}

T. imperforata, fusiformi-ovata, solida, aut lævigata aut basi lineis spiralibus plus minus obsolete impressa ; spirâ breviusculâ, conicâ, acutâ, anfractibus 8 planis, suturâ superficiali; aperturâ plicis 3 albidis instructâ, sc. 2 (subæqualibus, aut potius inferiore paululum majore, subparallelis) in pariete ventrali, et 1 minore columellari spiraliter contortâ; peristomate recto, acuto, marginibus callo tenuissimo politissimo junctis, columellari reflexo dilatato albido.-Long. lin. 4-5; diam. maj. 2-3.

a. rufocastanea, nitidiuscula.

$\beta$. [status normalis] plerumque paulo major, fulva, nitidiuscula.

[\%. (insulis Salvages propria, et forsan A. Ferminii, Payr., 
æquans) albescens, sc. pallide albido-fulva aut flavo-cornea ; necnon sublongior, subgracilior, magis opaca, et plus minus erosa.]

$\delta . ~(=A$. Vulcani, Morel.) peristomatis margine dextro in medio calloso, tuberculo plus minus distincte armato.

Melampus æqualis, Lowe, Zool. Journ. v. 288. t. 13. f. 1-5 (1835)

Auricula æqualis, Id., Proc. Zool. Soc. Lond. 217 (1854)

" Vulcani, Morel., Hist. Nat. des Açor. 207. t. 5. f. 8 (1860)

Drouet, Faun. Açor. 167 (1861)

Marinula æqualis, Paiva, Mon. Moll. Mad. 151 (1867)

Auricula Vulcani, Mouss., Faun. Mal. des Can. 135 (1872)

" æqualis, Watson, Journ. de Conch. 220 (1876)

Habitat Maderæ oras maritimas; ad rupes æstu maris quotidie submersas copiosè adhærens.

This is the universal Auricula on the tide-washed rocks of Madeira ; and it is a species, evidently, of a considerable geographical range,-occurring likewise at the Azores, Salvages, and Canaries; and it was found by Mr. Lowe not only at Mogador, on the opposite coast of Morocco, but also at Lisbon. It is extremely inconstant in colour, being sometimes of a rich chestnut-brown, at others (indeed generally) of a paler or more fulvescent hue, in which case it is on the average a trifle larger, and sometimes (var. $\gamma$. albescens) of a dirty yellowishhorn or whitish-yellow, under which last-mentioned aspect it swarms at the Salvages (from whence I have just overhauled no less than 1,580 examples, not one of which offers any appreciable divergence as regards either colour or the relative development of the two ventral and one columellary plaits). These somewhat albino individuals however from the Salvages are usually a trifle narrower and more elongated in outline, and their surface is not only less polished, but is also (as in the A. Paivana) more or less eroded or (as it were) eaten-out into small holes or cavities; nevertheless since the form passes imperceptibly into the normal one, I cannot detect anything about them to warrant a suspicion that they represent more than a slight topographical variety of the ordinary Madeiran type.

It is not only, however, in colour that the $A$. cequalis may be said to be unstable; for, however constant the two ventral plaits may be, the outer lip of its aperture is liable to an occasional thickening about the middle, - a thickening which is sometimes so strongly expressed as to shape out a conspicuous tuberculiform callosity. Out of 1,584 specimens which I have lately examined, only 36 have this tooth-like promi- 
nence largely developed, though in a vast number of others it is more or less traceable in a rudimentary condition,- - thus showing incontestably that the character cannot be made use of for specific purposes. It is on this account that $I$ have no doubt whatsoever that Morelet's A. Vulcani, from the Azores (and which he states is found also in the Canarian archipelago), is but the modification of the $A$. coqualis in which this labial thickening is distinctly expressed; for he particularly mentions that the only other feature in which it recedes from the latter consists in the presence of impressed spiral striæ towards the base of the shell, - a character which is so utterly unimportant that I find it sometimes traceable and at others wholly absent not only in normal individuals of the oqualis but likewise in those in which the outer lip is armed with a central denticle. Indeed the very excellent figure which he has given, of the $A$. Vulcani, does of itself almost settle the question. It is surprising to me that Mr. Lowe; in his original description of the species should have failed to notice this tendency for spiral striæ; but as I happen to be aware that many of his earlier diagnoses were drawn out from a very limited number of individuals, and also that in the majority of specimens these more or less fragmentary impressed lines are totally absent, the omission becomes at least explicable.

\section{Auricula Watsoni, n. sp.}

T. præcedenti similis sed multo minor ac paulo minus ovata (sc. magis fusiformis), sensim (saltem antice) subdistinctius striatula, subopaca (rarius subnitida), et vix minus solida; spirâ sensim exsertiore, acutiore, nucleolo plus minus eccentrico, anfractibus minus planatis foveolisque minutis in lineâ spirali pone suturas (magis impressas) distinctius notatis; aperturâ postice minus anguste acuminatâ, plicis 3 albidis superiore minutâ tuberculiformi instructâ ; peristomate recto, acuto,

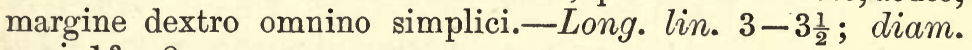
maj. $1 \frac{2}{3}-2$.

a. [status normalis] subventricosa, inflata, læte castaneofusca et plus minus distincte purpureo-tincta.

[ $\beta$. (insulis Salvages propria) scrobiculata.-paulo angustior aut minus inflata, ac plerumque sensim pallidior et vix (interdum nullo modo) purpureo-tincta.]

Auricula myosotis, Watson [nec Drap.], Journ. de Conch. 220 (1876)

Habitat Maderam; in locis similibus ac præcedens, sed multo rarior.

This is a much smaller species than the $A$. oxqualis, as well 
as a little less ovate (or more strictly fusiform), and one which occurs under a slightly different aspect both at Madeira and the Salvages,--the examples from the former (which I have treated as the normal ones) being a trifle broader and more ventricose than those from the latter, as well as (on the average) darker in hue and with a much more decidedly purple tinge. In both phases however the outer lip of the peristome is totally simple (or unarmed), and the upper of the two ventral plaits is reduced greatly in dimensions, - being more often represented by a minute isolated tubercle. The entire shell is somewhat less solid (at any rate when immature) than that of the cequalis; and it is usually subopake (though a few of the comparatively pallid ones from the Salvages are often a little shining), as well as rather more evidently striated (especially in front), and with more appreciable traces of a series of small impressions or pits arranged in a spiral line at a certain distance behind the suture. This last is more sunken (or less superficial) than in the oxqualis, the whorls are not quite so flattened, and the apex of the spire is not only more acute but very frequently tilted or eccentric.

From the Mediterranean A. myosotis, Drap., which it somewhat resembles (so far at least as I understand that species) in the number and proportions of its plaits, it differs in being smaller and relatively less elongated, as well as more solid and more opake, in the volutions of its spire being a little shorter and less convex, and in its aperture being narrower and less largely developed.

I have named this Auricula after the Rev. R. B. Watson, whose elaborate investigations on the Madeiran Mollusca, particularly the marine departments, have contributed so much to our knowledge of the fauna, and to whom I am also indebted for much valuable information concerning the Terrestrial species.

\section{Auricula gracilis.}

T. fusiformis (sc. præcedenti formâ fere similis, sed minor et vix subgracilior), sensim minus solida, subnitida, sæpius castaneo-fusca et plerumque subpurpureo-tincta; aperturâ plicis 3-4 albidis (superiore sæpius obsoletâ, secundâ semper parvâ subtuberculiformi, tertiâ magna intrante, et quartâ columellari contortâ) instructâ; peristomate recto, acuto, margine dextro denticulis $1-5$ intus armato (rariss. simplici). - Long. lin. $2 \frac{1}{2}-3$;

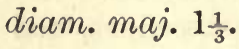

Melampus gracilis, Lowe, Zool. Journ. v. 288 (1835)

Auricula gracilis, Id., Proc. Zool. Soc. Lond. 217 (1854) 
Auricula vespertina, Morel., Hist. Nat. des Açor. 210. t. 5. f. 9 (1860)

Drouet, Faun. Açor. 169 (1861)

Alexia Loweana, Pfeiff., Mal. Blätt. xiii. 145 (1866)

Paiva, Mon. Moll. Mad. 154 (1867)

Auricula denticulata et Loweana, Watson, Journ. de Conch. 220 (1876)

Habitat Maderam; rupibus saxisque æstu maris quotidie submersis adhærens. Rarior.

It is exceedingly probable that the present Auricula is nothing more than a phasis of the European A. denticulata, Montagu; nevertheless as I cannot be quite sure of this, and it is without doubt the species which was described by Mr. Lowe under the name of Melampus gracilis, I have thought'it safer to retain the latter title until the question of its identity with the denticulata shall have been fully established. I possess Mr. Lowe's two original types of his $M$. gracilis (only one of which, although fractured, is mature), and there cannot be the slightest question whatsoever that they pertain to the species which was published subsequently by Morelet (from Azorean examples) under the name of Auricula vespertina, and by Pfeiffer (in 1866) under that of Alexia Loweana; so that Pfeiffer was certainly mistaken when he conjectured (Mal. Blätt. xiii. 133),- - conjecture which was unwittingly endorsed by the Baron Paiva (Mon. Moll. Mad. 152) during the following year,-that the gracilis of Lowe was founded on a mere individual variety of the oequalis. Indeed, apart from all other considerations, its very much smaller size, and the fact of its lower ventral tooth being considerably larger than the upper one (the latter indeed being reduced to a mere tubercle), ought at once to have prevented any such conjecture; but Mr. Lowe himself was partly answerable for this, inasmuch as he suggested (most strangely, as it seems to me) its possibility, and even failed to notice the minute denticle within the outer lip of one of his specimens, - a structure which immediately removes it (independently of its smaller size, less ovate outline, and the proportions of its ventral plaits) from the oxqualis, and affiliates it with a form so nearly allied to the denticulata of Montagu that it is open to consideration whether it does in reality differ from it at all.

Although totally unconnected with the arqualis, the $A$. gracilis has nevertheless much in common with the species which I have described above under the name of $A$. Watsoni. It may however be immediately recognized from the latter by its rather smaller size, by its more or less denticulated outer lip (the denticles, which are very rarely absent altogether, varying 
from 1 to 4 ), and by its ventral paries being not unfrequently armed with an extra plait or tubercle, -i.e. with three, instead of two. Still, this additional callosity, last-mentioned, is more often absent; and in that case, if the right margin of the peristome should happen at the same time to be unprovided with denticles, and the specimens to be large ones, the latter would be difficult to distinguish, no doubt, from those of the A. Watsoni; but as I have never yet observed this threefold contingency to take place, there is no reason why we should assume it to do so at all.

The $A$. gracilis occurs sparingly adhering to the tidewashed rocks in Madeira proper, but it appears to be more common in the north of the island than in the south. Mr. Lowe's original examples, however, were found (dead), during: February of 1827, on the shore to the westward of Funchal. By the Baron Paiva it has been obtained from Porto Moniz. It is recorded by both Morelet and Drouet from Pico, in the Azorean archipelago; but I am not aware that it has been observed hitherto at the Canaries.

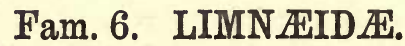

\section{Genus 18. LIMN ÆA, Drap.}

[script. Limneus.]

\section{Limnæa truncatula.}

Buccineum truncatulum, Müll., Verm. Hist. ii. 130 (1774) Limneus minutus, Drap., Hist. Nat. 53. t. 3. f. 5-7 (1805) Limnæus truncatulus, Lowe, Proc. Zool. Soc. Lond. 218 (1854)

Limnæa truncatula, Paiva, Mon. Moll. Mad. 146 (1867) Watson, Journ. de Conch. 224 (1876)

Habitat Maderam ; in aquis fluentibus et quietis, necnon ad rupes aquosas, ubique vulgaris.

The common little European L. truncatula, Müll. (=L. minuta, Drap.), abounds in nearly all the streams and Levadas of Madeira proper, but it has not yet been observed in any of the other islands. It occurs independently of elevation, particularly within the douche of the waterfalls, and is very variable in stature. The Madeiran specimens however are perhaps, on the average, a trifle smaller than those on the more ordinary northern type. We did not meet with it at the Canaries, nor indeed is it recorded by Mousson from that archipelago; but it is nevertheless registered as Canarian by $\mathrm{Mr}$. Watson. 


\section{Genus 19. PHYSA, Drap.}

\section{Physa acuta.}

Physa acuta, Drap., Hist. Nat. 55. t. 3. f. 10, 11 (1805)

" fontinalis, Paiva [nec Linn.], Mon. Moll. Mad. 147 (1867)

" acuta, Watson, Journ. de Conch. 224 (1876)

Habitat Maderam; in aquis juxta Funchal, plantis aquaticis adhærens. Certe ex Europâ introducta.

A Physa, of extreme variability as regards size, whick. appears to have been introduced during the last few years into Madeira, occurring abundantly in the tanks and streams around Funchal,-not merely in the town itself, but also in the Ribeira dos Soccoridos, the Ribeira de Gonçalo Ayres, \&c.; but one which seems to me to have been wrongly identified by the Baron Paiva with the common European P. fontinalis, Linn. Mr. Lowe, however, in a paper which was published in the 'Annals of Natural History' in 1862, says that 'in degree of ventricosity it is intermediate between the $P$. acuta, Drap., and the more elongated or slenderer Canarian shell so called by Webb.' This latter has since been characterized by Mousson under the name of ' $P$. tenerifoe;' though my own belief is that both it and the Madeiran species are nothing more than very slight geographical phases of the common P. acuta.

\section{Genus 20. PLANORBIS, Müll.}

\section{Planorbis glaber.}

Planorbis glaber, Jeffr., Trans. Linn. Soc. Lond. xvi. 387

$$
\begin{aligned}
& " \quad \text { lævis, Alder, Trans. Newcast. ii. } 337 \\
& " \quad \text { glaber, Paiva, Mon. Moll. Mad. } 149(1867) \\
& \quad " \quad \text { Watson, Journ. de Conch. } 224(1876)
\end{aligned}
$$

Habitat Maderam; ad fontes rivulosque circa Funchal. Sine dubio introductus.

This little European Planorbis has (like the Physa acuta) established itself, during the last few years, in the streams and cisterns around Funchal,-where it was first met with by $\mathrm{Mr}$. J. Y. Johnson in a tank in Dr. Lister's garden, and where it was afterwards found (in the same spot) by the late Mr. E. Leacock. Mr. Lowe, in adverting to some examples which had been sent to him by the latter, remarks ('Ann. Nat. Hist.' for July 1860) that they 'belong unquestionably to the $P$. glaber, Jeffr. (=lavis, Alder); and (like the H. aspersa, Müll., in another garden at Funchal) the species has been doubtless introduced within the last few years from Portugal,-where Dr. Bocage, 
Director of the Lisbon Museum, finds abundantly, in stagnant water, tanks, \&c., everywhere, a shell precisely identical. Examples from Cintra, kindly communicated by this able naturalist, perfectly agree with these Madeiran specimens, one of which is remarkable for exhibiting faint traces of spiral striæ towards the peristome on the under (or lower and more concave) side of the shell,-invalidating thus far the specific difference, which has been indeed already called in question (see 'Gray's Man.', 260; though compare also 'Forbes \& Hanley, Brit. Moll.' iv. 151) between the P. glaber, Jeffr., and the P. albus, Müll.'

\section{Genus 21. ANCYLUS, Geoffr.}

\section{Ancylus striatus.}

Ancylus striatus, Quoy et Gaim., Voy. de l'Astrol. iii. 207. t. 58. f. 35-38 (1833)

" $\quad$ W. et B., Ann. des Sc. Nat. 28. Syn. 323 (1833)

" aduncus, Gould., Proc. Bost. Soc. N. H. ii. 210 (1848)

". fluviatilis, Lowe [vix Müll., 1774], Proc.Zool. Soc. Lond. 218 (1854)

" aduncus, Alb., Mal. Mad. 74. t. 16. f. 37, 38 (1854)

" fluviatilis, Paiva, Mon. Moll. Mad. 148 (1867)

" striatus, Mouss., Faun. Mal. des Can. 141 (1872)

" fluviatilis, Watson, Journ. de Conch. 224 (1876)

Habitat Maderam; in aquis fluentibus (præcipue editioribus) ubique vulgaris.

Whether this Ancylus, which is so abundant in the streams of intermediate and lofty elevations throughout Madeira proper, is more in reality than a geographical phasis (as indeed it was regarded by Mr. Lowe) of the common European A. fluviatilis, I am extremely doubtful; nevertheless since it does certainly differ somewhat, at any rate in sculpture, from the more northern type, and it appears to me to be absolntely undistinguishable from the universal species of the Canarian archipelago (which has been acknowledged by various monographers under the name of striatus), I have no hesitation in citing it accordingly,-and that too even whilst admitting (as just implied) that it may perhaps represent but a local modification of its widely-spread European analogue.

Being extremely inconstant in stature, I cannot perceive that this Madeiran Ancylus is larger (as was asserted by Mr. Lowe, and after him by the Baron Paiva) than the ordinary A. Auviatilis; but it is unquestionably a trifle more powerfully 
striate, and has the striæ moreover (although sometimes, from the worn and corroded state of the shell, difficult to examine) appreciably further apart, - a peculiarity which would seem to be occasioned by the alternate ones having a tendency to become more or less evanescent. But beyond this primâ facie feature (which is about equally expressed in the examples from the Madeiras and the Canaries) I can detect no character of sufficient constancy, or importance, to warrant its separation from the latter; though the specific identity of the Madeiran and Canarian individuals is, I think (as, in point of fact, might naturally have been anticipated), undeniable.

There is a smaller aspect of this shell, which was taken by Mr. Lowe at the mouth of the Ribeira do Inferno, in the north of the island, which appears at first sight to be so distinct that it might almost represent an additional species. Nevertheless since the $A$. striatus is eminently unstable as regards size, and the examples before me (apart from their greatly reduced bulk) seem merely to differ in having their surface less perceptibly sculptured, I am content to cite them as the 'var. $\beta$. depauperatus.'

\section{Sectio II. OPERCULATA.}

\section{Fam. 1. CYCLOPHORID尼.}

\section{Genus 1. CRASPEDOPOMA, Pfeiffer.}

Craspedopoma lucidum.

Cyclostoma lucidum, Lowe, Cambr. Phil. S. Trans. iv. 66. t. 6. f. 40 (1831)

\begin{tabular}{|c|c|}
\hline ? & Pfeiff., Mon. Pnéum. 51 (1852) \\
\hline צ' & $\begin{array}{l}\text { Lowe, Proc. Zool. Soc. Lond. } 216 \\
\text { (1854) }\end{array}$ \\
\hline "9 & $\begin{array}{l}\text { Alb., Mal. Mad. 72. t. 16. f. 29-31 } \\
(1854)\end{array}$ \\
\hline & $\begin{array}{l}\text { flavescens, et ner } \\
\text { Nat. Hist. vi. }\end{array}$ \\
\hline
\end{tabular}

Craspedopoma lucidum, Paiva, Mon. Moll. Mad. 156 (1867)

Habitat Maderam; in declivibus sylvaticis intermediis ubique vulgaris. In statu semifossili ad Caniçal abundans; necnon etiam in Portu Sancto atque in ins. Desertâ Australi, semifossile, parcissime reperitur.

This is the universal Cyclostomid of the Madeiran Group, 
where it abounds throughout Madeira proper in sylvan spots of an intermediate elevation,-occurring on the ledges of the rocks, and amongst loose friable soil and vegetable detritus, in most of the damp ravines. It is extremely variable in hue (and slightly so in sculpture, - there being sometimes faint indications of obsolete spiral lines, in addition to the conspicuous but unequal transverse ones), - which ranges from a dark coffeebrown, sparingly dashed with irregular patches of a pale straw colour, into a greenish- or olivaceous-yellow, occasionally with a leaden or even a decidedly blue tinge.

Amongst the many varieties of this inconstant Craspedopoma, two were singled out by Mr. Lowe, in 1860, as perhaps specifically distinct, and were enunciated by him under the names flavescens and neritoides. They seem to me, however, to pass into the other states so completely that I cannot think they possess the slightest claim to be separated as species,-the flavescens (in its extreme phasis) being merely a trifle smaller, yellower, and thinner than the ordinary pallid type; while the neritoides (which is certainly a little more pronounced in its peculiarities) has also a somewhat diminished stature, accompanied by a bluer surface, and a rather less rounded or ventricose contour, the volutions being appreciably more flattened, and the entire shell more compact and trochiform. But even this latter aspect (namely the $C$. neritoides, Lowe) merges into the other, unless I am much mistaken, by imperceptible gradations; so that I have no scruples in citing it as a mere variety, in conjunction with the flavescens (which can hardly be defined as even a 'variety' at all).

In a recent state the $C$. lucidum has not hitherto been observed, so far as I am aware, out of Madeira proper (although abounding in that island); but it occurs sparingly in a subfossil condition both in Porto Santo and on the summit of the Southern Deserta. In the former it was obtained by Mr. Lowe in the calcareous deposits at the Fonte d'Areia, by myself at the Porto dos Frades, and by the Baron Paiva on the Campo de Baixo; and I possess a single example of it from the Bugio. The Porto-Santan specimens are rather small in stature, and might pertain possibly to either the var. flavescens or the var. neritoides. In Madeira proper it is extremely common in the subfossiliferous beds at Caniçal.

\section{Craspedopoma Monizianum.}

Cyclostoma Monizianum, Lowe, Anñ. Nat. Hist. vi. 116 (1860)

Craspedopoma Monizianum, Paiva, Mon. Moll. Mad. 158 (1867) 
Craspedopoma Monizianum, Pfeiff., Novitat. Conchol. iii. 447. pl. 98. f. 31 (1869)

Habitat Maderam; in rupibus submaritimis occurrens, sed rarius.

I think there can be no doubt that this Craspedopoma is truly distinct from every phasis of the C.lucidum,-from which it differs in its uniformly rather smaller size, its subopake, almost concolorous, dark coffee-brown hue (the apical region however being usually a shade paler), by its more finely and closely, but minutely subreticulate (or decussated) surtace (the transverse striæ being reduced in dimensions, and set closer together, while the spiral ones appear, under a high magnifying power, to be more appreciably developed), and by its spire being relatively somewhat more produced, with the volutions still more tumid, and with the suture consequently even more deeply impressed. Its aperture, too, and operculum are proportionately smaller; the latter being likewise of a browner and paler, or less reddish-chestnut, colour, and with the concentric ribs, or circular costæ, more numerous, more regular, and more elevated.

The C. Monizianum occurs on the maritime and submaritime declivities of Madeira proper, at only a moderate elevation above the sea, and does not appear to enter the ' wooded districts' (properly so called). Its principal habitat is about the Brazen Head and Caniço, in the south-east of the island,-where it has been met with by Sr. J. M. Moniz, Mr. Lowe, Mr. Leacock, myself, and others; but there are likewise traces of it in the northern regions also, a few examples having been found by Mr. Leacock in 1861 and by Mr. Lowe in 1862 at the mouth of the Ribeira do Inferno.

As to the Baron Paiva's assumption that the C.Monizianum exists in Porto Santo, I think that we cannot endorse it until further evidence has been obtained; for the Baron's material was not usually collected by himself, and there seems nothing (so far as I can ascertaiu) to warrant that hypothesis.

\section{Craspedopoma Lyonnetianum.}

Cyclostoma Lyonnetianum, Lowe, Ann. Nat.. Hist. ix. (1852)

Craspedopoma Lyonnetianum, Pfeiff., Mon. Pneum. 52 (1852)

Cyclostoma Lyonnetianum, Lowe, Proc. Zool. Soc. Lond. $217(1854)$ 
Cyclostoma Lyonnetianum, Lowe, Ann. Nat. Hist. 117 (1860)

Craspedopoma Lyonnetianum, Paiva, Mon. Moll. Mad. 159 (1867)

Habitat Maderam; in umbrosis humidis sylvaticis intermediis, hinc inde ad rupes irriguas, sat vulgaris.

This species and the following one are on a smaller and more Trochus-shaped type than the preceding two; and their basal volution is on a different pattern,-it being not only more distinctly keeled, but also somewhat unduly enlarged (or upwardly widened) towards the aperture, which gives that particular region a rather distorted appearance, causing the suture to be upwardly curved, and diminishing the breadth at that point of the penultimate whorl. This configuration of the basal volution is carried out on a very much larger scale, and to an exaggerated extent, in the Bulimus Lyonnetianus, Pallas, from the Mauritius, - a fact which suggested to Mr. Lowe the trivial name of the first-discovered (but unfortunately the least characteristic) of these two Madeiran Craspedopomas.

The $C$. Lyonnetianum is considerably smaller than the $C$. Monizianum; and it varies in hue from a dark uniform coffeebrown (which would seem to be normal) into a yellowish sienna, both states being occasionally blotched with patches and streaks of a pale straw-colour. The spire is proportionately more drawn-out or produced, the peculiar construction of the ultimate whorl causing it sometimes to appear a little eccentric or tilted; and its sculpture is close and somewhat coarse, the minute spiral subundulating lines being more appreciably developed than is the case in either of the preceding species.

The present Craspedopoma, which is confined to the damp wooded ravines of Madeira proper, was first detected by myself towards the head of the Ribeira de Sta. Luzia,-where it is abundant, amongst loose friable soil and vegetable detritus, at the base (and on the ledges) of the lofty perpendicular rocks, in company often with the C.lucidum and various Pupce; and it has been taken also in the Ribeira do Inferno, in the north of the island, and likewise (according to the Baron Paiva) in the Ribeiro Frio.

Mr. Lowe stated that the C. Lyonnetianum is common in a subfossil condition at Caniçal; but this was an error, the Caniçal species being unmistakeably the C. trochoideum.

\section{Craspedopoma trochoideum.}

Cyclostoma trochoideum, Lowe, Ann. Nat. Hist. 117 (1860) Craspedopoma trochoideum, Paiva, Mon. Moll. Mad. 159 (1867) 
Habitat Maderam borealem; in humidis sylvaticis rarissimum. Sed ad Caniçal in statu semifossili sat copiose invenitur.

As already implied, the present Craspedopoma is more strictly Trochiform than the preceding one,-its more conical upper and more flattened under portions (shaping the ultimate whorl into a much sharper keel), added to its altogether more compact and flatter volutions and the peculiar distortion (to which I have already alluded) about the aperture, giving it a very singular appearance. Its colour too is exceedingly remarkable,-being either of a straw-yellow with slightly darker (but irregular) spiral-hair-like lines, or else of a dull coffee-brown with the spiral lines of a paler tint. Its sculpture is coarser than that of the C. Lyonnetianum, the minute closely-set spiral costæ being more distinct.

The $C$. trochoideum is much rarer than its ally, being decidedly a scarce species. So far as has been observed hitherto, it is confined to the damp wooded ravines in the north of Madeira proper (such as the Ribeira do Inferno, the Ribeira Funda, the Ribeira de S. Jorge, and the Boa Ventura), -where it has been met with by Mr. Leacock, Sr. Moniz, and others. In the subfossiliferous deposits, however, at Caniçal, it is comparatively abundant (where it was inadvertently identified by Mr. Lowe with the $C$. Lyonnetianum), - a fact which would seem to imply that it may formerly have been a dominant species in the Madeiran fauna.

\section{Fam. 2. TRUNCATELLID床.}

Genus 2. TRUNCATELLA, Risso.

Truncatella truncatula.

Cyclostoma truncatulum, Drap., Hist. Nat. des Moll. 40 t. 1. f. 28-31 (1805)

Truncatella truncatula, Lowe, Zool. Journ. v. 302. t. 13. f. 13-18 (1835)

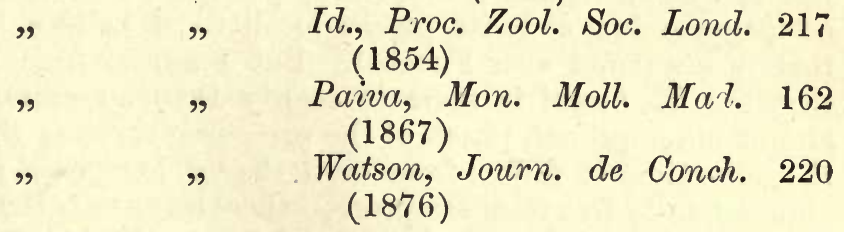

Habitat Maderam; sub lapidibus æstu maris quotidie submersis, hinc inde una cum Pedipedibus, Auriculis, Melampidibusque occurrens.

The European T. truncatula (so remarkable for the apically 
lopped-off, or decollated, spire of the adult shell) is not uncommon below high-water mark in Madeira proper, beneath large stones washed by the tide,-where it was first detected by Mr. Lowe on the northern shore of the Ponta de São Lourenço. As in higher latitudes, it assumes two tolerably distinct forms, one of them (which appears in Madeira to be normal) having the volutions powerfully ribbed with elevated costæ, and the other ( $\beta$. laevigata) being more shining, and with the costæ more or less obsolete, the only place in which there are usually conspicuous traces of them being towards the anterior margin of each whorl. In other respects the T. truncatula is characterized by its cylindrical outline but nevertheless tumid volutions, as well as by its rather narrow aperture, its solid substance, and its pallid hue.

In its strongly costate state the $T$. truncatula is somewhat abundant in certain spots along the shores of Madeira proper; but the ' $\beta$. locvigata' seems to be scarce, though it is cited by the Baron Paiva as occurring at the Gorgulho near Funchal. From the Great Salvage, however, the latter phasis was received in considerable numbers by the Baron, whilst the former (or ribbed) one was less common.

The young shells of the Truncatelloe differ so curiously from the adult ones, in their more conical outline and unbroken apex, that they have occasionally been described not only as a distinct species, but as pertaining to even another genus.

\section{Truncatella Lowei.}

Truncatella Lowei, Shuttl., Bern. Mitth. 146 (1852)

" $\quad$ Mouss., Faun. Mal. des Can. 147

Habitat Maderam; a Dom. Bewicke semel lecta.

A single example of this Truncatella (which occurs in the Canarian archipelago, and which I myself met with at the Salinas in the north of Lauzarote) was taken in Madeira by the late Mr. Bewicke, and is now in my possession; though I have no memorandum as to its precise locality. I believe, however, that it was found near Funchal. But I am far from satisfied that the $T$. Lowei is more in reality than an extreme, and almost unsculptured, phasis of the preceding species; though at the same time it differs from even the ' $\beta$. loevigata' in being almost totally free from sculpture,--there being only the faintest possible traces of a few little pits and abbreviated hair-like costæ on the front edge of the volutions. These latter, moreover, are not quite so convex.

The Madeiran specimen now before me differs from the 
Canarian ones of the T. Lowei in being altogether a trifle smaller and narrower; but I have no means of judging whether it is a normal one of its race.

\section{Fam. 3. ASSIMINEID屟.}

\section{Genus 3. ASSIMINEA, Leach.}

\section{Assiminea littorina.}

Helix littorina, Del. Chiaje, Mem. An. Nap. iii. 215. Assiminia littorea, Paiva, Mon Moll. Mad. 163 (1867) Assiminea littorina, Watson, Journ. des Conch. 220 (1876)

Habitat Maderam; sub lapidibus æstu maris quotidie submersis, hinc inde congregans.

This very diminutive Assiminea, which occurs also in more northern latitudes, and which is easily recognizable by its compact, globose-ovate, Paludina-like form, its solid substance, almost unsculptured surface, pallid hue, and perfectly edentate aperture, is locally abundant on the shores of Madeira proper,where it was first detected by the Rev. R. B. Watson in 1865 . And it has been obtained also by the Baron Paiva from the Great Salvage.

\section{Fam. 4. HYDROBIID无.}

\section{Genus 4. HYDROBIA, Hartm.}

\section{Hydrobia similis.}

Cyclostoma simile, Drap., Hist. Nat. 34. pl. 1. f. 15 (1805) Rissoa anatina, Forb. et Hanl., Hist. Brit. Moll. iii. 134 Hydrobia similis, Jeffr., Brit. Conch. i. 64

" " Paiva, Mon. Moll. Mad. 161 (1867)

" $\quad$ Watson, Jouin. de Conch. 224 (1876)

Habitat Maderam; in aquis quietis circa Funchal hinc inde vulgaris.

The European $H$. similis (which I found also at Mogador on the opposide coast of Morocco) occurs abundantly in the rivers and tanks of Madeira proper,-where it was detected in 1865 by the Rev. R. B. Watson, and where I have myself subsequently met with it (near Funchal) in considerable profusion. It bears at first sight so strong a resemblance to the Limnoca. truncatula that, before accurately examined, it might almost be mistaken for that species; nevertheless, apart from its modus vivendi, which appears to be as much in brackish water as in fresh, and the fact of its possessing an operculum, it will be 
seen, when closely inspected, to have many even primâ facie differences. Thus it is not only shorter (relatively) and more ventricose than the $L$. truncatula, and with its surface (instead of being slightly shining and densely crowded with minute oblique striæ) almost unsculptured and opake, but its aperture is less elongate and more rounded, and has the peristome (instead of being broadly interrupted) conspicuously continuous across the body-volution.

MADEIRAN CATALOGUE.

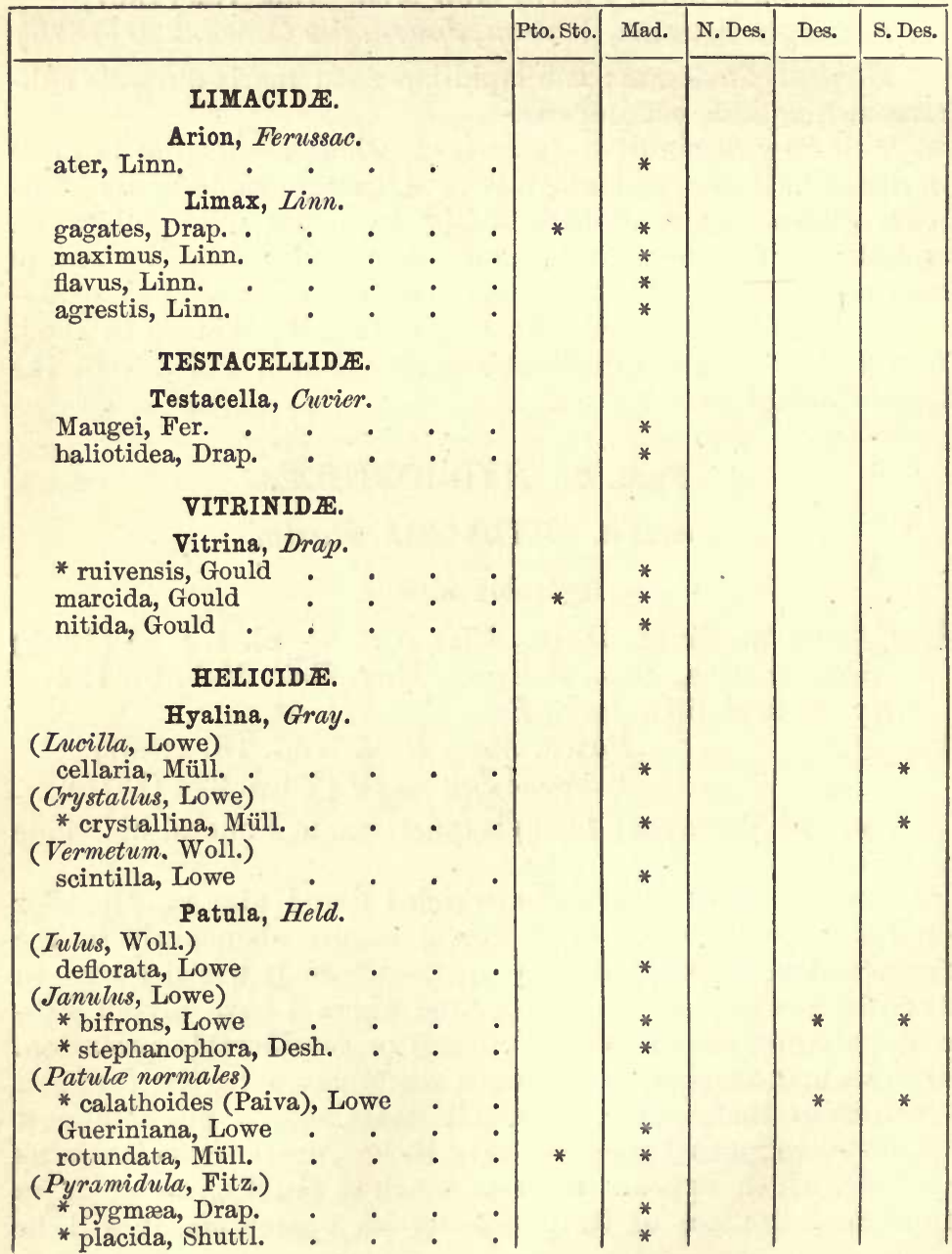


madeiran Catalogue-(continued).

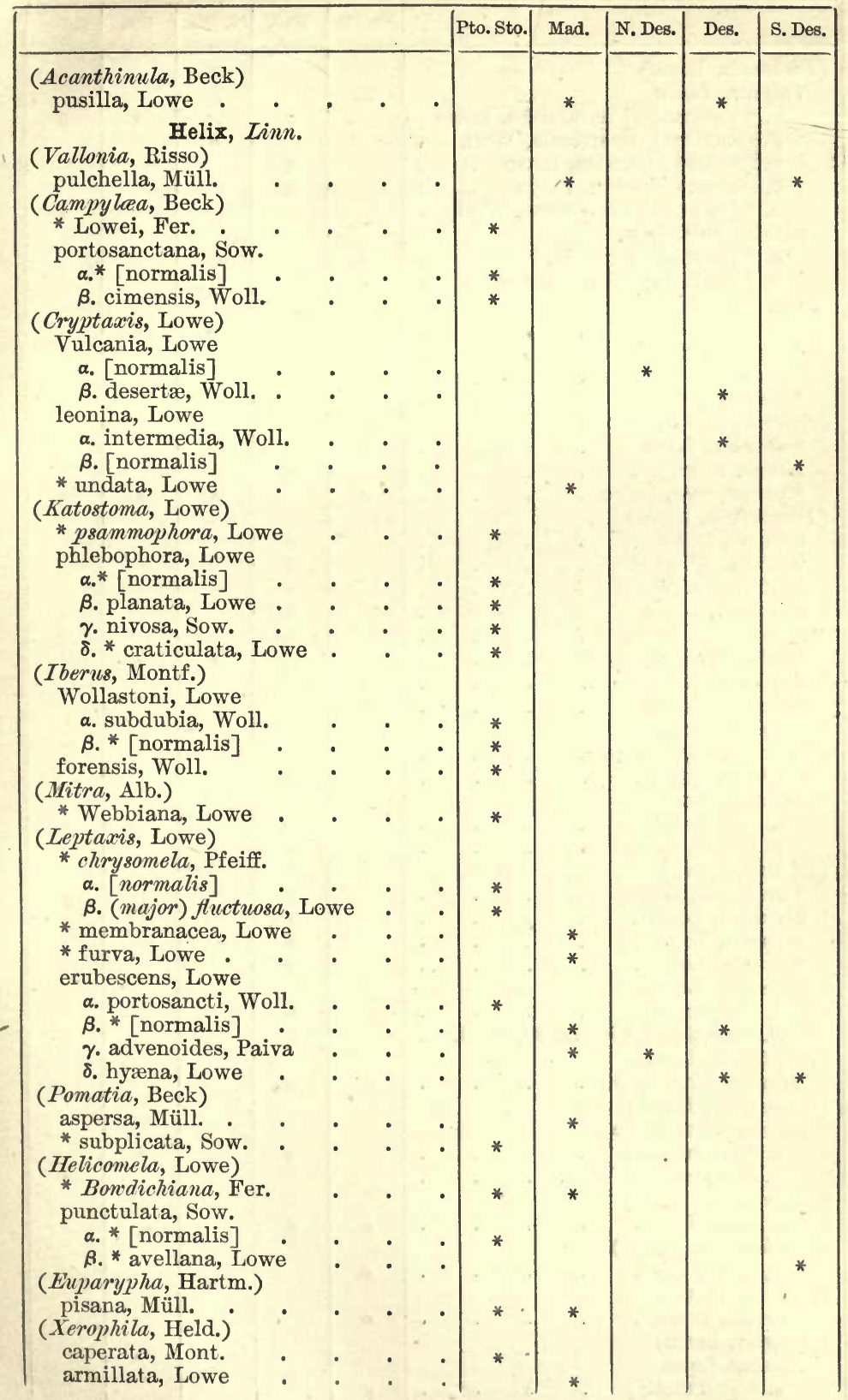


Madeiran Catalogue-(continued).

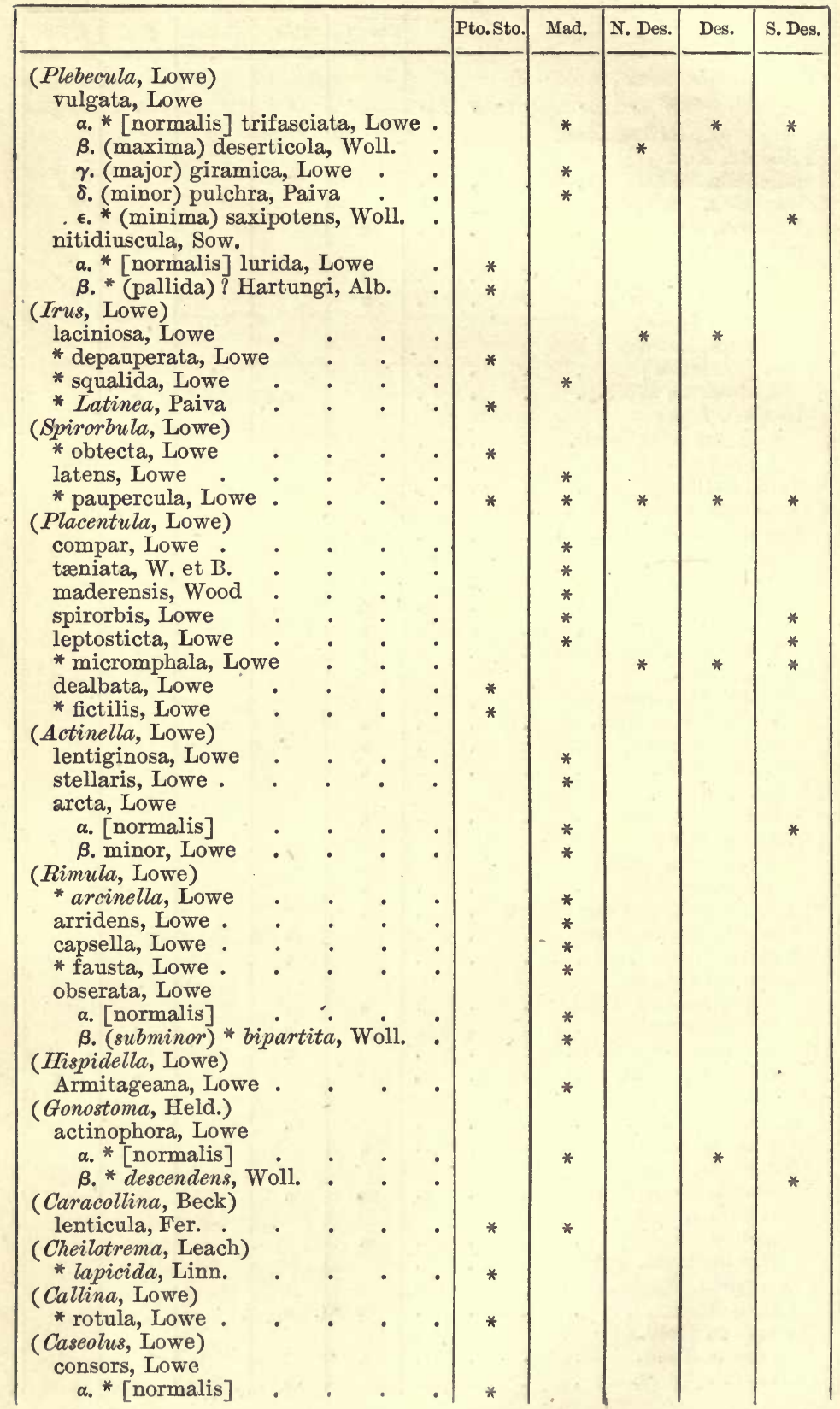


Madeiran Catalogue-(continued).

\begin{tabular}{|c|c|c|c|c|c|c|c|c|}
\hline . & & & & Pto. Sto. & Mad. & N. Des. & Des. & S. Des. \\
\hline 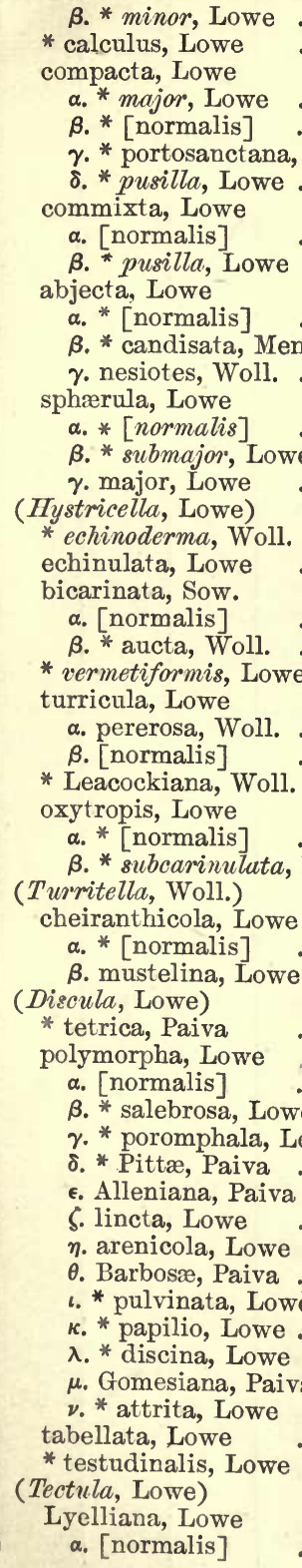 & : & 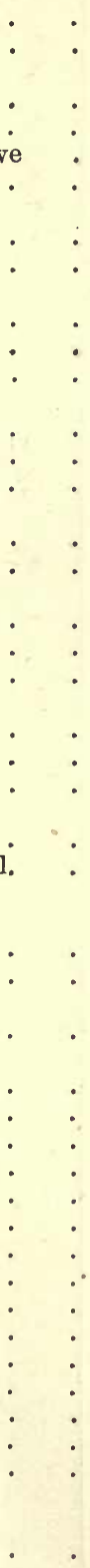 & $\begin{array}{l}\cdot \\
\cdot \\
\cdot \\
\cdot \\
\cdot \\
\cdot \\
\cdot \\
\cdot \\
: \\
\cdot \\
\cdot \\
\cdot \\
\cdot \\
\cdot \\
\cdot \\
\cdot\end{array}$ & $\begin{array}{l}* \\
* \\
* \\
* \\
*\end{array}$ & $\begin{array}{l}* \\
* \\
* \\
* \\
* \\
*\end{array}$ & $\begin{array}{l}* \\
*\end{array}$ & $\begin{array}{l}* \\
*\end{array}$ & $\begin{array}{l}\text { * } \\
\text { * } \\
\text { * }\end{array}$ \\
\hline
\end{tabular}


Madeiran Catalogue-(continued).

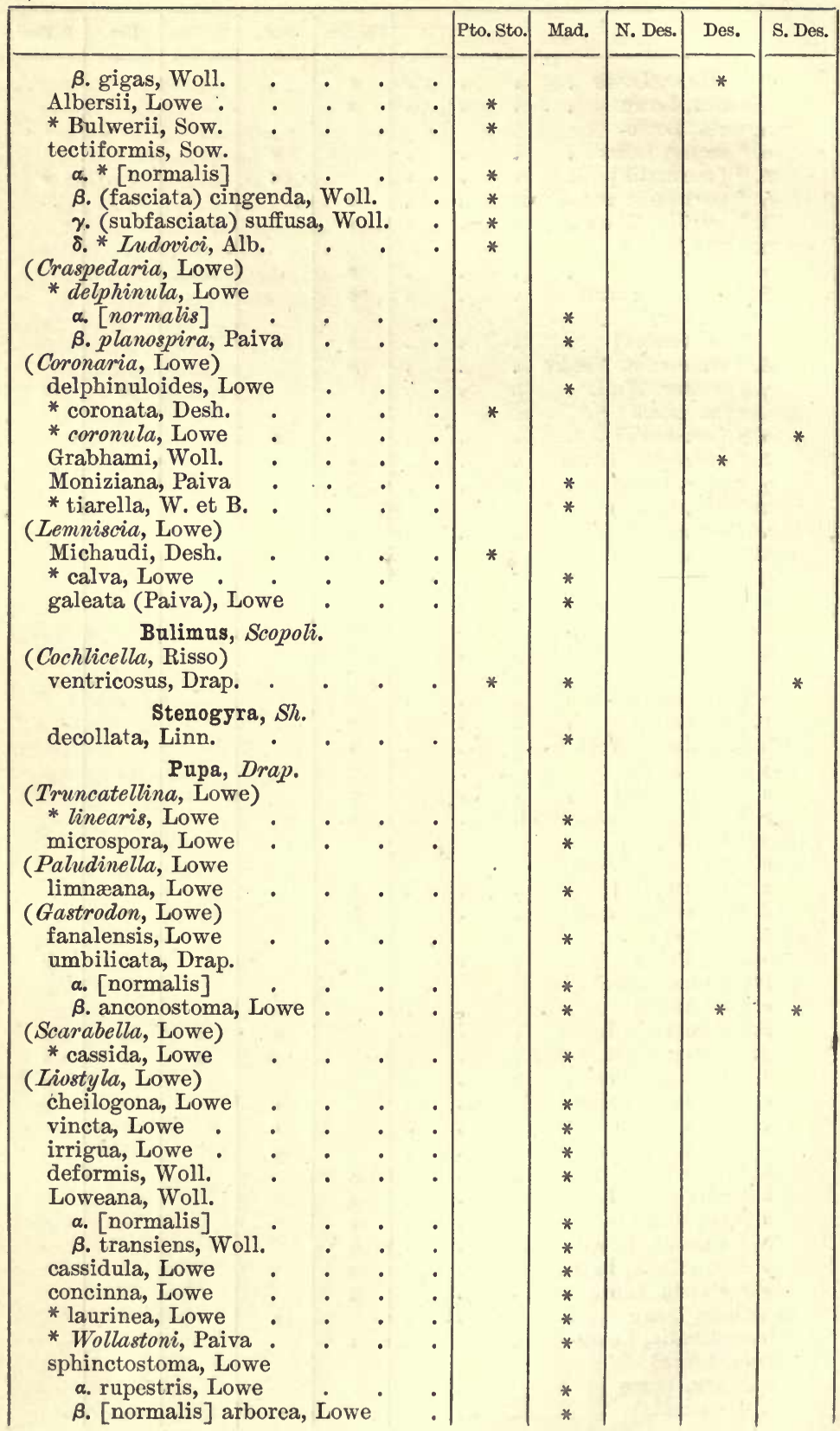


Madeiran Catalogue-(continued).

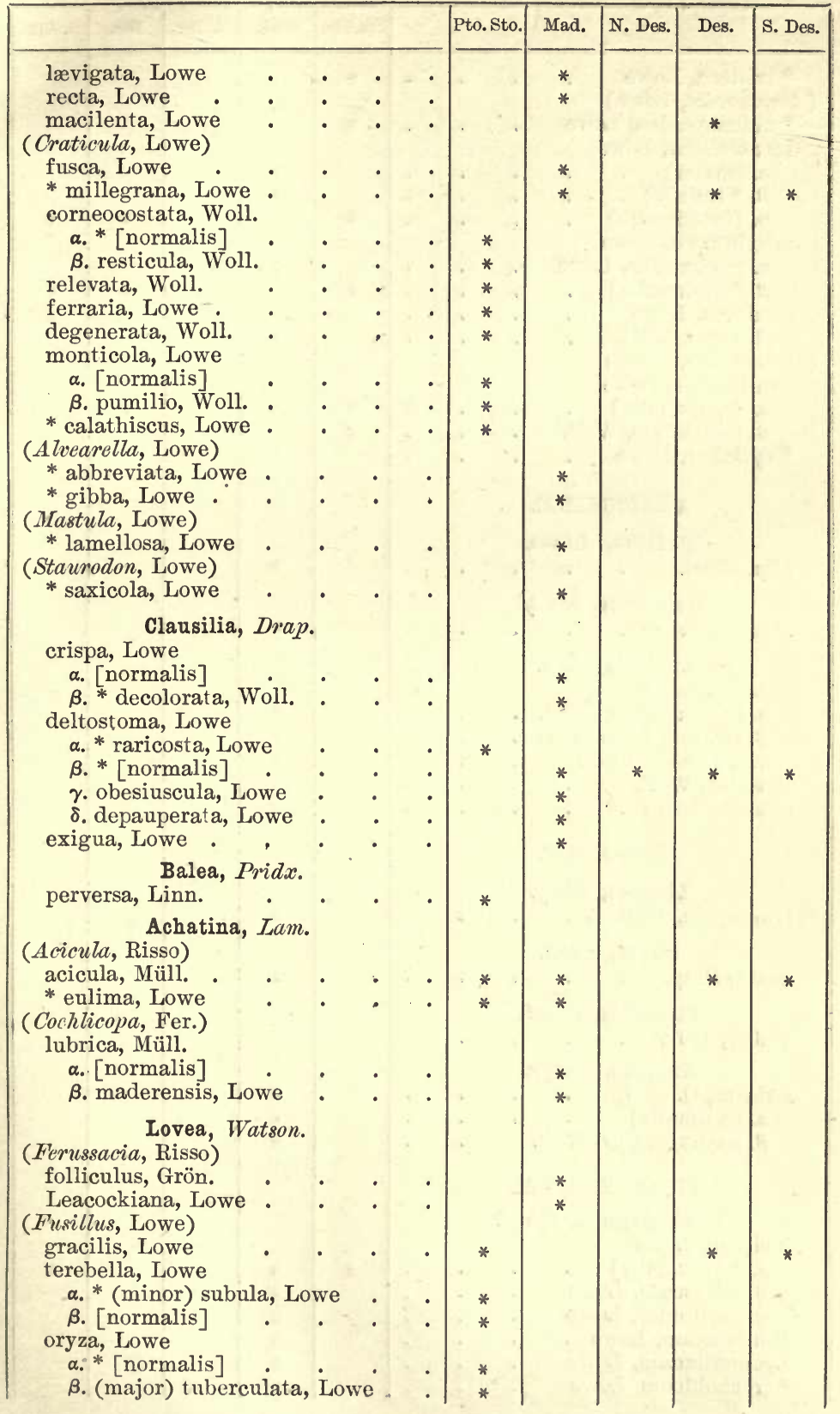


Madeiran Catalogue-(continued).

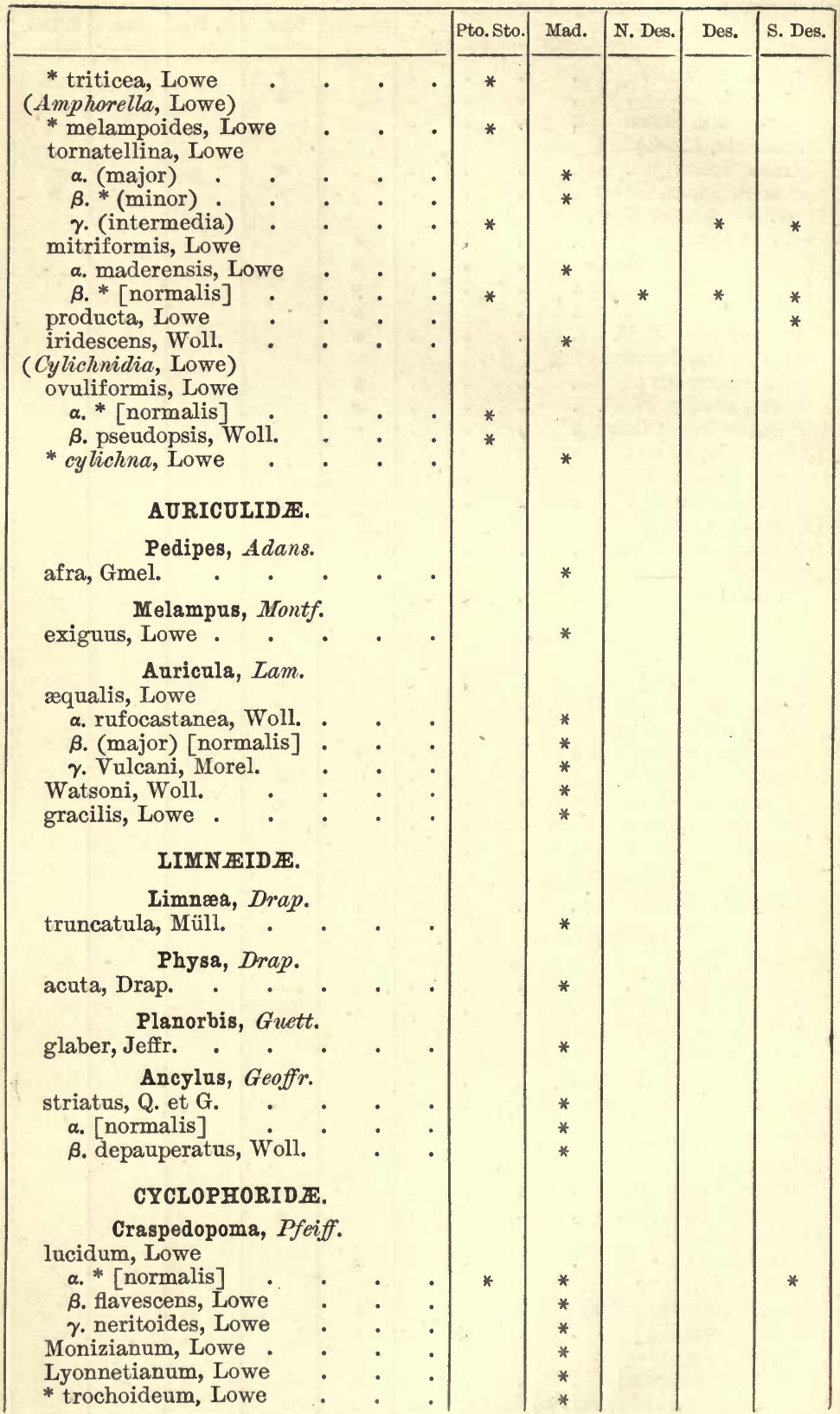


Madeiran Catalogue-(continued).

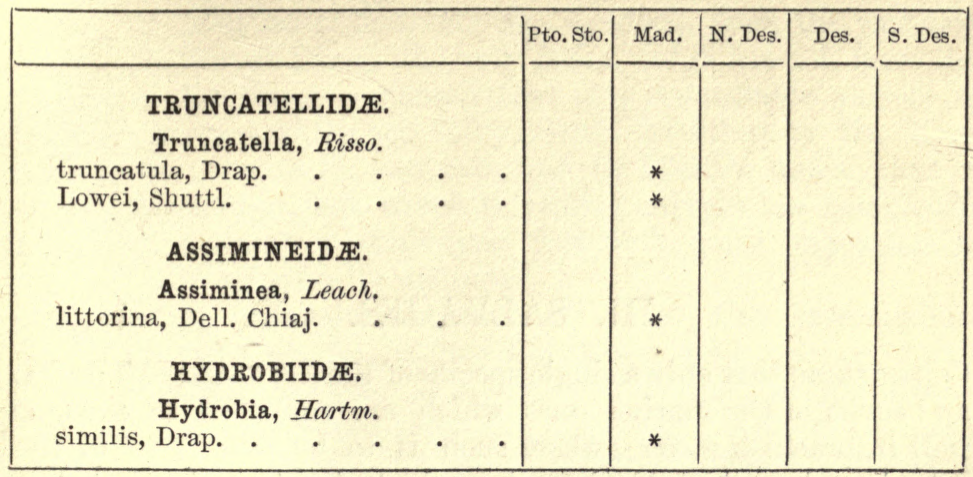




\section{SALVAGES.}

Considering that only a single species of the Terrestrial Mollusca, and seven of the marine ones which are supposed to exist as well in brackish water (where such is to be found) as in the actual sea have hitherto been brought to light on these remote and almost unapproachable rocks, it would appear at first sight absurd to devote a separate Section to their consideration ; yet since geographically the Salvages cannot be included within either the Madeiran or the Canarian archipelagos, and it is quite possible that other members of the Pulmonata may eventually be found to occur on one or the other of the two outlying islands which constitute this little oceanic assemblage (for the minute third one is absolutely inaccessible, and therefore practically need not be taken into account), we may perhaps be pardoned if we venture to recognize them as a small but independent Group,-intermediate both in situation and productions between those which lie immediately to the north and south of them. ${ }^{1}$

It is to Mr. T. S. Leacock, of Funchal, that we are indebted for almost our first knowledge of the Natural History of these distant rocks, - a landing on both of them having been effected by him during the spring of 1851 ; and since that date small consignments of shells, insects, and plants have been obtained, from time to time, by the Baron Paiva,-chiefly through the medium of the Portuguese fishing-boats which are now and then freighted from Madeira for the purpose of gathering orchil and barilla, with which most of the Atlantic islands more or less abound. The late Mr. MacAndrew in 1852, visited the Salvages in his yacht; but as his purpose was mainly to dredge for the marine species, he added nothing to

1 Although it does not come within my province in this volume to enter into anything beyond the Gastropodous statistics, I may nevertheless just add that the other members of the fauna, no less than the flora (as hitherto ascertained), bear testimony to the strictly intermediate character of the Salvages with respect to the Madeiras and Canaries, though at the same time implying most unmistakably that they partake far more of the peculiarities of the latter than of those of the former. 
our information concerning the Terrestial fauna,-even whilst bringing away with him, like Mr. Leacock, from the southern island, or 'Great Piton,' the only Helix which has yet been detected in the Group, - namely that very remarkable variety of the $H$. pisana which was subsequently described by Mr. Lowe under the name of $H$. ustulata, and by Pfeiffer under that of MacAndrewiana, but which in reality merges so completely into the ordinary pisana-type that it is quite impossible to uphold it as specifically distinct. ${ }^{1}$

The two uninhabited islands of which this intermediate Group is made up (for, as just stated, the third one, or 'Little Salvage,' which is said to be low and with an appreciable amount of vegetation, must be dismissed as altogether and hopelessly inaccessible) are the northern or larger one, known as the ' Great Salvage,' and the southern or smaller one (separated from the former by a channel of about eleven or twelve miles in breadth), called the 'Great Piton.' The Great Salvage contains the largest superficial area; and the landing there, in a certain cove, when the sea is tolerably calm, although more or less dangerous, is by no means impracticable. But the Great Piton (which, from a distance, appears like a gigantic ruin, or castle, rising out of the ocean) seems to be the more interesting, and was described by Mr. Leacock as a rocky cone covered rather thickly with vegetation, and resting upon a sandy base. I need scarcely mention that it is chiefly on this 'sandy base' that the Helix pisana, with its most beautiful and characteristic varieties, more particularly abounds ; and one can hardly believe that the densely clothed cone, if carefully searched, would not be found to harbour something equally curious in the way of Terrestrial Mollusks. At any rate, judging from the analogy of the Beetles, which, although Canarian in their affinities, are nearly all of them peculiar, we may expect that this would be the case; though the opportunities for reaching spots which are thus isolated, and difficult of access, must ever remain so extremely exceptional that it is impossible to look forward to a thorough investigation of the Salvages as coming within the range of even a remote probability.

1 I may just mention that a landing on the Great Salvage was attempted by Mr. Gray and myself, on the 6th of January, 1858, when we were bound for the Canaries in his yacht, the 'Miranda'; but the sea was running so high at the time that no boat could have approached the cliffs nearer than within a stone's throw without the utmost risk. Nevertheless we did our best to accomplish what we so much desired, though the inhospitable aspect of the rocks as we neared them made us anything but reluctant to pull back again to the vessel and resume our voyage to Teneriffe. 


\section{Sectio I. INOPERCULATA.}

\section{Fam. 1. HELICID压.}

\section{Genus 1. HELIX, Linné}

(§ Euparypha, Hartm.)

\section{Helix pisana.}

Helix pisana [var.], Müll., Verm. Hist. ii. 60 (1774)

" ustulata, Lowe, Ann. Nat. Hist. ix. 114 (1852)

" MacAndrewiana, Pfeiff., Mon. Hel. iii. 625 (1853)

"' ustulata, Lowe, Proc. Zool. Soc. Lond. 171 (1854)

" MacAndrewiana, Paiva, Mon. Moll. Mad. 71 (1867)

Habitat ins. Salvages; in aridis calcariis, abundans.

The particular Helix which represents at the Salvages the European $H$. pisana has so remarkable an aspect that it might well be regarded, at first sight, as specifically distinct. And indeed both Dr. Pfeiffer and Mr. Lowe have thus disposed of it,-the former under the name of H. MacAndrewiana, and the latter under that of $H$. ustulata ; yet I am satisfied, after a very careful consideration, that it does not possess features of sufficient importance to warrant its being treated as separate-its peculiarity of sculpture being in exact accordance with that of the pisana, whilst even its coloration (beautiful though it be) is not more singular than what obtains in certain of the other permanent (but undoubted) varieties of the latter. Indeed, apart from colour, we can merely define it as (on the average) a little thinner and more globose than is usual in the more northern type,-its basal whorl being a trifle more inflated, and therefore utterly free from every trace of a keel. But these points, as well as its nearly closed-up perforation, are all paralleled in recognised states, and examples, of the pisana; and we have nothing, therefore, left for us to fall back upon but its very remarkable hue; whilst even this ceases to be distinctive when I mention that there are two well-marked phases of the shell on the Salvages, one of which is pure white with only the peristome rosy, and that this so closely resembles the ordinary pallid one of the pisana that, after accidentally mixing them together, I have experienced the greatest difficulty in re-separating them in accordance with their respective habitats.

I have already mentioned, however, that the normal aspect of this elegant Salvages shell is most extraordinary,the examples which are not white being more or less suffused 
with a pinkish, or lilac, tint, whilst the whorls (at any rate from the dorsal line upwards) are for the most part densely ornamented with narrow spiral bands of a browner hue ; though with the nucleus itself prominent, and (like the peristome) more decidedly rosy.

\section{Fam. 2. AURICULID死.}

Genus 2. PEDIPES, Adans.

\section{Pedipes afra.}

Le Pietin, Pedipes, Adans., Hist. du Senég. 11. t 1. f. 4 (1757)

Helix afra, Gmelin, Syst. Nat. i. part 6 (1790)

Pedipes afra, Lowe, Zool. Journ. v. 296 (1835)

" Id., Proc. Zool. Soc. Lond. 218 (1854)

" afer, Drouet, Faun. Açor. 169 (1861)

" "Paiva, Mon. Moll. Mad. 153 (1867)

Habitat Salvagem Grandem ; sub lapidibus, æstu maris submersis, vulgaris.

The Pedipes afra, which is so common in the Madeiran archipelago, and which occurs also at the Azores as well as on the coast of Africa, is abundant on the sea-washed rocks at the Great Salvage,-from whence it has been obtained by the Baron Paiva. The examples from the Salvages do not appear to differ from those of Madeira.

\section{Genus 3. MELAMPUS, Montf.}

\section{Melampus exiguus.}

Melampus exiguus, Lowe, Zool. Journ. v. 291 (1835) Auricula exigua, Id., Proc. Zool. Soc. Lond. 218 (1854) Melampus exiguus, Pfeiff., Mal. Blätt. xiii. 133 (1866)

$$
\text { " } \quad \text { Paiva, Mon. Moll. Mad. } 150 \text { (186i) }
$$

Habitat Salvagem Grandem; in locis similibus ac præcedens, et una cum illo degens.

Examples of the Madeiran $M$. exiguus were obtained by the Baron Paiva from the Great Salvage,-where it appears to occur, in company with the Pedipes afra, the 'var. $\gamma$. albescens' of the Auricula cequalis, the A. Watsoni, the Truncatella truncatula, and the Assiminea littorina, on sea-washed rocks. I can detect no difference between the Salvages specimens and those from Madeira,- except perhaps that the roseate, or somewhat lilac, tint is, on the average, a little more strongly expressed in them. 


\section{Genus 4. AURICULA, Lam.}

\section{Auricula æqualis.}

Melampus æqualis, Lowe, Zool. Journ. v. 288. t. 13. f. 1-5 (1835)

Auricula æqualis, Id., Proc. Zool. Soc. Lond. 217 (1854)

" Vulcani, Morel., Hist. Nat. des Açor. 207. t. 5. f. 8 (1860)

Marinula æqualis, Paiva, Mon. Moll. Mad. 151 (1867)

Auricula Vulcani, Mouss., Faun. Mal. des Can. 135 (1872)

" $\quad$ æqualis, Watson, Journ. de Conch. 220 (1876)

Habitat per oras maritimas insulæ Majoris; ad rupes æstu maris quotidie submersas copiosissime adhærens.

The particular form which this common Auricula assumes at the Salvages, and which may perhaps be identical with the A. Ferminii, Payr., is slightly different from that which is so abundant in the Madeiran archipelago; and as I have already characterised it (as the 'var. $\gamma$. albescens') at p. 267 of this volume, I need scarcely do so afresh. Suffice it to observe that the $A$. cequalis is appreciably paler here than it is at the Madeiras, as well as (relatively) a trifle longer, slenderer, and more opake ; and its surface is, for the most part, a good deal eroded, or eaten-into,-much as in the A. Paivana. I have examined a perfect multitude of specimens, which were obtained from the Great Salvage, and I find that these small differential features (however unimportant) are well-nigh invariable; but as one or two examples which are now before me, and which were communicated by Mr. Watson, appear to be on the ordinary Madeiran type, and a few out of my own assortment are likewise connective, I am not able to register the 6 var $\gamma$. albescens' as the only phasis of the shell which is found on these remote rocks. Still, it is quite evident that it is the principal one, and that the rather darker and more ventricose form is at the Salvages the rarer of the two.

The occasional thickening of the outer lip is about as often traceable (however seldom) in the 'var. $\gamma$. albescens' as it is in the ordinary type.

\section{Auricula Watsoni.}

Auricula myosotis, Watson [nec Drap.], Journ. de Conch. 220 (1876)

Watsoni, Woll., vide ante, p. 269 huj. operis.

Habitat insulam Majorem; una cum A. cequali commixta, sed multo rarior. 
This appears to be by far the rarest of the three Auriculas which have been detected hitherto at the Salvages,- the few examples which I have seen having been partly received from the Baron Paiva, and partly separated by myself from a mass of the 'var. $\gamma$. albescens' of the A. coqualis which had been obtained by him from those islands. The species may readily be known from the latter by being considerably smaller and less elongate-ovate (or more strictly fusiform), and by the upper one of its two ventral plaits being so far reduced in dimensions as to assume the form for the most part, of a minute and isolated tubercle. Its colour too is darker than that of the cequalis (at any rate as represented at the Salvages), - it being of a pale reddish brown, with a more or less decided violet tinge. So far as I have yet observed, its outer lip is wholly unarmed, or free from denticles. I may just add, however, that the examples of this shell from the Great Salvage (which I have cited as reprenting a 'var. $\beta$. scrobiculata') are not quite so dark and purpurascent, on the average, as the Madeiran ones; and they are likewise a trifle slenderer in outline, and when young more glossy in surface; but in everything important the two phases are undistinguishable.

Having given a diagnosis of the $A$. Watson $i$ in my notice of it under the Madeiran Group, I need not do more than refer to p. 269 of the present volume for any further particulars concerning it.

\section{Auricula Paivana.}

T. ovato-fusiformis, solida, opaca (et plus minus erosa), cretaceo- aut (interdum) subflavo-albida ; spirâ breviusculâ, conicâ, anfractibus $5 \frac{1}{2}-6$ planis, ultimo elongato, suturâ sæpius laceratâ ; aperturâ elongatâ, plicis 2 instructâ,- -sc. 1 magnâ intrante ventrali, vix supra columellam sitâ, et alterâ minore obliquâ columellari ; peristomate recto, acuto, marginibus callo nitidiore junctis, dextro simplici, columellari reflexo dilatato.-Long. lin. $2 \frac{1}{2}-3 \frac{1}{2}$; diam. maj. vix $1 \frac{1}{2}$.

Alexia Paivana, Pfeiff., Mal. Blätt. xiii. 146 (1866)

Paiva, Mon. Moll.Mad. 155 (1867)

Auricula bidentata et Paivana, Wats., Journ. de Conch. $220(1876)$ garis.

Habitat Salvages; in ins. Majore ad rupes maritimas, vul-

This appears to be a most abundant Auricula on the tidewashed rocks at the Salvages, from the larger island of which it has been obtained in profusion by the Baron Paiva; but I am not aware that it has been observed hitherto in any of the other archipelagos. I am extremely doubtful however whether 
it represents more in reality than a slight geographical variety of the European A. bidentata, Mont., with which indeed it has been identified both by Dr. Fischer and Mr. Watson; though as Pfeiffer, who must have had good opportunities of being acquainted with the latter, has enunciated it lately under the name of Alexia Paivana, I will not do otherwise than treat it as distinct.

The A. Paivana may easily be recognized. from the other members of the genus which have been found in these various Atlantic archipelagos by its extremely pallid colour (which is usually white with a very faint yellowish tinge), and by its having only a single plait (and that one large, and somewhat inferior in position) on its ventral paries, - the oblique columellary one being the less enlarged of the two. It is rather a small shell for an Auricula, and extremely solid ; its surface, which is nearly opake, is a good deal eaten-into or eroded; its suture is more or less uneven, or lacerate; its spire is short, and composed of somewhat fewer whorls than in the generality of the species; its ultimate volution is slightly elongated; and the outer lip of its aperture is quite free from denticulations.

Having given a diagnosis of the various Auriculas which occur in the Madeiran and Canarian archipelagos, I have thought it desirable to oompile one for the A. Paivana likewise,-in order to point out more readily in what particular points it differs from the others,

\section{Sectio II. OPERCULATA.}

\section{Fam. 1. TRUNCATELLID尼.}

Genus 1. TRUNCATELLA, Risso.

\section{Truncatella truncatula.}

Cyclostoma truncatulum, Drap., Hist. Nat. des Moll.40. t. 1. f. 28-31 (1805)

Truncatella truncatula, Lowe, Zool. Journ. v. 302. t. 13. f. 13-18 (1835)

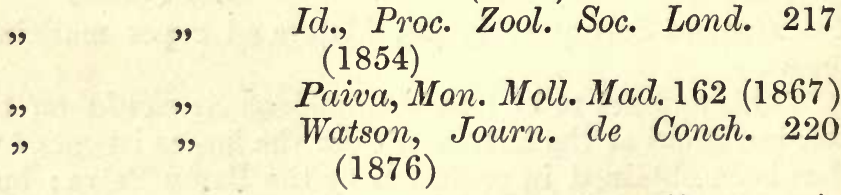

Habitat Salvagem Grandem; sub lapidibus per litora maris congregans. 
The European T. truncatula, which is locally abundant on the tide-washed rocks in Madeira, has been obtained by the Baron Paiva, both in its costate and comparatively unsculptured phases, from the Great Salvage,-where he records that it was met with in tolerable numbers (and particularly under the form to which I have already alluded, vide ante p. 280, as the ' $\beta$. lavigata') at the 'Furna de Nordeste.'

\section{Fam. 2. ASSIMINEID㷊.}

\section{-Genus 2. ASSIMINEA, Leach.}

\section{Assiminea littorina.}

Helix littorina, Delle Chiaje, Mem. Ann. s. Vert. Nap. iii. 215. t. 49. f. $36-38$.

Rissoa littorea, F. et H., Hist. Brit. Moll. 1ii. 132. pl. 81, f. 6,7 .

Assiminea littorina, Jeffr., Br. Conch. v. 101 (1869) " " Watson, Journ. de Conch.220 (1876)

Habitat insulam Majorem; rupibus saxisque, æstu maris quotidie submersis, adhærens.

As already stated at p. 281 of the present volume, this minute European Assiminea was obtained in abundance by the Baron Paiva from the Great Salvage,-where it would seem to occur, much as it does at the Canaries, Madeira, and elsewhere, adhering to the large masses of rock which are washed by the tide. Its very diminutive bulk and rounded-ovate contour, added to its nearly unsculptured surface, solid substance, pallid huę, and perfectly edentate aperture, will suffice to distinguish it. 


\section{CANARIAN GROUP.}

Auтнобян far less perfectly explored than the Madeiran Group, the Canaries have had immeasurably more attention bestowed upon them than either the Azores or Cape Verdes. Since the days of Adanson, who touched there on his passage to Senegal, now more than a century ago, they have been visited at intervals by many naturalists, - though often hurriedly and with but feeble results; and before the sojourn of MM. Webb and Berthelot, whose 'Synopsis,' published in 1833, marks what may be termed the first epoch in the Canarian fauna, the travellers Maugé and Ledru, Quoy and Gaimard had gathered a scanty contribution towards the commencement of a local catalogue. Meagre and inaccurate as was the enumeration of even Webb and Berthelot (the forty-four species of which embraced a considerable number which had nothing to do with the Canaries at all, having been obtained from bags of dried orchil the precise origin of which was confessedly unknown), it nevertheless formed a basis on which future collectors were able to build; and it was by means of this, augmented by a few which he himself met with during a short stay at the Canaries, on his voyage to the West Indies, that M. d'Orbigny so far increased the list, in 1839, as to make it include fifty-four species.

After the publication of d'Orbigny's catalogue, which constituted an integral part of MM. Webb and Berthelot's 'Histoire Naturelle,' no additions to the Gastropodous fauna seem to have been brought to light for about thirteen years,- when M. Shuttleworth described, in the 'Berner Mittheilungen' for 1852, thirty new species which had been detected by Blauner; supplementing the number by eight others (now in the Museum at Marseilles) from the collection of M. Terver, which however (as having been gathered, like some of the previous ones which had been given to Mr. Webb, from consignments of 'Djers' moss,' or orchil, the exact country of which was admitted to be uncertain) possessed but doubtful claims to be treated as unquestionably Canarian.

In 1856 eight additions were enumerated by Grasset (Journ. 
de Conch. v. 345), which had been discovered by himself and M. de la Perraudière in Teneriffe and Hierro; and during the following year Mousson contributed four others (Denksch. der Allg. Schweiz. Gesellsch. für die Naturwiss. xv. 132) from the material which had been collected by Dr. Hartung in Lanzarote and Fuerteventura.

In 1861 sixteen Helices were published as new (Ann. Nat. Hist., 3rd ser. viii. 104) by Mr. Lowe,-the result of his own researches, in conjunction with those of myself, during two expeditions to the Canaries (in 1858 and 1859), when we visited, in Mr. Gray's-yacht 'the Miranda,' the whole seven islands of the Group; and in 1864 Morelet enunciated four others (Journ. de Conch. xii. 16) as having been found in Gomera.

It remained yet, however, to elaborate these various contributions to the Canarian catalogue into a systematic whole; and accordingly in 1872 Mousson issued his 'Révision de la Faune Malacologique des Canaries,' in which he brought together what had previously been published, and embodied the result of certain fresh material which had come to hand,-particularly that of M. de Fritsch, a Professor of Geology at Frankfort, who had spent eight months in the archipelago and had visited all the islands. ${ }^{1}$ To that of M. de Fritsch was added the material which had been obtained in Teneriffe by Reiss ; and as Mousson possessed the advantage of a large number of the collections, to which I have just called attention, having been entrusted to him, he was in a position to give a trustworthy résumé of what had been done. Although I cannot but think that he has made the species of his Monograph far too numerous, - the ' 197 ' requiring, according to my estimate, and that too in spite of no less than twenty-one additions with which he was not acquainted, to be reduced by at least eight (in reality perhaps by more),-we are nevertheless greatly indebted to him for the careful and conscientious manner in which he applied himself to the difficult task of examining the extensive material (including a considerable portion of my own) which was placed in his hands ; and if, in the course of the present enumeration, I have occasionally felt compelled to differ from the conclusions at which he arrived, it is in many instances, simply, because, having had fuller opportunities of observation in situ, somewhat greater latitude for the general principle of insular variation has been, to a certain extent, forced upon me.

' Mousson says that 'sept des huit îles principales du groupe' were explored by de Fritsch; but he must surely be aware that there are but seven islands altogether which could be described, in any sense, as 'îles principales,' - the little rock of Lobos, in the Bocayna strait, having always been cited as a portion of Fuerteventura, and Graciosa, Allegranza, and Clara being mere detachments of Lanzarote. 
Although a certain number of mere titles have been altered, in this catalogue, consequent on the shells which they represent having hitherto been wrongly referred to them, and which might leave the erroneous impression, at first sight, that the species themselves (rather than their names) had been rejected, there are nevertheless twelve species, usually registered as-Canarian, which I would expunge altogether from the list, as having been accepted upon evidence which is totally insufficient; and since the majority of them were equally doubted by Mousson, it is much to be regretted that he should have admitted any of them into his ' Revision,' - which certainly ought not to have been augmented by forms which are so manifestly extraneous. The twelve to which I allude are as follows:-(1) Vitrina fasciolata, Fer.;-introduced by the older naturalists, probably through a mere confusion in the habitat as originally reported, its Canarian claims having been disputed by even Webb and Berthelot. (2) Hyalina semicostula, Beck;-a species found in Portugal, and said by Reeve (Conch. Icon. 879), but without proper evidence, to occur in Grand Canary. (3) Helix advena, W. et B. ; -a Helix which is now thoroughly demonstrated to be peculiar to the Cape Verde archipelago, having no connection whatever with the Canaries, and one which (like so many other species which were admitted by Webb, absolutely without proof as to their precise countries, into his Canarian fauna) would seem to have been obtained originally from bags of dried orchil, or Dyers' lichen, which had been shipped to Europe for sale. (4) Helix marcida, Shuttl.;--founded on a unique specimen in the Marseilles Museum, imperfect and (according to Mousson) 'dont l'origine precise est inconnue;' and in all probability therefore from the collection of M. Terver, by whom it must have been found in the consignments of orchil to which I shall often be compelled to allude as having been the occasion of so much unnecessary error. (5) Helix melolontha, Shuttl.;-likewise established on a single example in the Museum at Marseilles, and from the cabinet of M. Terver,-whose orchil-gathered material has created an amount of confusion in the faunas of these various Atlantic archipelagos which is simply deplorable. (6) Helix toeniata, W. et B.;-an essentially Madeiran form, absolutely peculiar to Madeira proper, and not permeating even the other islands of that archipelago, and doubtless obtained by Webb (through M. Terver, of Lyons) from casks of orchil, or 'Dyers' Moss.' (7) Helix tiarella, W. et B. ;-likewise emphatically Madeiran, and thoroughly distinctive of that archipelago, - having unquestionably come into the hands of Webb (who had no scruple in citing it as Canarian) along with the $H$. toeniata. (8) Bulimus Terverianus, W. et B.;-a species belonging to 
the fauna of Morocco (occurring around Mogador), and having nothing whatever to do with that of the Canaries. (9) Stenogyra subdiaphana, King;-a species which is peculiar to the Cape Verdes, and (like the last) having nothing whatever to do with the Canaries; and one indeed whose claims to be Canarian were questioned by even Webb and Berthelot, and subsequently by d'Orbigny. (10 and 11) Achatina Paroliniana, W. et B., and A. Tandoniana, Shuttl.;-founded on the Lovea triticea and oryza, Lowe, collected by Webb on the mountains of Porto Santo and erroneously regarded as Canarian. And (12) Pomatias Barthelemianum, Shuttl.; - established on a single example in the Museum at Marseilles 'sans indication précise,' according to Mousson, 'de localité,' and doubtless from the collection of M. Terver of Lyons, -its citation as Canarian resting upon evidence which is quite as untrustworthy as it is in the case of so many other species which are in a similar predicament.

Although more or less called in question by Mousson, as to their true Canarian claims, 10 out of the 12 species to which I have just referred are nevertheless admitted practically into his fauna, - the only ones which are altogether cast out being the Helix advena and the Bulimus Terverianus, W. et $B$.

In addition however to these, there are at least fourteen others, treated by Mousson as species, which I do not absolutely reject but which I look upon as mere states, or phases, of certain proximate types, - thus reducing his catalogue still further, as regards extent. These fourteen are as follows:-(1) Hyalina canarioe, Mouss.;-scarcely distinguishable from the common $H$. cellaria, Miill., of which it seems to me to be hardly even a 'variety.' (2, 3) Helix geminata, Mouss., and H. Grasseti (Tarn.), Mouss.;-mere forms of the pisana, Müll., which are manifestly connected by intermediate links with the ordinary type. $(4,5)$ Helix canariensis (Shuttl.), Mouss., and H. herbicola (Shuttl.), Mouss.; - slight modifications of the very inconstant $H$. lineata, Oliv. (6) Helix adoptata, Mouss.;-an undoubted state (if distinguishable at all, as such) of the universal $H$. lancerottensis, W. et B. (7) Helix pavida, Mouss.; -identical with the $H$. nubigena, Lowe, but the mere name nevertheless employed on account of the latter one having been preoccupied. (8) Helix Bertheloti, Fer.;-a somewbat larger race, but merging completely into the other, of the $H$. hispidula, Lam. (9) Helix nodosostriata, Mouss.;-a common and very ordinary development of the $H$. miranda, Lowe, from Gomera. (10) Helix proeposita, Mouss. ; founded upon a single individual which was taken by myself on the mountains of Grand Canary, but which appears to me to be absolutely identical with 
Shuttleworth's $H$. persimilis. (11) Bulimus roccellicola, W. et B.;-certainly not distinct specifically from the $B$. variatus, W. et B. (12) Cionella Webbi, d'Orb. ;-identical, unquestionably, with the Bulimus mysotis, W. et B. (13) Cyclostoma adjunctum, Mouss.; -not separable specifically from the $C$. canariense, d'Orb., of which it constitutes one of the many insular races. And (14) Physa ventricosa, Mouss.;-a mere phasis, I think, of the P. acuta, Drap.

The species which I have myself added to the Canarian catalogue, but which are not included in Mousson's work (though two of them, the Helix planaria and Bulimus palmensis, are treated by him as 'vars.'), are the following twentyone:-(1) Hyalina osoriensis, Woll.; a strongly defined member, from a high elevation in Grand Canary, of Mousson's section ' Lyra,' yet certainly not belonging to the genus Patula (as the closely allied circumsessa, Shuttl., was erroneously supposed to be by him), but to Hyalina. (2) Patula garachicoensis, Woll.;-discovered by Mr. Lowe near Garachico in the north of Teneriffe, and quite distinct from everything else which has been acknowledged as Canarian. (3) Helix gibboso-basalis, Woll.;- -allied to the H. lactea, Müll., but, I believe, truly distinct: from the collection of M. Vargas, and found in the north of Teneriffe. $(4,5)$ Helix vermiplicata, Woll., and H. granomalleata, Woll.; two rather large Helices, of the Hemicycla section, detected in Palma. (6) Helix nivarioe, Woll.;-a species, both recent and subfossilized, of the $H$. malleata type, occurring in the north of Teneriffe. (7) Helix apicina, Lam.; - two examples of which were lately met with in Teneriffe, during the expedition of H.M.S. 'Challenger.' (8) Helix crispolanata, Woll.; - a remarkably pilose species, of the Gonostoma section, from Palma. (9) Helix beata, Woll.; likewise of the Gonostoma group, and from Fuerteventura, but nearly related to the Teneriffan $H$. fortunata, Shuttl. (10) Helix planaria, Lam.;-treated by Mousson and others as a Teneriffan state of the $H$. afficta, Fer., of Palma, but which I believe to possess a greater claim for specific separation than most of its immediate allies. (11) Helix Gomeroe, Woll.; -detected both in a subfossil and semi-recent condition in Gomera, and a good deal akin to (though perfectly distinct from) the $H$. discobolus, Shuttl., of that same island. (12) Helix Watsoniana, Woll.; - a rather obscure little species, from Grand Canary and Teneriffe, of the Lemniscia group. (13-18) Six Bulimi,-the B. palmensis, osoriensis, chrysaloides, interpunctatus, Lowei, and savinosa, - of which the first is from Palma, the second, third, and fourth are from Grand Canary, the fifth is from Teneriffe, and the last is from Gomera and Hierro.

(19) Lovea 
tornatellina, Lowe; -an 'Achatina' which abounds in the Madeiras, and a single example of which was met with by $\mathrm{Mr}$. Watson a few years ago in Grand Canary. (20) Limnoea truncatula, Müll.;-likewise common at Madeira, but found by Mr. Watson in the Canarian archipelago. And (21) Assiminea littorina, Delle Chiaje;-a European, submarine species, abundant at Madeira and the Salvages, which was obtained by Mr. McAndrew in Teneriffe.

After making these various additions to, and deductions from, the local catalogue as given by Mousson, it will be seen, by a reference to the list at the close of the present Section, that the true species (whether indigenous or introduced), so far as I can understand them, which I should be inclined to acknowledge as Canarian, amount to 189 ; and it is somewhat remarkable that it should happen to be a little in advance of the number which is indicated (namely 176) in the very much more perfectly explored Madeiran Group. This fact however must not be permitted to leave the impression that the Canaries are better stocked as regards their Pulmoniferous Mollusks than the Madeiras; for it should be borne in mind that the former are made up of seven large islands, the central one of which rises to an altitude of more than 12,000 feet, whereas the latter (the loftiest point of which is only 6,000 ) have but five islands, -or if we count (as is most natural) the rocks of the Desertas as one, merely three. Hence the circumstances are very different $\grave{a}$ priori, and 176 species at the Madeiras imply a very much more redundant fauna than 189 do at the Canaries. Added to which, the Madeiran catalogue embraces an immeasurably larger proportion of extra forms which (on account of their having been treated as only well.marked varieties rather than as separate species) are altogether lost sight of in a mere numerical enumeration,- the 'species,' as technically and rigidly understood by that term, being the only organisms which it is the custom to register under distinct numbers in a geographical catalogue. But although acknowledged as 'varieties' rather than as species, it does not necessarily follow that some of them may not in reality tally better with what we believe to be the latter, or at all events that they may not have an equal importance with many of the forms at the Canaries which (through the want perhaps of sufficient material from which to judge) have been accepted unreservedly as species. So that from this point of view likewise (indeed I might almost say $\grave{a}$ fortiori) the Madeiran catalogue can hardly fail to be recognised as a much richer one than that of the Canaries,numbering, when all the forms, as hitherto acknowledged, are taken into account, no less than 246, against only 224 which 
are indicated at the latter; though, on the other hand, I am willing to admit that the southern archipelago has been so much less fully investigated than the more northern one that some allowance must unquestionably be made on that account, - even whilst my own experience in them both would incline me to believe that the Madeiras, in proportion to their superficial area, will be found, even eventually, to be far more completely gorged with aboriginal types (and types, I may add, of a more isolated and peculiar character) than the Canaries.

It is indeed a rather puzzling fact, but one which is borne out equally hy the Coleopterous statistics, that, despite their more southern position, the Canaries have nevertheless a far more decided Mediterranean and north-African element about them than what we observe in the Madeiran Group. Take, for instance, the distinctively Canarian Helix lancerottensis, which is found in the whole seven islands of the archipelago, but which also ranges up the western coast of Morocco, or the no less essentially Canarian $H$. argonautula, which has recently been detected (under a scarcely altered phasis) further in the interior on the opposite mainland; or take the Helicideous department Hemicycla, and the genera Parmacella, Leucochroa, and Cyclostoma, which are not represented in even any of the other archipelagos, but the first of which (replaced at the Madeiras, Azores, and Cape Verdes by Leptaxis) numbers thirty-seven members (indeed probably more), whilst the fourth, although not numerous in species, has separate modifications for nearly every island of the Canarian cluster. The genus Bulimus, too, which has fully thirty exponents in the Canaries, is absolutely unknown at the Madeiras-except as embodied by the common $B$. ventricosus, which has simply been introduced. Then, at the Canaries, we meet with, also, none of the more anomalous and isolated types - such as the Helix delphinula, the members of the sections Coronaria, Tectula, Hystricella, Helicomela, Placentula, and Katostoma, and the Pupa cassida - which are so conspicuous in the Madeiran archipelago; though, on the other hand, it must be confessed that the European and otherwise widely-spread genus Clausilia, which is universal at the Madeiras, is without a representative - not only at the Canaries, but in every other island of the 'Atlantic province.'

Yet although the Canarian and Madeiran Groups are thus conspicuously disconnected as regards their Gastropodous fauna (only seven species, when the cosmopolitan and manifestly introduced ones have been removed, being common to them both ${ }^{1}$ ),

1 These seven truly 'Atlantic' Gastropods which are common to the Canaries and the Madeiras (after the merely naturalized and cosmopolitan ones have been deducted) are as follows:--the Patula placida, Shuttlw., and 
I have nevertheless shown at p. 60 of this volume that indications are not wanting of certain well-marked types which do nevertheless (even whilst represented by different species) permeate both archipelagos, and indeed more or less the whole of them,-giving an amount of individuality to the entire province, through its several component portions, which it is impossible not to recognize. Thus, to compare our present cluster with that of the Madeiras, we see (even amongst the forms which may be said to be 'characteristic') the sections Vermetum (of Hyalina), Janulus (of Patula), and Mitra, Irus, Spirorbuta and Discula (of Helix), as well as the genus Lovea (allied to Achatina) and Craspedopoma (allied to Cyclostoma), cropping up, under specifically distinct exponents, in them both. And yet, in spite of this, I also called attention to the circumstance that the unity of this whole Atlantic region, so clearly shadowed forth, is nevertheless immeasurably overbalanced by the marvellous isolation (the evidence for which is even still more pronounced) of its several parts. But what may be the exact bearing of all this upon the existing geographical phenomena I will not venture to suggest,- - the possible breaking-up (at an exceedingly remote epoch) of a more or less continuous land, which had been colonized along circuitous ridges, now lost beneath the ocean but connecting one or the other of its various portions, being but a single explanation out of many, and entering into the province, whatsoever be its plausibility, of mere conjecture.

Had we only the Land-shells from which to judge, this unity of the so-called 'Atlantic province,' although (I think), even Helicologically quite unmistakeable, would perhaps have been less positively insisted upon, in my present remarks, than it is ; but with the Coleopterous statistics likewise before me, on which to build up an independent judgment, I must plead guilty to a very full appreciation of the few conchological facts which would seem to bear on the 'individuality' (as I have ventured to express it) of the entire region. I do not, however, feel it necessary to apologise for this slight $\grave{a}$ priori bias,because, our sole object being to arrive at the truth, we ought to be thankful, rather than otherwise, for any extraneous evi-

pusilla, Lowe; the Helix paupercula, Lowe; the Pupa microspora, Lowe ; the ' $B$. anconostoma,' of the $P$. umbilicata, Drap., and the P. fanalensis, Lowe, and the Lovea tornatellina, Lowe. Mousson mentions that there are but three species thus circumstanced,-namely, the Helix paupercula, the Pupa microspora, and the $P$. anconostoma; but that arose principally from his not having been aware (1) that the Patula servilis, Shuttlw., is identical with the pusilla, Lowe ; (2) that Lowe's 'pusilla, var. B. sericina,' is Shuttleworth's $P$. placida; and (3) that his own Pupa,debilis is conspecific with the $P$. fanalensis of Lowe. 
dence, which might serve as a guide towards the solution of a problem which requires to be approached from many different directions. But the general character of the beetles, no less than that of the plants, even though often evinced by species which are totally distinct, is so marvellously similar throughout the whole of these sub-African archipelagos, that it is difficult not to acknowledge the latter as but detached portions (however isolated inter se) of a single geographical system. The more sedentary nature of the Pulmoniferous Gastropods, as compared with the majority of the insects, would lead us beforehand to suspect that the truly indigenous exponents of the former (unconnected specially with the 'inhabited districts') would be found to be less dispersed, or more localized, than those of the latter, - as indeed is conspicuously the case even on tracts which are still unbroken; therefore we need hardly feel surprised that what is thus strongly indicated in other departments of the Natural History, should be expressed somewhat more feebly in the Terrestrial Mollusks.

With the Cape Verde archipelago the Canaries, as regards their Gastropods, seem practically to be altogether disunited,three species out of the four which have been found in both Groups (namely the Helix lenticula, the Bulimus ventricosus, and the Stenogyra decollata) having most likely been naturalized, and indeed the remaining one (the minute Patula pusilla) perhaps falling under the same category. The Cape Verdes, in point of fact, have a far closer connection with the Madeiras; for although it is true that the respective faunas have (so far as has been observed hitherto) but six members in common, and that there is an equal appearance of even these (with the possible exception of the Patula pusilla) having been introduced, nevertheless a marked coincidence exists between some of the dominant types in the two archipelagos-as, for instance, the Leptaxis section of the genus Helix, - which (although present under species which are specifically dissimilar) would tend, in some degree, to affiliate, as it were, the respective areas of distribution. 1

Out of the 189 species which I would enumerate for the Canarian archipelago, 13 have been found hitherto in a subfossil state only; and although this is no proof that they may not occur recent likewise (for the majority of those which have been met with in the conchyliferous deposits exist equally in a living condition), they must nevertheless, of necessity, be re-

1 The six actual species which are common to the Cape Verdes and Madeira are as follows:--Patula pusilla, Lowe, Helix armillata, Lowe, and lenticula, Fer., Bulimus ventricosus, Drap., Stenogyra decollata, Linn., and Achatina lubrica, Müll. 
garded as extinct until the contrary has been shewn by actual observation. The 13 to which I allude are as follows:-

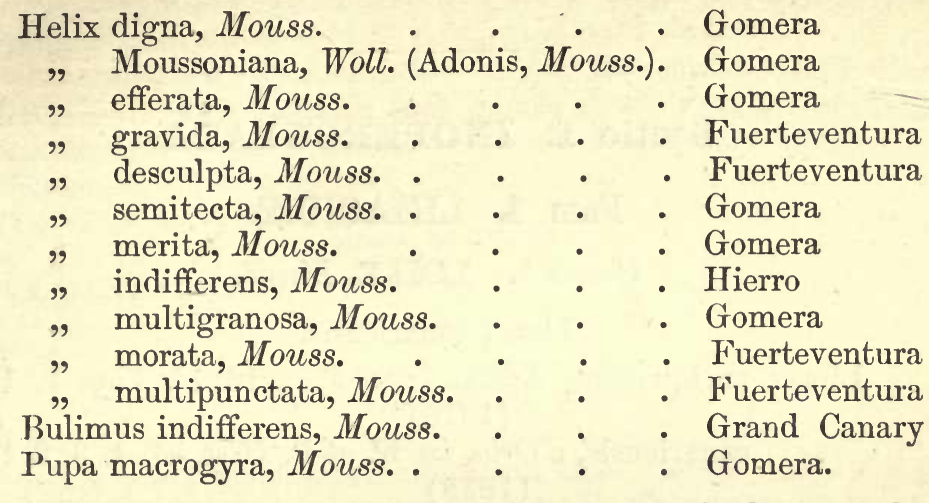

In addition however to these 13 species which must be looked upon practically (at any rate for the present) as having passed away, it will be seen by a reference to the local catalogue given at the close of this Section that about 30 others, out of the 189, have been collected also in a state which may be regarded as more or less 'subfossilized;' but, as mentioned at p. 63 (when commenting on the extinct fauna of the Madeiras), I place so little reliance upon these so-called 'subfossil' individuals, many of which have often appeared to me to be scarcely more than bleached and decorticated ones, that I shall not attempt to draw any deductions concerning them. Indeed until the several islands have been much more perfectly investigated, I cannot but think that this would be both premature and useless; though as the nature of the beds (whether calcareous or muddy) in which the specimens are usually to be procured are exactly analogous to those of the Madeiran archipelago, we may be pretty certain that whatever conclusions can be safely arrived at from Madeiran data (which have been altogether more accurately accumulated) will apply equally, so far as the geological aspects of the question are concerned, to the other islands. I have therefore considered it sufficient, in the present remarks, to call attention to the few forms which have not yet been brought to light except subfossilized.

Although without much signification, in the very imperfect state of our present knowledge concerning the conchyliferous deposits in the Canarian Group, I have nevertheless in the topographical list at the close of this Section prefixed an asterisk (*) to those species which have been found likewise in a more or less subfossil condition; and in those instances where the species have been observed only subfossilized (under which circum- 
stances they must be looked upon practically as extinct) the names have been printed, additionally, in italics.

\section{Sectio I. INOPERCULATA.}

\section{Fam. 1. LIMACID丑.}

Genus 1. IIMax, Linné.

\section{Limax canariensis.}

Limax antiquorum, Ledru [nec Fer., 1821], Voy. 1. 186 (1810)

" canariensis, d'Orb., in W. et B. Hist. 47. t. 3. f. 1-3

(1839)

" $\quad$ "Bourguignat, Amén. Mal.11 (1859)

" $\quad$ Mouss., Faun. Mal. des Can. 6 (1872)

Habitat Canariam Grandem, et Teneriffam (sec. d'Orbigny); a DD. Webb et Berthelot lectus.

I have not seen this Limax; but, judging from d'Orbigny's diagnosis, its almost uncarinated body would perhaps tend to place it near to the $L$. agrestis, L. It appears to have been taken by MM. Webb and Berthelot in Grand Canary and Teneriffe; and d'Orbigny's diagnosis of it is as follows:- 'Corpore elongato, graciliter albo-griseo, nigro-maculato, supra rugoso-striato, antice brevi, postice elongatissimo conico subacuminato; pallio irregulariter rugoso; carinâ subnullâ, retro solummodo signatâ.'

\section{Limax polyptyelus.}

Limax cinereus, Ledru [nec Müll., 1774], Voy. 1.186 (1810) " carinata, d'Orb. [nec carinata, Leach, 1820], in W. et B. Hist. 47. t. 3. f. 4-8 (1839)

" polyptyelus, Bourguignat, Amén. Mal. 11 (1859) " "Mouss., Faun. Mal. des Can.6 (1872)

Habitat Canariam Grandem, et Teneriffam; hinc inde in humidis.

This is an acutely carinated, somewhat compressed little slug, which seems to have been found by MM. Webb and Berthelot in damp places near Sta. Cruz in Teneriffe. It was met with by myself in the upper part of the region of El Monte in Grand Canary, close to the village of San Mateo; but, singularly enough, my examples were in a dried state,-picked from off a white-washed wall, where the lime would appear to 
have arrested their progress and caused them to adhere. M. d'Orbigny's diagnosis of the species is as follows:- Corpore elevato, compresso, griseo-cæruleo, supra rugoso sulcato, pallio oblongo rugoso medio-elevato ; carinâ elevatâ secante.'

According to Mousson, M. Mabille has recently proposed (Rev. Zool. 143 ; 1868) a new genus, Lallemantia, for this slug, the characters however of which would seem to be insufficient.

\section{Limax noctilucus.}

Limax noctilucus (d'Orb), Fer., Hist. 11. 70. t. 2. f. 8 (1819) " " $"$ Mouss., Faun. Mal. des Can. 7 (1872) dubia.

Habitat 'Teneriffam' (sec. d'Orb. olim); sed species valde

It is not without some hesitation that I admit this species into the Canarian catalogue; because M. d'Orbigny, on whose authority it would seem to have been originally introduced (in 1819) into Ferussac's work, makes no allusion to it whatsoever in his subsequent enumeration (in 1839) of the Mollusca of the Canaries. It is highly probable therefore that he had some actual reason for supposing that either the diagnosis or the asserted habitat was inaccurate; though if this was really the case he ought to have stated plainly what the evidence was on which it was allowed to appear in the 'Histoire Naturelle des Mollusques.' Still, the fact remains that it is both described and admirably figured in the latter magnificent publication, and that nothing has yet been placed on record to call in question its claims to be (as it professes) truly Teneriffan. Yet the complete silence of M. d'Orbigny concerning it in his after-list, and the circumstance that it was established professedly on a unique example (said to have been taken beneath dead leaves in the mountains of Teneriffe) are points, so far as they go, to cast a decided suspicion on the species, - whether as regards its Canarian origin or the truthfulness of its diagnosis. Moreover it is not said by whom the $L$. noctilucus was captured; for, as it was published in 1819, it clearly could not have been by d'Orbigny himself,-whose sojourn in the Canarian archipelago did not take place until 1826.

The great distinctive feature of this slug, - a feature which, if true, would certainly entitle it, as Mousson has well observed, to generic separation,-consists in the fact of its being supposed to possess a mucous disk on the hinder edge of its shield, which has the power of emitting a strong phosphorescent light; but how far this character is absolutely to be depended upon, it remains yet to be proved. 


\section{Fam. 2. TESTACELLID尼.}

Genus 2. PLECTROPHORUS, Ferussac.

\section{Plectrophorus Orbignii.}

Plectrophorus Orbignii, Fer., Hist. 11. 87. t. 6. f. 7 (1819) " "Mouss., Faun. Mal. des Can. 7 (1872) obvius.

Habitat 'Teneriffam' (sec. d'Orb. olim); sed mihi non

The present slug demands exactly the same strain on our credulity as the Limax noctilucus does,-for, like that species, it was both described and figured (in 1819) in Ferussac's ' Histoire Naturelle des Mollusques,' as 'Teneriffan, on the authority of M. d'Orbigny, who nevertheless made no sort of allusion to it in his subsequent Canarian catalogue issued in 1839 ! We are almost driven therefore to conclude that d'Orbigny must have had some particular reason for refusing admission to it in the portion of Webb and Berthelot's publication which he undertook to compile; yet since he ignores the subject altogether, and the diagnosis still remains uncommented upon, and uncancelled, in the great work of Ferussac, I scarcely see how we can exactly pass it over,-even though the silence of M. d'Orbigny may appear somewhat ominous as regards its true Teneriffan claims.

The most salient character for which the P. Orbignii would seem to be conspicuous (but which appears identical with the main feature of the Testacellas) is the presence of a small external Ancylus-like, crochet-shaped shell which is carried on the hinder region of its body, at a short distance from the tip,between which and the posterior edge of the shield there is a rough dorsal band. The animal however is said distinctly to possess a shield, which Testacella does not.

\section{Genus 3. TESTACELLA, Cuvier.}

Testacella Maugei.

Testacella Maugei, Fer., Tabl. Syst. 26 (1821)

" " Lowe, Cambr. Phil. S. Trans. iv. 40 (1831)

" Id., Proc. Zool. Soc. Lond. 163 (1854)

" Morel., Hist. Nat. des Açor. 143 (1860)

" $\quad$ Paiva, Mon. Moll. Mad.6 (1867)

" $\quad$ " Mouss., Faun. Mal. des Can.11 (1872)

Habitat Canariam Grandem, et Teneriffam ; in hortis cultis- 
que inferioribus parce occurrens. In Canariâ Grandi etiam semifossilis, juxta Tafira, cepit Revdus. R. B. Watson.

It was from Canarian examples that the T. Maugei was originally described; nevertheless the species does not appear to be very abundant in the archipelago, nor am I aware that it has been observed hitherto except in Grand Canary and Teneriffe. Indeed it is far from impossible that it may have been naturalized in these islands; though since an example which is now before me, and which was met with by Mr. Watson near Tafira in Grand Canary, is unmistakeably subfossilized, there is at least presumptive evidence that it is truly indigenous. It is found likewise in the Madeiran and Azorean archipelagos, as well as in central and southern Europe and northern Africa.

The shell of the T. Maugei is rather thick, ancyliform, and robust; and externally it is opake and more or less eroded and decorticated, of a pale yellowish-olivaceous hue, and with the lines of growth irregular but conspicuous, - a few of them, which are usually more or less filled up with a brownish deposit, being deeper and coarser than the rest. Internally, however, it is whitish, shining, and pearly, reflecting sometimes a faint opaline lustre; and its aperture, which is enormous and oblong, has its curvature a little interrupted by a slight sinuosity, or emargination, at the upper angle of the outer lip.

The animal, which tapers anteriorly and is unprovided with a shield, is of a livid-black, with the edge of the pedal disk (as seen from above) of a pale salmon colour-which shades-off gradually, by means of a number of minute specks, into the darker upper-surface. It is much ronghened with irregular grooves or coarse reticulations, and carries its limpet-like shell (which covers the respiratory orifice) immediately above its apical region.

Testacella haliotidea.

Testacella haliotidea, Drap., Tabl. des Moll. 99 (1801)

\begin{tabular}{|c|c|c|}
\hline " & " & $\begin{array}{l}\text { Lowe, Cambr. Phil. S. Trans. iv. } 40 \\
\text { (1831) }\end{array}$ \\
\hline & " & $\begin{array}{l}\text { W. et B., Ann. des Sc. Nat. 28. syn. } \\
\text { (1833) }\end{array}$ \\
\hline & " & d'Orb., in W. et B. Hist. 49 (1839) \\
\hline & " & $\begin{array}{l}\text { Lowe, Proc. Zool. Soc. Lond. } 16 \\
\text { (1854) }\end{array}$ \\
\hline & 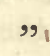 & Paiva, Mon. Moll. Mad. 5 (1867) \\
\hline & " & Mouss.,Faun. Mal \\
\hline
\end{tabular}

Habitat 'Canariam Grandem' (sec. Webb et Berthelot); mihi non obvia.

According to Webb and Berthelot the European T'. halio- 
tidea occurs in Grand Canary; nevertheless, considering the confusion which existed, at the time of the publication of their catalogue, in the nomenclature of the Testacellas, and bearing in mind also the extreme looseness of many of their determinations, I cannot but agree with Mousson in doubting the propriety of admitting this species, without further evidence, into the fauna of the archipelago at all. Nevertheless since it has occurred undoubtedly at Madeira (perhaps imported accidentally from more northern latitudes), I will not absolutely expunge it from the Canarian list.

\section{Genus 4. PARMACELLA, Cuvier.}

\section{Parmacella calyculata.}

Parmacella calyculata, Sow., Gen. of Shells, f. 103 (1823) Cryptella canariensis, $W$. et B., Ann. des Sc. Nat. 28 syn. 110 (1833)

99 ambigua, d'Orb. [nec Fer.], in W. et B. Hist. 50. t. 1. f. $1-12$ (1839)

Parmacella calyculata et auriculata, Mouss., 1. c. 8. t. 1. f. $1-3$ (1872)

Habitat Lanzarotam et Fuerteventuram; hinc inde in montibus haud infrequens.

After a very careful comparison of a long array of individuals of this Parmacella, collected by Mr. Lowe and myself in Lanzarote and Fuerteventura, I have come to the conclusion that Webb and Berthelot were correct, as well as d'Orbigny, in recognizing but a single species, found in those two eastern islands of the Group, and consequently that Mousson's $P$. auriculata cannot be looked upon as more than, at the utmost, a very slight and unimportant insular phasis, peculiar to Fuerteventura, of the P.. calyculata. Indeed the few diagnostic characters which he gives (and he himself says of thern 'sont à la vérité faibles') seem to me to be absolutely untraceable in the majority of the examples which are now before me,all that can be said of the Fuerteventuran ones being that they have their spatula, on the average, a trifle shorter and more solid (or thickened) than is the case in those from Lanzarote, the mere result in all probability of their having been matured on a still drier and more calcareous soil. I will, however, so far recognize their distinctions as to cite them as representing a 'var. $\beta$. auriculata.'

This Parmacella, which we found more common in Lanzarote than in Fuerteventura, occurs, so far at least as my own axperience would imply, at a rather lofty elevation; though it 
is more usually to be met with, perhaps, dead than alive,under which circumstances the specimens are often altogether separated from (or devoid of) their spatula. It was originally found by Webb in the Malpais (or ancient lava-current) of the Montana de la Corona, in the north of Lanzarote; and indeed the greater number of our own examples were obtained at no considerable distance from that particular spot,-namely overlooking the Salinas, and on the heights above Haria. It would seem to have been collected also by Fritsch, in both islands.

\section{Parmacella callosa.}

Parmacella callosa, Mouss., Faun. Mal. des Can. 10 (1872) lecta.

Habitat Fuerteventuram; a Dom. Fritsch semel tantum

A single example of a Parmacella, which was found by Fritsch in Fuerteventura, was employed by Mousson to indicate a new species-under the name of $P$. callosa; nevertheless he himself appears to have had grave doubts as to whether it should be regarded in reality as more than an accidental, or individual, variety, - shewing an unusual amount of thickening, the result of age, and a chance deterioration of its nucleus. ' Je considère,' says he, 'cette espèce, jusqu'à de nouvelles informations, comme très sujette à caution. Le nucléus diffère de ceux des Parmacelles, à moins de n'être qu'accidentellement dépourvu de son test extérieur; la spatule est remplie d'un dépôt calcaire; le bord droit s'insère directement sur le côté du nucléus, le bord gauche forme à la base du nucléus un arc plus relevé et dilaté que dans les deux autres espèces [according to me, only one]. Peut-être toutefois ces différences n'indiquent elles qu'un état sénile, modifié par la détérioration du nucléus et par des exsudations insolites.'

\section{Fam. 3. VITRINID床.}

\section{Genus 5. VITRINA, Draparnau .}

\section{Vitrina Lamarckii.}

Helicolimax Lamarckii, Fer., Prodr. 21 (1821)

Vitrina Lamarckii, Fer., Hist. ii. 69. t. 9. f. 9

"Teneriffæ, Quoy et Gaim., Voy. de l'Astrol. ii. 142.

t. 13. f. 4-9 (1832)

" Lamarckii, W. et B., Ann. des Sc. Nat. 28. syn. 311 (1833) 
Vitrina Lamarckii, Pfeiff., Mon. Hel. ii. 506 (1848)

" Lamarcki, Pfeiff., Mon. Hel. vii. 19 (1876)

Habitat Teneriffam, et (sec. Mousson) Palmam et Hierro; in sylvaticis intermediis humidis præcipue degens.

This usually large Vitrina is the universal one throughout the sylvan regions of Teneriffe; but I am not positive that I have myself observed it in any of the other islands of the Group, though it is stated by Mousson to occur both in Palma and Hierro. ${ }^{1}$ In Teneriffe however it is tolerably general, at intermediate and rather lofty altitudes,-having been met with by Mr. Lowe and myself about the Vueltas above Taganana, at the Agua Garcia, near Ycod el Alto, and in many other spots.

As implied at p. 78 of this volume, the $V$. Lamarckii would seem to take the place in (at all events) Teneriffe of the $V$. nitida at Madeira; and indeed there can be no doubt that the two species have a good deal in common. Nevertheless I feel assured that they are not absolutely identical; from which it follows, that if the Canarian one is to be accepted as the type of Ferussac's Helicolimax Lamarckii (which appears to be inevitable, inasmuch as it was recorded in the original diagnosis as having come from Teneriffe), the Madeiran one (although known hitherto, unfortunately, in Mr. Lowe's works, as the ' $V$. Lamarckii, Fer.') must be quoted by the next name (in the order of priority) under which it was described; and that title is (as has already been shewn) the ' nitida,' of Gould.

Judging from a considerable series which I have inspected, I should say that the $V$. Lamarckii, proper, is, on the average, a rather larger and flatter shell than the Madeiran $V$. nitida, with its aperture even relatively still more developed (or outwardly-produced, and elongated), and with its spire (which has at least half a volution less) more depressed, and the left-hand margin of its peristome, adjoining the columella, much more broadly, and decidedly, membraneous. From which it will be seen, that in some of its characters it would appear to make a slight approach, at first sight, to the $V$. ruivensis of the Madeiran archipelago, whilst in others (as just stated) it resembles the nitida; a circumstance which may perhaps account for Mr. Lowe having regarded it, successively, as identical with them both,-referring it, under the title ' $V$. Teneriffoe, Q. et G.' to the former, and under that of ' $V$. Lamarckii, Fer.'

1 I say 'positive,' because the examples in my collection from Hierro which were referred by Mousson to the $V$. Lamarckii appear to me to belong most unmistakeably to the $V$. latebasis; and I am not aware that there is any

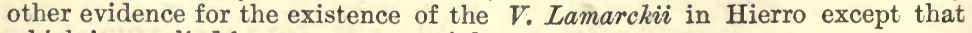
which is supplied by my own material. 
(which he did not seem to recognize was one and the same thing with the Teneriffec) to the latter.

\section{Vitrina canariensis.}

Vitrina canariensis, Mouss., Faun. Mal. des Can. 12. pl. 1. f. $10-12$ (1872)

" $\quad$ Pfeiff., Mon. Hel. vii. 19 (1876)

Habitat Teneriffam (?), Palmam (?), et Hierro; in locis similibus ac præcedens.

This is a smaller or more rounded, or globose, shell than the $V$. Lamarckii, with the nucleus a little more prominent, or less depressed, and the columellary border of the aperture furnished with a narrower membrane. I met with it sparingly in Hierro ; and although Mousson records it from both Teneriffe and Palma, on the authority of specimens supposed to have been taken by myself, I cannot but think that he has fallen into some error as regards his habitats, for it seems to me that my examples from at all events the latter of those two islands belong in reality to the $V$. latebasis, whilst those from the former are anything but typical ones. Mousson speaks of the $V$. canariensis as the commonest, and most widely spread, of all the Vitrinas in this archipelago (' la plus répandue de toutes '); but certainly that is not in accordance with my own experience.

\section{Vitrina reticulata.}

Vitrina reticulata, Mouss., Faun. Mal. des Can. 14. pl. 1. f. 13-15 (1872)

Pfeiff., Mon. Hel. vii. 20 (1876)

Habitat Teneriffam; a cl. Reiss parcissime reperta.

This is the only Canarian Vitrina which I have not myself met with; and it is one which.I have had no opportunity of inspecting. It seems to be the smallest of them all, extremely rare, and observed hitherto merely in Teneriffe, - in which island it was found by Reiss. The peculiarity of its sculpture would appear to be its main distinctive feature:--'Cette sculpture,' says Mousson, ' très-rare dans les Vitrines, se compose de stries d'accroissement fines, mais assez prononcées, et, sous une bonne loupe, de fines lignes décurrentes, qui sur. le contour sont presque aigûes, par contre plus faibles à la base, le long de la suture et vers le bord extérieur de l'ouverture.'

\section{Vitrina latebasis.}

Vitrina latebasis, Mouss., Faun. Mal. des Can. 13. pl. 1. f. $4-6(1872)$

" $\quad$ Pfeiff., Mon.Hel. vii. 20 (1876) 
Habitat Palmam, et Hierro ; in humidis sylvaticis editioribus præcipue gaudens.

The present Vitrina is, on the average, smaller, and a little paler, than the $V$. Lamarckii, its spire is a trifle more depressed, its aperture is relatively not quite so large, and its lower lip is not so broadly and conspicuously membraneous. But the character by which it seems to me to be the most easily separated consists in the fact of its nucleus (or apical volutions) being always more or less sculptured with (often very conspicuous) radiating costæ, - which are strongly expressed in the examples from Palma, though rather less so in those from Hierro.

The V. latebasis would appear to stand in much the same relation to the Lamarckii as the V. marcida, Gould (or media, Lowe) does, in the Madeiran Group to the nitida, Gould (the Lamarckii, Lowe, nec Fer.). Indeed, in their reduced stature and somewhat paler hue, the V. latebasis and the Porto-Santan $V$. marcida have a good deal in common; nevertheless the former is a little more decidedly flattened as regards its spire, its lower lip is less broadly membraneous, and its apical volutions are sculptured (as just mentioned) with radiating, and often granulated, costæ.

This Vitrina was met with by Fritsch in Palma, and by Mr. Lowe and myself in that island and Hierro. I possess indeed a few examples, taken in the wood of Las Mercedes in Teneriffe, which, from their small size and pallid hue, might well be supposed to belong to the $V$. latebasis; but since I can detect no traces of radiating costæ about their (nevertheless granulated) nucleus, I think perhaps it would scarcely be safe to treat them as conspecific with those from Palma and Hierro. My Palman examples are from the Barranco de Agua, the Barranco de Galga, and the Barranco de Herradura, as well as from Barlovento and about the Vueltas leading up to the Cumbre above Buenavista; whilst the Hierro ones are from the sylvan district of El Golfo. ${ }^{1}$

\section{Vitrina Blauneri.}

Vitrina Blauneri, Shuttl., Bern. Mitth. 138 (1852)

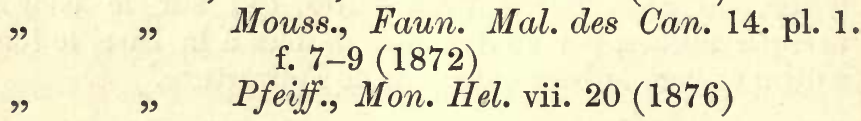

1 I possess two exceedingly young individuals of the V. latebasis, taken on the Cumbre in Palma, which at first sight it somewhat puzzled me to identify. They are so extremely minute as to consist only of the nucleus; and as that particular portion of the shell is sculptured (as just stated) with oblique radiating costæ, their primâ facie appearance is very peculiar. 
Habitat Canariam Grandem, Teneriffam, et Palmam; hinc inde (præsertim in Canariâ Grandi) sub lapidibus.

According to my own experience, this Vitrina is essentially characteristic of Grand Canary, in which island it was taken by Mr. Lowe and myself, not uncommonly, and more sparingly by Mr. Watson. It is however recorded by Mousson to have been obtained by Blauner (who met with a single example of it) in Teneriffe, and by Fritsch in Palma.

Although in its size, form, and hue it bears a considerable resemblance at first sight to the latebasis, the V. Blauneri is nevertheless a-very distinct species, -its shell (which is mush depressed, though without any minute costæ at the nucleus) being a trifle more solid, and somewhat. less transparent, than in the other Vitrinas, with the aperture proportionally smaller, and the lower lip of the peristome almost free from any appearance of lateral membrane, but dilated at its insertion into a small but appreciable lamella which covers the place of the umbilicus, and which is continued (as a just perceptible thickening) across the body-volution to the insertion of the upper lip. In which last-mentioned characters it recedes, according to Mousson, from the true Vitrinas, and makes a slight approach towards the perforated Daudebardias. ${ }^{1}$

\section{Fam. 4. HELICID无.}

\section{Genus 6. HYALINA, Gray.}

(§ Iyra, Mousson.)

\section{Hyalina circumsessa.}

Helix circumsessa, Shuttl., Bern. Mitth. 139 (1852)

" " Pfeiff., Mon. Hel. iii. 102 (1853)

Patula circumsessa, Mouss., Faun. Mal. des Can. 26

(1872)

Helix circumsessa, Pfeiff., Mon. Hel. vii. 173 (1876)

Habitat Teneriffam et Palmam, præcipue illam ; in sylvaticis intermediis vulgaris, sed quoque in locis etiam inferioribus minus frequens.

${ }^{1}$ I may just state that I reject altogether the V. fasciolata, Fer., from the Canarian fauna, being founded (as it seems to $\mathrm{me}$ ) on insufficient evidence as regards its habitat. It belongs to a type totally distinct from anything which has hitherto been observed in these Atlantic islands; and there is abundant reason for suspecting that the older naturalists who cited it as Teneriffan fell into some error concerning the country from whence it had been brought. 'Cette espece,' says Mousson, 'fort remarquable par ses fascies insolites, provient des premiers naturalistes, qui ont visité les Cana ries et dont les indications de patrie ne sont pas toujours certaines. Comme aucun voyageur ne l'a depuis retrouvée, il est permis de suivre l'exemple de MM. Webb et Berthelot et de douter de son existence dans les Canaries' (l.c. 15.) 
Mousson treats this shell as a Patula, associating it (under his section Lyra) with the Lanzarotan $H$. torrefacta, Lowe; but I cannot agree with him in either of these steps. For, in the first place, the minute spiral lines on which he rightly lays so much stress exist also, though very obscurely, in the $H$. lenis of Shuttleworth, which is most unmistakeably (and by his own admission) a Hyalina, and much more conspicuously in a new species ${ }^{1}$ which is so closely allied to the $H$. lenis that it is but just separable from it; whilst the affinities of the $H$. torrefacta are, in my opinion, with the Madeiran H.lentiginosa, Lowe,a form which is far removed from the whole of these immediate groups. Both Shuttleworth and Mousson, indeed, would appear to have completely overlooked in the $H$. lenis the existence of these "spiral lines" on which the latter has founded his section Lyra, and which, although usually very difficult to detect, I find to be quite appreciable (but often fragmentary) in about one specimen in every twenty; whilst (as just mentioned) in an intimately related form which was taken by Mr. Lowe at Osorio, on the mountains of Grand Canary (and which $I$ at first imagined might represent but an insular phasis of the one from Palma and Hierro), the spiral lines are as strongly developed as in the $H$. circumsessa. Hence I think there can be no question that the circumsessa, osoriensis, and lenis are intimately bound together by the very peculiar and significant character to which I have just called attention; and since there cannot be the slightest doubt that the second and third of these are true Hyalinas (being in point of fact, very manifestly akin to the common $H$. cellaria, Müll.), it follows that the circumsessa must be regarded as a Hyalina likewise, and not as a Patula.

The $H$. circumsess $a$ is, on the average, a trifle smaller and darker than the $H$. osoriensis, its spire is a little more depressed, the basal volution is (relatively) not quite so broadly developed, its umbilicus is appreciably wider (or more open), and its minute spiral lines are rather more numerous, or set closer together. It is an essentially characteristic species in Teneriffe, which appears to be its chief habitat; indeed it was not met with by either Mr. Lowe or myself in any of the other islands, though it is recorded to have been taken by both Blauner and Fritsch in Palma. In Teneriffe however it is abundant throughout the sylvan districts of an intermediate altitude,--where we obtained it at the Agua Garcia, at Las Mercedes, in the wooded region above Taganana, and even (though more sparingly), at a lower elevation, around both Garachico and Sta. Cruz.

1 The H. osoricnsis, Woll., enunciated below. 


\section{Hyalina osoriensis, n. sp.}

T. subrotundata, depressiuscula, subopaca, pallide albidoochracea; anfranctibus 5-6 convexiusculis, suturâ impressâ, costulis obliquis curvatis subinæqualibus subconfluentibus sat distincte sculpturatis, necnon lineolis spiralibus subtilissimis subcrenulatis (subtus subevanescentibus, atque in speciminibus junioribus ac bene conservatis minutissime subciliato-fimbriatis) parce vel remote instructis; umbilico magno, profundo.-Diam. maj. 4-4 $\frac{1}{2}$ lin.

Habitat Canariam Grandem ; in sylvis editioribus ad Osorio, Aprili 24, 1858,-a Revdo. R. T. Lowe satis copiose reperta.

Several examples of this Hyalina were taken by Mr. Lowe (on the 24th of April, 1858) in the woods on the Pico do Osorio, in Grand Canary, during our visit to that remote and elevated spot; and they have so much the appearance at first sight of the paler individuals of the H. lenis (from Palma and Hierro) that they might well nigh be confounded with that species, were it not for the minute spiral subcrenulated lines with which its whorls (when viewed beneath a powerful lens) are seen to be conspicuously though sparingly sculptured, and which in young and unrubbed shells have a curious tendency to be fringed with most diminutive filaments or hair-like scales. In most other respects the $H$. osoriensis appears to me to be nearly undistinguishable from the $H$. lenis, except perhaps that it is even still less shining (its under-portion no less than the upper, being almost free from gloss), and that its transverse plicæ are not quite so coarse.

From the $H$. circumsessi the present species differs in its rather larger size and its less flattened spire, as well as in its ultimate volution being altogether more broadly developed and in its umbilicus being proportionately not quite so open. Its colour, too, is appreciably paler; and its spiral lines are further apart, and therefore not quite so numerous.

The great interest, however, which attaches itself to this Hyalina consists (as I have already stated) in the light which it incidentally throws upon the affinities of the $H$. circumsessa, which Mousson has regarded as entering into a section of the genus Patula. I had always felt convinced that the latter belonged in reality to the Hyalina group; but now that the minute 'spiral lines' which so eminently characterise the circumsessa are found to exist (however feebly) in the H. lenis likewise, and to be strongly developed in a closely related form from Grand Canary, both of which are unmistakeable Hyalinas, and indeed but barely removed from the ordinary cellaria-type, there can be no longer any question that the affinities of the circumsessa are with Hyalina, and not with Patula. 


\section{Hyalina lenis.}

Zonites lenis, Shuttl., Bern. Mitth. 138 (1852)

$$
\text { Pfeiff., Mon. Hel. iii. } 86 \text { (1853) }
$$

Hyalina lenis, Mouss., Faur. Mal. des Can.16. pl. 1. f. 19 21 (1872)

Helix lenis, Pfeiff., Mon. Hel. vii. 145 (1876)

Habitat Palmam et Hierro ; in sylvaticis editioribus degens.

The present truly indigenous Hyalina has been observed hitherto only in Palma and Hierro, where it occurs in damp sylvan spots of an intermediate and lofty altitude. It was taken by $\mathrm{Mr}$. Lowe and myself in the Barranco de Galga, the Barranco de Agua, and at $\mathrm{El}$ Monte above Barlovento, as well as by the edges of the Vueltas leading up to the Cumbre above Buenavista, of the former, and in the wooded district of El Golfo, on the western slopes of the latter.

The $H$. lenis is generally of a clear olivaceous brown; but it has likewise a paler (though scarcely perhaps an 'albino') state, of a somewhat greenish white. It is, on the average, nearly as large as the $H$. cellaria,-from which, however, it differs (apart from colour) in its being less shining, particularly on the upper-side, and more strongly sculptured (the entire surface being densely covered with oblique, curved, subconfluent hair-like transverse lines, or costæ), as well as in its spire being rather less depressed and its umbilicus a little larger. Its ultimate volution is a good deal developed, but scarcely more so (I think) than in the $H$. cellaria, and certainly not more so than in the Grand-Canarian examples of the latter. As I have already stated under the $H$. circumsessa, it is not difficult to detect, in occasional examples of the $H$. lenis, faint traces, beneath a high magnifying power, of the minute spiral lines which are so easily to be seen in the closely allied $H$. osoriensis, and which are exceedingly conspicuous in the $H$. circumsessa.

\section{(§ Lucilla, Lowe.)}

\section{Hyalina cellaria.}

Helix cellaria, Müll., Hist. Verm. ii. 28 (1774)

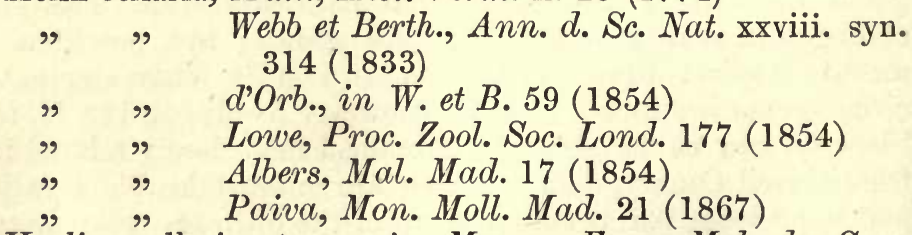

Hyalina cellaria et canariæ, Mouss., Faun. Mal. des Can. $15,16(1872)$ 
Helix cellaria et canariæ, Pfeiff., Mon. Hel. vii. 144, 178 (1876).

Habitat Canariam Grandem, Teneriffam, et Hierro; sub lapidibus, præcipue in cultis.

As in the Madeiran and Azorean archipelagos (and even as at St. Helena), the common European $H$. cellaria has established itself in the Canaries,-where it is locally rather abundant, for the most part within the cultivated districts, but likewise in sylvan spots of an intermediate altitude. It was taken by Mr. Lowe and myself throughout the region of El Monte in Grand Canary, at Las Mercedes and near Garachico and Ycod el Alto in Teneriffe, and on the western side of Hierro; and Grand-Canarian specimens are now before me which were met with by Mr. Watson.

The examples of this Hyalina from Grand Canary have been described by Mousson (l.c. 16. pl. 1. 16-18), under the name $H$. canarioe, as specifically distinct ; but I am totally unable to detect anything about them to warrant their separation. Their spire is a little less depressed and their umbilicus just perceptibly wider, and perhaps also (though I am not at all sure about this) their ultimate volution is a trifle more broadly developed; but each of these characters are barely appreciable, and are easily matched (as it seems to me) in selected individuals from the other islands of the Group; so that I can scarcely regard the Grand-Canarian ones as representing even a decided 'variety' (and, therefore, à fortiori, a species), though, out of deference to Mousson, I will cite them as, at all events, the ' $\beta$. canarioe.'

\section{Hyalina vermiculum.}

Helix vermiculum, Lowe, Ann. Nat. Hist. vii. 104 (1861)

" $" \quad$ Pfeiff., Mon. Hel. v. 109 (1868)

Hyalina vermiculum, Mouss., Faun. Mal. des Can. 18. pl.

$$
\text { 1. f. } 25-27 \text { (1872) }
$$

Helix vermiculum, Pfeiff., Mon. Hel. vii. 112 (1876)

Habitat Teneriffam; in aridis calcareis inter Portum Orotavæ et Realejo, necnon mox supra illud, sub lapidibus sat vulgaris.

Although partaking more, in its general proportions and contour, of the $H$. cellaria, this little Hyalina is in some respects intermediate between that species and the $H$. crystallina. Indeed in its comparatively small size, and in its white, hyaline, transparent surface it has more in common at first sight with the latter; nevertheless the form of its under-portion, which slopes off gradually into the umbilicus, at once removes 
it into the same group as the cellaria. This structure of the umbilical region will at once serve to separate even the young and minute examples from the crystallina,-from which it further differs (apart from the larger stature of the adult shells) in its basal whorl being relatively a trifle more widened towards the aperture, in its under-parts being of a somewhat more milky white (or rather less strictly glassy), and in its volutions being more appreciably impressed towards the suture with transverse radiating lines,--which become lighter, and almost evanescent, posteriorly.

The only district in which I am aware that the $H$. vermiculum has hitherto been observed (unless indeed the $H$. semicostula, Beck, which is reported from Grand Canary, be identical with it) is in the north of Teneriffe, - where it was taken by Mr. Lowe and myself, in abundance, beneath stones, on the dry calcareous ground between Realejo and the Puerto of Orotava, as also (at La Dehesa) immediately above the latter. ${ }^{1}$

\section{(§ Crystallus, Lowe.)}

\section{Hyalina crystallina.}

Helix crystallina, Müll., Hist. Verm. ii. 23 (1774)

" " Lowe, Cambr. Phil. S. Trans. iv. 47 (1831)

" $\quad$ Albers, Mal. Mad. 17. t. 2. f. 18-21 (1854)

Paiva, Mon. Moll. Mad. 22 (1867)

Hyalina "rystallina, Mouss., Faun. Mal. des Can. 17 (1872)

Helix crystallina, Pfeiff., Mon. Hel. vii. 106 (1876)

Habitat Fuerteventuram, Teneriffam, Palmam, et Hierro ; hinc inde sub lapidibus in graminosis.

I have no doubt that this little European Hyalina (which has established itself also in the Madeiran and Azorean Groups) will be found eventually to be universal at the Canaries,-thoigh hitherto it has been observed only in four islands, out of the seven. In those four, however, I have myself met with it,-namely at Sta. Maria Betancuria in Fuerteventura; at the Agua Mansa, the Agua Garcia, and near Orotava, in Teneriffe ; in the Barranco de Agua and the Barranco de Galga, as well as

1 I may just notice in this place the Hyalina semicostula, Beck, which is cited by Reeve from Grand Canary, but without any evidence for the correctness of his habitat. I have little doubt that Reeve was mistaken in quoting the species, which is said to occur in Portugal, as Canarian; and I am glad to observe that Mousson has arrived at the same conclusion. I have therefore no hesitation in omitting it from our catalogue. 
on the Cumbre above Buenavista, in Palma; and also, in semicultivated grounds, in Hierro.

The single example, now before me, from Fuerteventura has the umbilicus a trifle larger than is the case in the specimens from the other islands; but I can see nothing about it to warrant the suspicion that it represents more than a slight insular modification (which we might perhaps cite as the 'var. $\beta$. fuerteventuro') of the H. crystallina.

\section{(§ Vermetum, Woll.)}

\section{Hyalina festinans.}

Zonites festinans, Shuttl., Bern. Mitth. 138 (1852)

Helix festinans, Pfeiff., Mon. Hel. iii. 106 (1853)

Hyalina festinans, Mouss., Faun. Mal. des Can. 17. pl. 1. f. 22-24 (1872) diffusa.

Habitat Palmam; in sylvis editioribus late sed parce

This little Hyalina appears to be peculiar (so far at least as has been observed hitherto) to the island of Palma, where it occurs in damp sylvan spots of intermediate and lofty altitudes. It was met with by Mr. Lowe and myself in the Barranco de Galga, and by the sides of the Vueltas (on the ascent to the Cumbre) above Buenavista; and Mr. Lowe obtained it (on May 26, 1858, in the wood of $\mathrm{El} \mathrm{Bucco,} \mathrm{at} \mathrm{El} \mathrm{Monte,} \mathrm{above}$ Barlovento.

The $H$. festinans has somewhat the same whitish-green colour, or olivaceous-brown, as the $H$. lenis (which is likewise a Palman species, though found equally in Hierro); but it is very much smaller and less sculptured, with the spire more depressed, with the ultimate and penultimate volutions (particularly the former) conspicuously narrower or less developed, and with the umbilicus, although open and spirally visible from beneath, not quite so much so (relatively) as is the case in that species. In mere stature indeed it may be said to be intermediate between the $H$. lenis and the crystallina; though its much greater bulk, wider umbilicus, and yellowishgreen hue will at once separate it from the latter.

Perhaps in reality the nearest ally of the $H$. festinans is the minute and very rare $H$. scintilla, Lowe, of the Madeiran archipelago,- which in its general facies and colour it a good deal resembles. It is, however, considerably larger than that species, its umbilicus is (proportionately) less open, its spire is perhaps even still more depressed, and its surface is both less shining and more appreciably sculptured. 


\section{( $§$ Nautilinus, Mouss.)}

\section{Hyalina clyméne.}

Zonites Clymene, Shuttl., Bern. Mitth. 138 (1852)

Helix Clymene, Pfeiff., Mon. Hel. iii. 11 (1853)

Hyalina Clymene, Mouss., Faun. Mal. des Can. 19, pl. 1. f. 28-33 (1872)

Helix Clymene, Pfeiff., Mon.Hel. vii. 182 (1876)

Habitat Teneriffam; ad rupes aquaticas juxta oppidulum Garachico, una cum Pupâ, Physâ, Ancylo, et Hydroccenâ commixta, degens.

I am extremely doubtful whether this curious little Planorbis-like shell should be associated with Hyalina; nevertheless since it is considered by Mousson to be better placed here than elsewhere, I will not disturb the situation which he has assigned to it. But I will merely add, that its whole structure appears to me to be distinct from that of the Hyalinas; whilst its subaquatic mode of life (on dripping rocks, in company with Ancylus, Physo, and Hydroccena) is quite unprecedented, so far as I am aware, in the members of the present group.

The $H$. Clymene (the largest examples of which are, in their broadest part, about a line across) is a flattened, Planorbisshaped little shell, slightly transparent, and of a dark olivaceous-brown, - often a good deal corroded with a hard whitish deposit. Its volutions are transversely striated, and the ultimate one is very largely developed-(the upper lip of the aperture being more forwardly-produced than the lower); its spire is not merely depressed, but ábsolutely concave; and its umbilicus is wide, and spirally visible from beneath.

The only region in which I am aware that the $H$. Clymene has hitherto been observed is near Garachico, in the north of Teneriffe. I did not myself meet with it; but it was taken by Mr. Lowe (as it had been, apparently, a few years before, by Blauner) from off wet rocks, close to the waterfall, on the road leading to Ycod de los Vinhos,-namely adhering to bits of stick, \&c., in trickling places, along with the Pupa castanea, the Ancylus striatus, the Physa acuta, and the Hydrocona gutta.

\section{Genus 7. IEUCOCHROA, Beck.}

\section{Leucochroa ultima.}

Leucochroa ultima, Mouss., Faun. Mal. des Can. 19.pl. 1. f. 34-36 (1872)

Helix ultima, Pfeiff., Mon. Hel. vii. 193 (1876)

1 In some observations on the present genus, Mousson (l.c. 19) remarks : 'Les Leucochroes, Beck, ou Calcarines, Moq.-Tand., forment un ensemble 
Habitat Fuerteventuram; a cl. Fritsch lecta.

The present and two following Leucochroas were detected by Fritsch in Fuerteventura, and I know nothing about them except from the descriptions which are given by Mousson. Judging from the figures they appear to be very closely related inter se, and it may perhaps be a question whether more than at any rate two species are in reality represented by the three forms. The L. ultima seems to have a good deal in common with the L. cariosa, Oliv., from Palestine ; and, comparing it with that shell, Mousson says: 'Elle a, en effet, le même test crayeux, le même enroulement de la spire, une carène analogue, dentelée dans les tours supérieurs, enfin un même genre de granulations. Mais elle reste bien plus petite; elle est bien moins rugueuse, n’a pas de carène aussi prononcée, enfin manque de forte angulation autour de l'ombilic.' ' La plupart des individus ont été ramassés morts, quelques-uns cependant contenaient encore l'animal.' (l. c. 20).

\section{Leucochroa pressa.}

Leucochroa pressa, Mouss., l. c. 20. pl. 1. f. 37-39 (1872) Helix pressa, Pfeiff., Mon. Hel. vii. 194 (1876)

Habitat Fuerteventuram; una cum precedente degens.

In all probability but a modification of the $L$. ultima, with which it was found in company. Mousson says: 'Elle s'est trouvée mêlée à la précédente, dont elle diffère par son applatissement, son ombilic ouvert, sa granulation plus fine passant à des stries! Malgré ces différences elle pourrait n'en être qu'une modification individuelle. Les échantillons que j'ai sous les yeux ont tous été ramassés à l'état mort ; mais, à juger d'après l'état fraix de leur nucléus, ne peuvent pas appartenir à une ancienne époque.' (l. c. 20.)

\section{Leucochroa accola.}

Leucochroa accola, Mouss., l. c. 20. pl. 1. f. 40, 41 (1872) Helix accola, Pfeiff., Mon. Hel. vii. 200 (1876)

Habitat Fuerteventuram; et semifossilis et vix recens reperta.

This is the smallest of the three forms, and rather more conical than the others. 'Elle est,' says Mousson (l. c. 21), 'cependant, en moyenne, plus élevée, présente un nucléus un peu

d'espèces, étroitement liées par la nature solide et calcaire du test, par leurs habitudes de vie, occupant surtout des lieux fortement exposés au soleil, enfin par des rapports géographiques très-intimes. Dans un arrangement naturel lil convient, à ce qu'il me semble, de faire ressortir ces affinités, en élévant, 
proéminent par rapport au cône spiral obtus, une base plus applatie, une surface plus irrégulièrement et plus finement granuleuse, etc.'

The $L$. accola seems to have been found principally in a subfossil state, none of the specimens which were obtained by Fritsch being apparently quite recent,-though some of them were distinctly older than the rest. 'Elle se trouve en un double état, d'abord avec les caractères d'une coquille actuelle, recuillie à l'état mort, avec sa sculpture bien conservée; puis avec un aspect altéré, toute la sculpture ayant disparue sous une surface inégale, corrodée ou polie par l'usure. Ces individus, un peu plus coniques et à la base plus applatis que les autres, semblent appartenir à une faune ancienne, tandisque les autres relèvent de l'époque présente, ou de l'époque qui l'a immédiatement précédée.' (Mousson, l. c. 21).

\section{Genus 8. PATULA, Held.}

(§ Iulus, Woll.)

Patula garachicoensis, n. sp.

T. orbiculato-depressa, discoidea, profunde sed haud late perforata, pallide fusca, subtenuis, vix nitidiuscula, crebre subirregulariter aut subconfluente ruguloso-striata ; spirâ depressâ ; anfractibus $5-5 \frac{1}{2}$ convexis, transversim crebre sed subirregulariter arcuatim ruguloso-striatis, ultimo haud descendente, suturâ profunde impressâ; aperturâ lunatâ; peristomate tenui, acuto, versus columellam reflexiusculo._Diam. maj. vix $3 \frac{1}{2}$; alt. $1 \frac{1}{2}$ lin.

Var. $\beta$. submarmorata.-Vix magis tenuis, et paulo minus grosse sculpturata, spirâ minus depressâ, anfractibus obsolete subalbido-marmoratis.

Helix agrestis, Lowe, in litt.

Habitat Teneriffam; juxta oppidulum Garachico, mense Aprili 1861, a Revdo. R. T. Lowe inventa. Var. $\beta$. (in Teneriffâ certe lecta) a cl. Berthelot Domino Lowe donata.

Obs.-Species P. Bertholdiana, Pfeiff., insularum Cap. Viridis, affinis, sed præcipue differt testa magis depressa et rugosius sculpturata, anfractibus convexioribus (ultimo nullo modo carinato), suturâque profundiore.

Several examples of the present Patula, which seems to be quite different from everything else which has hitherto been described from the Canarian Group, were taken by Mr. Lowe, during April 1861, near Garachico, in the north of Teneriffe. Although exceedingly distinct, in its diminished stature, very much smaller umbilicus, and less polished under-portion, per- 
haps its nearest ally in this archipelago is the (nevertheless more highly coloured) $P$. putrescens, Lowe, from Palma, - with which in its flattened, discoidal contour and tumid volutions it to a certain extent agrees. From the Hyalina circumsessa, Shuttl., it is totally distinct by, inter alia, its smaller size and very much smaller umbilicus, by its more flattened spire and much less developed basal volution, and by its entirely wanting the spiral hair-like lines which are so eminently characteristic of that species and its two immediate allies. ${ }^{1}$

In its general size and hue, as well as in the proportion of its umbilicus, the $P$-garachicoensis has also, at first sight, a little in common with the $P$. Bertholdiana, Pfeiff., from the Cape Verdes. It is, however, more flattened and discoidal than that species (or less lenticular), its surface is more strongly and roughly sculptured, and, although the spire is much depressed, its volutions are nevertheless more tumid,- the basal one moreover being quite free from the slightest trace of a keel.

\section{(§ Janulus, Lowe.)}

\section{Patula Pompylia.}

Helix Pompylia, Shuttl., Bern. Mitth. 140 (1852)

Patula Pompylia, Mouss., Faun. Mal. des Can. 27. pl. 2. f. 29-32 (1872)

Helix Pompylia, Pfeiff., Mon. Hel. vii. 128 (1876)

Habitat Palmam; in sylvaticis editioribus rarissima.

This may be regarded, in the Canarian archipelago, as the representative of the Madeiran $P$. stephanophora, Desh.,-with which, in its general outline and in the character of its sculpture, it has a good deal in common. It is, however, considerably smaller than that species, and its umbilicus is both still more diminished in width and more suddenly scooped out; its spire is relatively a little more depressed; its under-portion is more convex, and rather less opake; and the costæ of its whorls are more closely set together, and, although much raised, not quite so elevated or quite so curved.

The P. Pompylia seems to be of the greatest rarity, and confined (so far as has been observed hitherto) to Palma,-where it occurs in the damp wooded districts of a high altitude. It

1 The single example, now before me, which I have enunciated above as representing a 'var. $\boldsymbol{\beta}$. submarmorata,' was received from M. Berthelot as undoubtedly Teneriffan; and in all probability it is the exponent of some local race, or slight modification, of the $P$. garachicoensis, peculiar to another district. It differs in being a trifle more fragile and less coarsely sculptured, in its spire being less depressed, and in its volutions being very obscurely dappled with a few faint and irregular paler markings. 
was met with by Mr. Lowe and myself on the Cumbre above Buenavista, as well as by the edges of the Vueltas on the ascent to that elevated region; and it would appear to have been found also by Blauner.

\section{(§ Patula normales.)}

\section{Patula textilis.}

Helix textilis, Shuttl., Bern. Mitth. 140 (1852) Pfeiff., Mon. Hel. iii. 121 (1853)

Patula textilis, Mouss., Faun. Mal. des Can.22. p. 1.f. 4244 (1872)

Helix textilis, Pfeiff., Mon. Hel. vii. 159 (1876).

Habitat Palmam; in sylvaticis humidis editioribus, rariss., una cum $P$. Pompylia, Shuttl., degens.

Like the P. Pompylia, Shuttl., the $P$. textilis occurs in the higher and wooded districts of Palma, - to which island (unless indeed the $P$. concinna, Lowe, from Hierro, be but a local modification of it) it would seem to be peculiar. It is evidently, like that species, of the greatest rarity, but was met with by Blauner, and subsequently both by Mr. Lowe and myself (during June, 1858), on the ascent of the Cumbre above Buena vista.

Although possessing much the same character of sculpture, the $P$. textilis may at once be known from the P.Pompylia by its larger size, its just perceptibly more elevated spire, and its very much wider and more open umbilicus. Its basal volution, too, is relatively a trifle broader or more developed; and its transverse costæ are conspicuously more oblique.

\section{Patula concinna.}

Helix concinna, Lowe, Ann. Nat. Hist. vii. 105 (1861)

$$
\text { Pfeiff., Mon. Hel. v. } 177 \text { (1868) }
$$

Patula concinna, Mouss., Faun. Mal. des Can. 22. pl. 1. f. $45-47$ (1872)

Helix concinna, Pfeiff., Mon. Hel. vii. 195 (1876)

Habitat Hierro ; in regione sylvaticâ ' El Golfo' dictâ, sub cortice truncorum putrescentium, a meipso inventa. Forsan præcedentis status insularis.

I am extremely doubtful whether this is anything more than an insular modification, peculiar to Hierro, of the Palman $P$. textilis; nevertheless since it has a few very minute characters of its own, and it was enunciated as distinct by Mr. Lowe, I will not attempt absolutely to amalgamate the two.

Judging from the five types which are now before me, 
and which were taken by myself (from beneath the bark of a rotten tree) in the sylvan district of $\mathrm{El}$ Golfo on the western slopes of Hierro, the $P$. concinna differs from the textilis, merely, in its transverse costæ being rather less raised or developed, in its ultimate volution being just appreciably wider, and its umbilicus being a trifle larger or more open. Its spire, too, is, if anything, just perceptibly more depressed. In colour it would seem to be either of a pale reddish brown, or else of a still paler albino-yellow.

\section{Patula putrescens.}

Helix putrescens, Lowe, Ann. Nat. Hist. vii. 104 (1861)

$$
\text { " " Pfeiff., Mon. Hel. v. } 143 \text { (1868) }
$$

Patula putrescens, Mouss., Faun. Mal. des Can. 23. pl. 1.

$$
\text { f. } 48-50 \text { (1872) }
$$

Helix putrescens, Pfeiff., Mon. Hel. vii. 144 (1876)

Habitat Palmam; a meipso in sylvaticis editioribus, subtruncis arborum putrescentibus, detecta.

The present Patula, like the P. Pompylia and textilis, has been observed hitherto only in the wooded districts of Palma,where it was met with by myself, abundantly, beneath the trunks of decaying trees and pieces of rotten wood, in the Barranco de Galga. It differs however from those species in its larger size, darker, coffee-brown hue (although it has an occasional albino variety or state), more open umbilicus, more shining surface, and less costate sculpture, -its volutions (which are fewer, and which, in spite of the spire beingmuch depressed, are extremely convex) being merely striated transversely with irregular subconfluent hair-like lines. The larger examples of the H. putrescens are about $4 \frac{1}{2}$ lines across, in the widest part.

\section{Patula engonata.}

Helix engonata, Shuttl., Bern. Mitth. 139 (1852)

$$
\text { Pfeiff., Mon. Hel. iii. } 114 \text { (1853) }
$$

Patula engonata, Mouss., Faun. Mal. des Can. 23. pl. 2.

$$
\text { f. } 1-4 \text { (1872) }
$$

Helix engonata, Pfeiff., Mon. Hel. vii. 211 (1876) sima.

Habitat Teneriffam; juxta oppidulum Garachico, raris-

The $P$. engonata may be regarded as one of the representatives at the Canaries of the common European $P$. rotundata,with which in size, colour, and sculpture it is almost coincident. It differs, however, essentially, from that species in the conformation of its very much larger umbilicus, - which is not only 
more open, but which shapes-out at its commencement a peculiar and very distinct circular keel on the under-part of the basal volution. It is also, on the whole, a little darker, or browner, than the rotundata; and it is less sculptured beneath (at any rate outside the above-mentioned circular keel) with costate lines.

This would appear to be one of the most local of the Canarian Land-shells, and indeed one of the rarest,- the only district in which I am aware that it has hitherto been found being around Garachico, in the north of Teneriffe. It was met with there, in 1861, not uncommonly, by Mr. Lowe,-having previously been taken, in the same locality, by Blauner.

\section{Patula retexta.}

Helix retexta, Shuttl., Bern. Mitth. 139 (1852) P $\bar{f}$ eiff., Mon. Hel. iii. 115 (1853)

Patula retexta, Mouss., Faun. Mal. des Can. 24. pl. 2. f. $5-8(1872)$

Helix retexta, Pfeiff., vii. 212 (1876)

Habitat Palmam; a cl. Blauner sub foliis dejectis lecta.

This species and the following one are the only Canarian Patulas which I have not myself had an opportunity of examining. Comparing it with the Teneriffan P. engonata, and the $P$. Guerineana, Lowe, from Madeira, Mousson says (l. c. 24): 'Elle ne présente ni la carène, ni l'angle au pourtour de l'ombilic de la $P$. engonata; le dernier tour est plus lisse; la suture marginée d'une fine ligne blanche. L'espèce la plus proche est la $P$. semiplicata, Pfr. (Guerineana, Lowe) de Madère, mais celle-ci n'a pas de suture marginée, un ombilic encore plus large, des tours plus étroits quoiqu'en nombre égal, et une costulation plus grossière.'

The $P$. retexta was taken by Blauner in Palma, where however it was not met with by either Mr. Lowe or myself.

\section{Patula scutula.}

Helix scutula, Shuttl., Bern. Mitth. 139 (1852)

" " Pfeiff., Mon. Hel. iii. 108 (1853)

Patula scutula, Mouss., Faun. Mal. des Can. 24 (1872)

Helix scutula, Pfeiff., Mon. Hel. vii. 186 (1876)

Habitat Teneriffam; sub ligno emortuo a cl. Blauner bis detecta.

As already stated, this is one of the few Canarian species which I have not been able to inspect. It appears to have been unknown also to Mousson, who remarks (l. c. 24): 'Cette espèce m'est inconnue. Par sa forme très déprimée, le nombre 
de ses tours, s'élevant à 9 , et la largeur de l'ombilic elle se présente comme un développement extrême du type de la rotundata, Müll.'

\section{(§ Pyramidula, Fitz.)}

\section{Patula placida.}

Helix pusilla (pars), Lowe, Cambr. Phil. S. Trans. iv. 46 (1831)

" placida, Shuttl., Bern. Mitth. 140 (1852)

" $\quad$ Pfeiff., Mon. Hel. iii. 82 (1853)

" pusilla, $\beta$. sericina, Lowe, Proc. Zool. Soc. Lond. 176 (1854)

"Luseana, Paiva, Mon. Moll. Mad. 83. t. 2. f. 3. (1867)

Patula placida, Mouss., Faun. Mal. des Can. 25. pl. 2. f. 9-12 (1872)

Helix placida, Pfeiff., Mon. Hel. vii. 139 (1876)

Habitat Teneriffam, Palmam, et Hierro ; in sylvaticis editioribus, passim.

As I have already stated, at p. 87 of this volume, the present minute Patula formed a portion of Mr. Lowe's original $H$. pusilla, but it was not until 1854 that he recognized it to be so far distinct as to define it as a 'var. $\beta$. sericina' of the latter. In the meanwhile however it had been described by Shuttleworth, from the Canaries, under the title $H$. placida. The exact characters which separate it from the pusilla have been fully pointed out.

The $P$. placida would seem to occur in precisely similar situations throughout the Canarian archipelago as it does at Madeira, its normal range being within the wooded districts of intermediate altitudes. I have taken it at Las Mercedas in Teneriffe, in the Barranco de Agua and the Barranco de Galga in Palma (where it was found also by Mr. Lowe at El Monte, above Barlovento), and in the sylvan region of El Golfo on the western slopes of Hierro. It appears also to have been found in Teneriffe (namely on the trunks of trees at Guimar) by Blauner.

\section{(§ Acanthinula, Beck.)}

Patula pusilla.

Helix pusilla, Lowe, Cambr. Phil. S. Trans. iv. 46. t. 5. f. 17 (1831)

" " Pfeiff., Mon. Hel. i. 101 (1848)

" servilis, Shuttl., Bern.Mitth. 140 (1852)

" " Pfeiff., Mon. Hel. iii. 101 (1853) 
Helix pusilla, a. annulata, Lowe, Proc. Zool. Soc. Lond. 176 (1854)

"Alb., Mal. Mad. 18. t. 2. f. 7-10 (1854)
" $\quad$ Paiva, Mon. Moll. Mad. 79 (1867)
hypocrita, Dohrn, in Mal. Blätt. xvi. 1 (1869)

Patula servilis, Mouss., Faun. Mal. des Can. 25. pl. 2. f. 13-16 (1872)

Habitat Teneriffam, Palmam, et Hierro ; in aridis sub lapidibus, minus frequens.

This extremely minute Patula seems to possess a wide geographical range,-occurring not only in the Madeiran and Canarian archipelagos, but likewise at the Cape Verdes (from whence it was described by Dr. H. Dohrn as the ' $P$. hypocrita'), and even at St. Helena, where it was detected by myself in 1875. At the Canaries I met with it only in Teneriffe and Hierro (in the former of which islands it was obtained by Mr. Lowe near Garachico); but it would appear, also, to have been found by Blauner in Palma.

I have already stated, at p. 89 of the present volume, what the exact characters are which separate the $P$. pusilla from the placida; but $I$ will again add that it is (on the average) a little smaller, browner (or less olivaceous), and more depressed (its spire being less raised), and that its volutions (which are a trifle less inflated) have a greater or less tendency to be furnished with a few additional, elevated, hair-like lines, or costæ, - which, although at times scarcely distinguishable, are more often (when viewed beneath a high magnifying power) quite conspicuous.

\section{Patula spinifera.}

Patula spinifera, Mouss., Faun. Mal. des Can. 25. pl. 2. f. $17-20(1872)$

Helix spinifera, Pfeiff., Mon. Hel. vii. 85 (1876)

Habitat Canariam Grandem, et Palmam; in sylvaticis editioribus, rarissima.

This remarkable little Patula appears to be one of the rarest of the Land-Shells of the Canarian archipelago,-where it occurs in the damp sylvan districts of intermediate and lofty elevations. I took a single specimen of it in Grand Canary (the first, I believe, which has been recorded from that island); and a few more were met with by Mr. Lowe and myself in the Barranco de Agua and the Barranco de Galga, as well as on the Cumbre above Buenavista, of Palma.

In its rather larger size and turbinate, Helix-shaped outline, the $P$. spinifera (which belongs to much the same type as 
the European $H$. aculeata, Müll.) approaches nearer to the $P$. placida than it does to the pusilla; nevertheless in the fact of its surface being furnished with a few distant, oblique, hairlike costæ (which however are occasionally developed into elongate lamelliform processes, or even spines) it partakes more of the peculiarities of the latter. It is both larger and more convex than even the placida, and of a more dull hyaline brown; whilst the extraordinary tendency for the development of its line-like lamelloe into spiniform appendages (sometimes monstrously expressed, even though occasionally worn and indistinct) completely removes it from the pusilla, -in which these additional thread-like lines are in a comparatively undeveloped state, and seldom very conspicuous.

\section{Genus 9. HELIX, Linné.}

\section{(§ Vallonia, Risso.)}

\section{Helix pulchella.}

\begin{tabular}{|c|c|c|}
\hline & & T \\
\hline & 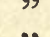 & $\begin{array}{l}\text { Lowe, Cambr. Phul. S. Tra } \\
\text { Id.. Proc. Zool. Soc. Lond }\end{array}$ \\
\hline & 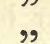 & Alb., Mal. Mad. 45. t. 12. f. $1-4(1854)$ \\
\hline & " & Paiva, Mon. Moll. Mad. 77 (1867) \\
\hline & & Mal des Can. 57 (18 \\
\hline
\end{tabular}

Habitat Canariam Grandem, Teneriffam, et Palmam; hinc inde sub lapidibus, præcipue in cultis.

The minute European $H$. pulchella, which occurs also in the Azorean and Madeiran archipelagos, and which I detected during 1875 in the intermediate districts of St. Helena, and which was found by Mr. Benson at even the Cape of Good Hope, is widely spread over the Canarian Group,-where in all probability it will be ascertained, sooner or later, to be universal. Hitherto however it has been observed only in Grand Canary, Teneriffe, and Palma, in the first and third of which I have myself met with it. Indeed on the western side of Palma it appeared to be common,- on the calcareous Llanos (in the region of La Banda) between Argual and the sea. And it would seem to have been found in the same island by Blauner; as well as in Teneriffe by Fritsch and Mr. Lowe, - the former of whom obtained it about Sta. Cruz and towards Point Anaga, and the latter at Garachico. The only form of the shell which I have as yet seen corresponds with the true pulchella, Müll., and not with the costata - which elsewhere is so often intermixed with the type. 
(§ Tberns, Monf.)

\section{Helix digna.}

Helix digna, Mouss., Faun. Mal. des Can. 68. pl. 4. f. 3 (1872)

Pfeiff., Mon. Hel. vii. 304 (1876) perta.

Detected by Fritsch, in a subfossil state, in Gomera, and a species of peculiar interest geographically as belonging to much the same type as the Porto-Santan H. Wollastoni, Lowe, and forensis, Woll., from the Madeiran Group, and the Mediterranean $H$. scabriuscula, Desh. It appears however to be considerably larger than the $H$. Wollastoni; 'le sommet,' says Mousson, 'est plus obtus, formé par un nucléolus relativement bien plus gros, le nombre des tours n'est que de 4 au lieu de 5 et ils grandissent plus promptement, la sculpture est moins régulière et plico-costulée, au lieu d'être simplement costulée, la surface intercostale n'est pas finement granulée, mais inégalement rude, la base, quoique de forme très semblable, est plus renflée autour de l'espace central, le bord basal de l'ouverture se courbe plus fortement vers l'insertion columellaire et se réfléchit plus largement et plus subitement pour cacher la perforation. Malgré ces différences, l'H. digna constitue une des analogies les plus intimes entre les deux groupes d'îles.' (l.c. 69)

\section{Helix Berkeleyi.}

Helix Berkeleii, Lowe, Ann. Nat. Hist. vii. 108 (1861) $"$ ", Pfeiff., Mon. Hel. v. 265 (1868)

" Berkelei, Mouss., Faun. Mal. des Can. 80. pl. 4. f. 7, $8(1872)$

, Berkeleii, Pfeiff., Mon. Hel. vii. 305 (1876)

Habitat Canariam Grandem; a Revdo. R.T. Lowe et meipso, Aprili 1858, inter Maspalomas et Juan Grande, et recens et semifossilis, reperta.

This curious Helix approaches nothing which has hitherto been detected in these various Atlantic archipelagos; though perhaps it is more nearly related to the $H$. Wollastoni of the Madeiran Group than to anything else, or possibly to the comparatively gigantic subfossil $H$. digna, Mouss. (which however I have had no opportunity of inspecting), from Gomera. Nevertheless with even the $H$. Wollastoni it has very little really in common,- though its discoidal contour, strongly developed keel, and completely closed umbilicus would tend perhaps to affiliate it a little with that species; whilst in its granulated 
(instead of obliquely plicate) surface it makes a certain approach towards the (otherwise altogether dissimilar) H. Webbiana, Lowe, of Porto Santo.

Apart from its flattened form and powerful keel, the $H$. Berkeleyi may be further recognized by its entire surface (which is opake and of a pale-brown) being asperated with large and irregular tubercles,- - which on the upper side diminish in bulk towards the nucleus, and which on the under are file-like, partially transverse, and very densely crowded together. Its lower part is comparatively convex; its keel is somewhat compressed above (through the adjoining portion being slightly worn-ont, or concave); its volutions are very obsoletely bifasciated; and its peristome (the upper and lower lips of which are not joined by a corneous plate across the basal whorl) is very broad, white, and reflexed.

The $H$. Berkeley $i$ was detected by Mr. Lowe and myself, on the 12th of April 1858, on a dry calcareous slope (close to the sea), between Maspalomas and Juan Grande, in the south-east of Grand Canary; where we likewise met with it (and somewhat less sparingly) in a subfossil condition.

\section{(§ Mitra, Albers.)}

\section{Helix cuticula.}

Helix cuticula, Shuttl., Bern. Mitth. 142 (1852)

\begin{tabular}{|c|c|c|}
\hline & פ & . iii. $39(1853)$ \\
\hline & " & $\begin{array}{l}\text { Mouss., Faun. Mal. des Can.69.pl. 4. f. 4-6 } \\
(1872)\end{array}$ \\
\hline & 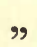 & Pfeiff., Mon. Hel. vii. 74 (1876) \\
\hline
\end{tabular}

Habitat Teneriffam, Gomeram, et Palmam; in sylvaticis humidis editioribus, rarior.

This singular, Vitrina-like little Helix may be known by the paucity of its (obliquely and densely, but delicately, striated) whorls, by its extremely thin, pellucid, pale-green (but not very shining) substance, by its relatively rather large aperture (the peristome of which is acute, and not at all recurved), and by its compressed, sharply developed keel, - which is visible also in the volutions of the spire, where it closely adjoins the suture, and occasionally well-nigh overhangs it.

The $H$. cuticula, which may be regarded as the Canarian representative of the (nevertheless comparatively gigantic) $H$. Webbiana, ${ }^{1}$ Lowe, of the Madeiran Group, appears to be scarce, and confined to damp sylvan spots of a rather high altitude,in which situations it has been met with in Teneriffe, Gomera,

${ }^{1}$ I have already pointed out, at p. 102 of this volume, what the most salient characters are in which the $H$. cuticula differs from the $H$. Webbiana. 
and Palma. In the first of those islands it was obtained by Mr. Lowe and myself in the woods above Taganana, at Las Mercedes, and above Orotava, as well as at Los Sillos and near Garachico and Ycod-el-Alto-; in the second by Mr. Lowe (on April 21, 1861) on the Cumbre above the San Sebastian Barranco; and in the third by Mr. Lowe and myself, on the ascent to the Cumbre above Buenavista, as well as in the Barranco de Agua, the Barranco de Galga, and at Barlovento. In Teneriffe it was found also by Blauner and Fritsch.

\section{(§ Pomatia, Beck.)}

\section{Helix aspersa.}

Helix aspersa, Müll., Hist. Verm. ii. 59 (1774)

$" \quad$ Pfeiff., Mon. Hel. i. 241 (1848)
$" \quad$ spumosa, Lowe, Ann. Nat. Hist. vii. $111(1861)$
aspersa, Mouss., Faun. Mal. des Can. 69 (1872)

Habitat Palmam; hinc inde in intermediis degens, forsan ex Europâ olim introducta.

The common European $H$. aspersa, Müll., which has acquired for itself so wide a geographical range, occurs sparingly, in many localities, in Palma; but as it has not been observed hitherto in any other portion of the Group, it is pretty certain that it must have become accidentally introduced, at some former period, into that particular island,--just as it has at the Azores, and (more recently) around Funchal in Madeira, and even at St. Helena. In Palma (where it was found also by Blauner and Fritsch) we met with it at the foot of the ascent to the Cumbre above Buenavista (on the road from Sta. Cruz to La Banda), as well as in the Barranco de Herradura (between Los Souces and Barlovento).

Although some of the Palman examples of this common Helix are apparently quite typical (a fact which does not seem to have been sufficiently recognised by Mr. Lowe), in others the shell is rather thinner and paler, with the spire perhaps a trifle smaller and more depressed, and with the aperture a little more transverse,-approaching in a slight degree the H. Mazzullii, Jan., from Sicily. I agree, however, with Mousson that there is nothing about them to warrant the suspicion that they are specifically distinct; though a rather fanciful capability which the animal appeared at the time to possess, of secreting mucus in greater abundance than is usual for the $H$. aspersa, induced Mr. Lowe to separate them as a species under the title of $H$. spumosa. 
(§ Macularia, Albers.)

\section{Helix Moussoniana.}

Helix Adonis, Mouss. [nec Angas, 1869], Faun. Mal. des

Can. 71 . pl. 6. f. 1 (1872)
Pfeiff., Mon. Hel. vii. 344 (1876)

Habitat Gomeram; a cl. Fritsch semifossilis lecta.

A large Helix which was discovered by Fritsch, in a subfossil condition, in Gomera, and one which would appear to be allied (for I have not, myself, had an opportunity of inspecting it) to the Porto-Santan H. subplicata, Sow., of the Madeiran archipelago. Mousson, who also compares it with the $H$. alonensis, Fer., from Spain, remarks (l.c. 71, 72): 'Cette grande et belle espèce rappelle par la forme de son ouverture, surtout par son bord basal excavé, d'un côté la $H$. subplicata, Lowe, de Madère, de l'autre l'H. alonensis, Fer., et se place entr'elles. La surface n'est ni costulée, ni granuleuse au nucléus comme dans la première, mais plus fortement plico-striée que dans la seconde, et dénuée des sillons décurrents charactéristiques. La spire est plus serrée et plus déprimée que dans la subplicata, et assez analogue à celle de l'alonensis, dont elle diffère par l'expansion et le renflement du dernier tour et son resserrement sensible à l'endroit où il commence à s'abaisser. L'ouverture forme en travers une ellipse un peu incliné et bien plus régulière que dans l'alonensis, dont les deux bords supérieur et inférieur sont également courbés ; cette ellipse est plus allongée que dans l'H. subplicata.'

\section{Helix efferata.}

Helix efferata, Mouss., Faun. Mal. des Can. 72. pl. 6. f. 2 (1872)

" $\quad$ Pfeiff., Mon. Hel. vii. 345 (1876)

Habitat Gomeram; una cum specie precedenti semifossilis reperta, et forsan ab illâ vix certe distincta.

Found likewise in a subfossil condition in Gomera, and apparently very closely allied to the preceding species,---from which perhaps, although somewhat smaller, and with a few characters of its own, it is hardly sufficiently distinct. 'Une seconde grande espèce,' says Mousson (l. c. 72), 'de l'époque diluvienne de la même île qui, malgré quelques analogies, ne saurait être réunie à l'H. Adonis. La forme en effet est plus conique, moins dilatée; les tours sont moins convexes et pourvus d'une angulation obtuse, qui ne disparaît qu'au dernier tour et se reconnait là encore à une ligne dorsale faiblement saillante. La surface présente un martelage obtus, passant à des stries 
anguleuses ou ondulées obliques, sans trace de granulations; l'Adonis par contre est simplement striée. Le bord inférieur de l'ouverture, laquelle forme un ovale un peu dilaté, est moins excavé et plus largement calleux.'

\section{Helix lactea.}

Helix lactea, Müll., Hist. Verm. ii. 19 (1774)

" $\quad$ " W. et B., Ann. des Sc. Nat.28. syn. 313 (1833)

" " dOrb., in W. et B. Hist. ii. 2. 55 (1839)

" " Mouss., Faun. Mal. des Can. 70 (1872)

Habitat Canariam. Grandem, Teneriffam, et Hierro; præcipue juxta oppidos, sed interdum etiam omnino in rure, in inferioribus degens.

The widely spread $H$. lactea, Müll., of Mediterranean latitudes, and which was obtained abundantly both by Mr. Leacock and Mr. Lowe on the opposite coast of Morocco, is common both in Grand Canary and Teneriffe,- where it is called by the inhabitants 'Boca negra ;' and it was met with by Fritsch, also, in Hierro. D'Orbigny considered that it was probably introduced originally from Spain as an article of food, and it must be admitted that in Grand Canary it is particularly plentiful about Las Palmas, and in Teneriffe about Sta. Cruz; yet the fact of its existing also, in profusion, in the sandy and well-nigh uninhabited region of El Charco, beyond Maspalomas, in the extreme south of Grand Canary (where it was taken by Mr. Lowe and myself in 1859), is certainly against that hypothesis. Hitherto it has not been observed in any other of these various Atlantic archipelagos; though a few Canarian individuals which were turned loose by Mr. Lowe, some years ago, in Madeira, may perhaps have succeeded (though I think that they have not done so) in introducing the species into at any rate the Funchal district of that island.

The $H$. lactea can be confounded with nothing else with which we have here to do,-its large size, elongate subdepressed contour, and solid substance, added to its broadly expanded peristome, its complete freedom from an umbilicus, the minute and rather irregular spiral striæ with which its volutions are finely decussated, and the peculiarity of its ornamentation (the ground-colour being of a more or less dirty yellowish-white, though with the greater portion of the surface taken-up by wide, brownish, whitely-freckled bands, whilst the aperture and its interior are highly polished and nearly black), being more than sufficient to distinguish it.

The Canarian examples of this large Helix appear to belong to the true lactea-type, and not to the nearly allied $H$.punctata, 
Müll.,-which nevertheless is cited by Pfeiffer (Mon. Hel. iv. 222, and vii. 332) as occurring in the Canarian Group. 'La forme des Canaries,' says Mousson (l. $c .71)$, 'appartient bien à la lactea, Müll., et non à la punctata, Müll., et se place entre le type et la var. murina, Rossm. (Icon. iii. 800-805), dont l'ouverture au bord supérieur est encore plus dilatée.'

\section{Helix gibboso-basalis, n. sp.}

T. imperforata, depresso-globosa, solida, subnitida, striis obliquis subevanescentibus irregularibus, aliisque indistinctis minutissimis spiralibus leviter decussata, suffuse subcarneo- et subplumbeo- aut sublivido-brunnea sed subtus in medio obscure et ad peristoma subclarius pallidior [aut, aliter, infuscate pallidula sed obsoletissime et omnino suffuse 4-fasciata, fasciis versus aperturam nebulose confluentibus]; spirâ minus elevatâ, ad apicem obtusâ; anfractibus $4 \frac{1}{2}$, ultimo rotundato, antice deflexo; aperturâ intus subnigrâ, peristomate (anguste solum expanso) intus nigro-castaneo sed extus pallide brunneo-flavo, marginibus callo nigro (longe intus sulcato) junctis, colımellari lato sed undulato-inæquali, quasi biflexuoso, in medio (aut paulo magis versus insertionem) obtuse gibboso.-Diam. maj. 12 ; alt. 7. lin.

Habitat 'Teneriffam borealem ;' exemplaria duo a D. Vargas collecta, obtinet Rev. R. T. Lowe.

Obs. - H. lactece, Müll., affinis, sed nisi fallor vere distincta. Differt testâ multo minore, ad apicem magis obtusâ, omnino levius decussatim sculpturatâ; anfractibus minus numerosis; aperturâ minore, antice minus desiliente, intus super parietem ventralem breviter plicato-sulcato; peristomate multo minus expanso minusque recurvo, margine basali bisinuatim inæquali aut in medio obtuse tuberculatim gibboso. Necnon in colore omnino ab $H$. lacteâ discedit;- - sc. testa suffuse subcarneo- et sublivido-tincta (quasi subconcolor), solum in regione umbilicali et extus aperturam infuscate flavescenti-grisea, fasciis obsoletissimis (rullo modo albo-irroratis) obscure ornata.

The two examples from which the above diagnosis has been compiled were given to Mr. Lowe, in 1861, from the collection of Senhor Vargas, and as having been taken undoubtedly ' in the north of Teneriffe,' but as to the exact spot he had no note. And indeed this locality (if really to be depended upon) might of itself have created a suspicion, had there been any doubt on the subject, that the species is truly distinct from the H. lactea,which, so far as Teneriffe is concerned, seems to be confined to the vicinity of Sta. Cruz. But, in point of fact, I think there can be no question about its specific claims; although it is 
equally certain, from its general contour and coloration, its blackened, highly-polished aperture, its total freedom from an umbilicus, and the minute spiral lines of its surface, that it belongs strictly to the lactea group.

If the sample now before me be a normal one of its kind, the $H$. gibboso-basalis differs from the lactea in its very much smaller size (its greatest diameter being only 12 lines, instead of about 20) and its comparatively dark or subconcolorous surface,-which is entirely free from pallid specks or freckles, appearing at first sight (at any rate when viewed from above) to be of an almost uniformly livid- or plumbeous-brown; though when more closely inspected, it will be seen, in reality, to be of a dull, dirty, yellowish-tinge (as is evident about the umbilical area and outside the aperture), but with four darker bands so obscure and diffused that on the upper side they are well-nigh indistinguishable, - nearly blending together (particularly on the anterior region of the basal whorl) so as to tone-down, or infuscate, the entire surface.

Apart however from contour and size, the present Helix has the spire (which is composed of a volution less) more obtuse than in the $H$. lactea, its aperture is relatively smaller and less deflexed, its peristome is very much less expanded or developed, its sculpture is altogether finer, and there are a few albbreviated grooves and ridges, far within the aperture, on the ventral wall of the body-volution. But a more curious feature (if indeed it be a constant one) consists in the uneven, or biflexuose, nature of the columellary portion of its lower lip,-occasioned by an unusual prominence, or gibbosity, amounting almost to a large obtuse tubercle or lump, at a little distance from the insertion of the latter into the axis. This last-mentioned feature, if not a mere accidental one, is at least very remarkable.

Whether the $H$. gibboso-basalis is in any way related to the H. Dupotetiana, Terver (Pfeiff., Mon. Hel. i. 274), from Northern Africa, with the diagnosis of which it has certainly something in common, I have no means of deciding.

(§ Hemicycha, Sow.)

Helix gravida.

Helix gravida, Mouss., Faun. Mal. des Can. 85 (1872) Pfeiff., Mon. Hel. vii. 343 (1876)

Habitat Fuerteventuram; a Dom. Fritsch semifossilis reperta.

I have had no opportunity of inspecting this large Helix, which appears to be somewhat intermediate between the sar- 
costoma and lactea types, and which was detected by Fritsch, in a subfossil condition, in Fuerteventura. 'Cette espèce,' says Mousson $(l . c .85,86)$, 'que je ne connais que subfossile, pourrait au premier abord être prise pour une forme dépendante de l'H. lactea, Müll., mais un examen attentif démontre qu'elle est bien différente et rentre les Hemicycles du groupe sarcostoma. La spire est plus régulièrement conique que dans la lactea, de sorte que le dernier tour a relativement moins de grandeur. La surface est striée, non granuleuse, moins fortement au dernier tour, lequel par contre présente sur toute sa surface un martelage grossier, mais peu profond, qu'on ne voit pas dans les espèces méditerranéennes. Le bord supérieur n'a pas de tendance à s'évaser, mais est presque parallèle au bord basal. Le péristome est gros et s'arrondit en se refléchissant. Le bord basal est épais, formant à l'intérieur une ligne un peu relevée, se repliant à l'extérieur et se collant largement sur la région ombilicale, qui est renflée et calleuse.'

\section{Helix sarcostoma.}

Helix sarcostoma, W. et B., Ann. des Sc. Nat. 28. syn. 312 (1833)

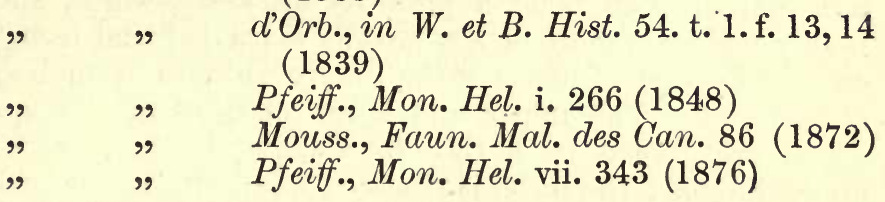

Habitat Lanzarotam, Fuerteventuram, et Canariam Grandem; in montibus hinc inde haud infrequens. Necnon etiam semifossilis in insulis iisdem reperitur.

It is more particularly of the two eastern islands of the archipelago, Lanzarote and Fuerteventura, that this large and beautiful Helix (highly developed examples of which measure about an inch across their broadest part) is characteristic; nevertheless it occurs also, though much more sparingly, in Grand Canary. It was in those three islands that it was originally detected by MM. Webb and Berthelot; and it is in the same three that it has subsequently been met with by Fritsch, Mr. Lowe, myself, and others. I feel almost satisfied that it does not exist in Teneriffe, and agree therefore with Mousson that the habitat 'Teneriffe' given by Zollinger is probably the result of mere looseness and inaccuracy ;-' La localité Ténérife,' says he, 'me paraît plus que douteuse, M. Zollinger ayant reçu cette espèce, et ne l'ayant pas trouvée lui-même.' It occurs on the mountains at a rather high elevation. In Lanzarote we found it principally at Chache and around Haria; and it was 
taken also by Webb in 1829 , in the extreme north of the same island,-particularly in the 'Malpais,' or ancient lava-current, of the Montana de la Corona. In Fuerteventura we obtained it rather abundantly on the summit of Monte Atalaya, overlooking the Rio Palmas, - where the examples are of a very large stature, and have their peristome monstrously developed.

In a subfossil condition Mousson records the $H$. sarcostoma from Lanzarote and Fuerteventura, though it is only from the latter of those islands that I possess it distinctly subfossilized; and I myself met with it in Grand Canary,-namely in the calcareous deposits on the maritime ridge between Las Palmas and the Puerto da Luz.

In the general character of its somewhat dappled colouring this fine Helix is a little suggestive at first sight (particularly when the specimens are young and the aperture is unformed) of the common European $H$. aspersa; nevertheless it is altogether of a warmer, and more livid, tint, and its bands (which are normally four or five in number) are sometimes comparatively distinct and uninterrupted,-in which case all resemblance with that species ceases. It is a solid shell, rather obliquely-elongated in contour, quite imperforate (when adult), and with its peristome (which is of a pinkish- or fleshy-white, and very highly polished) more or less broadly expanded and recurved,often indeed (as in many of the Fuerteventuran examples) monstrously so. The upper and lower margins of its aperture, which are joined by a thin intervening lamina, are slightly approximated; the latter is sinuated internally, at a considerable distance beyond the columellary portion, so as to shape out an elongated basal obtuse tooth-like ridge; and its whole surface is opake, and very densely and minutely granulated all over, but with the transverse lines of growth feeble and subobsolete. Apart from the freckles and interrupted bands, its upper region is often unequally clouded, or suffused, after the fashion of tortoiseshell,-yellowish ill-defined blotches being frequently traceable in various parts; and outside the aperture, which is very greatly deflexed, it is always more or less gradually flavescent.

\section{Helix Saulcyi.}

Helix Saulcyi, d'Orb., in W. et B. Hist. 56. t. 3. f. 9-11 (1839)

$\Rightarrow \quad$ Pfeiff., Mon. Hel. i. $267(1848)$
$" \quad$ Mouss., Faun. Mal. des Can. $87(1872)$
$", \quad$ temperata, Id., ibid. 87. pl. 5. f. 5, 6 (1872)
,$\quad$ et Saulcyi, Pf., l. c. vii. $343,344(1876)$


Habitat Canariam Grandem; ad et juxta promontorium 'Isleta' dictum, in boreali insulæ, et semifossilis et (multo rarior) recens.

I have not myself seen this large and variable Helix, which appears to be peculiar to Grand Canary, ${ }^{1}$ except in a subfossil condition; but I possess several examples of it subfossilized which were taken by Mr. Lowe on the Isleta (the semidetached subinsular promontory in the extreme north of that island), and others which were found by myself on the calcareous ground between the Isleta and Las Palmas, - where it has likewise been met with by Mr. Watson. It is probable therefore that the original specimens which were sent by Despréaux to MM. Webb and Berthelot were obtained in that same district, which is so readily accessible from Las Palmas. Mousson records it as having been found likewise by M. Grasset at 'Puerto de la Paz;' but it is most likely that the latter locality was a misprint for Puerto da Luz, which is a small fishing-village adjoining the Isleta.

The $H$. Saulcyi is but slightly smaller, on the average, than the $H$. sarcostoma, which in general outline and proportions it much resembles. Indeed, apart from colour (concerning which I cannot form an opinion from specimens which are subfossilized), it mainly recedes from that species in its totally different surface-which is almost destitute of minute granules, but is coarsely (and often deeply) sculptured or malleated, the malleations having a tendency to form (at any rate on the basal volution) more or less oblique subconfluent grooves; and in the lower margin of its peristome (which is altogether much less developed) being, in the typical examples, more broadly straightened, or well-nigh unscooped-out (and therefore nearly free from an obtuse angle or tooth), internally. Its underside, moreover, is liable to be rather tumid and gibbose, or suddenly inflated, immediately below the aperture.

Mousson's H. temperata (which was established on a single Grand-Canarian example from the collection of M. Berthelot) seems to me to differ in no respect from this extremely variable species except that it is less coarsely malleated (a character, judging from the specimens which are now before me, without the slightest significance) and that the lower division of its peristome is less straightened internally, or more suddenly

' The H. Saulcyi is cited by Pfeiffer, in his first volume of the 'Mon. Hel.', as coming from Fuerteventura likewise; but it is evident that both the habitat and characters of the species were mixed up with those of the sarcostoma; and there can be little doubt that the $H$. Saulcyi has no claim whatever to be regarded as Fuerteventuran. Indeed in his seventh volume the habitat has been corrected by Pfeiffer himself. 
scooped-out so as to form an obtuse ridge-like tooth; but I will merely remark that this latter feature is so eminently inconstant that it is scarcely possible to find two individuals of the $H$. Saulcyi which are precisely similar as regards the development of their peristome and aperture. Nevertheless I will at all events register this particular phasis of the shell, which passes into the other by the finest possible gradations, as the 'var, $\beta$. temperata.'

\section{Helix Päteliana.}

Helix Paeteliana, Shuttl., in litt.

$\begin{array}{lll}" & " & \text { Pfeiff., Mal. Blätt. vi. } 26(1859) \\ " & \Rightarrow & \text { Id., Mon. Hel. v. } 299(1868) \\ & \text { Mouss., Faun. Mal. des Can. 88. pl. v. } \\ & \quad & \text { f. } 7 \text { (1872) }\end{array}$
f. 7 (1872)

, Päteliana, Pfeiff., Mon. Hel. vii. 346 (1876)

Habitat Fuerteventuram (sec. Pfeiff.); ex exemplare unico, in Mus. Cumingiano, descripta.

I know nothing of this Helix except what may be gathered from Pfeiffer's diagnosis, which was drawn out from a unique example, said to have been taken in Fuerteventura, in the collection of the late Mr. Cuming. Mousson assigns to it, in doubt, a specimen which was obtained in that same island by Fritsch, but which he nevertheless says does not quite accord with the published description. A single individual, now before me, which was received by the Baron Paiva from M. Berthelot, and which is stated (though I do not think thăt this can be depended upon) to be Fuerteventuran, very much resembles the figure which is given by Mousson; though my own belief is that it represents nothing more, in reality, than a rather enlarged and elongated phasis of the $H$. Pouchet in which the striæ and granulations are somewhat less developed, and that in all probability it was met with in some district of Teneriffe, and not in 'Fuerteventura' at all. Hence I do not think that my own specimen, at any rate, although differing a little from the ordinary Pouchet-type, can be trusted, either as embodying the $H$. Päteliana or as having for certain been met with in the particular island from whence it is reported to have been brought.

\section{Helix Pouchet.}

Le Pouchet, Adans., Hist. du Senég. 10. t. 1. f. 2 (1757)

Helix Pouchet, Fer., Tabl. 32 (1821)

"Adansoni, W. et B., Ann. des Sc. Nat. 28. syn. 313 (1833)

" Pouchet, d'Orb., in W. et B. Hist. 56 (1839) 
Helix Adansoni, Pfeiff., Mon. Hel. i. 268 (1848)

" Pouchet, Mouss., Faun. Mal. des. Can. 82 (1872)

" Adansoni, Pfeiff., Mon. Hel. vii. 345 (1876)

Habitat Teneriffam; in aridis apricis juxta Sta. Cruz et Orotava degens. Necnon etiam semifossilis occurrit.

The $H$. Pouchet is a strictly Teneriffan species ; and I have little doubt that the additional habitat 'Grand Canary,' which was cited for it by Webb and Berthelot, was founded either on an inaccuracy of identification or else (which is far more probable) on their characteristic looseness, as regards data. Like the $H$. plicaria, it has been taken by almost every naturalist who has visited Teneriffe for many years past,-including Webb and Berthelot, d'Orbigny, Blauner, Hartung, Fritsch, Reiss, Lowe, Watson, and myself, and, I believe, in nearly all instances, on the sides of the Barranco del Passo Alto near Sta. Cruz. I have however met with it, likewise, on the opposite side of the island, near the Puerto of Orotava,-where it occurs equally in a subfossilized, or partially subfossilized, condition.

\section{Helix desculpta.}

Helix desculpta, Mouss., Faun. Mal. des Can. 83 (1872) " " Pfeiff., Mon. Hel. vii. 345 (1876)

Habitat Fuerteventuram, semifossilis; a cl. Fritsch lecta.

This species appears to have been described by Mousson from a subfossil example, or examples, found by Fritsch in Fuerteventura; and, judging from the diagnosis (for I have not been able to procure a type for examination), I might have been inclined to regard it as not very remote from the $H$. Pouchet, were it not expressly said to be free from granulations and to have no traces of even an obsolete keel on its basal volution, -which latter, moreover, is less abruptly deflexed at the aperture. It seems to be allied both to the $H$. Pouchet and the $H$. plicaria, though not referable to either. 'Cette espèce,' says Mousson, 'd'une époque ancienne, ne rentre bien ni dans les formes de l'H. plicaria, ni de l'H. Pouchet. Elle est plus globuleuse; le dernier tour n'a pas trace d'angulation; la sculpture consiste en simples stries, non serrées, peu relevées, et parfaitement lisses, tandis qui dans la première des deux autres espèces elles sont incisées, dans la second granuleuses; l'ouverture est plus contractée, plus petite, moins évasée en haut et pourvue d'un bord aussi largement réfléchi que dans les autres espèces.'

Helix retrodens.

Helix retrodens, Mouss., Faun. Mal. des Can. 89. p. 4. f. $14,15(1872)$ 
Helix retrodens, Pfeiff., Mon. Hel. vii. 347 (1876)

Habitat Teneriffam; a cl. Fritsch detecta.

The $H$. retrodens (of which I have no type for comparison) is described as a rather convex, strongly striated shell, partially malleated, somewhat shining, and of a pale-yellowish olive-brown (still paler beneath), and with three indistinct darker bands which are more or less interrupted by whitish lines and markings. Its nucleus is said to be finely granulated; and its peristome, which is white and very broadly expanded, has its basal portion thickened internally into an obtuse ridge-like plait. It is stated by Mousson to be allied to the $H$. modesta, Fer. (= Paivana, Lowe), and was taken by Fritsch in Teneriffe. I possess examples of a Helix from Arona which agree to a great extent with the diagnosis of the $H$. retrodens, though not sufficiently so to enable me to refer them for certain to that species.

\section{Helix modesta.}

\section{Helix modesta, Fer., Prodr. 71 (1821)}

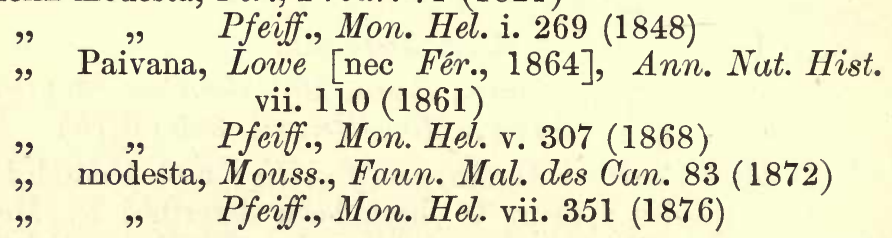

Habitat Teneriffam ; juxta Sta. Cruz, præcipue in Barranco Santo, vulgaris.

This is a common Helix near Sta. Cruz in Teneriffe, particularly in the Barranco Santo,--where it was met with abundantly by Mr. Lowe and myself, as it had been previously by Fritsch; and it was also taken by Blauner and Grasset. By d'Orbigny it appears to have been mixed up, or confused, with the $H$. Pouchet.

The $H$. modesta is of a dark greenish-brown hue above, but paler, yellower, and more glossy beneath, and occasionally with obscure indications of a few obsolete bands. In form it is rather compact and obtuse, with faint traces on its basal whorl of a keel, which however completely vanishes towards the aperture; its peristome is white and broadly developed, the basal portion being nearly straight but a good deal thickened; and its surface is roughened with irregular transverse costate lines, and is here and there conspicuously malleated.

As compared with the H. plicaria, the modesta is smaller, more depressed, and more compact, as well as of a darker greenish-brown hue; and (although strongly costate-striate) it is free from the remote and greatly elevated string-like trans- 
versely-sculptured ridges which are so characteristic of that (equally Teneriffan) species; and it has more appreciable traces, too, of an obsolete keel.

\section{Helix Bethencourtiana.}

Helix Bethencourtiana, Shuttl., Bern. Mitth. 143 (1852)

"

Pfeiff., Mon. Hel. iii. 270 (1853) Mouss., Faun. Mal. des Can. 84. pl. 5. f. 3, 4 (1872)

Pfeiff., Mon. Hel. vii. 478 (1876)

Habitat Teneriffam; a cl. Blauner inventa.

I have not seen this species, which was taken by Blauner in Teneriffe; but it is said to be much allied to the $H$. plicaria, from which it is mainly distinguished by its smaller size, and by having its costate ridges perfectly simple, or free from transverse sculpture. ' Cette espèce', says Mousson, ' confondue antérieurement avec l'H. plicaria, et subordonnée par M. Lowe (Ann. Nat. Hist. 3. ser. vii. 110) à l'H. Adansoni, Webb [i.e. H. Pouchet, Adans ], a été nettement définie par M. Shuttleworth, comme je me suis convaincu sur des échantillons de la main de l'auteur même. Elle se distingue de la plicaria par sa moindre grandeur, sa ténuité, par l'accroissement plus prompt des tours, par des plis distants élevés, mais parfaitement lissés, non crenélés, par une ouverture plus regulièrement ovale en travers, enfin par un péristome beaucoup moins large, en peu coloré. L'absence totale de martelage la sépare entièrement de la modesta, qui a la même grandeur.'

\section{Helix plicaria.}

Helix plicaria, Lam., Encyl. Meth. t. 462 f. 3

" plicatula, Id., Hist. viii. 81 (1822)

" plicaria, W. et B., Ann. des Sc. Nat. 28. syn. 313 (1833)

" $\quad$ d'Orb., in W. et B. Hist. 56 (1839)

" $\quad$ "Pfeiff., Mon.Hel. i. 291 (1848)

" $\quad$ Desh., Fer. Hist. i. 112 (1851)

" " Mouss., Faun. Mal. des Can.81 (1872)

Habitat Teneriffam; in collibus apricis circa Sta. Cruz, vulgaris. Etiam semifossilis parce reperitur.

The H. plicaria, Lam., is essentially characteristic of Teneriffe,- - where it is common on most of the dry and rocky hill-sides around, and above, Sta. Cruz, and from whence it has been brought by every collector who during the last fifty years has visited the island. There is no evidence that it is found elsewhere in 
the archipelago (though we might well expect, perhaps, to meet with it in Grand (anary), and it is simply monstrous therefore that MM. Webb and Berthelot should have cited it as spread over the entire Group. Such loose assertions as these are absolutely unpardonable in the fauna of any country in which the most punctilious accuracy as regards habitat is a sine quâ non; and even had there been reason to suspect that the $H$. plicaria was not altogether confined to Teneriffe, still MM. Webb and Berthelot could not have been in a position to vouch for its universality, inasmuch as they had collected but very imperfectly in some of the outlying islands, and indeed on Hierro had not so much as once even set foot! But throughout the whole of their gigantic 'Histoire' this extreme slovenliness on the important question of localities meets one on nearly every page; and although it was an easy method for themselves, to define the range of a species by simply citing 'toutes les Canaries' as its habitat, nevertheless no truthful monographer could possibly accept any such statement unless some proof was given, at the same time, that it is tenable; and in the present instance their innuendos concerning the $H$. plicaria are utterly discreditable,for, so far as we have any data for forming an opinion, the species would appear to be (not universally Canarian, but) exclusively Teneriffan.

There can be no fear of confounding the $H$. plicaria with anything else with which we are here concerned,-its rather flattened (though completely unkeeled) contour and corneous brown surface (which is paler, or yellower, beneath, and on which anything like darker bands are rarely traceable), in conjunction with its white and broadly-flattened peristome, and the remote but extremely elevated and transversely-sculptured costate ridges with which it is beset, giving it a character essentially its own. The very minute impressions which crenulate its oblique transverse ribs will be seen, when closely inspected, to be the result of a system of densely-packed spiral lines,which are conspicuous on the summits, or edges, of the costæ, but are obsolete in the spaces between them.

I possess a few examples of the $H$. plicaria in a distinctly subfossilized condition, and in which the ridges are rather less developed and less decidedly crenulate, but I cannot now quite recall whence I obtained them.

\section{Helix inutilis.}

Helix inutilis, Mouss., Faun. Mal. des Can. 81. pł. 5. f. 1,2 (1872)

" $\quad$ Pfeiff., Mon.Hel. vii. 425 (1876) 
Habitat Teneriffam; a cl. Grasset lecta.

It seems far from improbable that this Helix, which was taken by M. Grasset in Teneriffe, represents but an accidental state, or variety, of the H. plicaria, in which the umbilicus is unclosed-over by the expanded lamina of the lower lip; nevertheless its exposed or open umbilicus makes it in some degree connective between that species and the $H$. planorbella; though its affinities are clearly more with the plicaria than with the latter.

After his diagnosis of the $H$. inutilis, Mousson remarks: - Cette espèce se place entre la planorbella et la plicaria, Lam., en se rapprochant toutefois plus de la seconde. Elle se distingue des deux par un enroulement plus lâche, et un bord basal entièrement détaché. En outre elle diffère de la planorbella par une ouverture plus grande et une costulation ruguese et plus grossière; de la plicaria par contre, dont elle partage entièrement la sculpture, par l'ombilic très ouvert, malgré la large réflexion du bord, par la forme plus régulière de l'ouverture et le rapprochement des insertions marginales jusqu'à moins de $\frac{1}{10}$ du pourtour. Il me semble peu vraisemblable que ces différences ne soient qu'individuelles, dues à un développement anormal, bien que je n'aye vu qu'un individu de cette espèce, provenant, suivant M. Tarnier, comme la plicaria, de Téneriffe.'

\section{Helix planorbella.}

Helix planorbella, Lam., Hist. viii. 66 (1822)

" strigata, var. 13, Fer., No. 162. t. 67 . f. 8

" planorbella, Mouss., Faun. Mal. des Can. 76. pl. 4.

f. $18,19(1872)$

var. $\beta$. incisogranulata, Mousson.

Helix planorbella, Desh., Fer. Hist. i. 45 (1851)

$\begin{array}{ll}" & \quad \text { Pfeiff., Mon. Hel. v. 364 (1868) } \\ " & \quad \quad \text { Id., Novit. Conch. ii. 297. t. 72. f. 8-12 } \\ & \quad \quad \text { var. incisogranulata, Mouss., l. c. } 176\end{array}$

(1872)

Habitat Teneriffam, et Gomeram ; in illâ var. $\beta$., sed in hâc (sec. Mousson) status normalis.

This is one of thespecies which were not obtained by either Mr. Lowe or myself, and one which I have been unable to procure for examination; but according to Mousson it presents two totally distinct forms, - one of them peculiar to Gomera, with the costæ simple or ungranulated, which he believes to correspond with the Lamarckian type, and the other, which is more depressed and keeled, and has the ridges distinctly sculptured, to Teneriffe. This latter phasis, figured by Pfeiffer 
(Novitat. Conch. ii. 297. t. 72. f. $8=12$ ) as the normal state of the $H$. planorbella, Mousson treats as a 'var. incisogranulata', and defines it thus: ' umbilico paulo angustiore, plicis minus numerosis, sub lente minute granulatim incisis, margine basali minus adnato, minus incrassato, intus distinctius convexo.'

Judging from the diagnosis and figure, the H. planorbella (which, through a mistake, was cited originally from Porto Rico) is a rounded but depressed shell, with an open umbilicus, and rather strongly costate-striate on its upper portion,the costæ in the typical (or Gomeran) state being quite simple, but minutely sculptured across (or crenulated) in the 'var. $\beta$. incisogranulata' from Teneriffe. In colour it is of a pale yellowish-corneous, with two or three more or less evident darker bands; and its peristome has the margins (the basal one of which is widely thickened) a good deal approximated.

\section{Helix vermiplicata, n. sp.}

T. semiobtecte umbilicata, orbiculato-depressa, subtenuis, densissime et grosse vermiculato-plicata (plicis valde irregularibus, submalleato-confluentibus), et sub lente minutissime obsoletissimeque arenoso-granulata, subopaca, griseo- vel luteoalbida et fasciis obsoletis 4 vel 5 (sc. 1 vel 2 infra, et 1 vel 2 mox supra peripheriam, et 1 pone suturam) suffuse nebulosa; spirâ obtusâ, suturâ simplici impressâa anfractibus 5, ultimo magno inflato sed minute arguteque filo-carinato, antice paulo descendente ; aperturâ lunato-rotundatâ, peristomatis marginibus ad insertiones separatis disjunctis.-Diam. maj. $9 \frac{1}{2}$ lin.

Habitat Palmam; in calcareis ad Argual, regionis occidentalis 'Banda' dictæ, pauca specimina emortua collegi.

Out of five examples of this Helix which I met with on the calcareous 'Llanos' (below Argual) of the Banda, on the western side of Palma, only one is at all mature, and even that one has its peristome still unformed; nevertheless the species is so well defined by its sculpture and other features, that I have ventured to describe it,- - feeling satisfied that it cannot be associated with anything else with which we have here to do.

The specimen to which I have just called attention is so very nearly adult, and has its umbilicus (as in the younger ones) so greatly exposed (scarcely as much as half of it being closed over by the expanded lamina of the lower lip), that I feel almost confident that this character of 'semiobtecte perforata' will be found to hold good during all periods of its 
growth; and such being the case, its affinities, which at first sight are not readily apparent, will perhaps be ascertained to lie amongst the forms around the $H$. planorbella,-though, at the same time, the species has evidently something in common with the (equally Palman) H. granomalleata.

Not to mention this peculiarity of its umbilicus, the present species is smaller than the $H$. granomalleata, and it is also rather more depressed both above and below, and it has a fine thread-like though minute keel which is traceable even down to the very aperture. It is not much malleated,--its sculpture consisting mainly (apart from the excessively minute sandlike granules) of extremely irregular and densely-packed, coarse, subconfluent, oblique ridges, or subundulating vermiform folds; and in colour it would seem to be of a dingy olivaceous-white, suffused with a darker tint in consequence of the 4 or 5 obsolete bands which are indistinctly indicated.

\section{Helix Plutonia.}

Helix Plutonia, Lowe, Ann. Nat. Hist. vii. 108 (1861)

\begin{tabular}{|c|c|c|}
\hline & " & Pfeiff., Mon. Hel. v. 300 (1868) \\
\hline & " & $\begin{array}{l}\text { Mouss., Faun. Mal. des Can. } 76 . \text { pl. } 4 . \\
\text { f. } 12,13(1872)\end{array}$ \\
\hline & "थ & Pfeiff., Mon. Hel. vii. 423 (1876) \\
\hline
\end{tabular}

Habitat Lanzarotam, et Fuerteventuram ; in illâ recens, sed in hâc et recens et vix semifossilis ad Pozonegro parce reperitur.

By M. Fritsch this well-marked Helix was found both in Lanzarote and Fuerteventura, but it is only in the latter that it was obtained by Mr. Lowe, -who took several subfossilized examples of it (for I think that they are more than merely dead and bleached), along with one or two others immature and recent, at Pozonegro, on the eastern side of that island; but it is a species which I did not myself meet with.

The H. Plutonia is a large, rather flattened, obtuse, and almost sublenticular shell, nevertheless with the nucleus of the extremely compact and closely-set spire somewhat prominent, and with scarcely any indications of a keel on the ultimate volution, though there are evident traces of one up the spire,-manifested by a thread-like, subelevated, laterallycompressed line along the anterior edge of the suture. Its umbilicus is generally half-exposed, and thus far therefore open, but at times it is nearly closed up by the reflexed lamina of the columella ; its whorls are six in number, and all of them except the basal one much flattened; and its upper surface is covered with fine and light, irregular, scabrous, costate lines, intermingled with a few granules, whilst, beneath, it is more 
shining and comparatively unsculptured. Its aperture is large, with the upper and lower portions wide apart and disconnected; and its peristome, although recurved, is narrow and only slightly expanded.

When young and undeveloped the $H$. Plutonia is very much more sharply carinated (on account of the ultimate, unkeeled volution having still to be added); and, according to Mousson (for the example now before me does not shew it), there are a few hair-like filaments arising out of the asperated granulations. If this latter statement be true, it would seem to imply that the real affinities of the $H$. Plutonia are not with the exact forms amongst which I have placed it, and with which it is associated by Mousson. But, in point of fact, the species is a very difficult one as regards location; and what its nearest allies may be, it is by no means readily apparent.

\section{Helix semitecta.}

Helix semitecta, Mouss., Faun. Mal. des Can. 75. pl. 4. f. 17 (1872)

, $\quad$ "Pfeiff., Mon. Hel. vii. 423 (1876)

Habitat Gomeram, semifossilis ; collegit cl. Fritsch.

A Helix which was found by Fritsch in Gomera, and apparently in a subfossil condition; though as it was sufficiently well preserved for Mousson to give some idea both of its colour and markings, it can scarcely have been so strictly subfossilized as many of the species which we have had occasion to notice.

The $H$. semitecta seems, judging from the diagnosis and figure, to be distinctly umbilicated,-the umbilicus however being half closed over by the expanded lamina of the lower lip; in outline it is rather convex, obtuse, and compact, and without any traces of a keel; its surface is not only strongly and regularly striated, but likewise unequally beset with coarse granules ; and its aperture is relatively rather small, with the upper and lower margins of the peristome a good deal, and subequally, curved. 'La coloration,' says Mousson, ' ne se compose pas de zônes continues simples, mais de 4 fascies, qu'interrompent des taches anguleuses blanches, qui se continuent sur les intervalles ;' and, as regards size, it would appear to measure about 11 lines across its broadest part.

\section{Helix Paivana.}

Helix Paivana, Morelet [nec Lowe], Journ. de Conch. xii. 186 (1864)

$\Rightarrow \quad$ " $\quad$ Mouss., Faun. Mal. des Can. 77 (1872).


Habitat Gomeram; a Barone de Paiva communicata. Rarissima.

The H. Paivana, which appears to be peculiar to Gomera, and which measures about 10 lines across its broadest part, is a rather depressed but obtuse shell, there being no indications of a regular keel; its spire is only slightly raised, but somewhat blunt and dome-shaped; and its umbilicus is partially visible, it being only half closed-over (or perhaps rather more) by the reflexed lamina of the peristome. It is somewhat thin in substance, tumid beneath, and of a yellowish-brown hue (paler on the underside), but ornamented with four narrow and regularly interrupted darker bands, which give a somewhat freckled appearance to the whole upper portion; and the surface is beset with coarse tubercles (which become obsolete towards the nucleus, and gradually disappear below on the umbilical areawhich is more shining and polished),-caused by the breakingup of the densely-packed oblique transverse lines of growth. Its peristome, which is acute and not much recurved, has the upper and lower insertions slightly approximated.

\section{Helix Villiersil,}

Helix Villiersii, d'Orb., in W. et B. Hist. 57. t. 3. f. 11, 12 (1839)

$$
\text { Pfeiff., Mon. Hel. i. } 378 \text { (1848) }
$$

"Villiersi, Mouss., Faun. Mal. des Can. 79 (1872)

Habitat Gomeram; a Dom Despréaux olim reperta.

As stated below, the 'var. $a$. 8ubaucta' of the H. quadricincta would seem to me to approach very near to this species (which I have not been able to inspect, and which apparently is but little known), though the acuteness of its keel prevents it from being actually identified with it. Indeed, judging from the diagnosis, the $H$. Villiersii is not more carinated than the H. Planorbella, and probably not more so than the Paivana; and its transverse costate ridges are said to be interrupted beneath, and the whole shell thin and fragile.

The $H$. Villiersii, which was found many years ago in Gomera by M. Despréaux, was also unknown to Mousson,-who nevertheless seemed inclined to believe that it may prove in reality (when further material shall have been obtained) to represent some variety, or state, of either the $H$. planorbella or the $H$. quadrioincta ; though, I suspect, unless indeed the description be very inaccurate, that it must be distinct from at all events the latter. 


\section{Helix quadricincta.}

Helix quadricincta, Morelet, Journ. de Conch. xii. 156 (1864)

$\begin{array}{lll}" & M & \text { Pfeiff., Mon. Hel. v. } 371(1868) \\ " & M & \text { Id., Novit. Conch. ii. t. 72. f. 13-16 } \\ \text { Mouss., Faun. Mal. des Can. } 78 \\ (1872)\end{array}$

Habitat Gomeram ; in collibus aridis apricis juxta San Sebastian vulgaris. 'Var. a. subaucta' in locis magis elevatis degit.

Morelet's $H$. quadricincta seems to be peculiar to Gomera, -where it was taken abundantly by Mr. Lowe and myself on the dry rocky slopes immediately above San Sebastian, on the northern side of the ravine; and it would appear to have been met with previously by Fritsch. It is stated by Pfeiffer, on the authority of the Baron Paiva, to occur also in Teneriffe; but this, I think, requires corroboration.

The $H$. quadricincta, which measures about 8 lines across it broadest part, is a depressed and lenticular shell, acutely keeled, with about half of its umbilicus exposed (or uncovered), and beset all over with simple and very regular oblique transverse costate lines. It is rather tumid on the underside, but its volutions above are flattened; and its surface is of a pale yellowish-corneous hue (whiter and paler beneath), but ornamented with four narrow darker bands, - of which one is immediately above (and adjoining) the keel, another at a short distance below it, and the remaining two on the anterior half of the whorls. Its peristome (which is white and polished) is a good deal expanded and recurved, the basal portion being broadly incrassated.

There is a slightly larger phasis of this species, which is found at a higher elevation, and which was taken by Mr. Lowe, on April 21, 1861, immediately below the Cumbre (on the southeastern side) at the head of the San Sebastian ravine, and which I should have been inclined to regard as the $H$. Villiersii of d'Orbigny was not its keel quite as strongly expressed as in the typical $H$. quadricincta. In addition to its being somewhat larger than the latter, its costæ are not quite so regular, its aperture is relatively a little more developed and outwardlyextended, the basal margin of its peristome is a trifle less thickened and less curved, and its fasciæ are just appreciably less continuous, or more interrupted,--giving a slightly more freckled appearance to the upper portion of the shell than is the case in the H. quadricincta proper, though very much less so 
than in the $H$. Paivana. This particular state of the species may be thus briefly defined:

Var. a. subaucta.-paulo major, costis vix minus regularibus, aperturâ submajore, peristomatis margine basali sensim minus incrassato minusque curvato, fasciisque vix magis fractis. -Diam. maj. 9 lin.

\section{Helix saponacea.}

Helix saponacea, Lowe, Ann. Nat. Hist. vii. 108 (1861)

" " Pfeiff., Mon. Hel. v. 300 (1868)

" Mouss., Faun. Mal. des Can. 91. pl. v. f. 9-11 (1872)

Pfeiff., Mon. Hel. vii. 350 (1876)

Habitat Canariam Grandem; in aridis saxosis ad El Charco, ultra Maspalomas, copiose lecta. Necnon semifossilis reperitur.

This flattened and lozenge-shaped, but uncarinated Helix (the larger examples of which measure about $7 \frac{1}{2}$ lines across their broadest part) is one of the most distinct species in the archipelago, and one which was detected by Mr. Lowe and myself, both in a recent and subfossil state, on dry rocky banks in the low and remote district of $\mathrm{El} \mathrm{Charco,} \mathrm{in} \mathrm{the} \mathrm{extreme}$ south of Grand Canary,- - beyond the sandy wastes of Maspalomas. We found it in tolerable abundance, in company with the $H$. Despreauxii, d'Orb., and the $H$. pulverulenta, Lowe.

Apart from its depressed but unkeeled contour, the $H$. saponacea may be known by its umbilicus being completely closed over, and by its surface being uniformly covered (except in the central area beneath, where it is paler and shining) with small but sharply defined granules,-caused by the breaking-up of the fine and inconspicuous transverse lines of growth. Its spire, although flattened, has the volutions somewhat convex; and its upper surface, which is slightly opake, is of a pale yellowishcorneous hue ornamented with three more or less obscure reddish-brown bands, the aperture (which is much deflected) being flavescent outside. Its peristome is white and highly polished, as well as broadly expanded and reflexed, and the insertions are wide apart and unconnected by an intervening lamina.

\section{Helix psathyra.}

Helix psathyra, Lowe, Ann. Nat. Hist. vii. 109 (1861)

$$
\begin{aligned}
& \text { " " Pfeiff., Mon. Hel. v. } 300 \text { (1868) } \\
& \text { " } \quad \text { Mouss., Faun. Mal. des Can. 90. pl. 5. f. } 8 \\
& \text { (1872) } \\
& \text { " } \quad \text { "Pfeiff., Mon. Hel. vii. } 350 \text { (1876) }
\end{aligned}
$$

Habitat Canariam Grandem ; in inferioribus, intermediis, locisque elevatis, late diffusa. Semifossilis rarius invenitur. 
It is to Grand Canary that this Helix appears to be peculiar, it having been taken by Mr. Lowe and myself in many remote spots both in the interior and south of that island. We met with it in abundance at the head of the Barranco leading down to Aldea de San Nicolas from Mogan; but we had previously taken it, more sparingly, at Mogan itself, as well as in the lofty Pinal of Tarajana (above San Bartolome), and even so low down as at Maspalomas and Arguineguin. On the northern side of the island we did not observe it; but Mousson records its detection by Fritsch near Las Palmas. In the calcareous region between Aldea de San Nicolas and Lagaete, we found it subfossilized.

In proportion to its size (for the larger examples measure so much as an inch across their widest part), the $H$. psathyra is a rather thin and fragile shell, with the umbilicus completely closed over, and the peristome (although acute) greatly expanded and recurved. It is slightly shining above, and brilliantly polished in the central area below,-where, moreover, it is of a much paler olivaceous-yellow. Its upper region is of a pale olivaceous-brown, with a slightly livid tinge (sometimes the green and sometimes the yellow predominating), the outside of the aperture being flavescent; and there are very obscure traces of four or five obsolete darker bands ; and its sculpture is very light,-consisting only of fine irregular oblique lines of growth (free from granules, except at the nucleus), mixed up with faint malleations.

\section{Helix Gaudryi.}

? Helix Gaudryi, d'Orb., in W. et B. Hist. 57. t. 3. f. 15-17 (1839)

\begin{tabular}{|c|c|c|}
\hline "פ & " & Pfeiff., Mon. Hel. iv. 231 (1859) \\
\hline " & , & $\begin{array}{l}\text { Mouss., Faun. Mal. des Can. 98. pl. 5. f. } \\
16,17(1872)\end{array}$ \\
\hline & و & Pfeiff., Mon. Hel. vii. 347 (1876) \\
\hline
\end{tabular}

Habitat Canariam Grandem ; in intermediis, præcipue per regionem El Monte dictam necnon in Caldeira magnâ montis Bandama, degens.

The $H$. Gaudryi (at any rate as understood by Mousson, though not, apparently, as accepted by Pfeiffer) would seem to be peculiar to the intermediate districts of Grand Canary,where, throughout the region of El Monte (particularly about Los Laurealos, and within the great crater of the Bandama mountain) it is by no means uncommon; and I have taken it above San Mateo, on the ascent to the Roca del Soucilho. It was met with in much the same localities by Mr. Lowe likewise; and Mousson records that it was also obtained in Grand 
Canary by Fritsch. It was probably a mistake of M. d'Orbigny's to have cited it from Gomera; but most likely he was merely guided by the references of Mr. Webb,-whose extreme inaccuracy on the subject of habitats I have had occasion more than once to dilate upon. I happen however to know that the El Monte district was collected in for some time by Webb, so that he could scarcely have failed to secure this large and conspicuous Helix.

Even Mousson, who gave an emended diagnosis of this species, has omitted to call attention to some of its most salient features,-such, for instance, as the minute granulations with which it is densely crowded (he even speaks of it as ' lævigata'!), and the pinkish purple tinge with which its peristome is conspicuously coloured; and he also defines it as 4 -fasciate, whereas the number of its fasciæ is most unmistakeably five,-two being below the dorsal line, two (which are subconfluent) immediately above it, and one adjoining the suture.

In its rather obliquely-elongated outline, laterally-extended aperture, and greatly developed, incrassated, recurved, pinkish peristome, no less than in its solid substance and its denselygranuled, 5-fasciated surface, the H. Gaudryi is a good deal on the type of the $H$. sarcostoma; nevertheless it is very much smaller and more depressed (both above and below) than that species (even though free from all indications of a keel), and has a much livelier and more dappled coloration,the bands being broken-up by more or less angular yellowish markings; added to which there is no trace of an elongated obtuse ridge-like tooth (formed by the scooping-out of the basal margin) within the peristome, and it is generally more appreciably malleated. It is, however, a variable shell,-the malleations being often comparatively inconspicuous; and even the umbilicus is sometimes (though rarely) not completely closed over. The larger examples of the $H$. Gaudryi measure about 11 lines across their broadest part, and the smaller ones about 8.

\section{Helix granomalleata, n. sp.}

T. imperforata, depresso-subglobosa, subtenuis, oblique plicato-malleata (plicis valde irregularibus, subconfluentibus), et minute densissimeque arenoso-granulata, supra opaca, subtus in medio lævior nitidior, griseo-lutea et fasciis 4 vel 5 (sc. 1 vel 2 infra et 2 omnino confluentibus mox supra peripheriam, et 1 plus minus indentato-interrupto pone suturam) castaneis ornata; spirâ obtusâ, suturâ simplici impressâ ; anfractibus 5, convexiusculis, ultimo magno inflato (nec, aut postice obsoletissime, carinato), antice valde descendente; aperturâ magnâ, 
lunato-ovali; peristomate acuto sed parum expanso et reflexo, marginibus ad insertiones subconvergentibus sed separatis (vix callo junctis), supero et basali subæqualitur arcuatis, hôc simplici (nec intus sinuate subdentato).-Diam. maj. 12 lin.

Habitat Palmam; in Barranoo de Herradura, necnon ad Los Souces, a Revdo. R. T. Lowe (et recens et semifossilis) detecta.

Nine examples (two or three of which are subfossilized) of this well-marked Helix were taken by Mr. Lowe in Palma,namely at Los Souces, and in the Barranco de Herradura; and it is remarkable as being the only tolerably large species, with the exception of the $H$. vermiplicata (and the clearly imported H. aspersa, Müll,) which has hitherto been observed in that island. Mousson's monograph does not enumerate a single Palman representative of the great section Hemioycla; nevertheless, seeing that Gomera is so rich in insular forms, we can hardly suppose that Palma, with its superior elevation and more extensive area, is deficient in them, but must merely conclude that the smaller amount of research which has been expended on it accounts for the fauna having been less investigated,

The present Helix is rather thin in substance, and depressoglobose in outline; its ultimate whorl is a good deal developed, rounded, and (except very obsoletely so posteriorly) unkeeled; its umbilicus is altogether closed over; and its surface (which is opake except in the central space below) is not only very densely crowded with minute sand-like granules, but also considerably malleated,- the malleations however being so mixed up (except towards the apex of the spire) with the very irregular oblique plica that the two systems of sculpture seem to be well-nigh completely blended together, or inseparable. In colour it is of a rich brownish- or olivaceous-yellow (paler around the axis beneath), and there are four or five darker and somewhat conspicuous bands, - either one or two of which are below the dorsal line, another (broader, and perhaps composed of two confluent ones) immediately above it, and another (which is more or less indented, or freckled, on its anterior margin) behind the suture.

\section{Helix merita}

Helix merita, Mouss., Faun. Mal. des Can. 174 (1872) " $\quad$ "Pfeiff., Mon. Hel. vii. 348 (1876)

Habitat Gomeram, semifossilis; a Dom. Fritsch reperta.

The present species and the H. harmonica I have not been able to inspect, and there seem to be but few characters about them of a very striking or distinctive nature. They were both 
of them obtained by Fritsch,-the H. merita (which is the larger of the two, measuring 27 millimetres across its broadest part) in Gomera, and only in a subfossil, or perhaps partially subfossil, state, fcr Mousson was able to call attention to its markings. Comparing it with the H. harmonica, to which it is manifestly allied, he observes:- 'La forme totale est plus conique, mais en même temps plus déprimée; les tours croissent d'abord plus promptement, puis plus lentement, et sont, malgré un certain renflement le long de la suture, peu hauts; le pourtour dorsal, anguleux anx tours supérieurs, s'arrondit au dernier tour, mais laisse découvrir, presque jusqu'à l'ouverture, une ligne faiblement saillante; l'ouverture est moins régulière, surtout le bord basal non excavé vers l'intérieur, mais droit ou au milieu faiblement relevé en un épaississement calleux, subdentiforme. Cette espèce, à juger d'après son état, appartient à la faune subfossile de l'île, mais a conservé un certain degré de fraîcheur, par rapport à sa sculpture et, quoiqu'affaiblie, à sa coloration.'

\section{Helix harmonica.}

Helix harmonica, Mouss., Faun. Mal. des Can.74. pl. 4. f. $11(1872)$

" $\quad$ $\quad$ Pfeiff., Mon. Hel. vii. 348 (1876)

Habitat Hierro; mihi non obvia. Collegit cl. Fritsch.

As just stated, this Helix, which was taken by Fritsch in Hierro, is unknown to me. It appears, however, to be of a yellowish-white tint, with two darker well-defined bands beneath, but more suffused on the upper portion. 'La surface,' says Mousson, ' présente des stries costulées extrêmement faibles et une fine granulation allongée microscopique, également faible, qui n'influe que sur le brillant un peu mat. L'ouverture ne s'abaisse que lentement et peu. Le bord externe est un peu réflèchi et blanc; l'inférieur s'épaissit sans s'applatir, reste concave, quoique moins que le supérieur, et se fond avec une faible callosité dans l'avant dernier tour.' It is described as measuring 22 millimetres across its broadest part.

\section{Helix gomerensis.}

Helix gomerensis, Morelet, Journ. de Conch. xii. 157 (1864)

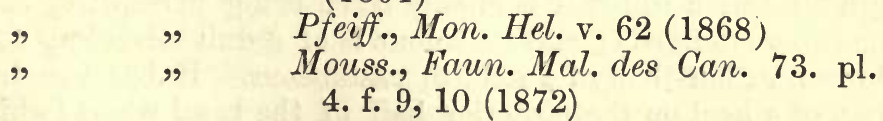

Habitat Gomeram; a Barone Castello de Paiva communicata.

I possess several examples of this fine Helix (the largest one 
of which measures about 11 lines across its widest part) which were received by the Baron Paiva from Gomera, and there can be no doubt that it is the species which was described by Morelet. In proportion to its size the shell is extremely thin and fragile, being more than usually sub-diaphanous when held up to the light; and its colour is a deep castaneous-brown, but rather paler (or more olivaceous) beneath, with extremely indistinct indications of three obsolete darker bands, - one of which is just below the dorsal line, another immediately above it, and the third a little behind the suture (the space between this last one and the suture being sometimes, apparently, though not in the specimens now before me, of a more lively ochreous yellow). In outline the $H$. gomerensis is somewhat depressed ; its ultimate volution, which is angulated posteriorly but rounded and obtuse in front, is very broadly developed; and its aperture is large, the peristome being thin but slightly recurved, with the margins (the basal one of which is only narrowly expanded) wide apart and disconnected. Its surface, which is subopake above but more shining in the certral area below, is finely and very densely, hut unequally, costate-striate; and, when viewed leneath a high magnifying power, it will be seen to be most closely covered with excessively minute and ill-defined sandlike granulations.

\section{Helix hierroensis.}

Helix Hierroensis, Grasset, Journ. de Conch. v. 345 (1856) " " Pfeiff., Mon. Hel. iv. 231 (1859)

" Valverdensis, Lowe, Ann. Nat. Hist. vii. 110 (1861)

" Hierroensis, Mouss., Faun. Mal. des Can. 98 (1872)

Habitat Hierro; in intermediis ad oppidum Valverde lecta.

This is a Helix which was taken abundantly by Mr. Lowe and myself in a garden at Valverde, in Hierro; and it appears to have been met with previously both by Grasset and Fritsch in the same island. It is much smaller than the H.gomerensis (measuring only about 9 lines across its widest part), and rather more globose in contour; but in colour and sculpture it has much in common with that species. It is, however, a little more strictly opake on the upper surface (the minute sand-like granules with which it is closely beset being perceptibly coarser and more defined); and its colour is of a dull olivaceous coffeebrown, rather than of a reddish castaneous. It has less traces, too, of a keel on the posterior half of the basal whorl (which is itself less broadly developed); its aperture is relatively smaller; and its peristome is whiter and a trifle more thickened. Its three bands are quite as obscure as in the $H$. gomerensis, being 
often altogether imperceptible; its oblique transverse lines are equally light and irregular (being, moreover, slightly undulated about the dorsal region, so as to give that part an obsoletely submalleated appearance); and its suture (as in that species) is often edged with an extremely narrow yellowish-white marginal line.

It is not altogether impossible that this Helix may prove eventually to be the true $H$. Maugeana of Shuttleworth (Bern. Mitth. Diagn. $292 ; 1852)$. At any rate what he believed to be Shuttleworth's actual type (in the collection of the late Mr. Cuming) was examined by Mr. Lowe, who declared it to be specifically identical with the Valverde shell. Still, as the diagnosis of the H. Maugeana does not sufficiently tally with the $H$. hierroensis, there is a difficulty about adopting Shuttleworth's title, and disturbing the synonymy as above quoted.

\section{Helix Perraudieri.}

Helix Perraudieri, Grasset, Journ. de Conch. v. 345. t. 13. f. 2 (1856)

" Pfeiff., Mon. Hel. iv. $232(1859)$
Mouss., Faun. Mal. des Can. 100
(1872)

Habitat Hierro ; mihi non obvia. Collegit cl. Grasset.

The H. Perraudieri is a species which was found by $\mathbf{M}$. Grasset in Hierro, but one which I have not myself had an opportunity of inspecting. It seems also to have been unknown to Mousson (except by the figure and published diagnosis), who nevertheless appeared satisfied as to its close affnity with the $H$. hierroensis. Judging from the description of M. Grasset, it is more depressed than the latter, as well as regularly and minutely malleated, and free from the granulations which give so marked a character to that species; but in point of size the two do not, apparently, greatly differ.

\section{Helix distensa.}

Helix distensa, Mouss., Faun. Mal. des Can. 100, pl. 5. f. $20,21(1872)$

Habitat Gomeram. Invenit cl. Fritsch.

A Gomeran Helix, detected by Fritsch, which is apparently a good deal allied to the $H$. Perraudieri, Grasset, from Hierro; but, according to Mousson (for I have not been able to inspect a type), 'elle est plus globuleuse ; le dernier tour est arrondi, bien qu'un peu déprimé vers l'angle dorsal de l'ouverture, la 
ligne dorsale est un peu au-dessus de la mi-hauteur du tour. La spire parait irrégulière, en ce que les tours du sommet grandissent plus lentement que le troisième et le quatrième. ... Quant à la coloration il y a des individus uniforme d'une teinte rouge-brune, tirant sur le violet vers le sommet, d'autres qui sur un tapis jaunâtre présentent les 5 bandes ordinaires foncées, interrompues par des taches jaunes irrégulières, qui envahissent également le fond. L'ouverture, comme dans la Perraudieri, est étroite dans le sens de la hauteur, étirée et anguleuse en travers. Le péristome se dilate sans se réfléchir, et s'orne à l'intérieur, comme à l'extérieur, d'une forte labiation blanche, qui, comme dans l'autre espèce, frappe à la première vue.'

\section{Helix indifferens.}

Helix indifferens, Mouss., Faun. Mal. des Can. 98 (1872) Pfeiff., Mon. Hel. vii. 349 (1876)

Habitat Hierro, semifossilis; exemplare unico a cl. Fritsch detecto.

Described by Mousson from a single worn example which was found by Fritsch, in a subfossil condition, in Hierro; and one can scarcely help regretting that it should have been deemed desirable to erect an additional species on material at once so insufficient and unsatisfactory. ' Espèce subfossile,' says Mousson, 'dont je n'ai vu qu'un individu usé, mais que, dans l'embarras, je doue d'un nouveau nom. La forme la place entres les H. hierroensis et Guanartemes, Grasset. . . . . Elle diffère par un bord faiblement évasé et réfléchi, par une ouverturé d'un ovale arrondi fort régulier, sans sinus supérieurs, ni angulation dorsale; les deux bords ont presque la même courbure. Le basal, bien concave comme dans le sousgenre Iberus, est arrondi, s'insère au moyen d'une callosité convexe, à la base renflée, et développe, profondément à l'intérieur près de la columelle, un tubercule arrondi, qu'on ne voit qu'en tenant l'ouverture très obliquement. Si ce caractère est constant et non accidentel, il serait tout particulier pour cette espèce.' The $H$. indifferens is said to measure 21 millimetres across its broadest part, with an altitude of 14 .

\section{Helix Maugeana.}

Helix Gaudryi, Pfeiff. [nec d'Orb., 1839] i. 269 (1848)

$" \quad$ Maugeana, Shuttl., Bern. Mitth. $292(1852)$
$" \quad$ " Mouss., Faun. Mal. des Can. 96 (1872)
$" \quad$ Pfeiff., Mon. Hel. vii. 347 (1876)

Habitat ' Canaries (mus. Cuming),' sec. Shuttleworth; mihi non obvia. 
As already mentioned, it is far from impossible that the H. hierroensis, Grasset, from Hierro, may prove to be Shuttleworth's $H$. Maugeana,-in which oase the latter name would have the priority. At any rate the specimen, in the collection of the late Mr. Cuming, from which Shuttleworth appears to have drawn up his diagnosis, was examined carefully by $\mathbf{M r}$. Lowe, who affirmed it to be conspecific with the one from Hierro. Still there is a possibility that Mr. Lowe was mistaken in assuming the example in question as Shuttleworth's absolute type, and more particularly so since the published diagnosis of the latter does not accord sufficiently well with Grasset's species (re-enunciated by Mr. Lowe under the name of ' $H$. valverdensis'); so that, in the uncertainty, I think that we are fully justified in retaining the title 'hierroensis' for the Valverde. Helix, and in concluding that Shuttleworth's term 'Maugeana' must apply to some other (cognate) form.

After what has just been said, it is scarcely to be expected that I should attempt to decide what the $H$. Maugeana of Shuttleworth really is. Yet examples of a Helix, now before me, which were received by the Baron Paiva from Arona in Teneriffe, had they not been totally ungranulated, would have tallied better perhaps with Shuttleworth's diagnosis than the Hierro one does. Still, being ungranulated, they cannot be treated as the H. Maugeana; and I fear therefore we must be content to leave the latter species in doubt, trusting that future researches, and a further comparison of the Shuttleworthian type (if it be still accessible), may yet succeed in solving the problem of its identity, or otherwise, with Grasset's $H$. hierroensis. Shuttleworth's diagnosis of his H. Maugeana is as follows:-- ${ }^{6} \mathrm{~T}$. obtecte perforata, tenuis, globoso-depressa, flavescente-fusca, fasciis fuscis obsoletis ornata, tenuiter plicatostriata et reticulatim malleata, sublente minute et creberrime granulata, nitidiuscula; spira subdepressa, anfr. $4 \frac{1}{2}$ convexi, ultimus antice subgloboso-inflatus, demum subito deflexus; apertura perobliqua, lunato-ovalis; perist. leviter expansum, reflexum, album, marginibus subparallelis, basali paululum dilatato-calloso.-Diam. maj. 21 ; min. 16 ; alt. 11 millim.'

\section{Helix Guanartemes.}

Helix Guanartemes, Grass., Journ. de Conch. v. 346. t.13. f. $15,16(1857)$

Pfeiff., Mon. Hel. iv. 232 (1859)

" Manriquiana, Lowe, Ann. Nat. Hist. vii. 111 (1861)

"Guanartemes, Mouss., Faun. Mal. des Can. 99 (1872)

Habitat Canariam Grandem ; in intermediis per regionem 
El Monte, necnon præcipue ad oppidulum Teror, hinc inde degens.

I am extremely doubtful whether this is more in reality than an insular modification, peculiar to Grand Canary, of the H. consobrina, Fer., of Teneriffe. Indeed, after a very careful comparison of an extensive series of both forms, it seems to me that they have positively nothing to separate them except that the $H$. Guanartemes has its peristome a trifle more thickened and (like the $H$. sarcostoma and Gaudryi) of a pinkish-purple, or flesh-coloured, tinge, and that its columella (when viewed obliquely) is just appreciably shorter. All other characters referred to in the published diagnoses are simply imaginary. Thus Mr. Lowe speaks of the $H$. Guanartemes $(i$.e. his H.Manriquiana') as 'lovigata (nec granulata),' and Mousson lays equal stress on the same feature; whereas granules are nearly always more or less traceable beneath a high magnifying power, and in many of my examples they are almost as strongly expressed as in even the $H$. sarcostoma or the $H$. Gudryi. Indeed these 'granulations' might well-nigh be said to be absolutely without signification in a diagnostic point of view, for they are equally variable both in the present Helix and in the $H$. consobrina. In mere colour and markings, moreover, both species are so inconstant that hardly two individuals can be found which are exactly alike; so that no distinctions can possibly be drawn from either pattern or hue.

The $H$. Guanartemes, like the $H$. consobrina, is a rather thin and malleated shell, with the transverse lines of growth very fine, lightly expressed, and unequal, and the peristome moderately expanded and recurved. Its surface is of a more or less brownish-yellow hue (occasional examples possessing a groundcolour of a comparatively clear yellow), and there are normally 5 conspicuous darker bands (some of which are often broad and suffused, but seldom quite absent), - two being placed below the dorsal line, two (which are at times confluent) immediately above it, and one (which is more or less indented or freckled) behind the suture.

The present Helix was taken in Grand Canary both by Grasset and Fritsch, and subsequently in considerable abundance by Mr. Lowe and myself. We found it principally in and around the little town of Teror (on one occasion even within the house of Don Pedro Manrique), but likewise in the region of El Monte,-particularly in the hollows of old trees at the Laurealos, where some of the specimens, in their large size and more strongly granulated surface, make a slight primâ facie approach in the direction of the H. Gaudryi, d'Orb. 


\section{Helix consobrina.}

Helix consobrina, Fer., Prodr. 72 (1821)
Mouss., Faun. Mal. des Can. 94. pl. 5. f. 14,15 (1872)
Pfeiff., Mon. Hel. 360 (1876)

Habitat Teneriffam ; in sylvaticis intermediis occurrens.

The $H$. consobrina, which is so closely allied to the GrandCanarian $H$. Guanartemes that I can detect absolutely nothing to separate it except its white and rather thinner peristome and its just appreciably longer columella, is peculiar apparently to the sylvan regions of Teneriffe, at intermediate altitudes, - my own examples being principally from the wood of the Agua Garcia. In primâ facie aspect it is almost inseparable from the H. Guanartemes; and I have already pointed out what the main characters are which apply equally to the two forms.

\section{Helix invernicata.}

Helix consobrina, W. et. B. [nec Fer., 1821], Ann. des Sc, Nat. 28. syn. 311 (1833) d'Orb., in W. et B. Hist. 54 (1839)

$" \quad$ " $\quad$ d'Orb., in W. et B. Hist. $54(1839)$

" invernicata, Mouss., Faun. Mal. des Can. 95. pl. 5. f. $13(1872)$

" $\quad$ " Pfeiff., Mon.Hel. vii. 346 (1876)

Habitat Teneriffam; in truncis cavernosis Laurorum et Ericce in sylvâ ad 'La Esperanza' (ultra Laguna sitâ) congregans.

This is a Helix which has generally been considered to be the true $H$. consobrina of Ferussac, but one which Mousson has separated from the consobrina proper; and I think perhaps that it may be accepted as specifically distinct, though I cannot feel absolutely satisfied that it is more in reality than a smaller and ungranulated race of the consobrina, in which the transverse lines of growth are a trifle less evident and the malleations relatively a little more so, and in which the surface is altogether more glossy and shining, and the colour is of a more uniform ochreo-olivaceous brown speckled with small irregular angulated blotches, and fragmentary reticulations, of yellow. Its ultimate volution, also, does not descend quite so much, or quite so suddenly, in front, and is rather less constricted (and therefore less gibbose) at the aperture. Judging from my own material and that of Mr. Lowe, the $H$. invernicata is decidedly a smaller shell than the consobrina proper, nevertheless Mousson's diagnosis would imply that it is larger. 
The $H$. invernicata, which is strictly Teneriffan (unless indeed the $H$. Guanartemes be regarded as the Grand-Canarian modification of the consobrina, -in which case the three forms would probably be referred to a single plastic type, having for its range the intermediate districts of Grand Canary and Tenériffe), was originally discovered by Webb within the hollow trunks of old laurels and heaths in the little wood of La Esperanza, a few miles to the south of Laguna; and I may add that it was met with by Mr. Lowe and myself, under precisely similar circumstances, in the same spot. Whether the other naturalists who have obtained it (namely Maugé, d'Orbigny, Zollinger, Fritsch, and Reiss) found it also at La Esperanza, I have no means of ascertaining.

\section{Helix malleata.}

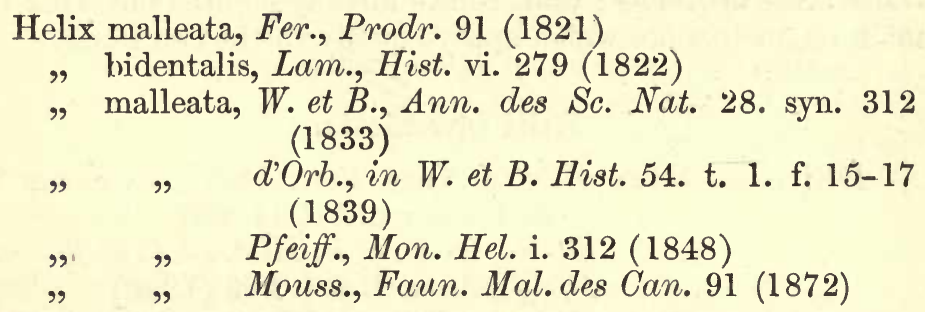

Habitat Teneriffam ; in sylvaticis intermediis editioribusque, inter muscos humidos, ad truncos arborum cavernosos, et sub lapidibus, hinc inde vulgaris.

Peculiar apparently to the sylvan regions of Teneriffe, at intermediate and rather lofty altitudes, particularly in the north-eastern division of the island. It was taken by Mr. Lowe and myself at the Agua Garcia, as well as at Las Mercedes, at the edges of the Vueltas above Taganana, and between Taganana and the Valle de Palmas (near Point Anaga); and it has been met with in Teneriffe by nearly every naturalist who has visited that island, - including Webb and Berthelot, Maugé, d'Orbigny, Blauner, Fritsch, and Reiss.

The $H$. malleata (which measures about $11 \frac{1}{2}$ lines across the widest part, with an altitude of about 9 ) is a strong and globose shell, at once distinguishable by its glossy, malleated surface, its dark rich olivaceous-brown hue (rendered darker by the broad, though not always apparent, coffee-coloured bands with which it is ornamented and suffused), by its suddenly and very greatly deflexed (posteriorly constricted) aperture, and by its peristome (which is thickened into a coarse and prominent white rib, rather than reflexed) being developed internally into two tooth-like callosities, - one of which is extremely large and placed at the angle, or insertion, of the upper margin, whilst 
the other is smaller and at a little distance from it in the direction of the dorsal line (the space between the two assuming the form of a curved sinus). These teeth are naturally more pronounced in some individuals than in others, and in the specimens from Taganana they are often monstrous; and although globose in outline, the posterior half of its basal volution is distinctly keeled; the apical portion of its spire is usually more or less worn and decorticated; and although there are no traces of granules (properly so called), the surface will nevertheless be seen, when viewed beneath a very high magnifying power, to be beset here and there with infinitesimal spirally-arranged granuliform markings, - as though composed of closely-packed but fragmentary (or broken-up) lines.

\section{Helix nivariæ, n. sp.}

T. imperforata, solida, subgloboso-depressa, malleata, superne subopaca et sublente minutissime arenoso-granulata, subtus in medio nitida egranulata et ibidem clare olivaceo-lutea, supra obscurius luteo-olivacea et fasciis brunneis 3 vel 4 suffuse cincta ; anfractibus $5 \frac{1}{2}$ convexiusculis, ultimo inflato (nec etiam postice carinato), antice descendente ; aperturâ parvâ, subtriangularilunatâ, valde constrictâ; peristomate albo, valde incrassato, rudi, intus convexo, extus expansiusculo acuto reflexo, ad angulum superiorem necnon inter angulum et lineam dorsalem plus minus obsolete subdentato-calloso, margine basali lato subin-

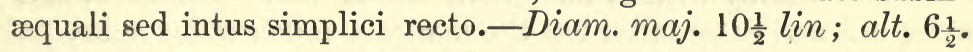

Habitat Teneriffam; in inferioribus juxta Portum Orotovæ a Revdo. R. T. Lowe reperta. Necnon etiam semifossilis ibidem exstat.

Obs.-Ab H. malleata, Fer., nisi fallor, vere distincta. Differt testâ majore, subdepressiore, subdilutius (sc. minus læte olivaceo-) coloratâ, ubique minutissime arenoso-granulatâ et subopacâ (nec lucidâ); anfractu ultimo nec etiam postice carinato, antice lentius minusque descendente; aperturâ multo magis triangulari, peristomate intus magis convexo, sed extus magis acuto producto recurvo, marginibus ad insertiones remotioribus, dentibus binis dextri obsoletis, basali intus crassiore magisque recto.

It is somewhat singular that so large and conspicuous a Helix as the present one should apparently have escaped the researches of the many naturalists who have visited Teneriffe; but if it be right to separate the Grand-Canarian $H$. Glasiana and the Gomeran $H$. Fritschi from the malleata (of which, I think, there can be but little doubt), it must be right, $\grave{a}$ fortiori, to deal in a similar manner with the $H$. nivaria, for while those two forms 
might possibly be looked upon as permanent insular phases of the Teneriffan type, no such conclusion could be arrived at in the case of the one now under consideration, seeing that it inhabits the same island (and has done so since the subfossil epoch) as the malleata proper. Apart also from its diagnostic characters, which are both numerous and striking, the habitats of the species in question seem quite dissimilar; for while the $H$. malleata is essentially sylvan in its mode of life, occurring normally from about 2,000 to 3,000 feet above the sea, the $H$. nivarioe, on the contrary, is found in comparatively low and arid spots towards the northern coast,- the examples before me having been taken by Mr. Lowe near the Puerto of Orotava, where it exists both in a recent and a semifossilized condition.

The $H$. nivarioe is larger and relatively perhaps is little more depressed than the malleata, and (except in its central area beneath) it will be seen, when viewed under a high magnifying power, to be everywhere crowded with infinitesimally minute sand-like granules (far smaller than those which are so conspicuous in the Grand-Canarian $H$. Glasiana),- - a peculiarity of sculpture which causes the surface (which is equally malleated, though less richly coffeaceo-olivaceous) to be less glossy than in that species. Its ultimate volution (which is free from all appearance of a keel even behind) is less deflected in front, and more gradually so; its aperture (which is small) is much more triangular in outline; and its peristome, which is more thickened and convex within, but more acute, more produced, and more reflexed externally, has the margins much wider apart at their points of insertion, - the basal one, moreover, being more straightened, and the upper one having the two teeth quite obsolete, or sometimes faintly represented by a slight thickening, or callosity, in the usual places.

\section{Helix Glasiana.}

Helix malleata, ß., Pfeiff., Mon. Hel. i. 312 (1848)

" Glasiana, Shuttl., Bern. Mitth. 143 (1852)

" pellis-lacerti, Reeve [teste Pfeiff.], Conch.Icon. t. 132. n. 841

$\begin{array}{ll}\quad & \begin{array}{c}\text { Mouss., Faun. Mal. des Can. } 92 \\ (1872)\end{array} \\ & \text { Pfeiff., Mon. Hel. vii. } 359\end{array}$

Habitat Canariam Grandem ; in intermediis, præcipue per regionem El Monte, in Caldeirâ magnâ montis Bandama, necnon in calcareis inter oppida Lagaete et Galdar, occurrens. In statu semifossili ad calcareos inter Las Palmas et Puerto da Luz copiose inveni. 
This may perhaps be regarded as the representative in Grand Canary of the Teneriffan $H$. malleata, Fer, though in reality it comes far nearer in its opake granulated surface and the obsolete teeth of its peristome, as also in its less sylvan mode of life, to the $H$. nivarioe. It is widely spread over the intermediate districts of Grand Canary, descending in a subfossil condition to quite a low altitude, for I have met with it, genuinely subfossillized, on the calcareous isthmus between Las Palmas and the Isleta. In a recent state it was taken abundantly by Mr. Lowe and myself throughout the region of $\mathrm{El} \mathrm{Monte,} \mathrm{as} \mathrm{well} \mathrm{as} \mathrm{within}$ the Great Caldeira of the Bandama mountain, and on the calcareous ground between Lagaete and Galdar ; and it is recorded by Mousson as having been obtained by Fritsch likewise in Grand Canary. It was first detected by Webb, in a bleached and decorticated condition, during August of 1829, who however mistook it for the $H$. malleata.

Apart from its smaller size and opake, coarsely granulate unmalleated surface (the granules of which are formed as it were by the broken-up closely-packed transverse lines of growth, and extend over the very nucleus itself, - the basal portion, which is bright and glossy, being alone devoid of them), the $H$. Glasiana recedes from the rualleata in being (as regards its ground-colour) of an altogether much paler or yellower hue, there being no indication of the deep rich olivaceous- and coffee-brown tints which are so characteristic of that species; its ultimate volution, which descends much less in front, is free from all traces of a keel even behind; and its aperture is not only more rounded and very differently shaped, but it has the tooth-like callosities obsolete, - the one towards the middle of the outer lip being represented by a mere thickening of the peristome (usually slight but sometimes considerable, and for the most part more strongly expressed in the subfossilized examples), while the other, which is so enlarged and conspicuous at the upper angle in the $H$. malleata, is uniformly and completely wanting. Its peristome is often, though by no means always, of a pinkish or flesh-coloured tinge; with the basal margin straightened, or even subconvex, internally, instead of being (as in the $H$. malleata) concave. The $H$. Glasiana measures about 10 lines across its broadest part, and has an altitude of about $7 \frac{1}{2}$ or 8 .

Mousson's subfossil 'var. deformis' which he affiliates with the Teneriffan $H$. malleata, but which he records to have been found by Grasset at 'Puerto da Cruz' in Grand Canary, requires further explanation, for I cannot but think that it will be ascertained in reality to be referable to the $H$. Glasiana,-the subfossilized examples of which have their peristome greatly thickened (causing the aperture to appear smaller and more 
misshapen), and the outer tooth considerably developed. Moreover its habitat 'Puerto da Cruz' looks exceedingly like a misprint for Puerto da Luz, which is the exact locality for the $H$. Glasiana in its subfossilized condition ; and, in further corroboration of this, it is noteworthy that Grasset is reported to have also met with the $H$. Saulcyi in a subfossil state,-a species which occurs in company with the (equally subfossilized) H. Glasiana, and emphatically in the vicinity of the Puerto da Luz. My belief therefore is, that Grasset's subfossilized specimens and my own are specifically identical, and that they both of them represent a very slightly modified phasis of the H. Glasiana (my examples, which are perbaps less decorticated than Mousson's were, having, in addition to the obsoleteness of the upper tooth of the peristome, the granulations distinctly traceable on to the very nucleus), and have nothing whatever to do with the exclusively Teneriffan $H$. malleata.

\section{Helix Fritschi.}

Helix Fritschi, Mouss., Faun. Mal. des Can. 93. pl. v. f. $12(1872)$

" $\quad$, Pfeiff., Mon. Hel. vii. 360 (1876)

Habitat Gomeram; recens circa San Sebastian, et semifossilis ad Hermigua, vulgaris.

Although belonging to the same type, this is a smaller, thinner, and more globose shell than any of the preceding three species, its aperture is more regularly rounded, and its peristome is much less incrassated, - the tooth-like callosities which are more or less evident in the other members of the malleata group, being here quite obsolete; though sometimes an exceedingly faint thickening in the two usual places is just traceable, as though to point out its affinities. The H. Fritschi moreover is remarkable for the greater opacity of its (unmalleated) surface, even the under portion being almost free from gloss, - a peculiarity which is due to its extremely densely and minutely roughened type of sculpture, which, although at first sight appearing to be granulose, will be seen (beneath a high magnifying power) to be the result of a system of closely-packed extremely diminutive transverse lines which are broken-up into elongated granuliform parts, some of them well-nigh merging into true granules. In colour the $H$. Fritschi is somewhat curious, - the ground-tint being of a dirty whitish- or brownishyellow, freckled all over with fragmentary lines and small angular subconfluent blotches of a slightly paler hue; and, in addition to all this, there are 4 narrow and not very conspicuous darker bands, - one of which is placed just below the dorsal 
line, and the other 3 above it. The nucleus is minutely granulose, but much less coarsely so than in the H. Glasiana.

The $H$. Fritschi may be said to be the Gomeran representative of the $H$. nivariae (rather than of the $H$. malleata) of Teneriffe, and of the $H$. Glasiana of Grand Canary. It was met with abundantly by Mr. Lowe and myself, as it had been previously by Fritsch, on the hill-sides above San Sebastian; and Mr. Lowe obtained it subsequently, in great profusion, in a subfossil condition, at Hermigua, on the opposite side of the island.

\section{(§ Euparypha, Hartm.)}

\section{Helix pisana.}

Helix pisana, Müll., Verm. Hist. ii. 60 (1774)

" " Lowe, Cambr. Phil. S. Trans. iv. 52 (1831)

" $\quad$, W. et B., Ann. des Sc. Nat. 28. 6 (1833)

" " d'Orb., in W. et B. Hist. 58 (1839)

" $\quad$ Lowe, Proc. Zool. Soc. Lond. 171 (1854)

" $\quad$ Alb., Mal. Mad.21.t. 3. f. 1-18 (1854)

" " Paiva, Mon. Moll. Mad. 70 (1867)

$" \quad$ " Mouss., Faun. Mal. des Can.28 (1872)

" $\quad$ Pfeiff., Mon. Hel. vii. 227 (1876)

var. geminata.

Helix pisana, v. geminata, Mouss., Schw. Denks. xv. 132 (1857)

" geminata, Id., Faun. Mal.des Can. 29 (1872)

var. Grasseti.

" Pfeiff., Mon. Hel. vii. 228 (1876)

Helix planata (pars), W. et B. [nec Chemn.] Ann. des Sc. Nat. 28. syn. 312 (1833)

" pisana monstrosa (pars), d'Orb., in W. et B. Hist. 59

, Grasseti, Tarnier in litt. (1839)

" Mouss., Faun. Mal. des Can. 31. pl. 2. f. 33,34 (1872)

Pfeiff., Mon. Hel. viii. 228 (1876)

Habitat Lanzarotam, Fuerteventuram, Canariam Grandem, Teneriffam, Gomeram, et Palmam (in Hierro solâ adhuc haud observata); calcareos inferiores præcipue colens. Etiam semifossilis in Fuerteventurâ a cl. Mousson occurrere dicitur.

After a very careful comparison of the almost endless phases (both in outline and colour) which cluster around (in the Canarian archipelago), or radiate from, the normal state of the common European H. pisana, I have been driven to the conclusion that not one of them can be held as specifically distinct,--for 
there is not a feature on which their various claims as (so-called) 'species' has been supposed to rest which does not seem to me to be totally unreliable and fluctuating. Thus the $H$. geminata of Mousson, which in its normal condition is larger, more solid, and more depressed than the typical pisana, with its sculpture perhaps a little coarser, its perforation entirely closed, and its colour peculiarly dark and lively, passes by such imperceptible gradations, in all these several particulars, into the usual aspect of the pisana proper, that many hundreds of examples which are now in my possession (from different islands, and districts, in the Group) leave me in complete uncertainty as to which of the supposed ' species' they should be referred; and I do not think that it would be possible to decide positively whether they are the true pisana (as limited by Mousson) or the geminata. I have no hesitation therefore in regarding the $H$. geminata as a mere geographical development of the pisana,-perhaps somewhat characteristic of the Canarian archipelago, but nevertheless assuredly passing into the ordinary Mediterranean type by every conceivable shade of intermediate link. And similar observations may apply to the $H$. Grasseti, Tarnier (=planata (pars) W. et B., nec Chemnitz), from the Isleta of Grand Canary,which retains all the essential characters of pisana proper, except that its spire is remarkably depressed, its keel is more acute, its perforation is nearly concealed, and its decussating striæ are quite as coarse as in the var. geminata. ${ }^{1}$

In its more typical aspect I have taken the $H$. pisana (which occurs likewise in the Azorean and Madeiran Groups) in Lanzarote, as well as on the little adjacent island of Graciosa, in Grand Canary (principally below Tafira), and in Teneriffe (about Laguna and Sta. Cruz). The examples from Fuerteventura (where Mousson records the species as having been found by Hartung in even a subfossil condition) are more emphatically referable to the var. geminata than those from any of the other islands,-being on the average extremely large, solid, and deeply coloured, with their perforation seldom otherwise than quite closed up. The Teneriffan ones are usually somewhat smaller, and are often (as regards their umbilicus and sculpture) intermediate between the geminata and the type; certain of them also, from Laguna and near Orotava, being of a uniform (and comparatively constant) buff hue, with but small and insignificant markings superadded. Whilst my Gomeran individuals

1 I am not indeed altogether sure that even the Lanzarotan $H$. impugnata, Mousson, would not be treated by certain monographers as an extreme development of the $H$. pisana,-its var., or status, 'subgeminata,' having a good deal in common with the 'var. Grasseti' of the pisana; nevertheless, as this is more doubtful, I will not attempt to open up the question. 
have more the aspect, I think, of the var. geminata than of the pisana proper; though their perforation is by no means quite concealed.

The variations in mere colour of this protean Helix are so endless (scarcely two specimens, except the totally white ones, being exactly alike) that it would be almost a waste of space to attempt to tabulate them.

\section{Helix impugnata.}

Helix planata (pars), W. et B. [nec Chemn.], Ann. des Sc. Nat. 28. syn. 312 (1833)

" pisana monstrosa (pars), d'Orb., in W. et B. Hist. 59 (1839)

" impugnata, Mouss., Schw. Denksch. xv. 132 (1857)

$" \quad "$ Id., Faun. Mal. des Can. 32. pl.2. f. 35, 36 (1872)

" $\quad$ Pfeiff., Mon. Hel. vii.248 (1876)

Habitat Lanzarotam, et ins. parvam adjacentem ' Graciosa' dictam: ad rupes maritimas circa oram borealem, vulgaris. Etiam semifossilis a cl. Mousson occurrere dicitur.

This species, which has been observed hitherto only in the north of Lanzarote, was mixed up by Webb with the (equally depressed, but otherwise dissimilar) var. Grasseti of the pisana, from the Isleta of Grand Canary,- the two together (as is evident from his habitat in 'Canaria, Lancerotta, et Graciosa') being referred to the H. planata, Chemn.; and thus a double error was placed on record,- - for not only are the Lanzarotan and Canarian shells distinct inter se, but neither the one nor the other of them accords with Chemnitz's species, which is totally different and belongs to the fauna of Morocco. ${ }^{1}$ The present Helix was first defined by Mousson, in 1857, from Lanzarotan examples which were collected by M. Hartung, who is said to have also met with it in a subfossil condition.

The H. impugnata was taken in profusion by Mr. Lowe and myself in the extreme north of Lanzarote, particularly about Chache and the lofty maritime cliffs (overlooking the Salinas) known as the Risco; and we likewise obtained it on the little adjacent island of Graciosa.

There can be no question that the $H$. impugnata belongs strictly to the pisana-type, and that the variety of the shell which is less acutely keeled (the 'var. subgeminata' of Mousson) makes a very decided approach towards the "var. Grasseti" of the pisana, which occurs in Grand Canary. Nevertheless, in

1 The true H. planata, Chemn., is abundant around Mogador, where it may be found adhering to the shrubs of Broom (Retama monosperma, L.). 
spite of the great aberrational range of the pisana, I think that the $H$. impugnata recedes from it in so many particulars, and so conspicuously, that we may fairly be permitted to cite it as distinct; though, at the same time, I cannot but feel that another mode of treatment is at any rate possible. The $\mathrm{H}$. impugnata is a solid and (in its normal condition) a very acutely keeled species, the keel being subcrenulate and filiform (or shaped out by a slight concavity on either side) and traceable up the (depressed) spire; its basal region is comparatively convex; its surface is almost opake, and roughened, being strongly sculptured with the usual decussating striæ (the spiral lines of which are exceedingly apparent); and its perforation is nearly closed. In the 'var. subgeminata' the keel is much less sharply expressed, and the spire is less flattened. ${ }^{1}$

From the 'var. Grasseti' of the pisana (to which it is more particularly allied) the $H$. impugnata differs in having the keel acuter, as well as more prominent and filiform (being scooped out on either side); in its spire being a little less flattened, its sculpture coarser, its surface more opake, its basal volution (especially towards the aperture) less ventricose, and its columellary margin somewhat less vertical. Its colour too is different,being less lively and defined, the markings being more obscure and fragmentary, and toned-down with a suffused yellowishbrown.

\section{(§ Xeroptiila, Held.)}

\section{Helix lineata.}

Helix lineata, Oliv., Zool. Adriat. 177 (1799) " maritima, Drap., Hist. Nat. 85. t. 5. f. 9, 10 (1805) $" \quad$ W. et B., Ann. des Sc. Nat. 28. syn. 316 (1833)

" simulata, W. et B. [nec Fer.], l. c. syn. 315.t. 24. f. 1 $(1833)^{2}$

1 It is remarkable that two precisely analogous states of the shell occur in the true H. planata, Chemin., from Mogador; and they were well defined by Mr. Lowe (vide 'Zool. Journ.,' 1860, pp. 196, 197) as the ' $\alpha$. acutangula' and the ' $\beta$. obtusangula.'

2 Mousson (l.c. 34) raises the question as to whether the H. simulata, W. et B. [which liowever is not the simulata of Ferussac, a species purely oriental], may not be identical with the scarcely differing state, or variety (?), of the lineata to which Shuttleworth appears to have applied the MS. name, 'canariensis;' and to this I would reply that the $H$. simulata, W. et B., is simply and purely the $H$. lineata, Oliv., in its normal Camarian aspect. Mr. Webb's examples were, in point of fact, collected by himself in the El Monte district of Grand Canary, and some of them he transmitted to Mr. Lowe in August, 1829 ; and in a note, now before me, written by Mr. Lowe in 1833, he (Mr. Lowe) identified them, without any doubt whatsoever, with the $H$. maritima, Drap.,-which indeed is the universal species of the El Monte region, differing only from the more northern type in the few and very insignificant points to which I have called attention. 
Helix maritima, d'Orb., in W. et B. Hist. 60 (1839)

" lineata, Mouss., Faun. Mal. des Can. 34 (1872)

" canariensis (Shuttl.) et herbicola (Shuttl.), Mouss., l. c. 33 et 35 (1872)

" $\quad$ lineata, et herbicola, Pfeiff., Mon. Hel. vii. 231,232 (1876)

Habitat Fuerteventuram, Canariam Grandem, et Teneriffam ; in aridis inferioribus intermediisque (præcipue in calcariis) hinc inde abundans.

The common European H. lineata, Oliv. (= maritima, Drap.), occurs here and there, in dry, grassy, and calcareous spots, at the Canaries; but I have no reason to suspect that it has been recorded hitherto except from Fuerteventura, Grand Canary, and Teneriffe. D'Orbigny indeed, with that characteristic want of accuracy, as regards habitat, which is so conspicuous throughout the whole of the gigantic 'Histoire Naturelle,' gives as its range 'toutes les Canaries' (an assertion which is copied by Pfeiffer, who adds, 'Habitat in omnibus insulis Canariis '); but I have merely to add that these loose generalizations (or, rather, guesses) are simply unpardonable in an instance like the present one-where he had not a shred of evidence to adduce that the species had been observed in more than, at the utmost, three islands (probably indeed not more than two) out of the seven. It is extremely probable that it may be found eventually to be pretty generally distributed; but that is no excuse for making a positive assertion which has at least a fair chance of turning out altogether fallacious.

By Mr. Lowe and myself the $H$. lineata was met with only (as indeed it was by Webb, and quite recently by Mr. Watson) in Grand Canary and Teneriffe,-namely between El Monte and Las Palmas, as well as between Lagaete and Galdar, of the former, and around Sta. Cruz and Laguna (particularly in the Barranco del Drago) of the latter ; but it is said by Mousson to have been obtained in Fuerteventura by Fritsch,-who, like ourselves, obtained it equally in Teneriffe and Grand Canary.

Judging from Spanish examples now before me, which were collected in the neighbourhood of Barcelona, the Canarian form of this variable European Helix does not differ materially from the ordinary one. Perhaps its striæ are somewhat more distinct, thread-like, and regular, causing its surface to be just appreciably duller or more opake; and the darker bands which are comparatively narrow and well defined in the majority of the more northern specimens, are wider and more broken-up (or interrupted) and suffused, at any rate on the upper portion,giving the spire a more mottled, or tessellated, appearance; but 
such differences as these are scarcely worth noticing in a species which is so eminently unstable as the $H$. lineata.

As for the $H$. canariensis and herbicola (both of them mere manuscript names of Shuttleworth), I cannot conceive that they represent more than the most ordinary local modifications of this naturally variable shell; and considering that even the anthor himself was so little convinced of their stability that he did not venture to publish so much as a diagnosis of them, one cannot but regret that so eminent a conchologist as Mousson should have thought it desirable to do so, and thus to add (on confessedly imperfect evidence) two more 'species' (so-called) to the perfect chaos which already exists around the lineata (or maritima, Drap.), the variabilis, and the virgata. ${ }^{1}$

\section{Helix conspurcata.}

Helix conspurcata, Drap., Hist. Nat. des Moll. 105. pl. 7. f. 23-25 (1805)

Theba conspurcata, Risso, Hist. Nat. iv. 74 (1826)

Helix conspurcata, Pfeiff., Mon. Hel. i. 170 (1848)

" $\quad$ Mouss., Faun. Mal. des Can. 36 (1872)

Habitat Teneriffam; in aridis apricis (vel inferioribus vel intermediis) hinc inde, præcipue in cultis, congregans.

The somewhat insignificant, European H. conspurcata, Drap., occurs in Teneriffe,-where it is occasionally abundant, in certain sunny spots of a low and intermediate elevation. It has been found near Sta. Cruz, and more plentifully around Laguna (where it was obtained by Mr. Lowe, in 1861, in the Barranco del Drago) and at Souzal. At first it a good deal resembles the $H$. armillata, Lowe, of the Azorean, Madeiran, and Cape Verde archipelagos (and which exists also, under a rather more strongly striated phasis, in Morocco,--from whence it was re-described inadvertently by $\mathrm{Mr}$. Lowe as the ' $H$. eumceus') ;

' I say 'confessedly,' because Mousson, in speaking of the $H$. canariensis, says : 'M. Shuttleworth a désigné sous le nom de $H$. canariensis une coquille, qu'il n'a pas diagnosée, sans doute parce qu'elle rentre par rapport à sa forme dans le chaos des modifications de la variabilis, Drap. Si donc nous donnons une description, ce n'est pas dans le but de l'ériger en espèce, mais pour ne pas admittre un nom sans définition.' And, again, in his notice of the $H$. herbicola, he writes: 'Encore une espèce difficile à placer, et non décrite par l'auteur;' and, after stating that the three features which seem to distinguish it from the lineata are its more depressed spire, its just appreciably more angulose basal whorl, and its slightly less opake surface, he further adds: 'D'autres individus, rapportés par M. de Fritsch, sont un peu plus élevés, quoique toujours obtus, moins anguleux, et moins polis. De nouvelles observations sur les rapports de vie de ces deux formes pourront seules décider sur leur réunion ou séparation.' With only such data as this, one cannot but think that it would have been better not to have taxed such a terribly confused group as the present one with two more 'new species,' which by his own admission were by no means absolutely necessary. 
nevertheless it is, on the average, a little smaller and more depressed, its umbilicus is not quite so large, and its entire surface (which is a trifle more shining, or subpellucid) is sparingly clothed, particularly when the shells are young, with fine hairs or ciliæ. It is usually, too, a little more brightly variegated with pallid markings; and there are more or less obsolete indications beneath (as in the $H$. lancerottensis, W. et B.) of a few indistinct spiral, or concentric, bands and line-like rings.

\section{Helix apicina.}

Helix apicina, Lam., Hist. vi. 102 (1822)

Xerophila apicina, Held, in Isis, 913 (1837)

Helix apicina, Morel., Moll. du Port. 63 (1845)

$\begin{array}{lll}" & \Rightarrow & \text { Pfeiff., Mon. Hel. i. } 170(1848) \\ " & " & \text { Morel., Hist. Nat. Açor. } 174(1860) \\ " & " & \text { Drouet, Faun. Açor. } 158(1861) \\ & " & \text { Pfeiff., Mon. Hel. vii. } 242(1876)\end{array}$

Habitat Teneriffam; examplaria dua nuperrime communicavit Revdus. R. B. Watson.

Two examples of the $H$. apicina, Lam.,-which occurs in southern Europe, the Azores, and northern Africa,-have lately been communicated by the Rev. R. B. Watson, as forming a portion of the material which was collected in Teneriffe during the expedition of H.M.S. ' Challenger'; and as Mr. Watson has kindly permitted me to examine the whole of the species which were found in that island, and which represent the most ordinary and commonplace of the Canarian forms, there can be no question whatsoever concerning the perfect accuracy of its habitat. I possess the $H$. apicina from Marseilles, Tangier, and Mazagan (in the last of which places it was found by Mr. T. S. Leacock); and the Teneriffan individuals agree with them precisely in every particular.

At first sight the $H$. apicina might seem to have a little in common with certain examples of the $H$. lancerottensis which happen to be abnormally depressed; nevertheless the spire is still more flattened than in even such individuals as these, and the ultimate volution is more-suddenly enlarged,-giving the shell somewhat the primâ facie contour of the Madeiran $H$. obtecta and latens, or of Lowe's H. Irus from Mogador. Added to which, the substance is more solid, and the surface (which is free from hairs) is not only more sharply striated but has an appreciable broken-up, or tessellated, fascia immediately behind the suture. Moreover the umbilicus is relatively a trifle larger. 


\section{Helix lancerottensis.}

Helix lancerottensis, W. et B., Ann. des Sc. Nat. 33. syn. 12 (1833) d'Orb. [nec diagn. p. 60], in W. et B.

Hist. t. 1. f. 24, 25 (1839)
"Orbignyi, var. calcarea, Mouss., Faun. Mal. des Can. $37(1872)$

var. Orbignyi.

, lancerottensis, Pfeiff, Mon. Hel. vii. 560 (1876)

Helix Orbignyi (W. et B.), d'Orb., in W. et B. Hist. 59. t. 2.

f. 31-33 [nec coll. d'Orb] (1839)

var. adoptata. et var. mitigata, Mouss., l. c. 36, 37 (1872)

Helix adoptata, Mouss., l. c. 37. pl. 2. f. 39-41 (1872)

Habitat ins. omnes Canarienses; in inferioribus intermediisque, sub lapidibus, degens.

Owing to the excessive carelessness of M. d'Orbigny, who has altogether misunderstood and confused this common $\mathrm{Ca}$ narian shell, both Pfeiffer and Mousson seem to have been in a hopeless state of doubt concerning it; and no wonder, considering that d'Orbigny (in 1839) drew out his diagnosis of it from a single bleached example of the $H$. monilifera, W. et B., whilst the figures to which he refers, and which had been long engraved under Webb's supervision and represent the species which was published in the 'Synopsis' in 1833, apply to a totally different shell,-correctly depicting, in fact, the true $H$. lancerottensis! In reality the H. Orbignyi, W. et B., is only a rather larger, thinner, and occasionally hispid form of the lancerottensis, which obtains more particularly in the central and western portions of the archipelago, - the smaller, more calcareous, and glabrous one (the ' $H$. Orbignyi, var. calcarea' of Mousson), and which is Webb's type of his lancerottensis, being especially characteristic of, though by no means peculiar to, the two eastern, and much drier, islands of the Group. ${ }^{1}$

The above is in complete accordance with the remarks of Mr. Lowe in his paper on the shells observed at Mogador. Alluding to the surprising inaccuracy of M. d'Orbigny, he says:

1 The $H$. lancerottensis occurs also at Mogador, on the opposite coast of Morocco (from whence I possess many examples); and Mr. Lowe, in referring to this typical form of the shell, says (vide 'Journ. of the Linn. Soc.' for 1860, p. 199), 'It agrees perfectly with six original Lanzarotan specimens sent to me by Webb in 1829, of his $H$. lancerottensis, and with others found by myself and Mr. Wollaston last year not only in Lanzarote and Fuerteventura, but also (together with the $H$. Orbignyi, Webb) in all the Canary Islands.' These six original types are now in my own collection, and I can vouch for the correctness of Mr. Lowe's conclusion. 
'D'Orbigny's description of H.lancerottensis proves by his original single type to have been drawn up from an old dead bleached example of $H$. monilifera, Webb! The figures, however, to which he refers (t. 1 . ff. 24, 25) represent the true $H$. lancerottensis of Webb, whose first two plates of shells had been engraved under his own management by Terver long previous to d'Orbigny's engagement in the work, and correctly exhibit the species originally intended, and published by Webb in his Synopsis, but of which the present is unfortunately not the only one subsequently misunderstood and thrown into confusion by d'Orbigny' (l. c. 199). And, again (l.c. 200); 'D'Orbigny has wonderfully misunderstood this common species. Not only, as already noted, has he placed in his collection and described in Webb's " Histoire" for the true $H$. lancerottensis, Webb, an old dead shell of $H$. monilifera, ${ }^{1}$ Webb; but five genuine examples of the true $H$. lancerottensis in his collection have been mistaken for, and actually stand as types of, the larger variety, $H$. Orbignyi, Webb.'

Although seldom very abundant, there is not a single shell which is more universally spread, than the H.lancerottensis, over the entire Canarian archipelago,-in the whole seven islands of which I have indeed myself taken it. It is extremely variable, both in size and surface, putting on a slightly modified phasis according to the local influences, especially dryness and moisture, of the particular district in which it is found; and I cannot understand on what principle the Gomeran form of it, which is perhaps a trifle more depressed and conspurcata-like, should have been singled out by Mousson (under the title of $H$. adoptata) for specific separation,- - thus destroying unnecessarily, as it seems to me, by a single link, the chain of faintly differing races which gives so marked a topographical interest to the species as a whole. In Lanzarote and Fuerteventura it more often assumes a rather small, bleached, and calcareous aspect, free from all indications (even when immature) of minute hairs; and in the former of those islands I more particularly met with it about the lofty cliffs (known as the Risco) in the extreme north, overlooking the Salinas, - a locality which I happen to know, from letters now in my possession, was comparatively well searched by Mr. Webb, and where he evidently obtained the examples which were figured as his types of the H. lancerottensis. In Teneriffe the larger and thinner form, described by d'Orbigny as the ' $H$. Orbignyi, W. et B.,' and in which the surface is often minutely pilose, may perhaps be said to predominate; though both phases of it (and every intermediate

1 This specimen I have myself also examined accurately, and can vouch for Mr. Lowe's observation being correct. 
grade) are to be found. This ' $H$. Orbignyi', which is sometimes rather abundent about Sta. Cruz, Orotava, and Garachico, occasionally attains an appreciably larger size (when it corresponds with the 'var. mitigata,' Mouss.), and is apt to live gregariously beneath stones, where it encrusts itself with a more or less hardened covering of the dusty soil,--much after the fashion of the Madeiran $H$. vulgata, Lowe, with which species indeed I cannot but think that it has, despite its comparatively diminutive bulk, something very decidedly in common.

My Palman specimens are principally from the Barranco de Herradura.

\section{(§ Irus, Lowe.)}

Helix eutropis.

Helix eutropis, Shuttl., Mal. Blätt. vii. 237 (1860)

" $\quad$ " Pfeiff., Mon. Hel. v. 371 (1868)

" "Mouss., Faun. Mal. des Can. 58. pl. 3. f. 28-30 (1872)

Habitat Fuerteventuram, rarissima ; a Dom. Berthelot olim communicata, necnon a cl. Fritsch nuper collecta.

This is one of the rarest, and most peculiar, of the Canarian Land-shells, and one which entirely escaped the observations of myself and Mr. Lowe in the archipelago. It appears to have been observed hitherto only in Fuerteventura, from whence I possess a single example from the collection of M. Berthelot; and others seem to have been found, more recently, in the same island, by Fritsch.

The H. eutropis (which is rather thin in substance, and which measures about seven lines across its broadest part) is an umbilicated and slightly lenticular species, somewhat convex beneath, and with a strong crenulated subfiliform keel ; its surface is coarsely ribbed, both above and below, with oblique, regular, remote, and much elevated costæ, and its colour is of a dull griseous-green. Although considerably smaller, it a little calls to mind, at first sight, both in its outline and sculpture, the Porto-Santan $H$. Wollastoni and forensis, of the Madeiran Group; but its conspicuously open umbilicus will, even of itself, at once remove it from the scabriuscula type.

\section{Helix multigranosa.}

Helix multigranosa, Mouss., Faun. Mal. des Can. 59. pl. 3. f. 25-27 (1872)

Pfeiff., Mon. Hel. vii. 292 (1876)

Habitat Gomeram; semifossilis; a cl. Fritsch, in Valle de Gran-Rey, reperta. 
This is a species which was found by Fritsch, in the Valle de Gran-Rey, in Gomera; and as it appears to have been in a subfossil condition, it may perhaps have become extinct,- - though this is a question which can only be solved by future, and more careful, researches, in the same island. I have had no opportunity of inspecting it; but it is compared by Mousson to the Porto-Santan $H$. depauperata, Lowe, of the Madeiran archipelago; and, judging from the figure, it would certainly seem to have something in common (as regards size, sculpture, and contour) with that species.

In his remarks which follow the diagnosis, Mousson says : 'Tout le test est couvert de granulations allongées dans le sens des stries d'accroissement et tellement serrées, qu'elles semblent résulter de deux systèmes de sillons se croisant sous un angle très aigu. L'ombilic eśt médiocre, ne s'évase que peu et s'enfonce presque cylindriquement. L'ouverture est assez oblique, presque circulaire et peu modifiée par l'avant-dernier tour. Le péristome peu évasé au bord supérieur, refléchi et labié à l'inférieur, se continue dans la callosité un peu détachée qui relie les deux bords. Le nucléolus est plus grand qu'ordinairement et lisse. Parmi les espèces de Madère, l'H. depauperata, Lowe (Pfr. Mon. No. 493) s'en rapproche le plus, mais elle a les tours plus serrés et plus convexes, le pourtour moins anguleux, les stries plus grossières et plus irrégulières, par contre les granulations beaucoup plus fines. Toutefois elle fixé la place de notre espèce dans la système' $(l . c . p p .59,60)$.

\section{(§ Spirorbula, Lowe.)}

\section{Helix paupercula.}

Helix paupercula, Lowe, Cambr. Phil. S. Trans. iv. 47.t. 5. f. 19 (1831)

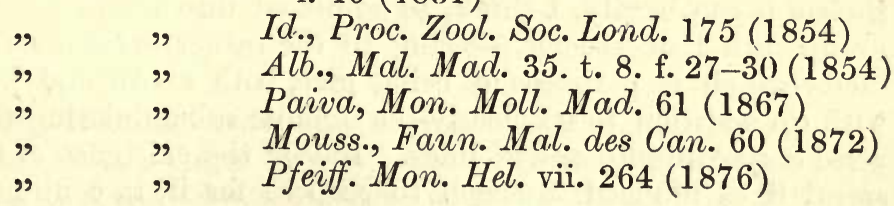

Habitat Lanzarotam; circa Haria, versus borealem insulæ, rarissima.

The solid, flattened, and Planorbiform little $H$. paupercula, which is composed of about four whorls, the spire being extremely depressed (indeed often a little concave), occurs very sparingly in Lanzarote, - where it was obtained originally by M. Hartung, and subsequently (near Haria, in the north of that island) by Mr. Lowe. It is universal throughout the Madeiran 
Group (absolutely swarming in Porto Santo), and is found likewise at the Azores ; but it is nevertheless strictly an 'Atlantic' species, not having been observed hitherto either in Europe or Africa.

The $H$. paupercula (which measures about $2 \frac{1}{4}$ lines across its broadest part, and which possesses the curious habit of coating itself over, though not always, with a hardened envelope of dirt) is opake in surface, and either brown or grey in hue; and it is closely and minutely granulated all over, with the oblique transverse lines of growth rather conspicuous. Its umbilicus is large and spiral; and although its peristome is acute, circular, and elevated, its aperture is much bent down and very powerfully constricted, so as to shape out a corneous ring-like prominence behind the former.

\section{(§ Lyrula, Woll.)}

\section{Helix Loweana.}

Helix torrefacta, Lowe [nec Adams, 1849], Ann. Nat. Hist. vii. 106 (1861)

$$
\text { Pfeiff., Mon. Hel. v. } 261 \text { (1868) }
$$

Patula torrefacta, Mouss., Faun. Mal. des Can. 27. pl. 2. f. $25-28(1872)$

Helix torrefacta, Pfeiff., Mon. Hel. vii. 298 (1876)

Habitat Lanzarotam; ad rupes aridas apricas torrefactas, præcipue versus oram borealem, inter lichenes, occurrens.

This is a most elegant, lenticular little Helix, very delicately and shortly pilose, or spirally laciniated, conspicuously umbilicate, and beautifully blotched on the upper portion with irregular white markings on a brown ground. In affinity it is not far removed from the $H$. lentiginosa, Lowe, of Madeira ; nevertheless it can hardly, I think, be admitted into the same actual group with that species, - owing to the rather anomalous character which it possesses of being girt, both above and below, with (in addition to its closely-set oblique subundulating transverse costæ) minute spiral lines. Indeed the existence of these spiral lines induced Mousson to propose for it, in conjunction with the $H$. circumsessa of Shuttleworth, a new section ('Lyra'),-regarding them both, however, as Patulas; but I have already shewn (vide ante, p. 318) that the $H$. circumsessa is no Patula at all, but a Hyalina (intimately related to the H.lenis, Shuttl., and my H. osoriensis), and it would be preposterous to treat the present Helix as a Hyalina! And indeed I cannot but believe that it is almost equally removed from even the genus Patula as it is from Hyalina,-its affini- 
ties being far more with the Actinella-section of Madeira, represented by the $H$. lentiginos $\alpha$ and its immediate allies. ${ }^{1}$

As compared with the Madeiran $H$. lentiginosa, the present species (the name of which I have been compelled to change, the title torrefacta having been preoccupied in 1849 for a Helix from Jamaica) is a trifle larger and more solid (or less subtransparent), with a rather wider umbilicus, and with its aperture somewhat more developed and less circular, - the peristome being both less recurved and more interrupted (or less continuous) across the body-volution. Then, as regards ornamentation, clothing, and sculpture, the differences are still more apparent, - the H. Loweana being almost white beneath (instead of a dull yellowish horny-brown), with merely a brokenup fascia near to the keel, whilst the whole portion visible from above is reddish-brown but blotched with a few irregular though well-defined white transverse patches. Moreover the $H$. lentiginosa is a strictly (though sparingly) pilose species; whereas the Loweana has only its spiral lines furnished with excessively diminutive and abbreviated laciniox-like fragile bristles: and the sculpture of the lentiginosa consists merely in irregular, oblique subconfluent costæ, instead of the sharp densely-packed undulating ridges of the Loweana, intersected (or decussated) by the infinitesimal spiral lines to which I have already called attention.

The H. Loweana has been observed hitherto only in Lanzarote,-where it was met with by myself, and subsequently by Mr. Lowe, on the dry exposed maritime cliffs, known as the Risco, in the extreme north of that island and overlooking the Salinas. They were taken chiefly from amongst lichen, within the crevices, and on the actual surface, of the hot rocks, in places directly exposed to the sun; and Mr. Lowe also obtained examples in the neighbouring district of Chache.

\section{(§ Hispidella, Lowe.)}

Helix leprosa.

Helix leprosa, Shuttl., Bern. Mitth. 142 (1852)

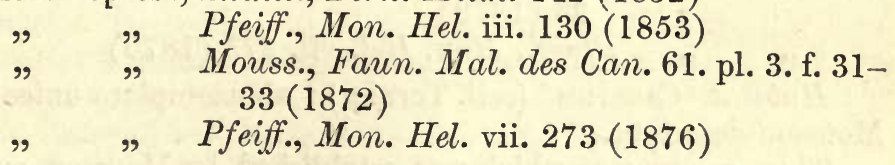

'It was not until after I had arrived at this conclusion independently, that I observed Mr. Lowe's note, to exactly the same effect, accompanying his diagnosis of the $H$. torrefacta. ' The nearest ally,' says he, 'of this very distinct and well-marked little species is the Madeiran H. lentiginosa. The numerous fine thread-like or lamellar spiral striæ resemble those of the common sylvan Teneriffan H. circumsessa, Shuttl., which is however as distinct in habit as in habitat,--belonging to the group Lncilla.' 

sima.

Habitat Teneriffam; in humidis sylvaticis editioribus, raris-

The $H$. leprosa is one of the rarer species of the archipelago, and one which has been found hitherto only in the damp sylvan districts, at a rather high altitude, in Teneriffe,- - where it was taken by Mr. Lowe and myself at the Agua Mansa (on the mountains above the Villa of Orotava), and previously in the same spot by Blauner and Grasset; and we also met with it at the edges of the Vueltas above Taganana.

Were it not for the smallness of its almost concealed umbilicus, the present Helix might well-nigh be treated as a Patula,-it having somewhat the primâa facie appearance of certain forms (such as the Madeiran $H$. deflorata, Lowe) which I have arranged under the section Iulus; but its comparatively minute and nearly closed-up perforation, in conjunction with its more conspicuously pilose surface, cause it to be better associated with the members of the Hispidella-group; though I am inclined to suspect that at any rate the Madeiran $H$. actinophora, to which Mousson considers it allied, is more naturally placed amongst the keeled and slightly hispid Patulas of the gorgonarum- and Bertholdiana-type.

Apart from its somewhat lenticular, obtuse, depresso-globose Patula-like contour and almost closed umbilicus, the H.leprosa (the larger examples of which measure nearly 5 lines across the broadest part) may be known by its thin, fragile substance, and pale corneous yellowish-brown hue, and by its hairy and nearly opake surface being coarsely sculptured with oblique and closelypacked costate striæ. Its apex is rounded and blunt, its basal whorl is almost free from angulation, and its peristome is acute and unthickened, but nevertheless a little expanded and reflexed, with the margins wide apart at their insertion,--being totally unconnected inter se by a corneous lamella.

\section{Helix lanosa.}

Helix lanosa, Mouss., Faun. Mal. des Can. 61. pl. 3. f. 3436 (1872)

" $\quad$ "Pfeiff., Mon. Hel. vii. 273 (1876)

Habitat 'Canaries' (coll. Tarnier); ab exemplare unico a cl. Mousson descripta.

This is a species which was established by Mousson on the evidence of a single example which had been communicated to him by M. Tarnier, of Dijon, as having come from the 'Canaries,' but without any kind of note as to its precise locality; and, considering how nearly related it manifestly must be to the $H$. leprosa, and considering also the absolute uncertainty of its 
habitat, one cannot but regret that material so meagre and unsatisfactory should have been made use of to augment an island fauna in which the most perfect accuracy as regards the several areas of distribution is of primary importance. Still, having been once admitted and described, it cannot be subsequently ignored.

Judging from Mousson's diagnosis and figure, I cannot perceive that the H.lanosa differs materially from the leprosa, Shuttl.,-and more particularly so, since the 'granules claires,' on the absence of which he depends for one of its main distinctions from the latter, are to me scarcely (if at all) recognizable in any of the specimens of even the true leprosa which I have yet examined. Neither can I acknowledge the great affinity of either of these species (so-called) with the Madeiran $H$. actinophora. The remarks of Mousson on the H. lanosa are as follows: 'Je n'ai vu qu'un individu de cette espèce, que je dois à la bonté de M. Tarnier, mais sans indication précise de localité. Elle diffère de la leprosa, dont elle partage assez la forme, par l'absence de granules claires et par la présence d'un duvet de filaments laineux, bien que courts, placés sur les dos des stries. Les premiers tours, ainsi que le milieu de la base, sont dépourvus de filaments. La petitesse, la ténuité, le faible développement du bord, l'absence d'ombilic pénétrant, la pilosité différente, etc., la séparent du groupe de la $H$. hispidula et la rangent dans le groupe voisin des $H$. ciliata, Ven., et actinophora, Lowe.'

\section{Helix pavida.}

Helix nubigena, Lowe [nec Saulcy, 1852], Ann. Nat. Hist. vii. 105 (1861)

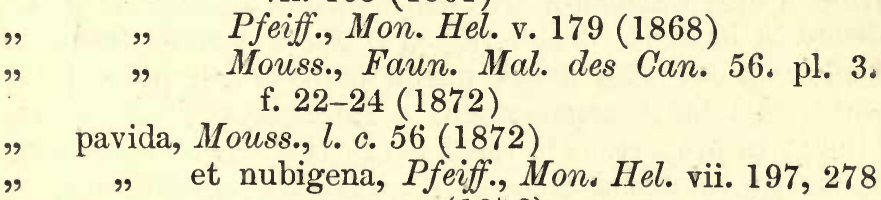
(1876)

Habitat Teneriffam, et Palmam; sub foliis ramulisque Retamæ (i. e. Spartium nubigena) in locis valde elevatis a meipso lecta.

The insignificant little $H$. nubigena, Lowe (which I have been compelled to cite under Mousson's subsequent name of pavida, 'nubigena' having been pre-occupied in 1852 for a Helix from the Pyrenees), appears to have been found hitherto only by myself, - first, at a high elevation in Palma, and afterwards at a still higher one in Teneriffe. It was on the Cumbre, of the former island, above Buenavista (some 6,000 feet above 
the sea), that I originally met with it,-though merely two examples, and those in an immature condition. But it subsequently occurred to me, in much greater abundance, at an altitude of about 9,000 feet, in Teneriffe,-namely amongst the dead sticks and rubbish which had accumulated beneath the bushes of the 'Retama' (or Canarian Broom), on the Cumbre above Ycod el Alto, for which that $1 \mathrm{fty}$ region is so celebrated; and since I likewise took it, under precisely similar conditions, on the opposite Cumbre, above the Agua Mansa, the species may perhaps be defined as occupying more particularly the upland scoriaceous districts which are characterized by the Retamas.

Although so remarkable in its habitat, the present Helix is a most inconspicuous, depresso-rotundate little species (mature individuals measuring only about 2 lines across their widest part); and indeed whatever peculiarities it may possess are well-nigh obscured by the habit which it has of coating itself over with a covering of dirt. Moreover the excessive thinness, and flexibility, of the shell renders this outer envelope extremely difficult to be removed without at the same time destroying the clothing, and occasionally also even the cuticle; but when it has been sufficiently got rid of to permit the various features to become visible, the $H$. pavida will be seen to be of a pale yellowish- (or often olivaceous-) horny-brown, semitransparent in substance, but with its surface (which is nearly opake, and finely sculptured with subconfluent transverse lines) studded all over with most minute and very abbreviated, but rather remote, silvery squamiform bristles, - which give it, when the specimens are unrubbed, a slightly frosted appearance; and, although at times quite unicolorous, it has more frequently a curious tendency to have its dorsal region (though nearly destitute of a keel) marked with a few unequal, detached, paler, yellowishwhite blotches,-representing a fragmentary fascia. Its umbilicus, in proportion to the size of the shell, is rather large and open; its volutions are a little convex, with the suture a good deal sunken; and its peristome is acute, with the upper and lower margins unconnected and wide apart.

The two Palman examples of this shell, to which allusion has already been made, have always appeared to me to be absolutely conspecific with the Teneriffan ones, and such likewise was the opinion (judging from their general facies, and the unmistakeable peculiarity of their habitat) of Mr. Lowe; yet Mousson has described them, although confessedly immature and unsatisfactory, as a new species, under the title of ' $H$. pavida.' But their characters, to which he calls attention in his diagnosis, are simply, and purely, those of the ordinary $H$. 
nubigena (as will at once be seen by comparing them with my remarks given above); and I am totally unable to conclude, from such material, that they represent so much as even a 'variety' of the Teneriffan type. Yet, singularly enough, he does not attempt to point out in what they differ from the latter, but contents himself with observing (which is of course self-evident) that they cannot be referred to either the $H$. leprosa, the lanosa, or the hispidula!

The $H$. pavida may be looked upon as the Canarian representative of the H. Armitageana, Lowe, of the highest elevations of Madeira; though that species (which is almost equally fragile, and of a similar olivaceo-corneous hue) is considerably larger and a little less flattened, and has a somewhat smaller umbilicus, its surface is beset with coarse elongate-subtriangular, file-like filaments (instead of infinitesimal abbreviated bristles), its peristome (although acute) is more developed and recurved, and there are usually obscure indications of two indistinct, narrow, reddish-brown bands.

\section{(§ Gonostoma, Held.)}

\section{Helix crispo-lanata, $\mathrm{n}$. sp.}

T. umbilicata, lenticularis, parum acute carinata, tenuis, opaca, dense et grosse plicatulo-striata et pilis longissimis subcrispatis cinereis ubique (sed præsertim in regione dorsali) vestita; spirâ depressấ; anfractibus 5, celeriter crescentibus, ultimo supra ad carinam (in spirâ mox supra suturam continuam) obsolete compresso, subtus convexo ; aperturâ obliquâ, peristomate acuto, marginibus late separatis et laminâ subnullâ junctis, columellari umbilicum (profundum et subito, sed haud angulatim, excavatum) non attingente-Diam. maj. lin. 4; alt. $1 \frac{1}{2}$.

Obs.-Species, sculpturâ grosse plicato-striatâ et formâ depressâ carinatâ, cum $H$. fortunata, Shuttl., congruens; tamen multo minor, umbilico angustiore, et ubique pilis crispatis longissimis vestitá. Ab H. hispidula, Lam., differt spirâ depressiore, umbilico paulum majore, necnon testâ grossius striatâ pilisque multo longioribus ac rudioribus induta.

Habitat Palmam; exemplar unicum, Maio exeunte 1858, in Barranco de Galga repertum.

A single example (not quite mature as regards its peristome) of this very remarkable Helix was taken by Mr. Lowe's servant, Antonio Rodrigues, on the 2 lst of May, 1858, in the Barranco de Galga, in Palma; and there cannot be a question that it represents a truly distinct member of the Gonostoma section,partaking in some measure of the characters both of the $H$. 
hispidula and of the fortunata. Although very much smaller, yet in its flattened spire, strongly developed keel, and coarsely striated surface, it agrees better with the latter of those species than it does with the former; nevertheless the exceedingly long and coarse hairs with which it is everywhere clothed entirely remove it from the $H$. fortunata, as indeed they do (though in a less degree) from the hispidula. It is thin and fragile in substance, and (although opake) somewhat transparent; and its umbilicus is deeply and rather suddenly (but by no means angularly) scooped-out.

From the $H$. lanosa, Mouss., which was described from a single individual the precise island of which was uncertain, it appears to recede (judging from the diagnosis) in being smaller and more depressed, as well as more sharply keeled, and in its umbilicus being very much larger and exposed, and in its hairs (which clothe the under portion of the shell as well as the upper) being considerably longer and more developed.

\section{Helix hispidula.}

Carocolla hispidula, Lam., Hist. vi. 99 (1822)

Helix hispidula, W. et B., Ann. des Sc. Nat. 28. 314 (1833)

$\begin{array}{ccc}" & " & \text { Pfeiff., Mon. Hel. i. } 209(1848) \\ " & " & \text { Mouss., Faun. Mal. des Can. 62 (1872) } \\ \text { var. } \beta " \text { (major), Bertheloti, Fer. }\end{array}$

Helix Bertheloti, Fer., Bull. Zool. 90 (1835)

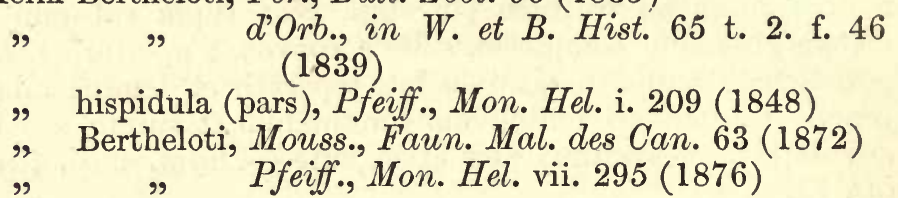

Habitat Teneriffam, et (sec. Fritsch, sed an vere?) Gomeram; præcipue in inferioribus intermediisque vulgaris.

The $H$. hispidula, Lam., according to my own experience, is essentially Teneriffan; though, according to Mousson, it appears to have been obtained by Fritsch in Gomera likewise. ${ }^{1}$ But around Sta. Cruz and Orotava, in Teneriffe, I have inet with it in profusion; and it was taken in equal abundance by Mr. Lowe about Garachico, and in the Barranco de Majuelo of Los Silos. It appears however to present a larger and a smaller state (the latter of which is generally assumed to correspond with Lamarck's type), - for after a most careful comparison of a

1 I cannot but feel it possible that the species which I have described below as the $H$. gomerce may have been mistaken by Fritsch for the $H$. hispidula. 
long array of examples collected in various localities, I cannot persuade myself that the $H$. Bertheloti of Ferussac is anything more than a slightly enlarged and robuster phasis of the ordinary $H$. hispidula, in which the costate lines are a little coarser, the umbilicus just appreciably wider, and the entire surface more distinctly studded with a few remote (more or less hairbearing) granules. Every other character which is mentioned in the published diagnoses seems to me to be simply imaginary; and moreover, unless I am greatly mistaken, the two forms merge gradually into each other. At any rate the habitats above referred to are for the smaller (or 'typical') state. The larger one, or 'var. $\beta$. Bertheloti,' was taken commonly by Mr. Lowe and myself above the Puerto of Orotava; and it is said to have been found by Fritsch at Taganana and Guimar. ${ }^{1}$

The H. hispidula is a rather discoidal shell, with the keel not very sharply expressed, and the umbilicus small but open and cylindrical. It is thin and fragile in substance, of a pale horny-brown, closely sculptured with fine transverse costate lines, and more or less clothed (when the specimens are fresh and unrubbed, and particularly when young) with short squamiform hairs. Its peristome is acute, but a little recurved, and with the upper and lower margins wide apart and unconnected by an intervening lamina. Although on the whole depressed, the $H$. hispidula is less so than any of the following members of the present section.

\section{Helix fortunata.}

Helix lens, W. et B. [nec Fer., 1821], Ann. des Sc. Nat. 28. syn. 315 (1823)

" " d'Orb., in W. et B. Hist. 66. t. 2. f. 7-9 (1839)

" fortunata, Shuttl., Bern. Mitth. 141 (1853)

" $\quad$ Pfeiff., Mon. Hel. iii. $162(1852)$

" $\quad$ Mouss., Faun. Mal. des Can. 64 (1872)

Habitat Teneriffam, et (sec. Fritsch sed an vere?) Gomeram; supra Sanctam Crucem (in illâ) præcipue occurrens. Usque ad 2,000' s.m. ascendit.

Like the $H$. hispidula, this is more particularly Teneriffan, though (as in the case of that species) it would appear to have been found by Fritsch in Gomera also. Near Sta. Cruz in Teneriffe it was met with by Mr. Lowe and myself in tolerable abundance, - where it seems to ascend to a somewhat higher

1 If so slight a modification as the $I$. Bertheloti, which is often barely distinguishable from the smaller type, is necessarily to be treated as specific, I can only say that the Madeiran $H$. polymorpha should, by parity of reasoning, be split up into at least twenty 'species' (so called). 
elevation than the hispidula. Our examples were principally from the Barranco del Passo Alto, and the ravine beyond it (in the direction of Point Anaga), as well as from the hills to the north of the town, especially towards El Campo,-where Mr. Lowe obtained it in profusion on the summit of a rocky eminence about 2,000 feet above the sea.

The $H$. fortunata is a larger, more lenticular, and a trifle more depressed shell than the H. hispida, and with its keel very much more acute and appreciably flattened-out (on the upper side), or compressed, and traceable up the spire; its surface (which is free from the remote granules which mark, on the upper side, the positions of the hairs in the young examples at all events of the 'var. $\beta$. Bertheloti') is less opake, and rather more closely costate-striate ; its umbilicus is considerably wider; and the lower margin of its peristome is perhaps somewhat more broadly expanded.

\section{Helix beata, n. sp.}

T. umbilicata, lenticularis, acute carinata, nitidula, dense et grosse plicatulo-striata, (saltem in statu adulto, sed an in immaturo?) calva, pallido-cornea ; spirâ planatâ, valde depressâ;

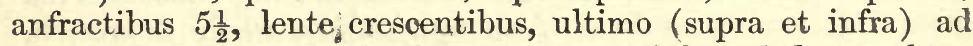
carinam compresso, antice breviter et paululum deflexo, subtus convexo-inflatiusculo ; aperturâ obliquâ, securiformi, peristomate acuto, marginibus late separatis et laminâ subnullâ junctis, columellari anguste expanso, reflexo, umbilicum (parvum, profundum, et subito, sed haud angulatim, excavatum) vix attingente.-Diam. maj. lin. vix 6 ; alt. 2.

Obs.- H. fortunatce, Teneriffæ, affinis, sed paulum minor, subnitidior, spirâ depressiore, valde deplanatâ, carinâ sensim magis compressâ sed vix supra suturam in spirâ visibili, anfractu ultimo subtus convexiore et magis inflato, umbilico sensim angustiore magisque subito excavato, necnon peristomatis marginibus (columellari minus expanso) magis remotis.

Ab H. planaria, Lam., differt testâ multo minore grossiusque striatâ, carinâ multo minus acutâ, anfractu ultimo antice magis descendente, necnon umbilico angustiore, minus spiraliter visibili, et minus angulatim exoavato.

Habitat Fuerteventuram; exemplar unicum communicavit Baronus de Paiva.

The single example from which the above diagnosis has been compiled was obtained by the Baron Paiva from Fuerteventura, and it certainly seems to me to represent a distinct and undescribed member of the hispidula group. It is more nearly allied to the $H$. fortunata, Shuttl., of Teneriffe, than to 
anything else with which I am acquainted; nevertheless it is smaller and less opake than that species, as also very much more flattened on the upper side (its spire being almost as much depressed as in the $H$. planaria), but a little more convex and inflated beneath,- causing the umbilicus, which is appreciably narrower, to be more suddenly, or abruptly, scooped-out. Its keel, too, is more acute, and a little more evidently compressed both above and below ; and the margins of its peristome are relatively wider apart.

\section{Helix planaria.}

Carocolla planaria, Lam., Hist. vi. 99 (1822)

Helix afficta, var. planaria, Mouss., Faun. Mal. des Can. 65 (1872)

" " " Pfeiff., Mon. Hel. vii. 296 (1876)

Habitat Teneriffam; in montibus supra et ultra Taganana degens.

The H. planaria of Teneriffe, the afficta of Palma, and the discobolus of Gomera, in their general structure and practically bald surface, as well as in the sudden and somewhat angular scooping-out of their perpendicular-sided umbilicus, may be regarded as representative forms; but whether it be desirable to treat them as insular modifications or as separate species I am scarcely prepared to say. Perhaps either view is equally tenable; for as it is pretty clear that they can never be absolutely connected by intermediate links, it is impossible to pronounce for certain that they are merely developments of a single type. At any rate they each stand in precisely the same relation to each other; and it seems unreasonable therefore to cite the planaria (as Mousson has done) as a variety of the afficta, and yet to retain the latter as specifically distinct from the discobolus. Whichever principle we adopt should be applied equally to them all ; and since at any rate the afficta and discobolus have always been looked upon as properly-defined species, I am inclined to be guided by that assumption, and to extend it to Lamarck's $H$. planaria,-which, if anything, is perhaps the best characterised of the three.

It was only on the mountains in the north-east of Teneriffe, above and beyond Taganana, that we met with the H. planaria; and it appears to have been found in the same district by Fritsch and Reiss. The particular spot in which Mr. Lowe subsequertly obtained it was on a hill called 'Benijo,' between Taganana and Point Anaga. It is at once separated from its Gomeran and Palman allies by its extremely flattened and very 
sharply carinated form, its acutely angulated aperture, and it: rather thin, subpellucid substance. Its keel is broadly compressed, both above and below, and is more or less traceable up the spire,-forming often on the penultimate whorl a narrow line overhanging the suture; its volutions are flattened; and its surface is of a pale clear whitish-brown, merging beneath into a brownish-white. In size it is a little larger than the afficta (measuring about $6 \frac{1}{2}$ lines across its broadest part), but smaller than the discobolus; its umbilicus is a trifle wider than that of the former, but narrower than that of the latter; and its ultimate whorl hardly descends at all anteriorly.

\section{Helix afficta.}

Helix afficta, Fer., Prodr. 151 (1821)

$$
\begin{array}{ll}
\prime \quad \text { (pars), Mouss., Faun. Mal. des Can. } 65 \\
\quad \quad \quad \text { (1872) } \\
, \quad \text { (pars), Pfeiff., Mon. Hel. vii. } 296(1876)
\end{array}
$$

Habitat Palmam; hinc inde sub lapidibus in intermediis.

As already mentioned, the present Helix may be regarded as the Palman representative of the $H$. discobolus of Gomera, and of the $H$. planaria of Teneriffe,-though it is certainly more allied to the former than to the latter. With the $H$. discobolus indeed it has very much in common,-agreeing with it in its general sculpture and surface, and in its volutions not being so extremely flattened as in the planaria; nevertheless it differs in its smaller size and considerably narrower umbilicus, and in its whorls being $6 \frac{1}{2}$ in number instead of 7 .

From the $H$. planaria the afficta recedes in being more solid, and very much less depressed both above and below, in its umbilicus being appreciably smaller, in its keel being very much less broadly flattened out, and in its aperture being much less angulated externally.

It was in the intermediate districts of Palma that the $H$. afficta was met with by Mr. Lowe and myself, particularly in the Barranco de Nogales; and it appears to have been found in the same island by Blauner.

\section{Helix gomeræ, $\mathrm{n}, \mathrm{sp}$.}

T. umbilicata, lenticularis, acutissime carinata, tenuis, subopaca, densissime et minute costulato-striata, pallide cornea ; spirâ obtuse convexiusculâ; anfractibus $6 \frac{1}{2}$, lente crescentibus, ultimo (supra et infra) ad carinam subalbidam anguste leviter compresso, antice breviter deflexo, subtus subconico-convexo; aperturâ obliquâ, securiformi, peristomate acuto, marginibus subapproximatis et laminâ subnullâ junctis, columellarj an- 
guste expanso, reflexo, umbilicum (profundum et subito angulatim excavatum) haud attingente.-Diam. maj. lin. 5; alt. 2.

Obs.-H. discobolo, -Shuttl., affinitate proxima, sed multo minor, magis tenuis, ac magis opaca, densius et multo minutius costulato-striata, necnon umbilico subminore et subminus evídenter spiraliter visibili.

H. affictoe, Fer., ab ins. Palma, staturâ umbilicoque minoribus, forsan magis affinis; sed differt, inter aliâ, testâ multo minore, magis tenui, necnon crebrius minutiusque striatâ.

Habitat Gomeram; in statu emortuo necnon semifossili, juxta Hermigua, collegit Rev. R. T. Lowe.

Twelve examples of a Helix which are now before me, and which were taken by Mr. Lowe, in a dead and imperfectly subfossilized state, near Hermigua, on the western side of Gomera, are clearly allied, in their suddenly and angularly scooped-out umbilicus, general contour, and the exact number of their volutions, to the $H$. discobolus, of that same island, as well as (and perhaps more conspicuously so) to the H. afficta of Palma; nevertheless it is quite impossible to affiliate them with either, - their very much smaller stature and narrower umbilicus, particularly (in both of these respects) as compared with the $H$. discobolus, being quite sufficient, even of themselves, to warrant their separation. But, in addition to these two discrepancies, their shell is much thinner and more fragile than in either of those species, and their surface is very much more densely and minutely striated. Whether the $H$. gomero, however, is an undoubted member of the present fauna I can scarcely decide; but since some of the examples (although bleached) are comparatively fresh and of a pale corneous hue, I am inclined to think that it can hardly be said to have passed wholly away. Others, nevertheless, seem to be as completely 'subfossilized' as, at any rate, many of the Helices which are usually defined as having been found in that condition.

\section{Helix discobolus.}

Helix afficta, d'Orb. [nec Fer., 1821], in W. et. B. Hist. 66. t. 3. f. 24-26 (1839)

" discobolus, Shuttl., Bern. Mitth. 290 (1852)

" $\quad$ Pfeiff., Mon. Hel. iii. 643 (1853)

" $\quad$ Mouss., Faun. Mal. des Can. 66 (1872)

" $\quad$ Pfeiff., Mon. Hel. vii. 296 (1876)

Habitat Gomeram ; in collibus aridis saxosis apricis juxta San Sebastian, vulgaris.

This is the largest of the Canarian members of the present 
section (measuring about $7 \frac{1}{2}$ lines across its broadest part), and one which was found abundantly by Mr. Lowe and myself in Gomera,--namely on the dry rocky slopes immediately above, and around, San Sebastian, particularly on the northern side of the ravine; and it appears to have-been met with in the same island by Fritsch.

The $H$. discobolus is very closely related to the $H$. afficta of Palma ; but apart from its larger size, it may be recognized from that species by its umbilicus being wider and more spirally visible, and by its volutions being seven in number instead of only six. ${ }^{1}$

\section{(§ Caracollina, Beck.)}

\section{Helix lenticula.}

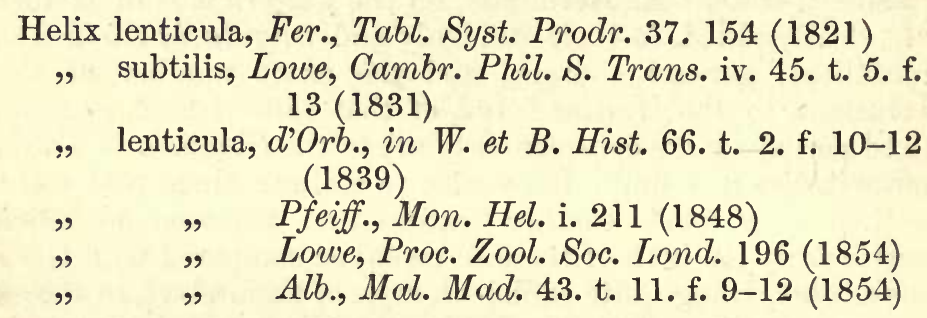

1 I may just notice, in this particular place, the $H$. marcida of Shuttleworth, (Bern. Mitth. 291; 1852), a single imperfect example of which, in the Museum at Marseilles, is supposed to have come, in all probability, from the Canaries. Species thus miserably represented (the $H$. marcida being both immature and unique), and resting upon evidence so completely untrustworthy, ought never to be admitted at all into the fauna of any country in which accuracy of habitat is absolutely essential ; and I at least will not consent to have anything whatever to do with it. Mousson, after including it in his Canarian monograph, adds: 'La description de cette espèce, qui n'est guère connue des malacologues, repose sur un seul individu incomplet, et dont l'origine précise est inconnue. Le test strio-granuleux, garni de petits poils velus, et la forme générale multispire, perforée, mais non carénée, la range suivant l'auteur dans le voisinage de l'H. hispidula, Lam.; mais elle en diffère par ses dimensions toutes différentes, par la ténuité de son test, et son duvet plus court et dense.' It is of course by no means impossible that future observations may prove the $H$. marcida to be Canarian; but, meanwhile, the evidence for its habitat is altogether so loose and insufficient that no truthful monographer could well do otherwise than decline to receive it into his topographical catalogue.

And I may also include, along with the $H$. marcida, a second Helix, which comes under precisely the same category,-the H. Niclolontha of Shuttle worth. Like the other it is unique, and exists only in the Marseilles museum, -both of them being manifestly from the collection of M. Terver, whose orchil-infesting species, the habitats of which were so incautiously assumed, have added a terrible amount of confusion, not only to the Canarian but also to the Madeiran fauna. Considering how utterly mistaken he was in the case of the $H$. tiarella and taniata,-pronouncing them to be Canarian while they are simply confined to Madeira proper, I must be excused if the evidence for the $H$. Melolontha should appear to me to be quite as unsatisfactory as that for those two species and for the $H$. marcida. 


\section{Helix lenticula, Paiva, Mon. Moll. Mad.96 (1867) Dohrn, Mal. Blätt. 3 (I869) \\ " " Dohrn, Mal. Blatt. $3(1869)$ \\ " $\quad$ " Mouss., Faun. Mal. des Can. 66 (1872)}

Habitat ins. omnes (i.e. septem) Canarienses; in aridis apricis longe lateque diffusa. Etiam semifossilis in Canariâ Grandi, sc. in arenis ad El Chareo ultra Maspalomas, reperitur; necnon cl. Mousson. 'var. virilis,' a Fuerteventura receptam et forsan (vix certe) in statu semifossili repertam, descripsit.

This common Mediterranean Helix (which occurs also in the Azores, Madeiras, and Cape Verdes) is widely diffused over the Canarian archipelago,-from the whole seven islands of which I have myself obtained it. My Lanzarotan examples are principally from Chache, and the Risco (overlooking the Salinas) in the extreme north of the island; the Fuerteventuran ones from the Rio Palmas, and the Monte Atalaya; the Grand Canarian ones from El Monte, El Charco (in the extreme south), Aldea de S. Nicolas, the Pinal of Tarajana (above S. -Bartolome), and between Maspalomas and Juan Grande; the Teneriffan ones from Orotava (where it was met with also by Mr. Watson); and the Palman ones from the Barranco de Herradura, the Barranco de Agua, the Barranco de Nogales, and the calcareous region below Argual of the Banda.

In the Madeiran Group the H. lenticula has much the appearance of having been originally naturalised,--occurring as it does, almost exclusively, within the cultivated districts; but at the Canaries it has a wider and more natural range; added to which, in the sandy wastes at El Charco (beyond Maspalomas) in the south of Grand Canary I met with it in even a subfossil condition; and some of the specimens which were obtained by Mr. Watson on the hills above Las Palmas, in the same island, appear also to be subfossilized. Mousson likewise reports a very solid form of the shell, from Fuerteventura, his ' var. virilis, which he seems to think may possibly belong to a fauna which has passed away,- though the fact that he has not cited it in his ultimate list as subfossil would at any rate seem to imply that he entertained some degree of doubt on the subject. His 'var. virilis,' which was obtained in Fuerteventura by Fritsch, he describes as thicker and more solid than the ordinary type,adding: 'Cette forme, assez particulière, s'est trouvée en quelques individus morts, qui, nonobstant une certaine fraîcheur, ne paraissent pas appartenir à l'époque actuelle, que caractérise, dans la même île, le type actuel. Elle s'en distingue par la solidité du test, la plus forte costulation, se prolongeant à la base, par la carène un peu crénelée, par le péristome remarquablement épaissi, par l'insertion supérieure qui avance et qui s'épaissit presque en un tubercle.' 
(§ Turricula, Beck.)

Helix inops.

Helix inops, Mouss., Faun. Mal. des Can. 48. pl. 3. f. 1-3 (1872)

Pfeiff., Mon. Hel. vii. 102 (1876)

Habitat Canariam Grandem; a cl. Fritsch (sec. Mousson) semel lecta.

I have had no opportunity of inspecting a type of this species, which was described by Mousson from a single example taken by Fritsch in Grand Canary; and I can merely refer, therefore, to Mousson's observations which accompany his diagnosis. 'Je n'ai vu qu'un individu,' says he, 'de cette espèce, qui se distingue des autres espèces Canariennes de ce groupe par sa simplicité. La surface n'a d'autre sculpture que de fines stries subcostulées sans nodulations quelconques; à la base elles sont encore moins marquées et irrégulières. Les tours du cône régulier, peu élevé, sont un peu convexes, surtout le long de la suture ; la carène, qui est peu aigûe, ne présente pas de crénelures prononcées, mais seulement des stries un peu plus accentuées. La coloration est simplement blanche, sans zônes ni taches, a l'exception du nucléolus, qui comme d'ordinaire se présente comme un grain hyalin et corné.' (l. c. 48.)

\section{Helix cyclodon.}

Helix cylodon, $W$. et $B$., in litt.

d'Orb, in W. et B. Hist. 64. t. 2. f. 1-3
$(1839)$

Habitat 'Canaries' (sec. W. et B.); mihi non obvia.

Although obtained by Webb through M. Terver, whose orchilinfesting Helices have proved so untrustworthy as regards habitat, and which have introduced so much confusion into the several faunas of the Atlantic archipelagos, I nevertheless cannot altogether reject (as Mousson has practically done, even whilst allowing the species to increase the number of the catalogue) the Canarian claims of the $H$. cyclodon-which, being quite on the Despreauxii and moderata type, seems to me to have a fair chance of having been received from one or the other of the seven islands of this widely scattered Group; though to be expected to believe that it occurs, as M. Terver had the effrontery to assert (and that too without the slightest shadow of evidence), in the Canaries, Cape Verdes, Madeiras, and Azores is simply preposterous. Mousson however was 
decidedly mistaken in concluding that it is identical with the H. pumilio, Chemn. (though it is quite possible that the example in the collection of Mr. Cuming which was examined by Pfeiffer may have been referable to that species), which is found in the sandy district around Mogador on the opposite coast of Morocco; for the $H$. pumilio differs in many important particulars from the H.cyclodon,-its spire being very much more elongated, conical, and acute, with the nodules and inequalities of its entire surface (including the medial keel) much more prominently developed, and with only a very faint appearance of a darker zone beneath; added to which, it is thinner in substance, and less white and porcelain-like, and the interior of its aperture is not darkened as in these immediately allied forms.

Two original examples of the $H$. cyclodon which are in the d'Orbignyan collection at the British Museum, have the spire a good deal elevated but nevertheless obtusely conical, or somewhat dome-shaped; the whorls are rather plane (their upper, or medial, keel being obsolete), but coarsely nodose just above the suture,-where they appear consequently to have a circle of blunt teeth, or nodules, rather downwardly (more than outwardly) directed, though scarcely overlapping the suture. Its volutions are about $6 \frac{1}{2}$ in number; in substance it is solid; and its surface, which is of a dingy or cinerous white, has a darker band (not very conspicuous) at a short distance from the keel on the underside of the shell.

\section{Helix Despreauxii.}

Helix Despreauxii, d'Orb., in W. et B. Hist. 65. t. 3. f. 21$23(1839)$

$\begin{array}{lll}" & & \text { Pfeiff., Mon. Hel. i. } 179(1848) \\ " & " & \text { Mouss., Faun. Mal. des Can. 49 (1872) } \\ " & \text { Pfeiff., Mon. Hel. vii. 250 (1876) }\end{array}$

Habitat Canariam Grandem ; in regione ' $\mathrm{El} \mathrm{Charco'} \mathrm{dictâ,}$ ultra Maspalomas, sub lapidibus in aridis apricis congregans. Necnon etiam semifossilis, et in statu normali et sub. 'var. $\beta$. immodica,' invenitur.

The $H$. Despreauxii, which is one of the most beautiful of the Canarian Land-shells, was taken abundantly by Mr. Lowe and myself in the extreme south of Grand Canary,--namely in the arid district of $\mathrm{El} \mathrm{Charco,} \mathrm{beyond} \mathrm{the} \mathrm{sandy} \mathrm{wastes} \mathrm{of}$ Maspalomas; and we also met with it in what I believe to be a truly subfossil condition, along with the $H$. pulverulenta and lenticula, in the same spot. Mousson describes a subfossil state of the species, obtained by Fritsch in Grand Canary, 
under the name 'var. immodica', as follows :- 'Crassior, spira magis elevata, rugis et nodulis minus numerosis sed fortioribus, apertura parvula, peristomate obtuso incrassato integro subsoluto;' but it does not seem to apply to the subfossilized specimens which we met with at El Charco, and which do not differ appreciably from their recent homologues. However an example is now before me, which was found (subfossilized) by Mr. Watson, I believe near Las Palmas, and which answers in every respect with the diagnosis of Mousson's variety.

In outline the H. Despreauxii is conical and trochiform; its colour is a dusky cinerous- or plumbeous-white, but a rich castaneous-brown inside the aperture; its perforation is small and punctiform; and its surface is much roughened with large irregular scabrous tubercles and vermiform flexuose callosities, which are more particularly coarse and conspicuous on the under side. Its main feature however consists in its elegantly, equally, and very deeply $d \in$ ntate keel, which is not only traceable up the spire but is supplemented by a second keel, of a similar kind but a little less prominent, in the middle of each whorl. The shell is solid in substance, and has the nucleus brown and corneous; and its aperture is much angulated externally, with the margins of the peristome a good deal approximated.

\section{Helix moderata.}

Helix Despreauxii, var. moderata, Mouss., Schw. Denksch. $\mathrm{xv} .135$ (1857)

" moderata, Id., Faun. Mal. des Can. 50. pl. 3. f. 4-6 (1872)

" $\quad$ Pfeiff., Mon. Hel. vii. 250 (1876)

Habitat Lanzarotam, et Fuerteventuram; a DD. Hartung et Fritsch lecta.

I possess four examples of this Helix which were taken in Fuerteventura by M. Hartung, and which were given by him to Mr. Lowe in 1855 ; and although I have little doubt that the H. moderata is in reality but an insular phasis (peculiar to Lanzarote and Fuerteventura) of the Grand-Canarian H. Despreauxii, nevertheless since the two forms are not likely ever to be absolutely connected, and the one now under consideration has been described by Mousson as specifically distinct, I will not actually unite them. Judging from the types before me, the $H$. moderata may be said to be a trifle larger, paler, and more depressed than the Despreauxii (the spire being less elevated), and to have both its tubercles and callosities less exaggerated or prominent,-indeed the upper, or medial, keel of the volutions is so far reduced in coarseness as sometimes to be 
comparatively indistinct. Its umbilicus, too, is relatively a little larger, or more open, and its aperture is not quite so rounded. 'Elle est,' says Mousson, 'plus déprimée que la Despreauxii, souvent presque plate en haut; l'ombilic plus étroit dans les individus coniques, s'ouvre dans les déprimés jusqu'à $\frac{1}{5} \mathrm{du}$ diamètre; les aspérités sont plus fines et moins dominantes; dans l'espace qui longe la suture et dans la partie de la base qui suit la carène, on observe de simples stries costulées, qui continuent sur les tubercles.(ce qui n'est pas le cas dans la Despreauxii); la carène secondaire est en retrait sur la dorsale et ne sort pas du cône spiral; souvent elle se réduit à une ligne de petites nodulations, qui quelquefois disparaissent entiérement,' l'ouverture est moins ronde, son bord est interrompu sur un certain espace et non entier. En un mot, cette forme, qui habite les deux îles de l'Est qui sous tous les rapports se lient intimement, est une Despreauxii, dans laquelle tous les caractères ont perdu le leur acuité et se sont rapprochés des H. miranda, Lowe, et granostriata, Mousson.'

\section{Helix mirandæ.}

Helix Mirandæ, Lowe, Ann. Nat. Hist. vii. 107 (1961)

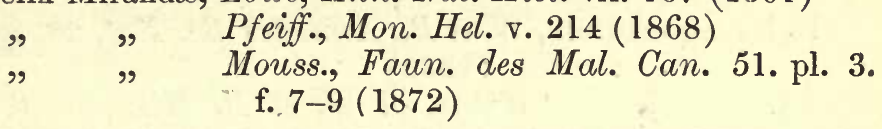

Habitat Gomeram et Hierro; in illâ in collibus aridis apricis prope San Sebastian sub lapidibus sat copiose reperta, sed in hâc inter portum et Valverde multo rarior.

This perhaps is rather the smallest member of the Turricula group which has hitherto been detected at the Canaries, the larger examples measuring only about $3 \frac{1}{2}$ lines across their broadest part; and it is also the most brightly coloured,-its surface being of a dusky white with a more or less interrupted darker band both above and below, and with the spire additionally mottled with very irregular transverse patches and lines. Although somewhat trochiform in outline, the shell is nevertheless less conical and elevated than that of the $H$. Despreauxii, its perforation is relatively larger, and its aperture (which is less angulated externally, and is somewhat darkened within) has the margins of the peristome (which is itself whitish) more distant and interrupted. Its under portion (instead of being roughened with coarse scabrous elongated tubercles and tortuous callosities) is simply striated with fine radiating costate lines; while the upper region has the latter very oblique and flexuose, but supplemented by short additional obtuse transverse ridges, or elongate tuberculiform prominences, 
which are elevated in the centre of each whorl into an obscure medial unequally crenulated keel, and into a rather more pronounced one in the usual place,-i.e. along the dorsal line of the basal volution.

The $H$. mirandae (the specific title of which was selected in commemoration of Mr. Gray's yacht 'the Miranda', in which we visited the several islands of the Canarian archipelago) was taken abundantly by Mr. Lowe and myself in Gomera,-namely on the dry and rocky slopes above and around San Sebastian, particularly those on the northern side of the ravine; and we subsequently met with a few examples of it in Hierro,-on the ascent from the landing-place to Valverde.

The $H$. nodosostriata, of Mousson, founded upon a single example, appears to be merely a larger and rather more depressed form of the $H$. mirandx, in which the prominences are more developed, and the base somewhat more coarsely and irregularly sculptured. We met with it in company with the typical form, into which it appears gradually to merge.

\section{(§ Discula, Lowe.)}

\section{Helix argonautula.}

Helix argonautula, W. et B., Ann. des Sc. Nat. 28. syn. 21 (1833)

\begin{tabular}{|c|c|c|}
\hline " & " & $\begin{array}{l}\text { d'Orb., in W. et B. Hist. 64. t. 2. f. } \\
\text { 16-18 [nec f. 13-15] (1839) }\end{array}$ \\
\hline פ" & " & Mouss., Faun. Mal des Can. 55 (1872) \\
\hline & " & $\begin{array}{l}\text { Pfeiff., Mon. Hel. vii. } 212 \text { et } 551 \\
\text { (1876) }\end{array}$ \\
\hline
\end{tabular}
lecta.

Habitat Canariam Grandem; sub lapidibus ad Arguineguin

The present Helix would appear to be one of those which was detected originally by M. Terver, of Lyons, amongst dried orchil ; and although the latter was of doubtful origin, the $H$. argonautula was nevertheless admitted by Webb, without further enquiry, into the Canarian fauna. However rash such a proceeding may have been (for the same amount of looseness, as regards the evidence for the exact localities, resulted in the introduction into his list of species which are essentially Madeiran, and others which are equally peculiar to the Cape Verdes), it at least in this particular-instance had the advantage of placing no geographical error upon record, for the Helix in question happens fortunately to be a Canarian one. Still, nothing could of course be said about the island in which it was found, for it was only (as it were) by mere accident that even the archipelago itself was correctly guessed at; and therefore it 
is satisfactory that the $H$. argonautula should have been met with by Mr. Lowe and myself,- - who, by finding it (in considerable abundance) at Arguineguin in the south of Grand Canary, were enabled to supply the required data concerning its precise habitat.

The $H$. argonautula (which measures about 4 lines across its broadest part, and which is composed of about $4 \frac{1}{2}$ rapidly increasing volutions), is a thin, sublenticular, and very acutely carinated shell,- the keel (which is irregularly crenulated) being strongly expressed on the upper side on account of a slight groove or erosion alongside it, and being usually traceable up the penultimate whorl as an elevated line adjoining the upper edge of the suture; its spire is greatly depressed, though with the nucleus a little prominent; its base is subconically convex, with the umbilicus rather suddenly and deeply scoopedout; its aperture (which is obsoletely elongate-quadrangular) has the upper and lower portions of the peristome acute and only obscurely connected by a thin intervening lamina ; and its surface is densely sculptured with coarse; irregular, undulating, oblique costate lines. In colour it is of a pale corneous brown (rather paler, and yellowish, beneath, particularly towards the umbilicus), obscurely marbled above with cinereous lines and a few fragmentary patches, and with a narrow band below (seldom two) at a short distance from the keel.

There is a certain primâ facie resemblance between this species and the Madeiran H. tabellata, Lowe; nevertheless tiıe latter is very much more flattened above, with the whorls narrower and more numerous, and (although quite as acutely carinated) the keel is not shaped-out (or compressed) by an adjoining erosion on the upper side, nor is it visible on the penultimate volution; its base (although inflated) is not conically-convex; its umbilicus is narrower; its aperture is less angular, with the peristome less acute and slightly recurved; and its surface is less coarsely costate-striate, but studded with large granules, as well as more broadly fasciated below.

Although supposed to be exclusively Canarian, Mousson has lately described (Jahrb. Malak. Ges. i. 81 ; 1874) what he regards as a mere phasis of this Helix from Casa Blanca in Morocco, - a fact of considerable importance geographically. But if the Grand-Canarian form of the species be truly the one which was originally enunciated by Webb and Berthelot (which perhaps, considering the unsatisfactory manner in which it was obtained - namely from amongst dried orchil,-may be open for consideration), it is quite clear that it must be accepted as the type, and that consequently the modification from the African continent (whatsoever it may be) should be treated practically 
as the 'variety'; and I cannot but think, therefore, that Mousson is hardly justified in adopting the opposite line, and regarding the Morocco shell as the normal one. Be this however as it may, his diagnosis of the latter, as compared with the Grand-Canarian one, is as follows:- 'Paulo minor, solidior, spira sæpe irregulariter scalata, alba, seriatim corneo-maculata, anfractibus supra planis, ad carinam crenulatam elevatis.' The form from Grand Canary, on the other hand, he defines, under the varietal name of ' canariensis,' thus :- 'Paulo major, spira fere plana, interdum subscalata, corneo-grisea, infra indistincte fasciata, anfractibus supra planiusculis, ad carinam non ascendentem impressis.'

\section{Helix pulverulenta.}

Helix argonautula (pars, i. e. f. 13-15) [nec f. 16-18, nec descriptionis], d'Orb., in W. et B. Hist. 64. t. 2 (1839)

" pulverulenta, Lowe, Ann. Nat. Hist. vii. 107 (1861) " $\quad$ Pfeiff., Mon. Hel. v. 191 (1868)

" $\quad$ Mouss., Faun. Mal. des Can. 52. pl. 3. f. $10-12$ (1872)

Habitat Canariam Grandem; ad El Charco, ultra Maspalomas, sub lapidibus in saxosis aridis apricis, una cum $H$. Despreauxii, d'Orb., degens, reperta. Necnon semifossilis ibidem parce inveni.

Although a little resembling it in primâ facie aspect and colouring, the present Helix is nevertheless exceedingly distinct from the $H$. argonautula; though it would appear to have been confounded with it both by Webb and by d'Orbigny, inasmuch as three out of their six figures of the latter clearly pertain, in reality, to this species, - the other three, along with the description, applying to the true $H$. argonautula. And, so far as mere locality is concerned, it is not at all surprising that they should have been in possession of both forms (even whilst failing to observe their actual distinctions); for they were obtained by Mr. Lowe and myself in almost adjoining districts in the south of Grand Canary, and it is far from unnatural therefore that the same consignment of orchil in which the $H$. argonautula was found would contain likewise the H. pulverulenta. Still it is inexplicable to me that, even if Webb should have omitted to recognise in them more than the exponents of a single species, their diagnostic characters should have been subsequently overlooked by d'Orbignv,--for. when 
viewed carefully together, it seems well-nigh impossible to mistake them.

The $H$. pulverulenta is a good deal smaller than the argonautula (measuring only 3 lines across its widest part), and it is very much less sharply carinated,-the keel, moreover, which is comparatively simple (or nearly uncrenulated), being less broadly compressed (or flattened-out) on the upper side; both its spire and volutions are rather more convex; its suture is more sunken or impressed, without any appearance of a threadlike keel at its upper edge ; its ultimate whorl is narrower ; its costate lines are considerably finer and less undulated; its basal region, although inflated, is less conically convex ; its umbilicus is smaller; its aperture is much less angular, with the margins of the peristome more completely disconnected by an intervening lamina; and the fascia of its underside is usually brighter and more developed.

It was in the dry and stony district of $\mathrm{El} \mathrm{Charco,} \mathrm{beyond}$ the sandy wastes of Maspalomas, in the extreme south of Grand Canary, that the $H$. pulverulenta was met with by Mr. Lowe and myself; and as that region is at no great distance from Arguineguin, the locality in which we found the $H$. argonautula, it is extremely probable that the gradually acquired areas of the two species approach each other very closely, even if they do not indeed absolutely overlap. We also obtained the $\dot{H}$. pulverulenta in what I cannot but think is a truly subfossilized state, in the immediate vicinity of its present habitat.

\section{Helix granostriata.}

Helix granostriata, Mouss., Schw. Denksch. xv. 135 (1857)

$\begin{array}{ll}" & \text { Id., Faun. Mal. des Can. pl. 3. f. 13-15 } \\ & (1872) \\ & \text { Pfeiff., Mon. Hel. vii. } 245(1876)\end{array}$

Habitat Lanzarotam, et Fuerteventuram; in illâ recens, sed in hâc nunc recens nunc semifossilis reperitur.

Three examples of this species are now before me which were given to Mr. Lowe in 1855 by M. Hartung, by whom they had been taken in Fuerteventura; and were it not for the comparative largeness of their umbilicus, I should perhaps have been more inclined to refer the $H$. granostriata to the Turricula group than to Discula. As it is, however, I think that its affinities are more with the argonautula and pulverulenta than they are with the forms around the Despreauxii and mirandoe.

The present Helix is perhaps a trifle larger, on the average, than the $H$. argonautula (measuring about 4 lines acrossits widest 
part) ; its spire, although obtuse, is more conical, or much less depressed; and its umbilicus is not quite so open. Its ultimate whorl, too, is not quite so acute or so broadly edged with a compressed keel, though the latter is perhaps more distinctly traceable (immediately above the suture) up the spire; its colour (above) is of a paler yellowish-horn, or buff, the volutions being more or less variegated by a narrow, tessellated fascia above the suture, on the actual keel, and sometimes by a second, and more indistinct, medial one; its aperture is a good deal thickened, or labiate, internally; and (which is the salient feature) its transverse ridges of growth are uniformly broken-up by (nevertheless somewhat obscure) spiral lines into granuliform, or tuberculiform, fragments,-giving the entire surface a very beautifully sculptured appearance.

The H. granostriata (which was not obtained by either $\mathrm{Mr}$. Lowe or myself) was found both by Hartung and Fritsch, and by both of them in Lanzarote as well as in Fuerteventura. In the latter island it seems to have been met with subfossilized likewise. 'Elle se trouve,' says Mousson, 'à Fuerteventura ègalement à l'état subfossile en dimensions plus faibles, à test plus solide et à surface dépourvue des details de la sculpture, qui là où l'on en découvre les traces, sont bien les mêmes.'

\section{Helix morata.}

Heliz morata, Mouss., Faun. Mal. des Can. 54 (1872) $" \quad$ "Pfeiff., Mon. Hel. vii. 246 (1876)

Habitat Fuerteventuram, semifossilis; a cl. Fritsch detecta.

This Helix (which is unknown to me except through the published diagnosis) appears to be closely allied to the granostriata, but smaller. It was found by Fritsch, in a subfossil state, in Fuerteventura, and was described by Mousson from a single example. 'Cette espèce,' says Mousson, ' provient de la même île que la granostriata, mais paraît en différer. La morata est plus petite, moins anguleuse, plus étroitement ombiliquée; la péristome n'est pas évasé, quoique fortement labié, les bords sont bien séparés à leur insertion; enfin, au lieu de granules allongées, il y a un tapis da granules plus fines serrées et rondes, qui détermine un double système de sillons transversaux et spiraux. Cette jolie espèce dont je n'ai vu qu'un seul échantillon, dénué de cuticule, appartient peutêtre également à une faune diluvienne éteinte.'

\section{Helix multipunctata.}

Helix multipunctata, Mouss., Faun. Mal. des Can. 54. pl. 3. f. $16-18(1872)$ 
Habitat Fuerteventuram, semifossilis; a cl. Fritsch lecta.

A sinall species, found likewise by Fritsch in Fuerteventura, and only in a subfossil condition. Indeed, as in the case of the $H$. morata, Mousson appears to have had but a single example to describe from. The following are his remarks concerning it: 'Cette petite espèce, qui se lie à la morata, appartient encore à une faune passée. Elle est plus petite, plus applatie, et se distingue de ses voisines par la déviation considérable du dernier tour, ce qui dégage l'ombilic sur $\frac{1}{3}$ de son pourtour. La surface est très finement réticulée, par des stries costulées serrées et des lignes spirales plus distantes, ce qui produit une fine granulation ponctiforme un peu allongée. Des taches blanches opaques alternent avec d'autres un peu cornées et diaphanes, et produisent sur la carène et le long de la suture un faible ondulation, ce que provient d'une plus facile destructibilité des parties cornées à côté des opaques. Le seul individu de cette espèce est à l'état subfossile et altéré.'

\section{(§ Lemniscia, Lowe.)}

\section{Helix tumulorum.}

Helix tumulorum, W. et B., Ann. des Sc. Nat. 28. syn. 315 (1833)

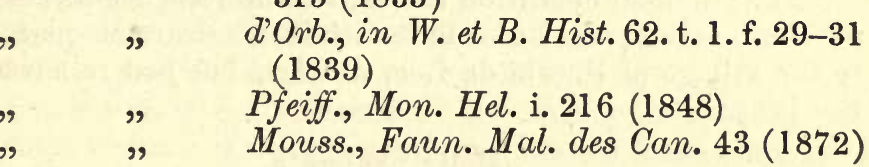

Habitat Canariam Grandem; in promontorio boreali 'Isleta ' dicto, præcipue inter tumulos Indigenarum, et recens et semifossilis, occurrens. Necnon semifossilis in calcariis juxta Puerto da Luz, Isletæ adjacentibus, parce legi.

This is the largest member of the Lemniscia section in the Canarian Group, and one which has been found hitherto only on the 'Isleta,'-the island-like promontory in the extreme north of Grand Canary, stretching out beyond the village of Puerto da Luz (which is itself a little to the north of Las Palmas). In that particular locality it was found originally by Webb (as it subsequently has been by Lowe, Fritsch, Watson, and others), principally amongst the tombs of the ancient inhabitants of the archipelago, the Guanches,-a fact which evidently suggested its specific name.

The $H$. tumulorum (the largest adult examples of which measure about 5 or 6 lines across the widest part) is, like most of its allies, a thin and rather broadly-or shortly-conical shell, strongly sculptured with the dense oblique transverse lines of growth, with its perforation extremely minute and almost con- 
cealed, and with its keel (which is more powerfully expressed from the fact of there being a slight compression, or concavity, on either side of it) very sharply defined. Its ground colour is either white or brownish-white; and it is ornamented with two more or less conspicuous darker fasciæ,-one of which is placed beneath, and becomes lost within the (acute, unthickened) aperture, whilst the other is above the keel, and is broad and much mottled or interrupted,-occupying the volutions of the spire to nearly its apex. The whorls themselves are, on the whole, flat; nevertheless the keel is distinctly traceable alongside the suture up about two-thirds of the spire, - which causes them to be a little angular, or prominent, posteriorly.

The nearest Canarian ally of the present species to the Teriffan $H$. phalerata, W. et B. ; but I think nevertheless that the two cannot be treated as insular modifications of each other, - the tumulorum being very much larger and more obtusely conical, as well as more strongly striated; and its keel is sharper and (as just mentioned) laterally compressed, and traceable up the spire. The fascia, too, on the upper portion of the shell is wider, it being generally suffused over the greater part of the surface-so as to give the latter a brightly speckled, or mottled, appearance.

In a subfossil condition the $H$. tumulorum occurs near to its present, habitat; and I also met with it in calcareous places close to the village of Puerta da Luz, which is but just removed from the Isleta. ${ }^{1}$

\section{Helix phalerata.}

Helix Rosetti W. et B., [nec Mich.], Ann. des Sc. Nat. 28. syn. 317 (1833)

, phalerata, Id., l. c. Append. 325 (1833)

" Rosetti, d'Orb., in W. et B. Hist. 62. t. 1. f. 32-34 (1839)

" phalerata, Pfeiff., Mon. Hel. i. 158 (1848)

" nivariensis, Shuttl., Bern. Mitth. 141 (1852)

" ", Pfeiff., Mon. Hel. iii. 167 (1853)

" phalerata, Lowe, Ann. Nat. Hist. vii. 106 (186i)

" " Mouss., Faun. Mal. des Can. 41 (1872)

Habitat Teneriffam ; circa urbem Sanctæ Crucis sublapidibus vulgaris.

It appears, according to d'Orbigny (who examined the types),

1 In the Madeiran archipelago the nearest ally of the H.tumulomum is probably the $H$. tectiformis, Sow., from Porto Santo; nevertheless the much greater bulk of that species, added to its large and open umbilicus, its overhanging, roof-like keel, and its coarsely granulated surface, will, apart from coloration, at once separate it from all the members of the section Lemniscia. 
that the $H$. Rosetti and phalerata, of Webb and Berthelot, are one and the same species; though I think it is more probable that the former, which they expressly ascribe to Grand Canary, was founded on a small state of the nearly-allied H.tumulorum, which seems to be peculiar to that island. At any rate, whatever they intended to indicate by their ' $H$. Rosetti, it is not the H. Rozeti (mis-spelt by them 'Rosetti') of Michaud, as they would imply,- that species being an Algerian one, and distinct.

Unless I am much mistaken, the $H$. phalerata is strictly confined to Teneriffe; and I think it safer therefore to omit Palma as a habitat, even though recorded by Mousson,-feeling it exceedingly likely that Fritsch's example (or examples) was but the closely resembling $H$. persimilis (so common in that island) under perhaps a rather larger and more fasciated guise. In Teneriffe, however, the phalerata proper was found abundantly by Mr. Lowe and myself, around Sta. Cruz (particularly towards El Campo and in the Barranco del Passo Alto); and it had previously been met with in the same district by Webb and Berthelot, d'Orbigny, Blauner, Grasset, and Reiss.

As lately mentioned, the $H$. phalerata is intimately connected with the Grand Canarian $H$. tumulorum; nevertheless it is too distinct from it in many of its details, to be treated, I think, as a local, or insular, modification of that species. Of course it is possible that, in reality, this may be the case; nevertheless where the differential characters of two forms are sufficiently and readily conspicuous, and intermediate connective links are wanting, I cannot see what right we have to act on a mere hypothesis and to reject what have been already published, and recognized, as species.

The H. phalerata is a very much smaller shell than the tumulorum, with its upper, or spiral, band narrower and less mottled or suffused, its sculpture is not quite so coarse, and its keel is not only less prominent or acute but also free from the slight scooping-out on either side which causes it to be so pronounced in that species. Its spire too is more conical, or pointed; and the volutions are flatter, the keel not being traceable so far up towards the apex.

\section{Helix persimilis.}

Helix persimilis, Shuttl., Bern. Mitth. 141 (1852)

$\begin{array}{lll}" & \quad & \text { Pfeiff., Mon. Hel. iii. } 129(1853) \\ " & \text { Mouss., Schw. Denksch. xv. 134 (1857) } \\ " \quad \text { præposita, Id., l. c. } 45 \text { (1872) }\end{array}$


Habitat Fuertèventuram, Canariam Grandem, Teneriffam, Gomeram, Palmam, et Hierro (in Lanzerotâ solâ adhuc haud observata); late diffusa.

The $H$. persimilis, Shuttl., which is probably universal throughout the Canarian archipelago (Lanzarote being the only island, out of the seven, in which it does not happen hitherto to have been observed), is closely allied to the H. phalerata,from which it seems mainly to differ in its smaller size, still thinner substance, less strongly developed keel, and browner or more suffused surface. It varies somewhat, however, not only in size and the greater or less elevation of its spire, but likewise in hue,-occasional examples (as, for instance, a few which are now before me from Hierro) being almost as brightly coloured as the phalerata, or as the more variegated individuals of the monilifera; and I must confess that I am quite unable to detect any character to warrant the suspicion that Mousson's $H$. proeposita, which was established on a single example taken by myself (in the Pinal of Tarajana) on the mountains of Grand Canary, is anything more than a rather enlarged $H$. persimilis, - by no means so much above the normal stature of the species as is the more discoidal race from the maritime districts of the same island which I have defined as a 'var. $a$. umbilicata.'

I have taken this variable shell, under its more typical phasis, in Grand Canary, Teneriffe, Gomera, Palma, and Hierro,my Teneriffan examples being principally from around Sta. Cruz and Orotava, and towards Taganana, and the Palman ones from the district below Argual of the Banda; and it appears to have been met with by Fritsch in Fuerteventura, Grand Canary, Teneriffe, and Gomera, and by Blauner in Teneriffe and Palma.

The only aberrant aspect of the $H$. persimilis which seems to be sufficiently constant to be worth placing upon record is one which I would register as the ' $a$. umbilicata' and which was obtained by Mr. Lowe and myself, on the dry submaritime slopes both in the west and the south-east of Grand Canary, - namely on an exposed hillside (facing the sea) between Aldea de San Nicolas and Lagaete, and in a somewhat similar situation between Maspalomas and Juan Grande. This particular form is a trifle larger, less fragile, and more depressed than the ordinary type, as well as more sharply keeled, and more conspicuously ornamented with two less-interrupted darker bands, - of which the upper one is broader and has the appearance (from its being nearly continuous and unbroken) of almost adjoining the keel. The umbilicus too is appreciably larger, it being more than a mere 'perforation.' In spite of this latter 
character, however, I have not the least reason to think that the 'a. umbilicata' is anything more than a rather highly developed submaritime state of the persimilis, - the species being essentially an inconstant one ; though I may just add, that, like Mousson, I should probably have identified it with Shuttleworth's $H$. coementitia, was not the latter (which is a shell without any positively defined habitat) expressly said to have its aperture calloso-labiate within, and the upper and lower portions joined àcross the body volution by a white corneous lamina. These two characters are of themselves so important that I think it well-nigh impossible to treat this form of the persimilis which we are now discussing as representing the (very much larger) $H$. coementitia of Shuttleworth,-the precise country of which is practically unknown.

\section{Helix oleacea.}

Helix oleacea, Shuttl., Bern. Mitth. 142 (1852)

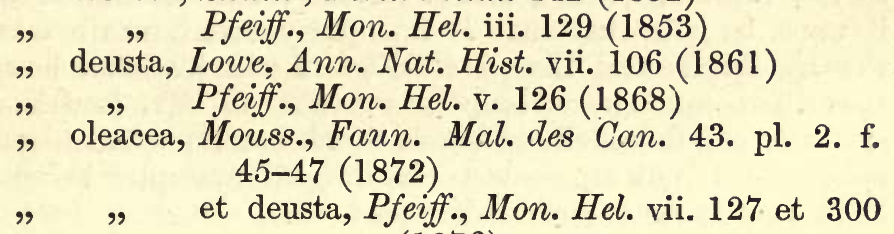
(1876)

Habitat Palmam; in intermediis editioribusque sylvaticis humidis, rarius.

If the many examples which I obtained in the intermediate and lofty sylvan districts of Palma are truly referable to the $H$. oleacea, Shuttl. (and I have every reason to believe that they are) the present species may be said to be a little larger and more lenticular (or Patula-shaped) than the persimilis, the keel being appreciably less developed, and the spire (which is composed of at least half a volution less) more obtuse; and it is also still thinner, or more fragile, rather less strongly striiated, and of a more uniform pale yellowish-brown, - there being few indications (indeed scarcely any at all) of fasciæ and spots. Its peristome, although thin and acute, has a little more tendency to be subrecurved, at any rate towards the umbilicus (which is, consequently, rather more concealed from view); and its surface is nearly free from gloss. It is a species which has been observed hitherto only in Palma,-where it was found by Blauner, and subsequently by Mr. Lowe and myself. Amongst the various localities in which we met with it, I may cite the Barranco de Agua, the Barranco de Galga, El Monte, Barlovento, and the Cumbre above Buenavista. 
After a careful examination of the $H$. deusta, Lowe, which was detected by myself at a high altitude in the same island (namely amongst wet sticks and leaves at the edge of a small trickling stream which issues from some rocks in the Great Pinal, close to, but outside, the Caldeira), I have come to the conclusion that it will be better treated as a dwarfed and more distinctly fasciated state of the oleacea than as a variety of the persimilis. Most of its characters, such as they are, accord better with those of the former than of the latter,-such, for instance, as its apically obtuse, sublenticular contour, its less keeled basal whorl, its somewhat finer sculpture, and its browner or less maculated (though by no means unfasciated) surface. Indeed there is very little except its smaller size, and more banded and perhaps just appreciably less broadly developed volutions, and its somewhat less covered umbilicus, which would seem to separate it from the (equally fragile) $H$. oleacea; and I think therefore that it will he sufficient to place it on record as the 'var. a. deusta, Lowe.' Nevertheless in some respects it must be admitted that it is slightly intermediate between the $H$. oleacea and the persimilis. I will just add, however, that there must have been a mistake in Mr. Lowe's measurement of the shell, which is much smaller than his diagnosis would indicate,-even the largest examples being only 3 lines across, in their broadest part.

\section{Helix Woodwardia.}

Helix Woodwardia, Tarnier, in litt.

$\begin{array}{ll}" \quad & \text { Mouss., Faun. Mal. des Can. 45. pl. } 2 . \\ & \text { f. } 48-50(1872) \\ & \text { Pfeiff., Mon. Hel. vii. } 102(1876)\end{array}$
rarior.

Habitat Teneriffam; in humidis sylvaticis editioribus,

This rare and exceedingly fragile little Helix has been observed hitherto only in the sylvan districts of Teneriffe,-where it was met with by Grasset, Fritsch, and Reiss, and subsequently (particularly in the forest region above Taganana) by Mr. Lowe and myself.

The $H$. Woodwardia (which is a good deal allied to the Palman H. oleacea, Shuttl.) is even thinner and more fragile than its immediate allies; and it further differs from them in its relatively larger and more open umbilicus, and its total freedom from spots and bands, - its entire surface being of a pale, uniform, yellowish- (or whitish-) corneous hue, though some of the coarse and densely-packed striæ with which it is uniformly covered will be seen (when closely inspected) to be a 
little more pallid than the rest. Its keel is sharply defined, and is traceable for a short distance up the spire, its suture is strongly marked, its nucleus is rather more prominent than in the H. oleacea; and it is altogether dull and opake.

\section{Helix Watsoniana. n. sp.}

T. anguste umbilicata, rotundato-lenticularis, tenuiuscula, calva, subopaca, rufo-brunnea, ubique dense et argute costulatostriata striis plus minus obscure pallidioribus, plagas valde irregulares obsoletas hinc inde efficientibus; spirâ depressiusculâ, anfractibus 5 convexiusculis, lente crescentibus, ultimo vix descendente et vix angulato Subtus obscure subfasciato-marmorata. Peristomate acuto, labris omnino disjunctis, columellari ad insertionem reflexo, umbilicum parvum subito excavatum paululum tegente.-Diam. maj. lin. 2 ; alt. $1 \frac{1}{3}$.

Habitat Canariam Grandem, et Teneriffam. Pauca specimina communicavit Revdus. R. B. Watson, cujus in honorem nomen triviale dedi.

A few examples of this inconspicuous little Helix have been communicated by Mr. Watson, as having been taken in Grand Canary and Teneriffe; and, although the affinities of the species are not very manifest, I am inclined to think that it has more in common with the H. Woodwurdia and oleacea, of the Lemniscia group, than with the Xerophilous forms around the armillata and conspurcata. Apart from its small size and rounded, sublenticular outline, the $H$. Watsoniana, which seems quite distinct from everything else recorded in the present catalogue, may be known by the fine but sharp and densely-packed costate-striæ with which it is uniformly sculptured, by its rather thin and fragile substance, and by its bald, reddish-brown surface being more or less obscurely marbled with very irregular paler dashes or streaks, - caused by the colour of the minute hairlike ribs being here and there more or less suffused or confluent. Its umbilicus is small but suddenly excavated, and is partially overhung by the acute but somewhat recurved columellary margin of the peristome.

\section{Helix cæmentitia.}

Helix cæmentitia, Shuttl., Bern. Mitth. 291 (1852)

Habitat “ Canaries' (Mus. de Marseille), sec. Shuttleworth.

I know nothing about this Helix, except that two examples of it are said to be in the Museum at Marseilles, which are labelled as having come from the 'Canaries,'-but from what 
island is altogether uncertain. Shuttleworth, who examined and described them, states that the species is near to the Teneriffan $H$. phalerata, W. et B., but that it is more depressed, and has its umbilicus more distinct and open; and thus far, therefore, I might well have followed Mousson in identifying it with the shell, from Grand Canary, which I have defined as a 'var. a. umbilicata' of the $H$. persimilis. But since it is further recorded as having a thickened rim-like callosity (as in the $H$. monilifera) immediately within the aperture, and its upper and lower lips connected by a white corneous lamina, it seems quite impossible to identify it with any phasis of the extremely variable (and very much smaller) $H$. persimilis. Like so many of the species therefore in the Marseilles collection, it must be left in doubt until its correct habitat has been ascertained.

\section{Helix umbicula.}

Helix rosetti, Pfeiff. [nec W. et B.], Mon. Hel. i. 156 (1848) [sec. Shuttl.]

" phalerata, Pfeiff. [nec W. et B.], Mon. Hel. ii. 393 (1848) [sec. Shuttl.]

" umbicula, Shuttl., Bern. Mitth. 290 (1852)

" $\quad$ Mouss., Faun. Mal. des Can. 41 (1872)

" $\quad$ "Pfeiff., Mon. Hel. vii. 230 (1876)

Habitat 'Canaries' (Mus. de Marseille, Coll. Terver), sec. Shuttleworth.

This is another of those Helices concerning the habitat of which nothing positive is known, it having been established on a single example which is said to exist in the Museum at Marseilles. That example is from Terver's collection, and was doubtless obtained, like so many of his shells, from bags of orchil,--even the exact country of which was frequently open to considerable doubt; and it is much to be regretted that species of such uncertain origin should ever have been admitted at all into a fauna which professes to be accurate and precise. Still it is far from unlikely that the $H$. umbicula may be, at any rate, truly 'Canarian,'-for it is stated by Shuttleworth to be allied to the $H$. monilifera, W. et B. Nevertheless, judging from the diagnosis, it appears to be considerably larger than the latter (its greatest diameter being 9 millimetres, instead of only 6 or 7 ), less solid in substance, and more distinctly perforated. Like it, however, the interior of its peristome is callosolabiate. ${ }^{1}$

1 Considering that I have rejected from the Canarian catalogue the $H$. marcida and melolontha, Shuttl., and the Pomatias Barthelemianum, Shuttl. (which exist only in the Marseilles Museum, and which would appear to 


\section{Helix monilifera.}

Helix monilifera, W. et B., Ann. des Sc. Nat. 38. syn. 315 (1833)

\begin{tabular}{|c|c|}
\hline & $\begin{array}{l}\text { d'Orb., in W. et B. Hist. 61. t. 1. f } \\
(1839)\end{array}$ \\
\hline & $\begin{array}{l}\text { lancerottensis, Id., [sed non fig.], ibid. } 60 \text { (1839) } \\
\text { monilifera, Pfeiff., Mon. Hel. i. } 160(1848)\end{array}$ \\
\hline & $\begin{array}{ll} & \text { Mouss., Schw. Denkschrift, xv. } 5 \text { (1857) } \\
& \text { Id., Faun. Mal. des Can. } 39 \text { (1872) }\end{array}$ \\
\hline
\end{tabular}

Habitat Lanzarotam, Fuerteventuram, Canariam Grandem, Teneriffam, Gomeram, et Palmam (in Hierro solâ adhuc haud detecta); in aridis apricis inferioribus, sub lapidibus, præsertim juxta mare.

A most distinct and well marked little Helix, and one which in all probability is quite universal throughout the Canarian archipelago, though it does not happen up to the present date to have been observed in Hierro. In the other six islands, however, it was taken by Mr. Lowe and myself; and it appears to have been found in Lanzarote and Fuerteventura by Webb and Berthelot, Fritsch, and Reiss, in Grand Canary by Webb and Berthelot, and Grasset, and in Palma by Blauner. Mousson says: 'Cette espèce traverse, comme on voit, toute la série des Canaries ;' yet, by his own shewing, he makes no reference to its existence in either Gomera or Hierro. Nevertheless we met with it in the former of those islands, and I have little doubt that it must occur equally in the latter.

In Lanzarote our specimens were principally from the lofty sea-cliffs known as the Risco (overlooking the Salinas), in the extreme north of that island,-which seems to be the locality from whence Webb's types were originally obtained; as well as from Chache, Los Llanos, Temisé, and the neighbourhood of Arrecife (particularly along the road to Yaiza). The Fuerteventuran ones were mainly from the Rio Palmas. Those from

have been obtained by M. Terver from bags of dried orchil, the precise origin of which was confessedly unknown), as species founded upon evidence which was altogether untrustworthy and insufficient, it may perhaps seem a little inconsistent that I should not have acted in a similar manner as regards Shuttleworth's H. umbicula and camentitia,-both of which are orchil shells of Terver's, and both of which exist equally (and only) in the collection at Marseilles; and possibly indeed it would have been wiser had I refused to admit them. Still, since both species (judging from their published diagnoses) are more on the Canarian pattern than the others to which I have above alluded, and since in one or two exceptional instances M. Terver's guesses concerning habitat turned out to be correct, I have given them the advartage of the doubt by admitting them; though I am nevertheless far from satisfied that it would not have been better, until respectable evidence has been adduced, to have rejected them in toto. 
Teneriffe were obtained chiefly around Sta. Cruz, Souzal, Orotava, and Garachico; and the Gomeran ones from San Sebastian and Hermigua. But there is hardly a district, provided it be sufficiently arid and at not too high an elevation, in which it will not be found to occur.

The $H$. monilifera is (as compared with its immediate Canarian allies) a solid, and rather globose but at the same time more or less depressed little shell (both above and below), with its perforation very minute and almost concealed in adult examples) by the reflexed columellary portion of the peristome, and with a raised whitish ring-like rib within the (acute) edge of its aperture. Although its spire is not usually much elevated, the volutions are convex, and densely sculptured with the oblique striæ of growth. And its surface is either white or brownish-white, and elegantly fasciated with two more or less distinct darker bands, - one of which is on the underside, becoming gradually lost sight of within the aperture, whilst the other is above the dorsal line, usually much broken-up (or interrupted by irregular transverse white blotches), and continued along the whorls (more or less broadly and conspicuously) to nearly the apex. This arrangement of colouring gives the entire shell, for the most part, an extremely mottled appearance.

I have already stated under the $H$. lancerottensis (vide, ante, p. 378), that an old, bleached, and decorticated example of this common Canarian shell was described by d'Orbigny as actually the type of that species, - of which he considered that he had never seen more than the single individual from which his diagnosis was drawn out! And this is all the more unpardonable since the lancerottensis and monilifer $\alpha$ are in reality quite distinct in structure, and both of them had been characteristically enunciated by Webb six years before,- - the well-engraved plates, moreover, which had been completed by Terver under Webb's superintendence long previous to d'Orbigny's engagement in his portion of the 'Histoire Naturelle,' leaving the features of the two species quite unmistakeable.

\section{Helix lemniscata.}

Helix lemniscata, W. et B., Ann. des Sc. Nat. 28. 317 (1833)

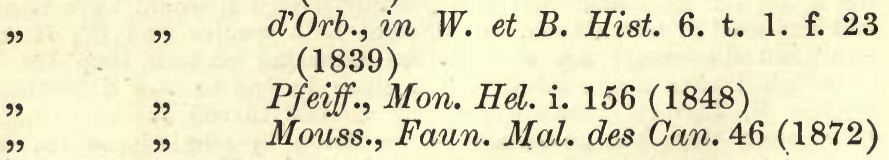

Habitat Canariam Grandem; in intermediis præcipue oc- 
currens. Semifossilis in calcariis inter urbem Las Palmas et Puerto da Luz parce reperitur.

The H. lemniscata is one of the most distinct and elegant of the Canarian Helices, and confined, so far as I have myself observed, to Grand Canary, - where it is rather common throughout the intermediate district of El Monte, ascending even to the Roca del Soucilho; and it was found in the same island by Messrs. Webb and Berthelot, Grasset, Fritsch, and Watson. Indeed in an old memorandum of Mr. Webb's which is now before me, it is stated to occur likewise in the south of Teneriffe; but as Webb was not always very accurate as regards his localities, this habitat certainly requires further corroboration. In Grand Canary I met with it also in a genuinely subfossil condition, namely in the calcareous deposits between Las Palmas and the Puerto da Luz.

In the slight prolongation of its axis, as it were, in a straight line (giving to the aperture a rather peculiar form), the $H$. lemniscata differs from the immediate species with which I have associated it; nevertheless there can be little doubt of its no distant affinity with the $H$. Michaudi and galeata of the Madeiran Group, and (though somewhat less perhaps) with the Canarian species around the $H$. persimilis and phalerata. Apart from its rounded-pyramidal, or turbinate, outline, it may be defined as a thin shell, of a rather lively hue,-many suffused tints, not easily to be expressed, being blended over its surface. Its ground-colour is more often of a yellowish or cinereous white (not unfrequently with a faint lilac tinge); and there is a single, well-defined, continuous, purplish-brown band on the underside, below the keel, which becomes lost within the aperture; whilst a second is placed immediately above the keel, and runs alongside the suture to almost the apex,-becoming more and more interrupted, or broken-up, in its course. The peristome (which is acute, and not thickened into a corneous rim) is generally somewhat flavescent; its perforation is minute, and well-nigh concealed; and its volutions (which are about $6 \frac{1}{2}$ in number, and a good deal flattened) are strongly sculptured with the oblique, irregular lines of growth. When immature the H. lemniscata is more decidedly keeled.

\section{Genus 10. BULIMUS, Scopoli.}

(§ Cochlicella, Risso.)

\section{Bulimus ventricosus.}

Bulimus ventricosus, Drap., Tabl. de Moll. 68 (1801) " 
Helix ventrosa, Fer., Prodr. 377. t. 52 (1807)

Bulimus ventrosus, Lowe, Cambr. Phil. Soc. Trans. iv. 62 (1831)

Helix acuta, W. et B., Ann. des Sc. Nat. 28. syn. 317 (1833) Bulimus ventrosus, $A l b$., Mal. Mad. 54. t. 14. f. 18,19 (1854) Paiva, Mon. Moll. Mad. 103 (1867)

Helix ventricosa, Mouss., Faun. Mal. des Can. 46 (1872)

Habitat Canariam Grandem, et Teneriffam; sub lapidibus, præcipue in cultis inferioribus, hinc inde congregans.

The common Mediterranean B. ventricosus, which occurs likewise in the Azorean, Madeiran, and Cape Verde archipelagos, has established itself in Grand Canary and Teneriffe; but, although probably existing in some of them, it has not yet been observed in any of the other islands. It abounds also at Mogador, on the opposite sandy coast of Morocco. My GrandCanarian examples are principally from the intermediate region of El Monte; and some which are now before me were taken by Mr. Watson on the road from Las Palmas to Arucas.

The truly indigenous Bulimi which occur in the Canarian archipelago are many of them so nearly related inter se, that, whether regarded as genuine species or as mere insular modifications of a few central types (- a question which can never perhaps be settled satisfactorily), it seems desirable to draw out short diagnoses of them afresh, in order to call attention more readily to the exact points in which their differences respectively consist. Six species, however, out of the 29 enumerated below (namely the B. Maffioteanus, Mouss., the indifferens, Mouss., the texturatus, Mouss. the tabidus, Shuttl., the anaga, Grass., and the servis, Mouss.), I have not been able to procure for inspection; and concerning these therefore I can add nothing, beyond what may be gathered from their published descriptions.

\section{Bulimus Guerreanus.}

T. [sæpius indumento lutoso dense vestita] minute rimata, breviuscula, conico-ovata, tenuissima, subpellucida, nitidiuscula, inæqualiter striatula, pallide olivaceo-cornea; spirâ breviter conicâ; anfractibus 6 , convexis, ultimo rotundato, subinflato; aperturâ parum obliquâ, peristomate simplici, acuto (nec expanso), marginibus sæpius laminâ tenuissimâ (vix perspicuâ) simplici junctis, dextro rotundate curvato, columellari breviter reflexo.-Long. lin. 4 ; diam. maj. 2. 
Bulimus Guerreanus, Grasset, Journ. de Conch. v. 347 (1856)

Pfeiff., Mon. Hel. iv. 50 (1859)

Buliminus Guerreanus, Mouss., Faun. Mal. des Can. 111 (1872)

Bulimus Guerreanus, Pfeiff., Mon. Hel. viii. 185 (1876)

Habitat Gomeram, et Hierro; ad rupes et muros in locis editioribus adhærens.

I cannot agree with Mousson that this singular Bulimus is in any respect allied to the badiosus, Fer.,-with which, as it seems to me, it has absolutely nothing whatever in common. It belongs to a totally different type, and stands completely isolated amongst the Canarian members of the group. Perhaps the form (although totally dissimilar from it) to which it makes the nearest approach is the Lanzarotan 'var. a. rufobrunneus' of the $B$. variatus, - which has a similar habit of coating itself over with a hardened envelope of coarse dirt, and which occurs (in like manner) on the rocks of a comparatively high altitude. Moreover both species are remarkable for their thin and subpellucid substance, their rather shining and totally ungranulated surface, the extreme convexity of their whorls, and the acuteness of their peristome,- which however is a little more thickened and expanded in the Lanzarotan one than it is in the $B$. Guerreanus (in which the border is quite thin and unreflexed, except towards the insertion of the columella).

Apart from its semitransparent and well-nigh.membraneous texture, the B. Guerreanus is conspicuous for its short, somewhat inflated, and conico-ovate outline, for the smallness of its umbilical chink, and for its olivaceous, or pale greenish-brown, hue. The intervening lamina, between the margins of its peristome, is (as in the Lanzarotan shell) so thin as to be barely traceable, and it is also perfectly simple.

The present Bulimus was taken abundantly by Mr. Lowe and myself, adhering principally to old walls, in and around Valverde, in the island of Hierro, where it would appear to have been met with previously by Grasset; and it was subsequently found by Mr. Lowe (namely on the 21st of April, 1861), at a high elevation, on rocks, a little below the Cumbre above San Sebastian, in Gomera.

\section{Bulimus variatus.}

T. sequenti (sc. B. myosotis) paululum minus gracilis, anfractu ultimo sc. subbreviore et vix magis subinflato, plerumque subnitidior (i.e sensim minus opaca), vix minus solida, sæpius magis obscure (i.e. minus pallide) brunnea, et interdum (tamen 
rarius conspicue) plagiato-variegata; in 'statu a.,' et fere in ' statu $\beta$.' etiam concolor.

a. rufobrunneus.-[sæpius indumento lutoso dense vestita] submajor ac magis rufo-brunnea, plerumque omnino concolor; spirâ antice paululum minus acutâ; anfractibus sensim convexioribus, suturâ profunde impressâ, paululum magis regulariter striatis; aperturâ submagis rotundatâ; peristomate acutiore, minus expanso, margine dextro ad insertionem simplici (nunquam tuberculo juncto), columellari subevidentius ar-

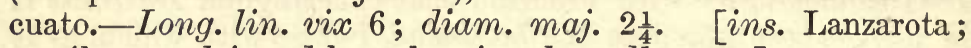
rupibus excelsis, ad borealem insuloe, adhoerens.]

$\beta$. roccellicola, W. et B. - subminor et vix magis ovata (aut magis ventricosa), fere omnino concolor (sc. pallide fusco-cornea) aut obsoletissime sublineolato-variegata; peristomate sublatius reflexiusculo, margine dextro ad insertionem tuberculo minuto indistincto sæpius juncto.-Long. lin. vix 5; diam. maj. vix $2 \frac{1}{4}$. [ins. 'Canarienses,' sec W. et B.; a statu normali, Canaria Grandis ac Teneriffo, vix certe distinctus.]

$\gamma$. [normalis].-subminor quam 'stat. a.,' et subventricosior, minus obscure aut magis subochraceo-brunnea, rarius concolor, sæpius plagis lineisque obliquis disjunctis irregularibus obscure ornata, paulo grossius sed magis irregulariter striatula; peristomate sublatius reflexiusculo, margine dextro ad insertionem tuberculo minuto plerumque juncto.-Long.lin. circa 5 ; diam. maj. $2 \frac{1}{4}$. [ins. Canaria Grandis et Teneriffa ; ad muros rupesque adhorens, procipue in locis subinferioribus.]

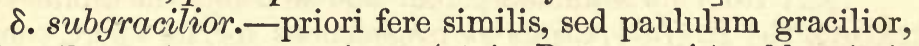
anfractibus minus convexis, et (ut in B. myosotis) sublongioribus, testâ subfragiliore et paulum magis nitidâ, vix plagiatâ; peristomate subacutiore.-Long. lin. $5 \frac{2}{3}$; diam. maj. vix $2 \frac{1}{4}$. [ins. Palma; in convalli supra Sanctam Crucem lecta.]

Bulimus variatus, W. et B., Ann. des Sc. Nat. 28 syn. 326 (1833)

" roccellicola, Id., ibid. syn. 323 (1833)

" variatus (pars), d'Orb., in W. et B. Hist. 71. t. 2. f. 25 (1839)

" roccellicola, Id., ibid. 70. t. 2. f. 23 (1839)

" variatus, Pfeiff., Mon. Hel. ii. 125 (1848)

" roccellicola, Id., ibid. ii. 126 (1848)

" variatus, Shuttl., Bern. Mitth. 293 (1852)

Buliminus variatus, Mouss., Faun. Mal. des Can. 105 (1872)

, roccellicola, Id., ibid. 102 (1872)

Bulimus variatus, Pfeiff., Mon. Hel. viii. 89 (1876)

Habitat Lanzarotan, Canariam Grandem, Teneriffam, et Palmam; in inferioribus et locis paulum magis elevatis, ad 
muros rupesque hinc inde adhærens. In Canariâ Grandi etiam semifossilis reperitur.

A common, though variable, Bulimus at low elevations in Teneriffe and Palma, and (under a tolerably well marked aspect) at higher ones in Lanzarote, and one which has been found by Mr. Watson in Grand Canary likewise. It may be said to differ, in a general way, from the $B$. myosotis of the last-mentioned island (if indeed the myosotis be anything more than a mere elongated and concolorous modification of the variatus characteristic of Grand Canary) in being a little less solid in substance and Iess slender (or more ovate) in outline,- the last two or three whorls being relatively a trifle more shortened; and it is also usually less opake, and of a less uniformly pale (or yellowish) brown,- the unmaculated state (' $a$. rufobrunneus') from Lanzarote being of a rich coffee-colour, and the smaller and more or less maculated one from Grand Canary and Teneriffe (which, like Mousson, I have regarded as the type), although occasionally of a pallid brunneo-olivaceous tint, being at the same time more or less marbled with obscure, longitudinal, oblique, irregular fragmentary lines and streaks of a rather lighter hue. 'The ' $\delta$. subgracilior, from Palma, has certainly the slenderer form and rather elongated volutions of the $B$. myosotis; but, on the other hand, its features of comparative thinness and brightness are even more expressed than in the ' $\gamma$.' or normal state of the species, - thus affiliating it with the $B$. variatus, rather than with the $B$. myosotis from Grand Canary.

Judging from two original examples which are now in the British Museum, the $B$. roccellicola, W. et B., is certainly nothing more than a variety (if indeed a true 'variety' at all) of the $B$. variatus,-differing far less from the ordinary Teneriffan and Grand-Canarian type than the 'status a. rufobrunneus' does, which is the common form in Lanzarote. It is perhaps a trifle more ovate, and (if anything) a little smaller, than the normal phasis of the shell; and its surface is of a palish brown,-in one of the specimens quite concolorous, and in the other just appreciably mottled with a few irregular fragmentary thread-like lines. After examining these two individuals with great care, I can perceive absolutely nothing about them to warrant specific separation,-their distinctions, such as they are, being scarcely even varietal.

The Lanzarotan phasis of this shell, which I cannot but think has quite as great a claim for specific separation as is possessed by the Grand-Canarian B. myosotis, occurs on the submaritime rocks of a rather high altitude,-it having been found in abundance by Mr. Lowe and myself on the lofty sea-cliffs 
known as the Risco, and overlooking the Salinas, in the extreme north of that island. Its habit of covering itself .over with a hardened envelope of earth is even more pronounced than in any of the following forms (being quite as remarkable as in the B. Guerreanus, Grasset, from Hierro); but when denuded of this strongly-cemented encasement, the shell will be seen to be somewhat more thin and subtranslucent than in the normal state from Teneriffe and Grand Canary, as well as of a deeper and richer coffee-brown and usually altogether unornamented with even a trace of paler markings. Its volutions, too, are remarkably tumid or convex, and the suture consequently much impressed; its spire is not quite so acutely pointed towards the apex; its aperture (which is a trifle more rounded) has the peristome not quite so thickened or so decidedly expanded outwards; and its stature is appreciably larger.

In its normal condition, under which circumstances it is seldom free from markings (there being generally more or less evident indications of obscure and irregular paler dashes and fragmentary oblique stripes), and in which the size is, on the average, smaller, the $B$. variatus was found by Mr. Lowe and myself, on walls and rocks, at comparatively low elevations around Garachico and the Puerto of Orotava, in the north of Teneriffe; and some specimens are now before me, both in a recent and subfossil state, which were taken by Mr. Watson at Tafira in Grand Canary. The ' $\delta$. subgracilior' I met with in the Barranco above Sta. Cruz, in the island of Palma.

The $B$. variatus is said by Morelet and Drouet to occur in Sta. Maria at the Azores; but as I have not been able to procure an Azorean type for comparison, I am unable to state whether the phasis which the species assumes in that archipelago differs in any material respect from what I have regarded as the normal one at the Canaries. Judging from Morelet's diagnosis, the differences do not appear to be very considerable.

\section{Bulimus myosotis.}

T. [sæpe indumento lutoso dense vestita] rimata, subgracilis, elongato-conica, solidiuscula, subopaca, parum distincte irregulariter striatula, pallide flavo-brunnea, concolor (nullo modo, aut potius rarissime, subvariegata); spirâ acutiusculâ ; anfractibus 7, convexiusculis, ultimo elongatulo sed vix inflato, et etiam intermediis haud valde abbreviatis ; aperturâ elongatulâ; subobliquâ, peristomate acutiusculo, albo, late expanso, reflexiusculo, intus calloso-incrassato, marginibus sæpius laminâ tenuissimâ (ad insertionem dextram plerumque albo-nodulosam) junctis, columellari rectiusculo.-Long. lin. 6 ; diam. maj. 2. 
Bulimus myosotis, W. et B., Ann. des Sc. Nat. 27. syn. 319 (1833)

" variatus (var.), d'Orb., in W. et B. Hist. 71. t. 2. f. 27 (1839)

Webbii, d'Orb., l. c. 72 (1839)

" myosotis, Pfeiff., Mon. Hel. ii. 126 (1848)

" Webbii, Id., l. c. iv. 419 (1867)

Buliminus myosotis, Mouss., Faun. Mal. des Can. 102 (1872)

Bulimus myosotis, Pfeiff., Mon. Hel. viii. 84 (1876)

Habitat Canariam Grandem; in aridis calcareis intermediis præcipue occurrens. In montibus paululum elevatis mox supra Las Palmas semifossilis invenitur.

I am exceedingly doubtful whether this Bulimus is anything more in reality than a phasis peculiar to Grand Canary of the very inconstant $B$. variatus, W. et $B$. ; nevertheless since it has usually been acknowledged as distinct (though cited, it is true, by d'Orbigny as a mere aspect of that species), and practically it is easy to be recognized, I will not do otherwise than treat it separately. Indeed the line of demarcation between these ' insular modifications' (if such indeed they may be looked upon) and 'species,' properly so called, is often so difficult to draw that it is simply impossible to do so with any degree of certainty; and it seems to me, therefore, that it signifies but little which we choose to regard them, provided that they are correctly located with reference to each other, and provided also that their characters are accurately pointed out.

The present Bulimus may be said to be the universal one (on the B. variatus type) in Grand Canary, where it occurs more particularly in dry and calcareous spots of intermediate altitudes,-frequently cementing itself over so completely with a hardened envelope of dirt that it is not always easy to be observed when adhering to the stone walls, the colour of which it exactly simulates. It was taken in abundance by Mr. Lowe and myself at Tafira (on the road from Las Palmas to El Monte), a locality in which it has subsequently been found by Mr. Watson; as also between Lagaete and Galdar, on the western side of the island. And on the hills immediately above Las Palmas it was collected in profusion by Mr. Watson, some of whose examples appear to me to be subfossilized. Mousson records that it was met with likewise, near Las Palmas, by Grasset and Fritsch.

From the numerous forms of the variatus the $B$. myosotis may be known by its rather slender and elongated contour (the basal and two following whorls being somewhat less abbreviated than in most of the aspects of that species), as well as by its slightly more solid substance, its less shining (in fact nearly 
opake) surface, and its usually pale yellowish-brown hue,-there being seldom (if ever) any indications of lighter dashes or streaks. Its peristome (which is white) is rather broadly developed, and the columellary margin is almost in a continuous curve with the outside of the penultimate whorl (when backwardly produced). ${ }^{1}$

Judging from one of his original types which is now in the British Museum, d'Orbigny's B. Webbii (enunciated in 1839) is nothing more than the myosotis, W. et B., in its perfectly normal state; and Pfeiffer also rightly defined it (twenty years later) as a Bulimus, - having drawn out his diagnosis from this very individual. Yet it is singular that the latter should not at once have perceived that it differs in no respect from a typical $B$. myosotis which is placed almost alongside it in the same collection. This exactly quadrates with the habitat which is given for it (on the authority of Webb and Berthelot) by d'Orbigny, namely ' Grand Canary,'-which is the particular island to which the $B$. myosotis (which however is scarcely more, I think, than a mere aspect of the variatus, W. et B.) is peculiar. Yet Mousson has fallen into the error of regarding it as a 'Cionella' (or Lovea), from which it clearly is altogether distinct. But that d'Orbigny, who had the types of Webb under his immediate eye, should have failed to identify it with the $B$. myosotis is truly astonishing,--for if this type to which I have just called attention is to be trusted, it does not represent so much as even a 'variety' (unless indeed it be just appreciably more shining) of that common Grand-Canarian shell.

\section{Bulimus encaustus.}

T. B. variati statum normalem simulans, sed sensim major, subsolidior, ac magis nitida; anfractibus distinctius 7 (nec distincte 6 , indistincte 7 ), sensim (ut in $B$. myosotis) longioribus, subgrossius sed etiam magis irregulariter costulato-striatis, striis perpaucis hinc inde altioribus necnon interstitiis sæpe sensim subexcavatis; aperturâ paululum majore, longiore, peristomate (albo) subevidentius calloso-incrassato, margine columellari sub-

1 The occasional obsolete indications of minute and fragmentary spiral striæ, which are just traceable on different parts of its surface, and which are alluded to in the published diagnoses of this and some of the cognate Butimi, are no differential character at all,-for they are equally to be observed, at times, in every one of the species. Neither is the exact number of the whorls; for although sometimes only six or seven are conspicuous, the eighth (which is at others fully dexeloped) may generally be seen, more or less immersed, at the extreme apex. Nor indeed is the presence of a minute corneous nodule (more or less expressed) near to the insertion of the righthand margin of the peristome; for that little callosity is as often absent as present in most of the forms, or species, and can scarcely claim therefore to be distinctive of any one of them in particular. 
rectiore. Sed præcipue differt colore diverso,-sc. plagis lineisque obliquis multo albidioribus, et multo majoribus, interdum etiam confluentibus, testæ majorem partem tingentibus.-Long. lin. 6 ; diam. maj. $2 \frac{1}{8}$.

Bulimus encaustus, Shuttl., Bern. Mitth. 293 (1852)

" $\quad$ Pfeiff., Mon. Hel. iii. 652 (1853)

Buliminus encaustus, Mouss., Faun. Mal. des Can. 105 pl. vi. f. 3,4 (1872)

Bulimus encaustus, Pfeiff., Mon. Hel. viii. 90 (1876)

Habitat Palmam; in declivibus intermediis, ad rupes et inter saxa latens.

This beautifully variegated Bulimus seems to be peculiar to the intermediate and rather lofty districts of Palma,- where it was found by Mr. Lowe and myself in several places, though more particularly in the Barranco de Nogales, chiefly amongst rubbish and small stones on the ledges of the rocks; and it appears to have been taken also by Blauner. Mousson, by some unaccountable mistake, has cited my examples from the Barranco de Nogales as referable to the $B$. variatus; whereas they possess every character of Shuttleworth's $B$. encaustus; though it may be a question perhaps whether the latter, though easily distinguishable, is anything more in reality than an insular and highly decorated modification of the $B$. variatus. Still I have already stated what my reasons are for preferring to retain these nearly-resembling Bulimi in the condition in which they have already been acknowledged and published.

It is to the typical form of the $B$. variatus (which is more or less obscurely ornamented with longitudinal paler dashes and streaks) that the $B$. encaustus the most intimately approaches; nevertheless it is, on the average, rather larger and more solid than the former, more shining and uneven in its surface (irregular longitudinal spaces of which, between certain striæ which are more elevated than the rest, have a tendency to be very obsoletely scooped-out, as it were, or grooved); and the fragmentary oblique patches and lines are not only very much increased in size,-frequently becoming confluent with each other, so as to cover nearly the whole shell. Its aperture, too, is relatively a trifle more developed, the columellary margin being (if anything) a little longer; and its whorls are altogether somewhat less abbreviated, causing the general outline to be more in accordance with that of the $B$. myosotis.

\section{Bulimus rupicola.}

T. præcedenti colore et superficie (læte albo et brunneo variegatâ) fere similis, sed staturâ longiore, graciliore, spirâ 
valde elongato-conicâ, anfractibus 8 , minus convexis, aperturâ submagis obliquâ, peristomate etiam sublatius expanso; lineis spiralibus (tamen minutissimis) interdum magis distinctis.-Long. lin. 6 $\frac{1}{2}-7$; diam. maj. $2 \frac{1}{4}$.

Bulimus rupicola, $W$. et $B$., in litt.

variatus (pars), d'Orb., in W. et B. Hist. 71 (1839)

Buliminus rupicola, Mouss. [nec rupicolus, Reeve, = variegatus, Pfeiff.], Faun. Mal. des Can. $104(1872)$

Bulimus rupicola, Pfeiff., Mon. Hel. viii. 89 (1876)

Habitat Gomeram ; juxta Hermigua, et recens et semifossilis, a Revdo. R. T. Lowe copiosissime reperta.

This Bulimus might well be looked upon as an insular modification peculiar to Gomera of the Palman B. encaustus, with which it agrees in the character of its similarly decorated surface; nevertheless if the $B$. myosotis and encaustus are to be treated as specifically distinct from the variatus (and not as Grand-Canarian and Palman phases of that shell), it seems to me that it would be inconsistent not to cite the B. rupicola as a species of equal importance and attached to Gomera; and I have therefore followed Mousson in so regarding it.

Although coinciding with the encaustus in its beautifully ornamented surface (in which the white portions, on the average, very much preponderate over the brown), the B. rupicola is nevertheless longer and slenderer than that species,-its spire being more drawn-out and conical, with the seventh (or apical) whorl more distinctly expressed. Its volutions are appreciably less convex; its aperture is (if anything) a trifle longer and more oblique, with the peristome very broadly expanded; and its minute spiral lines are usually somewhat more traceable.

The B. rupicola was taken in great profusion by Mr. Lowe, near Hermigua, on the western side of Gomera; and, out of many hundred examples which I have overhauled, a considerable proportion seem to be in a subfossilized (or, at any rate, in a very ancient and bleached) condition; and, from being filled almost invariably with a fine and loose friable soil, they have every appearance of having been long embedded in a kind of superficial earthy deposit. The specimens, moreover, which are thus circumstanced are more or less white and decorticated.

\section{Bulimus ocellatus.}

T. auguste rimata, elongato-ovata, solida, nitida, parum distincte irregulariter striatula, albida sed apicem versus necnon in maculis perpaucis irregularibus pallide flavo-cornea; anfracti- 
bus 7 , vix convexiusculis; aperturâ sat magnâ, lunato-ovali, intus fusculâ; peristomate incrassato, late albo-expanso, marginibus laminâ tenuissimâ (ad insertionem dextram subnodula-

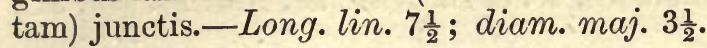

Buliminus ocellatus, Mouss., Faun. Mal. des Can. 107. pl. vi. f. 5-7 (1872)

Bulimus ocellatus, Pfeiff., Mon. Hel. viii. 90 (1876)

Habitat Gomeram, et Hierro; ab illâ a Barone de Paiva receptus, sed lectus in hâc a cl. Fritsch.

The only example which I have seen of this very elegant Bulimus, and from which the above diagnosis has been compiled, was received by the Baron Paiva from Hermigua, on the western side of Gomera; but the species is said by Mousson to have been taken by Fritsch in Hierro. Its large size (for a member of the variatus-type) and robust, elongate-ovate contour, added to its shining, solid, and porcelain-like surfacewhich is of a clear milky white, with the apical whorls and a few very irregular patches (which have a tendency to arrange themselves in two spiral rows) on the ultimate and penultimate ones of a pale yellowish-brown - will suffice at once to distinguish it. The aperture (which is fuscous within) is rather largely developed, with the peristome white and broadly expanded; and in the specimen before me there is a very indistinct row of minute and almost obsolete granuliform tubercles along the dorsal line of the basal volution, commencing from the righthand insertion of the peristome,-as though to represent the faint angle which is just traceable in the B. Moquinianus, and which is so strongly expressed in certain members of the Subulina Group. ${ }^{1}$

\section{Bulimus Moquinianus.}

$T$. rimato-perforata, elongato-subfusiformis, solidiuscula, nitidiuscula, distincte irregulariter striata, pallide ochraceo-cornea et plagis obliquis obsoletis subpallidioribus longitudinaliter obscure ornata; spirâ subcylindrico-conicâ; anfractibus 8, planiusculis, ultimo fere latitudine penultimi (sc. vix latiore) necnon ad lineam dorsalem obsoletissime subangulato, penultimo et antepenultimo subauctis ; aperturâ parvâ, peristomate crassiusculo sed breviter expanso, marginibus subapproximatis et laminâ tenuissimâ simplici junctis, columellari haud reflexo, rimam

1 The slight concavity of the columella which is referred to by Mousson in his diagnosis of this species is no specific character at all, for it exists in all the exponents of this immediate section, and is certainly more conspicuous in the $B$. myosotis and rupicola than it is in the ocellatus. 
magis apertam (sc. fere umbilicum) non tegente.-Long. lin. $6 \frac{1}{2}$; diam. maj. $2 \frac{1}{2}$.

Bulimus Moquinianus, W. et B., Ann. Sc. Nat. 27. syn. 319 (1833) d'Orb., in W. et B. Hist. 70. t. 2. f. 24 (1839) Pfeiff., Mon. Hel. ii. 165 (1848)

Buliminus Moquinianus, Mouss., Faun. Mal. des Can. 103 (1872)

Bulimus Moquinianus, Pfeiff., Mon. Hel. viii. 90 (1876)

Habitat Canariam Grandem: in intermediis, præcipue calcareis, rarior.

The B. Moquinianus is peculiar to Grand Canary, where it would appear to be scarce. It was, however, taken by Mr. Lowe and myself, on the 20th of April 1858, in the somewhat calcareous district between Lagaete and Galdar, on the western side of that island; and it is recorded by Mousson to have been met with by Fritsch near Las Palmas. It may be distinguished by its pale yellowish-brown, olivaceous surface,-which is a little shining, rather coarsely (though unevenly) striated, and obscurely marbled with faintly lighter but very irregular subconfluent oblique spaces or stripes, and by its somewhat more fusiform (or medially-thickened) contour, - the intermediate whorls (although not convex) being rather more enlarged than in the allied forms, and the basal one (which is most obsoletely subangulated across its dorsal region), consequently, hardly broader than the one which precedes it. Its aperture is relatively small, with the peristome, although thickened, but very little expanded; and its chinklike perforation is wider, or more open, than in the allied species, as well as less covered over (indeed scarcely so at all) by the columellary margin.

\section{Bulimus helvolus.}

$T$. angulatim rimata, elongate fusiformi-ovata, tenuis, pellucida, nitida, leviter irregulariter striatula, pallide et clare ochraceo-cornea, concolor; spirâ cylindrico-conicâ; anfractibus 7 , convexiusculis, ultimo elongato, intermediis, inflatiusculis, subauctis; aperturâ subrotundatâ, peristomate albo et anguste expanso, marginibus subapproximatis et callo lineari albo(ad insertionem dextram in nodulum, ab angulo incise disjunctum, aucto) junctis, columellari vix reflexo.-Long. lin. vix 7 ; diam. maj. 3 .

Bulimus helvolus, W. et B., Ann. des Sc. Nat. 27. app. 326 (1833)

" $\quad$ d'Orb., in W. et B. Hist. 71. t. 2. f. 21 (1839) 
Bulimus helvolus, I’feiff., Mon. Hel. iii. 348 (1853)

Buliminus helvolus, Mouss., Faun. Mal. des Can. 107 (1872)

Bulimus helvolus, Pfeiff., Mon. Hel. viii. 75 (1876)

Habitat Teneriffam; juxta Sta. Cruz lecta, sed rarissime.

The single example from which the above diagnosis has been drawn out, and which was received from Teneriffe by the Baron Paiva, appears to me to belong most unmistakeably to the $B$. helvolus, W. et B. (said by Mousson to have been found by Gondot, Blauner, and Fritsch near Sta. Cruz), - the only point in which it does not perfectly accord with the diagnosis of that shell consisting in the fact that I cannot detect any traces of a faint angle, or keel, along the dorsal line of its ultimate volution. But its other characters are so pronounced,--particularly. as regards its glossy, faintly striated, pale ochreo-corneous concolorous surface, and the presence of a small thickened tubercle at the right-hand insertion of the peristome, which is separated from the aingle itself (as in the B. badiosus, Bertheloti, and Consecoanus) by a deep cleft or incision,- - that I can have no hesitation in referring it to Webb and Berthelot's species, with a type indeed of which in the British Museum it seems perfectly to agree. In other respects the $B$. helvolus is elongate and ovato-fusiform, with its basal whorl a good deal lengthened, and its intermediate ones rather unusually increased; and its aperture, which is somewhat round, has the peristome but very narrowly expanded.

Judging from the examples before me, I should say that the $B$. helvolus is perhaps more nearly allied to the (nevertheless somewhat maculated and striped) B. Moquinianus of Grand Canary than to anything else,-forming a passage, in conjunction with that species, from the variatus-type, to the larger and less conical forms.

\section{Bulimus palmensis.}

T. rimato-perforata, ovato-fusiformis (in medio latiuscula), subtenuis, subpellucida, subopaca (rarius nitidiuscula), irregulariter striatula lineisque minutissimis spiralibus hinc inde distinctius et dense cincta, ad basin rugoso-granulata, pallide ochraceo-cornea, interdum etiam subflavescens, rarius plagis obscuris paululum pallidioribus obsolete maculata; spirâ breviter et acute conicâ; anfractibus 7, planiusculis, ultimo elongatulo; aperturâ magnâ, elongatâ, obliquâ, peristomate albido et anguste expanso, marginibus subparallelis, distantibus, laminâ tenuissimâ (interdum vix perspicuâ) simplici junctis, columellari obliquo et vix reflexo.-Lon. lin. circa 6 ; diam. maj. $2 \frac{1}{2}$. 
Buliminus nanodes, var. palmaensis, Mouss., Faun. Mal. des Can. 116 (1872)

Bulimus nanodes (pars), Pfeiff., Mon. Hel. viii. 73 (1876)

Habitat Palmam; in sylvaticis editioribus, late sed parce diffusus.

It is surprising to me that this Bulimus, which is one of the best defined of all the Canarian species, should have been cited by Mousson (from examples which I sent to him for inspection) as a mere 'var. palmensis' of Shuttleworth's $B$. nanodes,-which is utterly distinct from it in every one of its characters. Apart from its greater length (which is fully 6 lines, instead of scarcely 5), and its more fusiform, medially widened, apically acute outline (the spire being more regularly conical, with the whorls much flatter), it is additionally separated from every phasis of the $B$. nanodes by its thinner and more pellucid substance, its very much larger and more oblique aperture, its longer and less vertical columella, its less expanded peristome, its paler and more olivaceous surface (which is occasionally almost lutescent, and not unfrequently obscurely marked with lighter dashes and spots,-thus taking us back again, as it were, towards the variatus group), and its totally different sculpture,-the shell being altogether free (except towards the umbilical region) from the coarse varioles and irregular granulations which are so conspicuous in that species, but at the same time more or less covered with excessively minute (and often barely traceable) densely-packed spiral lines.

The present Bulimus seems to be universally (though sparingly) distributed over the intermediate and lofty sylvan districts of Palma, to which island it would appear to be peculiar. It was met with by Mr. Lowe and myself on the ascent of the Cumbre above Buenavista, as well as in the Barranco above Sta. Cruz, the Barranco de Agua, and the Barranco de Galga, and by. Mr. Lowe at El Monte above Barlovento.

\section{Bulimus badiosus.}

$\mathrm{T}$. [interdum indumento vestita] rimato-perforata, elongatoovata, nitidiuscula, distincte inæqualiter (rariss. subgranulatim) plicatulo-striata, ad basin rugoso-granulata, rufo-brunnea vel badia; spirâ breviter conicâ; anfractibus 6, convexiusculis ; aperturâ magnâ, obliquâ, peristomate late expanso, acuto, intus albo-incrassato, marginibus approximatis et callo lineari albo (ad insertionem dextram in nodulum, ab anyulo incise disjunctum, aucto) junctis, regulariter curvatis (nullo modo angulatim continuis), columellari obliquo et vix reflexo.-Long. lin. 6 ; diam. maj. 3. 
Helix badiosa, Fer., Prodr. 423 (1821)

Bulimus badiosus, W. et B., Ann. des Sc. Nat. 28. syn. 318 (1833)

" $\quad$ " d'Orb., in W. et B. Hist. 69. t. 2 f. 22 (1839)

Pfeiff., Mon. Hel. ii. 19 (1848)

Buliminus badiosus, Mouss., Faun. Mal. des Can. 110 (1872)

Bulimus badiosus, Pfeiff., Mon. Hel. viii. 74 (1876)

Habitat Teneriffam juxta Sta. Cruz, præcipue in 'Barranco del Passo Alto,' vulgaris.

This is one of the most abundant of the larger Bulimi around Sta. Cruz in Teneriffe, to which island it would seem to be peculiar. It was taken in profusion by $\mathrm{Mr}$. Lowe and myself near the mouth of the Barranco del Passo Alto, and it has been met with by almost every naturalist who has visited the Canaries,-including Maugé, Webb and Berthelot, d'Orbigny, Blauner, Fritsch, Reiss, and Watson.

Apart from its ovate (or basally-widened and apically-acute) outline and its reddish-brown, somewhat chestnut hue, the $B$. badiosus may be known by its rather enlarged, oblique, and regularly curved (unangulated) aperture, the whitened peristome of which is broadly thickened internally, and by the incrassated corneous rim (sometimes evanescent in the centre) which joins the margins of the latter, and which is developed near to the right-hand insertion into a nodule which is separated by a minute gash (or incision) from the angle itself. This lastmentioned character is possessed also by the $B$. helvolus, Bertheloti, and Consecoanus, but it is one which does not appear to be noticed in the published deseriptions of the species. Judging from the many examples which are now before me, the $B$. badiosus very seldom has its surface at all granulated except at the extreme base of the shell; but the irregular (or unequal) striæ are somewhat coarsely expressed.

\section{Bulimus propinquus.}

T. rimata, elongate ovato-, aut turrito-, subcylindrica, solida, opaca, irregulariter striata et inæqualiter scrobiculato(aut potius subrugato-)granulata, obscure rufo-brunnea; spirâ subcylindrico-conicâ; anfractibus 7, valde convexis, suturâ profunde impressâ ; aperturâ subrotundatâ, peristomate albo, acuto, late expanso, marginibus subapproximatis et laminầ tenuissimâ fere simplici junctis, columellari reflexiusculo.Long. lin. vix 6 ; diam. maj. $2 \frac{1}{2}$.

Bulimus propinquus, Shuttl., Bern. Mitth. 144 (1852) 
Bulimus propinquus, Pfeiff., Mon. Hel. iii. 348 (1853)

Buliminus propinquus, Mouss., Faun. Mal. des Can. 108. pl. vi. f. 8 (1872)

Bulimus propinquus, Pfeiff., Mon. Hel. viii. 74 (1876)

Habitat Téneriffam; juxta Sta. Cruz et (sec. Mousson), Tagueste, rariss.

I believe that I am right in identifying with the propinquus of Shuttleworth two examples of a rather solid, opake, and dark reddish-brown Bulimus which are now before me, and which were taken in the Barranco Santo near Sta. Cruz,- their elongate, cylindrico-ovate outline, extremely convex whorls, deeply impressed suture, and granulate (or, rather, rugoso-, or even scrobiculato-granulate) surface being quite in accordance with the published diagnosis of that species, - which, moreover, is expressly stated by Shuttleworth to have been found 'sub foliis plantarum prope Santa Cruz.' The only point in which it does not completely tally with the description is, that the basal volution can scarcely be said to be in any sense 'angulate;' but the faint tendency to an obsolete keel which is sometimes traceable in many of these Bulimi along the dorsal line of their ultimate whorl is so often apt to be undistinguishable that I cannot place much stress upon either its presence or its absence. In addition to the elongate and irregular granulations of the surface, the $B$. propinquus is also roughly (though unevenly) striate; and its aperture is somewhat rounded and oblique, with the peristome (although acute) a good deal developed.

I do not feel altogether satisfied that Mousson's B. propinquus is absolutely identical with Shuttleworth's,-it being, apparently a larger shell, and defined by him as ' nitidiuscula;' but, whether this be the case or not, his species appears to have been taken in Teneriffe by Blauner, Fritsch, and Grasset,-by the latter at Tagueste. Most likely, however, it represents but a phasis (perhaps more highly developed) of Shuttleworth's type.

\section{Bulimus osoriensis, n. sp.}

T. anguste rimata, ovato-fusiformis, solidiuscula, subnitida, irregulariter striata sed haud granulata, olivaceo-cornea; spirâ conicâ ; anfractibus 7, intermediis convexis et interdum subinflatis, suturâ profundâ; aperturâ subangustulâ, peristomate albo, acuto, parum late expanso, marginibus haud approximatis et laminâ tenuissimâ fere simplici (sc. ad insertionem dextram obsolete incrassatâ) junctis, columellari vix reflexo.-Long. lin. $4 \frac{1}{2}-5$; diam. maj. 2. 
Habitat Canariam Grandem ; in sylvis editioribus ad Osorio a Revdo. R. T. Lowe, Aprili 1858, parce lectus.

Although without any very conspicuous feature to characterise it, this little Bulimus certainly cannot be affiliated with any of the forms with which we are here concerned,-perhaps its unusually small size, as compared with the generality of these robust, barrel-shaped species, constituting one of its main peculiarities. Apart from its reduced stature, the $B$. osoriensis is narrower and less obtuse in outline than the Teneriffan $B$. nanodes (which is likewise a small member of the group), its spire, the whorls of which are rather inflated and convex, being relatively a little more exserted and conical; its umbilical chink is more closed-up; and its entire surface is not only more shining, but free from asperities and granules,-it being simply, though unequally, striated.

It is only in the sylvan regions of Grand Canary, at a high altitude, that the present Bulimus has hitherto been observed, - the few examples which I have seen, and from which the above diagnosis has been compiled, having been taken by $\mathrm{Mr}$. Lowe, on the 24th of April 1858, in the woods at Osorio.

\section{Bulimus chrysaloides, n. sp.}

T. aperte rimata, obtuse oblongo-cylindrica, solida, subopaca, valde irregulariter necnon in anfractibus intermediis (sensim elongatis) rugosius subgranulatim striata, olivaceo-cornea ; spirâ subconico-cylindricâ; anfractibus 7, planiusculis tamen suturâ profunde impressâ; aperturâ angustâ, haud obliquâ, peristomate albo, vix late expanso, marginibus distantibus (nec approximatis) et laminâ tenui (ad insertionem dextram paulum incrassatâ) junctis, columellari sat reflexo.-Long. lin. 6; diam. maj. vix 3 .

Bulimus chrysaloides, Lowe, in litt.

Habitat Canariam Grandem; in montibus centralibus valde elevatis (sc. in Pineto de Tarajana), Aprili ineunte 1858, collegit Revdus. R. T. Lowe.

The present species, like the last one, seems to be peculiar to Grand Canary, where it would appear to ascend to a still higher altitude, - the only examples (five in number) which I have met with having been taken by Mr. Lowe (on the 8th and 9th of April, 1858) in the lofty Pinal of Tarajana, above San Bartolomé, in the central district of that island.

Its obtuse and unusually cylindric contour would of itself suffice to separate the B. chrysaloides from the Bulimi with which it is immediately associated; but it may be further known by its somewhat flattened volutions, the intermediate ones of 
which are not only rather longer than in the generality of the species, but have also their striæ both rougher and subgranulated, and by its aperture being relatively rather small and narrow. The margins of its peristome are wide apart, and their connective lamina is a little incrassated (though hardly raised into a tubercle) at the upper insertion. I have retained for the species the name which Mr. Lowe proposed at the time that he found it.

\section{Bulimus Maffioteanus.}

Buliminus Maffioteanus, Mouss., Faun. Mal. des Can. 117. p. 6. f. 15 (1872)

Bulimus Maffioteanus, Pfeiff., Mon. Hel. viii. 95 (1876)

Habitat Canariam Grandem juxta Las Palmas (sec. Mousson) a cl. Fritsch parce, in statu emortuo, lectus.

Described by Mousson from three dead examples which were found by Fritsch near Las Palmas in Grand Canary; and, judging from the diagnosis, it would appear, in its rather cylindrical outline and more decidedly sculptured subgranulose intermediate whorls (the ultimate one being comparatively finely striate and shining), to have something in common with the $B$. chrysaloides of that same island. Nevertheless it seems to be considerably larger (measuring about $7 \frac{1}{2}$ lines in length, instead of only 6) and less decidedly cylindric. 'Les trois individus,' observes Mousson, 'que j'ai vu de cette espèce ont été trouvé à l'état mort, mais comme l'un présente d'un côté son épiderme et son brillant, je les crois faire partie de la faune actuelle. La forme de cette espèce, un cylindre amoindri des deux côtés, n'a jusqu'ici pas d'analogue dans les Canaries, mais rappelle d'une manière frappante celle du $B$. niveus, Fer., du midi de la Russie; celui-ci toutefois compte 9 tours, est un peu plus grêle, et n'offre pas la sculpture superficielle de la présente. Cette sculpture consiste en fines stries subcostulées, souvent un peu granuleuses, qui couvrent les tours moyens, et disparaissent entièrement au dernier tour, lequel est presque lisse et luisant, excepté à la base, qui reste un peu granuleuse.'

\section{Bulimus indifferens.}

Buliminus indifferens, Mouss., Faun. Mal. des Can. 116 (1872)

Bulimus indifferens, Pfeiff., Mon. Hel. viii. 75 (1876)

Habitat Canariam Grandem; in statu (an omnino?) semifossili collegit cl. Fritsch.

Apparently a rather small species (measuring only about 6 lines in length), and one which was found by Fritsch, in a 
state which is said by Mousson to be probably subfossilized, in Grand Canary. I have not been able to procure a type for inspection; but the $B$. indifferens seems to be ovate in outline, with the apex of its spire obtuse and not prominent, and with its peristome (the margins of which are distant, and joined by a thin and simple intervening lamina) only narrowly expanded.

\section{Bulimus texturatus:}

Buliminus texturatus, Mouss., Faun. Mal. des Can. 117 (1872)

Bulimus texturatus, Pfeiff., Mon. Hel. viii. 76 (1876)

Habitat Gomeram; duobus exemplaribus (emortuis) a cl. Fritsch repertis.

Like the last one, this is a small Bulimus,-having indeed much about the same length, namely 6 lines; and the species was established by Mousson on the evidence of two dead examples which were taken by Fritsch in Gomera. 'Cette petite espèce,' says Mousson, 'dont je n'ai vu que deux échantillons, recueillis morts, n'est guère plus grande que le nanodes, Shuttlw., mais ne peut lui être assimilée. Elle est plus allongée, assez effilée vers le sommet; ses tours sont presque plans, séparés par une suture superficielle, subcrénelée; la surface est couverte de fines rides serrées, ondulées et formant à la base une sorte de chagrinage granuleux. Le $B$. indifferens a par contre une forme plus ovoïde, des tours plus arrondis, et une surface sans traces de costulation.'

\section{Bulimus nanodes.}

T. rimato-perforata, breviter et obtuse oblongo-ovata, solidiuscula, subopaca, plus minus grosse varioloso-, aut reticulato(vix granuloso-), rugata, obscure flavo-cornea; spirâ semigloboso-conicâ, suturâ profunde impressâ; anfractibus $6 \frac{1}{2}$, valde convexis, intermediis subinflatis ; aperturâ minusculâ, vix angulatâ, peristomate late expanso, acutiusculo, albo, marginibus laminầ tenui simplici junctis, columellari parum reflexo.-Long. lin. circa 5 ; diam. maj. 3.

Bulimus nanus, Shuttl. [nec Reeve], Bern. Mitth. 144 (1852)

$\eta \quad$ nanodes, Id., ibid. 289 (1852)
$, \quad \quad, \quad$ Pfeiff., Mon. Hel. iii. 348 (1853)

Buliminus nanodes (pars), Mouss., Faun. Mal. des Can. 115. pl. vi. f. 10, 11 (1872)

Bulimus nanodes (pars), Pfeiff., Mon. Hel. viii. 73 (1876) 
Habitat Teneriffam; in regionibus valde elevatis (præsertim sylvaticis), usque ad $9,000^{\prime}$ s.m. parce ascendens.

Although larger than the osoriensis, this is one of the smallest of the Canarian Bulimi on the robust and more or less barrel-shaped type; and it is one which seems to be peculiar to the elevated districts of Teneriffe,-where it occurs beneath fallen leaves, stones, and logs of wood. I have taken it in the sylvan region above the Agua Mansa, and in the lofty Pinal above Ycod el Alto, as well (amongst the Retamas) on the Cumbre overlooking the Cañadas, - at an altitude of at least 9,000 feet; and it appears to have been found previously both by Blauner and Reiss.

Apart from its small size, as compared at any rate with most of the following members of the group, the $B$. nanodes may be recognized by its obtuse and rather oval outline (the intermediate whorls being a little inflated and very convex), by its surface being more or less coarsely roughened with short groove-like varioles, separated by undulating ridges or reticulations which have the appearance sometimes of merging into granules, by its colour being of a pale but dirty yellowishbrown, and by its aperture being not much enlarged, but with the peristome (the margins of which are joined by a thin and simple intervening lamina) broadly expanded.

\section{Bulimus bæticatus.}

T. rimata, inflate subrotundato-ovata, subtenuis, opaca, grosse subvermiculatim ac subreticulatim (vix granulatim) scabrosostriata, subolivaceo-rufobrunnea ; spirâ brevi, subconcave conicâ, subito attenuatâ, ad apicem ipsum prominulo-papilliformi; anfractibus $6 \frac{1}{2}$, vix convexis sed suturâ profunde incisâ ; aperturâ magnâ, latâ, subrotundatâ, peristomate albo, acuto, expanso, marginibus subapproximatis et laminâ tenui (in medio tenuissimâ)

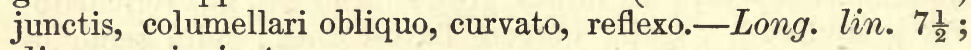
diam. maj. vix 4.

Helix bæticata, Fer., Prodr. 55 (1821)

Bulimus bæticatus, W. et B., Ann. des Sc. Nat. 28. syn. 318 (1833)

$\begin{array}{ll}\quad & \begin{array}{l}\text { d'Orb., in W. et B. Hist. 71. t. 2. f. } 19 \\ (1839)\end{array} \\ & \text { Pfeiff., Mon. Hel. ii. } 79 \text { (1848) }\end{array}$

Buliminus bæticatus, Mouss., Faun. Mal. des Can. 111 (1872)

Bulimus bæticatus, Pfeiff., Mon. Hel. viii. 72 (1876)

Habitat Teneriffam; præcipue in subinferioribus, minus frequens. 
The $B$. boticatus is a species which is peculiar to Teneriffe; and although it has been brought away by most of the naturalists who have visited that island (including Maugé, Webb and Berthelot, d'Orbigny, Blauner, and Grasset), it is nevertheless, so far as my own experience would imply, one of the rarer forms. I possess examples however from the neighbourhood of Sta. Cruz, and others which were taken by Mr. Lowe (during April of 1861) in the Barranco de Majuelo near Garachico.

The large size, and broad, inflated, rounded-ovate outline of the present Bulimus, the spire of which is short and suddenly acuminated (the extreme apex itself being somewhat prominent and papilliform) added to its rich reddish-brown and more or less olivaceous hue, its rather thin substance, its enlarged aperture, and its curious sculpture,- the surface (which is opake) being much roughened by irregular, undulating or somewhat vermiform, subconfluent folds or ridges (which give it a scabrose, rather than a granulated, appearance), will suffice to distinguish it.

\section{Bulimus Tarnerianus.}

T. aperte rimata, elongate oblongo-ovata, vix nitidiuscula, grosse granulatim striata, pallide olivaceo-cornea ; spirâ elongatâ, robustâ, conicâ ; anfractibus 7-8, convexiusculis, suturâ profunde incisâ ; aperturâ sat magnâ, longiusculâ, peristomate sordide albo, expanso, acutiusculo, intus incrassato, marginibus distantibus et sæpius laminâ nullâ junctis, basali cum sinistro angulatim continuo ; columellâ elongatâ, sinuatâ, et plus minus abrupte terminatâ.-Long. lin. 7-8; diam. maj. circa 4.

Bulimus Tarnerianus, Grasset, Journ. de Conch. 348. t. 13. f. 6 (1856)

$$
\text { Pfeiff., Mon. Hel. iv. } 413 \text { (1859) }
$$

Buliminus Tänerianus, Mouss., Faun. Mal. des Can. 109 (1872)

Bulimus Tarnerianus, Pfeiff., Mon. Hel. viii. 72 (1876)

Habitat Teneriffam; in intermediis sylvaticis, locisque valde elevatis, hinc inde vulgaris. An a $B$. tabido, Shuttl., vere distinctus?

A Teneriffan Bulimus, occurring more particularly in damp and wooded spots of intermediate and rather lofty altitudes, but ascending also (like the $B$. nanodes) into the region of the Retamas,-to an elevation of about 9,000 feet. I met with it principally, however, within the forest districts, properly so-called,- - such as at the Agua Mansa, the Agua Garcia, Las Mercedes, the wooded slopes above Taganana, and in the Pinal above Ycod el Alto; and it is stated by Mousson to have been 
found by Blauner and Fritsch in the Taganana ravine, as well as by Grasset on the 'Cumbre' (the one, I presume, overlooking the Cañadas).

The B. Tarnerianus is rather a large species, of an elongateovate outline and with the spire somewhat acute; and the greater portion of its surface (which is almost opake, and of a pale olivaceo-corneous hue) is coarsely sculptured with oblique plicate striæ which are more or less broken-up into elongated (though very irregular and unequal) granules. It columella is rather long and sinuate, and generally abruptly terminated behind (which causes the aperture to appear a little angulated); and the margins of its peristome (which is of a dingy white) are far apart, and for the most part altogether unconnected by an intervening lamina.

\section{Bulimus tabidus.}

Bulimus tabidus, Shuttl., Bern. Mitth. 143 (1852) Pfeiff., Mon. Hel. iii. 347 (1853)

Buliminus tabidus, Mouss., Faun. Mal. des Can. 114. t. 6. f. 9 (1872)

Bulimus tabidus, Pfeiff., Mon. Hel. viii. 71 (1876)

Habitat Teneriffam ; juxta Sta. Cruz (sec. cl. Shuttleworth) parce repertus. An a $B$. Tarneriano, Grasset, distinctus?

This is one of the few Bulimi of which I do not possess an example sufficiently authentic to be relied upon; but, judging from the diagnosis and figure which are given by Mousson, I should have said that it was absolutely inseparable from the $B$. Tarnerianus, which is likewise peculiar to Teneriffe. Indeed Shuttleworth's original description of it, in 1852, is, I may add, in precise accordance also with the subsequently-published $B$. Tarnerianus; nevertheless, as Mousson expressly states that he had received a type of the tabidus from Shuttleworth himself, and he had an abundance of specimens of the Tarnerianus (many of which I had sent to him) to compare with it, I presume that he must have satisfied himself that the two forms are not absolutely identical. But since both the diagnoses of it to which I have access (namely Shuttleworth's and Mousson's) tally with the $B$. Tarnerianus, the characters of which have already been pointed out, I need not attempt to sum them up afresh in this place. Suffice it to observe that Shuttleworth makes the following remark concerning his B. tabidus : - An varietas $B$. obesati, W. et B. ?; sed minor, gracilior, anfr. convexioribus, præsertim sculpturâ satis differre videtur.' ${ }^{1}$

\footnotetext{
${ }^{1}$ In support of my conjecture that the B. tabidus and Tarnerianus are in reality one and the same species, I may just add that although Mousson cites the former as having been taken by myself at Taganana, all the Taganana
} 


\section{Bulimus anaga.}

Bulimus anaga, Grasset, Journ. de Conch. v. 347. t. 13. f. 5. (1856)

Buliminus " Pfeiff., Mon. Hel. iv. 414 (1859) (1872)

Bulimus anaga, Pfeiff., Mon. Hel. viii. 71 (1876)

Habitat Teneriffam; inter rupes ad promontorium Anaga invenit cl. Grasset.

It would appear as if the present Bulimus (of which I have not been able to procure a type for comparison), the B. tabidus, and the B. Tarnerianus are so closely allied inter $s e$ as to be barely separable from each other. I have already stated that, judging from at all events the published diagnoses, the $B$. tabidus does not seem to me to be distinguishable from the Tarnerianus; and as regards the $B$. anaga, Mousson closes his remarks concerning it as follows:- 6 Cette particularité le rapproche du B. Tarnerianus, dont il ne diffère que par sa forme plus ventrue.' And, with reference to the $B$. anaga as compared with the tabidus, he adds ' Je dois un échantillon authentique de cette espèce à la bonté de M. Tarnier. On serait tenté de la joindre au B. tabidus, Shuttlw., dont il partage la forme générale.' He then points out in what the $B$. anaga (judging from the single type to which he had access) seemed to differ from the tabidus, - the main characters consisting, as it appears to me, in the shell being ungranulated except at the base, and in the connective lamina between the margins of the peristome being developed (as is liable to be the case in nearly all the species) into a small tubercle at the right-hand insertion.

\section{Bulimus obesatus.}

T. rimata, elongate oblongo-ovata, inflatiuscula, vix nitidiuscula, grosse, dense, et irregulariter plicato-striata (striis haud granulosis, et vix etiam interpunctatis), rufo-brunnea; spirâ subconcave ovato-conicâ, apice ipso prominulo-subpapilliformi ; anfractibus 7, planiusculis sed suturâ distincte incisâ ; aperturâ longiusculâ, peristomate albo, expanso, acutiusculo, intus incrassato, marginibus distantibus, aut omnino separatis aut laminâ tenuissimâ junctis, basali cum sinistro vix angulatim continuo ; columellâ elongatâ, subsinuatâ.-Long. lin. 8; diam. maj. 4.

examples in my collection belong nevertheless, most unmistakeably, to the Tarnerianus; and indeed they were so labelled by Mousson himself in the particular box which is appropriated to them, and which he afterwarcls returned to me. 
Helix obesata (pars), Fer., Prodr. 451 (1821)

Bulimus obesatus, W. et B., Ann. des Sc. Nat. 28. syn. 315

$\# \quad \begin{aligned} & \text { d'Orb., in W. et B. Hist. 68. t. 2. f. } 20 \\ & (1839)\end{aligned}$
$\quad$ Pfeiff., Mon. Hel. ii. $117(1848)$

Buliminus obesatus (pars), Mouss., Faun. Mal. des Can. 112 (1872)

Bulimus obesatus, Pfeiff., Mon. Hel. viii. 70 (1876)

Habitat Canariam Grandem; in intermediis, ad El Monte, et cæt., sat vulgaris. Etiam in statu semifossili reperitur.

This is the common Bulimus, on the large and barrelshaped type, in the intermediate and but slightly elevated districts of Grand Canary, - where it is universal throughout the region of El Monte and on the calcareous hills above Las Palmas, localities in which it was likewise met with by Webb and Berthelot, as well as by Fritsch. Many examples of it are also now before me which were taken by Mr. Watson, a certain number of which are in a subfossilized condition.

In its elongate-ovate outline and somewhat lengthened columella, the $B$. obesatus is on much the same pattern as the $B$. Tarnerianus of Teneriffe; nevertheless it is a little larger, broader, and more ventricose, with its volutions flatter, and with the extreme apex of its spire rather more prominently papilliform. The striæ, also, of its surface, although, coarse and irregular, are nearly simple,-being hardly, if indeed at all, broken-up into what might be defined as elongated granules.

\section{Bulimus interpunctatus, n. sp.}

T. rimata, angustule cylindrico-oblonga, subopaca, dense irregulariter striata (striis vix granulosis, sed, præcipue in anfr. intermediis, subfractis necnon punctis interjectis auctis) pallide brunnea (interdum subflavescenti-albescens); spirâ longiusculâ, versus basin fere cylindricâ; anfractibus $7 \frac{1}{2}$, planiusculis, suturâ interdum pallido-marginatâ ; aperturâ angustulâ, peristomate albo, expanso, acutiusculo, intus incrassato, marginibus vel omnino separatis, vel laminâ tenuissimâ junctis, basali cum sinistro

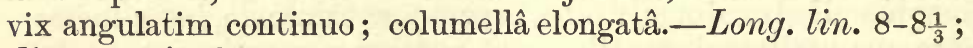
diam. maj. $3 \frac{1}{2}$.

Buliminus obesatus (pars), Mouss., Faun. Mal. des Can. 112 (1872)

Habitat Canariam Grandem ; in regione calcareâ versus occidentem insulæ, inter oppidula Lagaete et Galdar, mense Aprili 1858, repertus. 
Several examples of this large Bulimus which were taken by Mr. Lowe and myself in the calcareous district between Lagaete and Galdar, on the western side of Grand Canary, were referred by Mousson (to whom I sent them for inspection) to the $B$. obesatus, W. et B. ; and, curiously enough, he does not appear to have separated them at all (not even as representing a 6 variety') from some normal ones of that species, which I likewise forwarded to him, and which were met with in the region of $\mathrm{El}$ Monte and towards Las Palmas. Yet it seems to me that they are so totally different from the true obesatus-type that I cannot but regard them as specifically distinct; and I have consequently defined them as such, under the above title.

As regards mere length, the $B$. interpunctatus does not differ much from the obesatus; nevertheless from being narrower and more cylindrical, it has the appearance at first sight of being a little longer than that species. It is, however, conspicuously more parallel in outline and less ventricose,-its spire (which is less papilliform at the apex) being more strictly cylindric posteriorly, and its basal volution being less inflated and convex. Its colour too is apparently paler (or less brown), its surface is somewhat more decidedly opake, its aperture is perhaps not quite so broad (the upper and lower margins being appreciably less wide apart), and its sculpture is different,-the oblique striæ (which perhaps are not quite so coarse) being, particularly on the intermediate whorls, separated from each other by rather large but shallow, irregular, and ill-defined punctures.

\section{Bulimus Lowei, n. sp.}

T. rimata, obtuse cylindrico-ovalis, subopaca (sæpius corrosa), dense irregulariter striata (striis, præcipue in anfr. intermediis, irregulariter subgranulato-fractis aut rugulosis, lineolisque spiralibus minutissimis interruptis hinc inde obsoletissime decussatis), olivaceo-brunnea; spirâ semigloboso-conicâ, obtusâ; anfractibus $6 \frac{1}{2}$, convexiusculis, suturâ horizontali (nec obliquâ); aperturâ rotundato-ovali, peristomate sordide albo, anguste expanso, intus incrassato, marginibus distantibus et laminâ tenui (ad insertionem dextram sensim subtuberculato-incrassatâ) junctis, basali cum sinistro rotundate-continuo; columellâ longiusculâ, latâ, curvatâ, obliquâ.-Long. lin. $7 \frac{1}{2}$; diam. maj. $3 \frac{1}{2}$.

Habitat Teneriffam; in montibus mox supra Sta. Cruz, ad rupem versus El Campo adhærens, circa 2,000' s. m., parce invenit Revdus. R. T. Lowe.

The three examples from which the above diagnosis has been compiled were taken by Mr. Lowe (on the 22nd of February, 1859 ), on the mountains above Sta. Cruz, in Teneriffe, in the 
direction of El Campo, - at an elevation of about 2,000 feet; and it seems to me that it is quite impossible to affiliate them with any of the species which are included in the present enumeration. In general size they may be said to be a little smaller than the $B$. obesatus of Grand Canary; but their outline is nevertheless quite different,-it being blunt, cylindrico-oval, and obtuse, with the apex of the spire not drawn-out (or papilliform), with the volutions (although not very convex) less flattened, with the suture much more horizontal (or less oblique), with the columella wider and more curved, and with the margins of the peristome (which is less broadly expanded, and more rounded, or less angulose, posteriorly) more evidently joined by an intervening lamina, which is perceptibly thickened (though scarcely into a decided tubercle) at the upper insertion. The sculpture too is different from that of the $B$. obesatus, - the striæ, particularly on the intermediate whorls, being more broken-up, and roughened, into granuliform fragments, intersected here and there by excessively minute and interrupted obsolete spiral lines; though as the surface is a good deal corroded, or as it were eaten-into, this character is less easy of observation.

\section{Bulimus Bertheloti.}

T. (magna) rimata, elongate oblongo-cylindrica, nitidiuscula, levissime striatula (striis inæqualibus sed fere simplicibus, et hinc inde etiam obsoletis), clare albido-cornea; spirâ elongatâ, postice omnino cylindricâ, apicem versus subexcavate conicâ, ad apicem

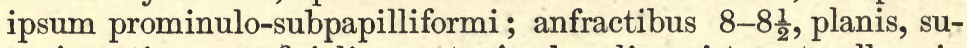
turâ postice superficiali ; aperturâ subovali, peristomate albo, vix late expanso, intus (præsertim versus angulum superiorem) incrassato, marginibus subapproximatis et callo sublineari (in medio sæpius subevanescente, sed ad insertionem dextram in tuberculum, ab angulo incise disjunctum, aucto) junctis, basali cum sinistro rotundate (nec angulatim) continuo,-Long. lin. $10 \frac{1}{2}$; diam. maj. 4.

Bulimus obesatus (pars), d'Orb., in W. et B. Hist. 68 (1839)

Bertheloti, Pfeiff., Mon. Hel. ii. 64 (1848)

Buliminus Bertheloti, Mouss., Faun. Mal. des. Can. 113 (1872)

Bulimus Bertheloti, Pfeiff., Mon. Hel. viii. 92 (1876)

Habitat Gomeram, et Hierro; in declivibus saxosis paululum elevatis, sub lapidibus et inter rupes, parum vulgaris.

With theexception of the (equally Gomeran) B. Consecoanus, this is the largest of the Canarian Bulimi; and although it is 
one which is more particularly characteristic of Gomera, where it abounds beneath stones on the rocky slopes above San Sebastian, I also met with it (more sparingly) in Hierro likewise,--from whence, however, the only quite matured example which I possess (and which I would cite as representing a 'var. $\beta$. subsimplex') differs from the Gomeran ones in being a trifle smaller, and in having the intervening callosity which unites the margins of its peristome (which may possibly be the result of mere accident, or individuality) obsolete.

The $B$. Bertheloti has very much the cylindrical contour and flattened volutions of the Grand-Canarian B. interpunctatus (with the rather more papilliform apex, however, of the $B$. obesatus of that same island), of which indeed it may be looked upon as the Gomeran representative. Nevertheless it is a considerably larger shell, its surface is more shining, very much more finely and lightly sculptured (the striæ moreover being almost simple, and in certain places nearly evanescent), and of a paler, clearer, and whiter hue; and the margins of its peristome are generally united by a somewhat line-like callosity, which is apt to be interrupted in the centre, but which is thickened at the upper insertion into a usually distinct tubercle, - which is separated from the angle itself (as in the B. helvolus, badiosus, and Consecoanus) by a minute incision or gash. Its suture (except towards the apex) is extremely superficial, and often a little uneven or lacerated

\section{Bulimus savinosa, $\mathrm{n}$. sp.}

T. (magna) rimata, late ovata, inflatiuscula, nitidiuscula, dense striatula (striis in anfr. posterioribus fere simplicibus, sed in subapicalibus subgranulatim fractis), pallide olivaceo-cornea; spirâ semiovali-conicâ, ad apicem ipsum prominulosubpapilliformi ; anfractibus 8, planis; aperturâ latiusculâ, rotundato-subovali, peristomate albo, late expanso, acuto, marginibus late separatis et laminâ subnullâ junctis, inter se rotundate (nec angulatim) continuis, columellari late reflexiusculo; columellâ breviusculâ, latâ, curvatâ, subsinuatâ. Long. lin. $10 \frac{1}{2}$; diam. maj. $5 \frac{1}{4}$.

var. $\beta$. inflatiusculus [an species distincta?] -anfractibus 7 , in spirâ subconvexioribus, aperturâ vix longiore, peristomate subcrassiore sed tamen minus late expanso, marginibus paululum minus distantibus et callo sensim distinctiore junctis, columellari minus reflexo, columellâ sensim minus latâ. [ins. Gomera.]

Habitat Gomeram, et Hierro, rarissíme ; in illâ statum ' $\beta$. inflatiusculus' assumens. 
The three examples from which I have compiled the above diagnosis were all of them taken by Mr. Lowe, - two (which I have regarded as typical of the species), on the 20th of April 1858, towards Savinosa, in the forest district of El Golfo, on the western side of Hierro; and the other (the 'var. $\beta$. inflatiusculus' of the present enumeration,' and which may perhaps represent in reality a closely-allied species), on the 21 st of April 1861, on a rock immediately below the Cumbre in Gomera, on the mountains above San Sebastian. My own belief is, that only a single species is indicated by these three individuals which are now before me,-the few small points of difference which are displayed by the one from Gomera being suggestive, as I cannot but think, of a mere race, or modification, peculiar to that island; though, at the same time, it is evident that further material can alone decide this question.

The large size, and broad, ovate, inflated outline of the $B$. savinosa, added to the prominent, subpapilliform apex of its spire (the volutions of which are a good deal flattened), its wide aperture, and acute, broadly-expanded peristome (the margins of which are far apart, and well-nigh unconnected by an intervening lamina), will sufficiently characterize it. Its surface is rather glossy and simply striated (except on the subapical whorls, where the striæ are more or less broken-up and obsoletely granulose); its columella is broad, short, and rather sinuated; and its colour is a pale olivaceo-corneous.

The single Gomeran example which is now before me (embodying the 'var. $\beta$. inflatiusculus' of the above diagnosis), and which is somewhat worn and decorticated, has only 7 whorls instead of 8 , and the volutions of its spire are not so completely flattened as in the Hierro ones. Its aperture, too, is, if anything, a trifle longer ; its peristome (the margins of which are not quite so far apart, and are more evidently joined by a thin intervening lamina) is less broadly expanded and less acute; and its columella, as seen internally, is not quite so widely developed.

\section{Bulimus Consecoanus.}

T. (magna) minute rimata, fere subclausa, elongate ovatoconica, solida, opaca, inæqualiter plicato-striata (striis hinc inde, sed præsertim in anfr. intermediis, punctato- et subgranulosoconfuse fractis), vel plumbeo- vel flavescenti-cornea strigisque (vel albidis vel flavo-albidis) valde irregularibus et plus minus confluentibus obscure ornata ; spirâ elọgatâ, conicâ, apice acuto, prominulo-subpapilliformi ; anfractibus 9, planiusculis, suturâ 
sublaceratâ ; aperturâ parvulâ, peristomate sordide albo, anguste expanso, obtuse incrassato, marginibus convergentibus et sæpius (nec semper) callo sublineari (in medio obsoleto, sed ad insertionem dextram in tuberculum, ab angulo incise subdisjunctum, aucto) junctis, dextro versum angulum superiorem et (rarius) etiam columellari mox ante insertionem magis incrassatis.-Long. lin. 9-11; diam. maj. vix 5.

Bulimus Consecoanus, Fritsch, in litt.

Buliminus Consecoanus, Mouss., Faun. Mal. des Can. 118. pl. 6. f. 12, 13 (1872)

Bulimus Consecoanus, Pfeiff., Mon. Hel. viii. 85 (1876)

Habitat Gomeram ; et recens et semifossilis, versus occidentem insulæ, hinc inde vulgaris.

This fine species, which seems to be peculiar to Gomera, is (on the average) the largest of all the Bulimi which have been found hitherto in the Canarian archipelago; though the (more cylindrical) $B$. Bertheloti very nearly equals it in length. It was taken in profusion by Mr. Lowe, both in a dead (although recent) and subfossilized state, near Hermigua; and it was met with (according to Mousson), at Mancha Yerba, by Fritsch.

Independently of its large size, solid substance, elongateovate outline, and conical, apically acute spire, the $B$. Consecoanus may be distinguished by its numerous and rather flattened volutions, and by its relatively somewhat small aperture,- the peristome of which is only narrowly expanded, but nevertheless thick, rim-like, and obtuse, with the upper and lower margins usually joined by an intervening callosity which is more or less obsolete in the centre, but raised at the right-hand insertion into an elongated tubercle which is partially separated by a gash from the angle itself. Its umbilical chink is well-nigh closed-up ; its surface is opake, rather pale, and of either a yellowish- or a corneous-brown (often with a faint plumbeous, or even purplish, tinge), but more or less obscurely variegated with very irregular, subconfluent whitish dashes and lines; and its sculpture is a little peculiar,- the oblique costate striæ (which are sometimes tolerably sharp, close, and regular, and at others obtuse and fold-like) being here and there broken-up, particularly on the intermediate whorls, into unequal and confused punctures and granules.

The $B$. Consecoanus belongs to the same group as the Mediterranean $B$. pupa, Linn., which is found more particularly in Sicily and Greece; but, as contrasted with that species, it is comparatively gigantic, its whorls are more numerous, its outline is less cylindric (the spire being more regularly conical and apically-acute), the right-hand margin of its peristome is more 
outwardly-rounded, the tubercle of its ventral callus is very much less developed, and both its colour and its sculpture are different.

\section{Bulimus servus.}

Buliminus servus, Mouss., Faun. Mal. des Can. 118. pl. 6. f. 14 (1872)

Bulimus servus, Pfeiff., Mon. Hel. viii. 94 (1876) lectus.

Habitat Gomeram ; in statu semifossili (?) a Dom. Fritsch

I have not been able to procure a type of this Bulimus, which was described by Mousson from some examples which were obtained by Fritsch (in a dead and apparently subfossilized state) in Gomera; but, judging from his published diagnosis, it seems to me to differ in no respect from the $B$. Consecoanus except in being smaller and a trifle more shortlyconical, and in its whorls being somewhat less numerous; and I should doubt therefore whether it represents more in reality than a form, or local modification, of that species. 'Les individus de cette espèce,' says Mousson, 'qu'a recueillis M. de Fritsch étaient morts, et paraissent appartenir à une faune éteinte. La forme totale rappelle les grandes variétés du $B \cdot p u p a$; mais le cône spiral est bien plus acuminé et commence dès le premier tour ; le bord droit de l'ouverture est plus régulièrement arqué et son insertion avance sur l'avant-dernier tour; ceci et l'abaissement du dernier tour rend l'ouverture plus petite et plus régulièrement ovale; le péristome n'est que faiblement réfléchi et obtus ; la surface a une sculpture très nette, mais fine, costulostriée. C'est une bonne espèce, que ne se rapproche d'aucune autre provenant des Canaries, excepté du B. Consecoanus.'

\section{Bulimus flavoterminatus, n. sp.}

T. minute rimata, obtuse ovato-oblonga, solida, opaca, grosse et valde irregulariter striata, sordide alba sed gradatim versus apicem rufulo-lutescens ; spirâ conicâ, apice vix subpapilliformi ; anfractibus $7 \frac{1}{2}$, planiusculis; aperturâ parvulâ, peristomate anguste expanso, obtuse incrassato, marginibus callo simplici (nec tuberculifero) junctis.-Long. lin. 8; diam. maj. 3.

Bulimus pupa, W. et B. [nec Linn.], in litt. $" \quad "$ d'Orb. [nec Linn.], in W. et B. Hist. 69 (1839)

Buliminus pupa, Mouss., Faun. Mal. des Can. 119 (1872)

IIabitat 'Canaries' (teste d'Orbigny), sec. W. et B.; mihi non obvius.

An original type of this Bulimus is in the d'Orbignyan col- 
lection at the British Museum, but the species which it represents is certainly not referable (as Webb and Berthelot appear to have supposed) to the B. pupa, Linn., of southern Europe,Sicilian examples of which I possess in tolerable abundance; for, apart from numerous other differences, its aperture has no indication whatsoever of the coarse and elevated tooth-like callosity which gives so marked a character to the ventral paries of that species, near to the insertion of its upper lip. Nevertheless, independently of this very important distinction, it seems to belong to much the same group as the B. Consecoanus,-its relatively small, short, and narrow aperture, in conjunction with its solid substance, coarsely but irregularly striated surface, and pale, somewhat cinereous hue (which, however, in this particular species, shades-off gradually into a clear reddish-yellow towards the apex of the shell), implying an unmistakeable amount of affinity with that (very much larger) Gomeran Bulimus. No precise island having been cited for it either by Webb and Berthelot or by d'Orbigny, one cannot feel altogether satisfied that it may not have been introduced (like so many of Webb's species) into the Canarian catalogue on evidence which is not trustworthy; nevertheless since it certainly is not identical with the $B$. pupa of Mediterranean latitudes, and it would appear primâ facie to have a certain relationship with the $B$. Consecoanus, I hardly see that we should be justified in refusing it admission into the fauna; and more particularly so, as I have not been able to affiliate it with any known member of the genus from any other country.

\section{Genus 11. STENOGYRA, Shuttl.}

\section{Stenogyra decollata.}

\section{Helix decollata, Linn., Syst. Nat. (edit. 10), 773 (1758)}

1 Before leaving the Bulimi of this archipelago, I may just call attention to the B. Terverianus, W. et B. ( $=B$. scalarioides, Reeve), - a Mogador species which was cited by Webb and Berthelot (Syn. 326), and subsequently by d'Orbigny, as Canarian. Original examples which are in the British Museum, and which are still labelled as Canarian, shew its affinities to be altogether remote from everything in these islands,--its very acutely, strongly, and regularly, but remotely, ribbed surface giving it a character peculiarly its own; yet even Pfeiffer does not appear to have found out until the publication of the 8th volume of his Monograph, during the present year, that it belongs in reality to the fauna of Morocco, and not to that of the Canaries. However, it supplies another instance of the incautious and reckless manner in which Webb accepted as 'Canarian,' without enquiry, almost everything that was sent to him as such,-even from such collectors as M. Terver, of Lyons, whose researches amongst the consignments of dried orchil, the origin of which was invariably obscure and often entirely unknown, have added so much confusion on the subject of geographical distribution that it is extremely doubtful whether the mischief will ever be completely neatralized. 
Bulimus decollatus, Lowe, Cambr. Phil. Soc. Trans. iv. 62 , $\quad$ " Alb., Mal. Mad. 54. t. 14. f. 16,17 (1854)

" $\quad$ Morel., Hist. Nat. des Açor. 196 (1860) Stenogyra decollata, Mouss., Faun. Mal. des Can. 120 (1872)

Bulimus decollatus, Morel., Journ. de Conch. xiii. 238 (1873)

Watson, ibid. 222 (1876)

Habitat Lanzarotam, Fuerteventuram, Canariam Grandem, Teneriffam, et Gomeram ; in aridis apricis, præcipue maritimis et præcipue (sed non solum) inferioribus, degens. Etiam semifossilis in Lanzarota et Canaria Grandi parce occurrit.

This widely distributed Mediterranean Stenogyra (which exists also in the Azores, Madeiras, and Cape Verdes) will probably be ascertained, sooner or later, to be quite universal at the Canaries, though I am not aware that it has been observed hitherto either in Palma or Hierro; but in the other five islands of the archipelago-namely Lanzarote, Fuerteventura, Grand Canary, Teneriffe, and Gomera-I have myself met with it ; and it is recorded likewise from Graciosa (off the extreme north of Lanzarote), as well as from Lobos, off the north of Fuerteventura. It is more particularly to be found in arid spots of a low elevation, towards the coast; nevertheless this is by no means invariably the case, for when in Fuerteventura I obtained it around Sta. Maria Betancuria as well as on the Monte Atalaya.

Mr. Watson, in referring to the widely acquired range of this Stenogyra, says (Journ. de Conch. 222; 1876) that it has been ' recently introduced into the Canaries;' but I scarcely think that there is sufficient evidence to warrant a positive assertion to that effect. So far as my own experience is concerned, I should say that it has a greater appearance at the Canaries of being aboriginal than it has in any of the other Groups ; indeed near Arrecife in Lanzarote, as well as near Las Palmas in Grand Canary, I met with it in a condition which is thoroughly and unmistakeably subfossilized,-which certainly would not have been the case if the species had but lately been naturalized in the archipelago. Perhaps it is, however, that the latitude of the Canaries appears too southern to enter within its supposed geographical province; but, be this as it may, that cannot alter the fact to which I have just called attention, to say nothing of the discovery of the species by M. de Cessac at the Cape Verdes, which is nearly a thousand miles still further to the south. ${ }^{1}$

1 Although I think that it can hardly be looked upon as a member of the Canarian fauna, I may nevertheless call attention in this place to the Bulimus 


\section{Genus 12. PUPA, Drap.}

(§ Gibbulina, Beck.)

\section{Pupa macrogira.}

Pupa macrogira, Mouss., Faun. Mal. des Can. 122 (1872) Pfeiff., Mon. Hel. viii. 349 (1876)

Habitat Gomeram ; a Dom. Fritsch semel tantum (sc. in statu semifossili, necnon valde mutilata) lecta.

A single example of a large Pupa, which is described as being more conical (or less cylindric) than the $P$. dealbata, was found by Fritsch in Gomera, in a subfossil state and much mutilated, and was treated by Mousson as a new species,- - under the name of $P$. macrogira. Having had no opportunity of inspecting the type, it may be sufficient to transcribe Mousson's remarks in which he calls attention to the particular features which serve to separate it from the $P$. dealbata. 'M. Fritsch n'a trouvé qu'un seul individu subfossile, malheureusement mutilé, de cette espèce, qui ne s'accorde pas avec la dealbata en toutes choses et qui me paraît constituer une seconde espèce voisine. Les dimensions bien plus fortes, la forme très ramassée, conico-cylindracée et non simplement cylindrique, le dernier tour un peu concave au-dessus de la ligne dorsale, au lieu d'être convexe, la base plane, faiblement conique vers le centre, tandis qu'elle est convexe dans l'autre espèce, même au jeune âge, enfin la perforation minime, à la place de l'ombilic que présentent les individus non adultes de la dealbata: tous ce caractères suffisent pour justifier une séparation. L'ouverture étant détruite je ne puis en indiquer que le contour quadrangulaire, que dessine la section du dernier tour' (l.c. p. 122 ).

\section{Pupa dealbata.}

\section{Pupa dealbata, W. et B., Ann. des Sc. Nat. 28. syn. 321} (1833)

(or Subulina) striatella, Rang. (Pfeiff., Mon. Hel. vi. 236), a few dead and mutilated examples of which were obtained by Mr. Lowe, during February of 1858, amongst some refuse in Mr. Hamilton's garden at Sta. Cruz. The S. striatella is a species which occurs in Princes Island, Senegal, and indeed at various points on the western coast of Africa; and since it belongs to a type of form (including the West-Indian S: octona, Chemn.) which is eminently liable to become transported accidentally through indirect human agencies, it may very possibly have been imported into Teneriffe, and yet may have not succeeded in establishing itself there. At any rate, as I have no certain evidence on this point, I cannot ignore the species altogether; but I think it sufficient to draw attention to it in the present foot-note. I have already given, at p. 206, both a diagnosis of the S. striatella and certain observations concerning it; so that I need not now do more than just repeat that it was met with at Madeira, by the late Mr. Bewicke, under circumstances almost exactly similar to those under which it was collected at Teneriffe,-namely (dead and somewhat decorticated), in a garden near Funchal. 
Pupa dealbata, d'Orb., in W. et B. Hist. 74 (1839)

, " $\quad$ Pfeiff., Mon. Hel. ii. 302 (1848)

" $\quad$ Mouss., Faun. Mal. des Can. 121 (1872)

Habitat Fuerteventuram, Canariam Grandem, Teneriffam, Gomeram, et Palmam ; sub lapidibus, præcipue in aridis inferioribus, late sed vix copiose diffusa.

This large, white, and edentate Pupa (so enormous as compared with any other member of the genus from these Atlantic archipelagos, with the exception of the subfossil $P$. macrogira, Mouss., from Gomera) is very widely spread at the Canaries, where, although it has not yet been observed in either Lanzarote or Hierro, it will probably be found to be universal. Apart from its gigantic size, and its white, opake, and densely and coarsely striated surface, it may be known by its parallel outline and blunt apex, by its volutions being flattened, or but very slightly convex, and by its aperture (which is semi-oval, and has the peristome thickened, although not continuous, and a good deal developed) being perfectly edentate.

The present $P$ upa appears to belong to a large type of form, of which there are representatives in Africa and the Isle of France. Indeed I possess a monstrous species (the P. fusus, Lam.) from the latter, which, although very much larger and more elongate, is greatly suggestive of the $P$. dealbata. Nevertheless it differs materially in having an obtuse ventral plait developed near the angle of the lip.

The $P$. dealbata was taken by Mr. Lowe and myself in the region of El Monte, and near Galdar, in Grand Canary (in which island it has been found abundantly also by Mr. Watson); as well as around Sta. Cruz, the Puerto Orotava, and Garachico in Teneriffe; and in the Barranco de Nogales, the B. de Galga, the B. de San Juan, the B. de Herradura, and above Buenavista, in Palma : and, according to Mousson, it was met with by Fritsch in Gomera and Fuerteventura. In Gomera it was obtained also by Mr. Lowe,- at Hermigua.

\section{(§ Truncatellina, Lowe.)}

\section{Pupa atomus.}

Pupa atomus, Shuttl., Bern. Mitth. 144 (1852)

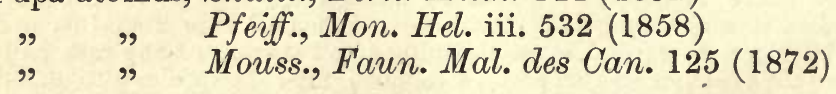

Habitat Teneriffam; a D. Blauner sub foliis detecta.

Having seen no type of this very diminutive $P u p a$, which was found by Blauner in Teneriffe, I can offer no remarks on its specific peculiarities beyond what may be gathered from the 
short diagnosis of it which was given by Shuttleworth. But as it is said to be closely allied to the European $P$. minutissima, Hartm., 'mais encore plus petite, plus fortement costulée, et formé d'un moindre nombre de tours,' jt would seem in all probability to have much in common with the subfossil $P$. linearis of the Madeiran Group, even if it be not absolutely identical with it. Indeed it is quite evident that the linearis, Lowe, and the atomus, Shuttl., together with the minutissima, Hartm., of Europe, and the molecula, Dohrn, from the Cape Verde archipelago, are intimately connected. However I have already recorded my conviction that at any rate the first and last of these four species are distinct from each other; but it remains yet to be ascertained whether the Canarian $P$. atomus can be regarded as a geographical modification of either of them.

\section{Pupa microspora.}

Pupa microspora, Lowe, Ann. Nat. Hist. ix. 275 (1852)

$" \quad$ Id., Proc. Zool. Soc. Lond. 207 (1854)
$"$ edentata var., Paiva, Mon. Moll. Mad. $119(1867)$
$"$ microspora, Mouss., Faun. Mal. des Can. 124 (1872)
" $\quad$ Pfeiff., Mon. Hel. viii. 357 (1876)

Habitat Teneriffam, et Palmam ; in sylvaticis editioribus, ad frondes filicum humidas, a meipso copiose inventa.

The little $P$. microspora, which is so abundant at a high elevation in the damp sylvan districts of Madeira, and which is recorded also from the Azores, was captured by myself in considerable profusion in the Canarian archipelago,-namely at Las Mercedes, Ycod el Alto, \&c., in Teneriffe, and on the ascent to the Cumbre above Buenavista in Palma. My examples were nearly all obtained from off the fronds of ferns, while brushing for insects, - a fact which implies a modus vivendi precisely similar to what I have observed in the Madeiran Group. The characters of the species have been already so fully pointed out at p. 208 of this volume, that I need not again allude to them.

\section{(§ Gastrodon, Lowe.)}

\section{Pupa fanalensis.}

Pupa fanalensis, Lowe, Ann. Nat. Hist. ix. (1852)

$$
\begin{gathered}
" \text { Id., Proc. Zool. Soc. Lond. } 208 \text { (1854) } \\
" \quad \text { umbilicata, var., Paiva, Mon. Moll. Mad. } 121(1867) \\
" \quad \text { anconostoma (pars), Pfeiff., Mon. Hel. viii. } 370(1876) \\
\text { G } G
\end{gathered}
$$


Habitat Teneriffam, et Palmam; ad truncos laurorum, in sylvaticis editioribus, degens.

I have already pointed out, at p. 209 of this volume, what the exact characters are which distinguish the present $P u p a$ from the 'var. $\beta$. anconostoma' of the P. umbilicata; and I have also stated that there can be no doubt whatsoever that it is identical with Mousson's P. debilis. Its mode of life too is entirely similar in the Madeiran and Canarian archipelagos,the species being pre-eminently indigenous, and attached to the damp sylvan districts of a high altitude, where it occurs for the most part amongst moss and lichen on the trunks of trees, particularly the laurels. Under such circumstances it was met with by Mr. Lowe and myself in Teneriffe and Palma; namely in the wood of Las Mercedes near Laguna, in the dense forest region above Taganana, at the Agua Mansa, and near Ycod el Alto, of the former, and the Barranco de Agua and the Barranco de Galga, as well as on the ascent of the Cumbre above Buenavista, of the latter.

\section{Pupa umbilicata.}

Pupa umbilicata [var.], Drap., Tabl.des Moll.58. 5 (1801) Helix anconostoma, Lowe, Cambr. Phil. S. Trans. iv. 62. t. 6 . f. 30 (1831)

Pupa anconostoma, Pfeiff., Mon. Hel. ii. 314 (1848)

Lowe, Proc. Zool. Soc. Lond. 208 (1854)

" umbilicata var., Paiva, Mon. Moll. Mad.121 (1867)

" anconostoma, Mouss., Faun. Mal. des Can. 123 (1872)

Habitat Fuerteventuram, Teneriffam, et Hierro ; in inferioribus (præcipue cultis, necnon ad muros) hinc inde vulgaris.

In my notes on the occurrence of this Pupa in the Madeiran Group (vide, ante, p. 210) I stated that the particular aspect which it would appear to assume throughout these Atlantic archipelagos, and which corresponds with Mr. Lowe's $P$. anconostoma, does not seem to me to embody characters of sufficient importance or constancy to be treated as specifically distinct from the ordinary one of more northern latitudes. Indeed, after comparing it with a long array of examples from different parts of Europe, the only points of divergence that I can detect consist in the somewhat less development of the ventral plait and of the peristome; whilst even these are by no means free from variation. Nevertheless since on the average the tooth just referred to is appreciably reduced in dimensions (so as to appear, for the most part, more decidedly separated from the angle of the lip), and the rim of the aperture is just perceptibly less widened, we may I think regard the $P$. an- 
conostoma as at all events a slight geographical phasis of the umbilicata, and treat it accordingly; but I fail to perceive that it merits any further degree of separation.

As thus understood, the $P$. umbilicata (which is represented in the Canarian Group by only the 'var. $\beta$. anconostoma') has been detected hitherto in Fuerteventura, Teneriffe, and Hierro ; but we may be tolerably sure that future researches will bring it to light elsewhere in the archipelago. As at Madeira, it is essentially characteristic of the cultivated districts, - often abounding about old walls and other buildings, amongst the Cactus-grounds, and elsewhere around the enclosures and towns. In Teneriffe it was met with in profusion by Mr. Lowe on a wall between the Puerto Orotava and Realejo, as well as by the Baron Paiva at Laguna and Souzal ; and I obtained it under similar circumstances in Hierro. We did not find it in the other islands, but Mousson records its discovery in Fuerteventura by Fritsch.

I have little doubt that the Pupa which was described by Dr. H. Dohrn from the Cape Verdes, as the P. Milleri (a title which has subsequently been altered by Pfeiffer into P. Dohrni, the name Milleri having been preoccupied), is but another very slight geographical modification of the widely-spread $P$. umbilicata (which has established itself also even at St. Helena); though, out of deference to the opinion of Dr. Dohrn, I have retained the species as distinct.

\section{(§ Torquilla, Studer.)}

\section{Pupa granum.}

Pupa granum, Drap., Tabl. des Moll. 59.9 (1801)

Torquilla granum, Stud., Syst. Verz. 19 (1820)

Pupa granum, Pfeiff., Mon. Hel. ii. 343 (1848)

$" \quad$ "Mouss., Faun. Mal. des Can. 123 (1872)

Habitat Lanzarotum, Fuerteventuram, et Canariam Grandem; sub lapidibus in aridis apricis (præcipue inferioribus), a meipso detecta.

I met with several examples of a Pupa which appears to be specifically identical with the European $P$. granum, in the three eastern islands of the Canarian archipelago,-namely, (on March 15th, 1859) amongst stones and scoriæ on a dry rocky bank near the coast, below Haria (in the direction of the Llanos de Temise), in the north of Lanzarote, where it was afterwards obtained likewise by Mr. Lowe; near Sta. Maria Betancuria in Fuerteventura; and on an arid slope, about midway between Maspalomas and Juan Grande, in the south of Grand Canary. 
Not having recognized them at the time to be conspecific with the $P$.granum, Mr. Lowe proposed for them the MS. name of bulimaformis; but a recent comparison of the whole with types of the 'P. granum, from Switzerland, has completely satisfied me that they cannot be regarded as distinct from that species; and I may add that such was also the opinion of Mousson, to whom I forwarded the entire series at the time when he was compiling his late Monograph of the Canarian Land-Mollusca. The only difference that I can detect between the Atlantic specimens and those from more northern latitudes is that the former are a trifle smaller, and that some of them (namely those from Lanzarote and Fuerteventura) are not quite so coarsely striated; but since the striæ of the Grand-Canarian ones appear to be as distinct as in those (now before me) from Switzerland, there seems nothing whatever in the representatives from the islands on which to erect an additional species. Nevertheless their slightly smaller size, and for the most part not quite so strongly sculptured volutions may perhaps just suffice for a 'var. $\beta$. bulimoeformis' to be recognized.

The $P$. granum may be known by its rather tapering, elongate form (for a shell not exceeding two lines in length), by its somewhat thin substance and pale-brown hue, as well as by the closely-set and very oblique striæ of its numerous and exceedingly convex volutions. Its aperture is suboval, with the denticle of the lip (which is itself regularly rounded, and not sinuate) altogether absent; whilst its plaits, which are seven in number, and all of them very deeply immersed, are rather peculiarly placed,- there being only a single ventral one (and that mential), two (small and dentiform) on the columella, of which the upper one is the larger, and four on the palate (of which the two outer ones are usually short and rudimentary, sometimes nearly obsolete, and the inner ones more conspicuously developed).

\section{(§ Liostyla, Lowe.)}

\section{Pupa castanea.}

T. inflate ovata, latiuscula, ventricosa, nitidiuscula, distincte inæqualiter striata, obscure rufo-castanea sed basi dilute flavescens; spirâ obtusâ; anfractibus 6, convexis, suturâ profunde impressấ; aperturâ late auriformi, 4-plicatâ,-sc. 2 (exteriore magnâ, lamelliformi, valde obliquâ, rariss. cum angulo labri sphinctere junctâ, sed interiore minore immersâ) ventralibus, 1 (elongatâ et valde obliquâ) columellari, et 1 (mediâ, filiformi, internâ) palatali; peristomate late expanso, crasso, sordide carneo-albido, marginibus latissime remotis, dextro superne exstanti, sinuato, intus obtuse tuberculiformi, sinum (una cum 
lamellâ ventrali superiori) sat evidenter efficiente.-Long. lin. $\operatorname{circa} 1 \frac{1}{2}$.

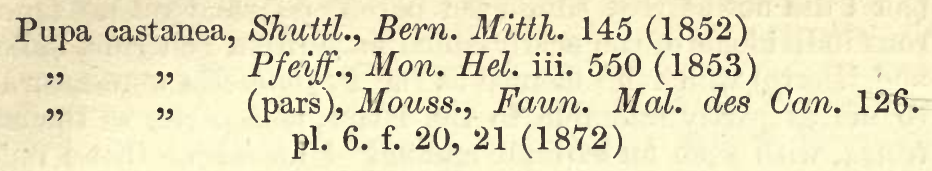

Habitat Teneriffam (et sec. Shuttleworth et Mousson, sed an vere?, Palmam) inter folia marcida, etc., ad rupes aquosas supra oppidulum Garachico, una cum Hyalina Clymene, Physa acuta, Ancylus striatus, et Hydrocoena gutta degens.

Obs.-P. pythielloe, Mouss., affinis, sed nisi fallor vere distincta. Differt præcipue testâ majore, conspicue latiore, ven-, tricosiore, magis ovatâ, grossiusque striatâ; anfractibus convexioribus, suturâ multo profundius impressâ ; aperturâ majore, multo latiore, et magis auriformi, plicis columellari et exteriore ventrali ( $\mathrm{ab}$ angulo labri remotiore, disjuncto) submagis obliquis ; necnon peristomate carneo-tincto magisque expanso, marginibus remotioribus, dextro magis rotundate sinuato atque intus plerumque magis conspicue tuberculiformi.

So far as I am aware, this Pupa has been found hitherto only in Teneriffe, and only ( $\mathrm{I}$ believe) about wet rocks in the neighbourhood of Garachico ; for although Shuttleworth cites it also from Palma, I am exceedingly doubtful whether be did not confound with it the nearly allied (but, at that time, unenunciated) $P$. pythiella, which swarms in that particular island. There can at any rate be no question that the types from which Shuttleworth's very accurate diagnosis was drawn out were from the vicinity of Garachico,- for in his remarks under the Hyalina Clymene (which has been observed exclusively in that district) he expressly adds 'Hab. sub saxis et ligno putrido, consort. Puparum, prope Garachico ;' and under the Hydrocona gutta (which abounds also on the very same dripping rocks, near Garachico) he says 'Hab. consort. Helicis Clymene, Pupa castanea, etc., sub saxis udis in Teneriffa.' From which it is quite clear, I think, that the examples which he described were Garachico ones, taken in company with the Hyalina Clymene and the Hydrocoena gutta,-on the identical rocks where the three species were subsequently obtained, similarly associated, by Mr. Lowe.

Mousson does not appear to have caught the exact features completely which separate this Pupa from his P. pythiella; for although the figures which he gives of the two species are tolerably characteristic, and even his diagnoses are in some measure discriminative, it is quite evident that he confused them, and consequently altogether mixed up their respective habitats. 
Indeed, out of the many examples of the genus Pupa which I sent to him for inspection, the $P$. castanea was not included (for I did not at that time even possess it); and yet my numerous individuals of the nearly-allied form (from Teneriffe, Palma, and Hierro) which he defined as the $P \cdot$ pythiella were returned to me as partly referable to the latter, and partly to the castanea, with such an extreme amount of indecision that I failed to recognize any distinctions between them. But now that what is manifestly Shuttleworth's true castanea has come into my hands, I can no longer entertain the slightest doubt that the two species are distinct.

As compared with the pythiella, the $P$. castanea is appreciably larger, broader, and more strictly ovate (or less oval), as well as more coarsely striated; its whorls are more convex (and the suture consequently deeper), and its aperture is more widely developed and more auriform,--the margins of its peristome (which is thicker, and of a more livid or carneous tinge, or less white) being much wider apart, and the right-hand one more outwardly-rounded below the insertion, as well as armed with a more distinct tubercle within. Its upper ventral plait, also, is more lamelliform and less sinuated, and not only a little further removed from the angle of the lip, but usually quite unconnected with the latter by a corneous sphincter.

Mr. Lowe's examples of this very distinct Pupa were taken, during April of 1861, above Garachico, in the north of Teneriffe,-namely adhering to wet rocks and sodden leaves, in the drip of a small waterfall, on the road from that place to Ycod de los Vinhos (in company with the Hyalina Clymene, Physa acuta, Ancylus striatus, and Hydrocoena gutta, the moistureloving habits of which it would appear to share).

\section{Pupa pythiella.}

T. præcedenti affinis, sed minor, angustior, magis ovalis (sc. minus ovata), ac sensim levius striata; anfractibus minus convexis (ergo suturâ magis superficiali); aperturâ minore, angustiore, margine dextro multo minus exstanti-rotundato, et intus obsoletius tuberculiformi, plicâ ventrali superiore crassiore, magis sinuatâ, et sæpius cum angulo sphinctere juncto (quare sinum evidentius efficiente), columellari subminus obliquâ, necnon peristomate albidiore minusque expanso, marginibus minus remotis.-Long. lin. 1-1 $\frac{1}{4}$.

Pupa pythiella, Mouss., Faun. Mal. des Can. 127. pl. 6. f, $22,23(1872)$

" $\quad$ " Pfeiff., Mon. Hel. viii. 389 (1876) 
Habitat Teneriffam, Palmam, et Hierro; in sylvaticis editioribus humidis præcipue occurrens.

This interesting little Pupa is widely spread throughout the Canarian archipelago, of which it is eminently characteristic,occurring in damp, and more or less sylvan, spots of a rather high elevation. It has been obtained in Teneriffe, Palma, and Hierro; and we may be pretty sure that it will be found to exist equally in at all events Grand Canary and Gomera. In Teneriffe I met with it in the forest district above Taganana, as well as at the Agua Garcia and in the wood of La Esperanza near Laguna; in Palma (where it was taken by Mr. Lowe at El Monte above Barlovento) on the ascent of the Cumbre above Buenavista, as well as on wet rocks in the Pinal (near to the edge of the great Caldeira) at the head of the small stream which supplies the Levada of the Banda; and, in Hierro, in the dense forest region of El Golfo.

The $P$. pythiella is a distinctly smaller, narrower, and more oval (or less ovate) species than the castanea, as also more lightly striated, and not quite of such a dark castaneousbrown, - the whole surface having often a slight olivaceous tinge, and the apical region being generally more or less pale and decorticated; its whorls are much more flattened, and the suture consequently less impressed; and its aperture is less developed,- the margins of its peristome (which is appreciably whiter and less expanded) being less wide apart, and the righthand one straighter or less outwardly rounded towards the insertion (as well as less tuberculiform within). Its upper ventral plait too is relatively thicker and more sinuate, and usually joined to the angle of the lip by a corneous sphincter.'

\section{Pupa tæniata.}

T. præcedenti affinis, et forsan vix certe distincta. Differt præcipue testâ grossius plicatulo-striatâ, anfractibus vix magis convexis, necnon colore omnino pallidiore,-sc. olivaceo-corneo,

1 The P. pythiella belongs to somewhat the same type as the $P$. Loweana of Madeira, which is perhaps its nearest ally from that island, having also a good deal in common with the $P$. laurinea. It is however very much smaller than both of those species, particularly the former; and the denticle of the lip which is so strongly developed in the Loweana is here usually obsolete,it being but seldom expressed, and for the most part merely represented by a slight internal thickening, often barely traceable, in the accustomed place. In other respects the $P$. pythiella is a barrel-shaped little species, having much the outline of the $P$. Loneana; but it is more shining and less coarsely striated, its volutions are less convex, the upper columellary plait is quite absent, and its outer ventral one (which is usually joined by a rather less thickened sphincter with the angle of the lip) is relatively a trifle longer, thinner, and more sinuate. Indeed this sphincter seems eminently variable, for in some examples (particularly those from Palma) it is, as in the case of the Madeiran $P$. concinna, altogether absent. 
sed fasciâ castaneâ latâ postice (ad suturam) in anfractibus omnibus plus minus conspicuâ.-Long. lin. circa $1 \frac{1}{4}$.

Pupa tæniata, Shuttl., Bern. Mitth. 145 (1852)

" " $\quad$ Pfeiff., Mon. Hel. iii. 549 (1853)

" $\quad$ Mouss., Faun. Mal. des Can. 125 (1872)

Habitat Teneriffam; in sylvaticis intermediis lecta. Etiam in ins. Palma a cl. Shuttleworth (sed an vere?) invenisse dicitur.

Some examples of a Pupa which I took in the wood at La Esperanza, near Laguna, in Teneriffe, p rtain clearly to the species which was described by Shuttleworth as the $P$. toeniata (stated also to have been met with by Blauner in Palma); nevertheless I am not at all sure that intermediate forms do not occur which will be found to connect them by imperceptible gradations with the somewhat variable $P$. pythiella. However since normal individuals do unquestionably differ, both in colour and sculpture, from the latter, and since the two forms have been published as specifically distinct, I will not attempt to unite them.

Judging from the few examples to which I have access, the $P$. toeniata may be said to have its volutions not quite so flattened and also more strongly striated (being sometimes indeed well-nigh costate); and its surface (instead of being of an almost uniform concolorous brown) is of an olivaceo-corneous hue, but conspicuously banded with a castaneous zone (immediately above its suture) on the hinder portion of each of the whorls.

\section{Genus 13. ACHATINA, Lam.}

( $\S$ Acicula, Risso.)

\section{Achatina acicula.}

Buccinium acicula, Müll., Verm. Hist. ii. 150 (1774)

Helix acicula, Lowe, Cambr. Phil. S. Trans. iv. 59 (1831)

Achatina acicula, Pfeiff., Mon.'Hel. ii. 274 (1848)

Glandina acicula, Alb., Mal. Mad. 59. t. 15. f. 17, 18 (1854)

Cionella acicula, Mouss., Faun. Mal. des Can. 135 (1872)

Achatina acicula, Watson, Journ. de Conch. 223 (1876)

Habitat Palmam; ad marginem aquæductæ infra Argual, versus occidentem insulæ, sub lapidibus plurima exemplaria collegi.

The only Canarian examples which I have seen of this small European Achatina (and which occurs likewise in the Madeiran Group) were taken by myself, beneath stones, at the edge of a Levada, or watercourse, on the western side of Palma,-namely in the (but slightly elevated) calcareous district between Argual 
and the coast. I cannot see that they differ appreciably from the Madeiran ones; and Mousson also came to the conclusion that they are specifically identical with the ordinary type, of more northern latitudes. 'M. Wollaston a recueilli,' says he, ' un bon nombre d'individus de cette petite coquille à l'état vivant, tandis qu'ordinairement on ne la trouve que morte. J'ai longtemps hésité à lui appliquer le nom de l'espèce européenne, mais un examen scrupuleux ne me permet pas d'établir des diffèrences palpables et constantes. Notamment la columelle un peu excavée, se prolongeant jusqu'à la base de l'ouverture et se terminant là par une troncature franche, est la même; c'est dans cette partie que se manifestent le plus aisément les différences spécifiques dans ce petit genre, si difficile à éclaircir.'

\section{Genus 14. IOVEA, Watson.}

I have already mentioned, at p. 247 of the present volume, that the Canarian 'Achatinas' of this particular type are too nearly related to the Madeiran ones not to be admitted (by presumption) into the same genus with them; though I would wish expressly to state that their animals, in which alone the generic peculiarities reside, have yet to be examined. The characteristics of Lovea, as recently established (Proc. Zool. Soc. Lond. 677 ; 1875) by Mr. Watson, consist in the tail of the animal being not only obliquely lopped-off at the tip and provided with a mucous gland at the angle of the truncation, but likewise in the mantle extending 'beyond the edge of the aperture, all round,' and in being prolonged backwards 'like a tongue, behind the posterior corner.' The very highly polished surfaces of the Lovece seem to be connected, as Mr. Watson properlyobserves, with the perpetual movement upon it of the mantle, and especially of its posterior prolongation; though at the same time I would remark that this particular feature is equally conspicuous in numerous other species, such as the $A$. acicula and lubrica, in which the latter has not been observed to hold good-at any rate to a similar extent.

As regards the species enumerated below, the $L$. Reissi is so nearly related to the folliculus, Gron., as to be barely separable from it; and since the latter has been ascertained, both by Mr. Watson and myself, to possess the exact distinctions of Lovea, we may feel pretty confident that the former will be found to possess them equally. And inasmuch as the Reissi belongs unmistakeably to the same type, or section, as the various species which succeed it, there can be little doubt that they are all of them Loveas, as defined, and limited, by Mr. Watson. 


\section{(§ Ferussacia, Risso.)}

\section{Lovea Reissi.}

Achatina folliculus, $W$. et $B$. [sed vix Gron?; 1871], Ann. des Sc. Nat. 29. syn. 320 (1833)

Cionella Reissi, Mouss., Faun. Mal. des Can. 129. pl. 6. f. 26, 27 (1872)

Ferussacia Reissi, Pfeiff., Mon. Hel. viii. 303 (1876)

Habitat Teneriffam; a DD. Reiss et Watson parce ablata.

Three examples of a shell which were obtained by Mr. Watson in Teneriffe are clearly referable to the Lovea which is described by Mousson under the name of 'Cionella Reissi,' though I am extremely doubtful whether they represent more in reality than a very slightly altered geographical phasis of the $L$. folliculus, - with which indeed the species was actually identified by Webb and Berthelot. Mousson, however, believes it to be still more nearly allied to the Vescoi, Bourg. (Maltese specimens of which are now before me, and which appear to me to be only just distinguishable from the Teneriffan ones), adding ' la forme totale est une idée moins allongée; le dernier tour est plus arrondi, sans tendance à devenir plan au milieu ; le bord droit s'éloigne plus sensiblement da la paroi aperturale; l'ouverture par là devient plus largement ovale; l'expansion calleuse du bord columellaire est un peu plus grande; le test est bien plus transparent, bien que corné; la margination blanchâtre de la suture est plus large et souvent accompagnée d'une ligne brune, qui toutefois paraît moins résider dans la substance du test que dans l'angle aigu qui relie les tours. Toutes ces différences sont faibles et pourraient peut-être se concilier avec l'idée d'une variété géographique.'

Judging from the three examples to which I have access, the $L$. Reissi is a trifle larger and more robust than the folliculus (the largest one being 5 lines in length, instead of only about four), and the outline of the shell on the left-hand side is a little more bi-arcuated,-owing to the penultimate and antepenultimate whorls (the latter of which perhaps is somewhat longer) being respectively more convex. Its suture is very oblique; and its columella is a little broader, and more concave and flexuose, as well as more abruptly terminated behind, than in at all events the Madeiran specimens of the folliculus,-in which the columella is perceptibly narrower and less developed. However, since each of the three individuals differ slightly in this particular respect, I cannot attach any value to it as a true specific character.

My own belief is that the L. folliculus, Vescoi, and Reissi 
are one and the same species,-representing but slight, and unimportant, indeed barely distinguishable, aspects of a single type.

\section{Lovea valida.}

Cionella valida, Mouss., Faun. Mal. des Can. 130. pl. 6. f. 24, 25 (1872)

Ferussacia valida, Pfeiff., Mon. Hel. viii. 304 (1877)

Habitat Fuerteventuram; ad Yandia, in meridionali insulæ, a D. Fritsch detecta.

I have not been able to procure a type of this Lovea, which was detected by Fritsch in the district of Yandia in the south of Fuerteventura; but it appears to be a large and solid species, measuring 7 lines in length, of a pale corneous hue, and very ightly striated. It is compared by Mousson with the Webbii d'Orb.; but I have already mentioned (vide, ante, p. 422) that the latter is not a Lovea at all, but a Bulimus,-as indeed it was originally reported by Webb, and subsequently by d'Orbigny himself, as well as by Pfeiffer, - it being, in fact, neither more nor less than $B$. myosotis of Grand Canary. Judging from the diagnosis, the $L$. valida is probably more allied to the (nevertheless considerably smaller) L. lanzarotensis, Mouss., than to anything else.

\section{Lovea Fritschi.}

Cionella Fritschi, Mouss., Faun. Mal. des Can. 131. pl. 6. f. $30,31(1872)$

Ferussacia Fritschi, Pfeiff., Mon. Hel. viii. 304 (1877)

Habitat Lanzarotam; sub lapidibus in editioribus, rarissima.

A single example of a Lovea which is now before me, and which I met with in the north of Lanzarote, I have no doubt is referable to Mousson's Cionella Fritschi, which was taken by Fritsch in that same island. It is 5 lines in length (thus agreeing exactly with the measurement given by Mousson), and rather broader and more ovate in outline (or ventricose) than the $L$. lanzarotensis (even as represented by the 'var. $\beta$. tumidula'). In colour it is pale livid, or olivaceo-corneous; its surface is very minutely and obsoletely striated; its suture (although equally margined) is planer, or less (even obsoletely) impressed, than in that species; its penultimate whorl is relatively a little shorter and less inflated; and its aperture is rather more angulate at the junction of the columella with the lower margin of the peristome. 


\section{Lovea lanzarotensis.}

Cionella Lanzarotensis, Mouss., Faun. Mal. des Can. 133. pl. 6. f. 28,29 (1872)

Ferussacia Lanzarotensis, Pfeiff., Mon. Hel. viii. 305 (1877)

Habitat Lanzarotam; sub lapidibus, in saxosis elevatis, hine inde congregans.

Judging from a long array of examples which are now before me, this beautiful and rather large Lovea (which measures from about $4 \frac{1}{2}$ to 5 lines in length) is eminently variable-not only in hue and solidity, but also in exact outline and the relative size of its volutions; nevertheless it may be defined, on the whole, as a cylindrical species, not much tapering towards the apex, with the suture exceedingly oblique, the peristome thick and incrassated, and with the penultimate whorl more or less largely developed.

The L. lanzarotensis, as here understood, was taken abundantly by Mr. Lowe and myself in Lanzarote,-namely, on the low craggy mountains (or ridges) above Haria, as well as on the lofty sea-cliff known as the 'Risco' (and overlooking the Salinas) in the extreme north of the island; and the specimens from the former of those localities (which, I think, as being more removed from the $L$. attenuata, should be regarded as the typical ones) are more solid, more highly polished, and of a paler ochreous-yellow, than those from the latter; and they are also, on the average, a trifle narrower and more cylindric, with their penultimate volution a little more tumid, and with their aperture (which is just appreciably shorter) rather more obtusely rounded (or less angular) at the point of junction with the columella. In fact the precise difference between the two forms, now under consideration, might be briefly enunciated thus :-

a. [normalis].-Solida, angustula, subcylindrica, clare ochrea, politissima; anfractu penultimo elongato, subinflatocylindrico; apertưâ breviusculâ, postice obtuse rotundatâ. (Habitat in montibus præruptis mox supra oppidulum Haria.)

$\beta$. tumidula.-Subminus solida, paululum minus angusta, cylindrico-fusiformis, obscure cornea, vix minus nitida; anfractu penultimo plerumque minus conspicue elongato, subinflatoconico; aperturâ sublongiore, postice paululum minus obtuse rotundatâ aut magis angulatâ. (Habitat ad rupes maritimas in boreali insulæ, supra Salinas.)

In point of fact the 'var. $\beta$. tumidula' is somewhat intermediate (in outline, substance, and hue) between the normal state (or ' $a$.') and the L. attenuata of Mousson; so that I should not be at all surprised if the attenuata should prove in 
reality to be but a phasis (more apically acute, and with the spire relatively more elongated) of the lanzarotensis. Or it might possibly be that the ' $a$.' is truly and separately distinct, and that what I have treated as the 'var. $\beta$. tumidula' may be only an obese and shortened form of the attenuata (with which it is found in company); though if this latter supposition be correct (which I think is hardly likely), Mousson was mistaken in recording his Cionella lanzarotensis as having occuried on the submaritime cliffs overlooking the Salinas, - the mountains above Haria_being, in that case, its sole habitat as hitherto ascertained.

\section{Lovea attenuata.}

Cionella attenuata, Mouss., Faun. Mal. des Can. 134. pl. 6. f. $32,33(1872)$

Ferussacia attenuata, Pfeiff., Mon. Hel. viii. 306 (1877)

Habitat Lanzarotam; ad rupes editiores maritimas, sub lapidibus degens.

Although relatively a little narrower and more tapering in outline, with usually an extra volution, and with the ultimate and penultimate ones rather less elongated (in proportion to the size of the shell), I am nevertheless far from certain that the present Lovea is truly distinct specifically from what I have regarded as the 'var. $\beta$. tumidula' of the lanzarotensis; and this is all the more possible, because I undoubtedly possess many examples which are more or less intermediate between the latter and the attenuata, and because also the Loveas are eminently liable (like some of the Clausilias and Pupce) to have a state which is more or less shortened and obese, and another which is comparatively elongated and acute. Added to which, the $L$. attenuata and what I have cited as a 'var. $\beta$.' of the lanzarotensis are found in company (for the most part in about equal proportions), - having been met with hitherto, so far as I am aware, only on the lofty submaritime cliffs (known as the Risco, and overlooking the Salinas) in the extreme north of Lanzarote.

Nevertheless, whether my surmises concerning the four phases now before me (two of which I have assigned to the lanzarotensis, and two to the attenuata) are correct or not, I will not attempt to amalgamate the two species which Mousson has established; for whatever be the fate of my 'var. $\beta$. tumidula' (that is to say, whether it be a variety of the lanzarotensis, as I have assumed, or of the attenuata, which is perhaps equally possible), there is at least a reasonable chance that two veritable species are indicated,-in which case it 
must remain an open question to which of them this apparently somewhat osculant form is more properly to be referred.

Even of the $L$. attenuata, however, as here understood, there appears to be a larger and a smaller state,-differing in nothing, I think, except in size; and therefore as Mousson speaks of his Cionella attenuata as being conspicuously smaller than the lanzarotensis, it would seem to follow that the comparatively minute examples of the shell were the only ones he possessed from which to compile his diagnosis. The examples which $I$ have measured vary from about 4 to nearly $5 \frac{1}{2}$ lines in length.

\section{Lovea vitrea.}

Achatina vitrea, W. et B., Ann. des Sc. Nat. 28. syn. 320 (1833)

Bulimus vitreus, d'Orb., in W. et B. Hist. 72. t. 2. f. 28 (1839)

",$\quad$ Pfeiff., Mon. Hel., iv. 453 (1859)

Cionella vitrea, Mouss., Faun. Mal. des Can. 131 (1872)

Ferussacia vitrea, Pfeiff., Mon. Hel. viii. 303 (1877)

Habitat Lanzarotam, et Fuerteventuram [necnon sec. W. et $B$., sed haud vere, Teneriffam]; sub lapidibus, præcipue in humidis; occurrens.

The straightened, rather cylindric-oblong outline of this comparatively small, very highly polished, pellucid, and pale greenishyellow, or olivaceo-corneous, Lovea (which measures from about 3 to $3 \frac{1}{2}$ lines in length), added to the thinness of its substance, the excessive obliquity of its suture, its enlarged and slightly tumid penultimate volution, its acute, unthickened peristome, and its somewhat short and posteriorly rounded (or unangulate) aperture, will sufficiently distinguish it.

The only island in which I have myself met with the L. vitrea is Fuerteventura,-where I secured many examples of it at the edges of a tank, near Sta. Maria Betancuria, in the Rio Palmas (a spot in which it was found subsequently, also, by Mr. Lowe), as well as on the ascent of the Monte Atalaya; and although it is stated by Webb and Berthelot to occur in damp places in 'Teneriffe,' I nevertheless reject that habitat altogether as having been founded (like so many of Webb's localities) on inaccurate data,-seeing that no other island is cited for it by them, and I myself possess three original types, which were sent by Webb to Mr. Lowe in 1829 (and which agree precisely with others in the d'Orbignyan cabinet at the British Museum), marked expressly as having been obtained in 'Lanzarote' -an island in which, in point of fact, it has subsequently been collected by Fritsch. There can be no 
question therefore that Webb's examples (which were found in a dead and whitened, or bleached, condition) were Lanzarotan ones, and not Teneriffan, and that consequently there is no evidence as yet that the L. vitrea has been observed except in the two eastern islands of the archipelago.

The specimens of this Lovea from Lanzarote, which must be looked upon as the normal ones, are a trifle smaller and narrower, and perhaps a little more cylindrical (or less ovate) than those from Fuerteventura; and their columella is, on the average, somewhat less truncated behind, or more gradually and imperceptibly rounded-off into the hinder margin of the peristome; but the latter character is so unmistakeably variable in both forms that I would merely register the Fuerteventuran individuals as representing a 'var. $\beta$. submajor,' distinctive of that particular island. ${ }^{1}$

1 I may just call attention in this place to two Loveas which, through the extreme inaccuracy of Mr. Webb, and the subsequent confusion created by d'Orbigny (who figured a shell which would not accord with either of them, and which flatly contradicted his own diagnosis), have been regarded hitherto, I cannot but think very erroneously, as members of the Canarian fauna,namely, the 'Achatina Paroliniana,' W. et B., and the 'A. Tandoniana,' Shuttleworth. I mentioned at p. 254 of the present volume that one of the original types of the former, which is now in the British Museum, is neither more nor less than the $L$. triticea, Lowe, which abounds on the mountains of Porto Santo in the Madeiran Group, and which appears to be literally peculiar to that particular island. Well knowing how liable Webb was to interchange his various habitats (as is instanced by the admission of the exclusively Madeiran Helix tiarella and teniata, and the no less unmistakeably CapeVerdian H. advena and Stenogyra subdiaphana, into his Canarian 'Synopsis'), I had long felt it probable, judging from the mere diagnosis, that his 'Achatina Paroliniana' was nothing but the Porto-Santan L. triticea, which he had collected in profusion, in company with Mr. Lowe, on the higher slopes of that island, in 1828; and therefore I was by no means surprised to find, on a closer enquiry, that this conjecture was correct. But there is yet another aspect of the question which has to be taken into account, and which we will now consider. It appears, from the observation of Moquin-Tandon, some years ago, that $\mathrm{Webb}$ had inadvertently included twa very distinct, but superficially resembling, species amongst the types of his ' $A$. Paroliniana,'a fact which induced Shuttleworth in $\mathbf{1 8 5 2}$ to propose a name for the examples with an edentate aperture ; and he consequently described them under the title of 'A. Tandoniana.' But a little circumstance is on record which throws some curious light on this nearly related but perfectly toothless form, but which of course would not be appreciated by naturalists who had not visited the places referred to, and who had no means therefore of testing their accuracy;-namely, that these Webbian exponents of the new ' $A$. Tandoniana,' in the collection of Moquin-Tandon, were labelled as coming from Pico Branco-misspelt by Mousson 'Pico Bianco.' Now it would never occur to them to suspect that this Pico Branco (or, according to Mousson, 'Pico Bianco') was anything but a Canarian locality; but I am not aware that there is any such spot throughout the whole of these Atlantic archipelagos except in Porto Santo,-where Pico Branco is one of the principal mountains, and one moreover on which the Lovea triticea and the closely resembling $L$. oryza are not only more decidedly plentiful but are generally found to a great extent associated. Added to which, I have the certain knowledge that Webb ascended the Pico Branco in 1828, in company with Mr. Lowe, for the 
( $\S$ Amphorella, Lowe.)

\section{Lovea tornatellina.}

Helix tornatellina, Lowe, Cambr. Phil. S. Trans. iv. 59. t. 6. f. 23 (1831)

Achatina tornatellina, Id., Proc. Zool. Soc. Lond. 203 (1854)

Glandina tornatellina, Alb., Mal. Mad. 58. t. 15. f. 11, 12 (1854)

Achatina tornatellina (pars), Paiva, Mon. Moll. Mad. 111 (1867)

Lovea tornatellina, Watson, Proc. Zool. Soc. Lond. 680 (1875)

Habitat Canariam Grandem; exemplar unicum (certe ad $L$. tornatellinam referendum) nuper collegit Rev. R. B. Watson.

The L. tornatellina, Lowe, has hitherto been looked upon as essentially peculiar to the Madeiran archipelago, where however it is more widely diffused than most of the other members of the genus,-inasmuch as it is found for certain on at any rate four out of the five islands, if not indeed on them all ; and it is therefore with some surprise, despite this latter fact, that I have examined lately a single individual which was taken a few years ago by Mr. Watson, without any doubt whatsoever, in Grand Canary. From a topographical point of view, the importance of this specimen (which I have inspected with the greatest care) can hardly be overrated,-for it introduces into the fauna of the present Group not merely an additional species, but an exponent of a Section of the genus Lovea (namely Amphorella, Lowe) which had not been observed hitherto except at the Madeiras. It must however be of considerable rarity in the Canarian archipelago,- - this being the first instance, so far as I am aware, in which it has been met with.

sole purpose of collecting shells and plants. There is consequently no single link wanting in the evidence to show that these two Achatinas (the Paroliniana and Tandoniana) which have puzzled naturalists through so many years are, in reality, not Canarian at all, but nothing more than the L.triticea and oryza, of Lowe, which had been taken by Webb himself in Porto Santo in 1828, and which were carelessly mixed up with his Canarian material which had shortly afterwards to be investigated in order to compile his 'Synopsis' of the Land-Mollusca of that Group. As for his specification of the three Canarian islands in which he is supposed to have met with the 'Achatina Paroliniana' (made up of the L.triticea and oryza of Porto Santo), it is quite evident that he confused the habitat with that of some other shell; and as for Mousson's assertion that he found ' un seul individu, mort et mutilé ' of the Tandoniana amongst Fritsch's material from Lanzarote, it must be taken for what it is worth,--seeing that he had no knowledge whatever either of that species or of the Paroliniana, the published diagnoses of which he simply copies. 


\section{Fam. 5. AURICULID压.}

\section{Genus 15. AURICULA, Lam.}

Auricula æqualis.

Melampus æqualis, Lowe, Zool. Journ. v. 288. t. 13. f. 1$5(1835)$

Auricula æqualis, Id., Proc. Zool. Soc. Lond. 217 (1854)

" Vulcani, Morel., Hist. Nat. des Açor. 207. t. 5. f. $8(1860)$

" $"$ Mouss., Faun. Mal. des Can. 135 (1872)

" $\quad$ Watson, Journ. de Conch. 220 (1876)

Habitat Teneriffam; a Dom. Grasset (sec. Morelet) reperta.

I had not myself any opportunity for searching the tidewashed rocks at the Canaries; and as Mr. Lowe had no leisure for examining them either, we did not obtain any Auriculas except the $A$.bicolor, Morel., which swarms along the edges of the Salinas, or brine-pits, in the extreme north of Lanzarote. There can be little question however that the $A$. cequalis, which is so common at the Salvages and Madeira, would be met with abundantly were the proper localities explored; and indeed I have already given my reasons for concluding (vide ante, p. 269) that the A. Vulcani, of Morelet, which is said to have been found by Grasset in Teneriffe, is in reality a mere phasis of the coqualis in which the outer lip of the aperture is thickened at about its middle point into a slight dentiform callosity; for the only other character on which its specific claims were made to rest consists in the presence of a few impressed spiral lines towards the base of the shell,-a feature which is so utterly worthless (as a distinctive one) that I find it conspicuously expressed in many examples which are, without doubt, referable to the cequalis proper. Indeed it is a tendency of this particular species to possess them, for they are just as often traceable, and just as often obsolete, in both forms,-i.e. in the one (corresponding to the normal state) in which the right margin of the peristome is entirely simple, and in that in which it is gradually more or less provided internally with a small tubercle or tooth. So that I have no hesitation whatever in registering the $A$. cequalis as Canarian. ${ }^{1}$

1 A Pedipes is stated (vide Brit. Mus. Cat. Can. Shells, Append. 29 ; 1854) to have been found by the late Mr. MacAndrew on the rocks at Orotava, in the north of Teneriffe; yet, although there can be little doubt that the afra is the particular species alluded to, nevertheless since this is not asserted absolutely to be the case, and I have no opportunity of inspecting the examples, I cannot actually record the $P$. ufra as a member of the Canarian fauna. 


\section{Auricula bicolor.}

T. elongate ovato-fusiformis, sensim irregulariter striatula, subtenuis, nitidula, pallide cornea sed plus minus distincte (præsertim in spirâ) purpureo-obscurata ; spirâ exsertâ, acutâ, nucleolo sæpius albido et plus minus eccentrico; anfractibus 8-9, convexiusculis, suturâ impressâ; aperturâ elongatâ, plicis 2 subalbidis (superâ magnâ, intrante, mox supra columellam sitâ; inferâ obtusâ, minus exstanti, columellari) instructâ ; peristomate recto, acuto, margine dextro omnino simplici, columellari reflexo dilatato.-Long. lin. 4-vix 5; diam. maj. circa 2.

var. $\beta$. subarmata.-Paries ventralis denticulo secundo minuto tuberculiformi supra armatus.

Auricula bicolor, Morel., Hist. Nat. des Açor. 209. t. 5. f. 7 (1860)

Drouet, Faun. Açor. 168 (1861)

Alexia bicolor, Mouss., Faun. Mal. des Can. 136 (1872)

Habitat Lanzarotam; ad Salinas versus borealem insulæ, sub lapidibus in lutosis salsosis congregans.

The present shell, which was found abundantly by $\mathrm{Mr}$. Lowe and myself in muddy places at the edges of the Salinas, or brine-pits, in the extreme north of Lanzarote, does not seem to me to differ from an Auricula in my collection, taken at Marseilles, which I have received as the A. myosotis, Drap., and which indeed agrees sufficiently well both with the diagnosis and the original figure of that species; nevertheless since it is possible that my examples from Marseilies may be wrongly identified (for the $A$. myosotis is said by some authors to be identical with the denticulata of Montagu), and it is certain that the Canarian shell is conspecific with an Azorean one which was enunciated by Morelet under the name of A. bicolor, I think it safer perhaps to quote it under the latter title in preference to that of myosotis. Nevertheless I think there cannot be the remotest doubt concerning the identity of the Lanzarotan species with that from Marseilles (whatsoever the latter may be called),-the only points in which I can detect the slightest shade of difference between the two consisting in the fact that in the Canarian shell the upper (or first) rudimentary tubercle on the ventral paries is more often absent than present, and the aperture is perhaps just appreciably narrower (or less outwardly enlarged) behind.

The A.-bicolor is a comparatively thin, Limnoea-like shell, a little shining and sub-pellucid, and with its pale horncoloured surface more or less darkly obscured (especially on the spire) with a deep purplish tinge or bloom. Its spire is 
rather exserted and acute, with the whorls somewhat convex, and the nucleus whitish and tilted; its aperture is furnished with a large plait on the lower portion of the ventral paries (the upper minute or tuberculiform one being usually altogether absent), and another, which is much more obtuse and less defined, on the columella; and the outer lip of its peristome is totally simple, or unarmed.

\section{Fam. 6. LIMN ÆID压.}

Genus 16. LIMN \&A, Drap.

[script. Limneus.]

\section{Limnæa truncatula.}

Buccineum truncatulum, Müll., Verm. Hist. ii. 130 (1774) Limneus minutus, Drap., Hist. Nat. 53. t. 3. f. 5-7 (1805) Limnæus truncatulus, Lowe, Proc. Zool. Soc. Lond. 218 (1854)

Limnæa truncatula, Paiva, Mon. Moll. Mad. 146 (1867) " $\quad$ Watson, Journ. de Conch. 224 (1876)

Habitat 'Canaries' (sec. Dom. Watson); mihi non obvia.

I did not myself observe this widely spread little Limnoea at the Canaries, nor indeed is it recorded from thence by Mousson; nevertheless Mr. Watson cites it as occurring in the archipelago, though he does not mention in what particular island he met with it. But considering how universal it is at Madeira, and how liable it must be to accidental dissemination, we should naturally expect it in the neighbouring Group. It is a common species in central and southern Europe, as well as in the north of Africa.

\section{Genus 17. PHYSA, Drap.}

\section{Physa acuta.}

Physa acuta, Drap., Hist. Nat. 55. t. 3. f. 10, 11 (1805)

" "W. et B., Ann. des Sc. Nat. 28. syn. 322 (1833)

" , d'Orb., in W. et B. Hist. 74 (1839)

" subopaca, Bourg., Amén. Mal. i. 172 (1856)

"fontinalis, Paiva [nec Linn.], Mon. Moll. Mad. 147 (1867)

„, tenerifæ, Mouss., Faun. Mal. des Can. 137 (1872)

var. major.

", acuta, Watson, Journ. de Conch. 224 (1876)

Physa ventricosa, Mouss., l.c. 139 (1872) 
Habitat Lanzarotam, Fuerteventuram, Canariam Grandem, Teneriffam, Gomeram, et Palmam; in Hierro solâ adhuc haud inventa.

The common European P. acuta, which has been introduced into the freshwater tarks of Madeira, occurs almost universally (if not indeed quite so) in the Canarian Group,-Hierro being the only island out of the seven where it does not happen hitherto to have been observed. Indeed I have myself taken it in Lanzarote, Fuerteventura, Grand Canary, Teneriffe, and Palma; and it was obtained in Gomera by Fritsch.

The $P$. acuta is, on the average, rather smaller and slenderer at the Canaries than in more northern latitudes, and the examples vary a little according to the exact locality, and island, in which they are found; but, judging from an immense series to which I have access, I cannot detect anything about them to induce me to think that they are specifically distinct, or that they represent anything more than one or two very slight and unimportant insular modifications of the variable European shell. I do not therefore agree with Mousson in considering it desirable to erect them into an additional species under the title of $P$. tenerifo,-believing, as I do, that we are already burdened with far too many 'species,' so-called, elaborated out of the mere geographical aspects of these eminently inconstant members of the Limnoeidoe. And I would even advance a step further and suggest that the somewhat larger and more inflated Physa which (although admitted by its original describer, Moquin Tandon, to be but a race of the $P$. acuta) is likewise upheld by Mousson as yet another exponent of the genus (under the name of $P$. ventricosa), and which is said to occur in the 'Environs [!] de Tenerife' (whatsoever that may mean), itself disproves the assertion that the Canarian species is uniformly smaller than the European one; the real fact being that only selected examples of it are smaller,occasional ones being quite as much enlarged as those which are commonly found in Europe, or as those from Madeira. Indeed Mousson himself, even whilst enunciating the ' $P$. tenerifoe' and a number of (supposed) subordinate varieties, was evidently uneasy as to its real specific claims,-for he expressly speaks of its 'affinité avec certaines petites formes française de la $P$. acuta.'

My Lanzarotan examples of this Physa were taken in the Lake Januvio, on the western coast of that island; the Fuerteventuran ones in the Rio Palmas; the Grand-Canarian ones in the district of $\mathrm{El} \mathrm{Monte;} \mathrm{and} \mathrm{the} \mathrm{Teneriffan} \mathrm{ones} \mathrm{near}$ Laguna. 


\section{Physa canariensis.}

Physa fontinalis, W. et $B$. , [nec Linn.] l. c. syn. 322 (1833)

" canariensis, Bourg., Amén. Mal. i. $175(1856)$

"Mouss., Faun. Mal. des Can. (1872)

Habitat 'Canaries' (sec. W. et B.) ; mihi non obvia.

I know nothing about this Physa, and should doubt its being truly distinct from the variable $P$. acuta. Mousson also appears to have had no information concerning it,-adding - Cette espèce, bien connue pour sa ténuité, sa forme ventrue, la petitesse de sa spire, non acuminée, le poli de sa surface, etc., ne s'est pas trouvée parmi les nombreuses Physes qui j'ai vues de Canaries. Je ne puis donc rien dire sur ses rapports avec la $P$. tenerifoc, qui a à peu près la même grandeur, mais qui est moins ventrue.'

\section{Genus 18. PLANORBIS, Guett.}

\section{Planorbis Reissi.}

Planorbis Reissi, Mouss., Faun. Mal. de Can. 140 (1872)

Habitat Teneriffam ; ad S. Ursula a cl. Reiss lectus.

I have not seen a type of this little Planorbis, which Mousson states was found by Reiss at S. Ursula in Teneriffe; but it appears to be very closely allied to the European $P$. lcevis, Alder. Whether therefore it is truly distinct from the species (glaber, Jeffr.) which has been introduced into Madeira, from Portugal, I have no means of deciding. 'Ce planorbe minime,' says Mousson, ' est le seul représentant de ce genre, si commun en Europe et en Algérie, mais qu'on croyait étranger aux Canaries. Il se rapproche du $P$. loevis, Alder, mais est plus petit, plus fortement strié en travers, et surtout autrement enroulé. Le dernier tour, plus élargi, embrasse l'avant-dernier tour, ce qui réduit le reste de la spire et l'ombilic à une moindre partie du diamètre; sa face supérieure s'incline vers la ligne dorsale arrondie, laquelle se rapproche de la base. L'ombilic est moins dilaté que dans les espèces voisines.'

\section{Genus 19. ANCYLUS, Geoffr.}

\section{Ancylus striatus.}

Ancylus striatus, Q. et G., Voy. de l'Astrol. iii. 207. t. 58. f. 35-38 (1833)

" $\quad$ W. et B., Ann. des Sc. Nat. 28. syn. 323 (1833) 
Ancylus striatus, d'Orb., in W. et B. Hist. 75 (1839)

" aduncus, Gould, Proc. Bost. S. N. H. ii. 210 (1848)

" fluviatilis, Lowe [vix Müll.], Proc. Zool. Soc. Lond. 218 (1854)

" aduncus, Alb., Mal. Mad. 74. t. 16. f. 37, 38 (1854)

" striatus, Mouss., Faun. Mal.des Can. 141 (1872)

" fluviatilis, Watson, Journ. de Conch. 224 (1876)

Habitat Canariam Grandem, Teneriffam, et Palmam; in aquis et aquosis hinc inde vulgaris.

This appears to be the same Ancylus which is so abundant at intermediate and lofty elevations in Madeira; and although it was regarded in that archipelago, by Mr. Lowe and subsequently by Mr. Watson, as not differing specifically from the common European A. fluviatilis, I have nevertheless already stated why I consider it better to follow those naturalists who have regarded it as distinct. Still, I am by no means satisfied that it represents more, in reality, than a geographical phasis of that species.

I have taken the A. striatus in Teneriffe and Palma,-in the former of which it was met with by Webb at the Agua Garcia (misspelt by Mousson 'Aguas Gracias'), and by Blauner and Lowe on wet rocks near Garachico. In Grand Canary it was obtained abundantly by Mr. Lowe, at a fountain in the lofty central Pinal of Tarajana, above San Bartolomé, during our visit to that remote locality on the 8th and 9th of April 1858 ; and I have lately inspected examples which were found, a few years ago, by Mr. Watson, at Tafira.

\section{Ancylus rupicola.}

Ancylus rupicola, S'huttl., in litt. " "Mouss., Faun. Mal. des Can. 141.p. 6. f. 34,35 (1872)

Habitat Teneriffam ; ad Guimar a D. Blauner repertus.

I should very much doubt whether this is anything more than a small and perhaps not quite mature, or at any rate an ill-developed state of the Protean $A$. striatus,- possibly corresponding with what I have cited as a 'var. $\beta$. depauperatus,' of that species in the Madeiran Group; for stunted examples of the shell often have their radiating costæ quite obsolete, and present a very different appearance at first sight from those which are larger and more highly matured. Nevertheless since I have not been able to procure a type for comparison, and Mousson's diagnosis gives several characters which might seem 
to distinguish it, I will merely add his own remarks. - Cette seconde espèce, que $\mathbf{M}$. Shuttleworth a nommée sans la décrire, et qui n'a été trouvée par M. Blauner, diffère essentiellement du striatus. Elle est bien plus petite, relativement plus élevée que le striatus; le sommet surplombe un peu la base, et sa pointe se trouve à moitié hauteur; l'ouverture se rapproche plus du cercle; enfin on ne remarque que d'inégales stries d'accroisement, sans nulle trace des stries longitudinales caractéristiques. Presque tous les individus sont fortement corrodés à partir du sommet.'

The A. rupicola would seem to have been found by Blauner at Guimar in Teneriffe.

\section{Sectio II. OPERCULATA.}

\section{Fam. \%. CYCLOSTOMATIDE.}

\section{Genus 20. CYCLOSTOMA, Montf.}

\section{Cyclostoma elegans.}

Nerita elegans, Müll., Verm. Hist. ii. 177 (17i4)

Cyclostoma elegans, W. et B., Ann. des Sc.Nat. 28. syn. 321 (1833)

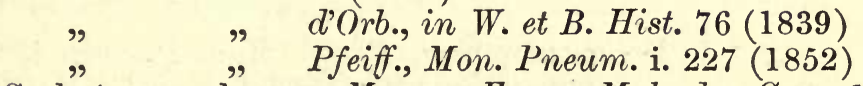

Cyclostomus elegans, Mouss., Faun. Mal. des Can. 142 (1872)

Habitat 'Canaries' (sec. W. et B.); mihi in insulis Canariensibus omnino ignotum.

I cannot but feel the greatest doubt whether this common European Cyclostoma does truly exist in the Canarian archipelago ; for I am not aware of any single locality, properly authenticated, in which it has been found, and no vestige of it was seen either by Mr. Lowe or myself during our twice-repeated explorations in the whole seven islands of the Group. Neither, so far as I can gather, does it appear to have been met with by any of the naturalists whose material was entrusted to Mousson for the compilation of his late Monograph. Yet, without specifying in what particular island, or islands, they obtained it, it was loosely stated by Webb and Berthelot to occur in 'the maritime regions of the Canaries,'-a vague and general assertion which would rather tend to throw discredit, than otherwise, as it seems to me (at any rate in the case of a species which has escaped the combined researches of all subsequent explorers), on its true 
Canarian claims. If MM. Webb and Berthelut really discovered it in the archipelago, why did they not tell us where? Whereas the certain fact that Webb carelessly introduced many landshells into his fauna on evidence which was altogether insufficient, and which have since been ascertained to belong to other countries, would go far to create a suspicion, under the circumstances, that the $C$. elegans (a broken example of which, from the so-called ' Canarian' material of Webb, is in the d'Orbignyan collection at the British Museum) may perhaps, in reality, have been one of the number. Nevertheless as this is not now actually demonstrable, and the species is on record (however vaguely) as Canarian, I think perhaps that we should hardly be justified in refusing it admission into the list.

Apart from all other characters, the $C$. elegans may at once be known from every phasis of the canariense by its suture being not only simple (or unlacerated) but also more deeply impressed (causing the volutions to be more convex), and by its aperture being more decidedly circular.

\section{Cyclostoma lævigatum.}

Cyclistoma lævigatum, W. et B., Ann. des Sc. Nat. 28. syn. 322 (1833)

" canariense, var., d'Orb., in W. et B. Hist. 76 (1839)

" lævigatum, pars, Pfeiff., Mon. Pneum. i. 229 (1852)

Cyclostomus lævigatus, Mouss., Faun. Mal. des Can. 143 (1872)

Habitat Gomeram ; in saxosis declivibus, et recens et semifossilis, occurrens.

As stated under the $C$. canariense, it is with considerable reluctance, and only out of deference to the opinion of previous monographers, that I record the present Cyclostoma as specifically distinct; nevertheless since, in addition to its peculiarity of sculpture (the spiral costæ being almost or even entirely obsolete except towards the apex of the shell, whilst the fine longitudinal hair-like lines are evenly and uninterruptedly developed), it possesses also a slightly more ovate, or less rounded, outline, I have the less compunction about treating it practically as a separate species, even whilst feeling it more probable that it is, in reality, but an insular phasis peculiar to Gomera of the extremely unstable $C$. canariense. But I would remark that one of the chief characters on which Mousson relied in keeping it apart, namely the paucity (in addition to the obso- 
leteness) of the spiral ribs, does not by any means tally with his diagnosis; for, instead of only 'four or five' on the subapical volutions (as he has recorded), I count, unmistakeably, in one of the examples now before me, no less than ten,- thus proving to a demonstration that the exact number of these costæ has (as in the numerous races of the $C$.canariense proper) no specific signification whatsoever, and can scarcely be employed to define accurately even the several insular varieties. However, considering that it also displays a slight difference, not merely in its somewhat more ovate outline but likewise in the fact of its aperture being if anything a trifle less circular, I am content to cite the C. loevigatum as a separate species.

With the exception of a few which are in the d'Orbignyan collection at the British Museum, all the examples of this $C y$ clostoma which I have yet seen are in a bleached, though perhaps not quite subfossilized, state,-which may indeed account to a certain extent (the external cuticle having been much destroyed) for the apparent obsoleteness of the spiral ridges. Still I think there can be little doubt they are always absent (or nearly so) except on the subapical whorls,-as, in point of fact, appears to be the case in the few recent individuals at the British Museum.

The examples at present before me were taken by Mr. Lowe, during our visit to Gomera in February of 1858, up the Barranco above San Sebastian.

\section{Cyclostoma canariense.}

Cyclostoma canariense, dOrb., in W. et B. Hist. 76. t. 2. f. 5 (1839)

Cyclostomus canariensis et adjunctus, Mouss., l.c. 144, 145 (1872)

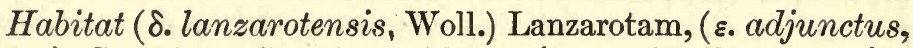
Mouss.) Canariam Grandem, ( $\beta$. raricosta, Woll., et $\gamma$. inaequalis, Woll.) Teneriffam, (a. palmensis, Woll.) Palmam, et, sec. cl. Fritsch, Hierro (saltem in statu semifossili).

After a careful consideration of a large assemblage of $\mathrm{Ca}$ narian Cyclostomas, collected in five different islands of the archipelago, I have come to the conclusion that they are probably all of them mere insular phases of a single plastic type; nevertheless, out of deference to previous monographers, I have retained the Gomeran form (which is rather more peculiar than the others) as specifically distinct,--deeming it sufficient to record my conviction that it will be found eventually to represent but another race (somewhat more pronounced perhaps, than the remainder, as to its features) of this eminently incon- 
stant Cyclostoma.' Indeed the C. canariense appears to me to occupy much the same kind of position, in point of variability, as the Clausilia deltostoma does throughout the Madeiran Group,-its costal ridges (both as regards their number and development), no less than the intermediate longitudinal sculpture, passing through an amount of change which is very analogous to what we observe in that protean species, and putting on a different aspect not only for every island but (in a less degree) for almost every altitude and region in which the shell has become established.

On this account it is that $I$ have been unable to perceive that the $C$. adjunctum, Mouss., presents characters of sufficient importance to render its isolation, as a species, either necessary or desirable; for the peculiarities of sculpture on which it was principally made to rest are so little to be depended upon, and pass into the opposite type by transitions which are so unmistakeable, that it is impossible, I think, to treat it otherwise than as a variety-as well marked as, but certainly not better defined than, the remaining forms. If however I have understood the $C$. adjunctum aright (and his diagnosis leaves little doubt in my mind upon the subject), Mousson was certainly mistaken in recording it as the phasis which is pre-eminently characteristic of 'Teneriffe'; for Grand Canary is the island to which it pertains, and indeed I have not as yet met with a single instance of its occurrence elsewhere throughout the archipelago.

Subtracting the $C$. lowigatum from the different aspects of the present species (which I must repeat that I do with a certain amount of reluctance), the $C$. canariense may be described as a rather large and spirally costate shell, with an intermediate longitudinal sculpture (between the ridges) which varies from minute, closely packed, almost obsolete hair-like lines into comparatively distant undulating ribs separated by a succession of little pit-shaped impressions, - this latter condition (which occurs in the ' $\delta$. lanzarotensis,' and which attains its maximum in the ' $\varepsilon$. adjunctus') causing the entire surface to be decussated, or somewhat reticulate. It has also a great peculiarity about its suture, which overlaps the base of the adjoining volution in the form of a more or less broad and closely-applied lamina,which latter, however, is more or less irregularly lacerated, it being often deeply gashed like the broken teeth of a saw. This

If this surmise should prove to be correct, it follows that the title ' lavigatum' (which is the one proposed by Webb for the Gomeran form in 1833) will take the precedence over that of 'canariense'-which was published by d'Orbigny in 1839; though the latter would, in reality, be far more appropriate. 
singularity of structure, combined with its less circular aperture (or less continuous and less elevated peristome), and its shorter and less convex subapical whorls, will, apart from other features, altogether separate the species from the European $C$. elegans,-as well as from the sulcatum, Drap., the siculum, Sow., and other members of that Mediterranean type. In colour the $C$. canariense varies from a bleached yellowish white into a dark leaden brown, passing through a clear reddishtestaceous state into one which is adorned with three (sometimes dark and sometimes pallid) bands; but these hues are so little characteristic of the particular phases which are brought about by a change of sculpture that it is scarcely worth while to attempt to make use of them in enunciating the latter. Perhaps therefore the following short diagnoses of the principal varieties which are now before me may suffice to place on record what I would regard as at any rate some of the most important aspects of this truly protean Cyclostoma.

a. palmensis.-Magnus, costis spiralibus alte elevatis, lineolis intermediis longitudinalibus confertis regularibus curvatis ; suturæ lamellâ late appressâ, valde irregulariter sed parce laceratâ. [ins. Palma, in Barranco de Harradura a Rev. R. T. Lowe lectus.]

B. raricosta.-Magnus, costis spiralibus altissime et subito elevatis sed latiusculis, lineolis intermediis longitudinalibus subobsoletis ; suturæ lamellâ paulo minus late appressâ, ac densius, profundius, magisque regulariter dentato-laceratâ. [ins. Teneriffæ sylvatici editiores; in montibus supra Taganana sat vulgaris.]

$\gamma$. incequalis. - stat. $\beta$. magnitudine formâque similis, sed costis spiralibus minus elevatis ac (præcipue in anfractibus posterioribus) magis numerosis necnon subinæqualibus, lineolisque intermediis longitudinalibus confertissimis subregularibus subrectis. [ins. Teneriffæ regiones minus elevatoe, juxta Portum Orotave in statu vix semifossili abundans.]

$\delta$. lanzarotensis.-Subminor, costis spiralibus paulo minoribus minusque elevatis, lineolisque intermediis longitudinalibus in anfractibus anterioribus confertis regularibus subrectis, sed in posterioribus magis remotis ac magis conspicuis, foveolas intermedias longitudinales punctiformes efficientibus; suturæ lamellâ plerumque minus laceratâ. [ins. Lanzarota; in declivibus proeruptis excelsioribus supra 'Salinas', necnon sec. Dom. Webb in ins. parvâ adjacente 'Graciosa' dictâ, congregans.]

$\varepsilon$. adjunctus, Mouss.-stat. $\delta$. fere similis, subtenuis, plerumque lætius coloratus minusque opacus, costis spiralibus minus elevatis sed etiam submagis numerosis necnon in anfractibus anterioribus interdum evanescentibus; sed lineolis longi- 
tudinalibus ubique sensim subdistinctioribus, necnon in anfractibus posterioribus foveolas ovales conspicuas dense positas efficientibus. [ins. Canaria Grandis (an vere 'Teneriffa'?), in regione 'El Monte' dictâ, necnon prope Aldea de San Nicolas, atque Lagaete et Galdar, hinc inde, et recens et semifossilis, copiose repertus.]

\section{Fam. 8. CYCLOPHORID不.}

Genus 21. CRASPEDOPOMA, Pfeiffer.

Craspedopoma costatum.

Cyclostoma costatum, Shuttl., Bern. Mitth. 145 (1852)

Craspedopoma costatum, Pfeiff., Mon. Pneum. 415 (1852)

Cyclostoma annulatum, Lowe, Ann. Nat. Hist. 116 (1860)

Craspedopoma costatum, Pfeiff., Novitat. Conchol. iii. 446.

$$
\text { t. 28-30 (1869) }
$$

Cyclostomus costatus, Mouss., Faun. Mal. des Can. 146 $(1872)$

Habitat Palmam, et Hierro ; in humidis sylvaticis intermediis, rarissimum.

This interesting little species is the only Craspedopoma which has hitherto been observed in the Canarian Group,-where it appears to be extremely rare, and confined to the damp sylvan regions of an intermediate altitude. I met with it both in Palma (where it was found also by Mr. Lowe and Blauner) and Hierro,-namely in the Barranco de Galga and the Barranco de Agua of the former, and in the densely wooded district of El Golfo on the western slopes of the latter.

The $C$. costatum, in its general facies and dark coffee-brown hue, is perhaps more nearly related to the Madeiran C. Monizianum than to any of the other species of that archipelago. It is, however, smaller and more abbreviated, and has its volutions still more tumid or convex (the suture therefore being very deeply impressed), and elegantly sculptured with powerful (though not very constant) transverse costæ, or oblique, slightly curved ribs, - which become gradually evanescent towards the nucleus and the aperture.

Fam. 9. TRUNCATELLID压.

Genus 22. TRUNCATELLA, Risso.

Truncatella Lowei.

Truncatella Lowei, Shuttl., Bern. Mitth. 146 (1852)

" Mouss., Faun. Mal. des Can. 14t (1872) 
Habitat Lanzarotam, et Teneriffam ; sub lapidibus in salinis hinc inde degens.

Several examples of a Truncatella which were taken by Mr. Lowe and myself at the Salinas in the extreme north of Lanzarote (in company with the Auricula bicolor, Morelet) have been identified by Mousson with Shuttleworth's T. Lowei; and the same species appears to have been met with also, by Blauner, in Teneriffe. As already stated, however (vide p. 280), I feel far from satisfied that the T. Lowe is more in reality than an almost totally unsculptured phasis of the T. truncatula; though as it has been acknowledged as distinct both by Shuttleworth and Mousson, I will not cite the two as conspecific. The T. Lowei (judging from the examples before me) differs from even the 'var. $\beta$. loevigata' of the T. truncatula in being still more completely unsculptured,- - there being only the faintest traces of a few obsolete pits and abbreviated hair-like lines towards the anterior edge of each volution ; and perhaps the volutions themselves are, if anything, a trifle less tumid.

\section{Fam. 10. ASSIMINEID尼.}

\section{Genus 23. ASSIMINEA, Leach.}

Assiminea littorina.

Helix littorina, Delle Chiaje, Mem. An. s. Vert. Nap. iii. 215. t. 49. f. $36-38$

Rissoa littorea, F. et H., Hist. Brit. Moll. iii. 132. pl. 81. f. 6,7

Assiminea littorina, Jeffr., Brit. Conch. v. 101 (1869) " $\quad$ Watson, Journ. de Conch. 220 (1876)

Habitat Teneriffam; a D. McAndrew, sec. cl. Jeffreys, reperta.

This minute European Assiminea, which occurs on the tidewashed rocks in the Madeiras and Salvages, is stated by Jeffreys (l.c. v. 102) to have been found by the late Mr. McAndrew at Teneriffe; but I have not, myself, inspected Canarian examples.

\section{Fam. 11. HELICINID无.}

\section{Genus 24. HYDROCÆENA, Parr.}

\section{Hydrocæna gutta.}

Hydrocæna gutta, Shuttl., Bern. Mitth. 145 (1852)

" "Pfeiff., Mon. Pneum. Suppl. i. 157 (1852)

" $\quad$ M Morel., Hist. Nat. des Açor. 214 (1860) 
Hydrocæna Gutta, Drouet, Faun. Açor. 170 (1861) " $\quad$ "Mouss., Faun. Mal. des Can. 147 (1872)

Habitat Teneriffam, et Palmam ; in locis valde humidis, sæpe etiam subaquosis, et præcipue sylvaticis, occurrens. Ad rupes præruptas udas, supra oppidulum Garachico Teneriffæ, abundat,-una cum Hyalina Clymene, Pupa castanea, Physa acuta, et Ancylus striatus consociata; et nunquam (nisi fallor) in aridis, ut ait clariss. Mousson, degit.

This extremely minute, Paludina-like shell, which occurs also in the Azorean archipelago but which has not yet been observed at the Madeiras, will most likely be found eventually to be widely spread over the Canarian Group, although hitherto it has not been observed except in Teneriffe and Palma. I have myself, however, met with it abundantly in both of those islands, -namely amongst the detritus about the roots of ferns, as well as by beating their fronds, on some damp rocks in the wood of Las Mercedes, of the former, within the constant douche of the spray of a waterfall, and likewise in a somewhat similar situation at the edges of the Vueltas above Taganana; whilst in Palma my specimens were principally obtained, in the same kind of moist places, in the Barranco de Galga. Mousson has consequently fallen into an unaccountable error in citing it as living 'sous les pierres arides,' and (again) 'sous les pierres dans les lieux arides,' for nothing could possibly be more untrue to its modus vivendi. Indeed he has himself (however unwittingly) settled the question as to its real habitat in the same actual sentence; for he expressly mentions that it was found in company with the Hyalina Clymene and the Pupa castanea, and the only spot in which the former has hitherto occurred (and I believe, also, the latter) is some trickling rocks, adjoining a small waterfall, above Garachico, in the north of 'Teneriffe. Indeed that is the original locality from whence Blauner's examples, subsequently described by Shuttleworth, were brought; and the latter particularly notes that they were taken 'sub saxis udis in Teneriffâ.'

Apart from its diminutive bulk and imperforate shell, the H. gutta may be known by its comparative freedom from sculpture (the minute lines of growth being often very obscure) and its only slightly shining surface. The examples from the neighbourhood of Garachico, which (as being the ones which were described by Shuttleworth) must be regarded as typical, are larger and of a more reddish-yellow tinge than those (the ${ }^{6}$ var. B. minor') from the higher altitudes of both Teneriffe and Palma. Shuttleworth having no other Teneriffan specimens to judge from except those from the vicinity of Garachico, naturally regarded the Palman ones only as representing his 'var. 
minor'; but it is singular that Mousson should have arrived at the same conclusion, seeing that he had my own examples from Las Mercedes and Taganana, which are quite as small, and quite as obscurely coloured, as the Palman ones, under his immediate eye.

The larger (or typical) individuals of the $H$. gutta measure about $1 \frac{1}{3}$ lines in length, and the smaller ones (or 'var. $\beta$. minor') about 1 line.

\section{GASTROPODA (PECTINIBRANCHIATA).}

\section{Fam. 12. RISSOID无.}

\section{Genus 25. HYDROBIA, Hartm.}

\section{Hydrobia Pleneri.}

Hydrobia Pleneri, Frauenf., Verh. d. Zool. Ges. Wien, 1024 (1863)

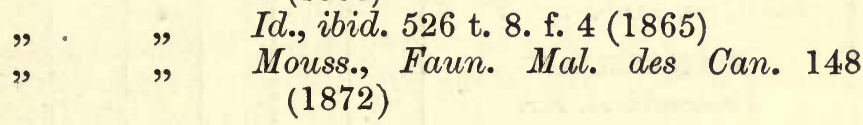

Habitat Teneriffam; ad Realejos, sec. mus. Cuming, lecta.

This is a Hydrobia with which I am not acquainted; and Mousson also appeared to have no knowledge of it beyond what he was able to gather from the short published diagnosis. Whether therefore it be truly distinct from his $H$. canariensis, which was detected by myself in Fuerteventura, and which is likewise conical and quite imperforate, may perhaps be open to enquiry. Frauenfeld's description of it is as follows:- $6 \mathrm{~T}$. conoidea, tenuis, diaphana, oleaceo-grisea, lardeo-nitida. Anfr. $6 \frac{1}{2}$, planiusculi, supra subdeclivis, suturâ vix impressâ. Apertura elongata, infra valde producta, intus alba, supra angulata. Columella tota arcte adnata, sine rimâ umbilicari.' -Long. lin. $2 \frac{1}{2}$; diam. vix $1 \frac{1}{2}$.

Hydrobia canariensis.

Hydrobia canariensis, Mouss., Faun. Mal. des Can. 148 (1872)

Habitat Fuerteventuram; a meipso in cisternâ quâdam juxta oppidulum Sta. Maria Betancuria, inter plantas Typho, detecta.

A few examples of a rather elongate and conical Hydrobia which I met with in a Typha-crowded tank near Sta. Maria Betancuria, the ancient capital of Fuerteventura, were described 
by Mousson in his late 'Revision' under the trivial name of canariensis. In its pallid bue and nearly opake, well-nigh unsculptured surface the species agrees with the more northern $H$. similis, Drap., which occurs also in the Madeiran Group ; nevertheless in every other particular it is totally different,-its larger size and much more elongate and conical outline, added to its more numerous and less ventricose volutions and its less rounded aperture, the peristome of which is less elevated and less conspicuonsly continuous across the ventral region of the basal whorl, removing it altogether from that species.

CANARIAN CATALOGUE.

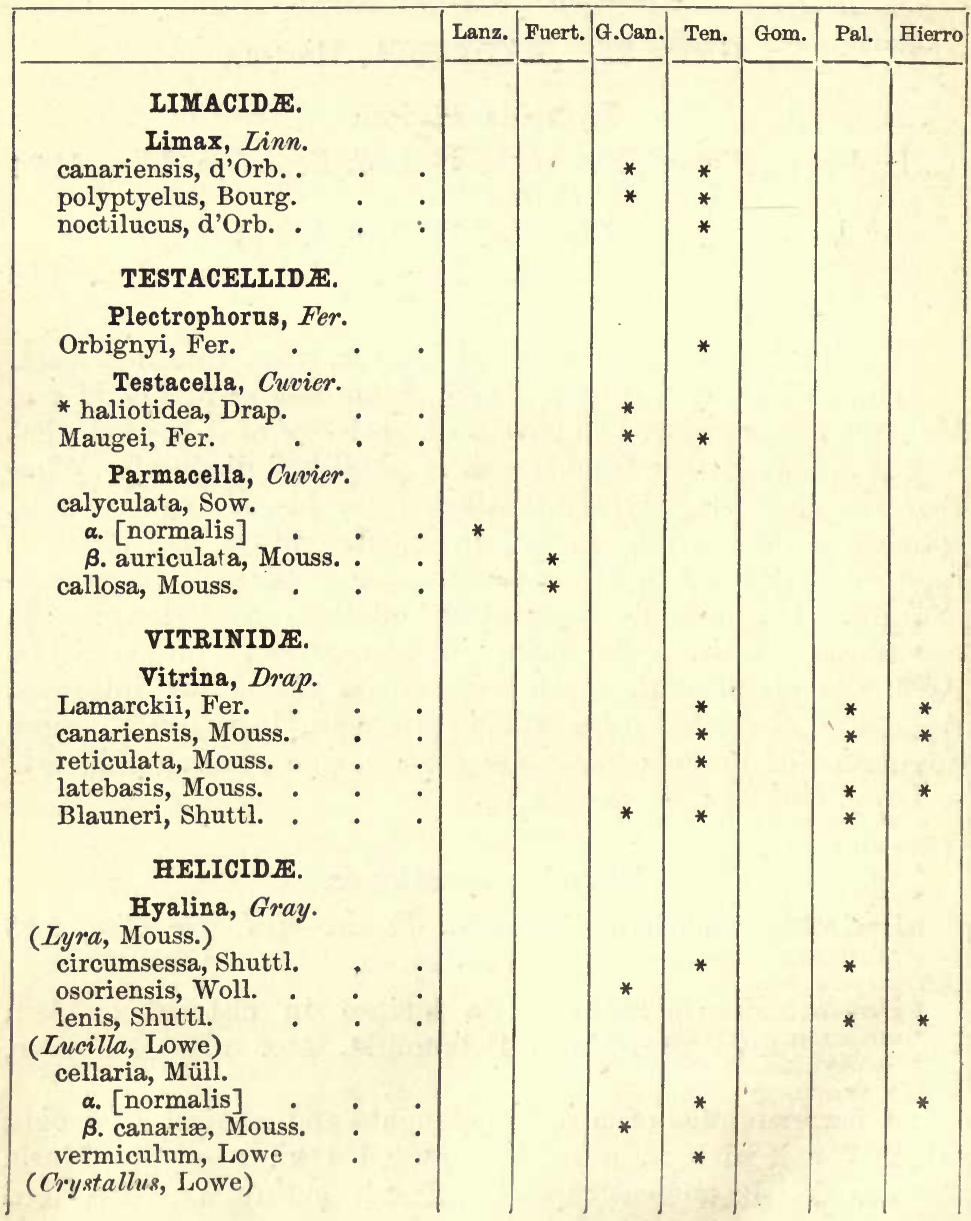


Canarian Catalogue-(continued).

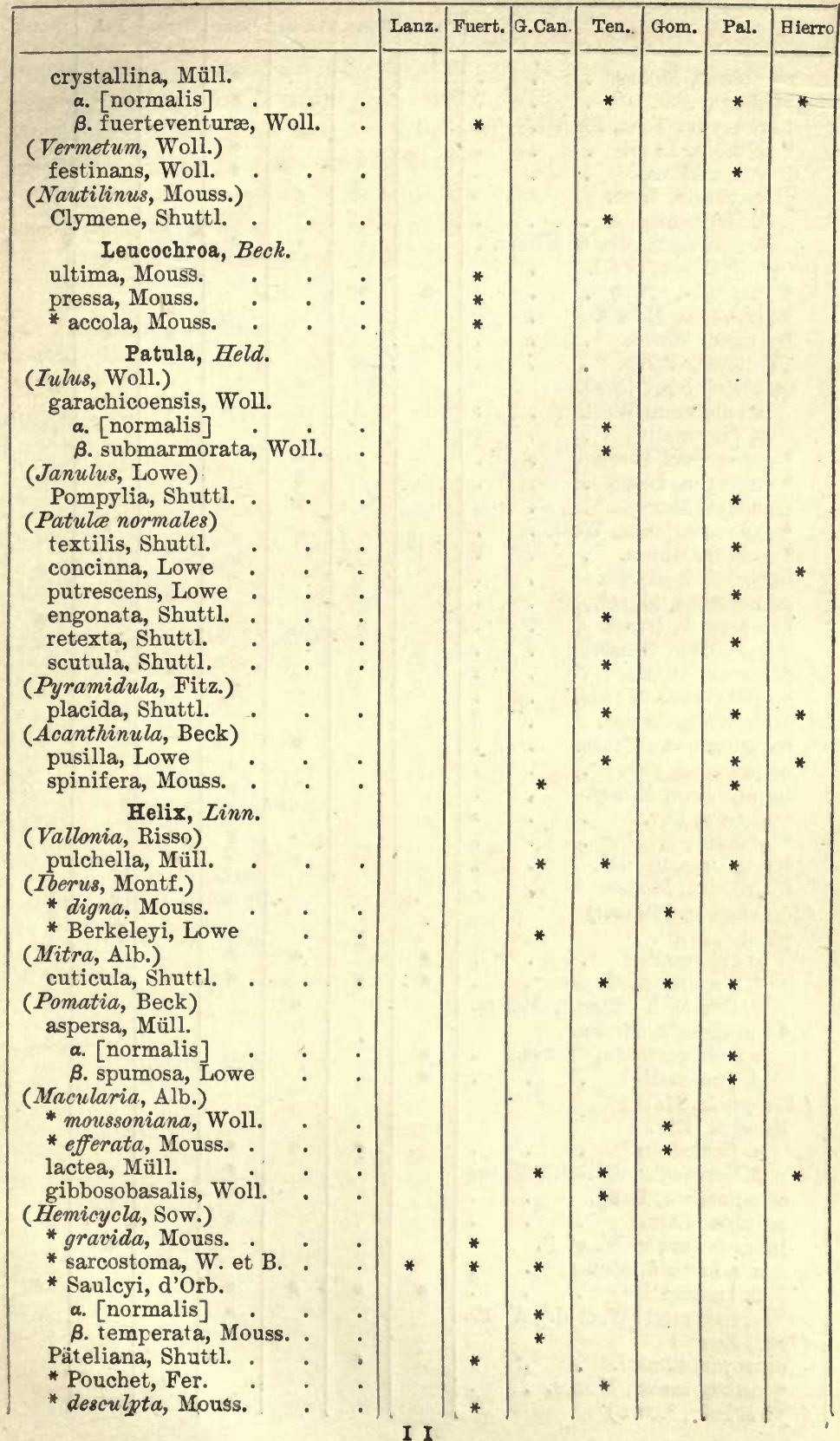


Canarian Catalogue-(continued).

retrodens, Mouss. .

modesta, Fer.

Bethencourtiana, Shuttl.

* plicaria, Lam.

inutilis, Mouss.

planorbella, Lam.

a. [normalis]

B. incisogranulata, Mouss. . vermiplicata, Woll.

* Plutonia, Lowe.

* semitecta, Mouss.

Paivana, Morel.

Villiersii, d'Orb.

quadricincta, Morel.

a. subaucta, Woll.

$\boldsymbol{\beta}$. [normalis]

* saponacea, Lowe

* psathyra, Lowe

Gaudryi, Mouss.

* granomalleata, woll.

* merita, Mouss.

harmonica, Mouss.

gomerensis, Morel

hierroensis, Grass.

Perraudieri, Grass.

distensa, Mouss.

* indifferens, Mouss.

Maugeana, Shuttl.

Guanartemes, Grass.

consobrina, Fer.

invernicata, Mouss.

malleata, Fer.

* nivariæ, Woll.

* Glasiana, Shuttl.

* Fritschi, Mouss.

(Euparypha, Hartm.)

pisana, Müll.

a. [normalis]

$\beta$. geminata, Mouss.

$\gamma$. Grasseti, (Tarn.), Mouss.

* impugnata, Mouss.

a. suhgeminata, Mouss. . *

B. [normalis]

(Xerophila, Held)

lineata, Oliv.

a. [normalis]

ק. herbicola (Shuttl.), Mouss. conspurcata, Drap.

apicina, Lam.

lancerottensis, W. et $B$.

$\alpha$. adoptata, Mouss.

B. [normalis]

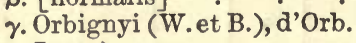

(Irus, Lowe)

eutropis, Shuttl.

* multigranosa, Mouss.

(Spirorbula, Lowe) 
Canarian Catalogue-(continued).

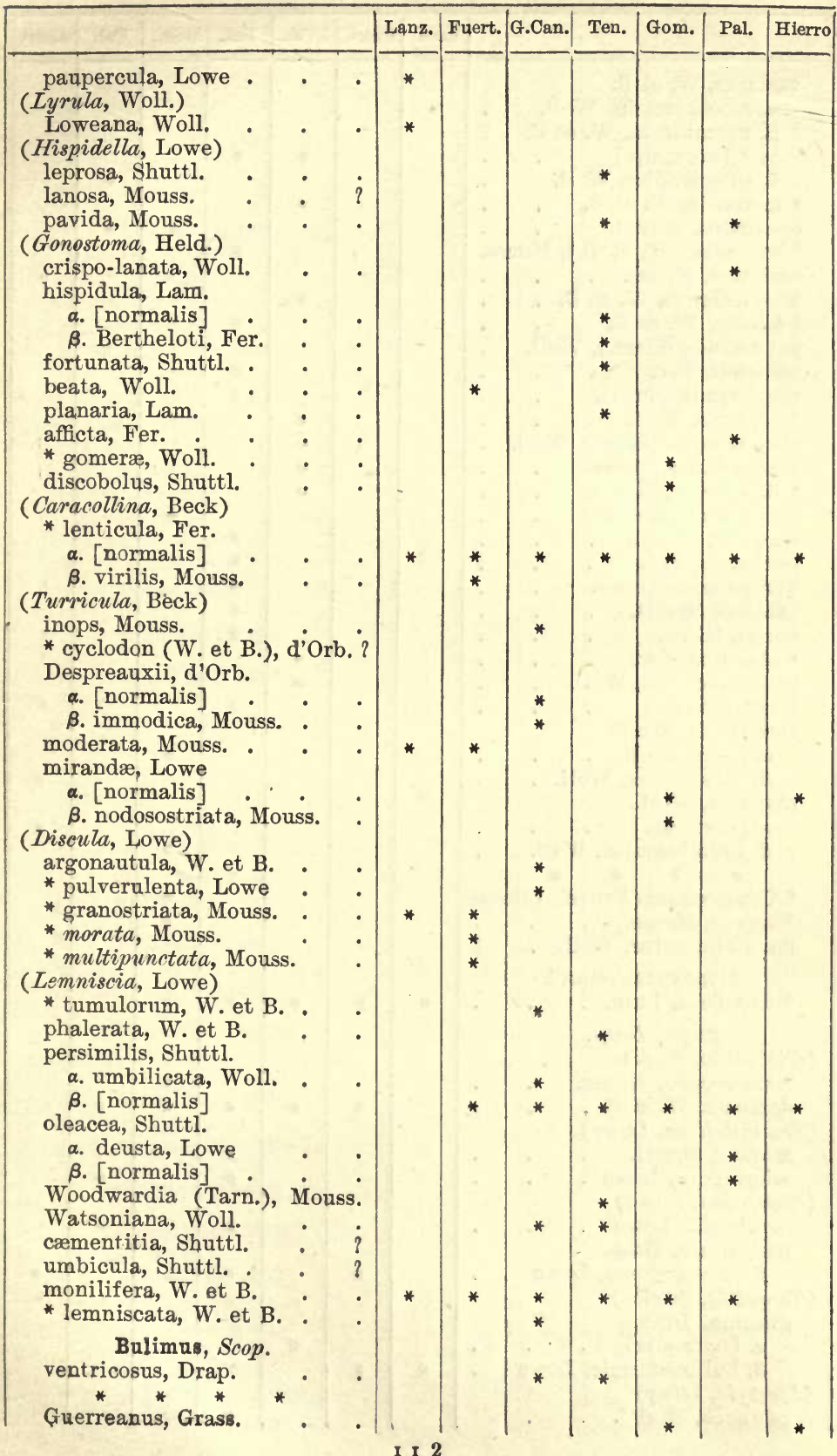


Canarian Catalogue-(continued).

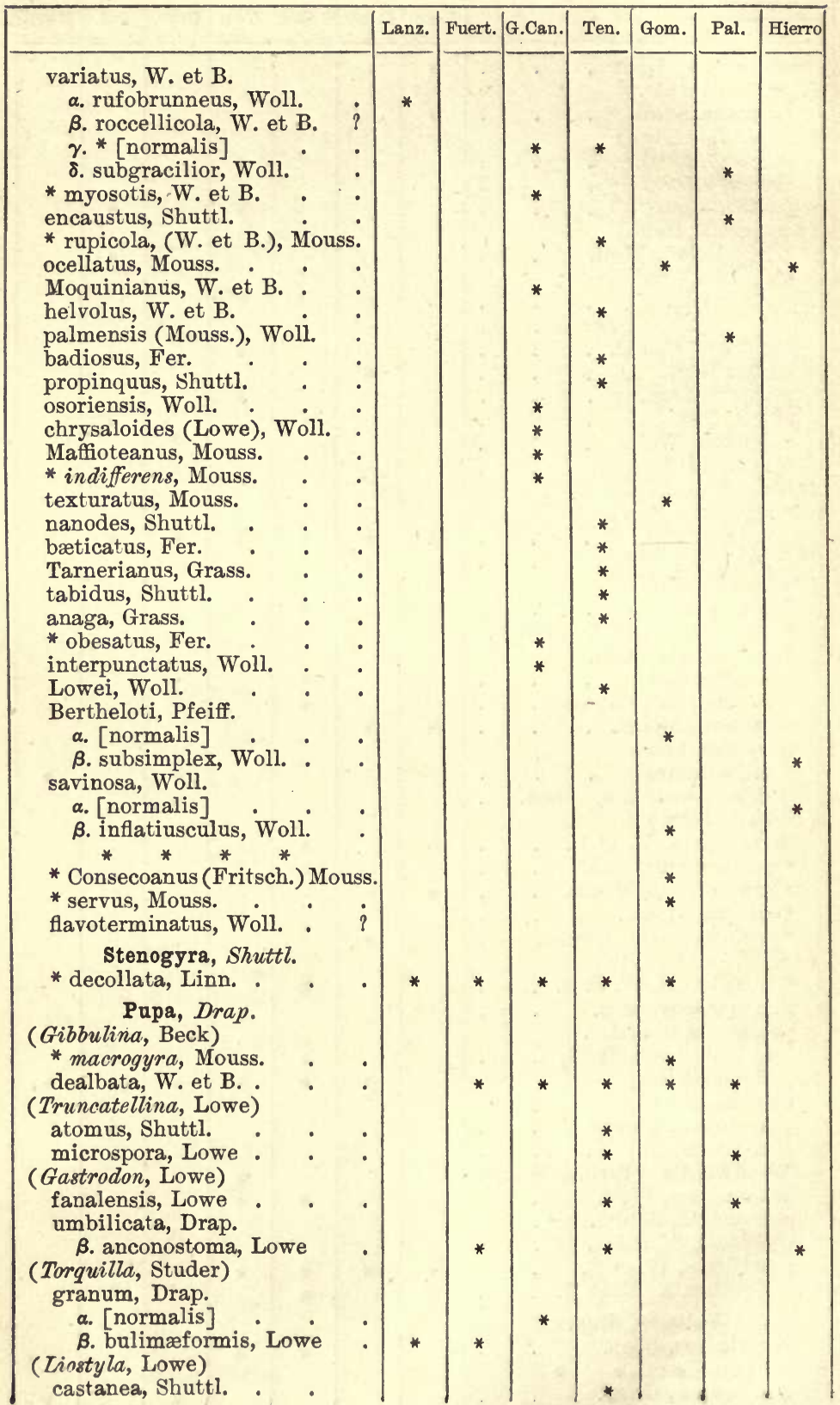


Canarian Catalogtte-(continued).

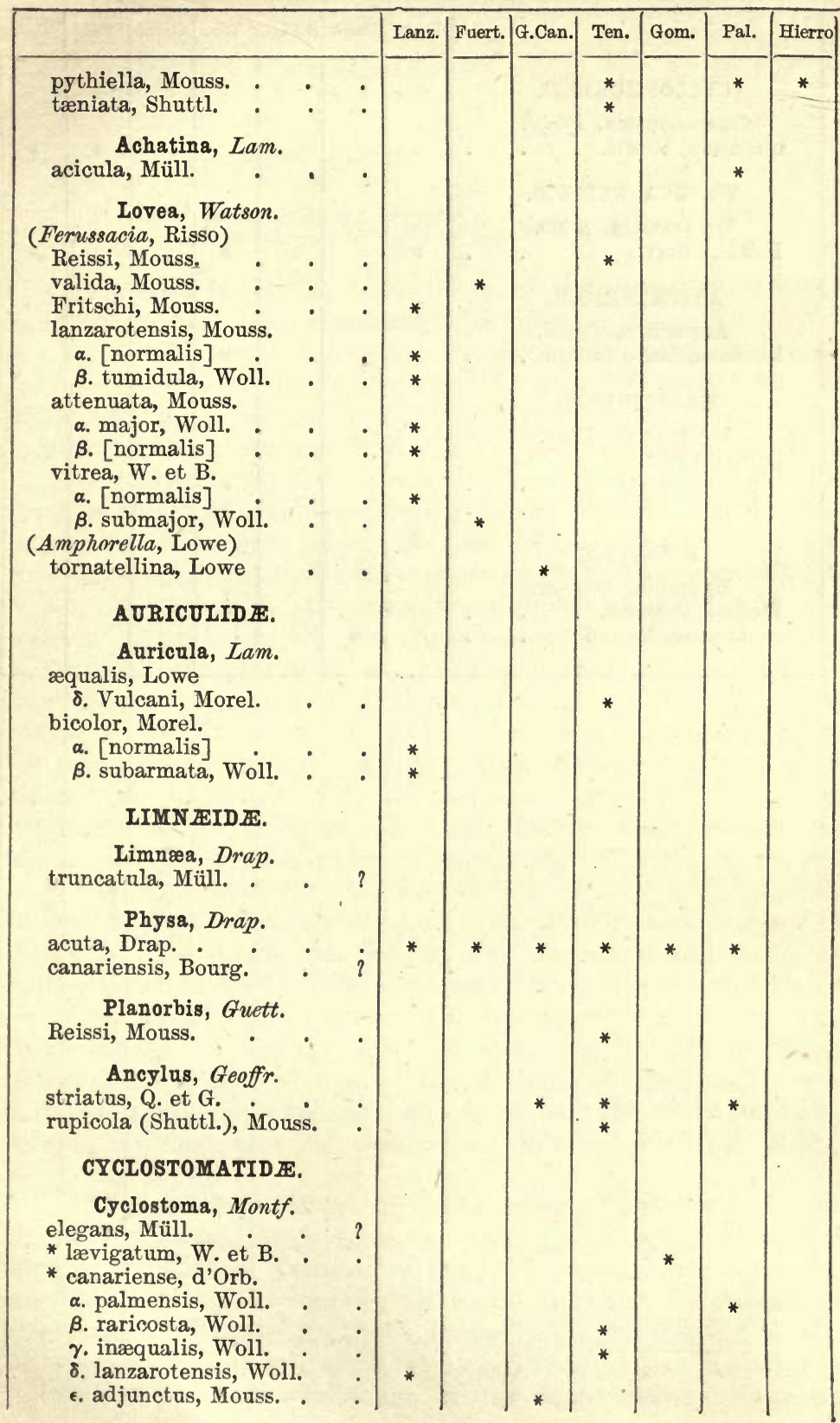


Canarian Catalogue-(continued).

\begin{tabular}{|c|c|c|c|c|c|c|c|c|}
\hline & & Lanz. & Fuert. & G.Can. & Ten. & Gom. & Pal. & Hierro \\
\hline $\begin{array}{c}\text { CYCLOPHORIDE. } \\
\text { Craspedopoma, Pfeiff. } \\
\text { costatum, Shuttl. } \\
\text { TRUNCATELIIDE. } \\
\text { Truncatella, Pisso. } \\
\text { Lowei, Shuttl. } \\
\text { AssIMINEIDE. } \\
\text { Assiminea, Leach. } \\
\text { littorina, Delle Chiaje } \\
\text { HELICINIDE. } \\
\text { Hydrocæna, Parr. } \\
\text { gutta, Shuttl. } \\
\text { a. [normalis] } \\
\text { B. minor, Shuttl. } \\
\text { RIssoIDF. } \\
\text { Hydrobia, Hartm. } \\
\text { Pleneri, Frauenf. } \\
\text { canariense, Mouss. }\end{array}$ & . & * & * & . & * & & * & * \\
\hline
\end{tabular}




\section{CAPE-VERDE GROUP.}

OvR knowledge of the Land-Shells of the Cape-Verde archipelago can scarcely be regarded, hitherto, as more than fragmentary. The extremely depauperated condition of the islandswhich have been reduced, through the complete destruction of their aboriginal timber, to a state of dryness and sterility far beyond what we observe in the more northern clusters-added to the comparatively short visits which have been paid to them by the different naturalists who have attempted, from time to time, to investigate their natural history productions, has precluded any thorough acquaintance, as yet, with even the few types of life which still remain to represent their primeval fauna. Considering the large number of the islands, the great extent of their combined superficial area, and the considerable elevation which many of them attain (Fogo, the loftiest of all, rising to an altitude of 9,760 feet above the sea), there can be little doubt that a corresponding Molluscous population must once have flourished; but the wholesale annihilation, by the improvident inhabitants, of their native trees has so far destroyed the central source of humidity that what only a few centuries ago must have been densely wooded ravines and wellfilled mountain torrents are now scarcely more than a chaos of black basaltic rocks, abutting on dry cindery slopes and hardened volcanic mud. Yet even under circumstances so adverse as these some slight traces of the aboriginal Gastropods have been brought to light,- about 41 species being the result, so far as I am able to judge, of the united exertions of the very limited number of explorers who have had the opportunity of examining one part or another of this remote and widely scattered Group.

Although stray notices of a few of the Cape-Verde LandShells appeared, from time to time, in earlier publications (including those of Ferussac in 1827, of King in 1831, of Beck in 1838, of Pfeiffer and Shuttleworth in 1852, of Albers in 18.54 and of Benson in 1856), it was not until 1865 that the catalogue of Reibisch cited 11 species as a first instalment towards a Gastropodous fauna of the archipelago. Nothing 
worthy of being mentioned, however, can be said to have been placed upon record until the appearance of the list of Dr. H. Dohrn, in the 16th volume of the 'Malacozoologische Blätter,' in 1869 ,-where no less than 29 species were carefully and systematically enumerated. These 29 members, chiefly of the Pulmonobranchiata, although including a few which had been collected by the Rev. R. T. Lowe and myself in January and February of 1866, were chiefly due to Dohrn's personal researches amongst the islands in 1864 and 1865 ; and had it not been for an unlucky accident in the after-loss of the greater portion of his material, the number might perhaps have been still further increased.

The next, and latest, résumé of the Land-Shells of the Cape-Verdes was given by Morelet in the 13th volume of Crosse's 'Journal de Conchyliologie,' in 1873. It was while noticing a few additions to the catalogue which had recently been made by MM. Bouvier and de Cessac that Morelet took the opportunity of calling attention to the species which had been observed, up to that date, in the whole archipelago; and, judging from his list which is now before me, he seems to have brought up their number to 40. Although he speaks of eight of them as having been contributed by MM. Bouvier and de Cessac, it appears to me that eleven are alluded to which at all events had not been cited by Dohrn,-namely

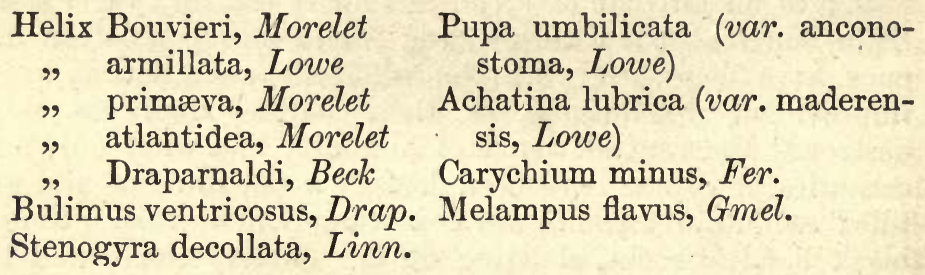

Out of these, however, the 'var. anconostomas of the Pupa umbilicata, Drap., I have rejected, as being referable more probably to the very closely allied (and perhaps scarcely distinct) Pupa Dohrni, Pfeiff.; as well as the Helix Draparnaldi, Beck, as having been established on evidence which is not sufficiently trustworthy. Moreover the Bulimus ventricosus and Achatina lubrica are not very satisfactory additions to the fauna, inasmuch as Morelet does not mention either in which islands they were fourd or by whom; nor indeed is there a syllable said about the Carychium minus which figures in his list, and which may perhaps therefore have been inserted on nothing more than the original authority of Ferussac, -in whose long-discredited article (Bulletin Universel des Sciences et de l'Industrie; 1827) the species was mixed up. with others the 
asserted habitats of which are more than questionable. It was on this account indeed that Dohrn absolutely refused to admit it (and, as I cannot but think, rightly) into his enumeration of the Gastropods of the archipelago, no less than he did the Helix gyrostoma-a north-African form, likewise registered from $\mathrm{S}$. Iago, concerning which some strange confusion seems to have been brought about by Ferussac, who himself had previously described it. If however the Carychium minus has been re-detected lately by MM. Bouvier and de Cessac, it is much to be regretted that Morelet should not have stated this plainly, and moreover let us know in what particular island (or islands) they met with it. The mere insertion of a name into a geographical catalogue without any information being supplied as to the authority on which it rests, or as to the place in which the species which it represents is supposed to have been obtained, is utterly insufficient in cases where the most extreme and absolute accuracy is of primary importance.

It was in Mr. Gray's yacht, the 'Garland,' that the islands of the Cape-Verde archipelago were visited by the Rev. R. T. Lowe and myself; but our two months' sojourn amongst them, in January and February of 1866, was so short that we had but little time (our main object being to investigate the insects and plants) to devote to the Land-Shells. Still, we never failed to collect them when they came in our way; though the season was so exceptionally dry, and the conditions for molluscous life were so unfavourable, that we did not meet with more than 16 out of the 41 species which are enumerated in the present catalogue. And yet, through Mr. Gray's assistance and co-operation, we examined, as carefully as we were able, the five principal islands, -namely S. Antão, S. Vicente, S. Iago, Fogo, and Brava; S. Nicolão having been explored by Messrs. Gray and Lowe on a previous occasion (during February and March of 1864) when it was not in my power to accompany them. The islands which were visited by Dohrn, in 1864 and 1865, appear to have been S. Antão, S. Vicente, S. Nicolão, and S. Iago; so that the three eastern ones of the Group-Sal, Boavista, and Maio (known locally as the 'Salt-islands') - would seem to have been altogether untouched, as regards their fauna, until glanced at lately (and, as is but too manifest, very superficially so) by M.M. Bouvier and de Cessac.

Having been accustomed, in the more northern archipelagos, to a great diversity in the Gastropodous list of each separate island, from that which obtains in the various others, respectively, even of the same Group, one of the first facts which struck me at the Cape-Verdes was the comparative uniformity of the species throughout the cluster,-many of them, such as 
the Helix advena, Bulimus gemmula, Stenogyra Goodallii and subdiaphana, and Pupa acarus and gorgonica, having all the appearance, as it seemed to me, of being well-nigh universal. Still, this may have been more apparent, perhaps, than real; for the very limited number of the forms which came beneath our notice precluded any safe inferences on the general subject of local distribution.

With only $4 \mathrm{l}$ exponents from which to judge, it is scarcely possible to build up any very trustworthy theory on the affinities of the Pulmonobranchiata of the Cape-Verdes; and yet even the fragmentary catalogue which has hitherto been brought to light reveals a certain amount of evidence which points unequivocally, as I cannot but think, to their connection with those of the Madeiran Group. In venturing on this opinion, however, I would lay little or no stress upon the presence of a few forms-such as the Helix armillata and lenticula, the Bulimus ventricosus, the Stenogyra decollata, and the Achatina lubrica - which there is every reason to suspect may have been accidentally introduced through indirect human agencies, and which abound, to a greater or less extent, in the more northern archipelagos; for those particular species belong to a small assemblage which are eminently liable to transmission (sumetimes along with ballast in vessels, though more often in consignments of plants), and the intercommunication between Madeira and the Cape-Verdes (which are likewise Portuguese), although perhaps never very considerable, would be more than sufficient, during a period of two or three hundred years, to account for the establishment of any or all of them in this more southern cluster. But, putting these out of the question, as possessing but a doubtful significance for the purposes of generalization, there still remains a conspicuous relationship between the most important Helices of the Group and those of the erubescens and membranacea type which constitute so marked a feature in the Madeiran fauna. This will be at once apparent from the unmistakeable resemblance of the $H$. advena, W. et B., to the state of the protean $H$. erubescens, Lowe (from the east of Madeira proper, and from the Ilheo Chão), which I have cited as the 'var. $\gamma$. advenoides;' from the kinship (as it were) of the H. Bollei, Alb., the H. leptostyla, Dhn., and the $H$. serta, Alb., with other modifications of the erubescens; from that of the $H$. subroseotincta, Woll., with the Madeiran H. membranacea, Lowe; and perhaps also from even that of the subfossil $H$. atlantidea, Morelet, with the (equally extinct) $H$. chrysomela, Pfr., from Porto Santo;-all of which, and others (from both archipelagos), are embraced by the particular section to which Mr. Lowe gave the name of Leptaxis. And it 
is likewise traceable in the presence at the Cape-Verdes of the minute Patula pusilla, Lowe (so common at the Madeiras, and which exists also at the Canaries and the Azores), as well as in the close affinity of the Pupa molecula, Dohrn, and Dohrni, Pfeiff., with the Madeiran subfossil P. linearis, and with the 'var. anconostoma' of the European P. umbilicata, Drap., which is so universal throughout the more northern Groups. Moreover the subfossilized $H$. primoeva, from Sal, is compared by Morelet to Lowe's $H$. undata, of Madeira.

It is to be noted also that the group Leptaxis, which is so largely developed in the Madeiran and Cape-Verde archipelagos, and even at the Azores, does not possess so much as an exponent at the Canaries; for although it has occasionally been cited for certain Canarian species (as, for instance, by Mousson, for the subfossil $H$. digna from Gomera, and for the $H$. Berkeleyi from Grand Canary), the latter do not in reality fall under Leptaxis at all as originally defined by $M r$. Lowe,-the H. chrysomela, membranacea, furva, and erubescens, which are essentially Madeiran, being the sole types, apart from these Cape-Verdian ones (and eight from the Azores), of that particular section. And as regards the Canarian fauna, there seems to be no special point in which it touches that of the Cape-Verdes, such forms as the Helix lenticula, Bulimus ventricosus, and Stenogyra decollata having already been shewn to be of doubtful import in the general questions of geographical distribution. Still the diminutive Patula pusilla, Lowe, occurs in both Groups; and it is just possible that the subfossil Pupa macrogyra, of Mousson, from Gomera, may be found to make some slight approach, as regards affinity, to the Stenogyra subdiaphana, King, which is so characteristic of the Cape-Verdes; but, as I have had no opportunity of inspecting the type, this is merely a conjecture. Also the Patula Bertholdiana, Pfr., has manifestly a good deal in common with my $P$. garachicoensis from Teneriffe, though not sufficiently so perhaps to be of much significance.

The presence in the Cape Verdes of the widely spread genus Succinea, which is so strongly expressed at St. Helena, but which has no representative in the more northern archipelagos, is geographically interesting; and the existence of Melania, which possesses so extensive a range in the littoral districts of the African continent but which does not make its appearance in any of the other islands, should be particularly noticed.

In the systematic catalogue at the close of the present Section I have (as in the corresponding ones pertaining to the other Groups) placed an asterisk (*) against those few species which have been met with also in a subfossil state; and in 
cases where the species have been found hitherto only subfossilized (under which circumstances they must be looked upon practically as extinct) the names have been printed likewise in italics.

\section{Fam. 1. LIMACID艮.}

Genus 1. IIMAX, Linné.

Limax, sp.?

Limax sp., Dohrn, Mal. Blätt. xvi. 1 (1869)

Habitat S. Antão, et S. Nicolão; a cl. H. Dohrn in montibus copiose deprehensus.

A Limax was taken by Dr. H. Dohrn in S. Antão and S. Nicolão, but the subsequent loss of his material prevented him from identifying the species; and I can only therefore record the fact, that the genus (as in the case of Vitrina) is undoubtedly represented in the Cape Verde archipelago.

\section{Fam. 2. VITRINID艮.}

\section{Genus 2. VITRINA, Drap.}

Vitrina, sp.?

Vitrina sp., Dohrn, Mal. Blätt. xvi. 1 (1869)

Habitat S. Antão; ad 'Barro do ferro' a cl. Dohrn semel reperta.

Although unable to state what the exact species is which was obtained by Dohrn in S. Antão (for he himself had no opportunity of identifying it with any known form), I think it desirable nevertheless to call attention to the fact that a Vitrina was found by him at the Barro do Ferro in that island; and it is at least interesting, therefore, to know that the genus is not altogether unrepresented in the Cape-Verde archipelago. Dohrn's short remark about it is as follows:- Einmal von mir in S. Antão bei Barro do ferro circa 400 Fuss hoch gefunden. Diese beiden Arten sind mir leider nebst anderen in Spiritus bewahrten Sachen verloren gegangen.'

\section{Fam. 3. HELICID压.}

Genus 3. PATULA, Held.

( $\$$ Iulus, Woll.)

Patula gorgonarum.

Helix aluta, Alb., in litt.

" gorgonarum (Patula), Dohrn, Mal. Blätt. xvi. 3(1869)

" " Morel., Journ. de Conch. xiii. 242 (1873)

" $\quad$ Pfeiff., Mon. Hel. vii. 209 (1876) 
Habitat S. Vicente, S. Nicolão, et ('var. $\beta$. minor) S. Antão ; a cl. Dohrn a $2000^{\prime}$ usque ad $4000^{\prime}$ s.m. deprehensa.

I do not feel altogether certain that this species should be regarded as a Patula; nevertheless since at all events the H. Bertholdiana, Pfr., is, I think, an undoubted member of that group, and there is an intermediate form between the two (treated by Dohrn as a 'var. minor' of the gorgonarum) which might well-nigh be affiliated with either of them, I am content to leave it in the position (as regards its supposed affinities) in which it has already been placed. ${ }^{1}$

The P. gorgonarum (the larger examples of which are, in their broadest part, about $4 \frac{1}{2}$ lines across) may be defined as being a somewhat lenticular shell, rather sharply keeled, and fragile in substance, of a pale-brown hue, but more or less marbled (particularly on the underside) with a few small, obscure, and irregular whitish blotches, and having the volutions densely sculptured with very oblique and waved transverse lines or costæ. Its umbilicus, although deep, is not very large, and is partially concealed by the recurved overhanging edge of the columellary plate. It was taken in S. Vicente and S. Nicolão by Dr. H. Dohrn, who kindly communicated the types which are now before me.

There is however a smaller shell which was obtained by Dohrn in S. Antão, and which is less strongly keeled and not quite so pallid in hue, and which is cited by him as a 'var. minor' of the P. gorgonarum; though I cannot but think that it ought to be treated as specifically distinct. In general size and contour it is nearly identical with the P. Bertholdiana, Pfr.; nevertheless its rather smaller umbilicus, which is also partially overhung by the columellary edge of the peristome, would assign it better (as indeed Dohrn has done) to the $P$. gorgonarum. It is perhaps more closely related still to the H. Bouvieri of Morelet, - from which it differs almost solely (if indeed I understand the latter species aright) in its under-

1 At first sight the $P$. gorgonarum has so strong a resemblance (in its keeled outline, as well as in its general size, contour, sculpture, and hue) to the $H$. actinophora of the Madeiran archipelago that it is difficult to believe that it should not rather be assigned to one of the sections (such as Gonostoma and Hispidella) which embraces that species and its immediate allies. Apart however from its surface having no tendency, so far as I can detect, to be hispid, the different structure of its aperture will suffice to separate it from those particular forms. However its suggestiveness of the latter is certainly not much strengthened by the fact that Morelet in enunciating lately his very closely allied $H$. Bouvieri, compares that species with the $H$. hispida, Linn., (which is altogether distinct from the actinophorx). Moreover Dohrn speaks of the nearly-related $H$. Bertholdiana, Pfr., which he nevertheless acknonledges as a Patula, as having a decided affinity with the Madeiran $H$. Armitageana, Lowe, which belongs to Mr. Lowe's group Hispidella; an affinity, however, which seems to me to be somewhat more questionable. 
portion being more decidedly opake and more regularly and distinctly striated, the costæ in the $P$. Bouvieri being both less evident and more interrupted (and subconfluent), giving a more wrinkled appearance to the surface.

\section{Patula Bouvieri.}

Helix Bouvieri, Morel., Journ. de Conch. xiii. 235 (1873) " " Pfeiff., Mon. Hel. vii. 200 (1876)

Habitat S. Vicente; in editioribus juxta Monte Verde a DD. Lowe et Bouvier reperta.

Judging from the published diagnosis, I have little doubt that a single example which is now before me, and which was taken by Mr. Lowe in S. Vicente (on the ascent, I feel almost sure, of Monte Verde), is identical with Morelet's recently described $H$. Bouvieri; and if this be the case, the 'var. minor' (from S. Antão) of Dohrn's Patula gorgonarum seems to me to be so unmistakeably related to the Bouvieri that I am exceedingly doubtful whether the latter is more in reality than a mere insular modification of that (S. Antão) species, - the Bouvieri proper being apparently a $S$. Vicente form. Indeed if this individual (to which I have just called attention, and which was obtained by Mr. Lowe in S. Vicente) be absolutely typical of the Bouvieri, and I have every reason to believe that it is, the present Patula may be defined as being smaller, and less keeled, than the gorgonarum, not quite so opake, at any rate on the under region, and with the striæ in that part less regular and more interrupted and subconfluent,-occasioning the surface to appear, when viewed beneath a high magnifying power, as more wrinkled.

Although calling to mind some of the members of the sections Hispidella and Gonostoma, amongst the true Helices, I have already implied (vide foot-note on preceding page) why it is that I think it will be more natural to treat these three intimately allied species,-namely the P.gorgonarum, Bouvieri, and Bertholdiana (the last of which moreover is closely akin to the Canarian $P$.garachicoensis, which could hardly be looked upon as otherwise than a veritable Patula), - as members of the present genus.

\section{Patula Bertholdiana.}

Helix Bertholdiana, Pfeiff., Mal. Blätt. 149 (1852)

" $\quad$ " $\quad$ Dohrn, Mal. Blätt. xvi. $2(1869)$

Habitat S. Antão, et S. Vicente; a cl. Dohrn lecta. The present shell, which is rather more on the ordinary 
Patula type than the preceding two, is smaller, darker, and much less keeled than the $P$. gorgonarum (indeed perhaps a trifle less so than even the so-called 'var. $\beta$. minor' of that species, and the $P$. Bouvieri), and it is also a trifle less fragile in substance, its umbilicus is relatively larger and more open, and its spire is a little more compact and apically obtuse,-the volutions not being quite so prominent and convex. When in a young state it is studded all over, though especially about the keel, with minute hairs.

The $P$. Bertholdiana is, so far as I am aware, peculiar to S. Antão and S. Vicente, -in which islands it was obtained by Dr. H. Dohrn, and to whom I am indebted (for it was not met with either by Mr. Lowe or myself) for the types which are now before me.

\section{(§ Acanthinula, Beck.)}

\section{Patula pusilla.}

Helix pusilla, Love, Cambr. Phil. S. Trans. iv. 46. t. 5. f. 17 (1831)

$" \quad$ " Pfeiff., Mon. Hel. i. $101(1848)$
$" \quad$ servilis, Shuttl., Bern. Mitth. $140(1852)$
$" \quad$ pusilla, A. annulata, Lowe, Proc. Zool. Soc. Lond.
$176(1854)$

" $\quad$ Alh., Mal. Mad. 18. t. 2. f. 7-10(1854)

" servilis, Morel., Hist. Nat. des Açor. 173. t. 3. f. 6 (1860)

hypocrita, Dohrn, Mal. Blätt. ] (1869)

Patula servilis, Mouss., Faun. Mal. des Can. 25. pl. 2.

$$
\text { f. 13-16 (1872) }
$$

Helix hypocrita, Morel., Journ. de Conch. xiii. 242 (1873)

Habitat S. Antão; a cl. H. Dohrn parce deprehensa.

Several examples of a very minute Patula have been communicated to me by Dohrn as types of his P. hypocrita, and which were taken by himself in S. Antão; but after a long and rigid inspection of them I can come to no other conclusion than that they are absolutely inseparable from the common Madeiran $H$. pusilla, Lowe,-a species which occurs also in the Azorean and Canarian archipelagos as well as at St. Helena, and which would seem therefore to possess a somewhat wide geographical range.

The extremely diminutive size, discoidal contour, and uniformly brown hue of the $P$. pusilla, in conjunction with its curious tendency to have a few rather more elevated hair-like lines (in addition to the still finer ones which will be seen 
beneath the microscope to crowd its surface) across its volutions, and which, although sometimes scarcely traceable, are at others quite costiform and conspicuous, will suffice to distinguish it from everything else with which we are concerned in the CapeVerde archipelago.

Dohrn mentions expressly that this little Patula is allied to the ' $H$. servilis, Shuttl., from the Canaries,'-i. e. to Lowe's $H$. pusilla; adding, however, that it ' differs from it in its superior sculpture and its small umbilicus, as well as in its ultimate volution not descending, and in its lacking the obtuse angle at the peripherium;' but I can only say that, after a most rigid comparison of his examples with Madeiran and Canarian ones, I can detect absolutely nothing about them to indicate a specific difference; though as the $P$. pusilla is eminently variable as regards its sculpture, I can quite understand that chance specimens from the Canaries might well have appeared to him to be not quite similar to those from the Cape Verdes. ${ }^{1}$

\section{Genus 4. HELIX, Linné.}

(§ Cryptaxis, Lowe.)

\section{Helix primæva.}

Helix primæva, Morel., Journ. de Conch. xiii. 236 (1873) Pfeiff., Mon. Hel. vii. 486 (1876)

Habitat Sal, semifossilis; a DD. Bouvier et de Cessac lecta. This Helix, which I have had no opportunity of inspecting,

' I may just notice the Helix Draparnaldi, Beck, which figures in Morelet's list of the Land-Shells of the Cape Verdes, but concerning which not a single syllable of information is given to us,-either as to the exact island in which it was found, or by whom. So far as I understand the H. Draparnaldi, it is probably identical with the previously described and common European Helix (or Hyalina) lucida, Drap.; and there is no evidence hitherto of that species having been met with in any of these various archipelagos. If, therefore, Morelet has discovered it amongst the material of MM. Bouvier and de Cessac, or elsewhere, he was bound to tell us so, and to give us the particulars of its exact locality, - at any rate if he expects so important an addition to the general fauna to be acknowledged. If, however, by the ' $H$. Draparnaldi, Beck,' he means (as I should rather suspect) the H. cellaria, Müll., which has been observed in the whole of these Atlantic Groups except the Cape Verdes, there is a greater probability of its insertion being correct. But even in that case he would be bound to say-not orly by whom it had been detected, and where, but (still more) to be quite sure that his nomenclature is accurate; for it is a matter of no slight importance whether the species to which he alludes is the ordinary European $H$. cellaria, Müll., which is so widely spread throughout these archipelagos, or the nearly allied H. lucida, Drap., which has not as yet been recorded in any of them. The mere entry of a name into a local catalogue, unaccompanied by the smallest information concerning it, is more apt to create confusion than otherwise ; and more particularly so when there is reason to feel uncertain (as in the present instance) as to whether even the title itself has been accurately employed. 
and which is compared by Morelet to the $H$. undata, Lowe, of Madeira, was found in a subfossil state, by MM. Bouvier and de Cessac, in the island of Sal [mis-spelt ' $\mathrm{Pal}$ ' in the observations which accompany the diagnosis, - an error which is unwittingly endorsed, subsequently, by Pfeiffer]. Being imbedded firmly in 'un plateau calcaire de la côte est,' in all probability it belongs to a fauna which has passed away; nevertheless, with my experience of the many subfossilized species in the Madeiran and Canarian Groups which were long supposed to be extinct, but which have gradually assumed a place amongst living organisms, I cannot adopt the conclusion of Moreletthat the H. primoeva' sans doute a cessé de vivre dans l'archipel.' That is a point which can only be decided by further, and more careful, enquiry; for some of the subfossil Helices of Madeira and Porto Santo which have lately been brought to light in a recent condition had escaped, except as fossils, the united researches of many naturalists for nearly fifty years.

In his remarks on the $H$. primoeva, Morelet says: 'Cette coquille, par sa forme et par sa sculpture, offre quelque ressemblance avec l' $H$. undata de Madère. Elle en diffère, toutefois, par une costulation plus grossière, qui n'est point ondulée, et par la direction normale du dernier tour qui se maintient au niveau de la périphérie. La plupart dés échantillons sont des moules intérieurs qui permettent seulement d'apprécier la profondeur de l'ombilic : chez d'autres, mieux conservés, on reconnaît très-bien la forme de la coquille dont la spire est conique et généralement atténuée au sommet. L'ouverture ne laisse pas d'incertitude: il n'en est pas ainsi du péristome, engagé partiellement dans une pâte calcaire de la plus grande dureté.' [l. c. 236, 237]

(§ Leptaxis, Lowe.)

Helix atlantidea.

Helix atlantidea, Morel., Journ. des Conch. xiii. 237 (1873) " $\quad$ "Pfeiff., Mon. Hel. vii. 482 (1876)

Habitat Sal, semifossilis; a DD. Bouvier et de Cessac reperta.

Like the $H$. primove, this species was detected in a subfossil condition in Sal by MM. Bouvier and de Cessac; and it seems to have been found in the same calcareous formation, on the eastern coast of that island. It is said to be somewhat related to the (likewise semifossilized, and apparently extinct) $H$. chrysomela, Pfeiff., of Porto Santo, in the Madeiran Group ; and Morelet, in his observations concerning it which follow the diagnosis, says: 'Elle rappelle, au premier aspect, l' $H$. chryso- 
melu de Porto Santo; mais elle est un peu plus déprimée, avec un tour et demi de moins; le dernier est, en même temps, plus dilaté. On remarque, à la surface du test, une costulation blanchâtre, fine, serrée, régulière, et, en outre, des vestiges de marbrure qui le temps n'a pas complèternent effacés. L'angle périphérial, d'abord assez prononcé, s'atténue graduellement en approchant de l'ouverture.' [l. c. 237]

\section{Helix subroseotincta, n. sp.}

T. imperforata, depresso-globosa, vix subcarinulata, nitidiuscula, albidiuscula (interdum subfusco- aut etiam obsoletissime subroseo-tincta), obsolete et irregulariter (præcipue versus suturam) sublacteo-liturata, jun. subpellucida ; anfractibus 5 convexiusculis, suturâ distinctâ, ultimo antice paulo descendente; aperturæ labris disjunctis ; peristomate acuto, distinctius roseo; columellâ oblique subrectâ, cum labro angulum sub-efformante. -Diam. maj. 5-6; alt. 4 lin.

Habitat Brava; in montibus excelsioribus supra Povoação, plantis Euphorbice Tuckeyance, Webb, adhærens, Martio_28, 1864, a Revdo. R. T. Lowe copiose deprehensa.

Although larger, more opake, and of a more chalky-white hue with an obsolete rosy tinge (much as we see in some of the pallid varieties of the $H$. pisana), this Helix has something about it, at any rate when not fully mature, which recals the Madeiran $H$. membranacea, Lowe; and although perhaps, in reality, more on the erubescens type, we may be permitted to regard it as the Cape-Verde representative of that species,looking on the H. Bollei, leptostyla, and advena as the analogues of the latter.

The $H$. subroseotincta, in its small size and totally ungranulated surface, has more in common with the $H$. Bollei than it has with the leptostyla; nevertheless it is thicker, whiter, and more calcareous; its peristome has nearly always a faint rosy tinge (indeed the entire shell is often suffused with an obscure pinkish brown); its volutions (the basal one of which is not quite so perceptibly keeled) are a trifle more tumid, and the suture consequently somewhat more impressed; its columella is just appreciably straighter, forming somewhat of an angle at its junction with the lower lip; and its entire surface has a tendency to be irregularly blotched, or freckled, with very obscure, paler, frequently confluent patches, - which, although now and then absent (and never condensed into fasciæ), are at times quite conspicuous.

The present Helix was found abundantly by Mr. Lowe (on March the 28th, 1864) on the mountains above the Povoação 
de S. João Batista, in Brava,-adhering to the shrubs of Euphorbia Tuckeyana, Webb, as well as under stones, at about 3,500 feet above the sea.

\section{Helix Bollei.}

Helix Bollei, Alb., Mal. Blätt. i. 215 (1854)

$\begin{array}{lll}" \quad & \text { Pfeiff., Mon. Hel. iv. 19 (1859) } \\ " \quad & \quad \text { Dohrn, Mal. Blätt. xvi. 4 (1869) } \\ & \quad \text { Morel., Journ. de Conch. xii. 235 (1873) }\end{array}$

Habitat S. Vicente (sec. Dohrn et Morelet), et S. Nicolão, in intermediis editioribusque, sub lapidibus.

This species and the following one, which I cannot but think . will prove eventually to be but insular modifications of each other, may be regarded as the representatives in the Cape-Verde archipelago of the very variable Madeiran $H$. erubescens; indeed (judging from the analogy of the latter, in its numerous and very different phases) I am not at all satisfied that the whole of them, including even the $H$. subroseotincta, are anything more than local aspects of a single plastic type which has permeated the length and breadth of this entire Atlantic province. Still, since they have been published as specifically distinct, and they can be recognised (not always, however, without some difficulty) in a general way, I will not attempt to do otherwise than cite them accordingly; though I would wish it to be understood that I look upon them, as regards their differential characters, with a certain amount of distrust.

With these observations, I may add that the $H$. Bollei seems to be rather smaller and more pellucid than the leptostyla, and usually of a pale yellowish-corneous hue,-sometimes with a faint rosy tinge, but apparently never fasciated or even blotched; its spire is just appreciably more obtuse or less elevated, with the suture not quite so deeply marked;' its basal volution (although obsoletely so) is more appreciably keeled; the lower lip of its aperture is not quite so rounded; and its surface is just perceptibly brighter,- - being altogether free, so far as I can detect (even beneath a high magnifying power), from the extremely diminutive granules which are more or less traceable in its ally.

From the Madeiran $H$. erubescens the unwrinkled, unmalleated surface of the whole of these three immediately cognate forms will, apart from other and less evident characters, at once separate them.

The H. Bollei was found both by Dr. H. Dohrn and Mr. Lowe in S. Nicolão, where it would appear to be tolerably common; and, although I have not myself seen examples from 
that island, it is recorded both by Dohrn and Morelet to have been taken on Monte Verde in S. Vicente.

\section{Helix leptostyla.}

Helix leptostyla, Dohrn, Mal. Blätt. xvi. 4 (1869)

$" \quad$ " $\quad$ Morel., Journ. de Conch. xiii. 242 (1873)

Habitat S. Antão; a cl. H. Dohrn benigne communicata.

As already implied, this Helix (which has been communicated by Dohrn, as found in S. Antão) may be regarded, in conjunction with the preceding one, as the Cape-Verde representative of the Madeiran $H$. erubescens, - to which indeed, in its rather larger size and more highly coloured (often fasciated) surface it makes a still nearer approach. Nevertheless, its totally unwrinkled, unmalleated, and more granulose sculpture will, of itself, remove it from all the numerous phases of that protean species.

The $H$.leptostyla (which in its young state is rather sharply carinated) appears to be a trifle larger (on the average) than the $H$. Bollei, as well as a little thicker in substance or less pellucid: and it is also more variegated (having a greater tendency to be both fasciated and dappled), somewhat less shining, and (when viewed beneath a high magnifying power) very diminutively granuled. Its ultimate volution is just appreciably more ventricose, or less keeled, its lower lip is perceptibly more rounded, and its spire is a little more elevated or less obtuse.

\section{Helix advena.}

Helix advena, W. et B., Ann. des Sc. Nat. 28. syn. 324 (1833)

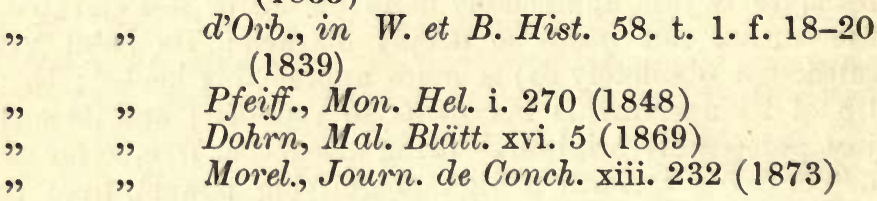

Habitat S. Antão, et S. Vicente, necnon sec. Morelet S. Nicolão et Maio ; sub lapidibus in intermediis, hinc inde vulgaris. In $\mathrm{S}$. Antão quoque semifossilis reperitur.

This seems to be one of the most generally distributed of the Helices which are peculiar to the Cape Verde archipelago; for although it is only in S. Vicente that I have myself met with it (where I obtained it in great profusion, beneath stones, on the ascent of Monte Verde), it was taken by Dohrn (both recent and in a subfossilized condition) in S. Antão, and Morelet reports 
that it has been found by MM. Bouvier and de Cessac in S. Nicolão and Maio. Nevertheless it is perhaps open for enquiry whether the examples from $\mathrm{S}$. Nicolão are not in reality referable to Albers' $H$. serta. It was manifestly through an error that Webb described it originally, in his 'Synopsis', as coming from the Canaries; but his extreme carelessness as regards his habitats was well known to those who (like Mr. Lowe) were in communication with him at the time, and it would appear that another Cape-Verde species (namely the Stenogyra subdiaphana) shared the same fate as the present one, and was wrongly introduced into the fauna of that Group. ${ }^{1}$

Mr. Lowe, in his last catalogue of the Madeiran Land-Mollusca (Proc. Zool. Soc. Lond. $165 ;$ 1854), identified Webb's $H$. advena with the particular state, or variety, of the erubescens (well enunciated by the Baron Paiva under the name of ' $\gamma \cdot a d$ venoides') which obtains on the São Lourenço promontory of Madeira proper, and which is still more characteristic of the Northern Deserta (or Ilheo Chão) ; but in this he was evidently mistaken, Mr. Edgar Smith having examined for me with great care one of the original types (now in the British Museum) on which the $H$. advena was founded, and which he assures me is, without any doubt whatsoever, identical with the Cape-Verde species,-thus corroborating the conclusions which had previously been arrived at by Dohrn and others. ${ }^{2}$ Dr. Albers, in

1 Indeed Madeiran species likewise would appear to have been pressed recklessly into his service,- the $H$. tiarella and taniata, both essentially characteristic of Madeira proper, having been made to figure in the Canarian list; as was also the Bulimus Terverianus, from Morocco.

2 Since the above was written I have myself inspected these British Museum types of the H. advena; and if the species is to be settled by the majority of the individuals which are placed to represent it, there is fortunately no question that the H. advena is truly (as has latterly been supposed) the Cape Verde shell which we are now considering; for out of the three examples (all more or less immature) which are there preserved, as having formed a portion of Webb's so-called 'Canarian' material, two are undoubtedly our present Helix. The third (or central) one, however, does not appear to me to be specifically identical with the others,-its malleated, and less coarsely and much less regularly striated, surface (which is likewise very minutely granulose) affiliating it, I think, unmistakeably, with the Madeiran H. erubescens (perhaps under its Desertan aspect). Tnus if Mr. Lowe examined this particular specimen only, his conclusions concerning the $H$. advena were probably correct; but the other two individuals constitute a majority which give a different verdict. At any rate it is quite in harmony with the characteristic carelessness of Mr. Webb on the subject of habitats, that of these three immature Helices (gathered from consignments of dried orchil) which he so unhesitatingly published as 'Canarian,' two should prove to be from the Cape Verdes and the other from Madeira! But this, unfortunately, is not the whole of it ; for we were required also to believe, by these very confident probers of 'dyers' moss,' until at least it was shewn to be absolutely absurd, that the $H$. advena was a native likewise of the Azores! Perhaps, however, the mixing-up of the Cape Verde shell with the real embescens may possibly account for a certain percentage of all this confusion. 
his 'Malacographia Maderensis,' figures a shell as the $H$. advena, from a unique example which was found by Hartung in Porto Santo; but, whatever species it may represent, it certainly has nothing whatever to do with our present one from the Cape Verdes.

The $H$. advena belongs to exactly the same type as the $H$. Visgeriana and serta (both, likewise, from the Cape Verdes), and differs from all the numerous forms of the Madeiran $H$. erubescens in its surface being more shining and totally unmalleated, but with nevertheless the oblique transverse striæ, much more coarsely and regularly developed. 'Its spire, too, is appreciably more obtuse, or less elevated; its aperture is a trifle rounder, and relatively not quite so large; its peristome (which has the upper portion somewhat less deflected) is not quite so expanded or recurved; and its umbilicus is not always so completely closed over. Added to which, the colour in the $H$. advena is different,- - there being scarcely any rosy tint on any part of the surface, but more or less of a faint blueish or leaden one, which although now and then obscure is seldom entirely absent. The fasciæ seem very variable, but are often broad, dark-brown, and (although normally four in number) more or less suffused.

The examples now before me from S. Vicente, which have been regarded as the typical ones, are (on the average) smaller and darker, and not quite so coarsely striated as those from S. Antão.

\section{Helix serta.}

Helix serta, Alb., Mal. Blätt. i. 215 (1854)

$$
\begin{array}{ll}
" \quad & \quad \text { Dohrn, Mal. Blätt. xvi. } 7 \text { (1869) } \\
" \quad & \quad \text { Morel., Journ. de Conch. xiii. 242 (1873) }
\end{array}
$$

Habitat S. Nicolão; a DD. Lowe et Dohrn inter Euphorbias in monte Gordo lecta. An vere ab $H$. advena distincta?

Judging from the analogy of the $H$. erubescens in the Madeiran archipelago, every island of which appears to harbour a phasis more or less its own, I should be inclined to regard the present shell as but an insular modification, peculiar to $\mathrm{S}$. Nicolão, of the advena; nevertheless if the latter in a more typical state be really found in that island, as seems to be implied by the remarks of Morelet, this supposition is perhaps scarcely tenable,- - though I cannot but suspect that the particular form to which he made allusion when he added ' cette variété [of the H. adven $\alpha$, figurée dans la seconde édition de Chemnitz, paraît dominante à l'île San Nicolão' may be the very Helix which we are now considering, and which was described by Albers in the 
Mal. Blätt. under the name of serta. Still, since the $H$. serta has already been published, and it is just possible to distinguish it, in a general way, both as regards colour and sculpture, I will not attempt to do more than record my belief that it will be found eventually to be but a local aspect of the advena.

After these observations I will merely remark, that, judging from a long array of individuals which are now before me, the $H$. serta would appear to differ from the advena, merely, in being just perceptibly less coarsely striate (at any rate than the S. Vicente type), and in its colour being. both more varied and with less of the leaden, or blueish, tinge which characterises the latter in its normal condition. Perhaps too its umbilicus is, if anything, a little less decidedly closed over, though this is a feature which is eminently inconstant. Its bands, however, are (on the average) very much narrower, as well as more broken-up and irregular, - which causes the entire surface to seem paler and much more variegated, or clappled.

The $H$. serta (if indeed it be more than a phasis of the advena) was taken by Mr. Lowe and Dr. H. Dohrn in S. Nicolão,namely in the Euphorbiaregion on the declivities of Monte Gordo.

\section{Helix Visgeriana.}

Helix Visgeriana, Dohrn, Mal. Blätt. xvi. 6 (1869)

$" \quad$ " $\quad$ Morel., Journ. de Conch. xiii. $242(18$

Habitat S. Iago ; in montibus a cl. Dohrn reperta.

The present species and the $H$. fogoensis, although on the advena type, possess a peculiarity of sculpture which will serve to separate them from the preceding ones, -in the presence of extremely minute spiral thread-like lines, which are more or less visible between the oblique transverse costæ. In the $H$. Visgeriana, however, which is (on the average) rather smaller and less globose (indeed it is the smallest of these immediately allied species), the minute spiral lines are much more, and the oblique transverse ridges are very much more, strongly developed; in addition to which, the ribs, being for the most part of a pallid hue, and therefore breaking-up or intersecting the darker bands, impart a remarkably variegated appearance to the entire surface.

The $H$. Visgeriana, which has been communicated by Dr. H. Dohrn, was detected by him at a high elevation in the island of S. Iago.

Helix myristica.

Helix myristica, Shuttl., Bern. Mitth. 292 (1852)

$$
\text { „ ", Pfeitf., Mon. Hel. iii. } 645 \text { (1853) }
$$


Helix myristica, Dohrn, Mal. Blätt. xvi. 9 (1869) Morel., Journ. de Conch. xiii. 234 (1873)

Habitr.t S. Iago ; juxta Villa da Praia, et recens et semifossilis, nuper re-detexit (sec. Morelet) Dom. de Cessac.

I have not inspected a type of this Helix, which appears to occur in S. Iago, but it must be very near to (if not absolutely identical with) Dohrn's $H$. Visgeriana-which is likewise a S. Iago species. Morelet mentions that it has lately been redetected by M. de Cessac near the Villa da Praia, but (although recent) not in an actually living state ;-' Il ne l'a pas trouvée vivante, mais vide depuis longtemps et entraînée, sans doute, par les eaux fluviales dans les parages de la Praya. Il est donc présumable qu'elle vit sur quelque points élevé des alentours.'

Judging also from Morelet's remarks, the $H$. myristica (at any rate as understood by him) is, in its five or six interrupted fasciæ and whitish transverse ribs, wonderfully in accordance with Dohrn's species -in which (according to the latter) 'the two central bands have a tendency to split, so that sometimes six and sometimes five fasciæ are present, the whole shell being also marked with yellow lines and spots which give it a very variegated appearance.' (Mal. Blätt. xvi. 6.)

M. de Cessac seems likewise to have met with this Helix in a subfossilized condition, though under a rather more depressed (and therefore somewhat aberrant) phasis. It was found in a calcareous deposit near the Villa da Praia, and I have cited it in our present catalogue as the ' $\beta$. depressiuscula.' Morelet's observations concerning it are as follows:-' Une variété semifossile a été découverte par le même voyageur à la Praya de San Yago, dans un calcaire inférieur à une coulée de basalte, de 12 à 14 mètres d'épaisseur, qui s'étend sous la ville. Plus déprimée que la forme typique, elle compte un demi-tour de moins à la spire: le dernier est, en même temps, plus dilaté. La coloration, assez bien conservée, consiste en zones noirâtres sur un fond d'un gris livide; ces zones, excepté celle de la base, sont à peu près confondues entre elles, en sorte que la coquille, du côté de la spire, est d'un noir bleuâtre uniforme.' (Journ. de Conch. хiii. 234.)

\section{Helix fogoensis.}

Helix Fogoensis, Dohrn, Mal. Blätt. xvi. 8 (1869)

$$
" \quad \text { " } \quad \text { Morel., Journ. de Conch. xiii. } 242
$$

Habitat Fogo, et Brava; in illo ad Monte Nucho a meipso, sed in hâc in montibus supra Povoação a Revdo. R. T. Lowe lecta. 
In its rather globose outline, dull bue, and unintervupted bands, this Helix has somewhat the primâ facie aspect of the (nevertheless totally dissimilar) Porto-Santan H. punctulata, Sow.; though in reality it belongs to an altogether different group. It is indeed closely allied to the H. Visgeriana,-as is evident, not merely from its general plan of colouring and from its umbilicus not being completely closed over, but likewise from the presence of the minute spiral lines which (under a high magnifying power) are everywhere visible on its surface. Specifically however it is quite distinct,-it being not only larger and more globose, and of a uniformly duller tint, but likewise with the minute spiral lines (which look more like indistinct subundulating scratches) more irregular and obscure, and with the oblique transverse costæ well-nigh obsolete, and (such as they are) concolorous with the rest of the surface, the entire shell appearing comparatively smooth and unsculptured. Its umbilicus too is a little less closed over, and its suture is very deeply impressed.

The $H$. fogoensis was taken by myself at the Monte Nucho, in Fogo; and I also possess five examples (dead and decorticated) which were met with by Mr. Lowe in Brava,-namely on the mountains above the Povoação. These latter are a little less globose (or more compressed), and very delicately alutaceous; and, although this may probably be due to the worn state of the epidermis, I cannot detect any very decided traces of minute spiral lines. Clearly, therefore, they have sufficient about them to be treated as representing at all events an insular variety; and I would consequently cite them as the ' $\beta$. bravensis.'

\section{Helix corneovirens.}

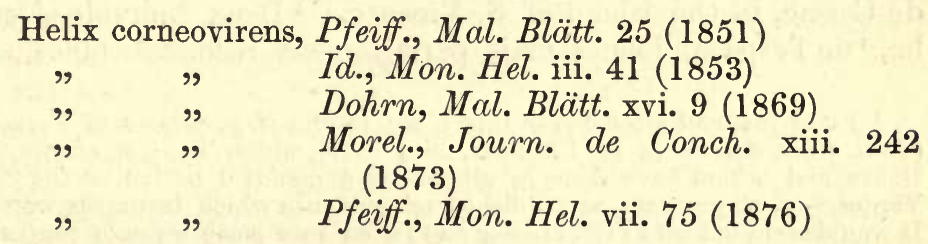

Habitat S. Nicolão (sec. mus. Cuming); mihi non obvia.

This Helix appears to have been described by Pfeiffer from a specimen, or specimens, in the collection of the late Mr. Cuming; but as I have not been able to obtain a sight of the type, its characters (beyond what may be gathered from the published diagnosis) are quite unknown to me. Although stated by Pfeiffer in 18.51 and 1853 to have been found in S. Nicolão, there is nevertheless clearly some confusion as regards its habitat,-for in the 7th volume of his 'Monographia Heliceorum' it is cited 
(on the authority of Mr. Pease) as occurring also in New South Wales! It is pretty evident therefore that either this latter locality or else Mr. Cuming's original one is erroneous; and until this particular point has been properly cleared up, the $H$. corneovirens can be admitted only provisionally into the fauna of the Cape Verdes. ${ }^{1}$

(§ Xerophila, Held.)

\section{Helix armillata.}

Helix 'striata, Drap. ?' Lowe, Cambr. Phil. S. Trans. iv. $53(1831)$

" Lowei, Pot. et Mich. [nee Fer., 1835], Gall. des Moll. 91 (1838)

,

armillata, Lowe, Ann. Nat. Hist. 113 (1852)

" $\quad$ Id., Proc. Zool. Soc. Lond. 170 (1854)

" $\quad$ " Alb., Mal. Mad.20. t. 2. f. 32-35 (1854)

" $\quad$ Morel., Hist. Nat. des Açor. 174. t. 3. f. 7 (1860)

" eumæus, Lowe, Proc. Linn. Soc. Lond. ; Zool. 198 (1860)

" armillata, Morel., Journ. de Conch. xiii. 236 (1873)

Habitat S. Vicente (sec. Morelet); a DD. Bouvier et de Cessac parcissime lecta.

I have not myself seen a type of this rather widely spread and insignificant submaritime little Helix from the Cape Verdes ; but since it exists in the Azorean and Madeiran archipelagos and likewise on the west coast of Morocco, it is extremely likely to extend to the present Group-where, according to Morelet, two examples have lately been met with, by MM. Bouvier and de Cessac, in the island of S. Vicente. 'Deux individus,' says he, 'de l'espèce, jeunes mais parfaitement reconnaissables, ont

1 I may just call attention in this place to the $H$. gyrostoma of Ferussac (Bull. Univ. des Sc. et de l'Industr. 301; 1827), which I reject entirely, as Dohrn and others have done, as altogether a doubtful native of the Cape Verdes, - or, at any rate, as published on evidence which is untrustworthy. It would seem indeed as if Ferussac had fallen into some strange confusion about it, for the species is cited by Pfeiffer (Mon. Hel. i. 238) as a NorthAfrican one,-occurring, according to Ferussac himself in his earlier works, in Tripoli ; and yet its 'habitat' is also given, a few years later on, as 'Praya in insulâ S. Iago.' Clearly, therefore, there is a mistake somewhere ; and it is impossible, without further data, to admit the species into the CapeVerde catalogue. Dohrn remarks of it, with reference to its asserted habitat:- "No species can be very common "on the downs by the sea," from the simple fact that there are no "downs" there at all; and in the neighbourhood of the sea, where I myself have constantly made excursions, no land-snails at all appear.' Pfeiffer, in his seventh volume (p. 272), in 1876, gives the habitat simply as 'Tripoli ;' which looks as if he had at length satisfied himself that the S. Jago one was erroneous. 
été recueillis avec la précédente [the $H$. Bouvieri] dans l'île de San Vicente. L'Helix armillata existe donc aux îles de CapVert, comme aux Madères et aux Açores; il est difficile de croire qu'elle manque aux Canaries, bien que M. Mousson n'en fasse aucune mention dans son ouvrage.'

\section{(§ Caracollina, Beck.)}

\section{Helix lenticula.}

Helix lenticula, Fer., Tabl. Syst. 37, 154 (1821)

" subtilis, Lowe, Cambr. Phil. S. Trans. iv. 45. t. 5. f. 13 (1831)

" lenticula, Id., Proc. Zool. Soc. Lond. 196 (1854)

" $\quad$ Alb., Mal. Mad. 43. t. 11. f. 9-12 (1854)

" $\quad$ Morel., Hist. Nat. des Açor. 169 (1860)

" $\quad$ "Dohrn, Mal. Blätt. xvi. 3 (1869)

" " Mouss., Faun. Mal. des Can. 66 (1872)

$" \quad$ " Morel., Journ. de Conch. xiii. 242

Habitat S. Nicolão; a cl. H. Dohrn deprehensa; forsan ex alienis introducta.

The widely-spread $H$. lenticula, of Mediterranean latitudes, which occurs also in the Azorean, Madeiran, and Canarian Groups, was met with by Dohrn in S. Nicolão; but it was not observed by either Mr. Lowe or myself in any of the Cape Verde islands. It is far from unlikely, as Dohrn has well observed, that it may owe its presence in this more southern archipelago to mere accidental introduction from Portugal,--its usual mode of life, within the cultivated districts, rendering it eminently liable to chance dissemination through indirect human agencies.

\section{Genus 5. BULIMUS, Scopoli.}

(§ Cochlicella, Risso.)

\section{Bulimus ventricosus.}

Bulimus ventricosus, Drap., Tabl. des Moll. 68 (1801)

Helix ventrosa, Fer., Prodr. 377. t. 52 (1807)

Bulimus ventrosus, Lowe, Cambr. Phil. S. Trans. iv. 62. (1831'

Morel., Hist. Nat. des Açor. 196 (1860)

Helix ventricosa, Mouss., Faun. Mal. des Can. 46 (1872)

Bulimus ventricosus, Morel., Journ. de Conch. xiii. 242 (1873)

" ventrosus, Watson, Journ. de Conch. 222 (1876) 
Habitat ins. Cap. Viridis (sec. Morelet); mihi non obvia.

It is much to be regretted that Morelet should have inserted this species, and three or four others, into his lately published list of the Cape-Verde Land-Shells without stating on whose authority they have been added to the fauna, and from what particular island (or islands) they were obtained. Not a syllable is placed on record concerning them; and I can only assume therefore that they were found by MM. Bouvier and de Cessac, who omitted to take any note of their precise habitats. There is nothing more probable than that this common and widely-spread Mediterranean Bulimus-which occurs in the Azorean, Madeiran, and Canarian archipelagos, as well as on the west coast of Morocco-should extend to the Cape Verdes, or perhaps should have been naturalized there accidentally from more northern latitudes : but, still, if true, it is essential that we should know this fact accurately,-which can scarcely be said to be the case from the mere admission of the name into a local catalogue without any information being given to justify its appearance. As Morelet, however, has entered it amongst the ascertained members of the fauna, I will not reject the $B$. ventricosus, - even whilst unable to report, through his total silence on the subject, either whence or by whom it was procured.

\section{(§ Napaus, Alb.)}

\section{Bulimus gemmula.}

Bulimus Gemmula, Bens., Ann. Nat. Hist. xviii. 434 (1856)

Pfeiff., Mon. Hel. iv. 415 (1859)

Buliminus gemmula, Dohrn, Mal. Blätt. xvi. 10 (1869)

Bulimus gemmula, Morel., Journ. de Conch. xiii. 242 (1873)

Habitat S. Antão, S. Vicente, S. Nicolâo, S. Iago, Fogo, et Brava; late sed vix copiose diffusus.

Although regarded generally as a Bulimus (pertaining, as Benson observes, to the group which embraces the B. nitidulus, Pfeiff., the putillus, Shuttl., the ccenopictus, Hutt., and the marginatus, Say, and being allied according to Dohrn to Morelet's B. senegalensis), this little shell is far more suggestive at first sight of a rather conical $P u p a$,-its shining, corneous, subdiaphanous surface and the obscure plait on its ventral paries adjoining the upper angle of the peristome (which, however, in the examples now before me, is quite as often totally obsolete as distinguishable) giving it, apart from the reduced numbers of its whorls, much the primâ facie appearance of certain species in the section Gastrodon of that 
genus akin to the Pupa umbilicata, Drap., and (more particularly) to its smaller state, which was described by Lowe under the name of $P$. anconostoma. Indeed, judging from the shell alone (and I am not aware that the animal has ever yet been noticed), I cannot see any very great reason why it should be separated from the Gastrodon-division of the Pupoe; though since it is treated as a Bulimus both by Benson and Dohrn, I will not attempt to refer it to any other group. I am surprised however that neither of those naturalists should have noticed the fact that the obscure parietal tooth which is sometimes traceable near the upper angle of its aperture is as often absent as present, - thus confirming the analogous inconstancy of the same character in the Pupa anconostoma and Dohrni, as distinguished from their central prototype the common P. umbilicata of Draparnaud. Amongst other features of the B. gemmula, its broadly expanded but acute peristome, the convexity of its few volutions (which are only five in number), and the singular habit which it possesses of coating itself over with a hardened envelope of dirt (which perhaps is more suggestive of Bulimus than it is of Pupa) should be particularly noticed. The B. gemmula varies in length from about $1 \frac{1}{2}$ to 2 lines.

So far as has been observed hitherto, there is no shell which is so universally spread over the Cape Verde archipelago as this diminutive and insignificant Bulimus, - it having been detected in all the islands except the three eastern ones, which however may be said to be as yet, practically, unexplored. It was first found by Mr. E. L. Layard, now many years ago, in S. Vicente, while halting there on his passage to the Cape of Good Hope; and Dohrn has subsequently met with it not only in that island but likewise in S. Antão, S. Nicolão, and S. Iago. By myself it was taken in S. Vicente, Fogo, and Brava.

\section{Genus 6. STENOGYRA, Shuttlw.}

\section{Stenogyra decollata.}

Helix decollata, Linn., Syst. Nat. (edit. 10). 773 (1758)

Bulimus decollatus, Lowe, Cambr. Phil. S. Trans. iv. 62 (1831)

\begin{tabular}{|c|c|c|}
\hline " & פ & Id., Proc. Zool. Soc. Lond. 199 (1854) \\
\hline & פ & $\begin{array}{l}\text { Alb., Mal. Mad. 54. t. 14. f. 16, } 417 \\
\text { (1854) } \\
\text { Morel. Hist. Nat. des Acor. } 196(1864)\end{array}$ \\
\hline
\end{tabular}

Stenogyra decollata, Mouss., Faun. Mal. des Can. $120(1872)$

Bulimus decollatus, Morel., Journ. de Conch. xiii. 238 (1873)

Habitat S. Nicolão, et Boavista; a Dom. de Cessac nuper detecta. 
This widely-spread Mediterranean Stenogyra has recently been detected, for the first time, in the Cape-Verde archipelago by M. de Cessac, - who met with it, according to Morelet, both in S. Nicolão and Boavista. No traces of it were seen by either Mr. Lowe or myself, in any of the six islands of the Group which we visited; but Boavista, at all events, was one of the three which we had no opportunity of exploring. And it appears to have been equally overlooked by Dohrn. In all probability however it has become naturalized accidentally at the Cape Verdes, as it seems to have been at Madeira. In the Canaries there is a greater appearance about it of aboriginality, for in Grand Canary it exists also in a truly subfossilized condition; but in the Azorean archipelago, where it occurs in Sta. Maria and S. Miguel, it is the opinion of Morelet that it has probably been introduced ( $c f$. 'Hist. Nat. des Açor.' 197).

\section{Stenogyra Goodallii.}

Helix Goodallii, Miller, Ann. of Phil. vii. 381 (1822)

" hannensis, Rang, Ann. Sc. Nat. xxiv. 41. t. 3. f. 8 (1831)

Bulimus Goodallii, Pfeiff., Mon. Hel. ii. 159 (1848)

Stenogyra sp. ?, Dohrn, Mal. Blätt. xvi. 9 (1869)

Bulimus hannensis, Morel., Journ. de Conch. xiii. 239 (1873)

Habitat S. Antão, S. Nicolão, S. Iago, et Brava; hinc inde sub lapidibus.

After a very careful comparison of the minute Stenogyra of the Cape-Verde archipelago, which has been identified by Morelet with the Helix hannensis, of Rang, from Cape Verde on the opposite coast of Africa, I have come to the conclusion that it is absolutely identical with the $S$. Goodallii, Mill.,-a species which has been naturalized in various widely-separated countries, probably through the transmission of plants, and which was also some years ago imported into England (where it was detected by the late Mr. Niller in a garden at Bristol). I have several of Mr. Miller's original types in my possession, which were given to Mr. Lowe by G. B. Sowerby in 1826, and which so completely resemble those from the Cape Verdes that I do not think it would be possible (if intermingled) to re-adjust the two sets. Like most of the Bulimi, however (and, I may add, also, of the Achatinas), the species is exceedingly inconstant, not only in stature but also in the precise number of its volutions; and I have examples from both regions ( $i$. e. from England and the Cape Verdes) which vary in the same manner, -those with an extra whorl having the spire more drawn-out (or elongated) and a trifle more parallel, causing the former to 
appear just appreciably more tumid and the suture a little more oblique. But as I perceive exactly the same tendency (as just stated) in the two sets which are now before me, I have no hesitation whatever in treating them as conspecific.

The small size, pallid hue, and subdiaphanous (though not very shining) surface of this little Stenogyra, which ranges from about $1 \frac{1}{2}$ to $2 \frac{1}{2}$ lines in length, added to its rather obtuse or blunted apex, and the peculiarity of its sculpture (it being more or less densely covered with minute and exceedingly curved hair-like lines, the alternate ones amounting almost to irregular costæ,- and which perhaps are a trifle less evident in the Cape-Verde examples than they are in those from England), will at once suffice to distinguish it from everything else with which we are here concerned.

I met with this Stenogyra somewhat abundantly both in S. Iago and Brava; and it was found by Dohrn in S. Antão, and by M. Bouvier ( $c f$. Morelet, l. c. 239) in S. Nicolão.

\section{Stenogyra subdiaphana.}

Helix Bamboucha, Fer., Cat. Rang. in Bull. Sc. Nat. (1827) Pupa subdiaphana, King, Zool. Journ. v. 340 (1831)

Bulimus Bamboucha, W. et B., Ann. des Sc. Nat. 38 (1833) subdiaphanus, Pfeiff., Mon. Hel. ii. 163 (1848)

Buliminus subdiaphanus, Dohrn, Mal. Blätt. xvi. 11 (1869) Pupa subdiaphanus, Mouss., Faun. Mal. des Can.122 (1872) Bulimus subdiaphanus, Morel., Journ. de Conch. xiii. 238 (1873)

Habitat S. Nicolão, S. Iago, Fogo, et Brava; sub lapidibus, præcipue in aridis submaritimis, occurrens.

This very peculiar Stenogyra belongs to a totally different type from the two preceding members of the genus; and in some respects indeed it has a closer resemblance, at any rate at first sight, to the large Pupa dealbata, W. et B., of the Canarian Group,- which is equally white, and has an equally edentate aperture. It is however considerably longer, in proportion, and relatively narrower, than that gigantic Pupa; and it gradually tapers towards the tip (instead of being shortlycylindric, and apically rounded and obtuse); and its surface is not only very much less coarsely striated, but likewise less

1 I include S. Antão amongst the ascertained habitats of this species, because out of two examples which were sent to me by Dr. H. Dohrn as types of his ' Cacilianella amcenitatum,' labelled as having come from that island, one of them belongs to our present Stenogyra; and I have no reason to suspect that there was any mistake as regards the place from whence they were implied to have been obtained. 
opake,-it being for the most part tolerably shining, and frequently almost subdiaphanous. Even adult examples vary exceedingly in length, - some of those now before me measuring only $5 \frac{1}{2}$ lines, whilst others are $7 \frac{1}{2}$. Indeed the same fact is commented upon by Dohrn-who adds that, while Pfeiffer gives it 7 whorls and a length of 11 millimetres, some of his own specimens had 8 and even 9 volutions, with a length of 17 millimetres.

As regards the synonymy of this Stenogyra, it will be seen that it was first cited by Ferussac under the very singular specific name of 'Bamboucha ;' but as his mention of it was not accompanied by either a diagnosis or a figure, it possesses of course no claim on the score of priority. In 1833, however, it was duly enunciated by Webb and Berthelot (who had inadvertently supposed it to be a Canarian shell) as the Bulimus Bamboucha; nevertheless in the interim (that is, in 1831) it had been published by King under the far more appropriate title of 'subdiaphana, - which fortunately is, for the reason just stated, its correct one.

I have myself taken the $S$. subdiaphana in S. Iago, Fogo, and Brava,-where it is tolerably common, beneath stones, at low and intermediate altitudes, particularly in barren places towards the coast; often half-burying itself in the loose, dry, friable soil, much after the fashion of the $S$. decollata or of the Canarian Pupa dealbata; and, judging from his remarks, it was found by Dohrn in S. Nicolão and S. Iago. ${ }^{1}$

\section{Genus 7. PUPA, Drap.}

(§ Truncatellina, Lowe.)

\section{Pupa molecula.}

\section{Pupa molecula, Dohrn, Mal. Blätt. xvi. 13 (1869)} , Morel., Journ. de Conch. xiii. 242 (1873)

1 It is another instance of the excessive inaccuracy of Mr. Webb, as regards his habitats, that this shell which is so distinctively characteristic of the Cape Verde Group (and concerning which there is not a shadow of evidence that it has been found hitherto in any other region) should have been introduced by him into his Canarian fauna. But perhaps we need not be surprised,--for the same misfortune happened to a Helix from S. Vicente which he described as Canavian under the title of advena, and to sundry Madeiran species which are no less peculiar to the more northern archipelago than the S. subdiaphana is to the southern one, and which would seem to have been admitted into his very meagre catalogue (one might really almost suppose) in order to increase its bulk! It was from bags of dried orchil (Roccella tinctoria), which had been sent to France, that these species and many others were first met with; and considering that their exact origin was confessedly unknown, it was absolutely unpardonable to publish them, without further information, as Canarian. 
Habitat S. Antão; a clariss. H. Dohrn detecta, necnon mihi benigne communicata.

The extremely minute size and linear outline of this little Pupa, added to its remarkably convex or tumid volutions (which are coarsely and very obliquely striated), its thin substance, its pale whitish-brown, or almost brownish-white, hue and but slightly shinin $y$ surface, and its perfectly edentate aperture, will prevent it from being confounded with any other member of the genus from at all events the Cape-Verde archipelago. It possesses however a peculiar interest geographically from its being so nearly allied to a subfossil species (the $P$. linearis, Lowe) from Madeira, which has not yet been met with in a recent state, that before $I$ had made a very close comparison I thought it most probable that the two would prove to be identical. However, although so intimately related, I feel sure, after an accurate examination, that they must be treated practically as distinct; for not only is the $P$. molecula, on the average, a trifle larger and broader than the linearis, but its volutions are perhaps even still more tumid, its suture is more oblique, or less horizontal, and (which is the most important of all) its aperture is appreciably larger and more developed.

How far the Canarian $P$. atomus, Shuttl. (which was found by Blauner in Teneriffe), is akin to the $P$. molecula from the Cape Verdes and to the $P$. linearis from Madeira $I$ have no means of pronouncing, since $I$ have not been able to procure a type of that species for inspection; but as it is stated to have much in common with the European $P$. minutissima, Hartm., it is far from impossible that it may prove eventually to be identical either with its Madeiran or its Cape-Verde ally.

The discovery of the $P$. molecula is due to the careful researches of Dr. H. Dohrn, by whom it was detected in S. Antão; and I am indebted to him for types, procured in that island

(§ Gastrodon, Lowe.)

Pupa Dohrni.

Pupa Milleri, Dohrn [nec Pfeiff., 1867], Mal. Blätt. xvi. 11 (1869)

" $\quad$ et anconostoma, Morel., Journ. de Conch. xiii. 242 (1873)

" Dohrni, Pfeiff., Mon. Hel. viii. 371 (1877)

Habitat (status normalis) S. Antão, et (var. a. perdubia) S. Nicolão. Invenerunt cl. H. Dohrn et R. T. Lowe.

I should have had but little hesitation in regarding this Pupa as a local phasis (and by no means an important one) of the $P$. umbilicata, Drap., corresponding with (and indeed only. 
just separable from) the 'var. $\beta$. anconostoma' which is so widely spread throughout the other Atlantic archipelagos, were I not unwilling to suppress a species which has already been proposed by so able a conchologist as Dr. H. Dohrn. But when we bear in mind that the $P$. umbilicata (as represented by its 'var. $\beta$. anconostoma') has found its way to the Azores, the Madeiras, the Canaries, and even to St. Helena, and that it is eminently variable, both in outline and exact colour, and slightly so even in the development of its aperture and plait, it seems to me that the very trifling differential characters which separate the present $P u p a$ from it might reasonably be looked upon as mere geographical ones indicative of a region so remote as the Cape Verdes. Still since it possesses a character or two (barely appreciable, however, in the 'var. a. perdubia') which a very careful observation will just enable us to recognize, I think perhaps that I have a sufficient excuse (even though contrary to what my own mode of treatment would have suggested) for retaining Dohrn's species (the title of which however has been altered by Pfeiffer, on account of 'Milleri' having been preoccupied, Mal. Blätt. xiv. 129, for a Pupa from the Bahama Islands) as distinct. ${ }^{1}$

After a very careful comparison of the P. Dohrni with a long series from Madeira, the Canaries, and St. Helena of the 'var. $\beta$. anconostoma' of the P. umbilicata, I can detect no other points on which to uphold it as separate, except that the entire shell is, on the average, just perceptibly more ovate (or widened posteriorly), with its aperture perhaps somewhat larger and more obtusely rounded below, with its outer lip a trifle more upwardly produced on the basal volution, and with its ventral plait more backwardly (or internally) prolonged. But in every other respect it seems to me to be undistinguishable from its ally.

Having therefore expressed my opinion concerning the specific value of the few distinctive features which are supposed to characterize the present $P u p a, I$ will merely add that it was met with by Dr. H. Dohrn (though sparingly) in the Ribeira de João Affonso in S. Antão, and by Mr. Lowe in S. Nicolão; but

1 Dohrn was aware that the title 'Milleri' had already been employed by Pfeiffer for a Pupa; but as he considered that Strophia (the particular group which embraces Pfeiffer's West-Indian species) is generically distinct from Ennea [or Gastrodon, Lowe], which contains the Cape Verde one, he deemed it unnecessary to alter the name which he had selected. Still, whatever be the ultimate genera within which these two forms may be made (respectively) to repose, it is certain that the laws of nomenclature will not admit of two distinct species being even published under absolutely the same title; and if one of them, therefore, must be withdrawn, we have no choice but to act in accordance with the rule of priority. 
I am not aware that it has been observed as yet in any of the other islands.

I may just remark, however, that if the $P$. Dohrni is to be regarded as specifically distinct from the 'var. $\beta$. anconostoma' of the $P$. umbilicata, the S. Antão examples must be accepted as more typical than those from S. Nicolão; for not only are they a trifle more widened behind, but their ventral plait is smaller and more completely disconnected with the angle of the lip, and the peristome is browner. Indeed the S. Nicolão specimens, in their general contour and more enlarged and more triangular plait, are well-nigh inseparable from the 'var. $\beta$. anconostoma' of the $P$. umbilicata; and I suspect that it is owing to this very circumstance that Morelet has recorded the $P$. anconostoma (in addition to the Milleri or Dohrni) as occurring in the Cape-Verde archipelago. Nevertheless I am satisfied that if the P. Dohrni is to be acknowledged as distinct, these S. Nicolão examples (which are in some degree aberrant) must be assigned strictly to it, and not to the anconostoma,-seeing that they possess the same peculiarity of rather enlarged, posteriorly-rounded aperture which characterizes the more normal individuals from S. Antão; though my own belief is, that the very existence of this intermediate phasis from S. Nicolão (which we may cite as the 'var. $a$. perdubia') would tend to corroborate my original conjecturethat the $P$. Dohrni is no more, in reality, than a mere geographical modification of the $P$. umbilicata, analogous to, but not exceeding (in importance), the 'var. anconostoma' of that same species. I will add that the 'var. a. perdubia,' from S. Nicolão, of the P. Dohrni, has the obsolete plait on the columella more developed than in the type (from S. Antão), -an oblique columellary callosity being quite appreciable.

\section{(§ Gastrocopta, Woll.)}

\section{Pupa acarus.}

Pupa acarus; Benson, Ann. Nat. Hist. xviii. 435 (1856)

$$
\begin{array}{ll}
" \quad & \text { Pfeiff., Mon. Hel. iv. } 686(1859) \\
" & \quad \text { Dohrn, Mal. Blätt. xvi. 12 (1869) } \\
\text { " } \quad \text { Morel., Journ. de Conch. xiii. 242 (1873) }
\end{array}
$$

Habitat S. Antão, S. Vicente, S. Nicolão, S. Iago, et Fogo; in intermediis, hinc inde (sæpe sub cortice Euphorbiarum laxo emortuo) congregans.

A minute Pupa (measuring only about a line in length) which is widely spread over the Cape-Verde archipelago, where in all probability it will be found (like the $P$. gorgonica, Dohrn) to occur well-nigh universally. It was first taken by 
Mr. E. L. Layard, now many years ago, in S. Vicente; and I have myself met with it in that same island, as well as in S. Antão and Fogo; and examples from S. Antão have been communicated by Dr. H. Dohrn, who likewise obtained it (as implied by his remarks) in S. Vicente, S. Nicolão, and S. Iago. I have generally found it under the dead, loosened bark of the old Euphorbias (as was eminently the case at the Monte Nucho in Fogo), and the consequence is that it is often so coated with viscous matter and dirt that it becomes an extremely difficult task to clean it thoroughly for examination.

The $P$. acarus is a well characterized little species, and one which may be recognized not only by its minute size, rather thin, subpellucid substance, very pale brown hue, and slightly shining, almost unstriated surface, but likewise by its ovate (or anteriorly gradually tapering) outline, by its somewhat few but relatively large and tumid whorls, and by its rounded aperture, which has the peristome broad and subrecurved, though interrupted across the body-volution. Its plaits, which are five in number, are very peculiar, - the inner ventral one being absent (or sometimes just represented by an extremely minute and scarcely perceptible, very deeply immersed rounded tubercle), whilst the outer one is developed into a large and thick internally-subemarginated process (more deeply immersed in its position than is usually the case, and, although not quite medial, considerably removed from the angle of the lip); then there is a large and incrassated one on the top of the columella, and three (remote, and widely separated) on the palate,- - of which the middle one is tolerably elongate and conspicuous, and the upper and lower ones short and tuberculiform.

\section{Pupa gorgonica.}

Pupa gorgonica, Dohrn, Mal. Blätt. xvi. 12 (1869)

" " Morel., Journ. de Conch. xiii. 242 (1873)

" $\quad$ " Pfeiff., Mon. Hel. viii. 397 (1877)

Habitat S. Antão, S. Vicente, S. Nicolão, S. Jago, Fogo, et Brava. In S. Nicolão statum majorem (=" var. a. subalutacea, mihi) monstrat.

This very distinct and interesting $P u p a$ will probably be found to be universal (or nearly so) throughout the Cape-Verde archipelago. At any rate I have myself taken it in S. Vicente, Fogo, and Brava; and it was met with by Dr. H. Dohrn in S. Antão, S. Nicolão, and S. Iago.

The $P$. gorgonica may be known by its rather short and broad, obtuse, cylindrical-oval form; by its tumid and very obliquely, but obsolstely, striated volutions; and by its surface 
being either (as in the status major, or ' $a$. subalutacea,' from S. Nicolão) subalutaceous and opake, and of a reddish castaneousbrown, or else (as in the status minor, from the other islands) a trifle more shining and for the most part considerably paler in hue. I should mention however that the examples now before me from Fogo are less pallid than those from S. Antão, S. Vicente, and Brava,-having a distinctly darker and slightly greenish tinge; but they are by no means of the rich chestnut which characterizes the ' $a$. subalutacea' from S. Nicolão. Some of the individuals from S. Antão and S. Vicente, which were sent to me by Dr. H. Dohrn, are relatively a trifle shorter, broader, and more obese, than the generality of those from S. Vicente and Brava, and were defined by him as the 'var. 3. brevior ;' and it seems to me that the Fogo specimens (although darker in tint) might certainly, as regards proportions and outline, be associated with them. But, as in nearly all the Pupce which I have hitherto examined from these Atlantic archipelagos, the two forms which are usually more or less traceable (namely one comparatively elongate, and the other comparatively abbreviated and obese) cannot be treated apart, but pass into each other by imperceptible gradations.

In its aperture and plaits the $P$. gorgonica is remarkably well defined,- the former being somewhat semi-oval (or with a slight tendency to be even semi-quadrate), rather small in proportion to the size of the shell (at any rate in the status minor, normalis), and with the peristome (which is not continuous across the body-volution) very widely developed (particularly in the examples from S. Vicente) or expanded; whilst the latter, which are four in number, are remarkable for there being only one ventral one (and that very deeply immersed, large, incrassated, and medial, as in the European and Canarian P.granum), the usual outer one near the angle of the lip being absent, one (thick, tuberculiform, and remote) at the top of the columella, and two palatial ones (small, and likewise deeply immersed), of which the upper one is reduced to a mere rounded tubercle.

\section{Genus 8. ACHATINA, Lam.}

( Acicula, Risso.)

\section{Achatina spiculum.}

Achatina spiculum, Benson, Ann. Nat. Hist. xviii. 435 (1856)

Cæcilianella amœnitatum, Dohrn, Mal. Blätt. xvi. 10 (1869) " " Morel., Journ. de Conch. xiii. 242 (1873)

Achatina spiculum, Pfeiff., Mon. Hel. viii. 289 (1877) 
Habitat S. Antão, et S. Vicente; sub lapidibus necnon ad radices arbustorum, rarior.

Although quite distinct from it specifically, the present very diminutive Achatina belongs to the same group as the European $A$. acicula (which occurs also in the Madeiran and Canarian archipelagos); nevertheless it is still smaller, narrower, thinner, paler, more highly polished, and more transparent; its spire (which has a volution less) is shorter and a little more obtuse at the apex, the whorls being not only a trifle more abbreviated but also just appreciably less flattened; its suture is less margined, and less oblique; its columella is relatively somewhat longer and straighter, and more flexuose; and its entire outline is both narrower and more fusiform.

This little Achatina was first met with by Mr. E. L. Layard, now many years ago, near the 'Duke's Head Mountain,' in S. Vicente, while touching at that island on his passage to the Cape of Good Hope ; and there can be no doubt that it is conspecific with Dohrn's 'Coecilianella amonitatum' a type of which (from S. Antão) is now before me;-for the only point in Benson's diagnosis of his A. spiculum which does not accord precisely with Dohrn's specimen consists in the fact that an extra volution or two would seem to be implied; but as the exact number of whorls is a character which is eminently variable in the whole Achatina group, I do not place much confidence in its specific importance.

\section{(§ Cochlicopa, Fer.)}

\section{Achatina lubrica.}

Helix lubrica [var.], Müll., Hist. Verm. ii. 104 (1774) Lowe, Cambr. Phil. S. Trans. iv.61.t. 6. f. 29 (1831)

Achatina lubrica, $\gamma$. , Pfeiff., Mon. Hel. ii. 273 (1848)

Bulimus maderensis, Lowe, Ann. Nat. Hist. ix. 119 (1852)

Achatina maderensis, Pfeiff., Mon. Hel. iii. 504 (1853)

" $\quad$ Lowe, Proc. Zool. Soc. Lond. 199 (1854)

Glandina maderensis, Alb., Mal. Mad. 55. t. 14. f. 20, 21 (1854)

9

Morel., Journ. de Conch. xiii. 242 (1873)

Achatina lubrica, Watson, Journ. de Conch. 223 (1876)

Habitat ins. Cap. Viridis (sec. Morelet); nisi fallor, a DD. Bouvier et de Cessac reperta.

In his recently published list of the Land-Shells of the Cape Verdes, Morelet includes this common European Achatina; 
but he gives us no information concerning it,-either as to the exact island in which it was brought to light, or by whom it was found; nevertheless as his paper was compiled for the express purpose of recording the species which were met with by MM. Bouvier and de Cessac, I can only conclude that this addition to the fauna was made by them. It is much to be regretted however that he does not tell us plainly where it was obtained, and on whose authority it is admitted. Moreover, although it may accord with the Glandina maderensis, of Albers' 'Malocographia,' it is inaccurate to cite it in a systematic catalogue as the 'maderensis, Albers,'-for Albers never proposed that name at all for a member of the present genus, but merely quoted the species, or form, which had previously been enunciated by Lowe. However this is of no great importance,-for the shell which was described by Mr. Lowe as the Bulimus maderensis, and which was referred to as the 'Glandina maderensis' by Albers, is but a slightly narrower and depauperated race of the ordinary Furopean A. lubrica; though as Morelet expressly refers the Cape Verde examples to the 'maderensis,' we may, I conclude, assume that that particular phasis of the shell (and not the somewhat larger type) is at any rate the one to which he would call attention.

Wherever it may have been found, it is at least extremely probable that the present Achatina has been imported accidentally into the Cape Verdes,--perhaps from the (equally Portuguese) island of Madeira, where, in low and cultivated spots, this variety of the A. lubrica abounds. Moreover the species is likewise common (though generally, I believe, in its more normal aspect) in the Azorean archipelago, which is also. Portuguese; and there can be little doubt that the occasional intercommunication between these island Groups would abundantly suffice to establish a few Gastropods which, like the present one, the Stenogyra decollata, the Bulimus ventricosus, and the Helix lenticula, are eminently liable to be conveyed along with either ballast or plants.

\section{Fam. 4. AURICULID压.}

\section{Genus 9. CARYCHIUM, Müll.}

\section{Carychium minus.}

Carychium minus, Fer., Bull. Univ. des Sc. et de l'Industr. (1827)

" " Morel., Journ. de Conch. xiii. 242 (1873)

Habitat S. Iago (sec. Ferussac); mihi non obvium, sed nuper a cl. Morelet citatum. 
This Carychium seems to have been cited by Ferussac, many years ago, as occurring near the Villa da Praia in S. Iago; but as it was associated with one or two species of doubtful origin, it was rejected by Dohrn as wanting in evidence which is sufficiently trustworthy. Morelet, however, has admitted it into his late enumeration of the Cape-Verde LandShells,-though, unfortunately, he does not state on what authority, or in which island it was found; in fact he does not make a single remark concerning it! Nevertheless as his paper was written in order to report the comparatively recent findings of MM. Bouvier and de Cessac, it is not impossible that it may have been re-detected by those naturalists; though if this was really the case, we certainly ought to have been informed of the fact, as well as of the precise spot in which the species has occurred. But if its presence in Morelet's list rests on no other foundation than the original article of Ferussac, which, as Dohrn well observes, ' has completely fallen into oblivion', I must doubt the expediency, without further data, of reinstating it as a veritable member of the Cape-Verde fauna. Still, it is far from unlikely that Morelet, although he does not mention it, may have had some additional evidence for assigning a place to the Carychium minus in his catalogue.

\section{Genus 10. MELAMPUS, Montf.}

\section{Melampus flavus.}

Voluta flava, Gmel., Syst. Nat. 3436 (1789)

Melampus flavus, Morel., Journ. de Conch. xiii. 239 (1873)

Habitat Maio (sec. Morelet); a DD. Bouvier et de Cessac, nisi fallor, lectus.

I know nothing about this Melampus, except that it is said by Morelet to have been found in Maio,-I conclude (though he does not say so) by MM. Bouvier and de Cessac. It appears to be a widely distributed species,-occurring also in Prince's Island, and even the West Indies.

\section{Fam. 5. SUCCINEID不.}

\section{Genus 11. SUCCINEA, Drap.}

\section{Succinea Lowei.}

Succinea Lowei, Dohrn, Mal. Blätt. xvi. 13 (1869)

$$
\text { " } \quad \text { " Morel., Journ. de Conch. xiii. } 241
$$

Habitat S. Antão ; imprimis collegit cl. H. Dohrn. 
I possess a type of this Succinea, which was taken in the ' Laguna da Ribeira Grande,' in S. Antão, by Dr. H. Dohrn,who speaks of it as allied to the $S$. oblonga, Drap., and the $S$. vermeta, Say. Dohrn's diagnosis of it is as follows:- 'T. oblongoacuta, tenuis, diaphana, arcuatim striata, parum nitens, rubellocornea ; spira elongata, conica, acutiuscula, submamillata ; anf. ultimus $\frac{4}{5}$ longitudinis subæquans, inflatus; apertura obliqua, ovalis, ad labri insertionem vix angulata, intus nitens; columella valde arcuata; perist. marginibus subsymmetricis, callo junctis.

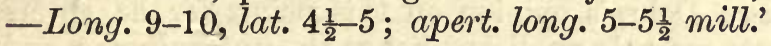

\section{Succinea Wollastoni.}

Succinea Wollastoni, Dohrn, Mal. Blätt. xvi. 13 (1869)

$\begin{array}{ccc} & \# \quad \begin{array}{c}\text { Morel., Journ. de Conch. xiii. } \\ (1873)\end{array} \\ & \quad \quad \text { Pfeiff., Mon. Hel. vii. } 39 \text { (1876) }\end{array}$

Habitat S. Nicolão; ad locum 'Top de Cachaz' dictum cl. Dohrn abundanter invenit.

I know nothing of this species, which appears to have been found abundantly by Dohrn at a place the 'Top de Cachaz' in S. Nicolão. He speaks of it as related to the S.concisa, Morel., and as being much coated, or thickened, like so many of the Succineas, with a dirty crust. The diagnosis of it, as given by Dohrn, is as follows:- 'T . oblongo-ovata, tenuis, diaphana, irregulariter striata, pallide virenti-cornea, agglutinans; spira conica ; anfr. ult. $\frac{5}{6}$ longitudinis subæquans, basi attenuatus; columella valde arcuata; apertura oblongo-ovata, obliqua; perist. simplex.-Long. $5 \frac{1}{2}$, lat. $3 \frac{1}{2}$; apert. long. $3 \frac{3}{4}$ mill.'

\section{Fam. 6. LIMN EIID正.}

Genus 12. IIMN EA, Drap.

\section{Limnæa auricularia.}

Limnæa auricularia [var.], Linn., Fna. Suec. 532, 2192 (1761)

Limnæus auricularius, v. ribeirensis, Reib. Cat. (1865)

Limnæa Ribeirensis, Dohrn, Mal. Blätt. xvi. 15 (1869)

" auricularia, Morel., Journ. de Conch. xiii. 242 (1873)

Habitat S. Antão ; in aquis, sec. cl. Dohrn, abundans.

This Limnoea seems to be very abundant, according to Dohrn, in the waters of S. Antão; but if truly conspecific with the common European $L$. auricularia, it certainly constitutes a marked geographical phasis,-and as such indeed it was 
regarded by Reibisch, who cited it under the varietal name of 'ribeirensis.' Dohrn however was inclined to treat it as truly distinct, - ' the dark horn-colour and smooth surface' being, as he thought, sufficient to separate it altogether from the $L$. auricularia; and he added that the title which was proposed by Reibisch for the variety might conveniently be carried on for the species; and it was consequently quoted by him as the ' L. ribeirensis, Reib.' Still, Morelet, who has paid considerable attention to the members of the present genus, does not appear to share Dohrn's opinion on this point, for he enters it into his more recently published list as the auricularia; and I am disposed to act on his conclusion, and to treat it, as Reibisch did, as a mere local state, or modification, of that species.

\section{Limnæa ovata.}

Limneus ovatus [var.], Drap., Hist. Nat. des Moll. 50 (1805) Limnæus ovatus, v. Stübeli, Reib., Cat. (1865)

Limnæa sordulenta, Dohrn [vix Morel.], Mal. Blätt. xvi. 14 (1869)

" ovata, Morel., Journ. de Conch. xiii. 239 (1873)

Habitat S. Antão, S. Nicolão, S. Iago, et Brava: hinc inde in aquis.

By Dohrn this Limnoea was taken in S. Antão, S. Nicolão, and S. Iago, and by myself in S. Iago and Brava. It differs a little from the common European form of the $L$. ovata,- ' the glossy surface of the shell' being particularly alluded to by Dohrn, who regarded the species not only as distinct but identical with the L. sordulenta, Morelet, from Angola. Reibisch, on the other hand, treated it as a mere phasis (a 'var. Stübeli') of the ovata, -a conclusion which Morelet seems inclined to accept. ' Je partage', says the latter, 'l'avis de M. Reibisch qui considère cette forme une simple variété de l'ovata: les sujets que j'ai sous les yeux ne me laissent aucun doute à cet égard. M. Dohrn a cru reconnaître, dans ceux qu'il a recueillis lui-même sur les lieux, la $L$. sordulenta d'Angola, ce qu'il faut attribuer, sans doute, à l'insuffisance de la description et de la figure que j'en ai données. Tout en conservant une grande analogie avec notre espèce d'Europe, la $L$. sordulenta est bien moins ventrue que l'ovata; son ouverture, par suite, est moins dilatée, et la spire est aussi moins aigue. J'ajouterai qu'aucun Mollusque de nos climats n'a été rencontré jusqu'ici sur la côte de Guinée.' 
Genus 13. PHYSA, Drap.

Physa Forskalii.

Physa Forskalii, Ehrenb., (teste Martens, Mal. Blätt. xvi.)

" Wahlbergi, Krauss, Sudafr. Moll. (1848)

" $\quad$ " Dohrn, Mal. Blätt. xvi. 15 (1869)

" " Morel., Journ. de Conch. xiii.243 (1873)

Habitat S. Iago; a cl. Dohrn deprehensa.

This is a most variable Physa, and one which occurs in many parts of continental Africa; but, in spite of the long and interesting account of it which is given by Dohrn, I do not gather that he met with it on any island at the Cape Verdes except S. Iago. It is scarcely probable however that a species which is so widely spread (occurring, apparently, from Egypt to Natal, and from Abyssinia to Angola) is otherwise, in reality, than pretty generally distributed throughout the archipelago.

According to Dohrn, the Bulimus scalaris and Schmidti, Dunker, the Isodora lamellosa, Roth, and the Physa apiculata, semiplicata, and claviculata, Morelet (the last three from Angola) are all of them mere forms of this widely-scattered African species.

\section{Genus 14. PLANORBIS, Guett.}

\section{Planorbis coretus.}

Planorbis coretus, Desh., An. S. V. (ed. 2) viii. 393 (1838) " " Dohrn, Mal. Blätt. xvi. (1869)

" " Morel., Journ. de Conch. xiii. 242 (1873)

Habitat S. Nicolão, et S. Iago; a cl. Dohrn communicatus.

An exceedingly minute Planorbis which was taken by Dohrn in S. Nicolão and S. Iago (and which is remarkable for its almost unsculptured, subpellucid surface, its pale whitish hue, and diminutive stature,--the largest of the specimens now before me being scarcely a line across the widest part) has been identified by him with the $P$. coretus, Desh. He remarks that 'Adanson's plate and description, apart from the erroneous assertion that the shell winds to the left (which is instantly refuted by the correctly drawn figure), leave nothing to be desired.'

Genus 15. ANCYLUS, Geoffr.

\section{Ancylus Milleri.}

Ancylus Milleri, Dohrn, Mal. Blätt. xvi. 18 (1869)

$" \quad$ "Morel., Journ. de Conch. xiii. 243 
Habitat S. Iago; in rivulis a cl. Dohrn repertus.

Judging from two examples of this Ancylus which were given to me by Dohrn, it is at once separated from the species of the Canarian and Madeiran archipelagos by its small size (it being only a line in length) and rather narrowed contour, by its thin subhyaline texture and pallid hue, and by there being scarcely any indication (so far as I can detect) of radiating costæ on its surface,-where, nevertheless, the hair-like spiral lines are quite distinguishable and closely set. ${ }^{1}$ Moreover in the types before me, the apex (behind which there is a short central obsolete channel or groove,-quite traceable when the shell is viewed obliquely) is just perceptibly tilted or eccentric ; but this may be only accidental.

The A. Milleri is from the island of S. Iago, where it was detected by Dr. H. Dohrn.

\section{GASTROPODA (PECTINIBRANCHIATA).}

\section{Fam. \%. RISSOID无.}

Genus 16. HYDROBIA, Hartm.

\section{Hydrobia acuta.}

Cyclostoma acutum, Drap., Hist. Nat. des Moll. 40. t. 1. f. 23 (1805)

Paludinella sp., Dohrn, Mal. Blätt. xvi. 20 (1869)

Hydrobia acuta, Morel., Journ. de Conch. xiii. 243 (1873)

Habitat S. Nicolão; in Ribeira de Castelhoens a cl. Dohrn copiose lecta.

This common European Hydrobia was found abundantly by Dohrn in the Ribeira de Castelhoens in the east of S. Nicolão; but, owing to an unfortunate accident, he lost the whole of his examples except one, - so that he did not feel justified in attempting to identify the species positively from a single individual. It would appear however that a further supply must have been obtained by MM. Bouvier and de Cessac, for Morelet was enabled to give the information which Dohrn could not; nevertheless he does not tell us so, nor indeed does he even mention in which island the fresh examples were met with. This is much to be regretted, for the following observations would certainly seem to indicate that additional material had come to hand since Dohrn's paper was published:- 'Cette

1 Dohrn's remark on his A. Milleri is, that it 'differs from all the dextral species of the Old World in the longish-ovate shape of its aperture, and in its total freedom from any radial ribbing.' 
petite Paludine est évidemment celle dont il est fait mention dans la notice de M. Dohrn, mais que l'auteur a laissée innommée, faute de matériaux suffisants, tout en jugeant qu'elle se rapprochait de l'acuta. L'identité, pour moi, ne fait nul doute; je ne trouve aucune différence entre cette coquille et l'espèce de Draparnaud. Au surplus, la présence de l'Hydrobia acuta dans ces parages ne surprendra pas plus que celle de la Limnoea ovata.'

\section{Fam. 8. MELANIID屟.}

\section{Genus 17. MELANIA, Lam.}

Melania tuberculata.

Nerita tuberculata, Müll., Verm. Hist. 191 (1774)

Melania Tamsi, Dunker, Ind. Moll. Tams, (1853)

" " Dohrn, Mal. Blätt. xvi. 19 (1869)

" tuberculata, Morel., Journ. de Conch. xiii. 240 (1873)

Habitat S. Antão, S. Nicolão, et, saltem in statu semifossili, S. Vicente; in aquis salinis et subsalinis ad ora rivulorum præcipue degens.

Of all these Atlantic archipelagos, the Cape Verdes are the only one in which the genus Melania, which is so widely spread along the littoral districts of the African continent, and which I have myself taken abundantly on the western coast of Morocco, has been ascertained to occur, - the present species having been met with in profusion by Dohrn in S. Antão and S. Nicolão, where it lives ' in the lagoon-like expansions near the mouths of the streams.' We may be pretty sure also that it will be found, sooner or later, in most of the other islands : indeed in S. Vicente it has already been obtained, by Mr. Lowe and others, in a subfossilized condition (though, singularly enough, at some distance from the sea), - which would assuredly imply that there at any rate (no less, probably, than elsewhere) it needs only to be searched for in the right localities.

The S. Antão examples of this Melania which were collected by Dohrn are, on the average, rather smaller than those from $\mathrm{S}$. Nicolão, and have their volutions a little more convex,--assimilating almost exactly the usual type of Müller's M.tuberculata; and the subfossilized examples from $\mathrm{S}$. Vicente may be said to be equally normal in their details. Those however from $\mathrm{S}$. Nicolão (which were met with by Dohrn, more particularly, at the mouth of the Ribeira de Castelhoens, near the eastern point of that island) are chiefly larger and have the whorls not only a 
trifle more flattened but usually altogether free (when mature) from longitudinal plaits, and they may be regarded, on the whole, as typical of Dunker's M. Tamsi; but Dohrn has shown most conclusively that the two races merge gradually into each other, and in short that all the features which are supposed to specialize the $M$. Tamsi are merely ' of an individual character' and that there is but little doubt therefore that the latter cannot properly be upheld as specifically distinct from the widely-spread $M$. tuberculata.

Morelet is likewise of opinion that this Cape Verde Melania is truly conspecific with the tuberculata of Müller,-adding, also, that Ferussac's $M$. virgulata is probably but a phasis of the same variable species. 'Je ne puis découvrir', says he, ' aucune différence spécifique entre cette Mélanie et la virgulata de Férussac, qui n'est elle-même qu'une variété de la tuberculata de Müller. M. Brot, qui professe une autre opinion, lui assigne comme caractères distinctifs moins de convexité dans les tours de spire, une bordure claire à la suture et une sculpture moins nette, donnant à la surface une apparence graisseuse. Or, si la réunion de ces particularités imprime à quelques individus un facies distinct qui permet de les classer à part, il faut avouer qu'elles manquent en partie ou en totalité chez beaucoup d'autres: rien alors ne sépare plus ces derniers de l'espèce de Müller. Si j'avais eu un doute sur la question d'identité, il m'eût été impossible de la conserver en présence de certains spécimens recueillis, à l'état semi-fossile, dans les sables agrégés de l'île San Vicente, entre Ribeira Don Juan et la mer. Ces spécimens concordent parfaitement avec plusieurs échantillons de $M$. tuberculata qui font partie de ma collection et qui ont été trouvés, dans la même état, parmi les sables de l'oasis de Qâsr, en Egypte. Les uns et les autres sont de la même taille (27 mill. sur 9), leurs tours de spire offrent la même convexité, et leur sculpture la même relief; on aurait peine à les distinguer s'ils étaient mélangés entre eux. Cet exemple paraît concluant.'

CAPE-VERDE CATALOGUE.

\begin{tabular}{|c|c|c|c|c|c|c|c|c|c|c|c|}
\hline & & & Ant. & Vic. & Nic. & Sal. & |B.v. & Maio & Jago & Fogo & Brava \\
\hline $\mathrm{sp}$. & $\begin{array}{l}\text { LIMACIDE. } \\
\text { Limax, Linn. } \\
\text { VITRINIDE. } \\
\text { Vitrina, Drap. }\end{array}$ & . & * & & * & & & & & & \\
\hline
\end{tabular}


Cape-Verde Catalogue-(continued).

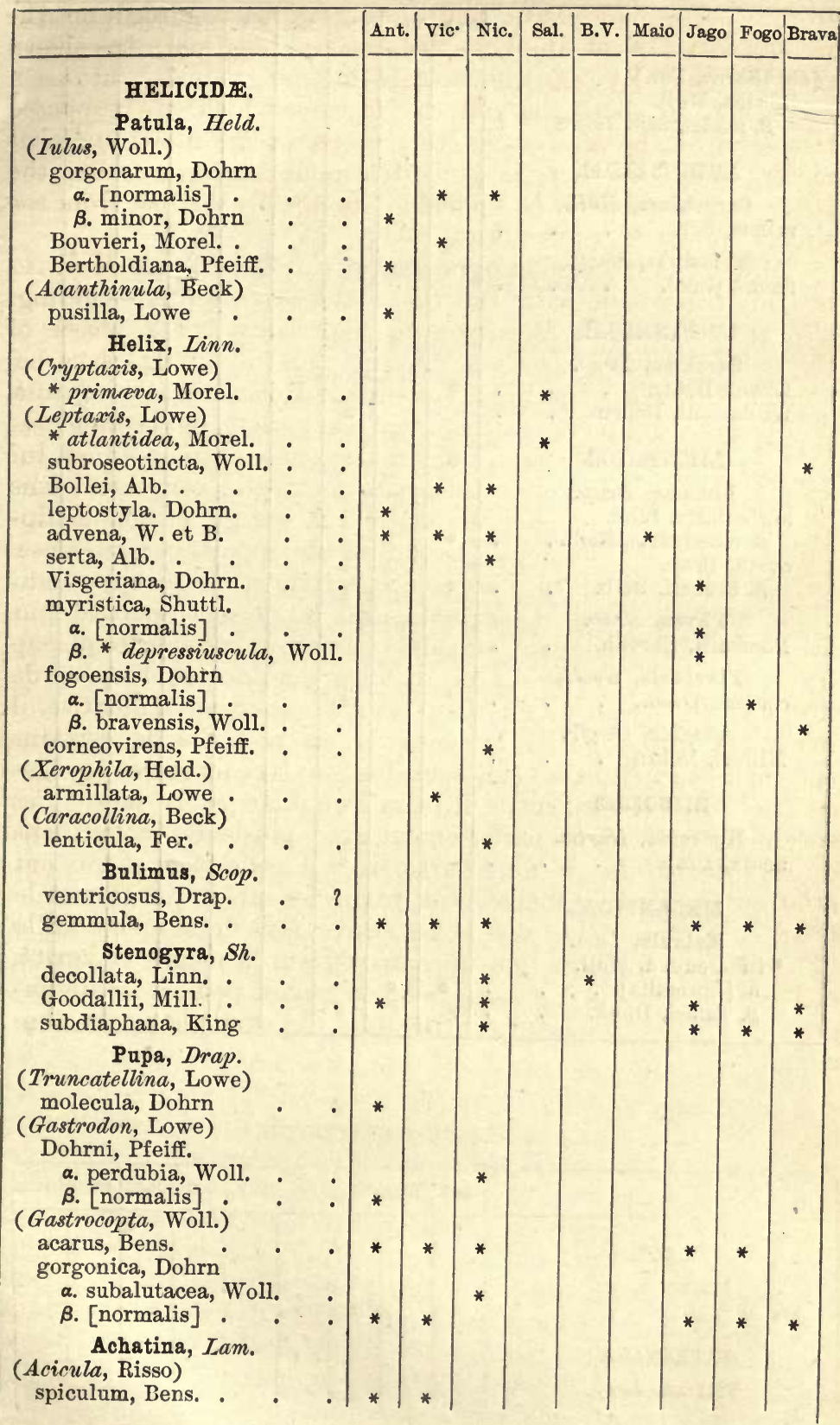


Cape-Verde Catalogue-(continued).

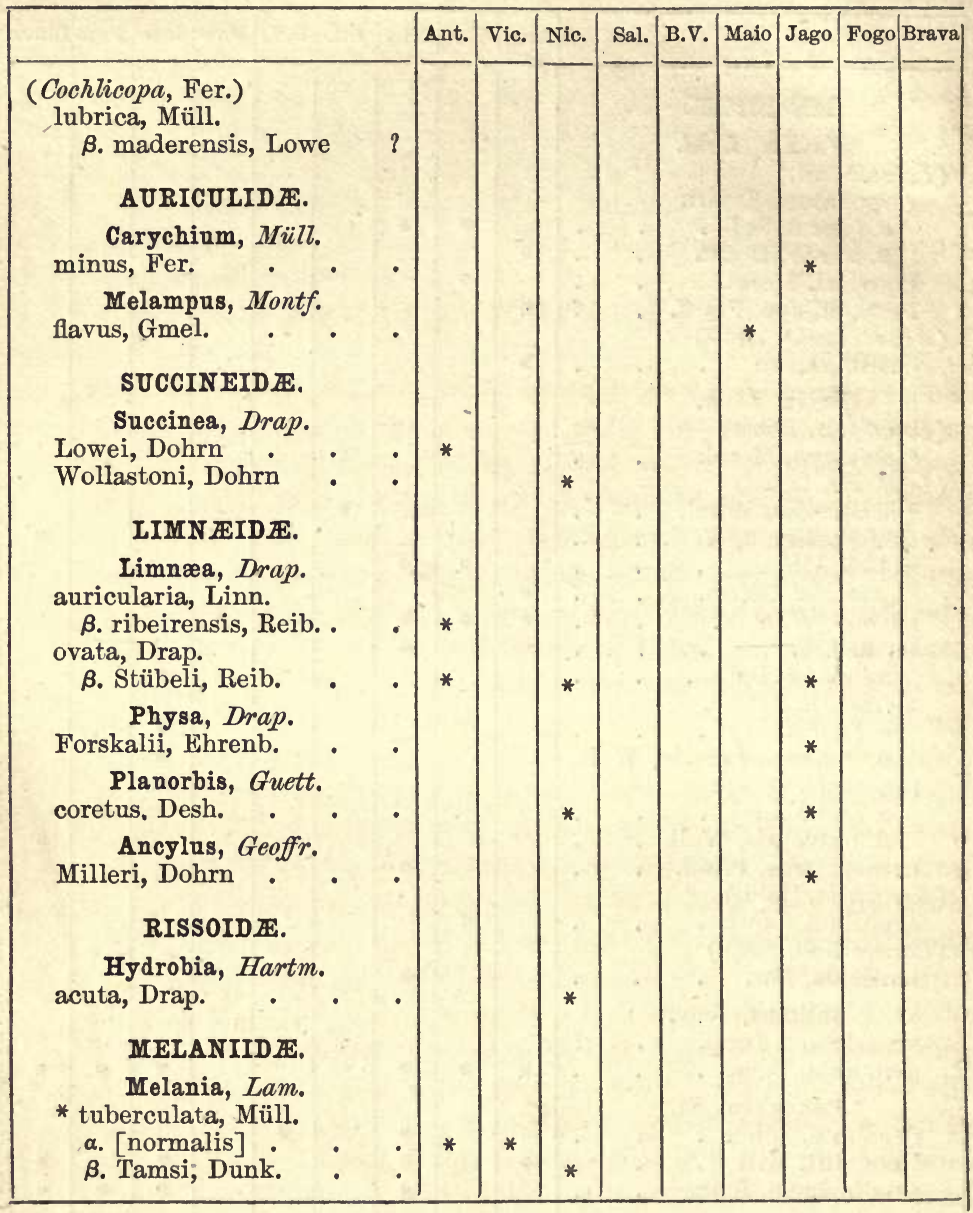




\section{SAINT HELENA.}

THE Gastropods of St. Helena are but few in number, as regards species; and yet the fauna is not quite so poor as has generaliy been supposed. Considering the smallness of its area, its extreme isolation, and the basaltic character of its rocks, we should hardly expect that Molluscous life in the island would be very greatly developed ; and I do not think, therefore, that twenty-nine specific forms, apart from certain important varietal modifications, can be regarded as much below the average of what may be said to obtain in most other spots which are more or less similarly circumstanced. True it is that about half of them (indeed more than half, if only the essentially indigenous ones be taken into account) are now extinct, occurring merely in a subfossil condition; but this is only what the deteriorated nature of the country might have led us to anticipate,- the wholesale destruction of its aboriginal wood having so far altered the climatical equilibrium as to bring entire districts, which must once have been comparatively fertile, into a hopeless state of arid sterility. But at a former epoch, when the forests of gumwood and ebony clothed many of the outer regions above the coast, and the great central ridge was an unbroken jungle of cabbage-trees, asters, and tree-ferns, it is easy to understand how the increased moisture and the presence of swamps would have afforded conditions better suited for the requirements of the Pulmonifera, and sustained Succinexe and Bulimi which have now either totally died out, or else linger sparingly on under a more or less depauperated aspect.

Although the genuine Bulimi of St. Helena may be said to belong essentially to a past epoch, two at least of them (the $B$. helena, Quoy, and the exulatus, Bens.) cannot long have become extinct. Indeed it is far from impossible that they may still survive on some of the rocky and well-nigh inaccessible slopes in the extreme north of the island,-many of the bleached examples of the B. helena which lie scattered loosely on the summit of the Barn having not only their outer cuticle but even their colour almost completely preserved. Mr. Melliss, in 
alluding to this latter species, adds that 'although the shells are now dead, they appear to be of more recent date' than the others ; and Mr. Benson referred to it in 1851 (vide 'Ann. of Nat. Hist.' vii. 263) as absolutely ' recent,'- though as he gives no evidence in support of his assertion, I think that in this he was probably mistaken. The two largest, and most remarkable, of these Bulimi (namely the B. auris-vulpina and the B. Darwinianus) belong somewhat to a type which has several exponents in Brazil; and this fact induced the late Professor E. Forbes to hazard a theory on the quondam connection of St. Helena with the east coast of South America. But it seems to me that so sweeping an hypothesis requires stronger evidence to support it than that which is supplied by the presence of a couple of Gastropods which confessedly resemble their transatlantic congeners only to a certain extent; whilst the circumstance that much the same type of form exists equally in the Solomon Islands and New Zealand makes its reception more difficult still,--necessitating, as it would, the extension of the same land of passage more than half-way round the circumference of the globe! Moreover there are the strongest reasons for believing that the area of St. Helena was never very much larger than it is at present,- the comparatively shallow sea-soundings within about a mile and a half of the shore revealing an abruptly-defined ledge beyond which no bottom is reached at a depth of 250 fathoms; so that the original basaltic mass which was gradually piled up by means of successive eruptions, from beneath the ocean, would appear to have its limit definitely marked out by this suddenly-terminating submarine eliff,--the space between it and the existing coast-line being reasonably referred to that slow process of disintegration by which the island has been reduced, through the eroding action of the elements, to its present dimensions. Therefore I cannot but think that the conclusion of Professor Forbes was scarcely warranted by the facts to which we have access; though to a mind for which mere speculation, as such, is attractive, it may carry with it its own amount of weight, whatsoever that may be ; and, as a still further aid to the acceptance of it, I may just add that Professor Forbes likewise thought that the marine mollusks of St. Helena (about which, nevertheless, almost nothing was then known) 'dimly indicated' 'a closer geographical relationship between the African and American continents than what now obtains' (vide the 'Quarterly Journal of the Geological Society' viii. $198 ; 1852)$, - an ultimatum at which I must candidly confess that I have not been able to arrive.

The genus Succinea constitutes a most conspicuous feature in the Gastropndous fauna of St. Helena; and this is all the 
more remarkable, inasmuch as, with the exception of at the Cape Verdes, where it just puts in a feeble appearance, it is totally unrepresented in the more northern archipelagos. Nevertheless, owing to the vicious habit which so many naturalists have practically adopted, and still persist in, of describing as new almost anything that is put into their hands from a distant country, often from unique examples and without taking the trouble to compare them at all with such types as may already have been published from the same locality, I cannot but think that the actual species have been made far too numerous. Indeed I am exceedingly doubtful whether more than two or three Succineas, at the utmost, are indicated, amongst the mass of individuals which may easily be obtained in the intermediate and elevated districts of the island; nevertheless one of them (the S. Bensoniana, Forbes) is so variable, both in stature and solidity, according to the dryness (or otherwise) of the exact region in which it occurs, that it seems to me to have done duty for at least four 'species' (so-called), if not indeed for five. Moreover as this particular member of the genus exists equally in a subfossil state, the subfossilized specimens have been regarded at once as specifically distinct from the recent ones; and thus an amount of confusion has been set-up which (as in the case of the Bulimi) is simply deplorable. The slovenly manner indeed in which the few St. Helena Land-Shells were treated by both Forbes and Benson,-who did not even attempt to point out in what their assumed novelties differ from those which had previously been enunciated, and who appeared to imagine that anything like a precise reference, or date, when alluding to the species of others, was altogether superfluous-is only worthy of the wild and fanciful theories which were recklessly, and almost without evidence, built upon them. In real fact, anybody who has studied in the slightest degree the St. Helena Succineas in situ could scarcely fail to perceive that inconstancy is their most prominent feature,-even the number and proportions of their whorls varying in the same actual spot, and their size and relative thickness according to the degree of moisture to which they have severally been exposed, as well as according to the nature of the foliage on which they may have been compelled to subsist. Therefore to describe as distinct every insignificant phasis, or race, which might happen to be a little larger or a little smaller than another, or perhaps a trifle more solid or less membraneous, is only to confuse the lines of specific demarcation, instead of rendering them intelligible; but, unpardonable as this is, it is at any rate less flagrant than to characterize forms afresh which have absolutely nothing 
whatever to separate them from others which had previously been defined and published.

The additions to the Land Mollusca of St. Helena which were made by myself and Mrs. Wollaston, during our late sojourn in the island, are only three in number,-namely the Hyalina Mellissii, n.s., the Patula pusilla, Lowe, and the Subulina melanioides, n.s.; for although it is true that the European Helix pulchella, Müll., which we found abundantly, was not included in Mr. Melliss's enumeration, a single example of it had nevertheless been met with many years ago, by Mr. E. L. Layard (teste Benson, Ann. Nat. Hist. xviii. 1856), while touching at the island, on his passage to the Cape of Good Hope. It will, however, perhaps, be a matter of some surprise that, in spite of these three genuine accessions, and in spite of three others (the Helis pulchella, Müll., the Stenogyra compressilabris, Bens., and the Achatina Veru, Bens.) which we owe to the researches of Mr. Layard, and of the Helix dianoe of Pfeiffer's Monograph, my present catalogue numbers absolutely less than Mr. Melliss's did,-containing, as it does, only twenty-nine species, as contrasted with his thirty-one. But the explanation of this is to be found in the fact that, according to my estimate of the fauna as placed hitherto upon record, a large proportion of the names which have been assumed (because published) to represent distinct species, are in reality mere synonyms of each other,-some of them not indicating even separate varieties. And if this is truly the case, as I believe it to be, Mr. Melliss's list should have been quoted at twenty-two instead of thirty-one. Two members, however, have been rejected, simply, because no evidence was supplied which renders it even possible to admit them into an accurate and systematic list. These are two slugs, which (in addition to the Limax gagates, Drap.) are said to occur in the island. Even though unidentified with any known forms, and although unaccompanied by any regular and detailed description, I might still have entered them as members of the fauna had a single character been given, or so much as an isolated remark, which might have taken the place of a partial diagnosis; but without anything at all by which they could by any possibility be recognized, and knowing as I do how the same slug may put on different primâ facie aspects according to its exact age and degree of development, I scarcely see that I should have been justified in treating them as properly ascertained exponents of the Pulmonobranchiata of St. Helena; and I have, therefore, preferred to leave them unnoticed.

In the list which is given at the close of this Section, I have, as in the preceding catalogues, appended an asterisk $\left(^{*}\right)$ to the species which have been met with also in a subfossil 
state; and in those instances where they have been found only subfossilized, under which circumstances they must be looked upon as extinct (at any rate until proved to the contrary), the names have been printed likewise in italics.

\section{Fam. 1. LIMACID正.}

\section{Genus 1. IIMAX, Linné.}

\section{Limax gagates.}

Limax gagates, Drap., Hist. Nat. 122. pl. 9. f. 1, 2 (1805)

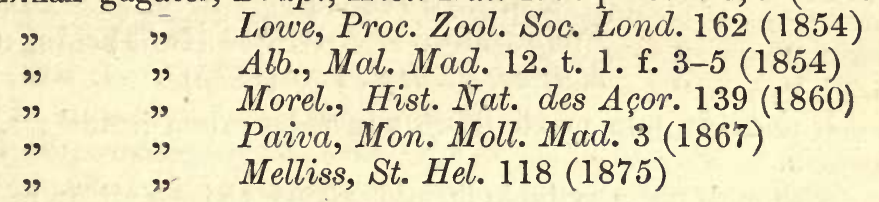

Habitat in intermediis Sanctæ Helenæ; forsan ex Europâ una cum plantis olim introductus.

Although I frequently observed a Limax during our six months' residence at Plantation, I had nevertheless so little leisure to devote to the Mollusca (my time having been fully taken up with the Insects) that I unfortunately omitted to identify the species critically. As Mr. Melliss however has cited the European $L$. gagates in his late volume on St. Helena, and he could scarcely have been mistaken in the determination of so common and well-marked a slug, I have little doubt that the one which occurred to us at Plantation and elsewhere was that species; though even if it is not, I have still no reason to suspect that Mr. Melliss's recognition of the L. gagates, as having been found in the island, is anything but strictly accurate.

The not very large size (for a slug) of the $L$. gagates (its average length being from about three-quarters of an inch to an inch), added to its more or less darkened upper surface (which is either brownish-black, cinereous-black, or ochreous-black, seldom black entirely), and the acute keel which extends down the dorsal line of its longitudinally-sulcated body, from the hinder edge of the shield to the extreme tip, will suffice to distinguish it. ${ }^{1}$

1 Having admitted the $L$. gagates into the St. Helena catalogue without personally identifying it, I cannot venture to make any further entry of slugs without at any rate good evidence for so doing. I mention this because Mr. Melliss indicates, as just stated, no less than two other species of Limax, without however assigning to either of them a name, or (in lieu of that) even a few words of diagnosis ; and I have'often experienced"how easy it is to be mistaken as regards the specific claims of (more particularly) the early states of these variable slugs. Without, therefore, thinking it at all improbable that another, or even two other members, of the present genus may be ascertained to occur in the island, I cannot consider that it would be safe at present to register more than the $L$. gagates. 


\section{Fam. 2. HELICID正.}

\section{Genus 2. HYALINA, Gray.}

( $\&$ Lucilla, Lowe.)

\section{Hyalina spurca.}

Helix spurca, Sow., in Darwin's Volc. Isl., Append. 157 (1844)

$\Rightarrow \quad$ Forbes, in Journ. Geol. Soc. Lond. viii. 199.
t. 5. f. $10(1852)$

Habitat in solo conchylifero, versus borealem insulæ; semifossilis.

Although not a syllable is said about the affinities of this Helix in the notices to which I have access, yet the figure of it which is given by Professor Forbes seems to me to imply that it must be very closely related to the common Hyalina cellaria. True it is that the shell is drawn in a position which unfortunately does not permit a view of its umbilicus (which is said, however, by Sowerby, to be small and deep); but its discoidal aspect and general contour are so remarkably suggestive of the (nevertheless comparatively gigantic) European $H$. cellaria, which abounds in the intermediate districts of St. Helena, that I soarcely think I can be far wrong in placing it as I have.

The $H$. spurca, which occurs, in company with other subfossilized species, near Flagstaff Hill, in the extreme north of the island, and which measures only about two lines across its broadest part (with an altitude of one line), appears to be rare. Sowerby's diagnosis of it is as follows :- ' T. suborbicularis, spirâ subconoideâ, obtusâ; anfractibus quatuor tumidis, substriatis; aperturâ magnâ, peristomate tenui ; umbilico parvo, profundo.'

\section{Hyalina dianæ.}

Helix Dianæ, Pfeiff., Mal. Blätt. iii. 206 (1856)

$$
\begin{array}{lll}
\prime & \quad \quad \quad I d ., \text { Mon. Hel. iv. } 103(1859) \\
& \quad, \quad I d ., \text { ibid. vii. } 179(1876)
\end{array}
$$

Habitat in editioribus insulæ; ad montem excelsum 'Diana's Peak' dictum a Dom. Cutter (sec. Pfeiffer) reperta.

Judging from Pfeiffer's diagnosis, this little Helix would appear to belong to the recent fauna; indeed if its habitat, 'Diana's Peak,' is to be trusted, it could scarcely be otherwise, - for there are no subfossiliferous deposits on the great central ridge. It is a minute shell, like the $H$. spurca, only about two 
lines across its broadest part (with an altitude of one line), and having its aperture totally free from plaits or teeth ; and so far as I can gather from the mere description, I should imagine that it must have a good deal in common with that species. Pfeiffer's diagnosis of it is as follows :- ' T. umbilicata, depressa, discoidea, tenuiuscula, conferte striata et irregulariter subvaricosa, vix nitidula, nigro-fusca; spira plana; anfr. 4 convexi, sensim accrescentes, ultimus non descendens, subdepresso-rotundatus; umbilicus pervius $\frac{1}{4}$ diametri subæquans; apertura fere diagonalis, lunato-circularis ; perist. simplex, rectum, marginibus convergentibus, columellari superne vix dilatato.'

\section{Hyalina cellaria.}

Helix cellaria, Müll., Hist. Verm. ii. 28 (1774)

$" \quad " \quad$ Albers, Mal. Mad. 17 (1854)

Hyalina cellaria, Mouss., Faun. Mal des Can. 15 (1872)

Zonites cellarius, Melliss, St. Hel. 120 (1875)

Habitat in cultis intermediis Sanctæ Helenæ, vulgaris ; ex Europâ forsan introducta.

This common European Hyalina is tolerably abundant in the intermediate districts of St. Helena, where in all probability it has been introduced from England along with consignments of shrubs and plants. We found it pretty general at and around Plantation, and it also ranges up to the central ridge,- - though less decidedly so than the $H$. alliaria, which is perhaps more at home in the loftier parts of the island than it is lower down.

The $H$. cellaria, owing probably to the easy manner in which it is liable to be transported through indirect human agencies, has become widely distributed, and is well-nigh universal within the cultivated regions of the Azorean, the Madeiran, and the Canarian archipelagos.

\section{Hyalina alliaria.}

Helix alliaria, Mill., Ann. Phil. (N.s.) vii. 379 (1822)

" fœtida, Brown, Brit. Shells, t. 40. f. 48-52

" alliaria, Pfeiff., Mon. Hel. i. 90 (1848)

" remota, Bens., Ann. Nat. Hist. vii. 263 (1851)

" $"$ Pfeiff., Mon. Hel. iii. 106 (1853)

Zonites alliarius, Melliss, St. Hel. 120 (1875)

Habitat in intermediis editioribusque Sanctæ Helenæ, præ sertim sub ligno putrido et lapidibus humidiusculis, frequens. Ex Europâ, nisi fallor, olim introducta. 
Like the last species, the European $H$. alliaria has become established at St. Helena, - where it ascends to the highest parts of the great central ridge, occurring beneath stones and pieces of moist rotten wood. It is indeed far more abundant in the loftier portions of the island than it is lower down; though I have met with it occasionally in the grounds at Plantation, which are only some 1800 feet above the sea. It was described as a new species, under the name of $H$. remota, by Mr. Benson, who stated that he found it, in 1832, between Plantation and Stitch's ridge, as well as in the valley near Napoleon's tomb (in the direction of Longwood). Mr. E. L. Layard, too, appears to have taken it ' on the upper side of the road leading from Jamestown to Longwood.' It is, however, universal above the altitude of about 2000 feet, particularly in the dampest districts and amongst the cabbage-trees.

The $H$. alliaria approaches very closely to the (no less highly polished and subpellucid) $H$. cellaria; but it is uniformly smaller, and (as regards its spire) even still more flattened; its umbilicus is just appreciably narrower, or more perpendicularly (i.e. less gradually) scooped-out; its whorls are only $5 \frac{1}{2}$ in number instead of 6 ; its colour is a little darker or more fulvous, and the animal has the very peculiar property of emitting a strong scent somewhat resembling that of garlic,a fact which must doubtless have suggested its specifio name.

\section{( $($ Conulus, Fitz.)}

\section{Hyalina Mellissii, n. sp.}

H. minuta, orbiculato-depressa, discoidea, minutissime perforata, ecarinata, tenuis, diaphana, nitida, glabra, pallide fulvocornea; anfractibus $4 \frac{1}{2}-5$ convexiusculis, lente crescentibus, præsertim versus suturam (impressam) transversim striolatis; umbilico brevi, infra minutissimo ; aperturâ magnâ, transversâ, lunari; peristomate simplici, acuto, versus columellam obsoleti-sime subrecurvo.-Diam. maj. 1 ; alt. $\frac{1}{2}$ lin.

Habitat sub ligno truncisque arborum prolapsis in insulæ intermediis, præsertim graminosis; ad Plantation, circa 1800' s.m., a meipso sat copiose lecta.

I obtained several examples of this very minute Hyalina in the grounds of Plantation House, at an altitude of about 1800 feet above the sea. They were generally adhering to the undersides of logs of wood and fallen trunks of trees, particularly in damp grassy spots after showers. Specimens of it have been examined carefully by the Rev. R. B. Watson, who also forwarded some to Dr. Gwyn Jeffreys; and it is the opinion of both of those naturalists that the species is hitherto undescribed. 
The H. Mellissii seems to me to belong to much the same type as the European $H$. fulva, Müll.; but it is nevertheless considerably smaller, as well as a trifle darker and more shining ; its basal region is less coarsely striated; and it is not only more depressed and with a volution less, but its ultimate whorl (which has no tendency whatever to be even obsoletely keeled) is relatively not quite so narrow. Had it not been for its very minute size I might almost have been inclined to refer it (judging from the figure and diagnosis of that species) to the $H$. spurca,which hitherto has been found merely subfossilized; but considering that it is only half the size and has the spire (as I believe) not quite so depressed, I think that it would be unsafe to do so. As regards its specific title, I have had great pleasure in connecting it with that of my worthy friend J. C. Melliss, Esq.,- -whose recent volume on St. Helena is a proof of how successfully he laboured to bring together what had previously been accomplished in the several departments of the Natural History of the island.

\section{Genus 3. Patula, Held.}

( $§$ Endodonta, Pfeiff.)

Patula bilamellata.

Helix bilamellata, Sow., in Darwin's Volc. Isl., Append. 157 (1844)

Forbes, Journ. Geol. Soc. Lond. viii. 199. t. 5. f. 8 (1852)

Pfeiff., Mon. Hel. iv. 324 (1859)

Melliss, St. Hel. 121 (1875)

Habitat ad latera viæ, inter Jamestown et Longwood, circa $1200^{\prime}$ s.m., necnon versus montem Flagstaff in parte boreali insulæ; semifossilis.

The subfossilized $P$. bilamellata is found embedded in the surface soil both in the extreme north of the island (in company with the Bulimus auris-vulpina, etc.) near Flagstaff Hill, and likewise in the cutting (above the Briars) of the Sidepath-road between Jamestown and Longwood. Judging frorn the figure which was given by Forbes, it seems to have sufficiently in common, in its general features and outline, with the Madeiran $P$. bifrons to justify its being placed at no very great distance from the section Janulus, of Lowe, which embraces that species and a few others which are allied to it; nevertheless the fact of its aperture being armed on the ventral paries with two conspicuous plaits will of course remove it into at any rate a different division of the genus Patula. 
The excessive flatness of its spire, the whorls of which (even though the examples from which Sowerby drew up his diagnosis were subfossilized ones) appear to be more or less transverselydappled 'with irregular ferruginous rays,' in conjunction with the comparative convexity of its base, and its very small and well-nigh closed-up umbilicus, will serve additionally to distinguish the $P$. bilamellata from everything else with which we are here concerned. Its extreme breadth seems to be nearly 4 lines, but its altitude only about $1 \frac{1}{2}$. The following is Sowerby's diagnosis of it:- ' $T$. órbiculato-depressa, spirâ planâ, anfractibus senis, ultimo subtus ventricoso, superne angulari; umbilico parvo; aperturâ semilunari, superne extus angulatâ, labio externo tenui ; interno plicis duabus spiralibus, posticâ majori.'

\section{Patula biplicata.}

Helix biplicata, Sow., in Darwin's Volc. Isl., Append., 158 (1844)

" $\quad$ Melliss, St. Hel. 121 (1875)

Habitat in calcareis, versus borealem insulæ; semifossilis.

The only example which I have seen of this very minute Patula (which measures about $1 \frac{1}{3}$ lines across its broadest part) was obtained by myself from out of the calcareous soil which had filled-up the aperture of an equally subfossilized Bulimus Darwinianus; but its characters are so decided that there is no possibility of falling into error as regards the identification. It appears to be quite distinct from the $P$. bilamellata,-for not only is its form different (the spire being much less flattened, and the posterior edge of each volution not angular), but its umbilicus also is considerably larger and more open. Like that species it has two spiral plates, the upper one of which is rather the most elevated, on the ventral paries ; and it is transversely sculptured with very powerful and well-defined costæ.

From the polyodon, Sow. (=Alexandri, Forbes) the present Patula may be known by, inter alia, its less flattened spire, and more remote and raised ridges (which are continued, though perhaps not very coarsely so, on the underside of the shell), by its relatively much smaller umbilicus, and by its having no appearance of plaits inside the outer lip.

\section{Patula Cutteri.}

Helix Cutteri, Pfeiff., Mal. Blätt. 206 (1856)

$" \quad " \quad$ Id., Mon. Hel. iv. $155(1859)$

Habitat regiones editiores sylvaticas; ad 'Diana's Peak' a Dom. Cutter detecta. 
I think that Mr. Melliss has fallen into some mistake regarding this Helix,- - for he cites it as a subfossil species, found in company with the $H$. helensis or polyodon, at the edges of the Sidepath-road above the Briars; whereas if we turn to Pfeiffer's original diagnosis, in the 4th volume of his Monograph, we perceive that it was drawn-out from recent examples which were taken by Mr. Cutter on Diana's Peak, - a habitat which would of itself prove, as in the case of the H. dianoe, that it could not possibly belong to the extinct fauna. Like most of its immediate allies, it is small in stature (being about 2 lines broad, and $1 \frac{1}{2}$ high); and it is described as thin in substance, rather closely costate, free from gloss, and of a chestnut brown though tessellated above with a few yellowish markings. But its main feature consists in its aperture being armed with four plaits on the ventral wall, - the two upper ones of which are acute, and the two lower ones more dentiform and placed near to the columella. The following diagnosis of it is taken from Pfeiffer's Monograph :- 'T. perforata, conoideo-depressa, tenuis, subconferte chordato-costata: haud nitens, castanea, superne luteo-tessellata, subtus obsolete undulato-strigata ; spirâ breviter conoidea, vertice subtili ; anfr. $5 \frac{1}{2}$ convexi, ultimus non descendens, basi convexiusculus; apertura vix obliqua, lunaris, laminis 2 acutis parietalibus intrantibus, et 2 dentiformibus basalibus prope columellam, coarctata ; perist. simplex, rectum, marginibus remotis, columellari superne vix dilatato.'

\section{Patula polyodon.}

Helix polyodon, Sow., in Darwin's Volc. Isl., Append. 157 (1844)

" helenensis, Forbes, Proc. Zool. Soc. Lond. (1851)

"Alexandri, Id., Journ. Geol. Soc. Lond. viii. 198. t. 5. f. 9 (1852)

" Helenensis, Pfeiff., Mon. Hel. iii. 144 (1853)

" $\quad$ Id., ibid. iv. 154 (1859)

" $\quad$ " Id., ibid. vii. $256(1876)$

" $\quad$ "et polyodon, Melliss, St. Hel. 120 (1875)

Habitat in solo conchylifero versus borealem insulæ; semifossilis.

Although of such diminutive bulk as compared with that species, the present minute Patula (which measures only about $1 \frac{1}{3}$ line across its broadest part, and which has been found hitherto in merely a subfossil condition) has somewhat the primâ facie contour of the common European P. rotundata, Müll.,-its flattened, discoidal outline and closely striated whorls, added to the convexity of its base and the largeness of 
its open and spiral umbilicus, being much in accordance with the latter; nevertheless the fact of its aperture being furnished internally with a quantity of teeth, or plaits, will of course remove it into a totally different section of the genus. The exact number however of these plaits would seem to vary,there being according to Sowerby eight of them, and according to Forbes no less than eleven; whilst in a broken and unmatured example which is nuw before me (and which I obtained from out of the loose sandy soil which had filled up an equally subfossilized specimen of the Bulimus auris-vulpina, Chemn.) I cannot satisfy myself of the presence of more than, at the utmost, six, - three of which are (as is acknowledged in all the diagnoses to which I have access) on the ventral paries.

Considering how unmistakeably defined this singular little species is, as regards its several peculiarities, it is astounding how Forbes, with Sowerby's diagnosis before him, could have republished it, first under the name of $H$. helenensis, and then under that of Alexandri; moreover not a single remark concerning its affinities is ventured upon, nor is there a syllable to lead us to conclude that it has the slightest connection whatsoever with the $H$. polyodon,-the very title of which, not to mention its habitat, might well have afforded him somewhat of a clue towards its identification.

The umbilicus of this Patula, apart from its enormous size for a shell which is so diminutive, is further remarkable for its being unusually wide and conspicuous (and, as it were, broadly flattened) at even its extreme apex, or lowest depth.'

\section{(§ Acanthinula, Beck.)}

\section{Patula pusilla.}

Helix pusilla, Lowe, Cambr. Phil. S. Trans. iv. 46.t. 5. f. 17 (1831)

1 Although there could be little question that Forbes's H. Alexandri is conspecific with the previously published H. polyodon of Sowerby (for the precise number of the plaits within the curvature of the peristome is clearly variable), it is nevertheless solely on the authority of Pfeiffer that I refer also the helenensis, Forbes, to the latter; for in his diagnosis of that species Forbes defined the aperture as armed with only four plaits (namely, two on the ventral wall, and two within the outer margin),-instead of the 'eight,' or even 'eleven,' which are said to be conspicuous in the $H$. polyodon. Nevertheless Pfeiffer seems to have had some sufficient reason for concluding that Forbes's diagnosis, as well as his own, was inaccurate; for, whilst acknonledging the helenensis in the third volume of his Monograph, he expressly identifies it in his subsequent ones with the polyodon of Sowerby, adding the observation, in vol. iv., ' Legatur in descriptione :-aperturâ multodentatâ, laminis $2-3$ in pariete aperturali, denticulis usque 8 in margine dextro positis.' It would seem, therefore, that variability as regards the number of its plaits is one of the most distinctive features of this curious little Patula. 
Helix pusilla, Pfeiff., Mon. Hel. i. 101 (1848)

" servilis, Shuttl., Bern. Mitth. 140 (1852)

" " Pfeiff., Mon. Hel. iii. 101 (1853)

" pusilla, a. annulata, Lowe, Proc. Zool. S. Lond. 176

(1854)

" $\quad$ Alb., Mal. Mad. 18. t. 2. f. 7-10 (1854)

" hypocrita, Dohrn, Mal. Blätt. 1 (1869)

Patula servilis, Mouss., Faun. Mal. des Can. 25. pl. 2. f. 13-16 (1872)

Habitat in intermediis insulæ; ad Plantation, West Lodge, et Thompson's Wood a meipso copiose lecta.

This extremely minute Patula (which occurs in the Azorean, Madeiran, Canarian, and Cape-Verde archipelagos) I met with, not uncommonly, in the intermediate districts of St. Helena,particularly in the grounds at Plantation, where it is found in damp spots beneath fir-cones and pieces of timber, as well as at West Lodge and Thompson's Wood. It is not unlikely that it may have been originally imported into the island, along perhaps with consignments of shrubs and plants; though the fact that the latter were introduced chiefly from England and the Cape of Good Hope, where the $P$. pusilla has not been ascertained to exist, is against that hypothesis.

Apart from its very diminutive size (the largest examples measuring scarcely a line across their broadest part), the $P$. pusilla may be known by its rounded but flattened contour and large open umbilicus, as well as by its brown and subopake surface being more or less evidently furnished with a few additional, remote, appreciably raised, oblique, thread-like lines,which, although sometimes so indistinct as to be barely traceable, are at others considerably developed and conspicuous. Its aperture is quite free from plaits, and its peristome is acute.

\section{Genus 4. HELIX, Linn.}

\section{(§ Vallonia, Risso.)}

\section{Helix pulchella.}

Helix pulchella, Müll., Verm. Hist. ii. 30 (1774)

" $\quad$ " Lowe, Cambr. Phil. S. Trans. iv. 45 (1831)

" $\quad$ Alb., Mal. Mad. 45. t. 12. f. 1-4 (1854)

" " Morel., Hist. Nat. des Açor. 175 (1860)

" $\quad$ " Mouss., Faun. Mal. des Can. 57 (1872)

Habitat præcipue in intermediis; ad Plantation, Thompson's Wood, Peak Gut, et cæt., abundans. Forsan ex alienis (sc. Angliâ), una cum plantis, olim introducta. 
This little European Helix, which has acquired a wide geographical range (having gained for itself a footing in the Azorean, Madeiran, and Canarian archipelagos, and indeed having been met with by the late Mr. Benson even at the Cape of Good Hope), we obtained abundantly in the intermediate districts of St. Helena, - particularly about Plantation, in Thompson's Wood, and amongst some old Gumwoods at Peak Gut. It appears, however, that a single example of it was found by Mr. E. L. Layard, several years ago, while halting at St. Helena on his passage to southern Africa, - namely(in company with Stenogyra compressilabris and the Achatina Veru, Bens.) in the public garden at the entrance of Jamestown. In all probability the species was originally introduced into the island, along perhaps with consignments of trees and plants, and has since become completely established.

\section{(§ Pomatia, Beck.)}

\section{Helix aspersa.}

Helix aspersa, Müll., Verm. Hist. ii. 59 (1774)

$\begin{array}{lll}" & " & \text { Pfeiff., Mon. Hel. i. 241 (1848) } \\ " & " & \text { Morel, Hist. Nat. des Açor. 152 (1860) } \\ " & " & \text { Mouss., Faun. Mal. des Can. } 69(1872) \\ & \quad & \text { Melliss, St. Hel. } 120 \text { (1875) }\end{array}$

Habitat in cultis intermediis ; ad Plantation, necnon in locis similibus. Certe ex Europâ invecta.

The common European $H$. aspersa, which has become established in the Azorean and Canarian archipelagos, is rather abundant within the cultivated districts of St. Helena,- more particularly those of an intermediate altitude. In the grounds, and garden, at Plantation, we met with it in considerable numbers. There can be no doubt whatever that it has been naturalized accidentally in the island from more northern latitudes,-probably from England, along with consignments of trees and plants. Be this however as it may, the species is fairly now in statu naturali, being often only too destructive in many of the gardens.

\section{Genus 5. BULIMUS, Scop.}

\section{(§ Pseudachatina, Pfeiff.)}

\section{Bulimus exulatus.}

Achatina exulata, Bens., in litt.

$$
\text { Reeve, Conch. Icon. sp. } 77
$$

Bulimus exulatus, Id., ibid. t. 78. f. 572 
Bulimus exulatus, Pfeiff., Mon. Hel. iii. 301 (1853)

Achatina exulata, Melliss, St. Hel. 123 (1875)

Habitat 'in St. Helena' (Lefroy) ; an omnino semifossilis?

There is nothing in the published diagnoses of this species to imply that it was discovered in a subfossilized condition, nor can I perceive any note as to the exact spot where it was met with; therefore I do not know on what authority Mr. Melliss cites it as having been obtained in the cutting of the Sidepathroad above the Briars. My own belief however is that in all probability it was as much subfossilized as are the bleached and still coloured examples of the B. helena, Quoy, which lie scattered loosely in many places on the summit of the Barn; and until further evidence therefore has been adduced, I suspect that it will be safer to treat it as belonging to the extinct fauna of the island, though with the appearance of its having lingeredon (like the $B$. helen $a$ ) into comparatively recent times.

Judging from Pfeiffer's description (which appears to have been drawn out from a specimen in the collection of the late Mr. Benson, and which was found by Mr. Lefroy), as well as from the excellent figure which is given in Reeve's ' Conch. Icon.', the present Bulimus, which can hardly therefore be wholly subfossilized, would seem to be diaphanous and of a griseous white, but nevertheless dappled with a few still whiter and more opake spot-like markings; and it is also of a gradually yellower tinge towards the apex of the spire. It is rather smaller and narrower than any of the following species (its greatest length being scarcely 9 lines, and its greatest breadth about $3 \frac{1}{2}$ ), and its surface is said to be somewhat roughly and closely crowded with the fine thread-like costæ of growth.

\section{( $\S$ Nresiotus, Pfeiff.)}

\section{Bulimus helena.}

T. tenuis, ovato-conica, profunde perforata, dense et irregulariter costulato-striata striisque paucioribus spiralibus decussata, lutescenti-fusca (nisi, sæpius, decolorato-decorticata); anfractibus 6 convexiusculis, suturâ valde profunde et subito impressâ; columellâ subcontortâ; aperturâ ovali ; peristomate acuto, marginibus callo junctis, dextro superne (i.e. ad insertionem) subangulatim sinuoso, columellari late reflexo et albo. -Dirm. maj. $5 \frac{1}{2}$; long. $9 \frac{1}{2}$ lin.

Helix helena, Quoy et Gaim., Astrol. ii. 111. t. 9. f. 8, 9 (1833)

Bulimus helena, Lam. (ed. Desh.), 52. 245 (1836) 
Bulimus digitalis, Reeve, Conch. Icon. f. 308 , relegatus? Bens., Ann. Nat. Hist. vii. 264 (1851) " helena, Melliss, St. Hel. 122 (1875)

Habitat versus borealem insulæ, semifossilis; in excelsis præruptis, super terram jacens, fere quasi in statu recenti, hinc inde vulgaris.

The present Bulimus, which was admirably figured by Quoy in 1833, occurs rather abundantly on the extreme summit of the Barm, and in that immediate neighbourhood, lying loosely on the surface soil, beneath the shrubs of Salsola, \&c.,--where it has much the appearance of having lived at a comparatively recent period. At all events many of the examples have their colour and outer cuticle completely preserved,-though it is equally true that the majority of them are decomposed, decorticated, and colourless. It is far from unlikely therefore that the species may still linger on in that particular district, though I have no evidence that it has ever been met with in an absolutely living condition. Yet so little altered are some of the specimens, in their general features, that Pfeiffer makes no allusion to the B. helena as being 'subfossilized' at all, and Benson (Ann. Nat. Hist. vii. 263) does not hesitate to speak of it, in 1851,- - though, as I cannot but think, without sufficient enquiry, - as 'recent.' Mr. Melliss remarks that, 'although the shells are now dead, they appear of a more recent date than those of the other species.' I possess a considerable number of this Bulimus which were taken by Colonel Warren, and by Mr. P. Whitehead, on the Barn, as well as others by Mr. N. Janisch in that immediate vicinity.

The $B$. helena is ovate-conical in outline, thin in substance, and (when in a sufficient state of preservation) of a yellowishbrown hue; its suture is very deeply and suddenly impressed, causing the anterior edge of each whorl to appear (though not exactly prominent) somewhat abruptly terminated (a fact which gives an obtusely subangulate, or rather elbowed, shape to the outer lip of its aperture at the point of insertion); its perforation is distinct and deep; its peristome is acute, with the margins joined by an intervening lamina; and its surface is densely crowded with irregular costulate lines of growth, which are decussated by more remote spiral ones,-more or less evident according as the specimens are fresh, and free from superficial decomposition.

So far as I am able to form an opinion from a short diagnosis unaccompanied by a single observation, I should say that the $B$. relegatus of Benson differs in no respect whatsoever from Quoy's B. helena,-as represented by the bleached, colourless, and strictly subfossilized aspect of that species. 
The Bulimus which is referred by Reeve to the helena of Quoy is certainly distinct from the present one; and if it be truly found at St. Helena at all (concerning which I think that we require further evidence), I do not see, judging from the figure, why it might not represent a recent, or nearly-recent, state of the B. Blofeldi; in which case it might perhaps answer to the species which is said by Forbes to have been found by Mr. Alexander, many years ago, in a living condition, and feeding on the foliage of the cabbage-trees, on the highest part of the great central ridge.

\section{Bulimus fossilis.}

T. præcedenti fere similis, et forsan vix specifice distincta. Differt testâ paululum minore subsolidiore, spirâ subbreviore, anfractibus circa 5 (nec 6) compositâ, anfractibus subbrevioribus, ultimo vix magis inflato-rotundato, aperturâ paululum minore angustiore, margine columellari sensim latius dilatato magisque rotundato $(i$. e. minus verticaliter recto).-Diam. maj. 5 ; long. $7 \frac{1}{2} \operatorname{lin}$.

Cochlogena fossilis, Sow., in Darwin's Volc. Isl., Append. 156 (1844)

Bulimus fossilis, Forbes, Journ. Geol. Soc. Lond. viii. 199. t. 5. f. 4 (1852)

$" \quad \quad \quad \quad$ Pfeiff., Mon. Hel. iv. $506(1859)$

Habitat in solo insulæ conchylifero; semifossilis.

Judging from the variability of the $B$. helena, which is apt to take a slightly different outline according to the exact spot, or ridge, on which it is found, I feel extremely doubtful whether the present Bulimus is anything more than a somewhat unimportant modification of that species which has become a little more solid through a longer process of semifossilization, and in which, consequently, the spiral lines are well-nigh effaced. It is true that it is a trifle shorter and more ventricose, and its apex seems to have a whorl (or perhaps only half a whorl) less, but in the genus Bulimus such characters as these are hardly worth alluding to ; nevertheless since the aperture also is just appreciably smaller, and the columella is not quite so straightened, I will not suppress it as a species, though I must frankly admit that I have very little faith in its claims for separation.

I possess an example of the $B$. fossilis which was taken by Mr. P. Whitehead on the ridge between Flagstaff $\mathrm{Hill}$ and Sugarloaf, and which accords precisely with the figure as given by Forbes; but the original type from which Sowerby's diagnosis was drawn out was met with, I believe, in the cutting of 
the Sidepath Road (between Jamestown and Longwood) overlooking the 'Briars.'

\section{Bulimus Seleianus.}

Bulimus Seleianus, Forbes, Journ. Geol. Soc. Lond. viii. 198. t. 5. f. 3 (1852)

$\Rightarrow \quad$ " $\quad$ Pfeiff., Mon. Hel. iv. $506(1859)$

Habitat in iisdem locis ac præcedens; semifossilis.

The only points in Prof. Forbes' diagnosis of this Bulimus which would at all distinguish it from the $B$. helena are (1).its more thickened substance, and (2) the fact that no mention is made of the existence on its surface of spiral lines; but the former of these might have been merely due to the longer process of subfossilization to which the shell had been exposed, whilst the latter (or the obliteration of the spiral costæ) may have been the result of the selfsame cause,-the destruction of the outer cuticle having been naturally more complete. Still, judging from the figure, the $B$. Seleianus would appear to be a trifle smaller and less ventricose than the $B$. helena, with the aperture a little narrower and less developed; and its peristome, which is much more incrassated, has the upper and lower portions connected by a more robust lamina. It seems to have been described from a specimen which was found by Mr. E. Alexander.

\section{Bulimus Blofeldi.}

Bulimus Blofeldi, Forbes, Journ. Geol. Soc. Lond. viii. 198. t. 5 . f. 2 (1852)

$\begin{array}{ccc}" & \Rightarrow \quad \text { Pfeiff., Mon. Hel. iv. } 506(1859) \\ " & \Rightarrow & \text { Melliss, St. Hel. } 122(1875) \\ " & \text { helena? Reeve [nec Q. et G.], Conch. Icon. f. } 306\end{array}$

Habitat ins. St. Helenæ, semifossilis; ad latera viæ inter Jamestown et Longwood, circa $1200^{\prime}$ s. m., reperta.

Judging from the diagnosis and plate, which are given by Prof. Forbes, the present Bulimus (which is nearly an inch in length) ranges next, in point of size, to the $B$. auris-vulpina and Darwinianus; nevertheless it belongs to a very different type,-being altogether less solid, and having no thickenings or developments about its aperture. It is indeed more on the pattern of the three preceding species, but is larger than any of them, and has its columella longer and straighter; and the upper and lower divisions of its peristome (which is said to be acute) are unconnected by an intervening lamina. Still, the example figured having been an exceedingly imperfect one, I 
suspect that too great reliance must not be placed upon the latter characters, - the breaking-away of the aperture tending usually (to say nothing about the consequent destruction of the peristome) to cause the columella to appear more elongated than it really is.

Prof. Forbes speaks of the B. Blofeldi as nearly allied to a recent undescribed species which was 'found by Mr. Alexander feeding on the Cabbage-Trees on the highest points of the island.' I am totally unaware of any living Bulimus on so large a scale at St. Helena; but wher re-detected, and characterized, it will doubtless constitute a most significant addition to the fauna. If Forbes was really acquainted with it, as his remarks would almost imply, why did he not publish a description of it, and give us the advantage of a figure? Perhaps it may be absolutely identical with the Blofeldi, and with the species which was wrongly referred by Reeve to the B. helena, Quoy.

The B. Blofeldi appears to have been met with by Mr. J. H. Blofeld, in company with the (equally subfossilized) Helix bilamellata, in a reddish clay or loam, in a cutting of the 'Sidepath Road' (which leads from Jamestown to Longwood) overlooking the 'Briars,'-at an elevation of about 1200 feet above the sea.

\section{( Pachyotus, Beck.)}

\section{Bulimus auris-vulpina.}

T. magna, crassa, ovato-conica, aperte rimata, densissime transversim (i.e. longitudinaliter) striata (striis inæqualibus, subconfluentibus), plerumque albida ecolorata sed in exemplaribus bene conservatis pallide corneo- et albido-nebulosa; spirâ conicâ; anfractibus 7 , antice $(i . e$. pone suturam grosse crenatam), præcipue in ultimo, sub-biangulatis et spiraliter subnodulosis; columellâ contortâ; aperturâ angustulâ, auriformi, peristomate subreflexo, incrassato, canaliculato, marginibus callo robusto junctis, dextro sinuato (sc. intus sæpius dilatate prominulo), columellari late reflexo.-Diam. maj. 13; long. 2223 lin.

var. $\beta$. subspiralis [an species vera?].-Obtecte rimata; anfractibus minus longitudinaliter striatis sed obsolete, parce, et obtuse spiraliter costatis ; callo ventrali longe intus in medio tuberculato-gibboso.

var. $\gamma$. obliteratus.-Obtecte rimata; anfractibus antice etiam obsoletius biangulatis; peristomate minus incrassato, margine dextro fere simplici (i.e. intus vix ampliato); callo ventrali longe intus in medio leviter tuberculato-gibboso. 
Auris vulpina, Chemn., Syst. Conch. xi. 287. t. 210. f. 2086, 87 (1795)

Melania Nonpareil, Perry, Conch. t. 29. f. 4 (1811)

Voluta auris-vulpina, Dillw., Cat. i. 503 (1817)

Helix auris-rulpina (Cochligena), Fer., Prodr. 445 (1819)

Pachyotus alopecotis, Beck, Ind. Moll. 56 (1837)

Bulimus auris-vulpina, Pfeiff., Mon. Hel. ii. 93 (1848)

" $"$ Melliss, St. Hel. 121. t. 22. f. 2 (1875)

Habitat versus borealem insulæ, semifossilis ; in terrâ aridâ (præcipue in præruptis inter montes 'Sugarloaf' et 'Flagstaff') sepulta, a circa $1400^{\prime}$ s.m., hinc inde abundans.

The extreme variability of this large subfossil Bulimus renders it desirable that I should characterize it afresh, in order to point out which it is that I believe to be the exact form from which Chemnitz's description was compiled, and which was subsequently recorded by Pfeiffer. It is possible indeed that more than a single species may be indicated amongst the many examples which are now before me; nevertheless since every feature appears to be more or less inconstant, I think that it will be the safest plan to treat the three modifications under which they would seem, on the whole, to distribute themselves as but phases of a plastic type. Judging from Pfeiffer's diagnosis, I should conceive the normal state to be the one in which the longitudinal striæ are coarsely expressed, in which the umbilicus is not altogether closed over by the reflexed columellary edge of the peristome, and in which there are no traces of a large tubercle-like nodule within the aperture on the middle of the ventral wall. From which it follows that the specimens in which this inner gibbosity is developed, and in which the umbilicus is sealed up by the recurved margin of the columella, (and in which also, I may add, a few obtuse and remote spiral costæ are more evidently visible,) represent an aberrant state, and one which corresponds with my 'var. $\beta$. subspiralis' as above enunciated. A certain number of individuals, however, although agreeing in other respects with the var. $\beta$., have their peristome much less thickened, with the right margin less internally-sinuate, and their whorls less decidedly prominent (or subangulated) anteriorly,-i.e. behind the suture; and it is these that I have defined as the 'var. $\boldsymbol{\gamma}$. obliteratus.'

This large and curious Bulimus was supposed originally to be a marine form, and was characterized as such ; but it is nevertheless truly terrestrial, belonging in a great measure to a type (Pachyotus, Beck) which has exponents in South America and in certain islands of the Pacific. Indeed it has been stated to occur, in a living condition, in China; but there can be little 
doubt, I think, that this assertion was founded either upon an inaccuracy of identification or else an inaccuracy of habitat.

The $B$. auris-vulpina, which has been brought from St. Helena by almost every naturalist who has visited the island during the last fifty years, appears to be quite extinct; though the comparatively perfect preservation of occasional examples, in which the outer cuticle is hardly destroyed and even the colour is partially traceable, would perhaps imply that it must have lingered on to a somewhat recent period. Still, by far the greater majority of the individuals, which are for the most part firmly imbedded in the surface soil at an altitude of from about 1400 to 1700 feet above the sea, are extremely thickened but decomposed, and shew unmistakeable signs of age. It is in the north and north-east of the island that the B. auris-vulpina exclusively occurs, - particularly in an indurated, whitish, calcareous kind of earth on the ridge between the conical mountains known as Sugarloaf and Flagstaff, and towards the Barn. Many of my examples were taken by the Rev. H. Whitehead and his son, and I also possess two which were found by Mr. N. Janisch.

\section{Bulimus Darwinianus.}

T. crassa, elongata, ovato-fusiformis, obtecte rimata, parce et irregulariter transversim (i.e., longitudinaliter) striata, albida, quasi cretacea, decolorata; anfractibus 6 , antice (i.e., mox pone suturam, impressam, obliquam, nucleum versus grosse crenatam) subconvexiusculis ; columellâ subcontortâ ; aperturâ angustulâ ; peristomate intus incrassato, marginibus callo robusto (longe intus in medio plicâ obtusâ tuberculiformi armato) junctis, columellari valde incrassato, subreflexo._Diam. maj. 8; long. 18 lin.

Bulimus Darvinianus, Forbes, Journ. Geol. Soc. viii. 198. t. 5. f. 1 (1852)

$" \quad$ " $\quad$ Pfeiff., Mon. Hel. iv. $506(1859)$

Habitat in locis similibus ac præcedens, versus borealem insulæ; semifossilis.

This is smaller, narrower, and more fusiform than the last species, less roughened or sculptured, with the suture more oblique, and (as in the vars. $\beta$ and $\gamma$ of the $B$. auris-vulpina) with an obtuse plait, or tuberculiform gibbosity, far within the aperture in the middle of the ventral wall. The shell is thick and colourless (the latter, however, being due, in all probability, to its subfossilized condition) ; the right margin of its peristome, although not reflexed, is a good deal incrassated internally, and 
the columellary portion completely seals up the umbilical perforation.

The B. Darwinianus is found in company with the $B$. auris-vulpina in the extreme north and north-east of the island,-imbedded on the ridge-like slopes of indurated soil in the vicinity of Sugarloaf, Flagstaff, and the Barn. I possess examples which were taken by the Rev. H. and Mr. P. Whitehead, and Mr. N. Janisch; but the species does not appear to be quite so common as the B. auris-vulpina.

\section{Genus 6. SUBULINA, Beck.}

\section{Subulina melanioides, $\mathrm{n}$. sp.}

'T. elongata, angustula, turrito-conica, subobtecte anguste perforata, nigro-brunnea (interdum subrufescens) strigisque ochreis (rarius rufo-ochreis) irregularibus plurimis confluentibus longitudinaliter marmorata, confertissime longitudinaliter costulato-striata, subopaca; anfractibus 8-9 convexiusculis, suturâ valde profunde subundulatim impressâ, ultimo ( $\frac{1}{3}$ longitudinis breviore) mox supra aperturam parvulam auriformem plus minus distincte angulato-carinato (carinâ sæpe evanescente, et etiam in lineolam impressam mergente), anfractibus antice oblique ochreo-subplicato-gibbosis (plicis, aut nodis, paucis, valde distantibus, et postice omnino evanescentibus) ergo antice inter nodos breviter subexcavatis ; columellâ albâ, nitidâ, intus subemarginato-sinuatâ et basi rotundate truncatâ; peristomate simplici, acuto.-Long. 9-11 ; apert. $3 \frac{1}{2}$; diam. maj. $3 \frac{1}{2}$ lin.

Obs.-anfractus interdum lineolis obsoletissimis perpaucis remotis spiralibus (æque discernendis) instructi sunt.

Habitat regionem centralem humidam excelsam insulæ; circa radices graminum ad rupes crescentium, rarissima.

This is unquestionably the most remarkable addition to the living Pulmoniferous Gastropods of St. Helena which we made during our late six months' sojourn in that island. It was first obtained by Mrs. Wollaston (and subsequently by myself and Mr. P. Whitehead in the same locality) in a damp and precipitous, but practically dried-up, watercourse issuing from the northern flanks of the great central ridge, about midway between Actæon and Diana's Peak; but as the specimens were invariably dead and mutilated (though, at the same time, recent and highly coloured), it was evident to me that they had been washed into that situation by the winter floods, and that their real home was in the densely wooded region immediately above the spot where we found them. Still, the sides of the precipice were too steep and inaccessible to admit of an exploration; thongh a single 
living example which was secured by Mr. P. Whitehead in an immediately adjoining locality sufficed abundantly to indicate the modus vivendi of the species, - it having been taken at the roots of one of the damp masses of intermingled moss and grass which pad the base of the perpendicular rocks formed by the excavation of what is known as the ' Cabbage-Tree Road.' There can be little doubt, consequently, that the S. melanioides will be ascertained to occur in humid places generally along the northern slopes of the ridge below Diana's Peak.

The numerous volutions and elongate-conical outline of this fine species, added to its close and sharp longitudinal costatestrix, and the obscure keel which is usually more or less traceable immediately above the aperture on the circumference of the basal whorl, appear to me to bespeak its affinity with the widely spread forms around the Bulimus octonus, Chemn. (now usually regarded as pertaining to the genus, or section, Subulina), particularly perhaps to the West African S. Fraseri, Pfr., and clavata, Gray; and I think that these same characters are equally suggestive of the fact, that it cannot be very remote from the (nevertheless exceedingly distinct) St.-Helenian subplicata and terebellum of Sowerby,-which have been observed hitherto only in a subfossil condition, and which have been referred by some authors to Bulimus and by others to Achatina (the late Prof. Forbes indeed having, in the same paper, assigned them, totidem verbis, to both! $)^{1}$

This singular shell has something about it which calls to mind at first sight certain members of the genus Melania,-its dark, rich, reddish-brown hue and nearly opake surface, which is more or less marbled with irregular, frequently subconfluent, longitudinal ochreous streaks, in conjunction with the oblique and remote, posteriorly-evanescent, obtuse, ridge-like nodules which (although occasionally not very prominent) undulate the anterior zone of each volution, and cause the very deeply impressed suture to be more or less waved, or scooped-out at regular intervals, giving it a character which it is impossible to mistake. However few, or however numerous, the yellow streaks may be, these oblique, short, posteriorly-evanescent, nodiform humps are themselves always more or less yellow, or ochreous; and, when accurately inspected, there will usually be seen to be a few obsolete traces of some very indistinct spiral lines (decussating the closely-set longitudinal ridges) on certain of the whorls.

1 As a not unnatural result of this indecision, the $S$. subplicata, Sow., is cited twice over in Mr. Melliss's catalogue,-first as a Bulimus, and afterwards as an Achatina. 


\section{Subulina subplicata.}

Cochlicopa subplicata, Sow., in Damvin's Volc. Isl., Append. 156 (1844)

Achatina subplicata, Forbes, Journ. Geal. Soc. Lond. viii. 197 (1852)

Bulimus subplicatus, Id., ibid. 199. pl. 5. f. 6 (1852)

" et Achatina subplicata, Melliss, St. Hel. 122, 123 (1875)

Habitat ad latera viæ ' Sidepath' dictæ, inter Jamestown et Longwood, semifossilis; hodie recens haud obvia.

Like the following one, the present species is subfossilized and apparently extinct, occurring in the surface soil on the side of the hill overlooking the Briars-in a cutting of the road leading from Jamestown to Longwood. According to Mr. J. H. Blofeld it would seem to exist equally in the direction of Flagstaff; inasmuch as he particularly mentioned (Quart. Journ. Geol. Soc. viii. 196) that he met with it in company with the Bulimus auris-vulpina,-which latter does not occur near the Briars, but is essentially characteristic of the district, or ridges, between the conical hills which are known as Flagstaff and Sugarloaf.

The S. subplicata, judging from its published figure, does not appear to differ greatly from the S. terebellum,-the two forms belonging to precisely the same type. It is however a little smaller than the latter (measuring about 7 lines in length), and there are faint indications of posteriorly-abbreviated longitudinal plicæ (adjoining the suture) on the anterior zone of each whorl. Being subfossilized of course nothing can be said, in the case of either species, as regards colour.

\section{Subulina terebellum.}

Cochlicopa terebellum, Sow., in Darwin's Volc. Isl., Append. 156 (1844)

Achatina terebellum, Forbes, Journ. Geol. Soc. Lond. viii. 197,198 (1852)

Bulimus terebellum, Id., ibid. 199. t. 5. f, 5 (1852) " $\quad$ Melliss, St. Hel. 122 (1875)

Habitat in locis similibus ac præcedens ; semifossilis.

Judging from the figure of this species which accompanies the late Prof. E. Forbes' paper in the 'Quarterly Journal of the Geological Society,' the subfossilized 'Cochlicopa terebellum' of Sowerby is, unless I am much mistaken, like his $C$. subplicuta, a decided Subulina,-its elongate-conical outline and shortened aperture, in conjunction with the manifest keel across 
its basal whorl immediately above the latter, affiliating it with the various forms which cluster around the S. striatella, Rang, and the octona, Chemn., and bespeaking also a certain affinity with the equally St.-Helenian (but, at the same time, still recent) S. melanioides, Woll.

The S. terebellum, which has been found in the cutting of the Sidepath Road, above the Briars, between Jamestown and Longwood, at an elevation of some' 1200 feet above the sea, is rather conico-fusiform in outline, and composed of about six whorls which are so much flattened as to cause the suture to appear but very slightly sunken or impressed; its columella is not sinuated (as in the S. melanioides), or posteriorly subtruncate, but rounded-off uniformly and gradually into the lower margin of the peristome; and its surface (at any rate in a subfossil condition, and probably in statu normali equally) is almost free from sculpture. Its extreme length would seem to be about $8 \frac{1}{2}$ lines.

\section{Genus 7. STENOGYRA, Shuttl.}

\section{Stenogyra compressilabris.}

Bulimus compressilabris, Benson, Ann. Nat. Hist. xviii. $434(1856)$

" $\quad$ "Pfeiff., Mon.Hel. iv. 461 (1859)

Habitat in horto publico ad Jamestown ; in aquæducto quodam parvulo a cl. E. L. Layard olim reperta.

The present Stenogyra, which I did not myself meet with during our sojourn at St. Helena, appears to have been found by Mr. E. L. Layard (while halting there for a short time on his passage to the Cape of Good Hope) in a small artificial watercourse in the public garden at the entrance to Jamestown. In all probability, therefore, it is a species which has been naturalized in the island. It seems to be white and subuliform, composed of about seven volutions, and closely sculptured with flexuose costate-striæ; and Mr. Benson adds 'This is a form of the widely-spread type to which Bulimuis Goodallii, octona, \&c., belong.' His diagnosis of it is as follows: 'Testa vix perforata, subuliformis, confertim flexuose costulato-striata, cerea, albida, suturâ subimpressâ apice obtusiusculo; anfractibus vix 7, ultimo $\frac{2}{7}$ longitudinis æquante; aperturâ truncato-ovali, basi rotundatâ; peristomate tenui, simplici, margine dextro superne antrorsum arcuatim producto, subcompresso, columellari verticali, breviter reflexo, subtus nullo modo truncato nec emarginato.-Long. $6 \frac{1}{2}$; diam. 2 mill.' 


\title{
Genus 8. PUPA, Drap.
}

\author{
(§ Gastrodon, Lowe.)
}

\section{Pupa umbilicata.}

Pupa umbilicata [var.], Drap., Tabl. des Moll. 58 (1801)

Helix anconostoma, Lowe, Cambr. Phil. S. Trans. iv. 62. t. 6. f. 30 (1831)

Pupa anconostoma, Id., Proc. Zool. Soc. Lond. 208 (1854)

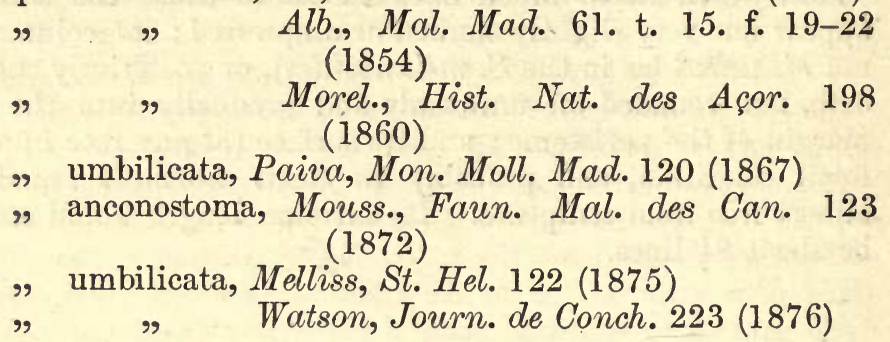
tissima.

Habitat in intermediis insulæ, præcipue cultis; vulga-

It is under its rather smaller form (with a less developed ventral plait), which was described by Mr. Lowe as the $P$. anconostoma, that this common European Pupa occurs at St. Helena ; and it is this particular aspect of the shell, which however passes by imperceptible gradations into the normal one, which abounds so greatly in the Madeiran, Canarian, and Azorean archipelagos: indeed I am extremely doubtful whether, Pfeiffer's $P$. Dohrni, from the Cape Verdes, is more in reality than another slight geographical modification of the selfsame type.

We may be almost sure that the present Pupa must originally have been introduced into the island, perhaps in the earth used for the packing of shrubs and plants; but, be this as it may, it now absolutely swarms in the intermediate cultivated districts,-such as Plantation, Thompson's Wood, \&c., where, while sifting for Coleoptera, I have taken it in countless multitudes. The first St. Helena notice of it with which I am acquainted was by the late Mr. Benson (Ann. Nat. Hist. for April, 1851 ; and for December, 1856), who met with it in 1832 'between Plantation House and Stitch's Ridge'; and it was found subsequently by Mr. E. L. Layard, while halting at the island en route to the Cape of Good Hope, ' under stones, in damp places, about Napoleon's Tomb.' Mr. Benson was inaccurate when he cited it as 'the smaller variety of the Pupa anconostoma, Lowe, - for it is the regular and typical state of that 
shell; had he said ' the smaller variety of the Pupa umbilicata, Drap., known as the $P$. anconostoma,' he would have been nearer the truth.

\title{
Genus 9. ACHATINA, Lam.
}

\author{
(§ Acicula, Risso.)
}

\section{Achatina Veru.}

Achatina Veru, Bens., Ann. Nat. Hist. xviii. 435 (1856) " $\quad$ "Pfeiff., Mon. Hel. iv. 615 (1859)

Habitat humidos in inferioribus insulæ; in horto publico ad Jamestown, una cum Stenogyra compressilabri, Bens., a cl. E. L. Layard semel lecta.

A single example of this little Achatina was found by $\mathrm{Mr}$. E. L. Layard in the public garden at the entrance to Jamestown, in company with the Helix pulchella, Müll., and the Stenogyra compressilabris, Bens.; and it is far from unlikely that both species may have been accidentally imported into the island, along with consignments of plants, and subsequently become naturalized. It appears to belong to the same type as the European $A$. acicula, Müll. (found equally in the Madeiran and Canarian archipelagos), and the A. spiculum, Bens. (=A. amonitatum, Dohrn), from the Cape Verdes. Mr. Benson, in his remarks on the $A$. Veru, says: 'It is deficient in the lucid transparency and the peculiar slenderness of the A. spiculum. The proportions of these two shells [i.e. the A. spiculum and the $A$. Veru] differ from those of their allies, the $A$. acicula and the $A$. Hohenwarti,-neither of which can compete with the former two in slenderness.' The extreme length of the $A$. Veru seems to be about 2 lines.

\section{Fam. 3. SUCCINEID艮.}

\section{Genus 10. SUCCINEA, Drap.}

\section{Succinea Sanctæ-Helenæ.}

Helisiga St. Helenæ, Lesson, Voy. Coq. ii. (1) 316. t. 15.

$$
\text { f. } 1 \text { (1830) }
$$

Succinea St. Helenæ, Pfeiff., Symb. ii. 132 (1842)

$$
\text { Id., Mon. Hel. ii. } 518 \text { (1848) }
$$

Helisiga Sanctæ-Helenæ, Melliss, St. Hel. 119. pl. 22. f. 1 (1875)

Habitat in regionibus elevatis insulæ, ad folia Compositarum arborescentium copiosissime adhærens. 
This and the $S$. picta are the largest of the island Succineas (measuring from about 7 to 8 lines in their greatest length, with an altitude of about 3), the S. Sanctoe-Helenoe being eminently characteristic of the most elevated portions of the central heights, -where it swarms on the foliage of the various species of Cabbage-tree about Diana's Peak, Actæon, and Stitch's Ridge. In the more western parts, however, of the great medial craterwall, around High Peak, its place seems to be taken by the very closely allied form which I have cited as the S. picta, Pfeiff.

Apart from its large stature (when fully matured), the $S$. Sanctoe-Helence may be known by its perfectly enormous hasal volution and aperture, and its extremely minute, papilliform spire. Its transverse lines of growth are coarse but very irregular; its substance (as in most of the Succineas) is thin, flexible, and pellucid ; its surface is generally very uneven, and slightly shining; and its colour (as is equally the case in the animals) is either of a pale yellowish- or olivaceo-corneous, or else of a warm and clear reddish-brown.

I am indebted to the Rev. R. B. Watson for making me a most careful tracing of this noble Succinea from the original plate which is given by Lesson; and had there been any doubt concerning the identification (which the extreme accuracy of the outline renders impossible), it would at once have been dispelled by the recorded habitat-' dans les feuilles des Cabbagetrees, ou Solidago, sur la montagne de Diana'; this particular species being the only one, so far as I am aware, which ascends to the highest points of the Diana-Peak ridge,-where, moreover, as just stated, it literally abounds.

\section{Succinea picta.}

Succinea picta, Pfeiff., Proc. Zool. Soc. Lond. 133 (1849) " imperialis, Bens., Ann. Nat. Hist. 262 (1851)

" picta, Pfeiff., Mon. Hel. iii. 12 (1853)

" rudorina, Melliss [nec 'Gould'], St. Hel. 119 (1875)

Habitat in locis similibus ac præcedens, sed magis versus occidentem insulæ; folia Compositarum ad 'High Peak' destruens.

I am in very great doubt whether this large Succinea should be regarded in reality as anything more than a slight local phasis of the $S$. Sancto-Helence, peculiar to the more western portions of the great central ridge,--where on the foliage of the Cabbage-trees which clothe the inner and precipitous slopes of High Peak it does precisely the same work of destruction as that species does in the direction of Diana's Peak and Actæon. 
Unfortunately the distinctions between the Succineas, in most parts of the world, are often so trifling that, unless we are prepared to make a tabula rasa of an overwhelming proportion of them, we have practically no choice left but to acknowledge, as specific, characters which would be utterly valueless in other departments of the Helicidae ; and, in the present instance, whether I am right or wrong in recording the $S$. picta as a true species (- a point which perhaps can never absolutely be settled), it will be admitted at any rate to be a distinguishable form, and one which, as such, ought not to be entirely ignored. My own unbiassed judgment would probably lead me to cite it as a mere local aspect of the S. Sancto-Helence; but since I take it to be the particular shell which Pfeiffer had in view as the 'S. picta' (concerning which he adds 'Habitat Diana's Peak ins. St. Helenæ '), and Mr. Melliss as the 'S. rudorina,' I prefer to give it the advantage of the doubt and to register it as separate. ${ }^{1}$

As regards mere length, the $S$. picta does not differ appreciably from the Sancto-Helence, the larger example measuring as much as $7 \frac{1}{2}$ or even 8 lines; but when viewed en masse, it will be seen to be just perceptibly narrower in outline, its basal volution being a trifle less inflated (or more laterally compressed) in front; and its spire, although small, is longer and more developed. Its aperture, too, is, in proportion, slightly more elongated and obliquely produced; its surface, which is perhaps somewhat more evenly striate, has indications of a few obsolete, fragmentary, remote, broken-up spiral lines or impressions; and its colour is usually of the dark reddish corneous-brown which characterises the less pallid state of the Sancto-Helenoe.

\section{Succinea Bensoniana.}

Succinea Bensoniana, Forbes, Journ. Zool. Soc. viii. 198. t. 5 . f. 7 (1852)

" asperula, Pfeiff., Proc. Zool. Soc. Lond. 326 (1856)

" $\quad$ Id., Mon. Hel. iv. 812 (1859)

" Bensoniana, Id., ibid. 818 (1859)

" asperula, Melliss, St. Hel. 119 (1875)

" picta, Id. [nec Pfeiff.], ibid. 119 (1875)

" helenæ, Idd. [nec Forbes], ibid. 119 (1875)

, solidula, Id. [nec Pfeiff.], ibid. 119 (1875)

1 Mr. Melliss, however, clearly made some mistake in referring it to the S. rudorina of ' Gould,'-for I cannot perceive that Gould ever published a Succinea under that title. He has a ' $S$. pudorina,' but that is not a St. Helena shell at all, but one which occurs in the Sandwich Islands. 
Habitat in intermediis ac subelevatis insulæ, et recens et semifossilis. Species staturâ et soliditate valde inconstans,sc. in locis humidis plerumque major fortiusque colorata, sed in aridis inferioribus minor, multo fragilior, pallidior, et sæpe indumento lutoso vestita.

After a very careful comparison of a vast array of Succineas from many different parts of the island (chiefly, however, of an intermediate altitude), I have come to the conclusion that it is quite impossible, despite the opposite appearance of their extremes, to uphold any of them as specifically distinct from the remainder; though I believe that they have been quoted, in isolated papers and monographs, under at least five or six different names, if not more. The fact is, the examples from nearly every locality seem to have some.little feature of their own,--mere size and solidity, within certain reasonable limits, and the greater or less development of the subapical whorls (and the consequent length of the spire), as specific characters, counting absolutely for nothing. Indeed so completely do the many phases of this Protean shell merge imperceptibly into each other that it is scarcely practicable to treat any of them as even. definite and well-marked 'varieties'; and I can only mention, therefore, in a broad and general way, that specimens from districts which are much dried up, and denuded of their original wood, are smaller, and thinner in substance, as well as paler in hue, than those from damper and more elevated ones where the shell has been more perfectly matured, and that they have also a greater tendency to coat themselves over (as though to compensate for the deficiency in substance) with a hardened envelope of dirt.

Examples in this latter condition will sometimes adhere to the faces of the rocks, their additional covering appearing not only to defend them from the rays of the sun, but likewise to conceal them from the depredations of the St. Helena plover, or 'Wire-Bird' (Agialitis Sancto-Helenoe, Harting), which is very partial to them as food. This is expressly alluded to by Mr. Melliss, who has informed me that individuals of the latter which were obtained by himself and Mr. E. L. Layard at New Ground (below Plantation) were observed, on being opened, to have their crops filled with examples of this small race of the Succinea. I cannot agree with him however in quoting that particular phasis of the shell under a distinct title; and still less could I affiliate it with the ' $S$. solidula' of Pfeiffer,-because on referring to Pfeiffer's original diagnosis of the latter, which was drawn-out from a specimen in the collection of the late Mr. Cuming, I find that he was absolutely ignorant of the country from whence it came, and that there is consequently no 
shadow of evidence for us to assume that it was from St. Helena at all; a fact which he again endorses in no less than two subsequent volumes of his Monograph, adding ' $\mathrm{Hab}$.?' both in 1853 and in 1876.

In the arid regions of only a moderate altitude which were once densely clothed with gum woods, - such as Thompson's Wood, West Lodge, and Peak Gut,-the shell is often so very thin and fragile that it is scarcely possible to get the animal out of it; and also on the now exposed sides of Flagstaff Hill (from whence it was described by Pfeiffer under the name of $S$. asperula, and where it is also equally common in a subfossilized condition) it is likewise seldom very robust. The subfossil examples however have often their spire rather more lengthened and developed (though by no means always so) than the recent ones, - not only on Flagstaff and Sugarloaf, but likewise on the Barn and in the cutting of the Sidepath-road (between Jamestown and Longwood) above the Briars.

Although just able to exist in the now barren districts to which I have called attention, the present Succinea (like most of the members of the genus) is far more at home in damp ones, -delighting in even the dampest of all, when they are to be had. Thus at the edge of the waterfall below the Briars Mr. $P$. Whitehead has met with it in the dripping vegetation and mud, such as might form the proper habitat of a Limnoea; though, singularly enough, highly developed as it was in consequence, examples which he took on the drier and more elevated Rock Rose Hill, on the opposite side of the island, are scarcely distinguishable from them. And this latter fact leads me to suspect that the shells which Mr. Melliss mentions as strewing the ground beneath the shrubs of the native boxwood (Mellissia begonifolia) in the adjoining locality of Longrange are nothing more than large and well-matured ones of this same species. At any rate it cannot be right to refer them, as he has done, to the $S$. picta of Pfeiffer (the imperialis of Benson), because in turning to Pfeiffer's description, we find that not only is the $S$. picta very much larger in stature (quite equalling the Sanctoe-Helenoe as regards length), but that its habitat is 'Diana's Peak,'-thus shewing, I think unmistakeably, that it belongs to the species, or form, from High Peak, \&c., which I have already noticed, and which Mr. Melliss has cited as the 'S. rudorina, Gould.'

The S. Bensoniana is the only Succinea which I have yet seen in a subfossil condition; and since it has lingered on to modern times, it would seem to be as plastic in its habits as it is in its substance and outward configuration. Although the larger examples, as regards size, nearly treble the smaller ones 
(those now before me varying from about $2 \frac{1}{2}$ lines to $6 \frac{1}{2}$ ), nevertheless even the most highly perfected ones are very much smaller than those of the picta and Sanctoe-Helence; added to which, its normal range must be considered, on the whole, to be within the 'intermediate,' rather than the loftiest, districts.

\section{SAINT-HELENA CATALOGUE.}

\section{IIMACID E.}

Limax, Linn.

gagates, Drap.

\section{HELICIDE.}

(Lncilla, Lowe)

Hyalina, Gray.

* spurca, Sow.

dianæ, Pfeiff.

cellaria, Müll.

alliaria, Mill.

(Conulus, Fitz.)

Mellissii, Woll.

Patula, Held.

(Endodonta, Pfeiff.)

* bilamellata, Sow.

* biplicata, Sow.

Cutteri, Pfeiff.

* polyodon, Sow.

(Acanthinula, Beck.) pusilla, Lowe

Helix, Linn.

(Vallonia, Risso) pulchella, Müll.

(Pomatia, Beck) aspersa, Müll.

Bulimus, Scop.

(Pseudachatina, Pfeiff.)

* exulatus (Bens.), Reeve

(Nasiotus, Pfeiff.)
* helena, Q. et $\mathrm{G}$.

* fossilis, Sow.

* Sealeianus, Forbes

* Blofeldi, Forbes

(Pachyotus, Beck)

* auris-vulpina, Chemn.

a. [normalis]

B. subspiralis, Woll.

$\gamma$. obliteratus, Woll.

* Darninianus, Forbes

Subulina, Beck. melanioides, Woll.

* subplicata, Sow.

* terebellum, Sow.

Stenogyra, Shuttl. compressilabris, Bens.

(Gastrodon, Lowe)

Pupa, Drap.

umbilicata, Drap.

B. anconostoma, Lowe

(Acicula, Risso)

Achatina, Lam.

Veru, Bens.

\section{SUCCINEID压.}

Succinea, Drap.

Sanctæ-Helenæ, Lesson picta, Pfeiff.

* Bensoniana, Forbes 


\section{SUMMARY.}

ALthodgr the species, pertaining to the whole of the archipelagos, which are included in this catalogue, amount to 440, nevertheless when the other forms, which have been treated as 'varieties' are taken likewise into account, the entire number is raised to 558. I think it desirable to draw particular attention to this, because the mere fact of allowing certain organisms to be registered as species and others as varieties, however conscientiously our conclusions may be arrived at, does not necessarily imply that they fulfil the absolute conditions, in every single instance, which we believe to be involved in those terms. For although it is true that we use our utmost endeavours so to sift the evidence, in each individual case, as to arrive ultimately at a just conclusion, it is by no means demonstrable that we are always successful in the attempt; from which it would appear to follow, that in a geographical enumeration like the one which constitutes the subject-matter of the present volume, every form which is suffciently well defined to be easily recognized should be punctiliously pointed out, whatever be the rank which we may think attaches to it; and, having done our best to indicate the affinities, and therefore the correct systematic position, of each separate form, we may fairly be content to regard our own precise views on the abstract question of 'varieties' and 'species' as binding upon no naturalist who is not willing to accept them. I would desire, however, not to be misunderstood, - for these remarks are by no means intended to insinuate that the lines of demarcation between species, when correctly interpreted, are ever, in my opinion, really confused or doubtful (the exact opposite having always been my firm belief); but for us to determine them aright is quite another matter, and I am willing therefore to admit that we may often be seriously mistaken in our endeavours to decypher them. And it is on this account, more emphatically, that I would wish to give a prominence almost as great to the many forms which I have assumed, throughout the present treatise, to represent varieties, as to those which seem better looked upon (so far as I am able to judge) as species, properly so called. 
There cannot be much question that our knowledge of the Land-Shells is still very imperfect for some of the archipelagos which are included in this memoir. This is notably the case with that of the Cape Verdes, which can scarcely be regarded as more than fragmentary; and there is clearly, also, much yet to be done in the Azorean Group. The Madeiras have undoubtedly had the greatest attention bestowed upon them; but, apart from this fact, the truly 'Atlantic' element may be said to attain its maximum in that particular cluster,- which is more densely stocked with types not only of a more isolated and peculiar character than is the case in the other islands, but apparently quite aboriginal. At the Canaries a wide field still remains practically to be investigated; yet the recent researches of many naturalists have contributed largely to the information which has been accumulating gradually concerning them. True it is that the absolute species which have hitherto been detected there are not fewer than those which have been brought to light in the Madeiran archipelago-being, in point of fact, a little in advance; but then the superficial area over which they range is very much more extensive, and the altitude of the mountains (the Peak of Teneriffe being upwards of 12,000 feet above the sea) is considerably greater, - so that a nearly equal number of specific modifications in the two Groups does not by any means imply an equal redundancy in their faunas; added to which, we have not the same array, at the Canaries, of the varietal developments (hardly less significant than the actual 'species') which constitute so marked a feature at the Madeiras. As for St. Helena, which is but a single island and in a state of great deterioration, there is every reason to suspect that the species which have been ascertained to occur there (and principally in a subfossil condition) will never be very materially augmented; though perhaps, when the deposits which contain the shells, more or less semifossilized (and which must have lived at a comparatively recent period), have been more fully examined, the extinct fauna may still be increased by a few stray members. A glance at the general catalogue will shew that, up to the present date, the forms, in the respective archipelagos, which I have looked upon as specific ones are embodied in the following numbers :-

\begin{tabular}{|c|c|}
\hline Azores & \\
\hline Madeiras & • \\
\hline Salvages & $\bullet$ \\
\hline Canaries & • \\
\hline Cape Verdes & - \\
\hline St. Helena & 。 \\
\hline
\end{tabular}


I have already directed attention to the fact that when the European and more distinctly 'Mediterranean' forms have been removed, and the catalogue has been cleared of everything but what we may be permitted to call its 'Atlantic element,' the actual species which range beyond the limits of a single archipelago are marvellously few,-about 4 or 5 being common to the Madeiras and Azores, about 5 or 6 to the Madeiras and Canaries, and about 1 to the Canaries and Cape Verdes; whilst between the Azores and Canaries there are only about 5, and between the Madeiras and Cape Verdes about 1. Moreover there are strong reasons for suspecting that some even of these (perhaps indeed most of them) may have been accidentally transported amongst the islands, through indirect human agencies, at a comparatively recent date; so that we are driven to conclude that, so far as the absolute species are concerned, of which their aboriginal faunas are respectively made up, the Groups are practically almost independent of each other. And yet, in spite of this, I have had occasion to insist more than once upon the many characteristic types which, under the aspect of totally different but nevertheless allied species, permeate to a greater or less extent the entire 'province,'-giving to it an amount of unity, through its several component parts, which it is scarcely possible not to recognize. As they have already been enumerated in detail, I need not recapitulate them; but we may just call to mind how that the Janulus section of Patula crops up at the Madeiras and Canaries, but has no ropresentative at the Azores and Cape Verdes,--how the Helicideous department Leptaxis is dominant in the Azores, Madeiras, and Cape Verdes, and yet does not exist at the Canaries,-how the Discula group, which attains its maximum in the Madeiras, extends feebly to the Canaries but is absent from the Azores and Cape Verdes,-how the curious genus Craspedopoma puts in an appearance in the three northern archipelagos, but has no exponent in the southern one,-how the Azores and Canaries harbour the minute Hydrocana, which nevertheless does not occur at the Madeiras, - and how an essentially 'Atlantic' type of $P$ upa is scattered broadcast over the whole region. Such facts as these, and many others of a like nature, betoken an individuality of the district which cannot well be ignored, even whilst the actual species (of a truly Atlantic character) which wander beyond the limits of a single cluster are so few in number as to be. well-nigh inappreciable. The latter circumstance, however, is quite in harmony with the perfectly marvellous segregation which is so conspicuous in most of the archipelagos, particularly in the Madeiran and Canarian ones,an overwhelming proportion of the species being confined to 
single $i s l a n d s$, and not having colonized even their respective Groups. In allusion to this subject, I mentioned at p. 58, that, out of the 176 Pulmoniferous Gastropods which have been ascertained to inhabit the Madeiras, 5 only are found on the whole five islands of the assemblage; and I may add that out of a somewhat greater number at the Canaries, only two (namely the European $H$. lenticula, Fer., and the $H$. lancerottensis, W. et B., which latter occurs likewise on the opposite coast of Morocco) have been shewn as yet to be universal. ${ }^{1}$

There may doubtless be many explanations, perhaps equally plausible, of these phenomena; but I must confess that none commends itself so thoroughly to my mind as the possible -breaking-up of a land which was once more or less continuous, and which had been intercolonized along ridges and tracts (now lost beneath the ocean, which brought into comparatively intimate connection many of its parts, - even whilst others, though topographically near at hand, were separated by channels which served practically to keep them very decidedly asunder. It is on some such principle as this that I would account for the Canaries appearing to be not only as widely removed from the Madeiras as perhaps even the Cape Verdes are, but (while

1 Although I believe the same principle of segregation to be indicated in a scarcely less degree at the Azores, yet since I have not myself collected in that Group, and am bound therefore by the published statements of MM. Morelet and Drouet, I have had no choice but to register as universal every species to which they append the observation, 'Habite tout l'archipel.' Considering, however, that they never visited the island of S. Jorge at all, and there is internal evidence that this expression is employed in the loosest possible manner, I must be excused if I should fail to be convinced, in every single instance, of its absolute truth. For whilst, out of the 176 species (aboriginal and naturalized) which have been met with at the Madeiras, five only are found on the whole five islands of the Group; and whilst out of the 189 at the Canaries (which are composed of seven islands), only two have as yet been proved to be universal, it is preposterous to suppose that the seventy-one species to which the Azorean fauna was brought up by Morelet and Drouet should include no less than twenty-three which were detected by them (and that too in the course of a single expedition, occupying but five months) on the whole nine islands of an archipelago which is far more widely scattered than either of those to which I have just called attention. And yet this is what we are compelled to acknowledge if their oft-repeated assertion, embodied in the expression 'Habite tout l'archipel,' is to be looked upon as undeniably true. To my own mind it is almost certain, not that MM. Morelet and Drouet had unmistakeable evidence, in each individual case, that the particular species which is thus reported had been ascertained positively to exist on the whole nine detachments of an assemblage the parts of which are so difficult of access, and so remotely dispersed, as the Azores; but rather that, having met with it on an appreciable number of the islands, they merely thought that it must be found upon the rest, and so did not 'scruple to register it as occurring 'dans toutes les îles.' But whether this is to be received as conclusive, and as necessarily in accordance with facts, the much more carefully compiled statistics of the neighbouring archipelagos (the Madriran data having been arrived at from researches which extend over a period of nearly fifty years) may perhaps serve to teach us. 
further to the south) to possess a fauna in which the 'Mediterranean' element is much more traceable. This latter circumstance, which is shadowed forth likewise by the Coleopterous statistics, is by no means a fanciful one,-whole groups which are indicative (more or less) of Mediterranean countries, but which have no single representative elsewhere in these subAfrican archipelagos, being quite at home at the Canaries. Thus the section Hemicycla of the genus Helix, which does not even put in an appearance at the Azores, Madeiras, and Cape Verdes, has no less than 37 exponents (indeed probably more) at the Canaries; and the same might be said of the section Turricula, Beck, which is so strongly developed on the opposite coast of Morocco. Cyclostoma, too (as distinguished from Craspedopoma), is dominant in nearly all the Canarian islands, while totally absent from the other Groups; and it is only in the Canarian cluster that the Mediterranean genera Parmacella and Leucochroa have been brought to light. Moreover several of the European types, of a submaritime habit and a widely acquired range, which occur equally in the other archipelagos, and which I had eliminated from the general catalogue (as without signification) when discussing the purely Atlantic element in the faunas, seem to possess a significance at the Canaries which they can hardly be said to do in the neighbouring clusters,-having the appearance there of being positively indigenous, rather than naturalized. Thus, unless I am greatly mistaken, the Helix lenticula, Fer., and the Stenogyra decollata, Linn., are found in Fuerteventura and Grand Canary in a genuinely subfossilized condition, as are also the latter and the Helix impugnata, Mouss. (which is scarcely more than an extreme development of the $H$. pisana), in Lanzarote. Facts like these render it at least probable that the particular forms to which I am alluding, and which are usually defined as 'Mediterranean' ones, have not been introduced into at any rate the Canarian islands since the occupation of the latter by man, and indeed that their presence there is due to natural canses, operating at a remote epoch,- - such, for instance, as a slow system of migration over a continuous land, stretching in a north-easterly direction along what is now the coast of Moroceo. At all events some such connective tract would answer the requirements of the present fauna, and solve many a problem which it is otherwise difficult to interpret.

How this theory may be brought to bear upon the principle of segregation, as now witnessed in so many of the archipelagos, it might perhaps be worth while to pause for a few moments to enquire; for it seems to me that if a more or less continuous land, which may be supposed to have occupied this particular 
region of the Atlantic, was ever broken up at all, we can hardly even contemplate a disruption on a scale so gigantic except through the medium of some catastrophe to which the various processes of disintegration with which we are acquainted give us no kind of clue, and offer no parallel. But if cataclysms, as such, can be permitted to form a portion (whether at stated intervals I need not stop to consider) of the geological record, it is quite clear that the depression of certain tracts, and the upheaval of others, would produce an amount of disturbance in the fauna which could not fail to shew itself in some way or other which would afterwards become more or less decypherable; and I cannot conceive much difficulty in picturing the kind of change which might be brought about by the isolation of a cluster of individuals on a small rock,--destined henceforth to become the habitat of a race which would, we may feel wellnigh certain, rapidly mature for itself some slight distinguishing mark. I say ' rapidly' (1) because the very fact of a great and sudden alteration in the surrounding influences would almost imply a corresponding one (however insignificant comparatively) in the organisms which had been thus cut-off abruptly from their fellows, - ' a corresponding one,' moreover, which there is no reason to suspect might not be consummated in the course of a few generations; and (2) because there is the strongest evidence for concluding that no modifying process, whether progressive or retrograde, is going on at the present moment, for it has not made itself so much as appreciable since even the subfossil period; so that whatever trifling varieties, or departures from a central type, are now to be traced, were, in all probability, brought about quickly, and as the mere natural result of a change in the conditions of the respective areas which their progenitors had severally overspread.

Considering how unmistakeable the evidence is for the variability (in this particular sense) of many of the Atlantic types which we have lately been discussing, - a ' variability' so decided that a slightly different phasis has been assumed, in certain of the archipelagos, for nearly every separate island, and solated rock, it may sound perhaps somewhat paradoxical to peak, nevertheless, of their apparent freedom from further change; and yet if there is one fact more distinctly shadowed forth than another, it is, without doubt, their present stability. It may be perfectly true that, when viewed from a geological standpoint, the various deposits in which the shells are found to vicur more or less subfossilized are comparatively recent; but since there is every reason to suspect that a vast change both in the conditions and extent of the surrounding districts has been brought about since the epoch of their formation ( - a change 
so radical as to lead to the belief that some of them were probably matured previous to the breaking-up of the intervening land), we have at any rate a monstrous period at our disposal from which to judge whether any modifications have been effected in the outward contour of the several forms; and, after the most rigid and conscientious enquiry, I am bound to add that the 'developments,' so-called, which might well be supposed to have been. slowly elaborated, are (if any) simply inappreciable. Here and there a species may present itself which would seem to have degenerated as regards the mere size of the individuals which compose it; but there is nothing to warrant the idea of any gradually advancing movement (however infinitesimal); and indeed even in the few instances to which I have just called attention, it is fairly open for enquiry whether the two aspects of the shell were not, after all, contemporaneous, - the smaller one having only taken the place of the larger, in point of individual numbers, in more modern times.

It would appear therefore as if we were driven to the conclusion that these numerous phases of certain central, dominant types (such as are observable, for instance, in the sections Discula, Coronaria, and Leptaxis) were brought about in the comparatively remote past, and in obedience to circumstances which may or may not have been exceptional, but which nevertheless answer better to what are commonly called ' catastrophes' (though perhaps wrongly so) than to anything else. And here it will immediately be perceived how the doctrine of excessive segregation dovetails-in (as it were) with that of the sudden breaking-up of a more or less continuous tract and the rapid after-elaboration of colonies which may be termed 'insular,' and which are characterized (to a greater or less extent) by certain distinctive marks too often looked upon as necessarily specific ones.

But these and kindred problems are so purely speculative that it will perhaps suffice to have merely glanced at one or two of them,-in order to direct attention to the kind of evidence which may hereafter prove to have been an unsuspected, but nevertheless appreciable, item towards their solution. 


\section{GENERAL CATALOGUE.}

N.B.-In the following catalogue $I$ have not considered it necessary to indicate which of the species have been found subfossilized, except in those particular instances where they have been observed only in that state,under which circumstances they must be looked upon practically as extinct. The names of those in this latter predicament have not only an asterisk (*) prefixed to them, but are also printed in italics.

\section{MOLLUSCA.}

GASTROPODA (PULMONOBRANCHIATA).

Sectio I. INOPERCULATA.

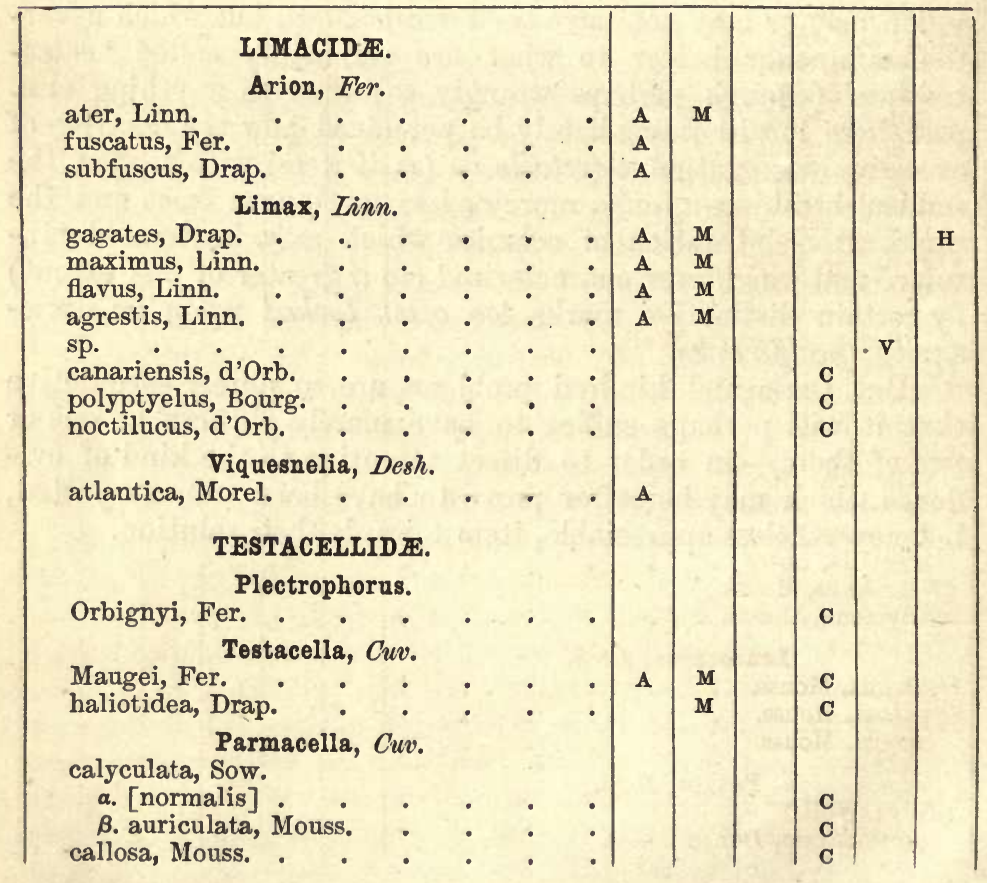




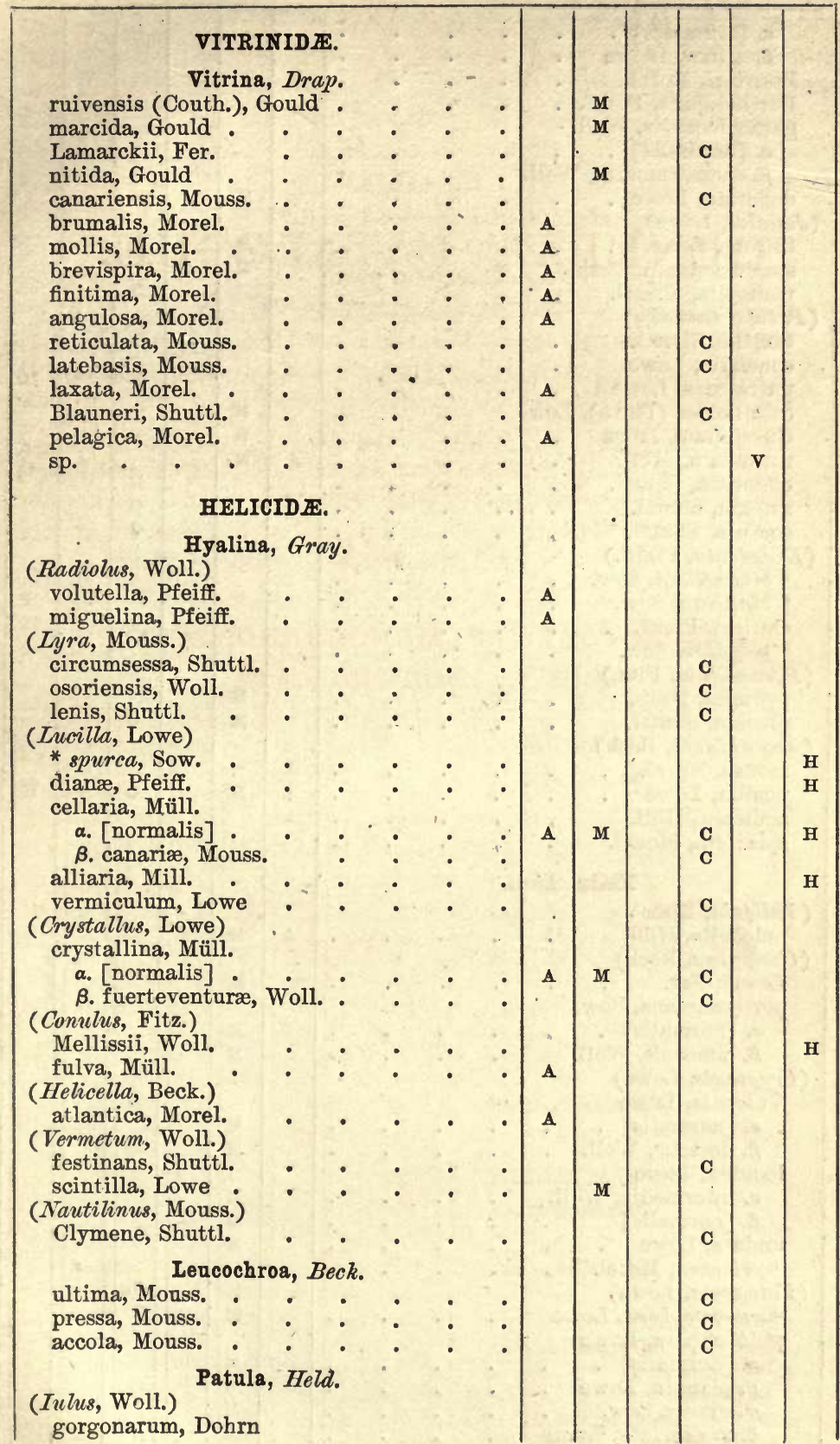




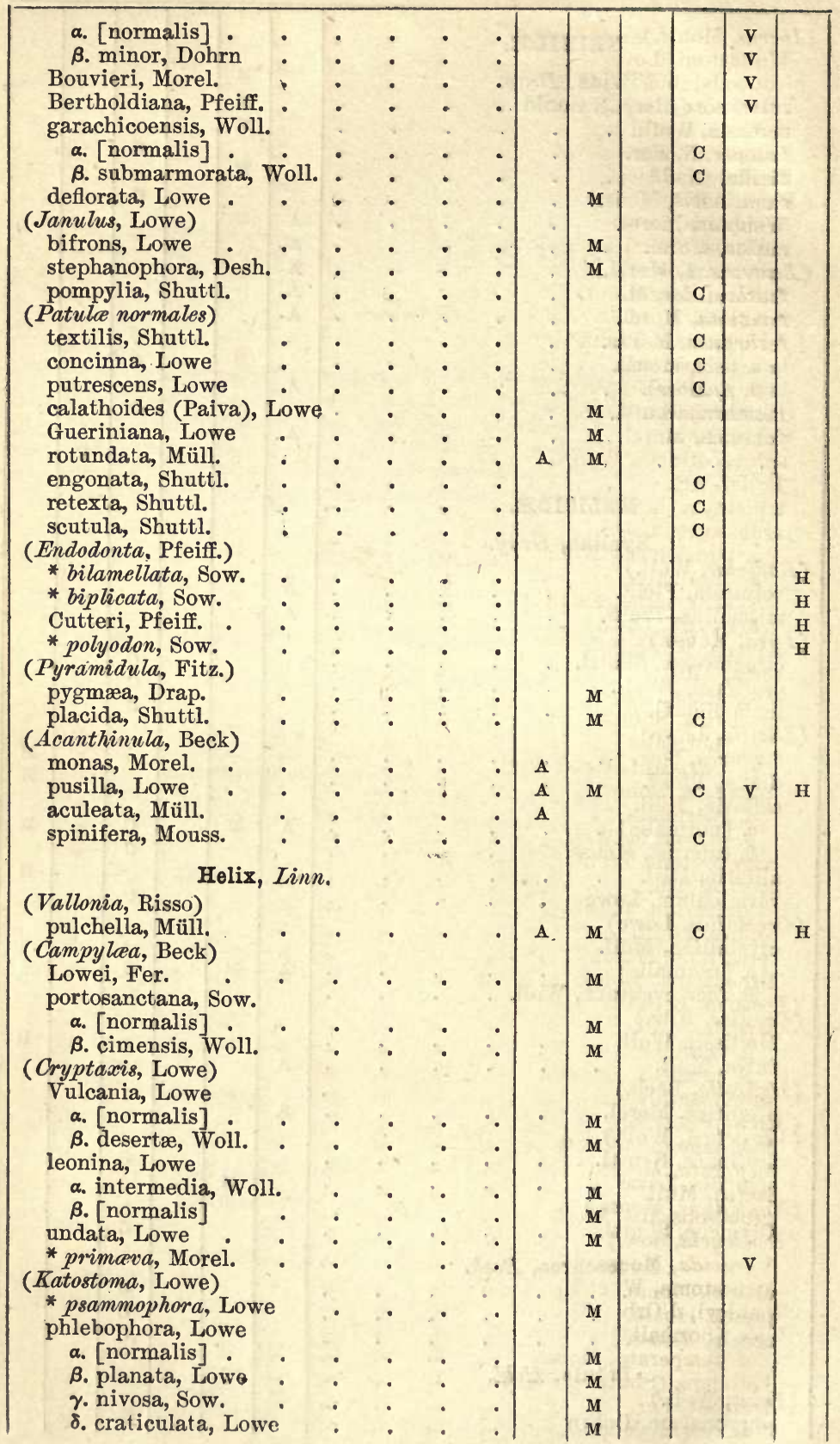




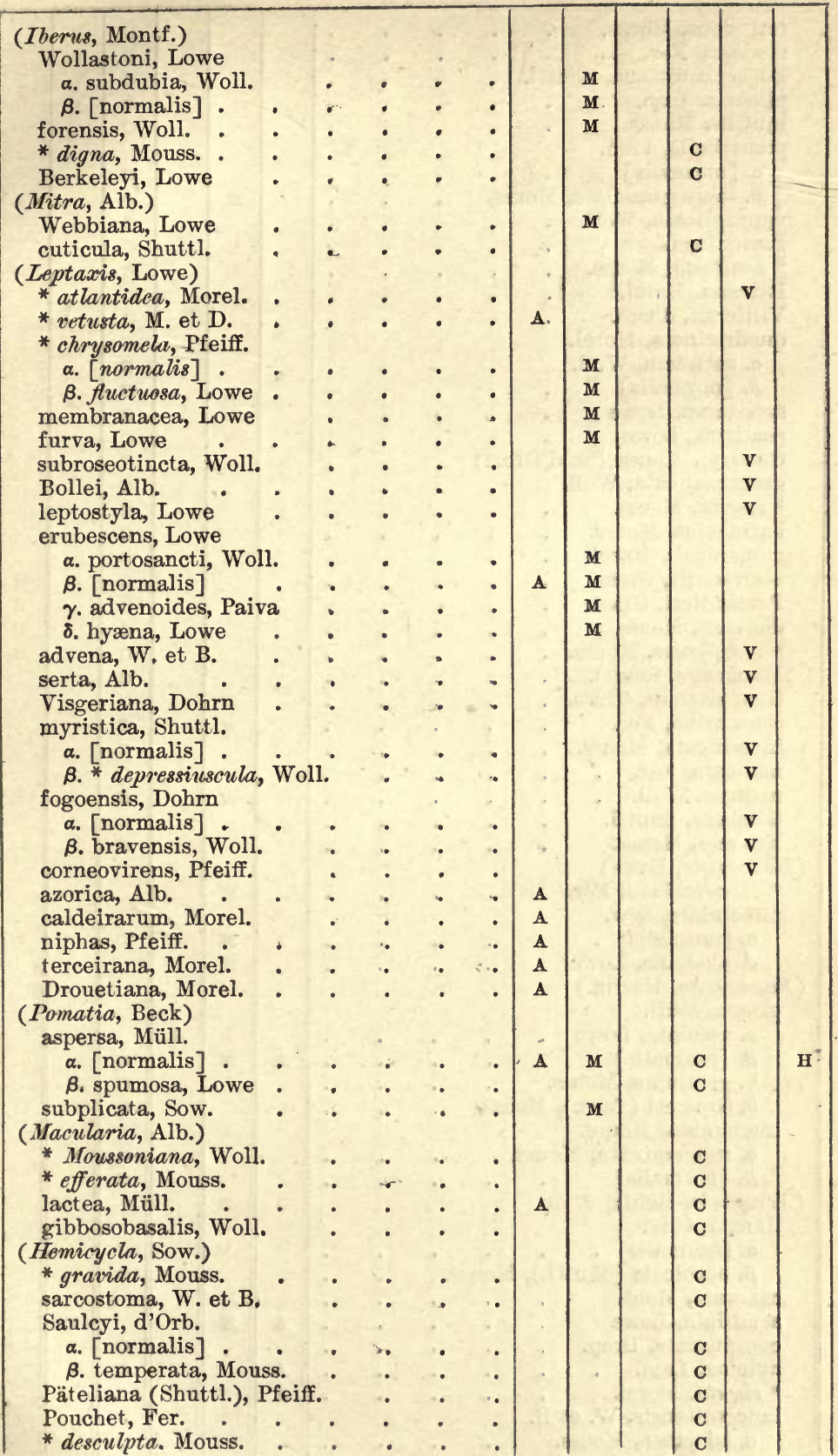


retrodens, Mouss.

modesta, Fer.

Bethencourtiana, Shuttl.

plicaria, Lam.

inutilis, Mouss.

planorbella, Lam.

a. [normalis]

B. incisogranulata, Mouss. vermiplicata, Woll.

Plutonia, Lowe

* semitecta, Mouss.

Paivana, Morel.

Villiersii, d'Orb.

quadricincta, Morel.

a. subaucta, Woll.

B. [normalis]

saponacea, Lowe

psathyra, Lowe

0.

Gaudryi, Mouss. (an d'Orb.?)

granomalleata, Woll.

* merita, Mouss.

harmonica, Mouss.

gomerensis, Morel.

hierroensis, Grass.

Perraudieri, Grass.

distensa, Mouss.

* indifferens, Mouss.

Maugeana, Shuttl.

Guanartemes, Grass.

consobrina, Fer.

invernicata, Mouss.

malleata, Fer.

nivariæ, Woll.

Glasiana, Shuttl.

Fritschi, Mouss.

(Helicomela, Lowe)

* Bondichiana, Fer. punctulata, Sow.

a. [normalis] .

B. avellana, Lowe

(Euparypha, Hartm.)

pisana, Müll.

a. ustulata, Lowe

B. [normalis]

$\gamma$. geminata, Mouss.

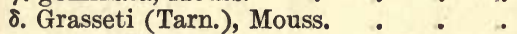
impugnata, Mouss.

a. subgeminata, Mouss.

B. [normalis]

(Xerophila, Held)

lineata, Oliv.

a. [normalis]

ß. herbicola (Shuttl.), Mouss.

caperata, Mont.

armillata, Lowe

conspurcata, Drap.

apicina, Lam.

* obruta, Morel.

lancerottensis, W. et $\dot{B}$.

a. adoptata, Mouss. 


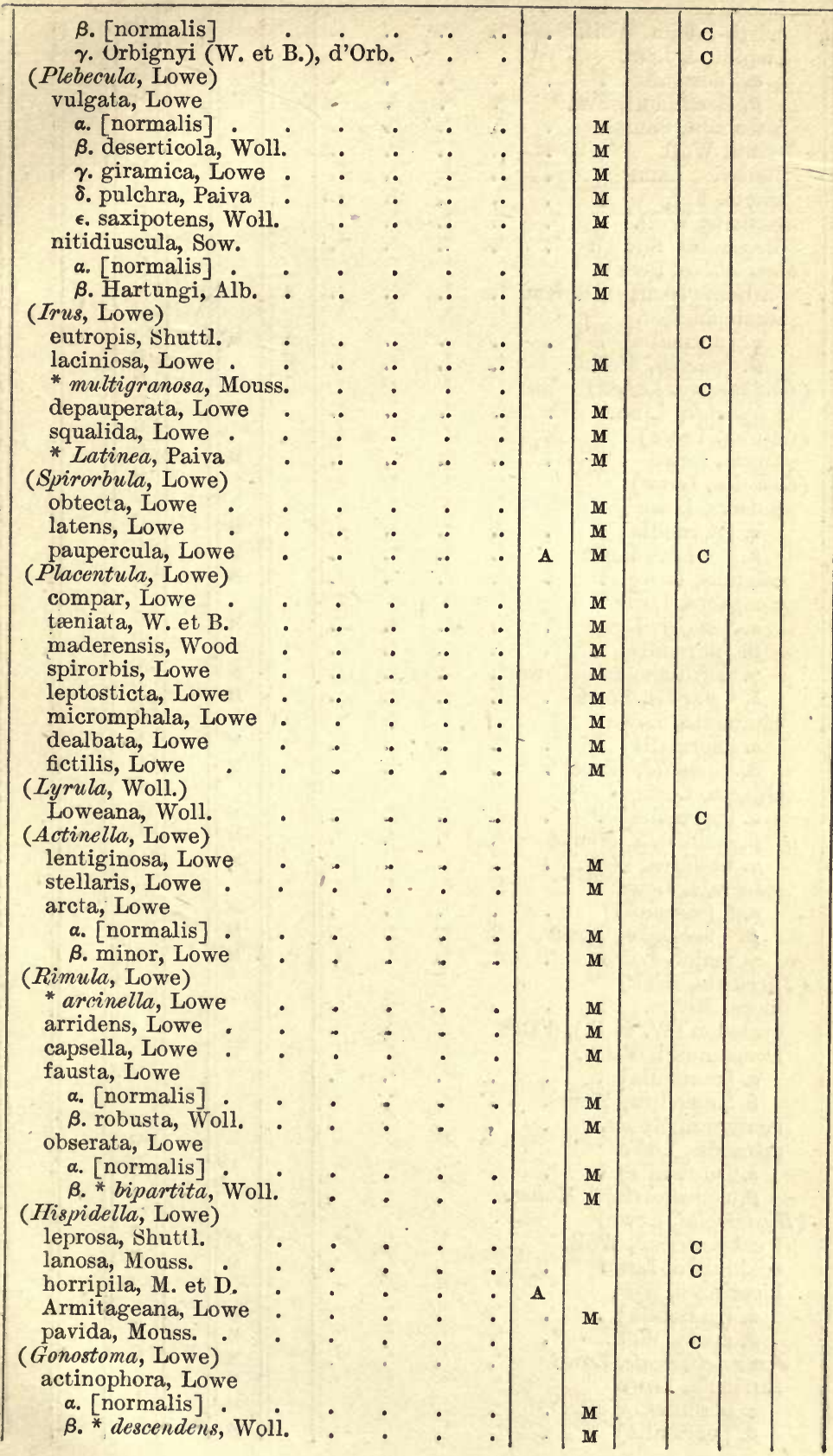




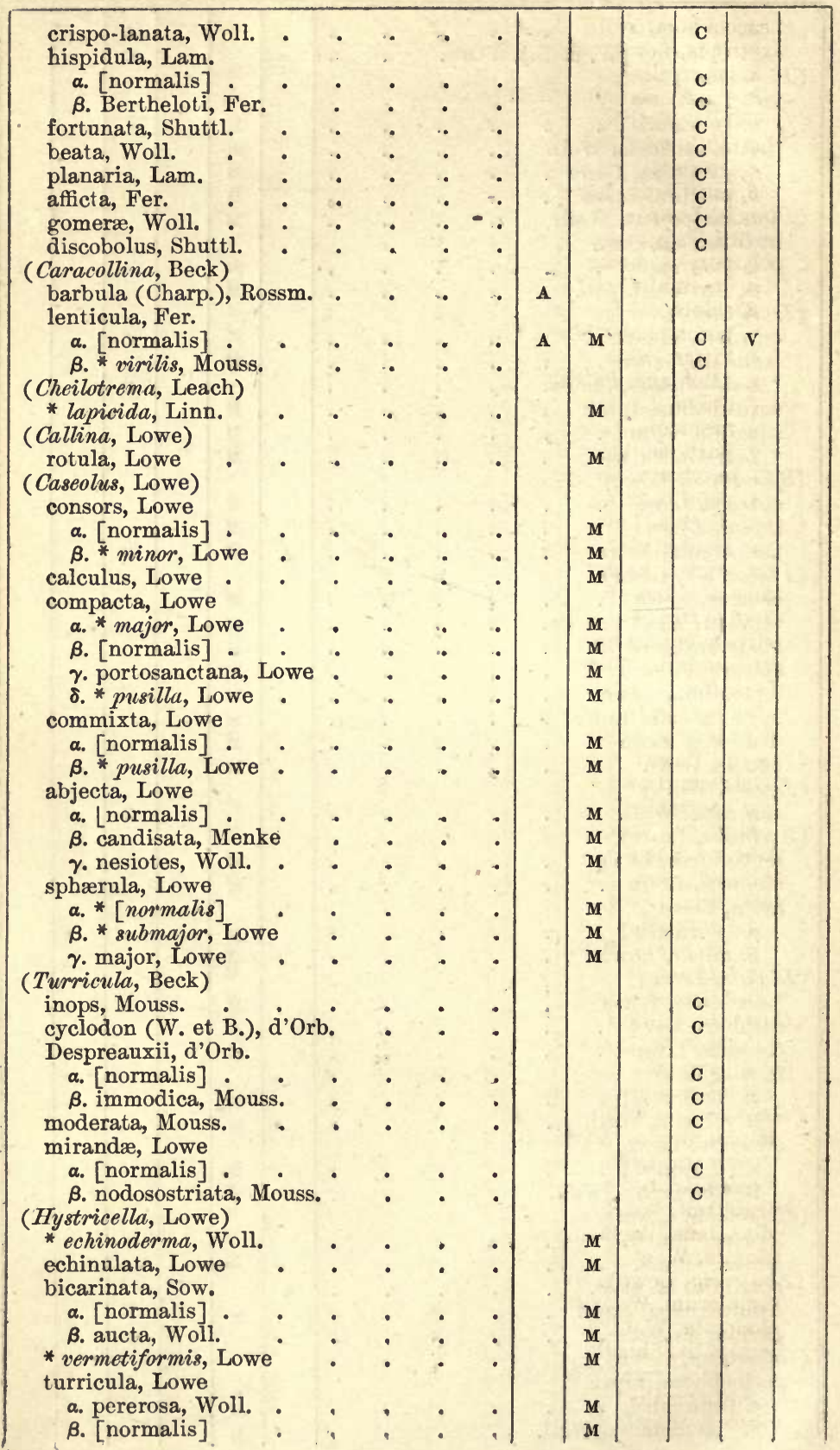




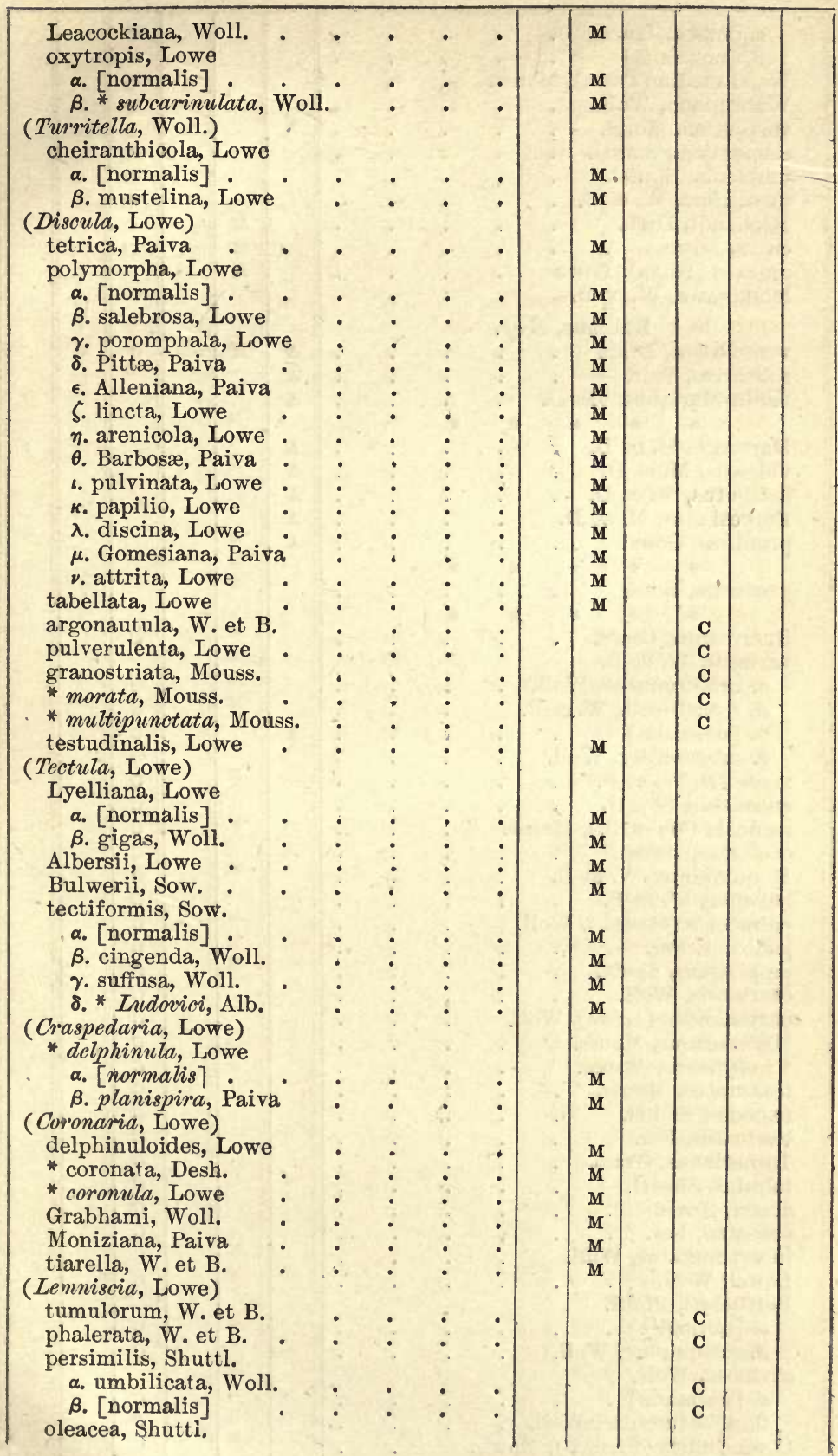


a. deusta, Lowe

B. [normalis]

Woodwardia (Tarn.), Mouss.

Watsoniana, Woll.

vespertina, Morel.

cæmentitia, Shuttl

umbicula, Shuttl.

monilifera, W. et B.

Michaudi, Desh.

calva, Lowe

galeata (Paiva), Lowe

lemniscata, W. et B.

Bulimus, Scop.

ventricosus, Drap.

solitarius, Poir.

Santa-Marianus, Morel.

* * * *

vulgaris, $M$. et $D$.

delibutus, M. et D.

Forbesianus, M. et D

pruninus, Gould

gemmula, Bens.

Guerreanus, Grass.

variatus, $W$. et $B$.

a. rufobrunneus, Woll.

$\beta$. roccellicola, W. et $B$.

$\boldsymbol{\gamma}$. [normalis]

$\cdot \quad \cdot \quad \cdot \quad \vdots$

subgracilior, Woll. $\cdot \quad \cdot \quad$ :

encaustus, Shuttl.

rnpicola (W. et B.), Mouss.'

ocellatus, Mouss.

Moquinianus, W. et B.

helvolus, W. et $B$.

palmensis (Mouss.), Woll.

badiosus, Fer.

propinquus, Shuttl.

osoriensis, Woll.

chrysaloides (Lowe), Woll.

Maffioteanus, Mouss.

* indifferens, Mouss.

texturatus, Mouss.

nanodes, Shuttl.

bæticatus, Fer.

Tarnerianus, Grass.

tabidus, Shuttl.

anaga, Grass.

obesatus, Fer.

interpunctatus, $\dot{\mathrm{w}} \mathrm{ll}$

Lowei, Woll.

Bertheloti, Pfeiff.

a. [normalis]

$\beta$. subsimplex, Woll. $\quad \therefore \quad \vdots \quad$. savinosa, Woll.

a. [normalis] .

$\beta$. inflatiusculus, Woll.

Consecoanus (Fritsch), Mouss.

A

M

M

M

A

M

C

C

A

C

V

C

C

(

c

C

C

c

c

c

C

c

c

C

C

C

C

C

C

C

C

c

C

C

C
C
C
C
C
C 
servus, Mouss.

flavo-terminatus, Woll

* exulatus (Bens.), Reeve

* helena, Q. et G.

* fossilis, Sow.

* Sealeianus, Forbes

* Blofeldi, Forbes

* auris-vulpina, Chemn.

a. [normalis]

B. subspiralis, Woll.

$\gamma$. obliteratus, Woll.

* Darninianus, Forbes

Subulina, Beck.

melanioides, Woll.

* subplicata, Sow.

* terebellum, Sow.

Stenogyra, Shuttl.

compressilabris, Bens.

Goodallii, Mill.

decollata, Linn.

subdiaphana, King

(Gibbulina, Beck)

\section{Pupa, Drap.}

* macrogyra, Mouss.

dealbata, W. et $\mathrm{B}$.

(Truncatellina, Lowe)

* linearis, Lowe

molecula, Dohrn

atomus, Shuttl.

microspora, Lowe

(Pahudinella, Lowe)

limnæana, Lowe

(Gastrodon, Lowe)

fanalensis, Lowe

umbilicata, Drap.

$\alpha$. [normalis].

$\boldsymbol{\beta}$. anconostoma, Lowe

Dohrni, Pfeiff.

a. perdubia, Woll.

$\beta$. [normalis]

(Torquilla, Studer)

granum, Drap.

a. [normalis]

$\beta$. bulimæformis, Lowe

(Gastrocnpta, Woll.)

acarus, Bens.

gorgonica, Dohrn

a. subalutacea, Woll.

B. [normalis]

(Scarabella, Lowe)

cassida, Lowe

(Iiostyla, Lowe)

cheilogona, Lowe

vincta, Lowe

irrigua, Lowe

deformis, Woll.

Loweana, Woll.

c

C

H

H

H.

H

H

H

H

H

$\mathrm{H}$

H

H

H

M

A

C

C 


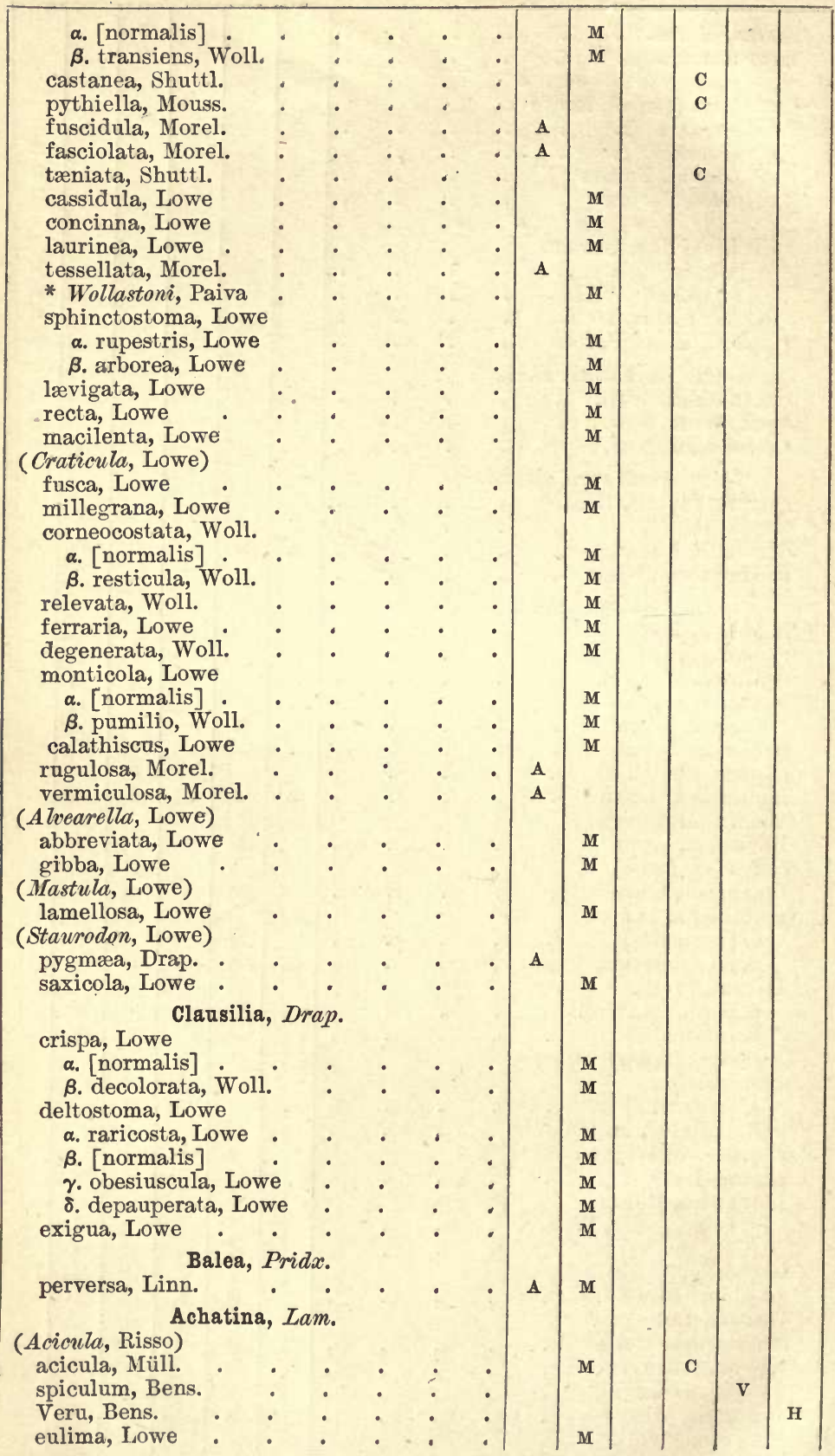




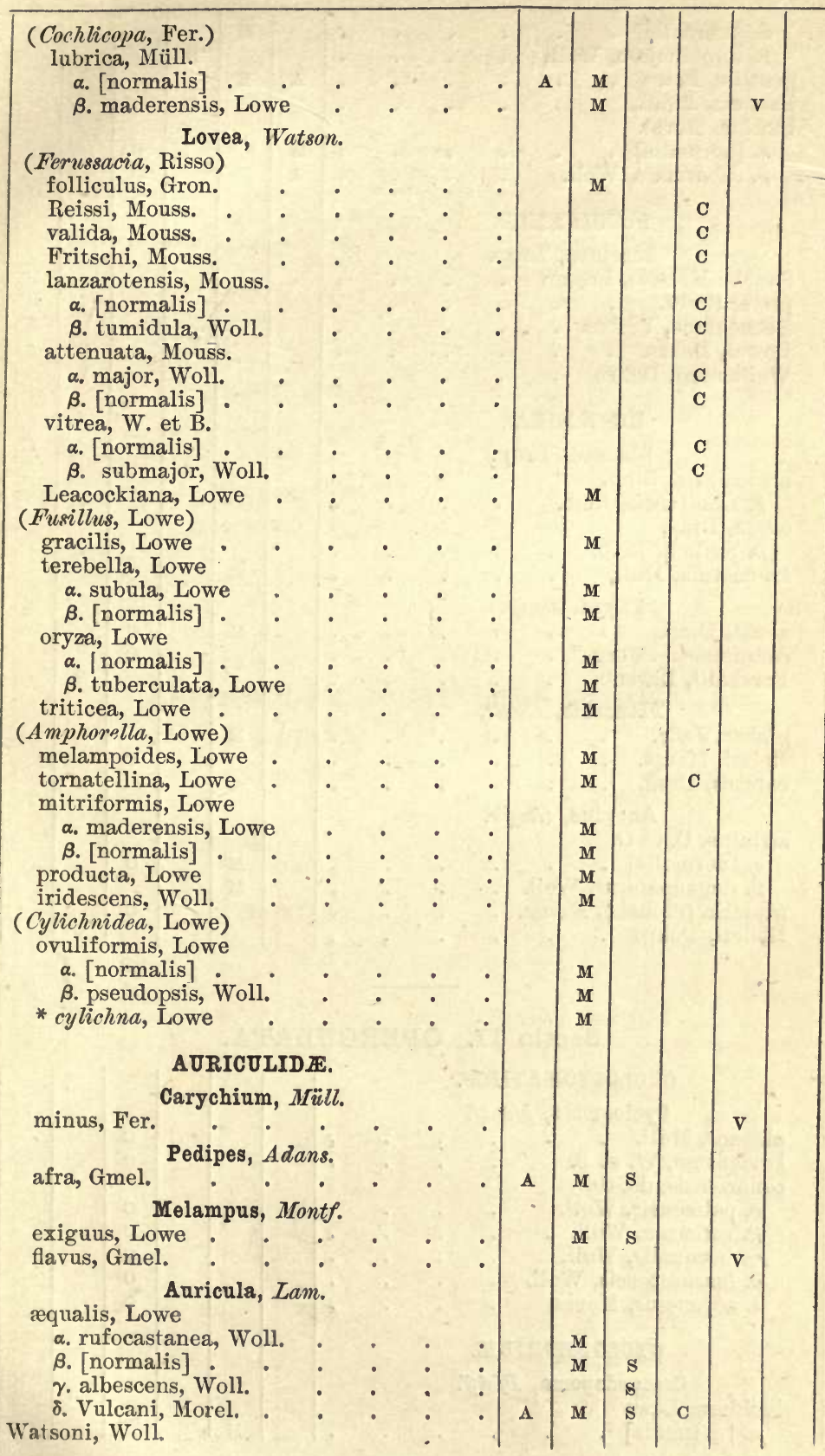


a. [normalis]

B. scrobiculata, Woll.

gracilis, Lowe

Paivana, Pfeiff.

bicolor, Morel.

a. [normalis]

B. subarmata, Woll.

\section{SUCCINEIDF.}

Succinea, Drap.

Sanctæ-Helenæ, Lesson

picta, Pfeiff.

Bensoniana, Forbes

Lowei, Dohrn

Wollastoni, Dohrn

\section{IIMN EID正。}

Limnæa, Drap.

auricularia, Linn.

B. ribeirensis, Reib.

ovata, Drap.

B. Stübeli, Reib.

truncatula, Müll.

acuta, Drap.

Physa, Drap.

canariensis, Bourg.

Forskalii, Ehrenb.

glaber, Jeffr.

Planorbis, Guett.

Reissi, Mouss.

coretus, Desh.

Ancylus, Geoffr.

striatus, Q. et G.

a. [normalis] .

B. depauperatus, Woll. rupicola (Shuttl.), Mouss. . Milleri, Dohrn

Sectio II. OPERCULATA. CYCLOSTOMATID死.

elegans, Müll

Cyclostoma, Montf.

lævigatum, W. et B. canariensis, d'Orb.

a. palmensis, Woll.

$\beta$. raricosta, Woll.

$\gamma$. inæqualis, Woll.

$\epsilon$. adjunctus, Mouss.

CYCLOPHORID五.

lucidum, Lowe

Craspedopoma, Pfeiff.

a. [normalis]

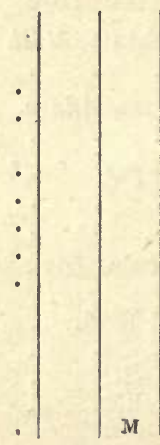


B. flavescens, Lowe $\gamma$. neritoides, Lowe Monizianum, Lowe hespericum, M. et D. Lyonnetianum, Lowe trochoideum, Lowe costatum, Shuttl.

\section{TRUNCATELLIDE.}

Truncatella, Risso. truncatula, Drap.

a. [normalis]

B. lævigata, Lowe .

Lowei, Shuttl.

\section{ASSIMINEID正.}

littorina, Delle Chiaje

\section{Assiminea, Leach.}

HELICINID正.

Hydrocæna, Parr.

gutta, Shuttl.

a. [normalis] . .

$\beta$. minor, Shuttl.

\begin{tabular}{|l} 
A \\
\end{tabular}

\section{GASTROPODA (PECTINIBRANCHIATA).}

RISSOID正.

Hydrobia, Hartm.

similis, Drap.

Pleneri, Frauenf.

canariensis, Mouss.

acuta, Drap.

\section{MELANIID正.}

tuberculata, Müll.

Melania, Lam.

a. [normalis] .

в. Tamsi, Dunk.

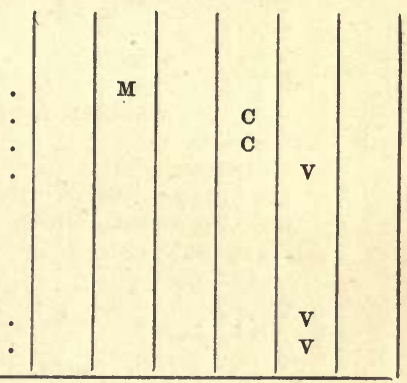





\section{INIEX OF GENERA AND SPECIES.}

Achatina

acicula, 243,456

azorica, 49

cylichna, 264

eulima, 244

exulata, 542

folliculus, 247,458

gracilis, 250, 251

Leacociana, 249

Lonei, 251

lubrica, 49, 245, 518

maderensis, 245, 518

mitriformis, 260

oryza, 253

orulifor'mis, 263

Paroliniana, 253, 255, 463

producta, 261

spiculum, 517

subplicata, 552

subula, 251

Tandoniana, 253, 463

terebella, 251

terebellum, 552

tornatellina, 257, 259, $260,262,464$

triticea, 253, 255

tuberculata, 253

Veru, 555

vitrea, 462

Alexia

bicolor, 52, 466

Loweana, 51, 271

Paivana, 295

Alsobia

Paroliniana, 255

Ancylus

aduncus, 274, 470

fluviatilis, 274, 470

Milleri, 523

rupicola, 470

striatus, 274, 469

Arion

ater, 8,68

cmpiricor'um, 8, 68

Synonyms are in Italics.

\section{Arion \\ fuscatus, 9 \\ fuscus, 9 \\ rufus, 8, 69 \\ subfuscus, 9 \\ Assiminea}

littorea, 281, 297

littorina, 281, 297, 477

Auricula

æqualis, 50, 267, 294, 465

bicolor, 52, 466

bidentata, 295

denticulata, 51, 271

exigua, 266, 293

gracilis, 51,270

myosotis, 294

Paivana, 295

vespertina, 51, 271

Vulcani, 50, 268, 294, 465

Watsoni, 269, 294

Auris

vulpina, 548

Azeca

mitriformis, 260

Paroliniana, 255

Balea

nitida, 48

perversa, 48, 242

Buccinium

acicula, 243, 456

truneatulum, 272, 467

Buliminus

anaga, 437

badiosus, 429

boticatus, 434

Bertheloti, 440

Consecoanus, 443

encaustus, 423

gemmula, 508

Guerreanus, 417

helvolus, 427

indifferens, 43?

\section{Buliminus \\ Maffioteanus, 432 \\ Moquinianus, 426 \\ nanodes, 428, 433 \\ myosotis, 421 \\ obesatus, 438 \\ ocellatus, 425 \\ propinquus, 430 \\ рupa, 444 \\ rupieola, 424 \\ servus, 444 \\ tabidus, 436}

Tamerianus, 435

texturatus, 433

variatus, 418

Bulimus

anaga, 437

atlanticus, 40

auris-vulpina, 547

badiosus, 428

bæticatus, 434

Bamboucha, 511

Bertheloti, 440 .

Blofeldi, 546

chrysaloides, 431

compressilabris, 553

Consecoanus, 442

cyaneus, 42

Darwinianus, 549

decollatus, 42, 206, 446, 509

delibutus, 40

digitalis, 544

encaust us, 422

exulatus, 542

flavoterminatus, 444

Forbesianus, 40

fossilis, 545

gemmula, 508

Goodallii, 510

Guerreanus, 416

hannensis, 510

Hartungi, 38

helena, 543

helvolus, 426 
Bulimus

indifferens, 432

interpunctatus, 438

Lowei, 439

maderensis, 245,518

Maffioteanus, 432

Moquinianus, 425

myosotis, 420

nanodes, 428,433

nanus, 433

obesatus, 437,440

ocellatus, 424

osoriensis, 430

palmensis, 427

Parolinianus, 255

propinquus, 429

pruninus, 42

pupa, 444

relegatus, 544

roccellicola, 418

rupicola, 423

Santa-Marianus, 38

Sancte-Maria, 38

savinosa, 441

scalarioides, 445

Seleianus, 546

servus, 444

solitarius, 37

subdiaphanus, 511

subplicatus, 552

tabidus, 436

Tarnerianus, 435

terebellum, 552

Terverianus, 300, 445

texturatus, 433

tremulans, 42

variatus, 41,417

ventricosus, 37, 20t, 415,507

ventrosus, 37, 204, 416, 507

vitreus, 462

vulgaris, 39

Webbii, 421

\section{Cacilianella}

amonitatum, 517

nyctelia, 243

Carocolla

hispidula, 388

planaria, 391

Carychium

minus, 519

Cionella

acicula, 243, 456

attenuata, 461

I'ritschi, 459

lanzarotensis, 460

Reissi, 458

Tundoniana, 253

rulida, 459
Cionella

vitrea, 462

Clausilia

crispa, 238

deltostoma, 239

exigua, 241

Lovei, 240

obesiuscula, 239

Cochlicopa

subplicata, 552

terebellum, 552

Cochlogena

fossilis, 545

Conulus

fulvus, 20

Craspedopoma

costatum, 476

hespericum, 53

lucidum, 275

Lyonnetianum, 277

Monizianum, 276

trochoideum, 278

Cryptella

ambigua, 312

canariensis, 312

Cyclostoma

acutum, 524

adjunctum, 473

annulatum, 476

canariense, 473

costatum, 476

elegans, 471

Havescens, 275

hespericum, 53

lævigatum, 472

lucidum, 275

Lyonnetianum, 277

Monizianum, 276

neritoides, 275

simile, 281

trochoidenim, 278

truncatulum, 279, 296

Delphinula sulcata, 190

Ferussacia

attenuata, 461

Fritschi, 459

lanzarotensis, 460

Reissi, 458

valida, 459

vitrea, 462

Glandina

acicula, 243, 456

azorica, 49

cylichna, 264

follicuhus, 248

gracilis, 250

Leacociana, 249
Glandina

lubrica, 49, 215

maderensis, 245, 518

melampoides, 257

mitriformis, 260

oryza, 253

ovuliformis, 263

producta, 261

subcyliudrica, 49, 245

terebella, 251

tornatellina, 259, 464

triticea, 255

Helicolimax

Lamarckii, 76, 313

Helisiga

Sancta.Helena, 555

Helix

abjecta, 156

accola, 325

acicula, 243, 456

actinophora, 147

aculeata, 23

acuta, 204, 416

Adansoni, 344

Adonis, 337

adoptata, 378

advena, 26, 105, 500

afficta, 392

afra, 50, 265, 293

Âlbersii, 186

Alexandri, 539

Alleniana, 175

alliaria, 535

aluta, 492

anconostoma, 43, 450, 454

apicina, 33,377

arcinella, 140

arcta, 139

arenicola, 176

argonautula, 400

armillata, 32, 115, 506

Armitageana, 146

arridens, 141

aspersa, 30, 108, 336, 542

atlantica, 20

atlantidea, 497

attrita, 181

auris-vulpina, 548

azorica, 27

badiosa, 428

baticata, 434

Bamboncha, 511

Barbosce, 177

barbula, 35

beata, 390

Berkeleyi, 334

Berthelnti, 388

Bertholliana, 494 
Helix

Bethencourtiana, 347

bicarinata, 161

bicolor, 201

bidentalis, 366

bifrons, 81

bilamellata, 537

biplicata, 538

Bollei, 499

Bouvieri, 494

Bowdichiana, 109

brumalis, 17

Bulveriana, 187

Bulweriana, 187

Bulwerii, 187

cæmentitia, 411

calathiscus, 234

calathoides, 83

calathus, 82

calculus, 153

caldeirarum, 28

calva, 202

canariensis, 375

candisata, 156

canicalensis, 116

caperata, 113

capsella, 142

cassida, 213

cellaria, 19, 78, 320, 535

cheilogona, 213

cheiranthicola, 168

chrysomela, 102

circumsessa, 317

clymene, 324

commixta, 155

compacta, 154

compar, 128

concinna, 328

conoidea, 37

consobrina, 365

consors, 152

conspurcata, 376

corneovirens, 505

coronata, 193

coronula, 195

craticulata, 96

crispa, 238

crispo-lanata, 387

crystallina, 19, 79, 322

cuticula, 335

Cutteri, 538

cyclodon, 396

dealbata, 135

decollata, 42, 206, 445, 509

deflorata, 80

delphinula, 190

delphinuloides, 192

deltostoma, 239

depauperata, 122

desculpta, 345
Helix

Despreauxii, 397

deusta, 409

diance, 534

digna, 334

discina, 179

discobolus, 393

distensa, 361

Draparnaldi, 496

Drouetiana, 30

duplicata, 161

echinoderma, 159

echinulata, 160

efferata, 337

engonata, 329

erubescens, 25, 105

eumcus, 32, 115, 506

eutropis, 380

exigua, 241

fausta, 140, 143

festinans, 323

fictilis, 136

fluctuosa, 102, 105

foetida, 535

fogoensis, 504

folliculus, 247

forensis, 99

fortunata, 389

Fritschi, 370

fulva, 20

furva, 104

galeata, 203

Gaudryi, 356, 362

geminata, 371

gibboso-basalis, 339

giramica, 117

Glasiana, 368

gomeræ, 392

gomerensis, 359

Gomesiana, 180

Goodallii, 510

gorgonar'um, 492

Grabhami, 196

gracilis, 250

granomalleata, 357

granostriata, 403

Grasseti, 371

gravida, 340

Guanartemes, 363

Guerineana, 84

gyrostoma, 506

hannensis, 510

harmonica, 359

Hartungi, 119

helena, 543

helenensis, 539

herbicola, 375

hierroensis, 360

hispida, 81

hispidula, 388

horripila, 34
Helix

hycena, 105

lypocritu, 22, 88, 332 . 495,541

impugnata, 373

indifferens, 362

inops, 396

inutilis, 348

invernicata, 365

juliformis, 193

laciniosa, 121

lactea, 31, 338

lancerottensis, 378,413

lanosa, 384

lapicida, 149

latens, 125

Latinea, 124

lauta, 113

Leacockiana, 165

lemniscata, 414

lenis, 320

lens, 389

lenticula, 36, 148, 394, 507

lentiginosa, 137

leonina, 94

leprosa, 383

leptosticta, 133

leptostyla, 500

lincta, 176

lineata, 374

littorina, 281, 297, 477

Loweana, 382

Lowei, 32, 90, 115, 506

lubrica, 49, 245, 518

Ludovici, 189

lurida, 119

Luseana, 87, 331

Lyelliana, 184

MacAndreniana, 292

maderensis, 131

malleata, 366

Manriquiana, 363

marcida, 300, 394

maritima, 374

Maugeana, 362

melampoides, 257

melolontha, 300, 394

membranacea, 38

membranacea, 103

merita, 358

Michaudi, 201

micromphala, 134

miguelina, 18

mirandæ, 399

moderata, 398

modesta, 346

monas, 21

monilifera, 413

Moniziana, 198 
Helix

monticola, 232

morata, 404

Moussoniana, 337

multigranosa, 380

multipunctata, 404

mustelina, 168

myristica, 503

niphas, 28

nitidiuscula, 116, 119

nivariæ, 367

nivariensis, 406

nirosa, 96

nubigena, 385

obesata, 438

obruta, 33

obserata, 144

obtecta, 125

anostoma, 102

oleacea, 409

Orbignyi, 378

ovuliformis, 263

oxytropis, 167

Paivana, 346

Paivana, 352

papilio, 179

Päteliana, 344

paupercula, 34, 126, 381

pavida, 385

pellis-lacerti, 368

Perraudieri, 361

persimilis, 407

phalerata, 406, 412

phlebophora, 96

pisana, 31, 112, 292, 371

Pittoe, 174

placida, 87, 331

planaria, 391

planata, 373

planorbella, 349

plicaria, 347

plicatula, 347

Plutonia, 351

polymorpha, 170

polyodon, 539

Pompylia, 327

poromphala, 173

portosanctana, 91

Pouchet, 344

praposita, 407

pressa, 325

primæva, 496

psammophora, 95

psathyra, 355

pulchella, 24, 89, 333,

541

pulverulenta, 402

pulvinata, 178

punctulata, 111
Helix
pusitza

pusilla, 22, 87, 88, 331, 495, 540

putrescens, 329

pygmaea, 86

quadricincta, 354

remota, 535

retexta, 330 .

retrodens, 345

Rosetti, 406, 412

rota, 188

rotula, 151

rotundata, 21, 85

saccharata, 171

salebrosa, 172

saponacea, 355

sarcostoma, 341

Saulcyi, 342

scintilla, 79

scrobiculata, 96

scutula, 330

semiplicata, 84

semitecta, 352

senilis, 172

serta, 502

servilis, 22, 88, 331, 495,541

simulata, 374

solitaria, 37

sphærula, 158

sphinctostoma, 222

spinifera, 332

spirorbis, 132

spumosa, 336

spurca, 534

squalida, 123

stellaris, 138

stephanophora, 82

striata, 32, 113, 115, 506

strigata, 349

subcallifera, 158

subcylindrica, 49

subplicata, 108

subroseotincta, 498

subtilis, 36, 148, 394, 507

tabellata, 182

tæniata, 129

tectiformis, 181, 188

temperata, 342

terceirana, 29

testudinalis, 179, 183

tetrica, 170

textilis, 328

tiarella, 200

tornatellina, 258, 464

torrefacta, 382

tritica, 252, 255

tumulorum, 405

turricula, 163
Helix

ultima, 324

umbicula, 412

undata, 95

ustulata, 292

Valverdensis, 360

Vargasiana, 109

ventricosa, 37, 204, 416, 507

ventrosa, 37, 204, 416, 507

vermiculum, 321

vermetiformis, 163

vermiplicata, 350

vespertina, 36

vetusta, 24

Vidaliana, 18

Villiersii, 353

Visgeriana, 503

volutella, 17

Vulcania, 92

vulgata, 116

-Watsoniana, 411

-Webbiana, 100

Wollastoni, 98.

Woodwardia, 410

Hyalina

alliaria, 535

atlantica, 20

canarice, 320

cellaria, 19, 78, 320, 535

circumsessa, 317

clymene, 324

crystallina, 19, 79, 322

dianæ, 534

festinans, 323

fulva, 20

lenis, 320

Mellissii, 536

miguelina, 18

osoriensis, 319

scintilla, 79

semicostula, 322

spurca, 534

vermiculum, 321

volutella, 17

Hydrobia

acuta, 524

canariensis, 479

Pleneri, 479

similis, 281

Hydrocæna

gutta, 53, 477

Le Pietin

pedipes, 50, 265, 293

Leucochroa

accola, 325

pressa, 325

ultima, 324 
Limax

agrestis, 11, 71

antiquorum, 10, 69, 70, 308

ater, 8,68

canariensis, 308

carinata, 308

cinereus, 10, 70, 308

flavus, 11,71

gagates, 10, 69, 533

maximus, 10,70

noctilucus, $309^{\circ}$

polyptyelus, 308

subfuscus, 9

variegatus, 11, 71

Limnæa

auricularia, 521

ovata, 522

Ribeirensis, 521

sordulenta, 522

truncatula, 272, 467

Limneus

minutus, 272,467 .

Lovea

attenuata, 461

cylichna, 264

folliculus, 247

Fritschi, 459

gracilis, 250

iridescens, 262

lanzarotensis, 460

Leacockiana, 249

melampoides ,257

mitriform1s, 260

oryza, 25\%

ovuliformis, $2 u s$

producta, 261

Reissi, 458

terebella, 251

tornutellina, 258, 464

triticea, 255

valida, 459

vitrea, 462

Wollastoni, 248

Marinuta requalis, 268, 294

Melampus

aqualis, 50, 268, 294, 465

exiguus, 266, 293

flavus, 520

gracilis, 51, 270

Melania

nonpareil, 548

Tamsi, 525

tuberculata, 525

\section{Nerita}

elegans, 471

tuberculata, 525
Pachyotus

alopecotis, 548

Parmacella

auriculata, 312

callosa, 313

calyculata, 312

Patula

aculeata, 23

Bertholdiana, 494

bifrons, 81

bilamellata, 537

biplicata, 538

Bouvieri, 494

calathoides, 83

circumsessa, 317

concinna, 328

Cutteri, 538

deflorata, 80

engonata, 329

garachicoensis, 326

gorgonarum, 492

Guerineana, 84

monas, 21

placida, 87, 331

polyodon, 539

Pompylia, 327

pusilla, 22, 88, 331, 495,540

putrescens, 329

pygmæa, 86

retexta, 330

rotundata, 21,85

scutula, 330

servilis, $22,88,332,495$, $541^{\circ}$

spinifera, 332

stephanophora, 82

textilis, 328

torrefacta, 382

Pedipes

afra, 50, 265, 293

Physa

acuta, 273, 467

canariensis, 469

fontinalis, 273, 467, 469

Forskalii, 523

subopaca, 467

tenerifa, 467

vent*icosa, 467

Wahlbergi, 523

Planorbis

coretus, 523

glaber, 273

lavis, 273

Reissi, 469

Plectrophorus

Orbignii, 310

Pomatias

Barthelemianum, 301

Pupa

abbreviata, 235
Pupa

acarus, 515

anconostoma, 43, 209, $210,450,513,534$

atomus, 448

calathiscus, 234

canicalensis, 221

cassida, 213

cassidula, 218

castanea, 452

cheilogona, 213

concinna, 219

corneocostata, 227

dealbata, 447

debilis, 209, 449

deformis, 216

degenerata, 231

Dohrni, 513

edentata, 249

edentula, 208

fanalensis, 209, 449

fasciolata, 45

Ferraria, 230

fusca, 226

fuscidula, 44

gibba, 235

gorgonica, 516

granum, 451

irrigua, 215

lævigata, 223

lamellosa, 236

laurinea, 220

limnæana, 208

linearis, 207

Loweana, 217

macilenta, 225

macrogira, 447

microspora, 43, 207, 449

millegrana, 227

Milleri, 513

minutissima, 207

molecula, 512

monticola, 232

pygmæa, 47

pythiella, 454

recta, 224

relevata, 229

rugulosa, 46

saxicola, 237

seminulum, 237

sphinctostoma

subdiaphanu, 51

tæniata, 455

tessellata, 46

umbilicata, 43, 21

450,554

vermiculosa, 47

vincta, 214

Wollastoni, 221

Wollastoni, 216 
Rissoa

anatina, 281

littorea, 297, 477

Stenogyra

compressilabris, 553

decollata, 42, 206, 445, 509

Goodalli, 510

subdiaphana, 511

Subulina

melanioides, 550

striatella, 206

subplicata, 552

terebellum, 552

Succinea

asperula, 557

Bensoniana, 557

helene, 557

imperialis, 556

Lowei, 520

picta, 556

rudorina, 556

Sanctæ-Helenæ, 555

solidula, 557

Wollastoni, 521

Testacella

haliotidea, 73, 311

Maugei, 13, 72, 310

Theba

conoidea, 37
Theba

conspurcata, 376

Tornatellina ovuliformis, 263

Torquilla granum, 451

Truncatella

Lowei, 280, 476

truncatula, 279, 296

Turbo

perversus, 48, 242

\section{Vertigo}

pygmaa, 47

Viquesnelia atlantica, 12

Vitrina

angulosa, 16

Belenii, 75

Blauneri, 316

Bocagei, 101

brevispira, 15

brumalis, 14

canariensis, 315

fasciolata, 300

finitima, 15

Lamarckii, 74, 77

Lamarckii, 313

latebasis, 315

laxata, 16

marcida, 76

media, 76
Vitrina
mollis, 14

nitida, 76

pelagica, 16

reticulata, 315

ruivensis, 74

Teneriff a, 75, 313

Voluta

auris-vulpina, 548

Xerophila

apicina, 33, 377

Zonites

alliarius, 535

atlanticus, 20

brumalis, 17

cellarius, 19, 535

clymene, 324

crystallinus, 19

festinans, 323

fulvus, 20

lenis, 320

miguellimus, 18

rotundatus, 21

Vidalianus, 18

volutella, 17

Zua

azorica, 49 


\section{LIS'T OF WORKS}

PUBLISHED BY

\section{REEVE \& CO.,}

5, Henrietta Street, Covent Garden, W.C.

\section{NEW SERIES OF NATURAL HISTORY FOR BEGINNERS.}

*** A good introductory series of books on Natural History for the use of students and amateurs is still a desideratum. Those at present in use have been too much compiled from antiquated sources ; whilst the figures, copied in many instances from sources equally antiquated, are far from accurate, the colouring of them having become degenerated through the adoption, for the sake of cheapness, of mechanical processes.

The present series will be entirely the result of original research carried to its most advanced point ; and the figures, which will be chiefly engraved on steel, by the artist most highly renowned in each department for his technical knowledge of the subjects, will in all cases be drawn from actual specimens, and coloured separately by hand.

Each work will treat of a department of Natural History sufficiently limited in extent to admit of a satisfactory degree of completeness.

\section{The following are now ready :-}

British Insects ; a Familiar Description of the Form, Structure, Habits, and Transformations of Insects. By E. F. Statruey. Crown 8vo, 16 Coloured Steel Plates, engraved from Natural Specimens expressly for the work by E. W. RoвInson, and numerous Wood-Engravings by E. C. RYE, 14s.

\section{British Butterflies and Moths ; an Introduction}

to the Study of our Native Lepidoptera. By H. T. Stainton.

Crown 8vo, 16 Coloured Steel Plates, containing Figures of 100

Species, engraved from Natural Specimens expressly for the work by E. W. Robinson, and Wood-Engravings, 10s. $6 d$. 
British Beetles; an Introduction to the Study of our Indigenous Coneoptera. By E. C. RYe. Crown 8vo, 16 Coloured Steel Plates, comprising Figures of nearly 100 Species, engraved from Natural Specimens, expressly for the work, by E. W. RoBinson, and 11 Wood-Engravings of Dissections by the Author, $10 s$. $6 d$.

British Bees ; an Introduction to the Study of the Natural History and Economy of the Bees indigenous to the British Isles. By W. E. SHuckand. Crown 8vo, 16 Co. loured Steel Plates, containing nearly 100 Figures, engraved from Natural Specimens, expressly for the work, by E. W. Robinson, and Woodcuts of Dissections, 10s. $6 d$.

British Spiders ; an Introduction to the Study of the ARANEIDE found in Great Britain and Ireland. By E. F. Stavelexy. Crown 8vo, 16 Plates, cuntaining Coloured Figures of nearly 100 Species, and 40 Diagrams, showing the number and position of the eyes in various Genera, drawn expressly for the work by TUFFEN WEST, and 44 Wood-engravings, 10s. $6 d$.

British Grasses ; an Introduction to the Study of the Grasses found in the British Isles. By M. Pruks. Crown 8vo, 16 Coloured Plates, drawn expressly for the work by W. FiтCH, and 100 Wood-Engravings, 10s. $6 d$.

British Ferns; an Introduction to the Study of the FerNs, LYCOPODS, and EQUISETA indigenous to the British Isles. With Chapters on the Structure, Propagation, Cultivation, Diseases, Uses, Preservation, and Distribution of Ferns. By M. Pudrs. Crown 8vo, 16 Coloured Plates, drawn expressly for the work by W. FircH, and 55 Wood-Engravings, 10s. $6 \mathrm{~d}$.

\section{British Seaweeds ; an Introduction to the Study} of the Marine ALGE of Great Britain, Ireland, and the Channel Islands. By S. O. Gray. Crown 8vo, 16 Coloured Plates, drawn expressly for the work by W. FiтcH, 10s. $6 d$.

\section{0ther Works in preparation.}




\section{BOTANY,}

The Narcissus, its History and Culture, with Coloured Figures of all known species and principal Varieties. By F. W. BURBIDGE, and a Review of the Classification by J. G. BAKER, F.L.S. Super-royal 8vo. 48 Coloured Plates, 32s.

The Young Collector's Handybook of Botany. By the Rev. H. P. Dunstek, M.A., 66 Wood-Engravings, 3s. $6 d$.

The Natural History of Plants. By $\mathrm{H}$. BaILlon, President of the Linnæan Society of Paris, Professor of Medical Natural History and Director of the Butanical Gaiden of the Faculty of Medicine of Paris. Super-royal 8vo. Vols. I. to IV., with 1800 Wood-Engravings, 25s. each.

\section{Domestic Botany; an Exposition of the} Structure and Classification of Plants, and of their uses for Food, Clothing, Medicine, and Manufacturing Purposes. Ву ЈонN Sмrte, A.L.S., ex-Curator of the Royal Botanic Gardens, Kew. Crown 8vo, 16 Coloured Plates and Wood-Engravings, 16s.

\section{Handbook of the British Flora; a Description} of the Flowering Plants and Ferns indigenous to, or naturalized in, the British Isles. For the Use of Beginners and Amateurs. By George Bentham, F.R.S., President of the Linnæan Society. New Edition, Crown 8vo, 12 s.

The Illustrated British Flora, a Description (with a Wood-Engraving, including dissections, of each species) of the Flowering Plants and Ferns indigenous to, or naturalized in, the British Isles. By Groram Bentram, F.R.S., President of the Linnæan Society. Demy 8vo, 2 vols., 1295 Wood-Engravings, from Original Drawings by W. FITCH, 70 s.

British Wild Flowers, Familiarly Described in the Four Seasons. A New Edition of "The Field Botanists" Companion." Ву 'Tномas Mооне, F.L.S. Demy 8vo, 24 Coloured Plates, by W. FiroH, 16 s. 
Outlines of Elementary Botany, as Introductory to Local Floras. By Geonge Bentham, F.R.S., President of the Linnæan Society. Second Edition, 2s. $6 d$.

British Grasses ; an Introduction to the Study of the Gramineæ of Great Britain and Ireland. By M. Pudes. Crown 8vo, with 16 Coloured Plates by W. Fitch, and 100 Wood-Engravings, 10s. $6 d$.

\section{The Botanical Magazine; Figures and} Descriptions of New and Rare Plants of Interest to the Botanical Student, and suitable for the Garden, Stove, or Greenhouse. By Dr. J. D. Hooker, C.B., Pres.R.S., Director of the Royal Gardens, Kew. Royal 8vo. Published Monthly, with 6 Plates, 3s. 6d. coloured. Annual Subscription, 42s.

RE-ISSUE of the THIRD SERIES in monthly vols., $42 s$. each; to Subscribers for the entire series, $36 s$. each.

The Floral Magazine; New Series, enlarged to Royal 4to. Figures and Descriptions of the choicest New Flowers for the Garden, Stove, or Conservatory. Monthly. with 4 beautifully Coloured Plates, 3s. 6d. Annual Subscription, $42 \mathrm{~s}$.

First series complete in 10 vols., with 560 beautifully Coloured Plates, $£ 18$ 7s. $6 d$.

Laws of Botanical Nomenclature adopted by the International Botanical Congress, with an Historical Introduction and a Commentary. By AllphoNse dE CaNdolle. $2 s .6 d$.

Contributions to the Flora of Mentone, and to a Winter Flora of the Riviera, including the Coast from Marseilles to Genoa. By J. Traherne Moggridge F.L.S. Royal 8vo. In 4 parts, each with 25 Coloured Plates, 158., or complete in one vol., $63 s$.

Flora Vitiensis; a description of the Plants of the Viti or Fiji Islands, with an Account of their History, Uses, and Properties. By Dr. Berthold SemmanN, F.L.S. Royal 4to, Coloured Plates, £8 5 s. 
Flora of British India. By Dr. J. D. Hooker, C.B., F.R.S., \&c.; assisted by various Botanists. Parts I. to IV., each 10s. 6d. Vol. I. (Parts I. to III.), cloth, 32s. Published under the Authority of the Secretary of State for India in Council.

Flora of Tropical Africa. By Daniel Oliver, F.R.S., F.L.S. Vols I. and II., 20s. each. Published under the authority of the First Commissioner of Her Majesty's Works.

\section{Handbook of the New Zealand Flora; a} Systematic Description of the Native Plants of New Zealand, and the Chatham, Kermadec's, Lord Auckland's, Campbell's, and Macquarrie's Islands. By Dr. J. D. Hooker, F.R.S. Complete in one vol., 30s. Published under the auspices of the Government of that colony.

Flora Australiensis; a Description of the Plants of the Australian Territory. By GEorge BenthaM, F.R.S., President of the Linnæan Society, assisted by FrRDINand Mueller, F.R.S.. Government Botanist, Melbourne, Victoria. Vols. I. to VI., 20s. each. Published under the auspices of the several Governments of Australia.

Flora of the British West Indian Islands. By Dr. Grisebach, F.L.S. 37s. 6d. Published under the auspices of the Secretary of State for the Colonies.

Flora Hongkongensis; a Description of the Flowering Plants and Ferns of the Island of Hongkong. By George Bentham, F.L.S. With a map of the Island, and a Supplement by Dr. Hancr. 18s. Published under the authority of Her Majesty's Secretary of State for the Colonies. The Supplement separately, 2s. $6 d$.

Flora Capensis: a Systematic Description of the Plants of the Cape Colony, Caffraria, and Port Natal. By William H. HaRvey, M.D., F.R.S., Professor of Botany in the University of Dublin, and Otro Wilhem Sondre, Pl.D. Vols. I and II., 12s. each. Vol. III., 18s. 
Elementary Lessons in Botanical Geography. By J. G. Baker, F.L.S., 3 s.

On the Flora of Australia, its Origin, Affinities and Distribution; being an Introductory Essay to the "Flora of Tasmania." By Dr. J. D. Hocker, F.R.S., 10s.

Genera Plantarum, ad Exemplaria imprimis in Herbariis Kewensibus servata definita. By George Bentham, F.R.S., F.L.S., and Dr. J. D. Hooker, Pres.R.S., Director of the Royal Gardens, Kew. Vol. I. Part I. Royal 8vo, 21s. Part II., 14s. ; Part III., 15s ; or Vol. I. complete, 50s. Vol. II. Part I. 24s. ; Part II. 32s. ; or Vol. II. complete, $56 s$.

Illustrations of the Genus Carex. By Francis Bootт, M.D. Folio, 600 Plates. Part I., 10l. Parts II. and III., each 5l. Part IV., $10 l$.

Illustrations of the Nueva Quinologia of Pavon, with Observations on the Barks described. By J. E. Howard, F.L.S. With 27 coloured Plates by W. Fitch. lmperial folio, half morroco, gilt tdges, $6 l$. 6 .

The Quinology of the East Indian Plantations. By J. E. Howard, F.L.S. Folio, 3 Coloured Plates, 218. Parts II. and III., with 10 Coloured and 2 Plain Plates, and 2 Photo-prints, cloth $63 s$, , or complete in one Vol., $84 s$.

Revision of the Natural Order Hederaceæ, being a reprint, with numerous additions and corrections, of a series of papers published in the "Journal of Botany, British and Foreign." By Benithold Segmaxn, Ph. D., F.L.S. 7 Plates, 10s. $6 d$.

Icones Plantarum. Figures, with Brief Descriptive Characters and Remarks, of New and Rare Plants selected from the Author's Herbarium. By Sir W. J. Hooken, F.R.S. New Series, Vol. V. 100 Plates, 31s. $6 d$. 
Orchids : and How to Grow them in India and other Tropical Climates. By SAMUeL Jenninas, F.L.S., F.R.H.S., late Vice-President of the Agri-Horticultural Society of India. Royal 4to. Complete in 1 Vol., cloth, gilt edges, $63 s$.

A Second Century of Orchidaceous Plants, selected from the Subjects published in Curtis's "Botanical Magazine" since the issue of the "First Century." Lited by JaMes BATEMAN, Esq., F.R.S. Complete in 1 Vol. royal 4to, 100 Coloured Plates, $5 l$. 5s.

Dedicated by Spevial Permission to H.R.H. the Princess of Wales.

Monograph of Odontoglossum, a Genus of the Vandeous Section of Orchidaceous Plants. By JAMrs BATEMaN, Esq., F.R.S. Imperial folio, complete in 6 Parts, each with 5 Coloured Plates, and occasional Wood-Engravings, 21s., or in one vol., half morocco, gilt edges, $7 l .7 \mathrm{~s}$.

Select Orchidaceous Plants. By RoBERT WARNER, F.R.H.S. With Notes on Culture by B. S. WILLIAMs. Folio, with 40 Coloured Plates, cloth gilt, $7 l$. $7 \mathrm{~s}$.

Second Series, complete, with 39 Coloured Plates, $7 l$. $7 s$.

The Rhododendrons of Sikkim-Himalaya; being an Account, Botanical and Geographical, of the Rhododendrons recently discovered in the Mountains of Eastern Himalaya, by Dr. J. D. Hooker, F.R.S. By Sir W. J. Hooker, F.RS. Folio, 30 Coloured Plates, 4l. 14s. $6 d$.

Botanical Names for English Readers. By RANDAL H. Alcock. 8vo, $6 s$.

\section{FERNS.}

British Ferns; an Introduction to the Study of the Frrns, Lycopons, and EQUISETA indigenous to the British Isles. With Chapters on the Structure, Propagation, Cultivation, Diseases, Uses, Preservation, and Distribution of Ferns. By M. Pluks. Crown 8vo, with 16 Coloured Plates by W. Fitcr, and 55 Wood-Engravings, 10s. $6 d$. 
The British Ferns ; Coloured Figures and Descriptions, with Analysis of the Fructification and Venation of the Ferns of Great Britain and Ireland. By Sir W. J. Hooker, F.R.S. Royal 8vo, 66 Coloured Plates, 2l. $2 s$.

Garden Ferns ; Coloured Figures and Descriptions, with Analysis of the Fructification and Venation, of a Selection of Exotic Ferns, adapted for Cultivation in the Garden, Hothouse, and Conservatory. By Sir W. J. Hoorer, F.R.S. Royal 8vo, 64, Coloured Plates, 2l. 2s.

Filices Exoticæ; Coloured Figures and Description of Exotic Ferns. By Sir W. J. Hooker, F.R.S. Royal 4to, 100 Coloured Plates, $6 l .11 s$.

Ferny Combes; a Ramble after Ferns in the Glens and Valleys of Devonshire. By Charlottr Chanter. Third Edition. Fcap. 8vo, 8 Coloured Plates by Firch, and a Map of the County, 58.

\section{MOSSES.}

Handbook of British Mosses, containing all that are known to be natives of the British Isles. By the Rev. M. J. Berkelex, M.A., F.L.S. Demy 8vo, 24 Coloured Plates, 21s.

Synopsis of British Mosses, containing Descriptions of all the Genera and Species (with localities of the rarer ones) found in Great Britain and Ireland. By CHarles P. Hobkirk, President of the Huddersfield Naturalist's Society. Crown 8vo, 7s. $6 d$.

\section{SEAWEEDS.}

British Seaweeds; an Introduction to the Study of the Marine A:GAs of Great Britain, Ireland, and the Channel Islands. By S. O. GraY. Crown 8vn, with 16 Coloured Plates, drawn expressly for the work by W. FiтcH, 10s. $6 d$. 
Phycologia Britannica ; or, History of British Seaweeds, containing Coloured Figures, Generic and Specific Characters, Synomyms and Descriptions of all the Species of Algæ inhabiting the shores of the British Islands. By Dr. W. H. Harvey, F.R.S. New Edition. Royal 8vo, 4 vols. 360 Coloured Plates, 7l. 10 s.

Phycologia Australica : a History of Australian Seaweeds, comprising Coloured Figures and Descriptions of the more characteristic Marine Algæ of New South Wales, Victoria, Tasmania, South Australia and Western Australia, and a Synopsis of all known Australian Algæ. By Dr. HARver, F.R.S. Royal 8vo, 5 vols, 300 Coloured Plıtes, 7l. 13 s.

\section{FUNGI.}

Outlines of British Fungology, containing Characters of above a Thousand Species of Fungi, and a Complete List of all that have been described as Natives of the British Isles. By the Rev. M. J. BERkeley, M.A., F.L.S. Demy 8vo, 24, Coloured Plates, 30s.

The Esculent Funguses of England. Containing an Account of their Classical History, Uses, Characters, Development, Structure, Nutritious Properties, Modes of Cooking and Preserving, \&c. By C. D. BАDHAM, M.D. Second Édition. Edited by F. Cunrey, F.R.S. Demy 8vo, 12 Coloured Plates, 12s.

Illustrations of British Mycology, comprising Figures and Descriptions of the Funguses of interest and novelty indigenous to Britain. By Mrs. T. J. HussEY. Royal 4to. Second Series, 50 Coloured Plates, $£ 410$ s.

Clavis Agaricinorum: an Analytical Key to the British Agaricini, with Characters of the Genera und Subgenera. By Worthington G. Smith, F.L.S. Six plates. 2s. $6 d$. 


\section{SHELLS AND :MOLLUSKS.}

Elements of Conchology; an Introduction to the Natural History of Shells, and of the Animals which form them. By Loveli Reeve, F.L.S. Royal 8vo, 2 vols. 62 Coloured Plates, £2 $16 s$.

Conchologia Iconica ; or, Figures and Descriptions of the Shells of Mollusks, with remarks on their Affinities, Synonymy, and Geographical Distribution. By Lovell Reeve, F.I.S. Demy 4to, in double Parts, with 16 Coloured Plates. 20 s.

A detailed list of Monographs and Volumes published may be had.

Conchologia Indica ; Illustrations of the Land and Frrshwater Shells of British India. Edited by Sruvanus Hanlex, F.L.S., and William Throbald, of the Geological Survey of India. 4to, Parts 1. to VIII., each with 20 Coloured Plates, 20s., or complete in one vol., cloth, $£ 85$.

The Edible Mollusks of Great Britain and Ireland, with the Modes of Cooking them. By M. S. Love LL. Crown Svo, with 12 Coloured Plates, 8s. $6 d$.

\section{INSECTS.}

Harvesting Ants and Trap-door Spiders; Notes and Observations on their Habits and Dwellings. By J. T. Mogarider, F.L.S. With a Supplement of $160 \mathrm{pp}$. and 8 additional Plates, 17 s. The Supplement separately, cloth, 7s. $6 d$.

British Insects. A Familiar Description of the Form, Structure, Habits, and Transformations of Insects. By E. F. STavelex, Author of "British Spiders." Crown 8vo, with 16 Coloured Steel Plates and numerous WoodFingravings, 14s.

British Beetles ; an Introduction to the Study of our Indigenous Colfoptera. By E. C. RYr. Crown 8vo, 16 Coloured Steel Plates, comprising Figures or nearly 100 Species, engraved from Natural Specimens, expressly for the work, by E. W. Robinson, and 11 Wood-Engravings of Dissections by the Author, $10 s .6 d$. 
British Bees; an Introduction to the Study of the Natural History and Enonomy of the Bees indigenous to the British Isles. By W. E. Sk UCKaRD. Crown 8vo, 16 Coloured Steel Plates, containing nearly 100 Figures, engraved from Natural Specimens, expressly for the work, by E. W. RoBINsos, and Woodcuts of Dissections, 10s. $6 d$.

British Butterflies and Moths; an Introduction to the Study of our Native Lepidopxera. By H. T. Starnton. Crown 8vo, 16 Coloured Steel Plates, containing Figures of 100 Species, engraved from Natural Specimens expressly for the work by E. W. RoBinson, and Wood-Engravings, $10 s .6 d$.

British Spiders; an introduction to the Study of the ARANeIDes found in Great Britain and Ireland. By E. F. Staverey. Crown 8vo. 16 Plates, containing Coloured Figures of nearly 100 species, and 40 Diagrams, showing the number and positior of the eyes in various Genera, drawn expressly for the work by TUFFEN WEST, and 44 Wood-Engravings, 10s. $6 d$.

Curtis's British Entomology. Illustrations and Descriptions of the Genera of Insects found in Great Britain and Ireland, containing Coloured Figures, from Nature, of the most rare and beautiful Species, and in many instances, upon the plants on which they are found. 8 vols. Royal 8vo, 770 Coloured Plates. £28.

\section{Or in Separate Monographs.}

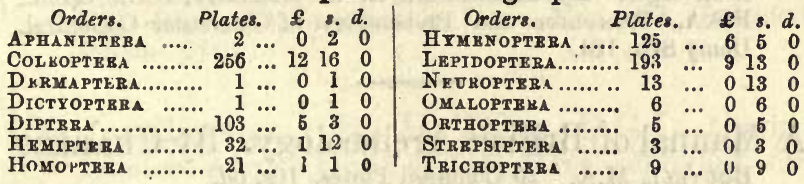

"Curtis's Entomology," which Cuvier pronounced to have "reached the ultimatum of parfection," is still the standard work on the Genera of British Insects. The Figures executed by the author himself, with wonderful minuteness and accuracy, have nerer been surpassed, even if equal'ed. The price at which the work was originally published was $£ 4316$ s.

Insecta Britannica; Vol. III., Diptera. By Francis Warker, F.L.S. 8vo, with 10 Plates, 25 s. 


\section{FINE ART.}

The Royal Academy Album; a Series of Photographs from Works of Art in the Exhibition of the Royal Academy of Arts, 1875. Atlas 4to, with 32 fine Photographs, cloth, gilt edges, $£ 66$ s. Half Morocco, $£ 77$ s. The same for 1876 , with 48 beautiful Photo-prints, cloth $£ 6$ 6s. Half Morocco £7 7s. Small Edition, Royal 4to, cloth, gilt edges, $63 s$.

Photographs from Modern Paintings by Eminent Artists. A New Copyright Series of Photographs, taken direct from the origiral paintings with the sanction of the Artists. Large size on Imperial India-tinted mounts, 9s. each. Smaller size on Atlas 4to, do., 4s. 6d. Lists of Subjects ready on application.

\section{ANTIQUARIAN.}

Sacred Archæology ; a Popular Dictionary of Ecclesiastical Art and Institutions, from Primitive to Modern Times. Comprising Architecture, Music, Vestments, Furniture Arrangement, Offices, Customs, Ritual Symbolism, Ceremonial Traditions, Religious Orders, \&c., of the Church Catholic in all Ages. By Mackenzie E. C. Walcorr, B.D., Oxon., F.S.A., Præcentor and Prebendary of Chichester Cathedral. Demy 8ro, $18 s$.

A Manual of British Archæology. By Charles Boutel, M.A. 20 Coloured Plates, 10s. $6 d$.

Man's Age in the World according to Holy Scripture and Science. By AN Essex Rector. 8s. $6 d$.

The Antiquity of Man; an Examination 'of Sir Charles Lyell's recent Work. By S. R. Pattison, F.G.S. Second Edition. 8vo, $1 s$. 


\section{MISCELLANEOUS.}

Natal; a History and Description of the Colony, including its Natural Features, Productions, Industrial Condition and Prospects. By Henry Brooks, for many years a resident. Edited by Dr. R. J. MANN, F.R.A.S., F.R.G.S., late Superintendent of Education in the Colony. Demy 8vo, with Maps, Coloured Plates, and Photographic Views, 21s.

St. Helena. A Physical, Historical, and Topographical Description of the Island, including its Geology, Fauna, Flora, and Meteorology. By J. C. Mruuiss, A.I.C.E., F.G.S., F.L.S. In one large Vol. Super royal 8vo, with 56 Plates and Maps, mostly Coloured. 42s.

International Series of Elementary Text Books of Natural Science.

Zoology. By Adrian J. Ebell, Ph.B., M.D. Part I. : Structural Distinctions, Functions, and Classification of the Orders of Animals, $1 s$.

Lahore to Yarkand. Incidents of the Route and Natural History of the Countries traversed by the Expedition of 1870, under T. D. Forsxth, Esq., C.B. By GeOrGe Henderson, M.D., F.L.S., F.R.G.S., and Aluav O. Hume, Esq., C.B., F.Z.S. With 32 Coloured Plates of Birds, 6 of Plants, 26 Photographic Views, Map, and Geological Sections, $42 s$.

On Intelligence. By H. Taine, D.C.L. Oxon. Translated from the French by T. D. HAYE, and revised, with additions, by the Author. Complete in One Volume, 18s.

The Young Collector's Handy Book of Recreative Science. By the Rev. H. P. Dunster, M.A. Cuts. 3s. $6 d$.

The Gladiolus : its History, Cultivation, and Exhibition. By the Rev. H. Honywood Dom BraIN, B.A. 1 s. 
The Birds of Sherwood Forest; with Observations on their Nesting, Habits, and Migrations. By W. J. Sterland. Crown 8vo, 4 plates. 7s. $6 d$. coloured.

The Naturalist in Norway; or, Notes on the Wild Animals, Birds, Fishes, and Plants of that Country, with some account of the principal Salmon Rivers. By the Rev. J. BowDEn, LL.D. Crown 8vo, 8 Coloured Plates. 10s. $6 d$.

The Zoology of the Voyage of H.M.S. Samarang, under the command of Captain Sir Edward Belcher, C.B. during the Years 1843-46. By Professor OwEN, Dr. J. E. Gray, Sir J. Riohardson, A. Adams, L. ReEve, and A. Whitк. Edited by ArThur AdaMs, F.L.S. Royal 4to, 55 Plates, mostly coloured, £3 10s.

A Survey of the Early Geography of Western Europe, as connected with the First Inhabitants of Britain, their Origin, Language, Religious Rites, and Edifices. By HeNry Lawes Long, Esq. 8vo, 68.

The Geologist. A Magazine of Geology, Palæontology, and Mineralogy. Illustrated with highly-finished Wood Engravings. Edited by S. J. MACKIE, F.G.S., F.S.A. Vols. V. and VI., each, with numerous Wood-Engravings, 18 s. Vol. VII. 9s.

The Stereoscopic Magazine. A Gallery for the Stereoscope of Landscape Scenery, Architecture, Antiquities, Natural History, Rustic Character, \&c. With Descriptions. 5 vols., each complete in itself and containing 50 Stereographs, £2 2s.

Everybody's Weather-Guide. The Use of Metereological Instruments clearly Explained, with Directions for Securing at any time n probable Prognostic of the Weather. By A. Stringetz, Esq., Author of "Sunshine and Showers," \&c. 1 s.

The Artificial Production of Fish. By PIsCARICS. Third Edition. 1s. 
Sunshine and Showers: their Influences throughout Creation. A Compendium ot Popular Meteorology. By Andrew Steinmetz, Esq. Crown 8ro, Cuts, 7s. $6 d$.

The Reasoning Power in Animals. By the Rev. J.S. Watson, M A. Crown 8vo, 9s.

Manual of Chemical Analysis, Qualitative and Quantitative; for the use of Students. By. Dr. Henry M. NoAd, F.R.S. New edition. Crown 8 ro. 109 Wood-Engravings, 16s. Or, separately, Part I., 'QUALITATIVE,' New Edition, new Notation, 6s. ; Part II., 'QUANTITATIVE,' 10s. $6 d$.

Phosphorescence; or, the Emission of Light by Minerals, Plants, and Animals. By Dr. T. L. Phipsor, F.C.S. Small 8vo, 30 Cuts and Coloured Frontispiece, 5 s.

Meteors, Aerolites, and Falling Stars. By Dr. T. L. Phipson, F.C.S. Crown 8vo, 25 Woodcuts and Lithographic Frontispiece, $6 s$.

Live Coals; or, Faces from the Fire. By L. M. BUDGEN, "Acheta," Author of 'Episodes of Insect Life,' etc., Dedicated, by Special Permission, to H.R.H. Field-Marshal the Duke of Cambridge. Royal 4to, 35 Original Sketches printed in colours, 21 s.

Caliphs and Sultans; being Tales omitted in the ordinary English Version of "The Arabian Nights' Entertainments," freely rewritten and rearranged. By S. HANLEY, F.L.S. 6s.

\section{PLATES.}

Floral Plates, from the Floral Magazine. Beautifully Coloured, for Screens, Scrap-books, Studies in Flower painting. \&cc. $6 d$. and 1s. each. Lists of over 700 varieties.

Botanical Plates, from the Botanical Magazine. Beautifully Coloured Figures of New and Rare Plants. 6d. and 1s. each. Lists of over 2000 . 


\section{SERIALS.}

The Botanical Magazine. Figures and Descriptions of New and Rare Plants. By Dr. J. D. Hooker, C.B., Pres.R.S. Monthly, with 6 Coloured Plates, 3s. 6d. Annual Subscription, post free, $42 s$.

Re-issue of the Third Series in monthly vols., 42s. each : to Subscribers for the entire Series, $36 s$. each.

The Floral Magazine. New Series, enlarged to Royal 4to. Figures and Descriptions of Select New Flowers for the Garden, Stove, or Conservatory. Monthly, with 4 Coloured Plates, 3s. 6d. Annual Subscription, post free, 42s.

Select Orchidaceous Plants. By RoBerT W ARner. 3 Coloured Plates, 10s. $6 d$.

Conchologia Iconica. By LOVelt Reeve, F.L.S., and G. B. Sowerby, F.L.S. In Double Parts, with 16 Coloured Plates, 20s.

\section{FORTHCOMING WORKS.}

West Yorkshire: its Geology, Physical Geography and Botany. By JAMES W. DAvis, F.G.S., F.L.S., and Frederic Arnold Lees, F.L.S.

The Food Plants of the British Lepidoptera. By Owen WILson.

Handbook to the Freshwater Fishes of India. By Captain R. Beavar.

Phalænopsis : a Genus of Orchidaceous Plants. Genera Plantarum. By Bentham and Hooker. Flora of India. By Dr. Hooker and others. Natural History of Plants. By Prof. Bajllon. Flora of the Mauritius. By J. G. BAKER, F.L.S.

Flora of Tropical Africa. By Prof. Oliver. Flora Australiensis. By G. Bentham. Vol. 7.

LoNdoN : L. REEVE \& CO., 5, HRNRIETTA ST., CoveNT GARDEN. 

THIS BOOK IS DUE ON THE LAST DATE STAMPED BELOW

AN INITIAL FINE OF 25 CENTS WILL BE ASSESSED FOR FAILURE TO RETURN THIS BOOK ON THE DATE DUE. THE PENALTY WILL INCREASE TO 50 CENTS ON THE FOURTH DAY AND TO \$1.gP ON THE SFYENTH DAY

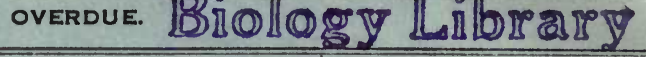

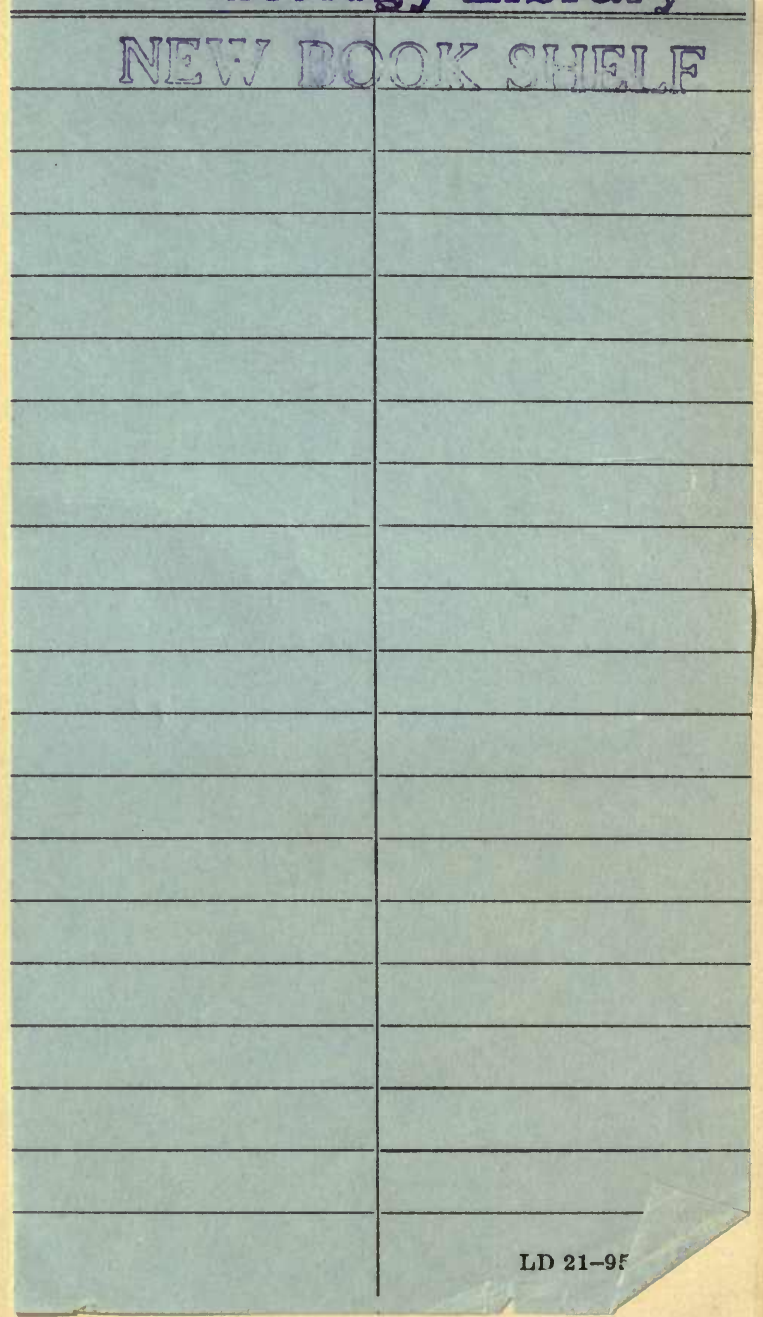




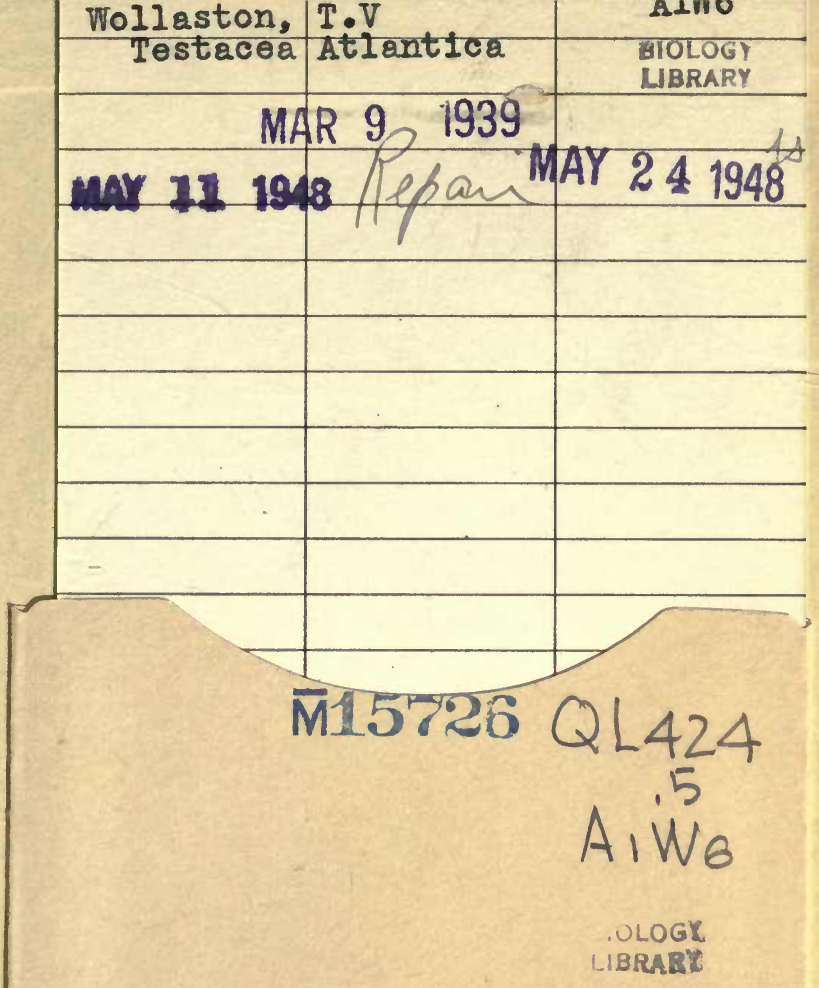

THE UNIVERSITY OF CALIFORNIA LIBRARY 


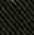

